$$
\begin{aligned}
& \text { UNIVERSIDADE DE SÃO PAULO } \\
& \text { INSTITUTO DE GEOCIÊNCIAS }
\end{aligned}
$$

\title{
ESTRATÉGIAS DE GEOCONSERVAÇÃO NO PARQUE ESTADUAL DA SERRA DO MAR - NÚCLEOS PICINGUABA E CARAGUATATUBA (SP)
}

\author{
Eliana Mazzucato
}

Orientadora: Prof $^{\mathrm{a}} \mathrm{Dr}^{\mathrm{a}}$ Denise de La Corte Bacci

\author{
DISSERTAÇÃO DE MESTRADO \\ Programa de Pós Graduação em Geociências \\ (Mineralogia e Petrologia)
}

SÃO PAULO

2017 



\section{UNIVERSIDADE DE SÃO PAULO \\ INSTITUTO DE GEOCIÊNCIAS}

\section{ESTRATÉGIAS DE GEOCONSERVAÇÃO NO PARQUE ESTADUAL DA SERRA DO MAR - NÚCLEOS PICINGUABA E CARAGUATATUBA (SP)}

\section{ELIANA MAZZUCATO}

Orientadora: Prof ${ }^{a}$. Dr ${ }^{\mathrm{a}}$. Denise de La Corte Bacci

Dissertação de Mestrado

№ 779

COMISSÃO JULGADORA

Drª. Denise de La Corte Bacci

Drª. Kátia Leite Mansur

Dr. Paulo César Boggiani

SÃO PAULO

2017 
Autorizo a reprodução e divulgação total ou parcial deste trabalho, por qualquer meio convencional ou eletrônico, para fins de estudo e pesquisa, desde que citada a fonte.

Ficha catalográfica preparada pelo Serviço de Biblioteca e Documentação do Instituto de Geociências da Universidade de São Paulo

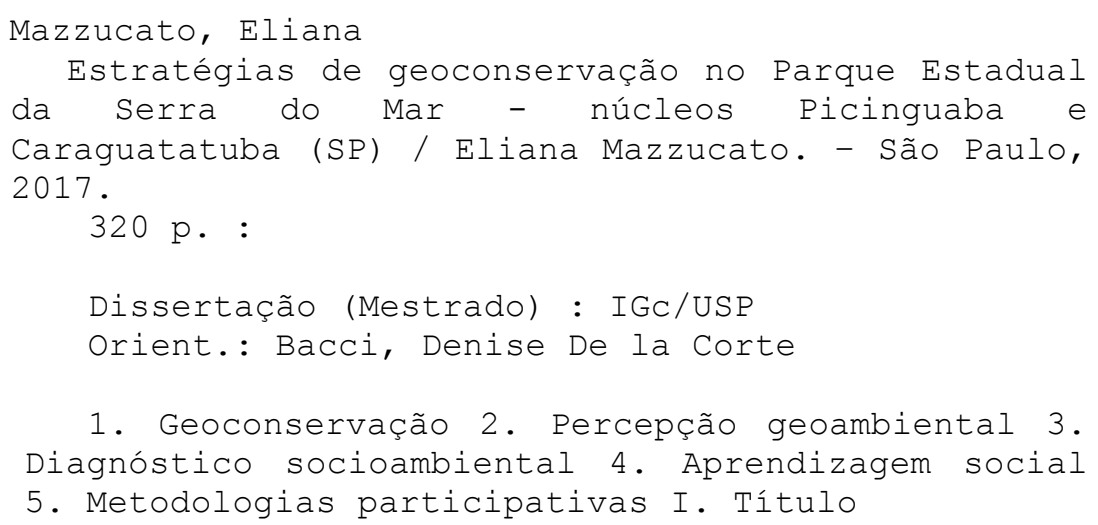


Dedico este trabalho aos meus pais Lico e Lica, pelo amor e dedicação com que me ensinam e apoiam em todos os momentos. 



\section{AGRADECIMENTOS}

Realizar este trabalho não teria sido possível sem a colaboração e ajuda de muitas pessoas. São tantas pessoas e tantos motivos para ser grata que tenho medo de não conseguir escrever algo que faça jus a minha gratidão para com todos, por esse motivo escreverei de forma simples mas sincera.

À minha orientadora, Professora Dr $^{\mathrm{a}}$ Denise de La Corte Bacci, em primeiro lugar por ter aceito essa pesquisadora de fora, por toda generosidade e carinho com que me orientou, pelo companheirismo e por ter se dedicado aos trabalhos de campo e à realização dos cursos.

À minha família, meu pai, José Maria Mazzucato, minha mãe, Maria Padoveis Mazzucato e minha irmã Joice Mazzucato, por todo o apoio e carinho com os quais sempre pude contar.

À Professora Dr ${ }^{\mathrm{a}}$ Vânia M.N. dos Santos, que com tanto zelo dedicou inúmeros momentos para contribuir com essa pesquisa, compartilhando seus conhecimentos para a formação continuada de professores e acompanhamentos em trabalhos de campo.

À Professora Dr ${ }^{\mathrm{a}}$ Maria da Glória M. Garcia, por ter sido meu primeiro contato na USP e ter indicado a área de pesquisa do litoral norte. Agradeço pelas oportunidades, pelas inúmeras contribuições, pelo compartilhamento de conhecimentos, materiais e pelo acompanhamento em trabalhos de campo.

À professora Marta F. M. Ferreira, da Universidade Federal de Alfenas - MG, por ter me guiado em meus primeiros passos na vida acadêmica.

Agradeço aos gestores dos núcleos Picinguaba e Caraguatatuba, pela receptividade e generosidade em possibilitar o desenvolvimento da pesquisa, e pelas inúmeras contribuições no decorrer dela. Aos funcionários dos núcleos Picinguaba e Caraguatatuba que não mediram esforços em colaborar com a realização dos cursos. Agradeço especialmente ao Danilo, ao Miguel, à Débora, Aline, Cristo e Cristiane. Parabéns pelo trabalho que realizam em Picinguaba e Caraguatatuba!

Aos professores da escola municipal de Ubatuba "José Belarmino Sobrinho", à Professora Fátima e ao Professor Juscelino, por terem aberto as portas da escola e pelo apoio fundamental para a realização do curso.

À Carla Beatriz do Instituto Argonauta por ter possibilitado o preenchimento dos questionários pelos funcionários do Instituto que é referência na conservação dos ambientes marinhos do litoral norte. 
Agradeço também a todos aqueles que colaboraram com meu trabalho, seja respondendo pesquisas, dividindo suas histórias em entrevistas e participando de cursos.

Aos amigos que não medem esforços para me auxiliar no meio acadêmico e na vida, Thaís Aparecida Silva, Vinicius Archanjo Ferraz e Vanessa Mucivuna.

Ao Instituto de Geociências da Universidade de São Paulo, e aos seus Professores, especialmente aqueles que pude participar de disciplinas. Agradeço também aos funcionários do IGc-USP pela atenção às necessidades que tive durante o mestrado e aos integrantes do NAP GeoHereditas.

Ao Conselho Nacional de Desenvolvimento Científico e Tecnológico, pela concessão de bolsa de mestrado.

Aos professores da Universidade Federal de Alfenas - MG e aos professores da Universidade do Minho, especialmente o Prof. Dr. José Brilha. Agradeço também ao pessoal do Geoparque Arouca e à Daniela Rocha.

À minha tia Dona Antônia e todos seus filhos e netos, por terem proporcionado momentos em família na minha estadia em São Paulo, agradeço também ao meu tio Tim (Benedito) in memoriam.

Ao Enzo, por segurar minhas mãos em todos os momentos, e à sua família, pelas palavras de apoio.

Aos laços de amizade estabelecidos durante esse período de mestrado no IGc USP, que foram essenciais para passar um período mais leve e repleto de conversas significativas, agradeço ao pessoal da sala B7 (Daniel, Natasha, John e Vinicius), aos amigos do Patrimônio, Alexandra, Fernanda, Karlla, Fabíola, Débora, Alexander, Carlos e à Patrícia pela preparação do abstract. Aos amigos do IGc, especialmente Mariana, Astrid, Maria Isabel e Caio. Não poderia deixar de manifestar meus agradecimentos às queridas amigas dos tempos em Alfenas, Cínthia, Tati, Rosana e Josiane e tantos outros que pude conviver nesse período.

À todos vocês, meu mais sincero muito obrigada! 
Mas, quando falo dessas pequenas felicidades certas, que estão diante de cada janela, uns dizem que essas coisas não existem, outros que só existem diante das minhas janelas, e outros, finalmente, que é preciso aprender a olhar, para poder vê-las assim. A arte de ser feliz - Cecília Meireles 


\section{RESUMO}

MAZZUCATO, Eliana. Estratégias de Geoconservação no Parque Estadual da Serra do Mar - núcleos Picinguaba e Caraguatatuba (SP). 2017. 320p. Dissertação (Mestrado em Ciências). Instituto de Geociências, Universidade de São Paulo, São Paulo, 2017.

A perspectiva socioambiental em Unidades de Conservação (UCs) tem fortalecido uma relação propositiva entre essas áreas e as populações, principalmente as que vivem em seu entorno. Tendo em vista que as UCs também visam à conservação do meio físico, é necessário que os aspectos da geodiversidade sejam protegidos tanto quanto os da biodiversidade. A geoconservação nessas UCs deve levar em conta os pressupostos da conservação da geodiversidade e a relação com as populações do entorno, de modo a utilizarse das diretrizes de sensibilização através da Educação Ambiental que vise o conhecimento e a participação social. Consolida-se assim uma estratégia significativa desde a definição até a implantação e monitoramento da geoconservação. O objetivo desta pesquisa foi definir estratégias de geoconservação pautadas em metodologias participativas nos núcleos Picinguaba e Caraguatatuba do Parque Estadual da Serra do Mar, a noroeste do estado de São Paulo. Diante das características singulares da área, avaliadas através do inventário e quantificação do patrimônio geológico, a presente pesquisa integrou a abordagem das geociências com a pesquisa social, lançando olhar sobre as percepções e dinâmicas socioambientais locais para constituir a etapa de valorização e divulgação das estratégias de geoconservação. Para atingir os objetivos propostos foram realizados os seguintes procedimentos: revisão bibliográfica, trabalhos de campo, questionários, entrevistas semiestruturadas e cursos relacionados à área das geociências e da geoconservação. A coleta de dados em campo envolveu 20 entrevistas com os moradores locais (tradicionais - caiçaras e quilombolas, e não tradicionais) e gestores dos núcleos; além disso, foram aplicados 70 questionários com os monitores ambientais e guias de turismo, professores de uma escola municipal de Ubatuba e, funcionários de uma ONG de atuação regional. O curso "Estratégias de Geoconservação no Parque Estadual da Serra do Mar" foi realizado em três módulos, no núcleo Picinguaba, no núcleo Caraguatatuba e em uma escola municipal de Ubatuba. Ao longo do curso de difusão foram utilizadas metodologias participativas sob a perspectiva da Aprendizagem Social (World Café e Mapeamento Socioambiental), buscando valorizar e divulgar a geodiversidade e o patrimônio geológico da área de estudo. Os resultados 
integraram o olhar dos atores locais através do diagnóstico socioambiental. As peculiaridades da relação dos habitantes com o lugar revelaram a atribuição de valores e sentidos para a paisagem e as interações socioculturais. Além disso, observou-se processos conflituosos e conciliatórios com a questão da UC, considerando também os conflitos e ameaças socioambientais inerentes a esse lugar. A análise da percepção geoambiental desses atores contribuiu com o entendimento dos valores atribuídos aos elementos da geodiversidade local. Dessa forma, apesar de não ter sido identificado a compreensão dos conceitos de geodiversidade e patrimônio geológico pelos atores envolvidos, ficou evidente a relação e o reconhecimento dos elementos da geodiversidade do lugar. Assim, através da abordagem dada pelo curso, houve a valorização e divulgação da geodiversidade e do patrimônio geológico, favorecendo a elaboração de estratégias de geoconservação através das metodologias participativas desenvolvidas durante o curso.

Palavras-chave: Geoconservação, Metodologias Participativas, Diagnósticos Socioambiental, Percepção Geoambiental, Aprendizagem Social. 


\begin{abstract}
MAZZUCATO, Eliana. Strategies of geoconservation in the Serra do Mar State Park Centers Picinguaba and Caraguatatuba (SP). 2017. 320p. Dissertation (Master in Science). Instituto f Geosciences, University of São Paulo, São Paulo, 2017.
\end{abstract}

The socioenvironmental perspective in Environmental Protection Areas (EPAs) has strengthened collaborative relationships between these areas and the populations, especially those living in their vicinities. Since EPAs also aim at the conservation of the physical environment, it is necessary to protect the geodiversity aspects as well as those of the biodiversity. Geoconservation actions in the EPAs must take into account the assumptions concerning geodiversity conservation and the relationship with the surrounding populations, in order to use the awareness guidelines through Environmental Education aiming at knowledge and social participation. This consolidates a significant strategy, from the definition to the implementation and monitoring of geoconservation. The aim of this research was to define geoconservation strategies based on participative methodologies, in Picinguaba and Caraguatatuba Centers of the Serra do Mar State Park, northwest of the State of São Paulo. Taking into account the unique characteristics of the area, assessed through the inventory and quantification of the geological heritage, the present research integrates geosciences approach with social research, considering local socioenvironmental perceptions and dynamics, aiming to constitute the step of valorization and dissemination of the geoconservation strategies. To achieve the proposed objectives, the following procedures were carried out: literature review, fieldwork, questionnaires, semi-structured interviews and courses related to geosciences and geoconservation. Data collection in the field involved 20 interviews with local residents (traditional - caiçaras and quilombolas, and non-traditional) and managers of the centers; in addition, 70 questionnaires were applied to environmental education instructors and tourist guides, teachers of a municipal school in Ubatuba and employees of a regional NGO. The course "Strategies of Geoconservation in the Serra do Mar State Park" was carried out in three modules, in the Picinguaba Center, in the Caraguatatuba Center and in a municipal school in Ubatuba. Throughout the dissemination course, participative methodologies were applied from the perspective of Social Learning (World Café and Socioenvironmental Mapping), seeking to value and disseminate the geodiversity and the geological heritage of the study area. The results integrated the view of local actors 
through socioenvironmental diagnosis. The peculiarities of the relationship between the inhabitants and the locality revealed the attribution of values and senses to the landscape, and the socio-cultural interactions. In addition, there were conflicting and conciliatory processes concerning the EPA, also considering the socioenvironmental conflicts and threats inherent to this place. The analysis of the geoenvironmental perception of these actors contributed to the understanding of the values attributed to the elements of the local geodiversity. Thus, although the understanding of the concepts of geodiversity and geological heritage by the involved actors was not identified, the relationship with and the recognition of the local geodiversity elements became evident. Hence, through the approach addressed in the course, valorization and dissemination of the geodiversity and the geological heritage were reached, favoring the elaboration of geoconservation strategies through the participative methodologies developed during the course.

Keywords: Geoconservation, Participative Methodologies, Socioenvironmental Diagnosis, Geoenvironmental Perception, Social Learning. 


\section{LISTA DE FIGURAS}

Figura 1 - Mapa de localização do litoral norte de São Paulo com destaque para os núcleos Picinguaba e Caraguatatuba do Parque Estadual da Serra do Mar 31

Figura 2 - Esquema ilustrativo do escopo da Geoconservação no contexto da Conservação da

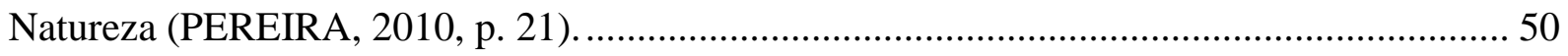

Figura 3 - Esquema teórico do processo perceptivo (DEL RIO, 1996, p. 3)......................... 57

Figura 4 - A relação da Geoconservação com o Ensino/Aprendizagem da Geologia (BRILHA, DIAS \& PEREIRA, 2006, p. 446).

Figura 5 - Províncias Estruturais do Brasil (BIZZI et al., 2003, adaptado de ALMEIDA, 1981). 66

Figura 6 - O Megacontinente Gondwana (HASUI, 2010, p. 145, modificado de WITT et al., 1999).

Figura 7 - O Sistema Orogênico do Tocantins e o Sistema Orogênico da Mantiqueira (HASUI, 2010, p. 142).

Figura 8 - Sistemas Transcorrentes Campo do Meio e Paraíba do Sul (HASUI, 2010, p. 154).

Figura 9 - Compartimentação tectônica da Faixa Ribeira entre a borda do Cráton do São Francisco e o litoral fluminense. 1 - Embasamento Paleoproterozoico; 2 - Cobertura metassedimentar pós $1,8 \mathrm{Ga} ; 3$ - Sequências metassedimentares à volta do arco magmático; ITV - Grupo Italva; BJ - Grupo Bom Jesus do Itabapoana; SF - Grupo São Fidélis; 4 Complexo Rio Negro, ortognaisses do Arco Magmático; 5 - Leucognaisses graníticos da Suíte Cordeiro; 6 - Gnaisses metaluminosos da Suíte Serra dos Órgãos; 7 - Granitos da Suíte Nova Friburgo (TUPINAMBÁ, TEIXEIRA \& HEILBRON, 2012, p. 143). 70

Figura 10 - Mapa geológico regional contemplando a área de estudo (Adaptado de CPRM, 2005 e PERROTA et al., 2005). 73

Figura 11 - Esquema da origem e recuo erosivo da Serra do Mar entre a Bacia do Paraná, no continente, e a Bacia de Santos, a sudeste. 1 - Soerguimento Senoniano erodido, causando deposição nas bacias de Santos e do Paraná. 2 - Desenvolvimento da superfície de aplainamento Japi no final do Senoniano. 3 - Deformação da Superfície Japi no Paleoceno. 4 - Recuo erosivo da Serra do Mar para a posição atual. A - Vulcanismo Alcalino; F - Falha de Santos; SM - Serra do Mar; P - plataforma continental na costa; DP - Depressão Periférica; $\mathrm{R}$ - Recuo erosivo da Serra do Mar (ALMEIDA \& CARNEIRO, 1998). 75 
Figura 12 - Modelo de evolução da denudação do Planalto da Bocaina. 1 - PermianoJurássico: anterior a fragmentação do continente; 2 - Cretáceo Inferior: ruptura continental e abertura do oceano Atlântico Sul, que foi precedida pela formação de fluxos de basalto toleítico e enxames de diques; 3 - Cretáceo Superior: magmatismo alcalino intenso; 4 Paleogeno: Gênese do rift continental do Sudeste do Brasil e magmatismo alcalino associado; 5 - Pleistoceno Superior/Holoceno - Presente: Reativação tectônica e soerguimento final da Serra do Mar e da Serra da Mantiqueira (Modificado de HIRUMA et al., 2010, p. 684)........76 Figura 13 - Mapa Geomorfológico regional contemplando a área de estudo. (Dados: DataGEO, 2017).

Figura 14 - Mapa de localização do Núcleo Picinguaba do Parque Estadual Serra do Mar. (Dados: DataGEO). 92

Figura 15 - Mapa de localização do Núcleo Caraguatatuba do Parque Estadual da Serra do Mar. (Dados: DataGEO). 95

Figura 16 - Imagens dos diálogos estabelecidos com os moradores locais da região (Fotos: A) Eliana Mazzucato, B) Denise de La Corte Bacci, C) Vânia Maria Nunes dos Santos). 127

Figura 17 - Imagens das comunidades tradicionais dos sertões de Ubatuba inseridas na ZHCAn. A) casa de pau a pique e via sem asfalto do Remanescente de Quilombolas do Cambury - Jambeiro; B) ponte de pedestres sobre o rio do Cedro no Cambury - Jambeiro; C) igreja de São Pedro na entrada do Sertão da Fazenda; D) casa de pau a pique no Sertão da Fazenda; E) Escola Municipal no Sertão do Ubatumirim com vista para rua asfaltada; F) estrada de acesso ao Sertão do Ubatumirim (Fotos: Eliana Mazzucato). 128

Figura 18 - Imagens das comunidades tradicionais nas praias de Ubatuba inseridas na ZHCAn, observando o avanço de comércios e serviços ao turismo nessas áreas. A e B) comércio e serviços disponíveis na praia do Cambury; C) e D) aspectos gerais da Vila Picinguaba (Fotos: A, B e D Eliana Mazzucato; C) guiadolitoral.uol.br).

Figura 19 - Desenvolvimento do curso "Estratégias de geoconservação no Parque Estadual da Serra do Mar”. A) realização do curso no núcleo Caraguatatuba; B) realização do curso no núcleo Picinguaba; C) e D) curso com os professores na escola da Rede Municipal de Ensino de Ubatuba - turma manhã e turma da tarde (Fotos: Eliana Mazzucato).

Figura 20 - Imagem de um grupo de visitantes na Casa da Farinha (Sertão da Fazenda) em interação com o líder comunitário e morador antigo da região (Senhor Zé Pedro) (Foto: Eliana Mazzucato). 146 
Figura 21 - A) Cozinha comunitária do projeto Juçara no Sertão do Ubatumirim, Ubatuba (SP); B) Maquinário para preparação polpa do juçara; C) câmaras frias da cozinha; D) Fruto do Juçara; E) Polpa do Juçara; F) interior da câmara fria, que armazena produtos diversos, como juçara, mandioca e cambuci; G) Fruto do Cambuci (Fotos: Eliana Mazzucato). ........ 148

Figura 22 - Imagem do fruto do Cambuci que também é um produzido de forma sustentável no Sertão do Ubatumirim (Foto: Eliana Mazzucato). 149

Figura 23 - Local onde é realizada a festa do Juçara em Ubatumirim (Foto: Eliana Mazzucato) 150

Figura 24 - Posto de coleta de lixo em más condições e sobrecarregado na entrada da Vila de Picinguaba, Ubatuba (SP) (Fotos: Eliana Mazzucato). 156

Figura 25 - Obras de duplicação da Rodovia Tamoios no entorno de Caraguatatuba (Fotos: Eliana Mazzucato). 158

Figura 26 - Casa da Farinha no Sertão da Fazenda. A) engenho de álcool e açúcar do século XVIII; B) roda d'água e outras ferramentas do engenho, com destaque para o poster com a figura do Seu Zé Pedro, líder comunitário e morador antigo que recebe grupos para rodas de conversa; C) sistema de canalização do rio Fazenda; D) pequena barragem par a canalização da água do rio Fazenda; D) vista do rio Fazenda à juzante da barragem (Fotos: Eliana Mazzucato).

Figura 27 - Hortas nos quintais das residências do Sertão da Fazenda, cultivando algumas hortaliças, mandioca, frutas, além de apresentar criação de galinha (Fotos: Eliana Mazzucato).

Figura 28 - Imagens de canoas utilizadas na região, construídas a partir de técnicas tradicionais de um tronco só, e outras canoas e embarcações modernas. A) representação casa de pau a pique e canoa caiçara no centro de visitantes do Parque Estadual Serra do Mar, núcleo Picinguaba; B) canoas caiçaras tradicionais e embarcações modernas na praia do Cambury. C) detalhe da canoa apresentada no centro de visitantes do núcleo Picinguaba (Fotos: Eliana Mazzucato). 166

Figura 29 - Modelo esquemático do cerco flutuante. Detalhe para as indicações do "costão rochoso", local onde geralmente é armado o cerco; a "espia", formada por uma malha que barra a passagem dos peixes e os orienta para entrarem na estrutura através da "boca"; a "casa" se assenta no fundo por âncoras e é sustentada por flutuantes, como boias ou canos de PVC, tem a função de armazenar os peixes; o "ensacador", na lateral da casa, possui malhas 
finas e mais resistentes para sustentar o peso durante a despesca" (VIEIRA et al. 1945 apud BLANK et al., 2009).

Figura 30 - Detalhe das boias flutuantes da rede de cerco flutuante próximo ao costão rochoso da Praia do Cambury, Ubatuba (SP) (Foto: Eliana Mazzucato).

Figura 31 - A) casa tradicional de pau a pique no Sertão da Fazenda; B) casa tradicional de pau a pique no Cambury; C) relevo acidentado no Cambury, e utilização blocos rochosos para assentamento do terreno; D) construção de escadas de acesso no afloramento (Fotos: Eliana Mazzucato). 168

Figura 32 - A) loja de artesanato tradicional no Sertão da Fazenda; B) artesanato tradicional do Sertão da Fazenda (Fotos: Denise de La Corte Bacci). 168

Figura 33 - Elementos da geodiversidade presentes na arquitetura de monumentos históricos em Ubatuba (SP). A) Casarão do Porto, apresentado rochas nos batentes das portas; B) placa em frente ao Casarão do Porto, em comemoração aos 20 anos da Fundart (1987 - 2007); C) detalhe da constituição da placa de "Granito Verde Ubatuba"; D) Igreja exaltação de Santa Cruz em Ubatuba; E) detalhe das portas revestidas de rochas G) detalhe da gnaisse no batente da porta (Fotos: Eliana Mazzucato).

Figura 34 - Formas de relevo destacadas na Serra do Mar em Ubatuba. A) Morro do Cuscuzeiro (Foto: Maria da Gloria Motta Garcia; B) Morro do Corcovado (Foto: Eliana Mazzucato). 178

Figura 35 - Trabalho de campo do curso "Estratégias de Geoconservação no PESM" no núcleo Picinguaba. A) preparação do trabalho de campo utilizando os painéis interpretativos; B) participantes do curso; C) trecho do percurso na praia da Fazenda, com detalhe para as marcas de ondulações na areia, e a paisagem das escarpas da Serra do Mar; D) explanação sobre as fraturas observadas no costão rochoso a noroeste da praia da Fazenda; E) abordagem sobre a dinâmica fluvial e o transporte de blocos rochosos; $\mathrm{F}$ e $\mathrm{H}$ ) explanação sobre a colocação dos diques máficos na região; G) grupo durante atividade no Saco das Taquaras (Praia das Conchas) (Fotos: Eliana Mazzucato). 218

Figura 36 - Trabalho de campo do curso "Estratégias de Geoconservação no PESM" no núcleo Caraguatatuba. A) fotos da "Catástrofe de 1967" no centro de visitantes do núcleo Caraguatatuba; B) explanação utilizando o painel interpretativo; C) minerais de mica observados nos afloramentos ao longo da trilha; D) explanação da relação geodiversidade e biodiversidade; E) análise dos diferentes tipos de rochas e estágios de alteração; F) explanação sobre a "Catástrofe de 1967" através dos blocos rochosos transportados pelo rio 
Santo Antônio; G) detalhe veios de quartzo presentes no leito rochoso do rio; H) blocos heterogêneos no rio Santo Antônio; I) grupo de participantes (Fotos: Eliana Mazzucato). .. 219 Figura 37 - Gruta que Chora na praia da Sununga, Ubatuba (SP). A) entrada da Gruta que Chora (Foto: Fernanda Reverte); B) interior da gruta que chora, com destaque para o fenômeno de gotejamento e das fraturas presentes na gruta (Foto: Vanessa Costa Mucivuna).

Figura 38 - Atividade valores/ameaças/estratégias de geoconservação para o geossítio "Gruta que Chora" realizada no núcleo Caraguatatuba. 223

Figura 39 - Geossíto "Piscina Natural" localizado na trilha do Jequitibá, do núcleo Caraguatatuba do PESM. A) rio Santo Antônio, B) detalhe dos veios de quartzo no leito rochoso do rio Santo Antônio; C) detalhe blocos heterogêneos no leito do rio Santo Antônio (Fotos: Eliana Mazzucato). 225

Figura 40 - Atividade valores/ameaças/estratégias de geoconservação para o geossítio "Piscina Natural" realizada no núcleo Caraguatatuba (Foto: Eliana Mazzucato). 226

Figura 41 - Atividade valores/ameaças/estratégias realizada pelo grupo 3 em Picinguaba (Ubatuba - SP) para o geossítio "Gruta que Chora".

Figura 42 - Geossítio "Gruta do Pirata" identificado pelos participantes do curso, localizado próximo à Praia das Sete Fontes (Ubatuba - SP). A) vista lateral do local conhecido como "Gruta do Pirata"; B) vista de cima da "Gruta do Pirata", com destaque para o conjunto de fraturas C) entrada da gruta do Pirata com destaque para o dique (Fotos: Roberto Peres). .. 229 Figura 43 - Atividade valores, ameaças e estratégias do grupo 4 em Picinguaba (Ubatuba SP) para o geossítio "Gruta do Pirata". 229

Figura 44 - Atividade valores, ameaças e estratégias do grupo 5 em Picinguaba (Ubatuba SP) considerando os geossítio "Cachoeira do Véu de Noiva (Ruínas da Lagoinha)", "Costão Rochoso da Praia Brava de Itamambuca", "Pico do Caxambú". 231

Figura 45 - Geossítios identificados pelos participantes do curso. A) Cachoeira Véu de Noiva (Foto: http://curiosidadesdeubatuba.com.br/cachoeira-veu-da-noiva/); B) Pico do Caxambu (Fonte: ITESP, 2007); C) Ruínas da Lagoinha (Foto: Vanessa Costa Mucivuna); D) Costão Rochoso Praia Brava de Itamambuca (Fonte: https://www.vivaubatuba.com.br/praias/praiabrava-de-itamambuca/)

Figura 46 - Respostas da Questão 1 do World Café: Há necessidade de Geoconservação na região? Por quê? Se sim, o que precisa ser feito? .235 
Figura 47 - Respostas da Questão 2 do World Café: O plano de manejo abrange a geodiversidade? O que você incluiria ou acrescentaria ao plano de manejo?

Figura 48 - Respostas da Questão 3 do World Café: Quais caminhos devem ser seguidos para a Geoconservação nos programas de Educação Ambiental e Educação Patrimonial? ... 240 Figura 49 - Respostas da Questão 4 do World Café: Quais locais podem ser considerados importantes para a Geoconservação? Por quê? Como valorizá-los? 242

Figura 50 - Trabalho de campo realizado durante o Mapeamento Socioambiental no bairro do Puruba, Ubatuba (SP). A) utilização do roteiro geointerpretativo para a localização dos aspectos observados na foz do Quiriri-Puruba; B) explanação no costão rochoso da praia do Puruba; C) realização do mapeamento na praia do Puruba; D) observação da biodiversidade na via principal do bairro do Puruba. (Fotos: Eliana Mazzucato). 245

Figura 51 - Mapa Socioambiental Síntese elaborado pelos participantes do curso "Estratégias de Geoconservação no PESM" na escola do Puruba. A legenda é composta pelos elementos percebidos visualmente, sendo identificados da esquerda para a direita como: toca do amor, árvore raiz exposta, árvore raiz interna, lixeira, capela, trilha, camping, canoas, mangue, restinga - jundú, foz, costão rochoso, igreja evangélica, campo de futebol, bar, cheiro de mangue. Os adesivos coloridos representam uma escala de qualidade do lugar compondo um índice de criticidade: a cor verde se refere aos aspectos positivos, representando no mapa a vegetação preservada; o amarelo os conflitos de escala intermediaria, representando o assoreamento, o abastecimento de água da escola e os conflitos do bairro; o vermelho corresponde ao conflito de maior criticidade, apresentando o problema da coleta de lixo, e o risco de atropelamento dos alunos no ponto de ônibus da rodovia. 246

Figura 52 - Imagens referentes aos tipos de vegetação encontrados durante o Mapeamento Socioambiental no bairro do Puruba. A) vegetação mais densa presente na área de planície; B) vegetação menos densa na planície próxima à praia; C) mangue na foz do rio Quiriri; D) ecossistema de costão rochoso; E) Jundu na praia do Puruba; F) vegetação de restinga na praia do Puruba (Fotos: Eliana Mazzucato) 248

Figura 53 - Imagens da dinâmica erosiva nas encostas da Serra do Mar e na praia do Puruba observadas no Mapeamento Socioambiental. A) detalhe das ocupações da Serra do Mar e marcas de escorregamentos; B) presença de patamares na praia, indicativo de processos de deposição e erosão costeira; C) detalhe da textura da areia presente na praia do Puruba (Fotos: Eliana Mazzucato) 
Figura 54 - Imagens referentes ao local de deposição de resíduos observados no Mapeamento Socioambiental (Fotos: Eliana Mazzucato)

Figura 55 - Imagens dos aspectos observados no Mapeamento Socioambiental relativos à hidrografia. A) percurso do rio Puruba; B) trecho mais à jusante do rio Puruba; B) percurso do rio Quiriri, próximo à área de mangue; C) Foz dos rios Quiriri e Puruba em período de maré baixa; D) Praia do Puruba (Foto: Eliana Mazzucato). 250

Figura 56 - Imagens dos aspectos habitacionais do Puruba observados no Mapeamento Socioambiental. A) Capela Santa Cruz; B) cruz localizada em frente à capela; C) residências da primeira parte do bairro, próximas à capela da igreja católica; D) área de camping; E) Igreja Pentecostal; F, G e H) aspectos das vias e residências da segunda parte do bairro, próximos à Igreja Pentecostal (Fotos: Eliana Mazzucato). 251

Figura 57 - Imagens dos aspectos habitacionais do Puruba observados no Mapeamento Socioambiental. A, C e D) bares e restaurantes próximos à praia do Puruba; B) campo de futebol; E) acesso pela foz dos rios Quiriri-Puruba para a praia do Puruba; F) via de acesso do bairro e linha de ônibus municipal (Foto: Eliana Mazzucato). 252

Figura 58 - Aspectos conflituosos e relações estabelecidas no bairro do Puruba no Mapeamento Socioambiental. A) placa instalada pela Sociedade de Amigos da Praia do Puruba (Saprapu) sobre os cuidados que devem ser tomados no bairro, como a proibição de levar animais de estimação à praia, a proibição de som alto, o limite de velocidade $(20 \mathrm{~km} / \mathrm{h})$, a proibição de acampar na praia, e, a proibição de ascender fogueira, chamando atenção também para as leis contra a perturbação do sossego e perturbação da tranquilidade. B) placa da Saprapu chamando a atenção para a presença de crianças na região, reforçando o limite de velocidade para $20 \mathrm{~km} / \mathrm{h}$; C e D) placas de não estacione, contendo também faixa delimitando a área; E) via de terra, com ausência de calçada ou qualquer marcação de mão dupla; F) residência destoando da maioria com presença de grade (Foto: Eliana Mazzucato) 255 Figura 59 - Canoas utilizadas pelos moradores locais do bairro, demonstrando o uso de canoas caiçaras e outras canoas concomitantemente (Foto: Eliana Mazzucato). 256 Figura 60 - Aspectos relacionados ao turismo crescente da região. A) mensagens deixadas pelos moradores do bairro chamando a atenção para a conservação da natureza da região; B) casa de moradores do bairro contendo mensagem receptiva; c) painel informativo sobre a praia do Puruba (Fotos: Eliana Mazzucato). 256 


\section{LISTA DE TABELAS}

Tabela 1 - Relação dos núcleos administrativos do PESM em 2017 .................................... 87

Tabela 2 - Síntese dos procedimentos metodológicos da pesquisa. .................................... 101

Tabela 3 - Relação dos atores locais e os instrumentos de coleta de dados utilizados...........109

Tabela 4 - Questões realizadas na aplicação da metodologia do World Café durante o curso "Estratégias de Geoconservação no PEM” nos núcleos Picinguaba e Caraguatatuba

Tabela 5 - Perfil dos indivíduos que responderam ao questionário

Tabela 6 - Número de habitantes em Caraguatatuba e Ubatuba nos anos de 1970, 1980, 1996, 2000,2007 e 2010

Tabela 7 - Síntese das principais indicações dos grupos para a questão 14 e 15 . 206

Tabela 8 - Síntese dos resultados do diagnósticos socioambiental com base nos atores locais.

Tabela 9 - Síntese dos resultados das percepções geoambientais com base nos atores locais.

Tabela 10 - Síntese dos resultados das percepções geoambientais dos atores locais que participaram do curso "Estratégias de geoconservação no Parque Estadual da Serra do Mar".

Tabela 11 - Síntese dos resultados das estratégias de geoconservação elaboradas através de metodologias participativas durante o curso "Estratégias de Geoconservação no Parque Estadual da Serra do Mar" 263

Tabela 12 - Perfil moradores locais entrevistados 296

Tabela 13 - Perfil gestores entrevistados 296

Tabela 14 - Perfil participantes curso "Estratégias de geoconservação no Parque Estadual da Serra do Mar" núcleo Caraguatatuba e Picinguaba 297

Tabela 15 - Perfil participantes curso "Estratégias de geoconservação no Parque Estadual Serra do Mar" na Escola Municipal José Belarmino Sobrinho 299

Tabela 16 - Perfil dos funcionários da ONG - Instituto Argonauta ..... 300

Tabela 17 - Quais benefícios você considera que o Parque traz para a região? (Questão 5) 314

Tabela 18 - Quais elementos você destacaria como mair importantes na sua cidade? (Questão 3).

Tabela 19 - Quando você houve a palavra patrimônio, o que pensa? (Questão 8) 316 
Tabela 20 - A quais elementos naturais e construídos você associa a palavra Patrimônio? (Questão 9).

Tabela 21 - Quem você acha que é responsável pela proteção do patrimônio do Litoral Norte? (Questão 14) 318

Tabela 22 - Quem você acha que deveria estar envolvido na proteção do Patrimônio do Litoral Norte? (Questão 15) 319

Tabela 23 - Geodiversidade é: (Questão 10) 320 


\section{LISTA DE GRÁFICOS}

Gráfico 1 - Total de indicações na questão 5: Quais benefícios você considera que o Parque traz para a região?

Gráfico 2 - Porcentagem de indicações por grupo de atores sociais para a questão 5: Quais benefícios você considera que o Parque traz para a região?

Gráfico 3 - Total de indicações na questão 3: Quais elementos você destacaria como mais importantes na sua cidade?

Gráfico 4 - Porcentagem de indicações por grupo de atores sociais para a questão 3: Quais elementos você destacaria como mais importantes na sua cidade?.

Gráfico 5 - Total de indicações relativas à questão 8: Quando você ouve a palavra Patrimônio, o que pensa?.

Gráfico 6 - Porcentagem de indicações por grupo de atores sociais para a questão 8: Quando você ouve a palavra Patrimônio, o que pensa?

Gráfico 7 - Total de indicações relativas à questão 9: A quais elementos naturais e construídos você associa a palavra patrimônio?

Gráfico 8 - Porcentagem de indicações por grupo de atores sociais para a questão 9: A quais elementos naturais e construídos você associa a palavra patrimônio?

Gráfico 9 - Total de indicações relativas à questão 14: Quem você acha que é responsável peça proteção do 203

Gráfico 10 - Total de indicações relativas à questão 15: Quem você acha que deveria estar envolvido na proteção do patrimônio do Litoral Norte? 204

Gráfico 11 - Porcentagem de indicações por grupo de atores sociais para questão 14: Quem você acha que é responsável pela proteção do patrimônio do Litoral Norte. 205

Gráfico 12 - Porcentagem de indicações por grupo de atores sociais para questão 15: Quem você acha que deveria estar envolvido na proteção do patrimônio do Litoral Norte? 206 


\section{LISTA DE SIGLAS}

APA - Área de Proteção Ambiental

CONDEPHAAT - Conselho de Defesa do Patrimônio Histórico, Arqueológico, Artístico e Turístico do Estado de São Paulo

CoMGeo - SP - Estadual de Monumentos Geológicos

CMT - Conselho Municipal de Turismo de Ubatuba

COMTUR - Companhia Municipal de Turismo de Ubatuba

CPLA - Coordenadoria de Planejamento Ambiental

CPRM - Companhia de Pesquisas de Recursos Minerais

DD - Declaração de Digne

DIA - Departamento de Informações Ambientais

DRE - Diretoria Regional de Ensino

DRM-RJ - Departamento de Recursos Naturais do Rio de Janeiro

EI - Educação Infantil

EF - Ensino Fundamental

Fundart - Fundação de Arte e Cultura de Ubatuba

GGN - Global Geoparks Networks

IBDF - Instituto Brasileiro de Desenvolvimento Florestal

ICMbio - Instituto Chico Mendes de Conservação da Biodiversidade

IG - Instituto Geológico

IG - UNICAMP - Instituto de Geociências da Universidade Estadual de Campinas

IGc - USP - Instituto de Geociências da Universidade de São Paulo

INCRA - Instituto Nacional de Colonização e Reforma Agrária

IPHAN - Instituto do Patrimônio Histórico e Artístico Nacional

IPEA - Instituto de Pesquisa Econômica Avançada

ITESP - Fundação Instituto de Terras do Estado de São Paulo

IUCN - União Internacional para a Conservação da Natureza

IUGS - União Internacional de Ciências Geológicas

MINEROPAR - Serviço Geológico do Paraná

MMA - Ministério do Meio Ambiente

NAP GeoHereditas - Núcleo de Apoio à Pesquisa em Patrimônio Geológico e Geoturismo

NP - Núcleo Picinguaba 
NuCar - Núcleo Caraguatatuba

ONG - Organização Não Governamental

ONU - Organização das Nações Unidas

PEB I - Professor de Educação Básica II ( $1^{\mathrm{a}}$ a $4^{\mathrm{a}}$ série $/ 1^{\mathrm{o}}$ ao $5^{\circ}$ ano Ensino Fundamental)

PEB II - Professor de Educação Básica II ( $5^{\mathrm{a}}$ a $8^{\mathrm{a}}$ série $/ 6^{\circ}$ ao $9^{\circ}$ ano Ensino Fundamental)

PESM - Parque Estadual da Serra do Mar

PNAP - Plano Nacional de Áreas Protegidas

PROMATA - Associação de Preservação e Recuperação da Mata Atlântica

RCSB - Rift Continental do Sudeste do Brasil

SEADE - Fundação Sistema Estadual de Análise de Dados

SEMA - Secretaria Especial de Meio Ambiente

SEMA - Ubatuba - Secretaria Municipal de Meio Ambiente de Ubatuba

SMA - Secretaria de Estado do Meio Ambiente

Setur - Secretaria de Turismo de Ubatuba

SIGEP - Comissão Brasileira dos Sítios Geológicos e Paleontológicos

SME - Secretaria Municipal de Ensino

SNIS - Sistema Nacional de Informações sobre Saneamento

SNUC - Sistema Nacional de Unidades de Conservação

UBS - Unidade Básica de Saúde

UC - Unidade de Conservação

UNEP - United Nations Environment Programme

UNESCO - United Nations Educational, Scientific and Cultural Organization

ZEE - Zoneamento Econômico Ecológico

ZHCAn - Zona Histórico-Cultural Antropológica

ZOT - Zona de Ocupação Temporária

WWF - World Wildlife Fund

WCPA - Comissão Mundial de Áreas Protegidas 



\section{SUMÁRIO}

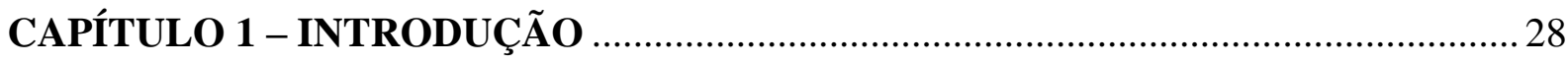

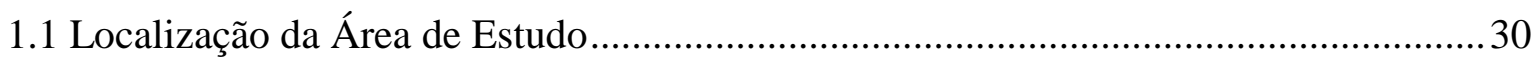

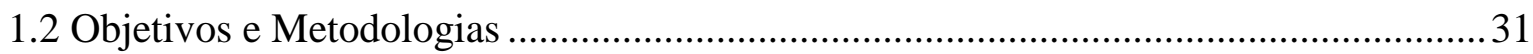

CAPÍTULO 2 - BREVE HISTÓRICO DA CONSERVAÇÃO DA NATUREZA E SUA

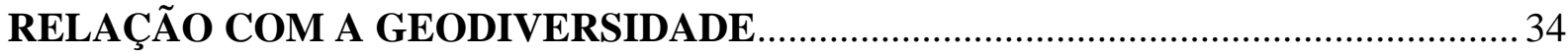

2.2 Conservação da Natureza e Áreas Protegidas............................................................... 36

2.3 Geoconservação em Unidades de Conservação........................................................... 42

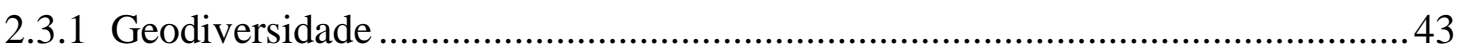

2.3.2 Patrimônio Geológico e Sítios de Geodiversidade .............................................46

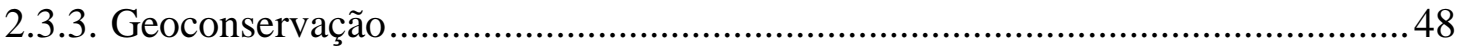

2.3.4 Iniciativas para a Geoconservação no Brasil ......................................................51

2.4 A Perspectiva Socioambiental e a Geoconservação .......................................................53

2.4.1 A Percepção Ambiental como contributo à Geoconservação .............................56

2.4.2 Geoconservação no âmbito das metodologias participativas ............................59

CAPÍTULO 3 - O AMBIENTE FÍSICO E HISTÓRICO-SOCIAL DOS NÚCLEOS

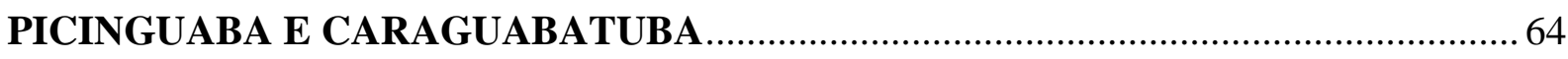

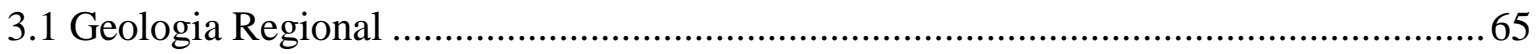

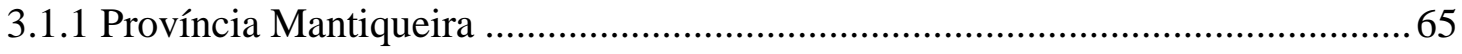

3.1.2 O Orógeno Ribeira e o Domínio Costeiro ..........................................................6 68

3.1.3 Reativação Mesozoica - Formação Rift Continental do Sudeste do Brasil ..........71

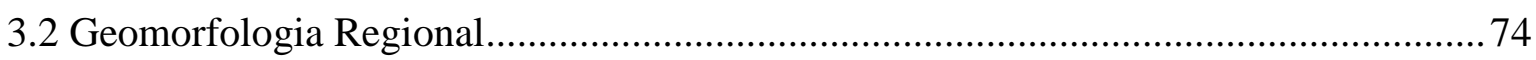

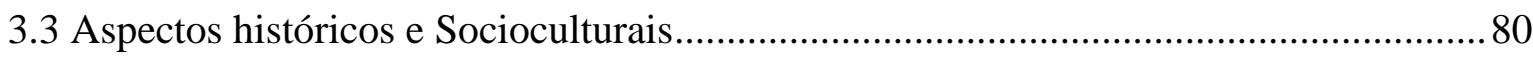

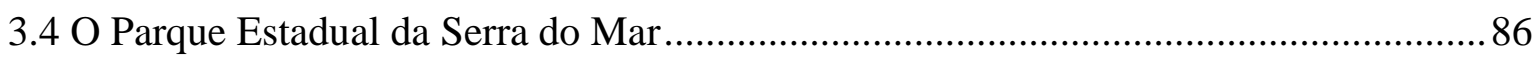

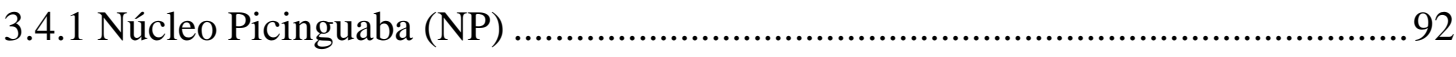

3.4.2 Núcleo Caraguatatuba (NuCar) .................................................................. 94

CAPÍTULO 4 - REFERENCIAL METODOLÓGICO .....................................................97

4.1 Etapas e Procedimentos da Pesquisa ................................................................... 100 
4.1.1 Diagnóstico prévio da área de estudo

4.1.2 Valorização e divulgação da geodiversidade e do patrimônio geológico com base na Aprendizagem Social.

4.1.3 Diagnóstico socioambiental e levantamento das percepções geoambientais.... 107

4.1.4 Elaboração participativa de estratégias de geoconservação .............................. 108

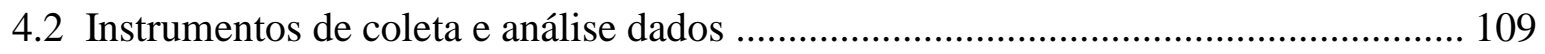

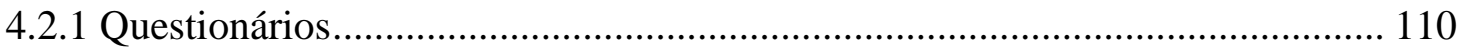

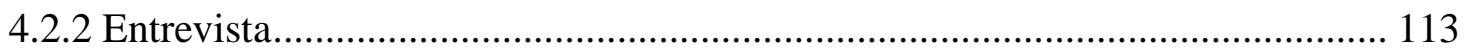

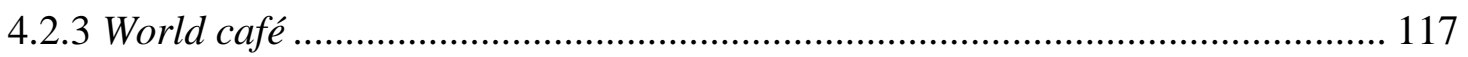

4.2.4 Mapeamento Socioambiental ................................................................. 120

CAPÍtUlO 5 - ESTRATÉgIAS PARA A GEOCONSERVAÇÃO NOS NÚCLEOS

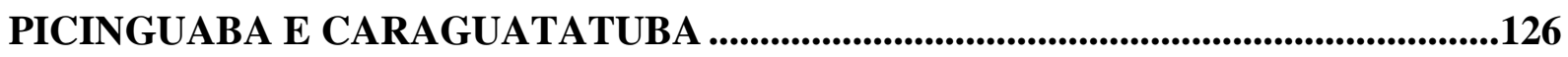

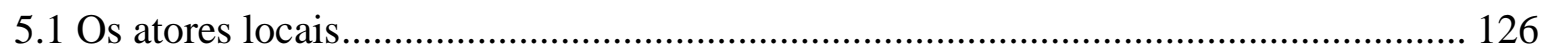

5. 2 Diagnóstico socioambiental a partir do olhar histórico dos atores locais .................. 133

5.2.1 A perspectiva dos moradores locais (tradicionais e não tradicionais) ............... 133

5.2.2 A perspectiva dos gestores dos núcleos Picinguaba e Caraguatatuba............... 152

5.2.3 A identificação dos conflitos socioambientais na perspectiva dos monitores, professores e funcionários de ONG …................................................................ 155

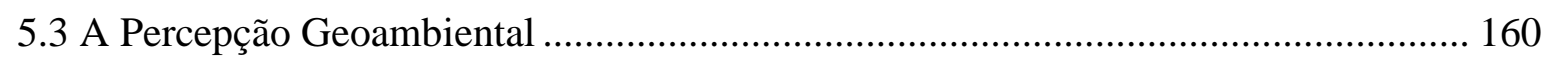

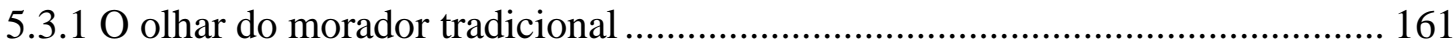

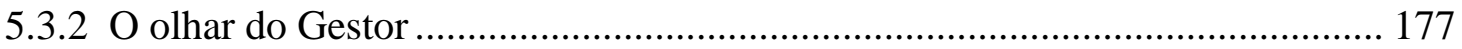

5.3.3 O olhar dos monitores, professores e funcionários da ONG ............................ 179

5.3.3.1 Conservação da natureza..................................................................... 179

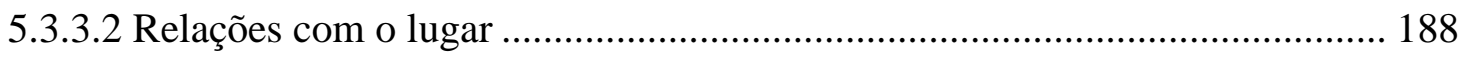

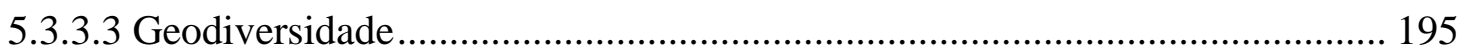

5.4 Ensino de Geociências e Estratégias de Geoconservação - Aprendizagem Social .... 214

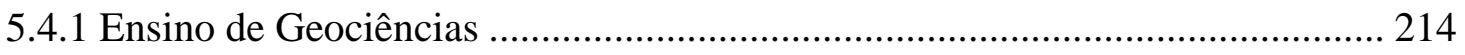

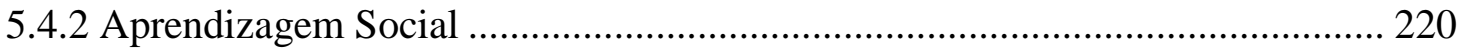


5.4.2.1 Metodologias participativas na elaboração de estratégias de geoconservação 220

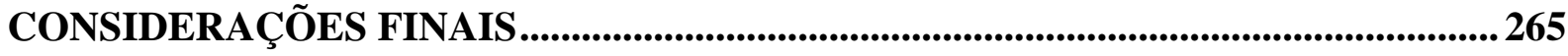

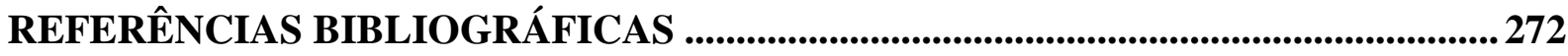

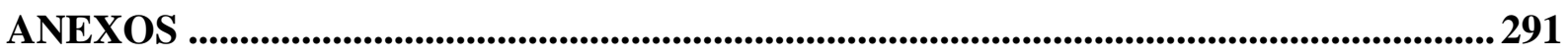

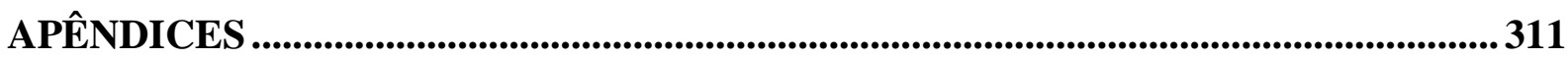




\section{CAPÍTULO 1 - INTRODUÇÃO}

A Geoconservação como área de pesquisa emerge da pouca valorização da natureza física e como ela é considerada nas ações de conservação da natureza. Dessa forma, segundo Brilha $(2005,2016)$ a Geoconservação orienta uma série de procedimentos que garantem a conservação da geodiversidade e do patrimônio geológico, sendo o primeiro deles o reconhecimento, estabelecido através do inventário do patrimônio geológico. A partir do inventário e de sua quantificação, podem ser elaborados instrumentos de gestão para a conservação da geodiversidade.

Essa pesquisa buscou trazer contribuições para esta área do conhecimento, apoiada na experiência investigativa realizada nos núcleos Picinguaba e Caraguatatuba do Parque Estadual da Serra do Mar (PESM), no Estado de São Paulo. Nesse sentido, foram tecidas relações entre as Geociências e a Pesquisa Social, a partir do diagnóstico socioambiental da área de estudo e do levantamento das percepções ambientais com ênfase na geodiversidade da área. As atividades formativas compuseram a valorização e divulgação do patrimônio geológico e promoveram a participação social como contributo à elaboração de estratégias de geoconservação da área de estudo.

A pesquisa constituiu-se como continuidade das propostas de Geoconservação desenvolvidas pelo Núcleo de Apoio à Pesquisa (NAP - GeoHereditas) que realizou inventário e quantificação do patrimônio geológico de Ubatuba (SANTOS, 2014) e Caraguatatuba (ARRUDA et al., 2015, 2017), bem como de suas ações de valorização e divulgação.

A pesquisa teve como base uma abordagem qualitativa, integrando a perspectiva socioambiental à Geoconservação, apoiada na compreensão do contexto socioambiental da área de estudo a partir das diversas perspectivas dos atores sociais locais, considerando ainda suas percepções quanto à geodiversidade. A pesquisa se orientou ainda em processos formativos a partir dos pressupostos da Aprendizagem Social e das metodologias participativas. Nesse sentido, as atividades formativas se sustentaram no entendimento e reconhecimento da geodiversidade e do patrimônio geológico pelos atores locais, bem como na relação com os problemas e conflitos socioambientais locais, possibilitando a articulação de ideias e concepções para refletir sobre estratégias de geoconservação.

A área de estudo insere-se nos núcleos Picinguaba e Caraguatatuba do Parque Estadual da Serra do Mar, Unidade de Conservação de Proteção Integral, no Estado de São 
Paulo. As relações de interdependência socioambientais são expressivas na região, que compreende principalmente os municípios de Ubatuba e Caraguatatuba no litoral norte.

Em relação ao meio biofísico possui uma paisagem de contrastes, entre o Planalto Atlântico, marcado pelas formações de escarpas da Serra do Mar e morros litorâneos, e as Planícies Litorâneas e Fluviais, com uma costa recortada e planícies restritas devido à proximidade da Serra do Mar (ROSS \& MOROZ, 2011). Soma-se a essa rica geodiversidade, a biodiversidade local, que preserva remanescentes da Mata Atlântica.

Vale ressaltar a relevância científica do local no contexto da história geológica, onde são encontrados registros da abertura do Oceano Atlântico e da evolução do Supercontinente Gondwana no Neoproterozoico, bem como os processos resultantes da reativação Mesozoica (GARCIA, 2012). Os valores científicos presentes nesses dois núcleos do PESM são referências para compreender a história geológica desse trecho do litoral paulista (SANTOS, 2014; ARRUDA et al., 2015, 2017).

No aspecto sociocultural, a região é marcada pelos períodos históricos relacionados aos ciclos econômicos do país e às políticas conservacionistas que influenciaram a dinâmica da região a partir da década de 70. Nessa perspectiva, o lugar remonta aos diversos modos de vida e culturas que se desenvolveram na paisagem do litoral norte, refletindo assim a riqueza cultural vivenciada na região com forte influência dos povos indígena, escravos africanos e colonizadores (portugueses majoritariamente), estabelecendo as comunidades tradicionais de caiçara e quilombolas.

Esses atributos socioambientais fazem da região um importante polo turístico, conjugando uma paisagem cênica e de natureza preservada, situada próxima às cidades de São Paulo, São José dos Campos e do Rio de Janeiro. Esse interesse turístico impõe também um processo de pressão sobre as comunidades tradicionais, alterando seus modos de vida, e, consequentemente interferindo na paisagem como um todo. Em contraste a essa realidade, a implementação da Unidade de Conservação de Proteção Integral (PESM) apresenta papel fundamental para a conservação da natureza local, o que tem apoiado a preservação de tradições e culturas dos povos denominados tradicionais e de estabelecimento anterior à criação do Parque Estadual.

Assim, observa-se que a geodiversidade e o patrimônio geológico local apresentam interesses científicos, didáticos e turísticos, com uma gama de possibilidades de abordagens de conteúdos geocientíficos. Além disso, as interações socioambientais favorecem a interdisciplinaridade nas abordagens das ciências humanas, da Terra e biológicas. No aspecto turístico, por constituir-se em polo que atrai os mais variados públicos, a região também é 
reconhecida pelo turismo ecológico e de aventura, promovido pelo PESM e por agências de turismo especializadas que atuam na Educação Ambiental e no turismo sustentável.

Diante tais fatores a presente pesquisa contribui com a implementação das estratégias de geoconservação na região, propondo trajetórias que incluam a formação e o envolvimento das comunidades locais para promover a geoconservação.

\subsection{Localização da Área de Estudo}

Os núcleos Picinguaba e Caraguatatuba do PESM estão localizados no litoral norte do Estado de São Paulo (Figura 1).

O núcleo Picinguaba (NP) localiza-se no extremo norte do PESM com total de 47.500 hectares de área, abrangendo 80\% do município de Ubatuba. Possui fronteira com o município de Paraty a norte, com Caraguatatuba a sul, e, com Cunha e São Luis do Paraitinga a oeste.

O núcleo Caraguatatuba (NuCar) também se encontra na seção norte do PESM, com 35.947 hectares. Corresponde a 78,27\% do município de Caraguatatuba, além de trechos de Paraibuna e Natividade da Serra. Limita-se a norte com o município de Ubatuba, e com São Sebastião, a sul, com São Luis do Paraitinga e Natividade da Serra, a oeste.

A população estimada do município de Ubatuba em 2016 foi de 87.364 habitantes em uma área de 723,883 km², e de 115.071 habitantes para o município de Caraguatatuba em uma área de 485,097 km² (IBGE, 2016). Ubatuba localiza-se a cerca de $235 \mathrm{~km}$ do município de São Paulo, e cerca de 320 km do município do Rio de Janeiro. Caraguatatuba encontra-se cerca de $171 \mathrm{~km}$ de distância da capital paulista. As principais vias de acesso para ambos municípios são a partir da BR - 101 (Rodovia Rio - Santos), a SP - 099 (Rodovia Tamoios) e através da SP - 125 (Rodovia Oswaldo Cruz). 


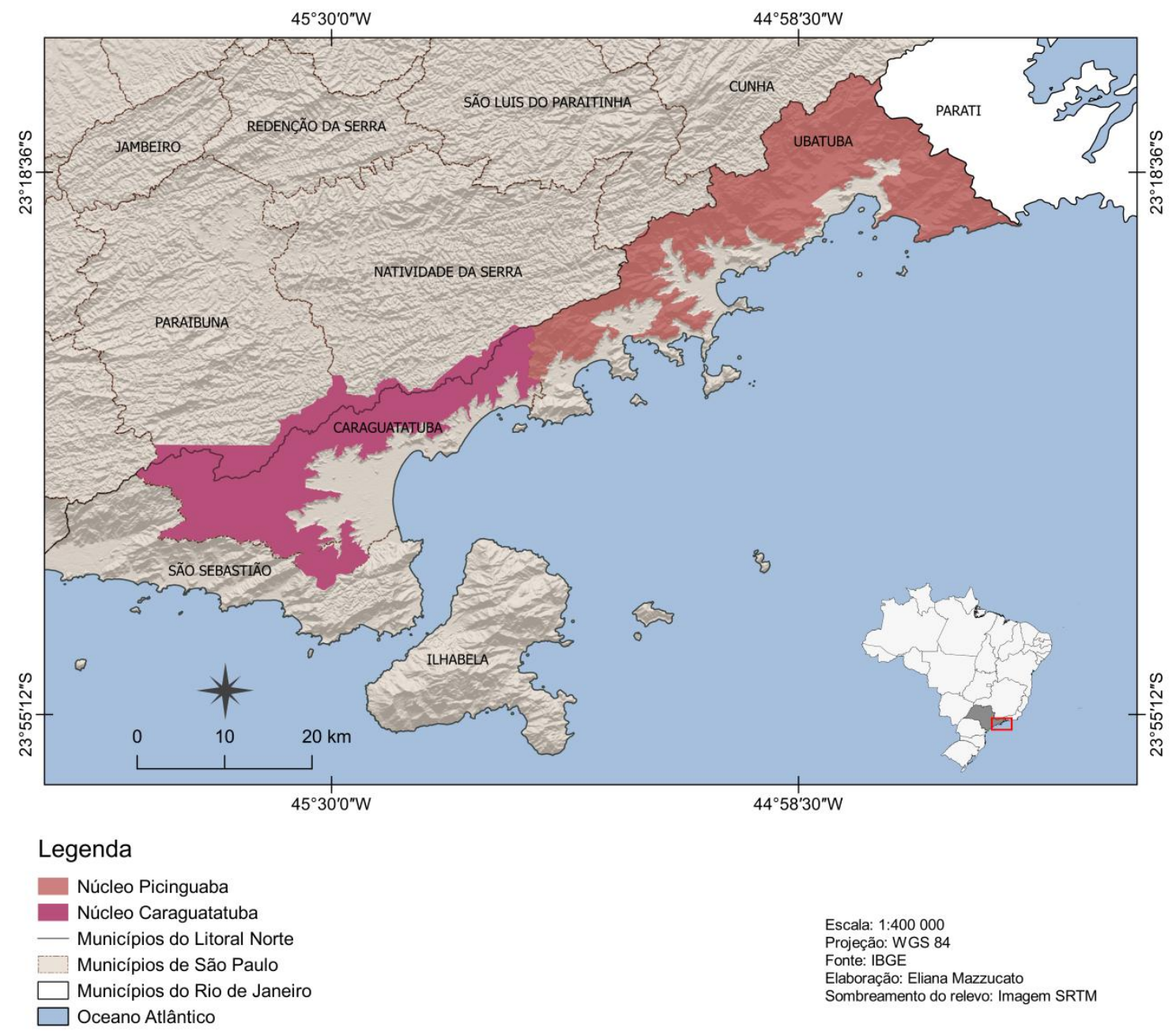

Figura 1 - Mapa de localização do litoral norte de São Paulo com destaque para os núcleos Picinguaba e Caraguatatuba do Parque Estadual da Serra do Mar

\subsection{Objetivos e Metodologias}

A pesquisa tem como objetivo principal desenvolver estratégias para a geoconservação no contexto das unidades de conservação, com o envolvimento e participação das comunidades locais e, promover a divulgação e valorização do patrimônio geológico em interação com o patrimônio natural e cultural.

Dessa forma, os objetivos específicos consistem em:

- Diagnosticar a dinâmica sociocultural nos núcleos Picinguaba e Caraguatatuba do PESM e seu entorno e identificar problemas e conflitos em relação à UC;

- Aplicar metodologias participativas na pesquisa e na divulgação das estratégias de geoconservação;

- Promover o ensino das Geociências a partir da valorização e divulgação do Patrimônio Geológico; 
- Fomentar a participação da população nas estratégias de geoconservação;

A presente pesquisa foi desenvolvida a partir dos seguintes eixos temáticos: análise prévia da área de estudo e estabelecimento de parcerias com atores locais; ações de valorização e divulgação do patrimônio geológico e da geodiversidade local; diagnóstico socioambiental e levantamento das percepções ambientais com ênfase na geodiversidade; e, elaboração participativa de estratégias de geoconservação.

As metodologias de pesquisa e os pressupostos teóricos adotados permitiram uma releitura da metodologia proposta por Brilha (2005) para as estratégias de geoconservação. Entrevistas, questionários e metodologias participativas foram utilizados no contexto da Aprendizagem Social para a coleta e análise quali e quantitativa dos dados. A perspectiva social foi introduzida como eixo norteador para a elaboração das estratégias de geoconservação, considerando os aspectos do lugar e a percepção dos atores sociais.

A estrutura da presente dissertação foi organizada em cinco capítulos.

Além deste capítulo introdutório, no qual são apresentados os aspectos gerais e a área da pesquisa, no segundo capítulo são abordadas as referências utilizadas na pesquisa, considerando as peculiaridades da área de estudo, além de um breve histórico sobre a concepção da conservação da natureza e estabelecimento das áreas protegidas no Brasil, essencialmente através do viés institucional e normativo. Nesse contexto, foram tecidas relações com a geodiversidade no processo de escolha e implementação das Unidades de Conservação. Apresenta-se na sequência os conceitos estruturantes da geoconservação, como geodiversidade e patrimônio geológico, a revisão das metodologias de geoconservação e de sua implantação no Brasil. Também estão inseridas as definições sobre a perspectiva socioambiental no contexto da conservação da natureza, salientando sua relevância para a geoconservação no âmbito da apreensão da percepção ambiental e das metodologias participativas.

No terceiro capítulo é apresentado de forma sucinta o contexto físico e histórico social da área de estudo, considerando inicialmente contextos regionais e posteriormente focalizando as áreas dos núcleos Picinguaba e Caraguatatuba. No caso da geologia, têm-se como base a delimitação das províncias estruturais do Brasil e sua localização na Província Mantiqueira e no Domínio Costeiro. Além disso, destaca-se o aspecto geomorfológico da região, marcado pelo contraste da Serra do Mar e da Planície Costeira. Na perspectiva do meio social, é realizada a apresentação dos aspectos históricos e socioculturais da área, seguindo-se para especificações dos núcleos. 
O quarto capítulo apresenta o referencial metodológico utilizado na pesquisa, a partir dos eixos norteadores que foram: diagnóstico prévio da área de estudo, valorização e divulgação da geodiversidade e do patrimônio geológico, diagnóstico socioambiental e levantamento das percepções ambientais com ênfase na geodiversidade (Percepção Geoambiental) e, elaboração participativa de estratégias de geoconservação. Dessa forma, a coleta e análise dos dados foram realizadas a partir de questionários, entrevistas semiestruturadas e metodologias participativas.

O quinto capítulo é composto pelos resultados alcançados na pesquisa. Nesse sentido são tecidas relações entre o olhar dos atores locais que compuseram o universo da pesquisa, sendo estes os moradores locais (tradicionais e não tradicionais), o poder público, monitores ambientais do parque, professores da rede pública e funcionários de uma Organização Não Governamental (ONG) sem fins lucrativos. Essas relações são estabelecidas a partir do diagnóstico socioambiental, da percepção geoambiental e da definição de estratégias de geoconservação de forma participativa.

Nas considerações finais retomam-se os objetivos da pesquisa tecendo-se reflexões e considerações sobre os resultados obtidos. 


\section{CAPÍTULO 2 - BREVE HISTÓRICO DA CONSERVAÇÃO DA NATUREZA E SUA RELAÇÃO COM A GEODIVERSIDADE}

Entender o processo de consolidação da Geoconservação no Brasil e no mundo prescinde de uma contextualização da evolução da conservação como área de pesquisa e suas implicações no campo político e na gestão do território, num panorama de intensas transformações socioambientais. A partir desses pressupostos, salientam-se as concepções de natureza ao longo desse histórico, que inicialmente centravam-se em um caráter naturalista e preservacionista, mas que incidem, num contexto mais recente, numa concepção socioambiental e integradora.

A perspectiva da conservação da natureza surgiu em oposição a um forte movimento de pressão sobre os recursos naturais que despertou certa preocupação em relação ao futuro do patrimônio natural, principalmente a partir da década de 1970. As pressões se enquadravam nas políticas desenvolvimentistas, no qual o progresso de um país estava associado ao crescimento urbano-industrial, sendo cruciais os investimento na exploração de recursos naturais, implementação da agropecuária extensiva, industrialização e outros fatores que desencadearam em problemas ambientais (DIEGUES, 2001; MEDEIROS, 2006).

Em meio a esse quadro, o movimento ambientalista surgia como contraponto para evidenciar os efeitos de longo prazo de tais projetos desenvolvimentistas, tanto para o meio ambiente, quanto para a sociedade. Dentre os primeiros encontros que surgiram nesta proposta, destacam-se o relatório de Founex na França em 1971 que reuniu especialistas preocupados com a dinâmica dos problemas ambientais e os altos índices de pobreza e subdesenvolvimento no contexto das políticas de desenvolvimento econômico. A Conferência de Estocolmo que ocorreu em 1972 obteve maior alcance entre os países desenvolvidos e em desenvolvimento, confrontando os padrões de crescimento econômico e suas consequências para o meio ambiente (SILVA, 2015).

Ainda a respeito do movimento ambientalista, Silva (2015) destaca que o Relatório Brundtland, elaborado entre 1983 a 1987, estimulou uma série de reflexões sobre estilos alternativos de desenvolvimento, culminando na incorporação do conceito de desenvolvimento sustentável durante a Conferência Internacional sobre o Meio Ambiente em 1992, conhecida também como Rio 92, que reuniu representantes da sociedade civil e do Estado. 
Portanto nesse caminho de contraposição ao modelo exploratório dominante, algumas estratégias foram se estabelecendo sob a perspectiva da conservação da natureza e inserindo-se no campo político-econômico.

Em relação ao conceito de conservação da natureza, destaca-se o papel da União Internacional para a Conservação da Natureza (IUCN), que compreende a conservação da natureza como a gestão do uso humano da biosfera, garantindo sua potencialidade em satisfazer as necessidades das gerações atuais e futuras. Prevê assim a necessidade da conservação, recuperação e melhoria do meio ambiente natural (IUCN, UNEP \& WWF, 1980). Portanto, já na década de 1980 há uma reflexão sobre a necessidade de gerir a atividade humana diante o meio ambiente natural, em uma perspectiva de conservar para as gerações atuais e futuras.

No Brasil, o Sistema Nacional de Unidades de Conservação define conservação da natureza como:

[...] o manejo do uso humano da natureza, compreendendo a preservação, a manutenção, a utilização sustentável, a restauração e a recuperação do ambiente natural, para que possa produzir o maior benefício, em bases sustentáveis, às atuais gerações, mantendo seu potencial de satisfazer as necessidades e aspirações das gerações futuras, e garantindo a sobrevivência dos seres vivos em geral (BRASIL, 2000).

A criação de áreas protegidas é reconhecida como estratégia no campo da conservação da natureza, considerando a possibilidade de garantir que locais que apresentem pouca alteração antrópica se mantenham preservados para o usufruto e bem estar das gerações atuais e futuras. Apesar dos conceitos de conservação e preservação serem utilizados muitas vezes como sinônimos, estes representam estratégias que influenciaram as concepções e ações para a gestão das áreas protegidas.

A preservação tem como principal estratégia o máximo de restrições de acesso ao meio natural que se deseja preservar, assegurando a não interferência humana neste local. Já a conservação apoia-se em estratégias de maior compatibilidade entre as atividades humanas e a preservação da natureza, sendo necessárias estratégias de gestão e manejo para garantir essa compatibilização.

se a essência da "conservação dos recursos" é o uso adequado e criterioso dos recursos naturais, a essência da corrente oposta, a preservacionista, pode ser descrita como a reverência à natureza no sentido da apreciação estética e espiritual da vida selvagem (wilderness). Ela pretende proteger a natureza 
contra o desenvolvimento moderno, industrial e urbano (DIEGUES, 2001, p. $30)$.

Portanto, essas duas tendências refletem o paradigma predominante sobre a concepção de natureza e o papel das sociedades na configuração atual do meio. A visão de natureza que se revela nas estratégias conservacionistas não se limita apenas àquilo que é natural e intocável, como a natureza mais selvagem, mas abrange a natureza em interação com as sociedades, como parte do desenvolvimento humano, sendo a atividade antrópica manejável e construtiva, mesmo do ponto de vista da conservação.

\subsection{Conservação da Natureza e Áreas Protegidas}

A conservação da natureza tem como um de seus principais instrumentos a delimitação de áreas que apresentam uma natureza intocada, fragmentos que não foram excessivamente afetados pelo modelo exploratório da natureza. Essa estratégia vincula-se à criação de áreas protegidas que ficam sujeitas às estratégias de gestão e manejo para salvaguardar a natureza, com vistas à manutenção da diversidade biológica e dos recursos naturais presentes.

Os Estados Unidos foram pioneiros nessas propostas, sendo que a criação de áreas protegidas priorizou locais de grandes extensões territoriais, exuberantes do ponto de vista paisagístico e natural e que ainda não apresentavam fortes alterações decorrentes da ação humana. A política adotada naquele momento determinava a retirada de habitações inseridas nessas áreas e impedia a chegada de novos moradores, porém, incentivava o desenvolvimento de atividades científicas, de lazer e turismo para a apreciação da natureza.

A ideia que fundamenta este modelo é a de que a alteração e domesticação de toda a biosfera pelo ser humano é inevitável, sendo necessário e possível conservar pedaços do mundo natural em seu estado originário, antes da intervenção humana. Lugares onde o ser humano possa reverenciar a natureza intocada, refazer suas energias materiais e espirituais e pesquisar a própria natureza (ARRUDA, 1999, p. 83).

Essa perspectiva deu origem aos primeiros parques nacionais da América do Norte como o de Yellowstone (1872), Yosemite (1890), Grand Canyon (1919), Rainier (1899) e Zion (1919). O Parque Nacional de Yellowstone foi um marco conceitual para as estratégias de áreas protegidas, foi a partir dele que os Estados Unidos desenvolveram suas políticas 
ambientais, influenciando a criação de parques nacionais em diversas partes do mundo (BENSUSAN, 2006).

As reflexões a respeito das políticas preservacionistas e conservacionistas acabaram influenciando a adoção de outras categorias para a proteção de áreas naturais com características diferentes dos parques nacionais. Surgiram assim, também nos Estados Unidos, as categorias de Florestas Nacionais, conciliando o uso racional de recursos naturais, como a madeira, e a conservação da natureza; e, o Refúgio de Vida Silvestre, destinado a proteger espécies ameaçadas (ARAUJO, 2007).

A questão tomou impulso mundialmente com a criação da União Internacional para a Conservação da Natureza (IUCN) em 1948, que tinha o objetivo de unificar as estratégias de conservação a nível global. A missão da IUCN consiste em "[...] influenciar, encorajar e assistir as sociedades em todo o globo, a conservar a integridade e diversidade da natureza e assegurar o uso dos recursos naturais de forma equitativa e ecologicamente sustentável" (IUCN, 2016).

A Comissão Mundial de Áreas Protegidas (WCPA), conforme publicação da IUCN (1994, p. 7), definiu áreas protegidas como "área marítima e/ou terrestre especialmente dedicada à proteção e manutenção da diversidade biológica e dos bens naturais e culturais a esta associados". Assim, foram estabelecidas as seguintes categorias de áreas protegidas: Reserva Natural Estrita, Área de Vida Selvagem, Parque Nacional, Monumento Natural, Área de Manejo de Hábitat e Espécies, Paisagem Protegida, e, Área Protegida para Manejo de Recursos Naturais.

No Brasil, em 1876 o engenheiro André Rebouças impulsionou a implantação de áreas protegidas. Inspirado no modelo norte americano do Parque Nacional de Yellowstone, André Rebouças vislumbrou a possibilidade de conservação da beleza natural de certas áreas no Brasil, valorizando também suas potencialidades turísticas e econômicas. Além disso, declarou que estas áreas seriam verdadeiras doações às gerações futuras, recomendando assim a criação de um parque que se estenderia de Sete Quedas até as Cataratas do Iguaçu (URBAN, 1998).

O contexto político do Brasil nesse período ainda era muito instável, sendo prioridade o crescimento econômico do país, em detrimento da degradação ambiental.

[...] o Brasil encontrava-se em grave crise política e financeira. Em 1898, o país estava à beira da bancarrota financeira. Assim, nesse ambiente de crise generalizada, regido por um Estado que não admitia intervencionismo sobre o direito de propriedade e no qual o poder político e econômico estava 
concentrado nas mãos das oligarquias ligadas à agroexportação, a discussão a respeito da proteção à natureza não tinha como prosperar (ARAUJO, 2007, p. 57).

Em 1934 o Presidente Getúlio Vargas aprovou o Código Florestal, de acordo com o Decreto $\mathrm{n}^{\mathrm{o}}$ 23.793/1934. Segundo Medeiros (2006) foi o primeiro momento em que a proteção da natureza passou a ser um princípio fundamental, sendo de responsabilidade da União e dos Estados. Foram definidas as categorias de florestas (protetoras, remanescentes, modelo e de rendimento) que consistiam em bens de interesse comum, com limitações aos direitos de propriedade. Além disso, o decreto apresenta diretrizes para a criação de parques referentes às florestas remanescentes.

Assim, apoiado no Código Florestal, foi criado o primeiro Parque Nacional Brasileiro de Itatiaia em 1937. Com a criação do Parque, a área estava destinada a ser "[...] perpetuamente conservada no seu aspecto primitivo e atender às necessidades de ordem científica [...]". Também propunha apoiar "[...] ((finalidades)) de ordem turística, que se apresentem em condições de fazer do Parque um centro de atração para viajantes, assim nacionais como estrangeiros" (BRASIL, 1937).

Posteriormente foram criados os Parques Nacionais do Iguaçu e da Serra dos Órgãos, ambos em 1939. Esse processo de criação de Parques só foi retomado 20 anos depois, em 1959, incluindo outras regiões do país. Medeiros (2006) analisa positivamente esse período de consolidação de estratégias de conservação da natureza visto que foi possível estabelecer um modelo de proteção caracterizando áreas que necessitam de medidas protetoras mais restritivas, porém, conciliando em outras categorias a utilização de recursos naturais de forma planejada.

Em 1965, durante o Regime Militar, foi instituído um novo Código Florestal, pela Lei $\mathrm{n}^{\circ}$ 4771. Com características similares ao código anterior, inseriu novas tipologias para áreas protegidas, sendo elas: Parque Nacional, Floresta Nacional, Área de Preservação Permanente e Reserva Legal. Essas categorias reforçavam a ideia de separar áreas exclusivas para a proteção da natureza e áreas que permitissem o acesso ao público e a realização de pesquisas científicas. Para Alceo Magnanini, um dos ex-diretores do Instituto Brasileiro de Desenvolvimento Florestal (IBDF) e influente na criação do código: "nos parques nacionais tradicionais, o público tinha acesso, a pesquisa tinha acesso e era uma área também manejável. Surgiu então a proposta das reservas biológicas, que não permitiriam tanto quanto possível a presença humana" (URBAN, 1998, p. 229). 
A categoria de Parque Nacional tinha como finalidade “[...] resguardar atributos excepcionais da natureza, conciliando a proteção integral da flora, da fauna e das belezas naturais com a utilização para objetivos educacionais, recreativos e científicos" (BRASIL, 1965 , art. $5^{\circ}$, a).

As Florestas, que também poderiam ser Nacionais, Estaduais ou Municipais possuíam "[...] fins econômicos, técnicos ou sociais, inclusive reservando áreas ainda não florestadas e destinadas a atingir aquele fim" (BRASIL, 1965, art. 5, b).

Ganha destaque também nesse período a Lei de Proteção à Fauna, Lei n ${ }^{\circ} 5197$ de 1967. Este instrumento garantiu a proteção de espécies de animais silvestres, sendo estes de propriedade do Estado, e proibindo a prática de caça profissional. Além disso, criou categorias que não estavam incluídas na versão de 1965 do Código Florestal, como a Reserva Biológica Nacional e os Parques de Caça Federal.

Com a criação da Secretaria Especial de Meio Ambiente (SEMA) em 1973 estabeleceu-se mais categorias de unidades de conservação. Em 1981 foram criadas a Estação Ecológica e as Áreas de Proteção Ambiental, em 1984 as Reservas Ecológicas e Áreas de Relevante Interesse Ecológico. As Reservas Particulares do Patrimônio Natural somente foram criadas em 1996 (MEDEIROS, 2006).

Bensusan (2006) destaca que a década de 70 foi marcada pela criação de parques nos principais ecossistemas do Brasil, tendo se diferenciado nas décadas seguintes para a conservação da biodiversidade em diferentes sistemas econômicos de produção sustentável (BENSUSAN, 2006, p. 44).

Foi também a partir dos anos 70 que diversas iniciativas, no sentido de criação ou reconhecimento internacional de áreas de relevante interesse ecológico ou cultural, começaram a ser discutidas e implementadas. A lógica deste processo era a de estimular e fomentar a conservação de áreas representativas e singulares ao redor do mundo e, ao mesmo tempo e em alguns casos, estabelecer áreas demonstrativas onde pesquisas científicas pudessem ser realizadas (MEDEIROS, 2006, p. 55).

A seleção de áreas protegidas passou a ser uma questão importante neste período, considerando que era necessário estabelecer critérios específicos para garantir a proteção da natureza, com enfoque à biodiversidade. Os primeiros parques tiveram as características cênicas valorizadas para sua criação, como no caso do Parque Nacional de Itatiaia, onde já havia a Estação Biológica desde 1929, reforçando sua relevância do ponto de vista paisagístico, com diversidade de ambientes excepcionais. 
A seguir destaca-se o relato de Maria Tereza Jorge Pádua que ocupou diversos cargos influentes relacionados à conservação da natureza e criação de áreas protegidas no antigo Instituto Brasileiro de Desenvolvimento Florestal (IBDF), apresentando informações sobre o processo de criação de parques nacionais na década de 1960: "Os parques nacionais, até aquele momento, eram criados mais por critérios de beleza cênica. Ninguém discutia a importância deles. [...] não havia um estudo sistemático, científico [...]” (URBAN, 1998, p. 258).

Na década de 1970 o projeto Radambrasil foi importante para a seleção de locais para áreas protegidas, uma vez que forneceu um levantamento sistemático do território brasileiro, com destaque para as características geológicas, geomorfológicas, pedológicas e da vegetação (ARAUJO, 2007).

Na década de 1990, prevaleceram critérios sustentados em análises biogeográficas de endemismo e riqueza de espécies, espécies raras ou ameaçadas e a presença de fenômenos geológicos especiais, além do grau de vulnerabilidade dos ecossistemas. Mesmo assim, o conhecimento acerca da riqueza natural do país ainda era muito escasso, prevalecendo a seleção de áreas que proporcionem variações de condições ecológicas, ou seja, ambientes diversos, garantindo a conservação das espécies (ARAUJO, 2007).

Concomitante ao desenvolvimento de legislação para áreas protegidas no Brasil, algumas convenções marcaram esse período, com a finalidade de garantir a conservação da natureza a nível internacional. Destaca-se o programa "O Homem e a Biosfera", ou Reserva da Biosfera, promovido pela UNESCO em 1972 que tinha como objetivo criar uma rede internacional de áreas protegidas. Em 1971 foi criado o programa "Sítios Ramsar" Convenção sobre Zonas Úmidas, visando a cooperação internacional para proteger as zonas úmidas (MEDEIROS, 2006).

No Brasil, a primeira reserva referente à categoria de Reserva da Biosfera foi na Mata Atlântica, em 1999. Tendo prosseguimento através da criação da Reserva da Biosfera do Cerrado (1994), Pantanal (2000), Caatinga e Amazônia Central (2001), e, do Espinhaço (2005) (ARAUJO, 2007). Já em relação aos Sítios Ramsar, o Brasil ratificou o acordo em 1993, incluindo 13 unidades de conservação à lista Ramsar (MMA, 2017).

Era emergente a necessidade de unificar as estratégias até então estabelecidas no Brasil, bem como refletir sobre a gestão dessas unidades criadas. Desta forma, em 2000 foi estabelecido um sistema integrado, o Sistema Nacional de Unidades de Conservação (SNUC), através da Lei no 9985 de 18 de Julho de 2000. 
O SNUC definiu critérios e normas para a criação, implantação e gestão das Unidades de Conservação (UCs). A Lei apresenta objetivos e diretrizes específicos para a conservação dos espaços naturais. As categorias de UCs foram divididas em dois grupos, as de proteção integral e as de uso sustentável, que se diferenciam quanto à forma de proteção e usos permitidos.

As Unidades de Proteção Integral priorizam a proteção da natureza, permitindo apenas o uso indireto dos recursos (ou seja, aquele que não envolve coleta e uso dos recursos naturais). Já as Unidades de Uso Sustentável tem como objetivo a compatibilização entre a conservação da natureza e o uso sustentável de parte de seus recursos naturais. A literatura destaca que o SNUC integrou as categorias de unidades de conservação que já haviam sido criadas, e também, abriu espaço para novas categorias (MEDEIROS, 2006).

Seus objetivos estão orientados principalmente para a manutenção da biodiversidade e proteção de espécies ameaçadas de extinção; a preservação e restauração da diversidade de ecossistemas naturais; promoção do desenvolvimento sustentável a partir dos recursos naturais; promoção da utilização dos princípios e práticas da conservação da natureza no processo de desenvolvimento; proteção das paisagens naturais; proteção das características de relevância geológica, geomorfológica, espeleológica, arqueológica, paleontológica e cultural; proteger e recuperar recursos hídricos e edáficos; incentivo de pesquisas científicas; valorização da diversidade biológica; promoção da educação e interpretação ambiental, recreação em contato com a natureza e turismo ecológico; proteção dos recursos necessários à sobrevivência das comunidades tradicionais, respeitando e valorizando seu conhecimento (BRASIL, 2000).

O SNUC insere também orientações relativas à criação, implementação e gestão dessas unidades, prevendo a elaboração do Plano de Manejo e o estabelecimento de Conselho Consultivo que é presidido pelo órgão responsável pela administração da unidade e garante a representatividade de órgãos públicos e a sociedade civil na gestão (BRASIL, 2000, 2002).

Em 2006 foi estabelecido o Plano Nacional de Áreas Protegidas (PNAP), criado no sentido de atingir as metas acordadas durante a Convenção sobre Diversidade Biológica na Conferência das Nações Unidas sobre Ambiente e Desenvolvimento em 1992, que prevê o desenvolvimento de "estratégias, políticas, planos e programas nacionais para áreas protegidas" (BRASIL, 2006).

O PNAP integrou suas estratégias para as áreas protegidas do Brasil, destacando também a relevância das terras indígenas e terras de quilombolas, reconhecendo que: 
esses grupos possuem papel chave na conservação da biodiversidade; é necessário a articulação e integração da gestão das UCs com as terras indígenas e quilombolas. Essa estratégia também promove a conservação da biodiversidade no sentido de beneficiar essas populações tradicionais e locais (MMA, 2006, p. 5).

Bensusan (2006) destacou o aspecto inovador das diretrizes do SNUC por inserir a importância da participação popular, a sustentabilidade econômica das unidades, a proteção do patrimônio natural abrangido pela unidade, e também, a consideração acerca da zona de amortecimento e os corredores ecológicos. Sendo assim, o SNUC apresenta uma visão estratégica, no sentido de garantir a conservação dos ecossistemas e da biodiversidade, mas também possibilitando a melhoria da qualidade de vida das comunidades locais e do Brasil e a geração de emprego e renda (MMA, 2017).

Pode-se apontar muitos desafios na gestão desses territórios que incorporem também os conflitos socioambientais relacionados com sobreposições territoriais. Nesse sentido, Velasquez (2008), destaca que:

Grandes desafios permeiam a viabilização e efetivação das UCs no Brasil, entre eles a consolidação do processo de regularização fundiária pertinente a quase todos os casos de unidade de proteção integral e uso sustentável (VELASQUEZ, 2008, p. 269).

A partir desses contrassensos, também é possível apontar a inclompetude destinada à conservação dos elementos físicos da natureza, no âmbito da criação, implementação e gestão das UCs. Nesse sentido, os conceitos que sustentam a necessidade de integração dessa abordagem serão apresentados no próximo item.

\subsection{Geoconservação em Unidades de Conservação}

De acordo com Ferreira (2016), no Brasil podem ser apontadas leis específicas para a proteção do Patrimônio Paleontológico e Espeleológico. No caso do Patrimônio Geológico como um todo, não há legislação específica, cabendo a utilização de instrumentos como o Decreto-Lei no 25/1937 de Proteção do Patrimônio Histórico Nacional e a Lei nº 9985/2000 que institui o SNUC.

Para a definiçãa do Patrimônio Histórico e Artístico Nacional, o Decreto-Lei no 25 de 1937 apresenta que

equiparam-se aos bens a que se refere o presente artigo e são também sujeitos a tombamento os monumentos naturais, bem como os sítios e 
paisagens que importe conservar e proteger pela feição notável com que tenham sido dotados pela natureza ou agenciados pela indústria humana (BRASIL, 2934, art. $1^{\circ}, \S 2^{\circ}$ ).

Observa-se que no contexto do atual Sistema Nacional de Unidades de Conservação (SNUC), os aspectos físicos do ambiente apresentam considerável relevância. Destacam-se as referências quanto à diversidade abiótica da natureza a partir dos seguintes objetivos do SNUC

VI - proteger paisagens naturais e pouco alteradas de notável beleza cênica; VII - proteger as características relevantes de natureza geológica, geomorfológica, espeleológica, arqueológica, paleontológica e cultural; VIII - proteger e recuperar recursos hídricos e edáficos (BRASIL, 2000, art. $\left.4^{\circ}\right)$.

Cabe apontar que há um esforço em âmbito internacional e nacional no sentido de garantir maiores perspectivas para a inserção dos elementos físico da natureza nas diretrizes e práticas em Conservação da Natureza. Esses esforços estruturam-se a partir de uma área emergente no contexto das Geociências, denominada "Geoconservação" (HENRIQUES et al., 2011), que possui como conceitos estruturantes a geodiversidade e o patrimônio geológico.

\subsubsection{Geodiversidade}

O conceito de geodiversidade está relacionado à diversidade de elementos que compõem a vertente abiótica da natureza. Consiste, portanto na

variedade natural (diversidade) de feições geológicas (rochas, minerais e fósseis), geomorfológicas (paisagens, topografia, processos físicos), solos e feições hidrogeológicas. Isso inclui as associações, estruturas, sistemas e contribuições para as paisagens (GRAY, 2013, p. 12, tradução nossa).

Esse termo foi concebido em comparação ao conceito de biodiversidade, ressaltando a importância dos elementos físicos na natureza que até então possuíam pouco espaço nas políticas e diretrizes para a conservação da natureza (PROSSER, 2002a). Segundo Gray (2004) o termo geodiversidade passou a ser utilizado por geólogos e geomorfólogos a partir da década de 1990, durante a Conferência de Malvern com a temática da Conservação Geológica e Paisagística. 
A consagração desse conceito em âmbito internacional resultou da contribuição de referências em várias partes do mundo, principalmente no Reino Unido (STANLEY, 2000; GRAY, 2004, 2013), Portugal (BRILHA, 2005, 2016; AZEVEDO, 2006), Espanha (NIETO, 2001; SERRANO E RUIZ-FLAÑO, 2007; URQUÍ et al., 2007), dentre outros (GRAY, 2008).

No Brasil, a definição apresentada por Brilha (2005) é amplamente divulgada e aceita no meio acadêmico. Seu conceito advém do proposto por Stanley (2000)

A geodiversidade é a variedade de ambientes geológicos, fenômenos e processos ativos que dão origem a paisagens, rochas, minerais, fósseis, solos e outros depósitos superficiais que fornece a estrutura para a vida na Terra (STANLEY, 2000, p. 15, tradução nossa).

O Serviço Geológico do Brasil (CPRM) tem norteado essas ações no país, alavancando as discussões e projetos na temática da geoconservação, adotando a seguinte definição

O estudo da natureza abiótica (meio físico) constituída por uma variedade de ambientes, composição, fenômenos e processos geológicos que dão origem às paisagens, rochas, minerais, águas, fósseis, solos, clima e outros depósitos superficiais que propiciam o desenvolvimento da vida na Terra, tendo como valores intrínsecos a cultura, o estético, o econômico, o científico, o educativo e o turístico (CPRM, 2006 apud SILVA, 2008, p. 12).

Essa definição abrange três dimensões importantes da geodiversidade. A primeira relaciona-se aos materiais ou elementos pelos quais ela é formada, considerando os ambientes, fenômenos e processos geológicos, ou seja, para além dos materiais como rochas, minerais, água, solos, fósseis e paisagens, destacam-se também os processos e fenômenos geológicos que dão origem a esses materiais. A segunda apresenta a relevância da geodiversidade em sua interação com o meio biótico, apresentando-se como suporte ao desenvolvimento da vida na Terra. E a terceira, refere-se aos valores da geodiversidade, sendo apresentados os valores cultural, estético, econômico, científico, educativo e turístico.

Esses valores se relacionam à própria definição apresentada por Brilha (2005), baseada na proposta de Gray (2004), destacando os seguintes valores da geodiversidade:

\section{a) Valor intrínseco}

O valor intrínseco corresponde ao valor que a geodiversidade possui pela sua própria existência, assim independe da interpretação humana sobre esse aspecto, bem como de seu valor de uso. Nesse sentido, Gray (2004) destaca que o valor intrínseco permeia as reflexões sobre as relações éticas e filosóficas entre o homem e a natureza. 


\section{b) Valor cultural}

O valor cultural apresenta as relações de identificação e reconhecimentos das sociedades humanas para com a geodiversidade, contendo assim referências para seu desenvolvimento social, cultural e religioso. Pode se expressar a partir de mitos e lendas, folclores, artesanatos típicos, gastronomia, construções, aspectos arqueológicos e históricos. Brilha (2005) também destaca as relações existentes entre o valor cultural da geodiversidade e a nomeação de localidades, que muitas vezes se refere a um elemento geológico do lugar.

\section{c) Valor estético}

O valor estético da geodiversidade está relacionado ao aspecto visual e topográfico do ambiente físico, considerando as diversas escalas, desde cordilheiras até aspectos locais (GRAY, 2004). As paisagens se constituem em pontos de referência para os indivíduos, sendo que muitas vezes as atividades de lazer e apreciação da natureza decorrem em locais de grande beleza cênica, além de serem objeto para a inspiração artística, e que apresenta como condicionante fundamental para a estética do lugar a própria geodiversidade.

d) Valor econômico

O valor econômico consiste no valor de uso da geodiversidade como recurso geológico. Assim, a dependência da civilização moderna para com a geodiversidade relaciona-se à necessidade de produção de energia (petróleo, carvão, gás natural; exploração de minerais radioativos; energia geotérmica), de materiais para a construção civil, a confecção de joias e ornamentos e o comércio de minerais e fósseis. Além disso, destaca-se o valor econômico das águas subsuperficiais.

\section{e) Valor funcional}

A geodiversidade se destaca funcionalmente no sentido de dar suporte para os sistemas físicos e ecológicos na superfície da Terra. Ressalta-se assim a interdependência entre geodiversidade e biodiversidade, observando as condições que a geodiversidade cria no ambiente para o desenvolvimento de espécies particulares.

Nesse valor também se enquadram os aspectos da geodiversidade que oferecem suporte ao desenvolvimento de atividades humanas, como o papel do solo para a agropecuária, a importância das características naturais que favorecem a construção de barragens, implantação de vias de comunicação, desenvolvimento de cidades, dentre outros. 


\section{f) Valor científico e educativo}

Esse valor se relaciona aos estudos científicos que se utilizam dos registros geológicos para a investigação sobre os processos e materiais que compõem a geodiversidade. A partir desses registros geológicos é possível interpretar a evolução geológica da Terra, tendo relevância os aspectos materiais da geodiversidade, como rochas e minerais, e os processos passados e atuais. Além disso, a análise desses testemunhos pode subsidiar a prevenção e a gestão de riscos, por exemplo.

Em relação ao valor educativo apresenta-se o papel da geodiversidade para o ensino, com destaque para o ensino de Geociências, possibilitando a exemplificação dos esquemas e modelos amplamente utilizados nessa área do conhecimento para a compreensão da dinâmica do ambiente e a história geológica da Terra.

\subsubsection{Patrimônio Geológico e Sítios de Geodiversidade}

Para Gray (2008), enquanto o termo geodiversidade é neutro e se refere à diversidade dos aspectos abióticos da natureza, o conceito de patrimônio geológico está associado a um valor, que deve orientar as ações para a geoconservação.

O patrimônio geológico pode ser compreendido em comparação ao conceito de patrimônio histórico que representa uma herança, algo que tem importância para a história do homem, o patrimônio geológico faz parte do patrimônio natural, pois representa a memória da Terra, é definido como aquilo que possui valor excepcional em relação à geodiversidade (BRILHA, 2005). Assim, essa parcela da geodiversidade se refere a "ocorrências geológicas que possuem inegável valor científico, pedagógico, cultural, turístico, ou outros”. O local onde é identificado o patrimônio geológico é denominado de geossítio.

Segundo Henriques et al. (2011) um geossítio

pode ser reconhecido através da aplicação do princípio da singularidade, o local torna-se geossítio devido a alguma propriedade específica que detém, reconhecida e apreciada por especialistas, e que é singular e portanto, relevante para o entendimento da história e dinâmica da Terra (HENRIQUES et al., 2011, p. 119, tradução nossa).

Assim, os autores destacam que o conceito de singularidade é globalmente atribuído ao patrimônio geológico, tendo relevância sua citação na Declaração Internacional dos 
Direitos à Memória da Terra (Declaração de Digne), realizada no Primeiro Simpósio Internacional para Conservação do Patrimônio Geológico, em Digne-les-Bains (França) destacando que

O Homem e a Terra compartilham uma mesma herança, um patrimônio comum. Cada ser humano e cada governo não são senão meros usufrutuários e depositários deste patrimônio. Todos os seres humanos devem compreender que a menor depredação do patrimônio geológico é uma mutilação que conduz a sua destruição, a uma perda irremediável. Todas as formas do desenvolvimento devem respeitar e levar em conta o valor e a singularidade desse patrimônio (DD, 1991, art. $8^{\circ}$ ).

Nesse âmbito, o patrimônio geológico está relacionado à todos elementos notáveis da geodiversidade, englobando assim o patrimônio paleontológico, mineralógico, geomorfológico, petrológico, hidrológico, e outros (BRILHA, 2005).

A identificação do patrimônio geológico requer uma metodologia para a definição de seus valores que implicam no reconhecimento de seus aspectos singulares e excepcionais. Entretanto, essa prática está sujeita a diversas interpretações, como destacaram Henriques et al. (2011), qualquer ação de seleção e avaliação envolve certa subjetividade, sendo ainda maior quando se busca caracterizar territórios de grandes proporções. Para Brilha (2016)

Há sempre uma certa subjetividade que deve ser minimizada pelo bom conhecimento científico dos geocientistas envolvidos nessas tarefas e pelo uso de uma metodologia sólida (BRILHA, 2016, p. 5, tradução nossa).

Em um sentido mais restrito, procurando sistematizar de forma mais objetiva a valorização da geodiversidade para a definição do patrimônio geológico, Brilha (2016) propôs uma revisão conceitual em que apenas a atribuição de valor científico excepcional deve qualificar o patrimônio geológico. Nesse sentido o patrimônio geológico constitui em localchave para compreender a história geológica da Terra (BRILHA, 2016).

Para o autor, a delimitação geográfica do Patrimônio Geológico in situ recebe a atribuição de "geossítio". Já o Patrimônio Geológico ex situ recebe a denominação de “elementos do patrimônio geológico" (BRILHA, 2016).

De acordo com essa definição, a identificação dos aspectos geológicos de valor didático ou turístico excepcionais recebe a atribuição de "elementos da geodiversidade", sendo que sua ocorrência geográfica é denominada de "sítios de geodiversidade", definido tanto para elementos da geodiversidade in situ quanto ex situ (BRILHA, 2016). 


\subsubsection{Geoconservação}

A Geoconservação está relacionada à fragilidade e vulnerabilidade que a geodiversidade apresenta em relação às ameaças naturais e antrópicas. Esses aspectos requerem ações específicas para sua conservação uma vez que são recursos não renováveis considerando a escala de tempo humano.

O inventário do patrimônio geológico é uma etapa essencial para elaborar estratégias de geoconservação uma vez que identifica os vestígios da evolução geológica da Terra, destacando sua conservação para as gerações atuais e futuras. Dessa forma, a Geoconservação possui um papel de responsabilidade social, garantindo o uso dos recursos e a conservação do patrimônio geológico (BRILHA, 2016).

Segundo Henriques et al. (2011) a Geoconservação possui maior enfoque na gestão dos elementos geológicos com valores excepcionais científicos, educativos e turísticos ou culturais, que compõem o patrimônio geológico representado pelos geossítios.

Nesse sentido, os elementos e processos de natureza física na paisagem, como rochas e montanhas, são geralmente percebidos como estáticos e de pouca fragilidade. Por isso, a preocupação com a biodiversidade tem prevalecido, sendo associada à uma maior suscetibilidade em relação às interferências antrópicas e naturais (GRAY, 2004). Assim, um dos obstáculos à geoconservação é a falta de visão da dinâmica terrestre, ou seja, a falta de entendimento das características desses elementos e processos e quais são suas fragilidades e ameaças.

Segundo Gray (2004), a geoconservação se insere na perspectiva da conservação, pois esta reconhece o caráter dinâmico da natureza e os processos naturais a ela associados. Envolve questões de planejamento e gestão a partir das características naturais de determinado ambiente. Diferente, portanto do conceito de proteção que está associado à proteção do status quo, que muitas vezes, desconsidera essa dinâmica natural.

De acordo com Brilha (2005), as estratégias de geoconservação consistem na concretização de uma metodologia de trabalho que visa sistematizar as tarefas no âmbito da conservação do patrimônio geológico. Em sua metodologia, a geoconservação pode ser agrupada nas seguintes etapas sequenciais: inventário, quantificação, classificação, conservação, valorização e divulgação e, monitoramento.

Considera-se que qualquer medida de conservação deve estar pautada num amplo conhecimento dos elementos a que se deseja conservar, assim, a fase do inventário é primordial. Essa fase inicial é, portanto, de reconhecimento sistemático de toda variedade dos 
elementos geológicos de determinada área, para assim, poder identificar os aspectos de maior singularidade, ou seja, o patrimônio geológico. Os geossítios são localizados em cartas e mapas, constando também uma extensiva caracterização por fichas de inventário.

Com isso, é possível realizar a quantificação dos geossítios, etapa realizada com base em critérios específicos, como fatores intrínsecos, usos potenciais e a necessidade de proteção. O objetivo desta quantificação é ordenar os geossítios, priorizando aqueles que estarão sujeitos às estratégias de geoconservação.

$\mathrm{Na}$ etapa da classificação, é interessante ressaltar que Brilha (2005) se baseou na legislação portuguesa, portanto, considera a classificação quanto à Rede Nacional de Áreas Protegidas, quando o geossítio for de relevância internacional ou nacional, ou então classificações municipais, quando a relevância for regional ou local. Assim, no Brasil, a classificação estará sujeita ao Sistema Nacional de Unidades de Conservação, que possuem unidades de âmbito nacional, estadual e municipal, além disso, pode-se utilizar a legislação de tombamento para a conservação.

As etapas subsequentes se relacionam com a gestão desses geossítios, definindo as medidas de conservação a partir dos dados levantados anteriormente e da avaliação da vulnerabilidade que estes geossítios possuem quanto à sua degradação ou perda, ocasionados por fatores naturais ou antrópicos. É necessário ter em conta as características específicas para cada geossítio, sendo que as intervenções devem priorizar a sua integridade física, bem como assegurar a acessibilidade. As estratégias nesse caso podem ser as mais variadas possíveis, desde a criação de barreiras que coíbam roubo ou depredação, estruturas de proteção e suporte, coberturas, contratação de pessoal técnico para orientar e garantir a preservação, e até mesmo medidas mais expressivas como a sua musealização.

Na etapa da valorização e divulgação é necessário considerar a vulnerabilidade que o geossítio está sujeito. Portanto, quando a vulnerabilidade for considerada baixa, a valorização e divulgação não prescindem das medidas de conservação citadas anteriormente. Mas, no caso dos geossítios de maior vulnerabilidade, devem estar sujeitos primeiro às medidas de conservação.

Assim, a valorização está relacionada à promoção da informação e interpretação do patrimônio geológico do local observado. Nesta fase são propostos e produzidos principalmente painéis interpretativos, percursos temáticos, folhetos e informações em meio digital. Já a divulgação está relacionada à comunicação e a forma de informar o público para sua sensibilização. Neste âmbito se enquadram os percursos e roteiros turísticos, bem como ações de educação geocientífica e/ou ambiental. 
A última etapa refere-se ao monitoramento desses geossítios que já foram alvo de todas as etapas anteriores. Mesmo que todo o trabalho anterior tenha sido bem realizado, a necessidade de verificar sua funcionalidade é fundamental para garantir a geoconservação, uma vez que isto pode implicar na perda de relevância dos geossítios. Caso seja verificado que o geossítio está sendo afetado negativamente, a análise deverá ser realizada novamente, reavaliando sua vulnerabilidade, e, também, uma nova elaboração ou aperfeiçoamento das medidas de conservação, valorização e divulgação destes geossítios.

Considerando a adequação metodológica de Brilha (2016), o inventário do patrimônio geológico deverá seguir metodologia diferenciada, considerando que o objetivo deste inventário é definir os geossítios que possuam valor científico. Para a quantificação dos geossítios deve-se ter como base uma tabela específica para o valor científico. Os sítios de geodiversidade também estarão englobados, a partir de um inventário que vise classificar os sítios de interesse educativo e turístico. Neste caso, utilizam-se fichas de inventário e de quantificação específicas.

Como destacado na Figura 2, essas estratégias aliadas à conservação da biodiversidade irão compor a Conservação da Natureza de forma mais completa.

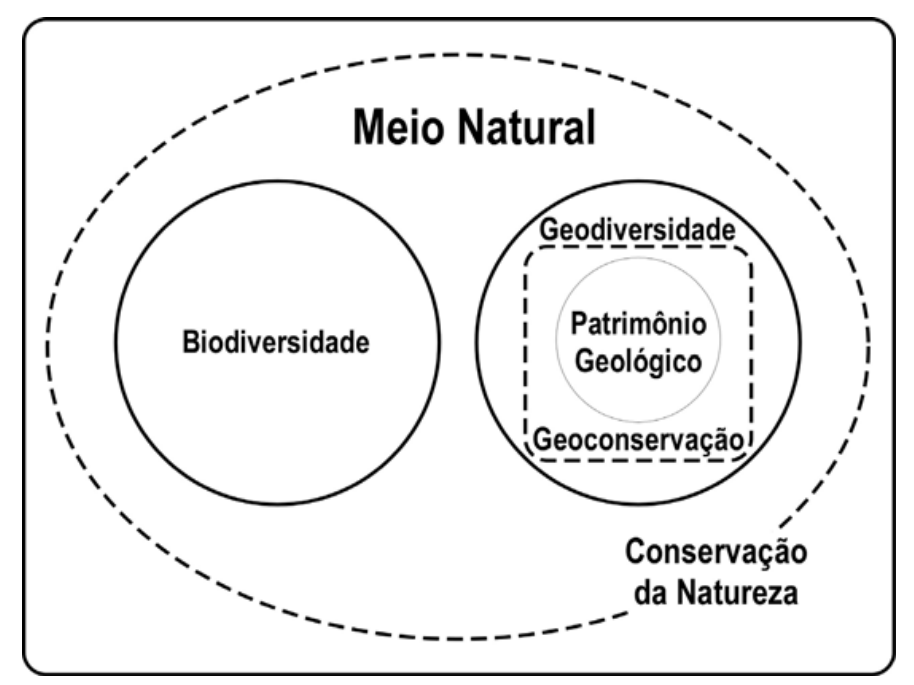

Figura 2 - Esquema ilustrativo do escopo da Geoconservação no contexto da Conservação da Natureza. (PEREIRA, 2010, p. 21).

A IUCN destacou a geodiversidade como elemento a ser conservado a partir de sua resolução de 2008, ressaltando a função da Global Geoparks Network (GGN) como propulsora do processo de conservação e uso sustentável do patrimônio geológico. Nesse documento destaca a necessidade de aumentar o reconhecimento da importância das Ciências da Terra para o desenvolvimento sustentável (IUCN, 2009). 
Em 2015, a IUCN lançou a publicação "Protected Area Governance and Management” inserindo um capítulo específico sobre a geoconservação em áreas protegidas. Nesse capítulo, é reconhecido que muitas áreas protegidas são designadas devido às suas características geológicas e geomorfológicas que dominam a paisagem de forma cênica. Além disso, essas feições possuem um significado icônico para a história da cultura de determinada área ou para o país. Assim, os componentes da geodiversidade podem estar diretamente relacionados aos significados culturais, como as cavernas que preservam pinturas rupestres. Considerando as diversas escalas de abrangência do patrimônio geológico em áreas protegidas, a geoconservação precisa ter em conta as feições e os processos em suas diferentes escalas, desde sítios locais até paisagens de grandes proposições (CROFTS \& GORDON, 2015).

\subsubsection{Iniciativas para a Geoconservação no Brasil}

No Brasil, algumas iniciativas têm sido desenvolvidas no sentido de promover a geoconservação, considerando também a tentativa de implementação de geoparques. Destacase a criação da Comissão Brasileira dos Sítios Geológicos e Paleontológicos (SIGEP) como a primeira e mais abrangente iniciativa brasileira em desenvolver ações concretas voltadas para a identificação, descrição e publicação de sítios do patrimônio geológico, em conjunto com a UNESCO. Essa iniciativa que teve a contribuição da comunidade acadêmica reúne e divulga de forma sistemática todo o acervo que representa o patrimônio geológico brasileiro (SCHOBBENHAUS \& SILVA, 2012; WINGE et al., 2013). A publicação dos geossítios em linguagem científica foi realizada a partir da publicação de três volumes do livro "Sítios Geológicos e Paleontológicos do Brasil", sendo que no primeiro foram apresentados 58 sítios (SCHOBBENHAUS et al, 2002), no segundo volume constavam 40 sítios (WINGE et al., 2009) e no terceiro, 18 sítios (WINGE et al., 2013).

O Geoparque Araripe é referência para as estratégias no Brasil. Foi o primeiro geoparque das Américas, e o primeiro no Brasil a ser integrado à Rede Global de Geoparques, sob os auspícios da UNESCO. Criado em 2006, na região do Cariri, sul do Ceará, vem desenvolvendo e apoiando pesquisas científicas sobre o patrimônio local, além de promover a geoconservação e o geoturismo (LIMA, 2008).

Ganha destaque também em 2006 o Projeto Geoparques do Serviço Geológico do Brasil (CPRM). Apresenta importante papel indutor para a criação de geoparques no país, uma vez que promove a identificação, levantamento, descrição, diagnóstico e divulgação de 
áreas com potencial para futuros geoparques (SCHOBBENHAUS \& SILVA, 2012). Essa instituição também possui o projeto "Geodiversidade" o qual desenvolveu o mapa da geodiversidade do Brasil em 2006, e os mapas de geodiversidade estaduais (CPRM, 2017).

Algumas propostas estaduais também se destacam como o Projeto Caminhos Geológicos, criado em 2000 pelo Departamento de Recursos Naturais do Rio de Janeiro (DRM-RJ). Esse projeto teve o objetivo de promover a popularização das Geociências a partir da instalação de painéis interpretativos nos monumentos naturais do Estado (MANSUR, 2009).

Seguindo esse projeto pioneiro do Rio de Janeiro, outros Estados também buscaram valorizar seus monumentos geológicos e integrá-los aos roteiros de turismo ecológico. Dentre eles, destaca-se o Projeto Sítios Geológicos e Paleontológicos, criado pelo Serviço Geológico do Paraná (Mineropar) em 2003; o Projeto Caminhos Geológicos da Bahia, iniciado em 2003; o Projeto Monumentos Geológicos do Rio Grande do Norte, de 2006 (LIMA, 2008).

Em São Paulo, o Conselho Estadual de Monumentos Geológicos (CoMGeo - SP) criado em 2009 tem buscado desenvolver o inventário, a conservação e a divulgação de informações sobre os monumentos geológicos no Estado junto à Secretaria de Estado do Meio Ambiente (SMA-SP) e o Instituto Geológico (IG) (GARCIA, 2012).

Em relação ao inventário, tem-se como referência o levantamento do patrimônio geológico de São Paulo (GARCIA et al., 2017), apresentando metodologia sistemática e critérios claros que envolveu a participação da comunidade geocientífica.

Ainda em São Paulo, uma série de projetos de pesquisas se destacam no âmbito do Núcleo de Apoio à Pesquisa (NAP) em Patrimônio Geológico e Geoturismo (GeoHereditas), criado em 2011, com sede no Instituto de Geociências da USP. Dentre os projetos está o inventário do patrimônio geológico do litoral de São Paulo, conduzido de forma sistemática com o objetivo de formar as bases para um amplo plano geoturístico sustentável na região (GARCIA et al., 2014). Nesse contexto estão inclusos os inventários de Ubatuba (SANTOS, 2014), Caraguatatuba (ARRUDA et al., 2015, 2017), Ilhabela (PROCHOROFF, 2014), São Sebastião (REVERTE, 2014), Bertioga (MUCIVUNA, 2016) e outros em desenvolvimento.

A partir do NAP também foram realizadas iniciativas paralelas como o projeto "Interpretação Geológica em Trilhas", que tem como objetivo inserir conteúdos das geociências ao longo de trilhas ecoturísticas da região. Assim, algumas ações se voltam para os monitores ambientais das unidades de conservação, sendo realizados cursos de difusão sobre conceitos geológicos e sua interpretação. Os cursos deram enfoque aos monitores 
ambientais para que se tornem agentes multiplicadores desse conhecimento junto aos visitantes e grupos escolares que frequentam a região (GARCIA et al., 2013).

\subsection{A Perspectiva Socioambiental e a Geoconservação}

As diversas formas que o indivíduo se orienta para compreender e interpretar o mundo se sustentam em suas concepções e ideias que influenciam os recortes e enquadramentos dos aspectos que são observados. De forma metafórica, esses conceitos e ideias podem ser considerados como "lentes" que se localizam entre o olhar do indivíduo e o ambiente observado (CARVALHO, 2004).

A partir dessa alegoria, os "óculos" que utilizamos para interpretar o real acabam se ajustando ao indivíduo e favorecendo apenas aquele recorte e interpretação dos objetos a partir dos conceitos ao qual está habituado. É necessária uma postura questionadora e que procure revisar os próprios conceitos para assim apreender uma visão mais ampla dos elementos presentes no ambiente, ou seja, proporcionar uma constante troca dessas "lentes" para complementar múltiplas visões e interpretações sobre o ambiente (CARVALHO, 2004).

Nessa perspectiva, destacam-se algumas lentes, ou concepções que orientam a interpretação e apreensão do ambiente. Essa definição considera principalmente a forma de apreensão da relação entre a sociedade e o ambiente. Com base no contexto histórico-cultural pode-se considerar uma apreensão em que o homem distancia-se do conceito de natureza, sendo esta corrente denominada de naturalista, e a que o homem é parte integrante dessa natureza, conhecida como corrente socioambiental (CARVALHO, 2004).

Na perspectiva naturalista há um distanciamento entre sociedade e natureza, portanto a natureza é relacionada aos aspectos que não sofreram transformações pelo homem. Identifica-se como natureza aquele ambiente intocado, com vida selvagem de rica diversidade de fauna e flora. Segundo Carvalho (2004)

Essa visão "naturalizada" tende a ver a natureza como o mundo da ordem biológica, essencialmente boa, pacificada, equilibrada, estável em suas interações ecossistêmicas, o qual segue vivendo como autônomo e independente da interação com o mundo cultural humano. Quando essa interação é focada, a presença humana amiúde aparece como problemática e nefasta para a natureza (CARVALHO, 2004, p. 35).

A perspectiva socioambiental emerge do reconhecimento de um ambiente natural que está relacionado e integrado com o social. A esfera social é percebida como parte da 
natureza, e parte dessa dinâmica, no qual se identifica uma relação de co-pertença. Para a autora:

A visão socioambiental orienta-se por uma racionalidade complexa e interdisciplinar e pensa o meio ambiente não como sinônimo de natureza modificada, mas como um campo de interações entre a cultura, a sociedade e a base física e biológica nos processos vitais, no qual todos os termos dessa relação se modificam dinâmica e mutuamente. Tal perspectiva considera o meio ambiente como espaço relacional, em que a presença humana, longe de ser percebida como extemporânea, intrusa ou desagregadora ("câncer do planeta"), aparece como um agente que pertence à teia de relações da vida social, natural e cultural e interage com ela. Assim, para o olhar socioambiental, as modificações resultantes da interação entre os seres humanos e a natureza nem sempre são nefastas; podem muitas vezes ser sustentáveis, propiciando, não raro, um aumento da biodiversidade pelo tipo de ação humana ali exercida (CARVALHO, 2004, p. 37).

No âmbito das práticas de Conservação da Natureza, as correntes apresentadas podem determinar estratégias que ora priorizam a conservação de uma natureza selvagem, ou intocada, e se distanciam da dinâmica social e cultural relacionada com o ambiente, ora que priorizam as formas de usos e ocupação sustentáveis de determinado ambiente, e valorizam as relações e interações entre o meio social e natural.

A contribuição da perspectiva socioambiental para a Geoconservação emerge da flexibilização das estratégias, ao centralizar uma abordagem mais integradora, que alia a conservação da geodiversidade e do patrimônio geológico ao seu contexto social. Fortalece assim ações orientadas para o (re)conhecimento da geodiversidade e do patrimônio geológico a partir das apreensões já existentes, decorrentes do seu olhar sobre o ambiente.

O desenvolvimento da Geoconservação como área emergente se dá a partir do olhar geocientífico, portanto, essa é uma das lentes que devem ser integradas às estratégias de Conservação. Santos $(2006,2011)$ introduz o conceito de "olhar geocientífico" em sua abordagem no contexto escolar, como contribuição à formação dos indivíduos (professores e alunos) para o tratamento de temas ambientais. A autora destaca que a Geologia ou Geociências "revela sua importância para a compreensão do desenvolvimento histórico do planeta e suas transformações, e, portanto, para o tratamento da Terra como uma totalidade" (SANTOS, 2006, p. 11), assim, na perspectiva de apreensão socioambiental do lugar, as Geociências "promovem o entendimento das relações sociedade-natureza e seus processos" (SANTOS, 2011, p. 33).

Portanto, integrar o olhar geocientífico às práticas de conservação da natureza permite incorporar os conhecimentos acerca do Sistema Terra, proporcionando a compreensão dos problemas ambientais de forma mais abrangente, contribuindo com a formação de 
cidadãos mais comprometidos com a sustentabilidade do planeta. Nesse sentido, as estratégias de conservação da natureza se relacionam a uma série de problemas complexos que demandam o olhar geocientífico, alguns deles foram apontados por Bacci e Boggiani (2015), como a expansão urbana sobre áreas irregulares e de risco, falta de planejamento quanto aos recursos hídricos e até mesmo a contaminação dos aquíferos e a exploração de recursos minerais.

Diante o papel das Geociências na formação cidadã para a sustentabilidade, Santos (2006) ressalta ainda que

\begin{abstract}
Ao propiciar uma compreensão integrada dos processos terrestres desempenha papel significativo na formação da consciência ambiental, o ensino em Geociências a partir da educação socioambiental tem fundamental contribuição na formação de cidadãos, aqui entendidos como sujeitos capazes de observar/conhecer o meio em que vivem; refletir sobre este meio e suas determinações, bem como propor/construir intervenções educativas frente aos problemas estudados visando o desenvolvimento de ações/soluções para estes, em busca da transformação da realidade socioambiental a compreensão integrada dos processos terrestres (SANTOS, 2006, p. 12).
\end{abstract}

Nessa perspectiva, a IUCN no âmbito das Resolutions and Recomendations (2009) toma nota da relevância da proclamação do Ano Internacional do Planeta Terra em 2008, que representou esforços da ONU, IUGS e da UNESCO em promover ações em âmbito local, nacional, regional e internacional para o incremento na consciência da importância do Sistema Terra para o desenvolvimento sustentável. Assim, reconhece que a geodiversidade "é um importante fator natural que sustenta a diversidade biológica, cultural e paisagística, bem como um importante parâmetro a ser considerado na avaliação e manejo das áreas naturais" (IUCN, 2009, p. 44).

Portanto, a perspectiva socioambiental está intrínseca aos conceitos de geodiversidade e patrimônio geológico, e orientam as estratégias e ações para sua conservação. Da mesma maneira, a apreensão dos próprios valores e ameaças da geodiversidade decorre de um contexto socioambiental.

As orientações propostas por Mansur e Silva (2010), Avelar et al. (2014), Castro, Mansur e Carvalho (2015) seguem a esse propósito por elucidar as contribuições advindas de metodologias de coleta e análise de dados que se voltam para os moradores locais para estabelecer estratégias de geoconservação em determinado contexto. 
Além disso, os caminhos traçados pelas metodologias participativas e Aprendizagem Social emergem nos contextos educativos e de envolvimento de diversos atores sociais para a Geoconservação, embasando propostas significativas, que vão ao encontro das pesquisas desenvolvidas por Bacci, Jacobi e Santos (2013), Jacobi (2011, 2013), Santos (2006, 2011) e Soares (2016).

A partir dessas considerações, segue-se a apresentação de duas abordagens consideradas essenciais nessa pesquisa que orientaram a aproximação dos pesquisadores com os moradores locais para adequar e propor as estratégias de geoconservação.

\subsubsection{A Percepção Ambiental como contributo à Geoconservação}

Os estudos em Percepção Ambiental voltam-se para a análise da interação do indivíduo com o ambiente. Assim, nessa dinâmica apresentam-se relações de lugar com ambientes vivenciados e experienciados a partir de um determinado contexto sociocultural. A forma com que percebemos a realidade e o ambiente é influenciada por uma série de fatores relacionados aos nossos sentidos, que possuem implicações diretas na conduta dos indivíduos em relação ao ambiente. Reforça-se aqui a concepção da dinâmica perceptiva em relação ao ambiente como subsídio a projetos de Educação Ambiental e de popularização das Geociências, contribuindo assim com uma nova forma de olhar e de perceber a natureza integrando a dinâmica física à realidade socioambiental.

Del Rio e Oliveira (1996) realizaram um importante ensaio em que reúnem referências de estudos em Percepção Ambiental desenvolvidos no Brasil. Nesse trabalho são apresentados esclarecimentos teóricos e metodológicos que tangenciam essas pesquisas. Além disso, os autores compartimentam os trabalhos em três grupos, o primeiro refere-se a pesquisas que através da percepção ambiental visam nortear projetos de intervenção, especialmente da área de Arquitetura e Urbanismo. No segundo grupo identificam pesquisas que se voltam para a interpretação da realidade, sendo a percepção contributo a essa interpretação dos fenômenos, estando no escopo principalmente da Psicologia da Percepção. No terceiro grupo, inserem-se os trabalhos que compreendem a percepção "na e para a educação ambiental" no seu sentido formativo e em relação ao sistema de valores.

Na coletânea, o conceito de percepção apresentado por Del Rio e Oliveira (1996) é o mais amplo possível, sendo um processo mental, em as pessoas estruturam e organizam a sua interface com a realidade e com o mundo, considerando seus interesses e necessidades. 
Selecionam-se assim as informações percebidas, que são armazenadas e recebem significados pelos indivíduos.

Del Rio (1996) ilustra esse processo perceptivo através do esquema teórico apresentado na Figura 3. Segundo o autor, a percepção é um processo mental que ocorre a partir da interação do indivíduo com o ambiente, decorrente de mecanismos perceptivos (visão, audição, tato, olfato e paladar) e cognitivos (com a influência da inteligência, envolve motivações, humor, necessidades, conhecimentos prévios, valores, julgamentos e expectativas).

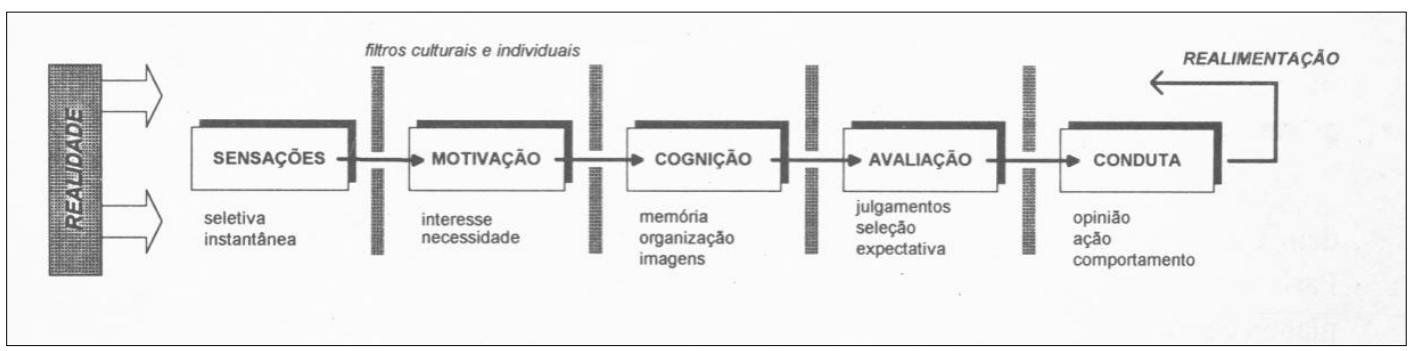

Figura 3 - Esquema teórico do processo perceptivo (DEL RIO, 1996, p. 3).

A partir de uma determinada realidade serão acionadas nossas sensações, mecanismos perceptivos referentes aos nossos sentidos (visão, audição, olfato, tato e paladar) e, num segundo momento ocorre a ação da inteligência. Neste caso, há uma interferência da nossa mente sobre aquilo que sentimos, considerando as motivações, os humores, necessidades, conhecimentos prévios, valores, julgamentos e expectativas. A organização e atribuição de significados pela realidade captada serão influenciadas pelos nossos filtros culturais e individuais, possuindo atributos específicos para cada indivíduo (DEL RIO, 1996).

Há neste tipo de estudo uma subjetividade inerente, porém analisar quais fatores influenciam a percepção das pessoas é um passo importante para compreender seus julgamentos e expectativas, bem como a conduta resultante deste processo, que é revelada a partir da opinião, ação e comportamento dos indivíduos, que estão em constante contato com a realidade e realimentando esse processo.

Kuhnen (2011) contribui com a análise do campo da Percepção Ambiental, apresentando em sua revisão os trabalhos de Ittelson (1978), que define a Percepção Ambiental 
socioculturais (significados, valores, estética) e históricos (contextos políticos, economia, etc.) (KUHNEN, 2011, p. 255).

Apreende-se que um conjunto de fatores irá influenciar essa relação entre o indivíduo e o ambiente, sendo, portanto a percepção uma forma de vivenciar e se relacionar com o lugar. O processo perceptivo é considerado a partir da dinâmica dos estímulos externos com o qual os indivíduos interagem, considerando também suas experiências, memórias, concepções, contextos socioculturais, e as formas de interpretar determinado fenômeno. Desse modo, a percepção ambiental se revela sob o olhar de cada indivíduo em relação ao seu lugar, apresentando elementos de sua experiência, aspectos que afirmam sua identificação com o lugar vivenciado.

Cada imagem e ideia sobre o mundo são compostas, portanto, de experiência pessoal, aprendizado, imaginação e memória. Os lugares em que vivemos, aqueles que visitamos e percorremos, os mundos sobre os quais lemos e vemos em trabalhos de arte, e os domínios da imaginação e da fantasia contribuem para as nossas imagens da natureza, de tudo o que o homem constrói e dele próprio. Todos os tipos de experiências, desde os mais estreitamente ligados com o nosso mundo diário até aqueles que parecem remotamente distanciados, vêm juntos compor o nosso quadro individual da realidade. A superfície da Terra é elaborada para cada pessoa pela refração por meio de lentes culturais e pessoais, de costumes e fantasias. Todos nós somos artistas e arquitetos de paisagens, criando ordem e organizando espaços, tempo e causalidade, de acordo com nossas percepções e predileções (MACHADO, 1996, p. 97).

No sentido das relações do indivíduo com o seu "mundo diário" como apresentou Machado (1996), há construção de uma relação de pertencimento e identificação com o lugar a partir das lentes que o indivíduo utiliza para a interpretação do real.

O conceito de lugar toma sentido na apreensão da percepção ambiental uma vez que compreende a perspectiva dos laços afetivos estabelecidos entre indivíduo e meio, relacionando o mundo físico e palpável ao mundo imagético e sensitivo. Segundo Carlos (1996)

Lugar é uma base para a reprodução da vida, podendo ser analisado pela tríade habitante-identidade-lugar. Esta base permite a reprodução das relações, da sociabilidade, da existência dos indivíduos, e este lugar terá significado graças justamente a essa experiência local cotidiana (CARLOS, 1996, p. 20).

Dessa forma, compreender a dinâmica perceptiva dos indivíduos em relação ao seu ambiente pode contribuir para o desenvolvimento de estratégias que se preocupam com 
mudanças no aspecto perceptivo para a construção de um novo olhar. No âmbito da conservação da natureza, propõe um olhar integrado, que reconhece e valoriza as interações entre os meios físico, biológico e sociocultural. Considera-se também as implicações comportamentais relacionadas à percepção, no qual se dá a compreensão dos problemas ambientais e a aquisição de novos sentidos e significados em relação à essa realidade, proporcionando uma nova atitude em relação a esse ambiente apreendido.

\subsubsection{Geoconservação no âmbito das metodologias participativas}

As estratégias de geoconservação baseadas no envolvimento e participação das comunidades locais perpassam por estratégias de comunicação e divulgação das Geociências, associando assim a Geoconservação ao contexto educativo.

Brilha, Dias e Pereira (2006) destacam a contribuição da educação em proporcionar a sensibilidade das pessoas em relação à relevância da conservação do patrimônio geológico. Na Figura 4 é apontada uma ligação direta entre a possibilidade de promover o ensino de Geologia/Geociências a partir da Geoconservação, com foco nos geossítios de interesse pedagógico, do mesmo modo que o ensino de Geologia/Geociências promove a sensibilização para a Geoconservação.

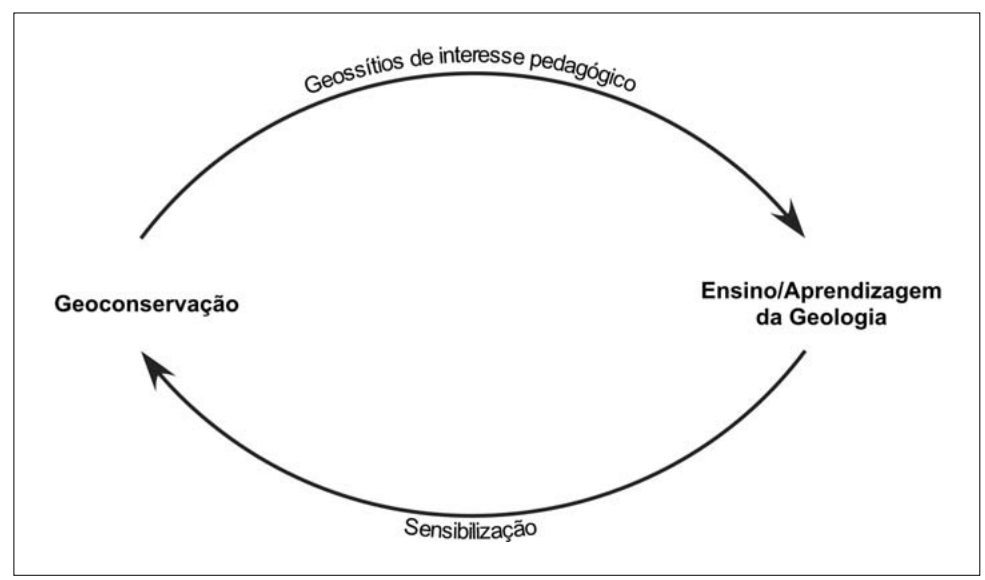

Figura 4 - A relação da Geoconservação com o Ensino/Aprendizagem da Geologia (BRILHA, DIAS \& PEREIRA, 2006, p. 446).

Pacheco e Brilha (2014) trazem à luz o papel da interpretação para a compreensão do significado do patrimônio geológico contribuindo para sua conservação. Com base em Tilden (1957) relacionam a interpretação como atividade educativa para fornecer informações, 
significados e relações. Assim, a interpretação está relacionada a uma amplitude de abordagens uma vez que

é um serviço que se presta aos visitantes no sentido de lhes revelar em parte a beleza, a maravilha, a inspiração e o significado espiritual do que se esconde por detrás do que o visitante é capaz de conjeturar só com os sentidos (TILDEN, 1957 apud PACHECO \& BRILHA, 2014, p. 102).

Assim, nessa revisão, os autores revelam o papel da interpretação como comunicação capaz de favorecer que o público estabeleça conexões (emocionais, intelectuais e físicas) com o elemento que está sendo interpretado. Os autores sintetizam os instrumentos ou recursos interpretativos amplamente utilizados para a interpretação do patrimônio natural e cultural segundo Morales (2001), sendo muitas vezes aplicáveis ao patrimônio geológico. Esses recursos se referem àqueles que podem ser utilizados de forma autônoma, ou com o auxilio de guias e/ou outros profissionais como os painéis, sinais e placas, exposições, simulações, percursos, dentre outros (PACHECO \& BRILHA, 2014).

O ensino em Geociências e a interpretação do patrimônio geológico têm sido desenvolvidas principalmente nas etapas de valorização e divulgação da geoconservação, sendo a valorização precedente à divulgação, referindo-se "ao conjunto de ações de informação e interpretação que vão ajudar o público a reconhecer o valor dos geossítios" (BRILHA, 2005, p. 108).

Também é possível tecer relações quanto à popularização das Geociências e a Geoconservação, no sentido de ampliar o acesso da população como um todo para compreender a importância científica e didática do patrimônio geológico, reforçando sua relevância como suporte para os sistemas ecológicos (MANSUR, 2009).

A autora supracitada destaca algumas ferramentas essenciais que vem compondo a valorização e divulgação do patrimônio geológico, tendo como base os pressupostos da Educação Ambiental, no contexto da sustentabilidade. Assim, o conhecimento geocientífico contribui para compreender a dinâmica histórica da vida na Terra a partir da visão geológica, e o papel do homem como agente geológico no ambiente.

Essas atividades têm sido amplamente desenvolvidas no contexto dos Geoparques. Os Geoparques são áreas delimitadas geograficamente que conjugam o desenvolvimento sustentável à conservação do patrimônio geológico, integrando essas estratégias aos patrimônios naturais e culturais desse lugar, proporcionando melhorias nas condições de vida dos seus habitantes (BRILHA, 2009). Nesse sentido, os Geoparques inseridos na Rede Global 
de Geoparques da UNESCO são locais singulares, com sítios e paisagens de relevância internacional, geridos a partir de um conceito holístico de proteção, educação e desenvolvimento sustentável (UNESCO, 2016).

Brilha (2005) considera o papel da Geoconservação no contexto da sustentabilidade, pois em seu sentido mais amplo, a Geoconservação prevê "a gestão sustentada dos recursos geológicos, assegurando as técnicas de exploração e de beneficiação mais adequadas e o menor impacto possível no ambiente" (p. 52) e, de um modo mais específico "consiste na implementação de estratégias que permitam a conservação de ocorrências geológicas que possuem inegável valor científico, pedagógico, cultural, turístico, ou outros - os geossítios" (p. 52).

Nessa acepção, Brilha (2005) destaca a definição do Relatório Brundtland para o desenvolvimento sustentável, sendo este o "desenvolvimento que satisfaz as necessidades presentes sem comprometer a capacidade das gerações futuras satisfazerem as suas próprias necessidades" (BRILHA, 2005).

Portanto, a ideia central que a sustentabilidade traz é do questionamento do modo com que a humanidade tem explorado os recursos naturais, sendo necessário fazer correlações com os aspectos da desigualdade entre os povos e o acesso à esses recursos. Nesse sentido, Jacobi (1999) aborda a questão da sustentabilidade sob o ângulo da "inter-relação entre justiça social, qualidade de vida, equilíbrio ambiental e a necessidade de desenvolvimento com capacidade de suporte" (JACOBI, 1999, p. 180).

Assim, vê-se que o conceito de sustentabilidade tem marcado de forma crescente os pressupostos da Geoconservação, encontrando lugar e dando maior significado às ações que visam à conscientização e sensibilização dos indivíduos para a importância da conservação do patrimônio geológico. Na apreensão do sentido de sensibilização a partir do olhar sobre a sustentabilidade e as estratégias educativas, Jacobi (2003, 2005) chama a atenção para um processo de sensibilização das pessoas para o enfrentamento dos problemas ambientais, fortalecendo a co-responsabilidade para fiscalizar e controlar a degradação ambiental.

A pertinência em abordar a Geoconservação no âmbito da sustentabilidade insere a reflexão sobre a necessidade de mudanças de comportamentos, valores e atitudes incidindo sobre a organização social e a participação. Segundo Jacobi $(2011$, p. 12) "O maior desafio é a "reforma do pensamento" avançando para uma nova forma de conhecimento, criando espaços de convivência que promovem mudanças de percepção e de valores”.

Nesse sentido, a nova forma de compreender a relação do homem com a natureza é parte do escopo da Educação Ambiental no contexto da educação para a cidadania, 
promovendo um processo permanente de aprendizagem, valorizando os diversos saberes e promovendo um processo de co-responsabilidade (JACOBI, 2009).

A problemática socioambiental, ao questionar ideologias teóricas e práticas, propõe a participação democrática da sociedade na gestão dos seus recursos atuais e potenciais, assim como no processo de tomada de decisões para a escolha de novos estilos de vida e a construção de futuros possíveis, sob a ótica da sustentabilidade ecológica e a equidade social (JACOBI, 2003, p. 200).

Recentemente, têm-se utilizado o conceito de Aprendizagem Social para ressaltar a aprendizagem decorrente de ações que reúnem uma diversidade de atores sociais mobilizados na resolução de uma problemática. No contexto educativo, a Aprendizagem Social valoriza a interdisciplinaridade entre diversos saberes e a participação de diferentes atores sociais em decorrência das transformações socioambientais (MONTEIRO, 2009).

Monteiro (2009) destaca três aspectos da Aprendizagem Social que corroboram com as reflexões desenvolvidas na presente pesquisa. Para o autor, num primeiro momento a Aprendizagem Social se refere à forma como os indivíduos constroem suas "visões de mundo", ou seja, quais as formas e processos pelos quais os indivíduos dão sentido à realidade. O segundo aspecto refere-se aos "conceitos", ou seja, a Aprendizagem Social prioriza um olhar holístico e sistêmico, reforçando as interdependências entre os elementos. Como terceiro aspecto, observa as "relações e interações entre os indivíduos", reforçando a importância dos diálogos e das conversas significativas ao proporcionar reflexões sobre suas concepções, valores e práticas, tendo como referência a participação social.

Observa-se que a inserção dessas questões no contexto da Geoconservação reforça a perspectiva da sustentabilidade nessa área do conhecimento, traçando caminhos a partir de ações educativas, ações de valorização e divulgação e de apreensão das percepções locais para a geoconservação.

Verifica-se assim a pertinência em relacionar o debate sobre sustentabilidade e a Geoconservação, destacando-se três fatores:

- A Geoconservação se insere na dimensão da concepção socioambiental e holística da natureza, integrando o meio social, biológico e físico;

- A Geoconservação prescinde do reconhecimento da geodiversidade e do patrimônio geológico pela sociedade como um todo. Nesse sentido, toma-se como referência as ações educativas e comunicativas sustentadas nos pressupostos da 
Educação Ambiental, ou, de uma forma mais abrangente da Aprendizagem Social, na perspectiva da sensibilização e enfrentamento das questões ambientais de forma participativa e propositiva;

- As estratégias de geoconservação fortalecem o sentimento de identificação e pertencimento com o lugar, e podem sustentar assim ações de desenvolvimento econômico sustentável com base no geoturismo e no turismo ecológico para o beneficiamento das comunidades do entorno, como preconizado pelas propostas dos Geoparques. 


\section{CAPÍTULO 3 - O AMBIENTE FÍSICO E HISTÓRICO-SOCIAL DOS NÚCLEOS PICINGUABA E CARAGUABATUBA}

A área de estudo corresponde aos núcleos Picinguaba e Caraguatatuba do Parque Estadual da Serra do Mar (PESM), que se estendem em grande parte pelos municípios de Ubatuba e Caraguatatuba respectivamente, na região do litoral norte de São Paulo. As características físicas e sociais dessa região compõem um quadro bastante diverso e singular em relação à sua paisagem e suas interações físico-sociais.

O bioma predominante na região é o da Mata Atlântica, sendo verificada, a partir de dados do Inventário Florestal de 2010 realizado pelo Instituto Florestal, a presença de Floresta Ombrófila Densa, Vegetação Secundária da Floresta Ombrófila Densa, Formação Arbórea/Arbustiva-herbácea sobre Sedimentos Marinhos Recentes, Formação Arbórea/Abustiva-herbácea de Terrenos Marinhos Lodosos, Formação Arbórea/Arbustivaherbácea em Região de Várzea. De acordo com dados da Secretaria de Estado do Meio Ambiente (SMA), Coordenadoria de Planejamento Ambiental (CPLA) e Departamento de Informações Ambientais (DIA) de 2009, o município de Ubatuba apresenta 89,90\% de cobertura vegetal nativa, e Caraguatatuba possui 79,10\% (SECRETARIA AMBIENTAL PAULISTA, 2017).

O Clima predominante é o tropical úmido, sendo que a região do litoral norte é controlada por massas equatoriais e tropicais, apresentando clima úmido nas costas expostas à massa tropical atlântica, com menor precipitação naquelas expostas às massas polares. Possui como características predominantes altas pluviosidades, mesmo nos períodos de inverno, determinadas pelo efeito orográfico da proximidade da Serra do Mar junto à costa (SÃO PAULO, 2006).

Segundo dados do Centro de Pesquisas Meteorológicas e Climáticas Aplicadas à Agricultura (CEPAGRI, 2017), Caraguatatuba e Ubatuba estão inseridas na faixa litorânea pela classificação climática de Koeppen, apresentando clima tropical chuvoso, sem estação seca, com precipitação média do mês mais seco superior a $60 \mathrm{~mm}$. O município de Caraguatatuba apresenta temperatura média anual de $24,9{ }^{\circ} \mathrm{C}$, sendo a média da temperatura mínima anual de $18,2^{\circ} \mathrm{C}$ e a máxima de $31,6{ }^{\circ} \mathrm{C}$. A quantidade média de chuva é de 1757,9 $\mathrm{mm} / \mathrm{ano}$. Em Ubatuba a temperatura média anual é de $22,6^{\circ} \mathrm{C}$, com média mínima anual de $17,8^{\circ} \mathrm{C}$, e máxima de $27,3{ }^{\circ} \mathrm{C}$. A quantidade média de chuva do município é de 2154,2 $\mathrm{mm} / \mathrm{ano}$. 
Os materiais e processos geológicos que compõem a geodiversidade do litoral norte

de São Paulo possuem relações com a fusão e quebra do Supercontinente Gondwana no Neoproterozoico - Paleogeno (GARCIA, 2012). O contexto geológico da região abrange o Orógeno Ribeira da Província Mantiqueira (ALMEIDA et al., 1977, 1981), marcado por processos de amalgamação, desenvolvimento e fragmentação do Supercontinente Gondwana e abertura do Atlântico Sul.

\subsection{Geologia Regional}

A área de estudo está inserida na Faixa Ribeira, que compõe junto com outros cinturões a Província Mantiqueira (ALMEIDA et al., 1977, 1981) de idade Neoproterozoica. Inserido nesse orógeno, destaca-se em uma escala de maior detalhamento o Domínios Costeiro e as Coberturas Sedimentares Cenozoicas.

A seguir estas unidades serão detalhadas, para dar suporte à compreensão do inventário do patrimônio geológico de Ubatuba e Caraguatatuba, e as estratégias de valorização e conservação propostas.

\subsubsection{Província Mantiqueira}

O conceito de Províncias Estruturais (ALMEIDA et al., 1977, 1981) agrupa unidades que apresentam feições semelhantes de evolução estratigráficas, tectônicas, magmáticas e metamórficas. Os limites destas unidades apresentam-se por vezes bem delimitados, através de feições estruturais, entretanto também podem aparecer de forma mais gradual, com limites ainda pouco definidos. Observa-se na Figura 5 as Províncias Estruturais do Brasil: 


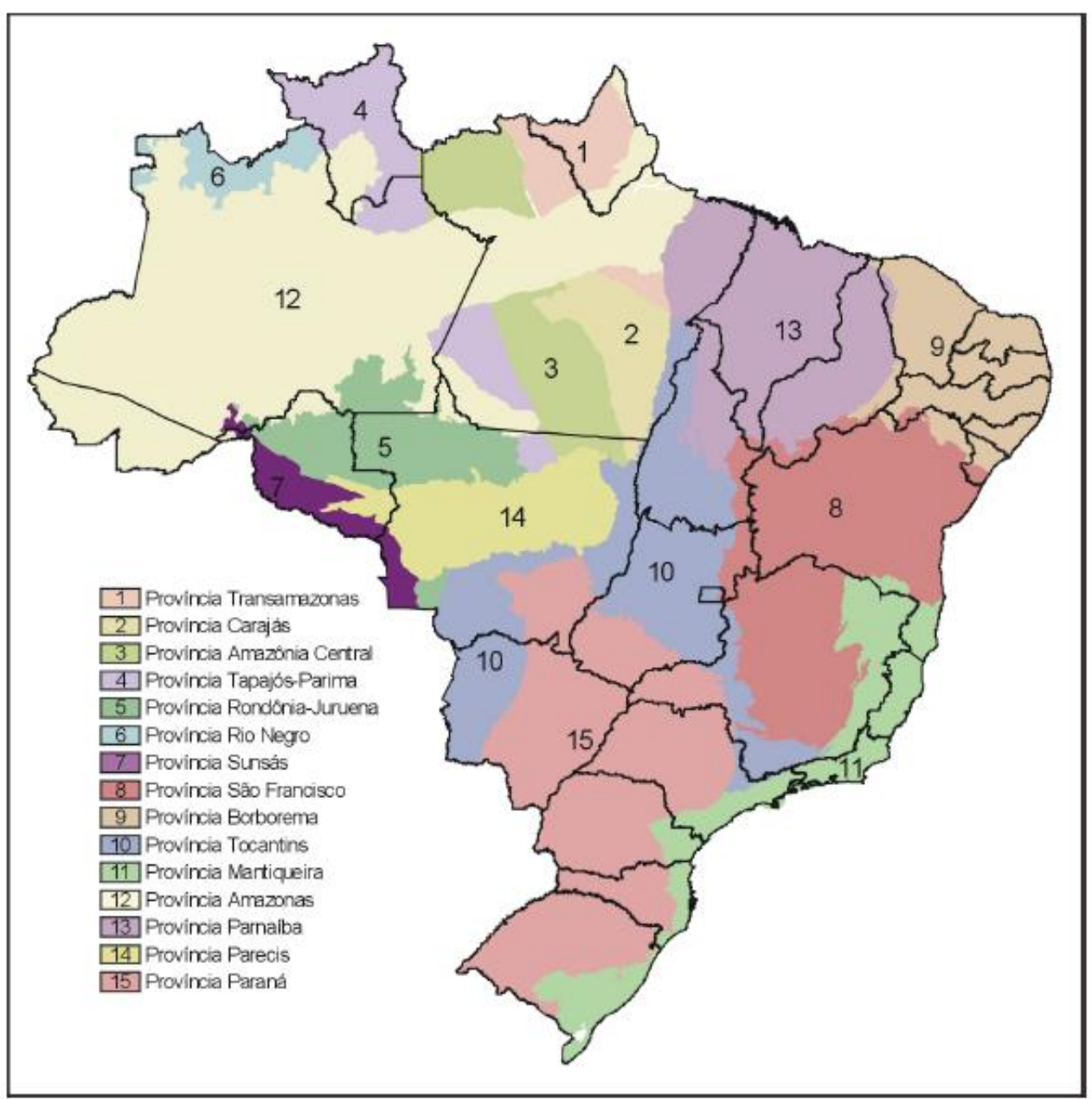

Figura 5 - Províncias Estruturais do Brasil (BIZZI et al., 2003, adaptado de ALMEIDA, 1981).

Pode-se verificar na Figura 5 que a Província Mantiqueira se estende paralelamente à costa sudeste e sul do Brasil, apresentando cerca de $3.000 \mathrm{~km}$ de comprimento, com orientação predominante NE-SW. No contexto geotectônico está inserida no Sistema Orogênico Mantiqueira, sendo composta de norte a sul pelos orógenos Araçuaí, Ribeira, Dom Feliciano e São Gabriel (HEILBRON et al., 2004).

O Sistema Orogênico da Mantiqueira se apresenta como resultado da amalgamação do Supercontinente Gondwana, durante o Neoproterozoico-Cambriano, reconhecido como orogênese brasiliana, se estendendo de 880 Ma a 480 Ma, quando houve a estabilização da plataforma. Nessa província, a orogênese brasiliana manifesta-se principalmente de forma diacrônica, incluindo processos acrescionários, de colisão continente-continente e de colapso extensional (HEILBROM et al., 2004).

Para Hasui (2010), os movimentos de colisão entre as placas tectônicas da América do Sul e da África tiveram início no Brasiliano I (900- $700 \mathrm{Ma}$ ), se estendendo por todo o Brasiliano II (670-530 Ma) e Brasiliano III (580 - 490 Ma). Na Placa Sul-Americana 
formaram-se os Sistemas Orogênicos Mantiqueira, Tocantins e Borborema. A consolidação final do Megacontinente Gondwana é datada em 460 Ma.

A Figura 6 ilustra o Supercontinente Gondwana, subdividido em Gondwana Ocidental e Oriental com destaque para os sistemas orogênicos.

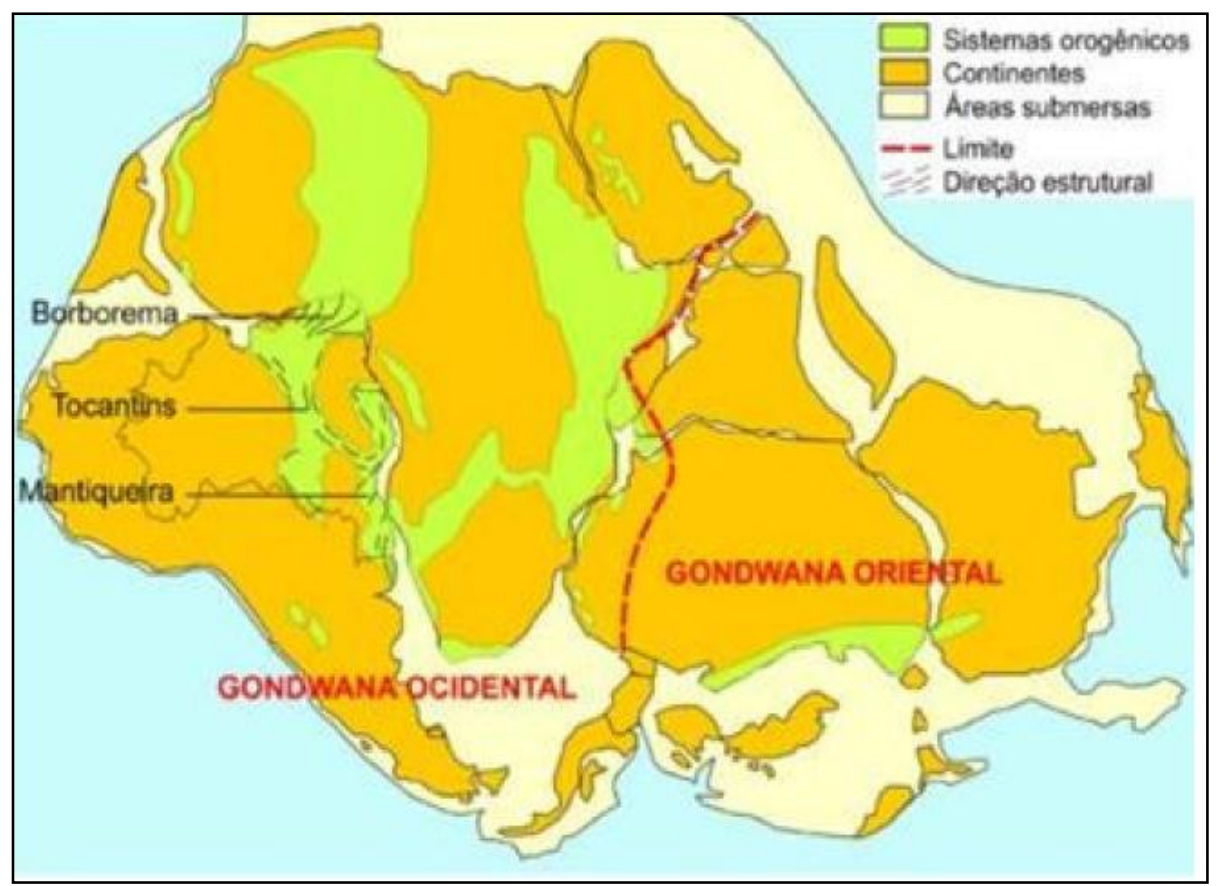

Figura 6 - O Megacontinente Gondwana (HASUI, 2010, p. 145, modificado de WITT et al., 1999).

A subdivisão do Sistema Orogênico Mantiqueira em orógenos (HEILBRON et al., 2004) é reflexo da diacronia durante o processo de colisão, provocando o empilhamento dos terrenos de leste para oeste. De acordo com Hasui (2012), o Sistema Orogênico Mantiqueira é composto pelo maior conjunto de supracrustais do Neoproterozoico ao Cambriano.

De acordo com Hasui (2010) em termos litoestruturais destacam-se:

1. Unidades do Arqueano a Paleoproterozoico (ciclos Transamazônico, Jequié e outros): Complexos granito-gnáissicos, com pequenas faixas de greestone belts, pacotes vulcanossedimentares e rochas máficas e ultramáficas;

2. Unidades do Paleoproterozoico e Mesoproterozoico (fragmentação continental): pacotes sedimentares de riftes e intrusivas e vulcânicas básicas e ácidas;

3. Unidades do Neoproterozoico (fragmentação do Rodínia e abertura do oceano): prismas de acresção envolvendo supracrustais vulcanossedimentares, intrusões sin e tardicolisionais (principalmente de granitos), coberturas do Cráton São Francisco, Pacotes vulcanossedimentares e corpos magmáticos pós-colisionais. 
A Figura 7 ilustra as entidades mais relevantes situadas a leste do Cráton Amazônico, sendo elas o Sistema Orogênico do Tocantins, e o Sistema Orogênico Mantiqueira (subdividido em Cinturão Araçuaí, Cinturão Ribeira e Cinturão Tijucas). Assim, pode-se observar as unidades predominantes nesse sistema.

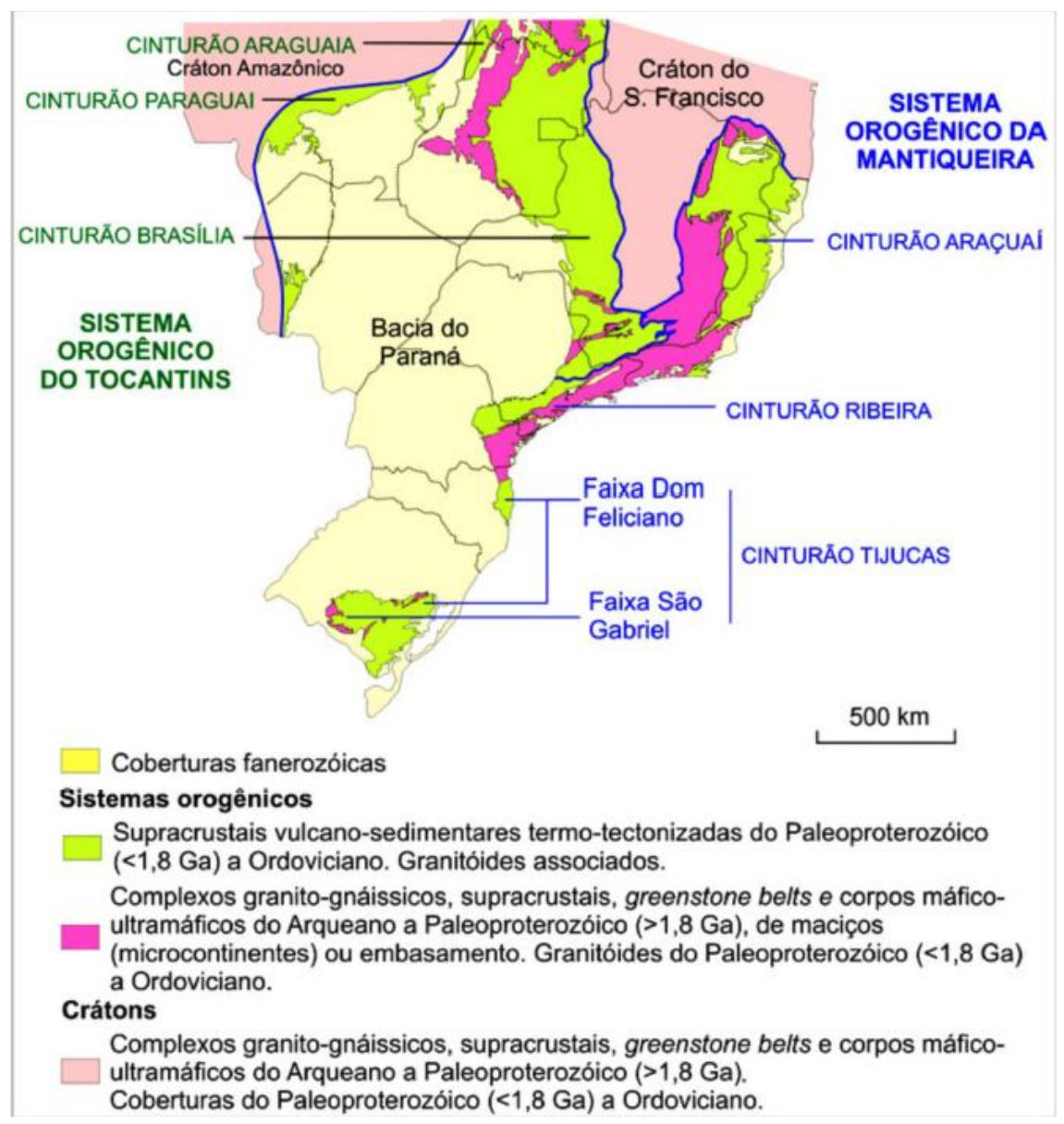

p. 142).

Figura 7 - O Sistema Orogênico do Tocantins e o Sistema Orogênico da Mantiqueira (HASUI, 2010,

\subsubsection{O Orógeno Ribeira e o Domínio Costeiro}

O Orógeno Ribeira (HEILBRON et al., 2004) que também pode ser denominado Faixa Ribeira (CORDANI et al., 1973) ou Cinturão Ribeira (HASUI, CARNEIRO \& COIMBRA, 1975) abrange o segmento central do Sistema Orogênico Mantiqueira. Sua formação resultou principalmente da interação entre o Cráton do São Francisco e o Cráton do Congo, ocasionando o empilhamento de terrenos de leste para oeste-noroeste (HEILBRON et al., 2004). 
Segundo Hasui (2010, 2012), nessa seção do Sistema Orogênico Mantiqueira houve convergência frontal de forma mais oblíqua, assim, a deformação transcorrente é o aspecto de maior destaque no cinturão Ribeira. Com a transfiguração do Cinturão formou-se um feixe de zonas de cisalhamento que compõem o Sistema Transcorrente Paraíba do Sul, marcado pela direção NE-SW (Figura 8). Tais estruturas são conhecidas como estruturas brasilianas, estando muito bem marcadas nas evidências estruturais.

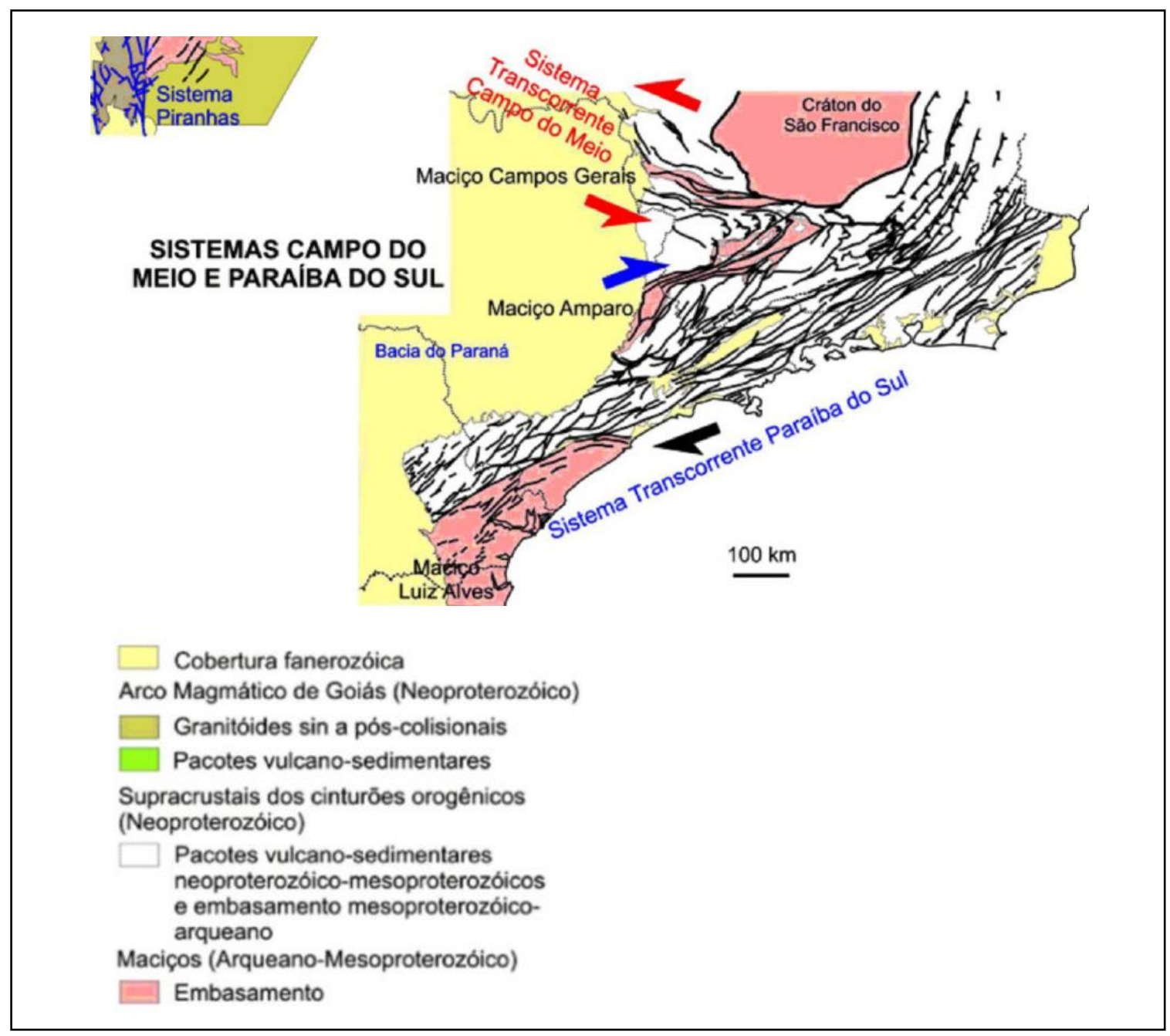

Figura 8 - Sistemas Transcorrentes Campo do Meio e Paraíba do Sul (HASUI, 2010, p. 154).

O Orógeno Ribeira é subdividido em cinco terrenos: Ocidental, Parnaíba do Sul, Embu, Oriental - Serra do Mar e Cabo Frio. A colisão oblíqua entre os terrenos determinou limites entre esses compartimentos que se apresentam a partir de falhas de empurrão com mergulho de $30^{\circ}$ ou mais. Esses limites também podem ser definidos por zonas de cisalhamento oblíquas (HEILBRON et al., 2004).

Para Heilbron et al. (2004), as seguintes unidades lito-estratigráficas compõem o Orógeno Ribeira: 
a) Embasamento Arqueano e/ou Paleoproterozoico mais velho que 1,7 Ga;

b) Sequências metassedimentares depositadas em bacias intracontinentais Paleoproterozoicas a Mesoproterozoicas;

c) Sequências metassedimentares e metavulcano-sedimentares Neoproterozoicas que incluem sequências de margem passiva (abertura oceânica), sequências relacionadas ao fechamento de oceanos (bacias de ante-arco e retro-arco), e ao estágio da colisão continental (bacias molássicas e de antepaís);

d) Granitóides Neoproterozoicos pré-colosionais, gerados em arco magmático intraoceânico ou de margem continental ativa, e, portanto, contemporâneos aos processos de subducção;

e) Granitóides Neoproterozoicos sincolisionais;

f) Coberturas Neoproterozoico-Cambrianas associadas a bacias tardi-orogênicas e magmatismo pós-colisional.

A área de estudo centra-se no Terreno Oriental do Orógeno Ribeira que é subdividido em Domínios Costeiro, Cambuci e Italva de acordo com a Figura 9, apresentando características litológicas e cronoestratigráficas diferenciadas (HASUI, 2012). Predominam neste terreno associações de anfibolitos e gnaisses, intercalados com mármores, quartzitos e camadas calco-silicáticas, além de rochas graníticas foliadas e não foliadas (HEILBRON \& MACHADO, 2003).

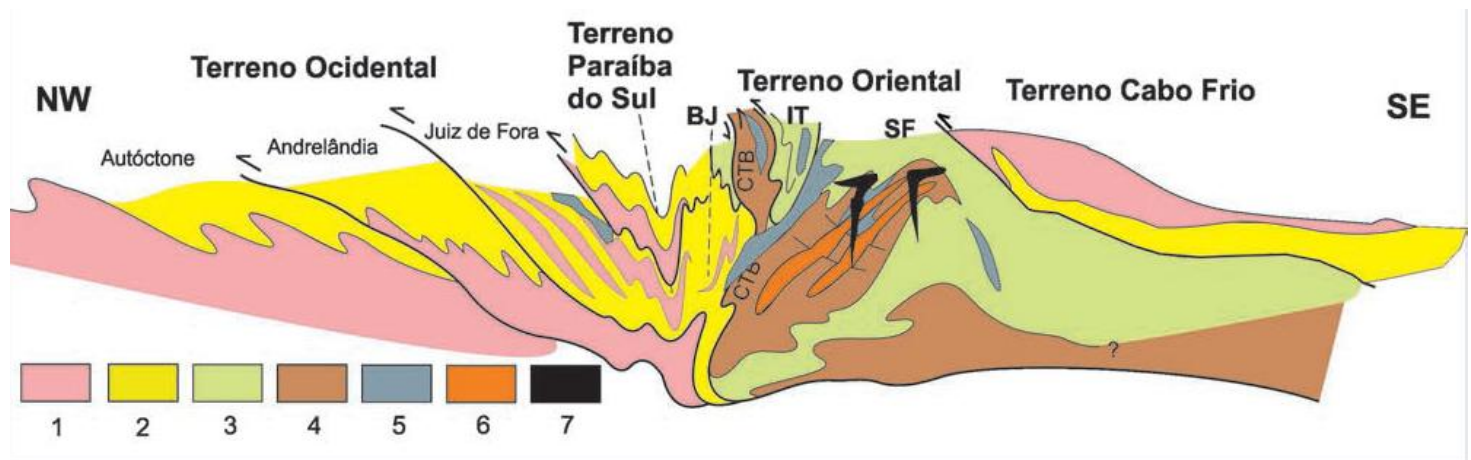

Figura 9 - Compartimentação tectônica da Faixa Ribeira entre a borda do Cráton do São Francisco e o litoral fluminense. 1 - Embasamento Paleoproterozoico; 2 - Cobertura metassedimentar pós 1,8 Ga; 3 - Sequências metassedimentares à volta do arco magmático; ITV - Grupo Italva; BJ - Grupo Bom Jesus do Itabapoana; SF Grupo São Fidélis; 4 - Complexo Rio Negro, ortognaisses do Arco Magmático; 5 - Leucognaisses graníticos da Suíte Cordeiro; 6 - Gnaisses metaluminosos da Suíte Serra dos Órgãos; 7 - Granitos da Suíte Nova Friburgo (TUPINAMBÁ, TEIXEIRA \& HEILBRON, 2012, p. 143).

O Complexo Costeiro (HASUI et al., 1981), ou Domínio Costeiro (HEILBRON \& MACHADO, 2003), se estende desde o sul da Bacia de São Paulo até o Paraná. A norte está 
limitado pela falha de Cubatão e o Domínio Embu, e a sul, se encontra com a linha de costa (PERROTA et al., 2005).

O Complexo Costeiro reflete os processos de aglutinação do Supercontinente Gondwana e a instalação do arco magmático Complexo Rio Negro. Compreende assim unidades metassedimentares e rochas graníticas jovens (HEILBRON \& MACHADO, 2003).

É descrito contendo principalmente ortognaisses, gnaisses bandados, rochas granulíticas, micaxistos, quartzitos arcoseanos, rochas cálcio-silicáticas, metamafitos e intrusões de granitoides e charnockitoides. Além disso, apresenta corpos pequenos de anfibolitos metamorfizados (HASUI, 2012).

\subsubsection{Reativação Mesozoica - Formação Rift Continental do Sudeste do Brasil}

A reativação mesozoica é reconhecida pelo conjunto de eventos do Jurássico ao Eoceno, com predomínio de esforços extensionais sobre as placas litosféricas, resultando na ruptura do Pangea, fragmentação do Gondwana e separação dos continentes sul americano e africano e abertura do Atlântico Sul (MIZUSAKI \& FILHO, 2004).

Essa reativação foi marcada por diversos episódios magmáticos, em fases de rifteamento e deriva continental. Essas manifestações deram preferência às regiões influenciadas pela orogênese brasiliana, a partir da reativação de antigas falhas e fraturas (ALMEIDA, CARNEIRO \& BARTORELLI, 2012).

Almeida (1967) refere-se aos processos que marcaram a ruptura do Gondwana Ocidental como Reativação Walderiana e posteriormente como Ativação Mesozoica (ALMEIDA, 1972), ou ainda, como Evento Sul-Atlantiano (SCHOBBENHAUS et al., 1984), tendo se iniciado com o derrame basáltico da Formação Serra Geral no Eocretáceo (RICCOMINI, SANT'ANNA \& FERARI, 2004). Este primeiro pulso refere-se ao magmatismo basáltico toleítico, que provocou a formação de feições extensionais de riftes, soerguimento de arcos e abatimento de bacias sedimentares (MOHRIAK, 2004).

Tais manifestações se deram por pulsos ou ciclos magmáticos descontínuos, desde o Cretáceo até o Terciário (ALMEIDA \& CARNEIRO, 1998). As manifestações alcalinas decorreram em três principais fases, sendo que a primeira fase do Permo-Triássico afetou a região amazônica. Já a fase que se seguiu ao Juro-Cretáceo abrangeu todo o Brasil, apresentando período de estabilidade do Neocretáceo ao Terciário (MIZUSAKI \& FILHO, 2004). 
A região sudeste do Brasil exibe diversas evidências do magmatismo mesozoico, apresentando diques de diabásio toleítico, gabro, diorito, andesito e quartzo-pórfiro, com idades do Jurássico-Cretáceo. Sua colocação possui direção predominantemente NE, concordante com as estruturas brasilianas. Esses corpos intrusivos são anteriores à Formação Serra Geral, sendo precursor às etapas de separação dos continentes sul-americano do africano (MIZUSAKI \& FILHO, 2004).

As manifestações neocretáceas possuem caráter alcalino, com a ocorrência de intrusões alcalinas representadas na região do litoral norte de São Paulo na Ilha de São Sebastião, contendo sienitos e gabros, e alguns corpos nas ilhas de Montão de Trigo, Búzios e Vitória (RICCOMINI, SANT’ANNA \& FERARI, 2004).

Riccomini, Sant'anna e Ferari (2004) destacam que é um consenso que a reativação Sul-Atlântiana culminou na formação do Rift Continental do Sudeste do Brasil, composto por um conjunto de bacias trafogênicas e pelas Serras do Mar e da Mantiqueira.

Para Almeida e Carneiro (1976) estas bacias trafogênicas que abrangem o sudeste do Brasil foram denominadas de "Sistema de Rifts da Serra do Mar", sendo posteriormente reconhecida como "Rift Continental do Sudeste do Brasil" por Riccomini (1990). Atualmente foi denominado de "Sistema de Riftes Cenozoicos do Sudeste do Brasil" (ZALÁN \& OLIVEIRA, 2005), convergindo em aspectos de origem e evolução para esta região (RICCOMINI, SANT'ANNA \& FERARI, 2004).

O Rift Continental do Sudeste do Brasil (RCSB) é definido como uma depressão alongada e deprimida, com extensão de $900 \mathrm{~km}$. Desenvolveu-se paralelamente à costa sudeste do Brasil durante o Paleógeno. É composto por uma série de depressões tectônicas em contraposição às regiões montanhosas da Serra do Mar e da Mantiqueira, situados em margem de placas passivas (RICCOMINI, SANT'ANNA \& FERARI, 2004).

A partir do mapa geológico (Figura 10) elaborado com base nos dados da CPRM (2005) e de Perrotta et al. (2005) é possível observar a contextualização geológica regional. 
LEGENDA

[--] LIMITE NÚCLEOS PICINGUABA E CARAGUATATUBA ESTRUTURAS

CONTATOS LITOLÓGICOS

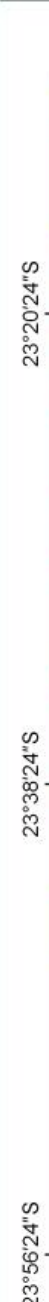

$45^{\circ} 42^{\prime} \mathrm{O}^{\prime \prime} \mathrm{W}$

$45^{\circ} 24^{\circ} \mathrm{O}^{\circ \mathrm{W}}$

$45^{\circ} 6^{\prime} \mathrm{O}^{\prime \prime W}$

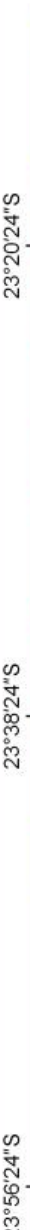

cayss

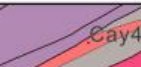

Er

每

NP3ey1SsI

NPexist

NP3ey1Spa.NP3entpi

Cay4Sna
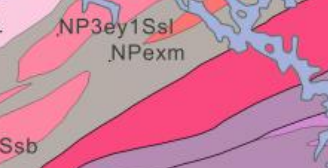

.

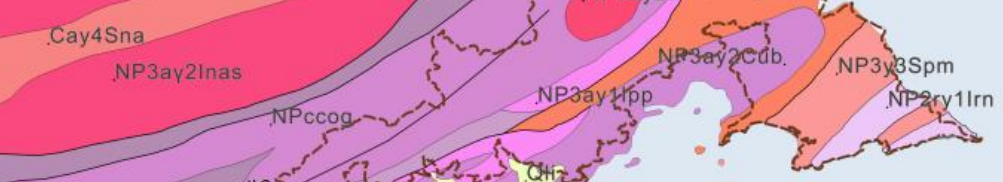

NPccgp

NPccgm

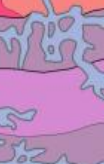

C do Bairro Alto
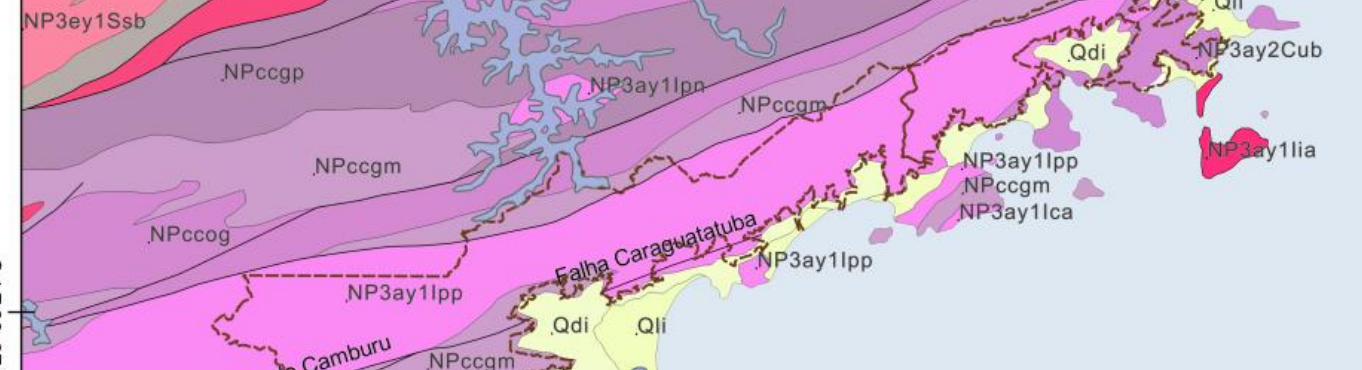

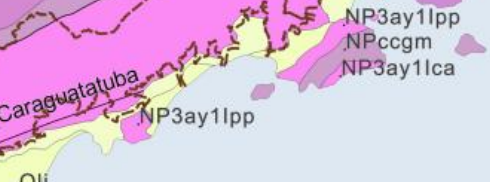

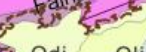

Falna deg cambur NP3ay11p
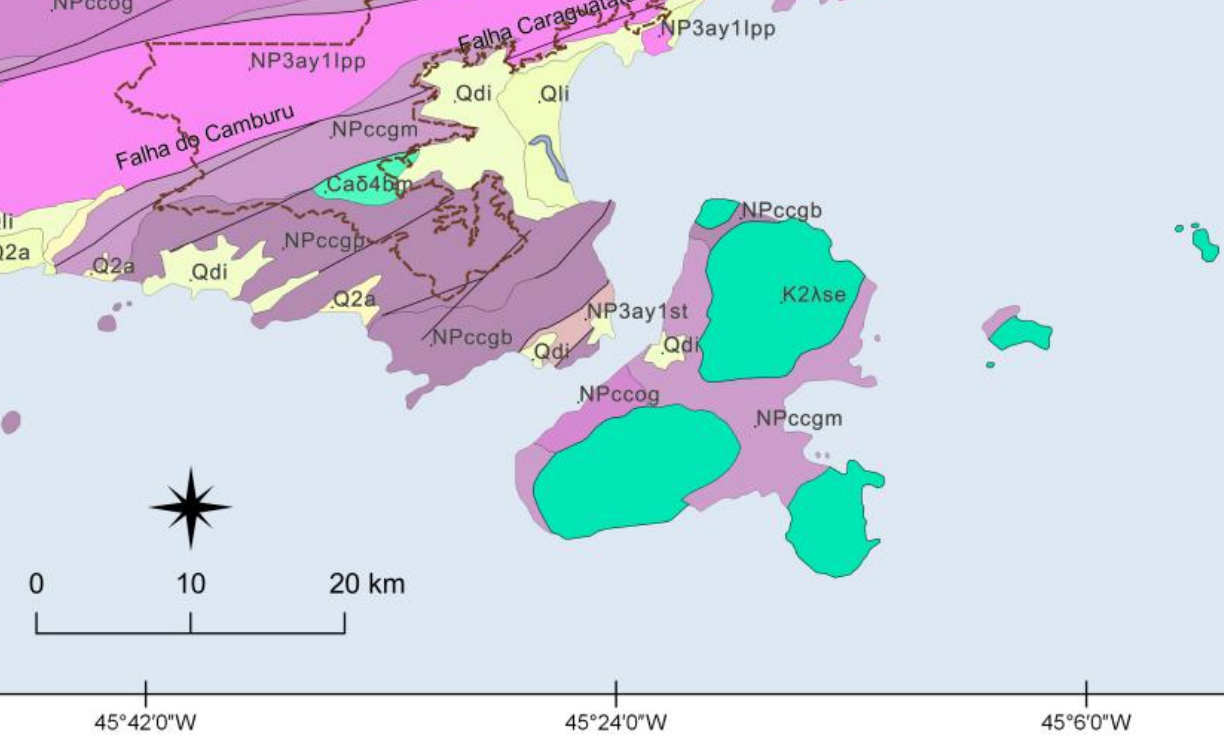

0

10

$20 \mathrm{~km}$

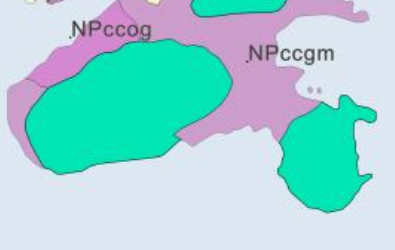

$45^{\circ} 42^{\prime} \mathrm{O}^{\prime \prime} \mathrm{W}$

$\frac{1}{45^{\circ} 24^{\prime} \mathrm{O}^{\prime \prime} \mathrm{W}}$

$45^{\circ} 6^{\prime} 0^{\circ} \mathrm{W}$

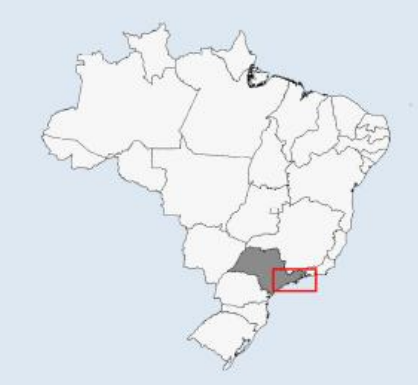

$44^{\circ} 48^{\prime} \mathrm{O}^{\prime \prime} \mathrm{W}$

Figura 10 - Mapa geológico regional contemplando a área de estudo (Adaptado de CPRM, 2005 e PERROTA et al., 2005)

ESCALA 1:350 000

FONTE DADOS: CPRM (2005) e PERROTA ETAL (2005)

ELABORAÇÃO: ELIANA MAZZUCATO
OCEÂNO ATLÂNTICO

\section{UNIDADES LITOLOGICAS}

CENOZOICO

Q2a - DEPÓSITOS ALUVIONARES

Qdi - COBERTURAS DETRITICAS INDIFERENCIADAS

Qli - DEPÓSITOS LTTORÂNEOS INDIFERENCIADOS

Er - FORMAČ̃̃ RESENDE

MESOZOICO

PALEOZOICO

Clay4Ipt - GRANITO PARATI, SUITE GETULÂNDIA

CaY4S - GRANITÓIDES TIPO S, PÓS-OROGÊNICOS DO ORÓGENO ARAGUA

- Cay4Sna - GRANITO NATIVIDADE DA SERRA, TIPO S

NEOPROTEROZOICO

NP3ay2Cub - CHARNOCKITO UBATUBA

NP3ay3Spm - GRANITO PARATI - MIRIM, SUÍTE SERRA DAS ARARAS

NP3ay1st - GRANITO SÃO SEBASTIÃO

\& NP3ay1Ipn - GRANITO PONTE NOVA - PARAIBUNA

NP3ay1Iia - GRANITO ILHA ANCHIETA

NP3ay1ICa - GRANITO CACANDOCA

NP3ay2Inas - GRANITO NATIVIDADE DA SERRA, TIPO I

- NP3ey1SIg - GRANITO LAGOINHA, SUÍTE SERRA DAS ARARAS

- NP3ey1Srs - GRANITO REDENÇ̃̃O DA SERRA

- NP3ey1Stu - GRANITO TUBARÃO

- NP3ey1SSr - GRANITO SERRA DA REDENÇ̃̃O

NP3ey1Spa - GRANITO SERRA DO PATI

NP3ey1Ssb - GRANITO SANTA BRANCA

nP3ey1pi - GRANTO PINHEIRO

- NP3ey1SSI - GRANITO SALTO

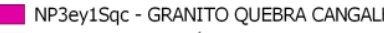

NP3aY2I - GRANITOIDES TIPO I, SIM A TARDI-OROGÊNICOS, DO ORÓGENO ARAGUAIA

NP3ay1Ipp - COMPLEXO GRANÍTICO, PICO DO PAPAGAIO

- NP2ry1Irn - COMPLEXO RIO NEGRO

NPccgb - COMPLEXO COSTERO, UNIDADE DE GNAISSES BANDADOS

NPCCgM - COMPLEXO COSTEIRO, UNIDADE GRANITO GNÁISSICA MIGMATÍTICA

NPCCgP - COMPLEXO COSTEIRO, UNIDADE GNAISSES PERALUMINOSOS

-

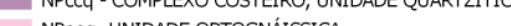

- NPeog- UNIDADE ORTOGNASSICA

- NPepg undade paRagNaISSICA

CALMENTE MIGMATÍTICOS

PALEOPROTEROZOICO

nPps - COMPLEXO PARAíba DO SUL

NEOARQUEANO

AAPP - COMPLEXO RIO CAPIVARI 
Observa-se que no núcleo Picinguaba predominam unidades do Neoproterozoico, compostas pelo Charnockito Ubatuba; Complexo Granítico Pico do Papagaio; Complexo Costeiro, Unidade Granito Gnáissica Migmatítica; Granito Caçandoca; Complexo Rio Negro; Granito Parati-Mirim, Suíte das Araras; Granito Parati; Granitos Calcialcalinos (Granitóides tipo I, sin a tardi-orogênicos do orógeno Araguaia). Apresentando também unidades do Cenozoico, relacionados aos sedimentos litorâneos e fluviais, como os Depósitos Aluvionares; Coberturas Detríticas Indiferenciadas; Depósitos Litorâneos Indiferenciados.

O núcleo Caraguatatuba apresenta unidades similares do Neoproterozoico, sendo elas o Complexo Granítico Pico do Papagaio; Complexo Costeiro, Unidade Granito Gnáissica Migmatítica; Complexo Costeiro, Unidade de Gnaisses Peraluminosos; Complexo Bairro do Marisco.

\subsection{Geomorfologia Regional}

A região sudeste da Plataforma Brasileira é marcada por um conjunto de relevos montanhosos que se destacam em uma borda de placa passiva. Nesta paisagem destaca-se a Serra do Mar, formada por um conjunto de escarpas, de inclinação bastante íngreme em sua vertente litorânea, e nivelada mais suavemente em direção ao continente. Sua extensão total é de cerca de $1000 \mathrm{~km}$ desde o Rio de Janeiro até Santa Catarina, estando recortada e individualizada em blocos mais elevados em alguns setores. Assim, regionalmente pode receber denominações como Serra da Bocaina em São Paulo e Serra dos Órgãos no Rio de Janeiro, atingindo altitudes no setor de São Paulo entre 800 a 1200m (ALMEIDA \& CARNEIRO, 1998).

Esse relevo montanhoso é fortemente controlado por fatores tectônicos, como condicionantes estruturais, e pela interação morfoclimática atuando com uma erosão diferencial sobre estas estruturas. Esses fatores podem ser verificados no próprio alinhamento da Serra, com orientação influenciada pelas estruturas brasilianas de direção aproximada NESW. Além disso, compõe junto com a Serra da Mantiqueira o limite tectônico do conjunto de bacias terciárias que correspondem ao Rift Continental do Sudeste do Brasil (RICCOMINI, 1990).

A Figura 11 representa a interpretação feita por Almeida e Carneiro (1998) para a formação da Serra do Mar. Para os autores a Serra do Mar teve origem no Eoceno, devido à reativação da falha de Santos, com o soerguimento do bloco ocidental e abatimento do oriental, sendo, portanto uma escarpa de falha que posteriormente sofreu recuo erosivo. 


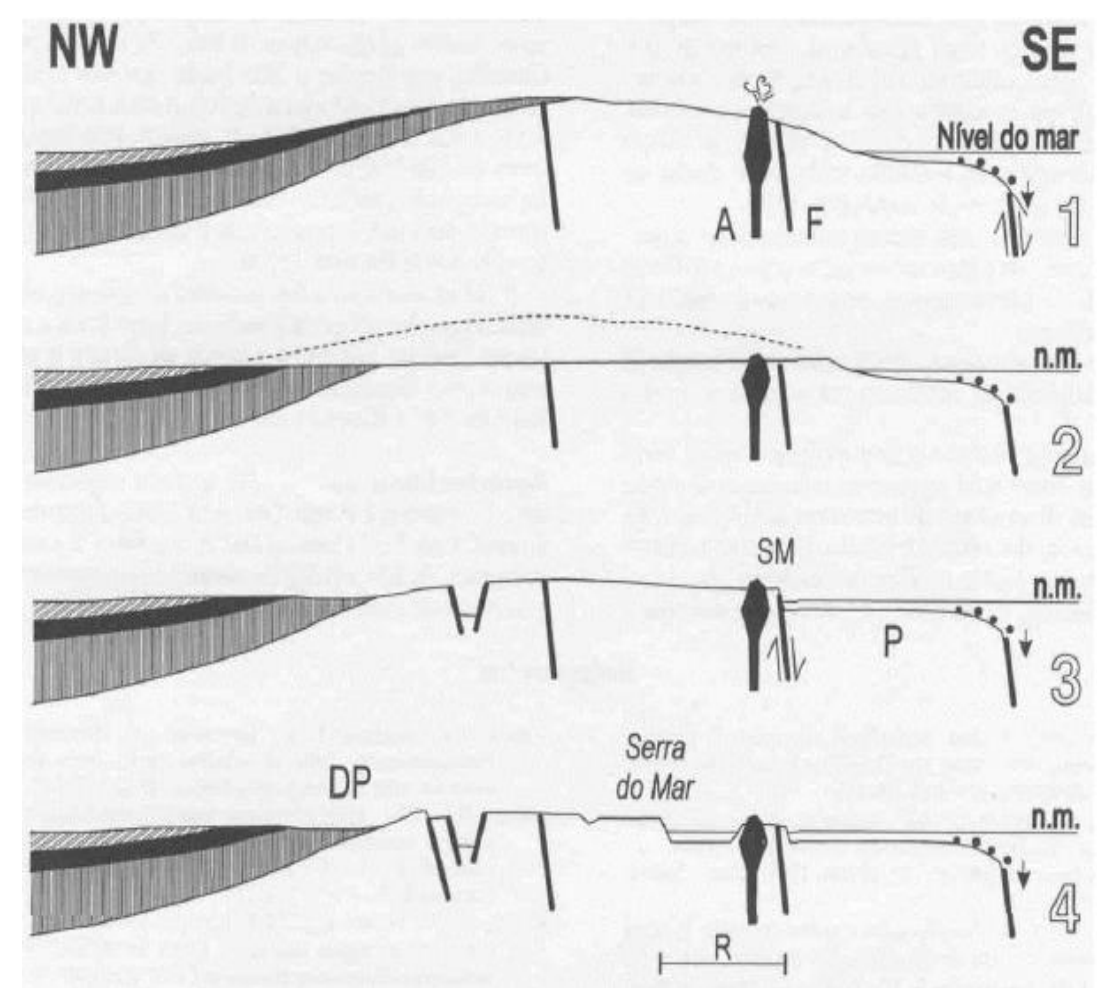

Figura 11 - Esquema da origem e recuo erosivo da Serra do Mar entre a Bacia do Paraná, no continente, e a Bacia de Santos, a sudeste. 1 - Soerguimento Senoniano erodido, causando deposição nas bacias de Santos e do Paraná. 2 - Desenvolvimento da superfície de aplainamento Japi no final do Senoniano. 3 - Deformação da Superfície Japi no Paleoceno. 4 - Recuo erosivo da Serra do Mar para a posição atual. A - Vulcanismo Alcalino; F - Falha de Santos; SM - Serra do Mar; P - plataforma continental na costa; DP - Depressão Periférica; R Recuo erosivo da Serra do Mar (ALMEIDA \& CARNEIRO, 1998).

Já outra linha de estudo, como Zalán e Oliveira (2005), sustentam que a origem da Serra do Mar está relacionada à reativação Mesozoica, responsável pelo seu soerguimento inicial, que recebeu a denominação de Serra do Mar Cretácea. Após este soerguimento, condicionado à uma tectônica distensiva, ocorreu um período de estabilidade tectônica, possibilitando a erosão generalizada desta região do Cretáceo Superior ao início do Paleoceno, conhecida como Superfície de Aplainamento Japi, sendo que o nivelamento ocorreu a aproximadamente $1100 \mathrm{~m}$ de altitude.

O segundo pulso preponderante para a formação da Serra corresponde ao soerguimento no Paleogeno, com clímax no Eoceno-Oligoceno, também de características distensivas. Neste momento são alçadas as feições da escarpa da Serra do Mar e da Mantiqueira. Todos esses eventos reativaram as zonas de cisalhamento brasilianas, como o Sistema Transcorrente Paraíba do Sul e outras descontinuidades, principalmente através de falhas normais, mas também como falhas transcorrentes e inversas, influenciados pela direção NE-SW. Este intenso rifteamento resultou em uma paisagem composta por horsts e grábens 
sucessivamente escalonados, desde a Serra da Mantiqueira até a charneira de Santos. Portanto atribuem a esse evento a formação da Serra do Mar e da Mantiqueira, além da formação das bacias cenozoicas entre o Paraná e Rio de Janeiro (ZALÁN \& OLIVEIRA, 2005).

Nesse sentido, Hiruma et al. (2010) apresenta um modelo de evolução da denudação do Planalto da Bocaina, no sudeste do Brasil (Figura 12) desde a fragmentação do Supercontinente Gondwana até o presente, relacionando dados de idade por traços de fissão a eventos tectono-magmáticos.

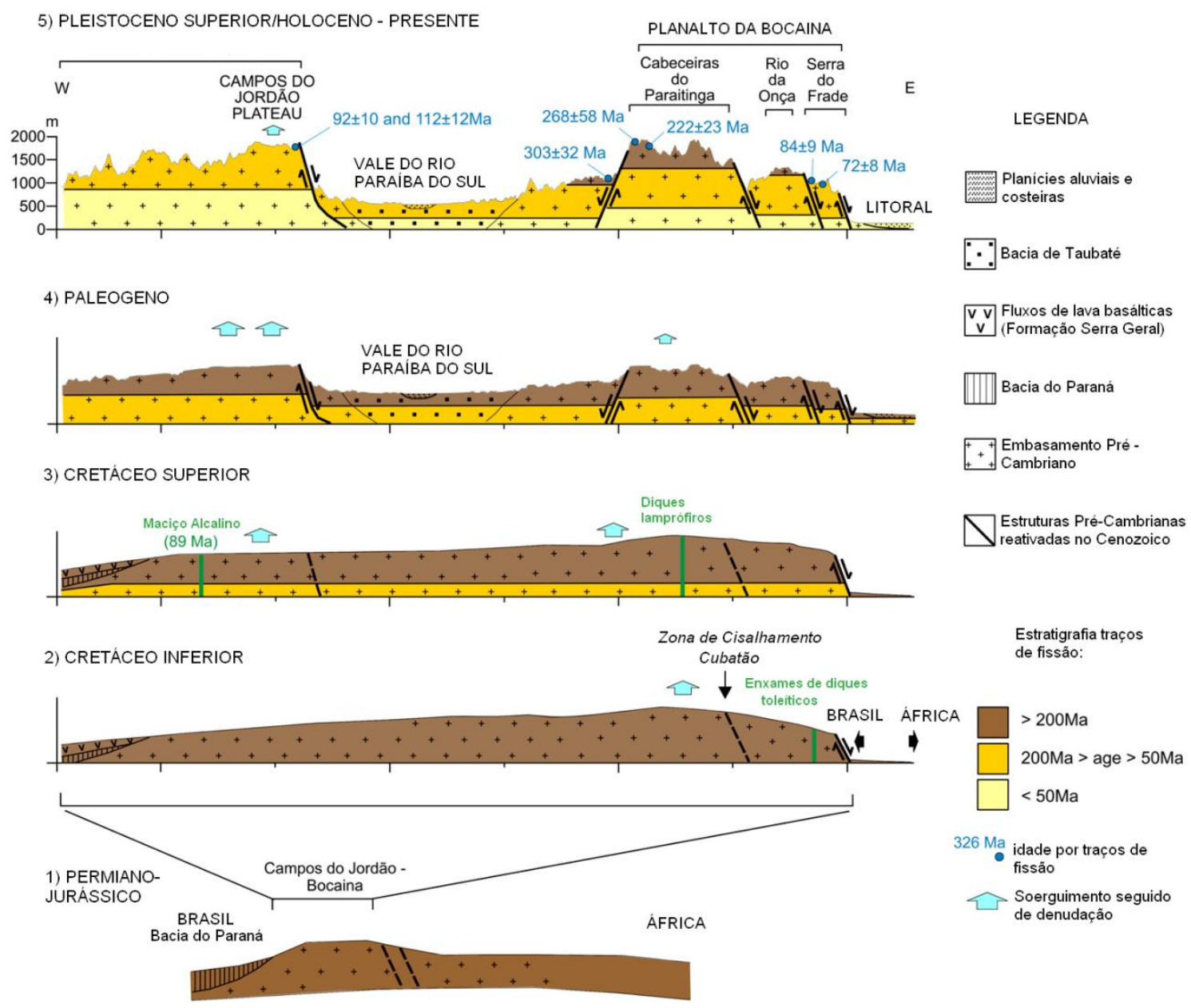

Figura 12 - Modelo de evolução da denudação do Planalto da Bocaina. 1 - Permiano-Jurássico: anterior a fragmentação do continente; 2 - Cretáceo Inferior: ruptura continental e abertura do oceano Atlântico Sul, que foi precedida pela formação de fluxos de basalto toleítico e enxames de diques; 3 - Cretáceo Superior: magmatismo alcalino intenso; 4 - Paleogeno: Gênese do rift continental do Sudeste do Brasil e magmatismo alcalino associado; 5 - Pleistoceno Superior/Holoceno - Presente: Reativação tectônica e soerguimento final da Serra do Mar e da Serra da Mantiqueira (Modificado de HIRUMA et al., 2010, p. 684).

A compartimentação geomorfológica da região é compreendida a partir dessa dinâmica geologia-geomorfologia, sendo que a Serra do Mar e os morros costeiros correspondem ao contexto do embasamento cristalino do complexo costeiro e, as planícies 
costeiras, praias e plataformas continentais se estruturam a partir dos depósitos quaternários (FIERZ, 2008).

Ross e Moroz (1997) classificam a área de serra da região no contexto morfoestrutural do Cinturão Orogênico Atlântico, que possui relação com os metamorfismos regionais, falhamentos e extensas intrusões dos ciclos de dobramentos no pré-cambriano, e das fases de reativação da Plataforma Sul Americana no Cenozoico que deram origem às feições de escarpas acentuadas (Serra do Mar e Serra da Mantiqueira) e grábens (Paraíba do Sul). Já as planícies costeiras situam-se no contexto morfoestrutural das Bacias Sedimentares Cenozoicas.

Com base no mapa geomorfológico (Figura 13) é possível apontar a área de estudo que está localizada no setor do Planalto Atlântico do Cinturão Orogênico Atlântico. As feições de relevo do Planalto Atlântico estão sustentadas em sua maioria por litologias metamórficas e ígneas, localmente marcadas por modelados que correspondem à Escarpa/Serra do Mar e Morros Litorâneos, Planalto e Serra da Bocaina e Planalto de Paraitinga/Paraibuna.

As Planícies Litorâneas e Fluviais são parte das Bacias Sedimentares Cenozoicas, e estão localmente concentradas nas Planícies Litorâneas (litoral norte). As características de seus sedimentos estão relacionadas às fases quaternárias de mudanças do nível do mar. As planícies do litoral norte possuem menor expressão de processos deposicionais, apresentandose como planícies embutidas (LIMA, MELO \& COIMBRA, 1991). 


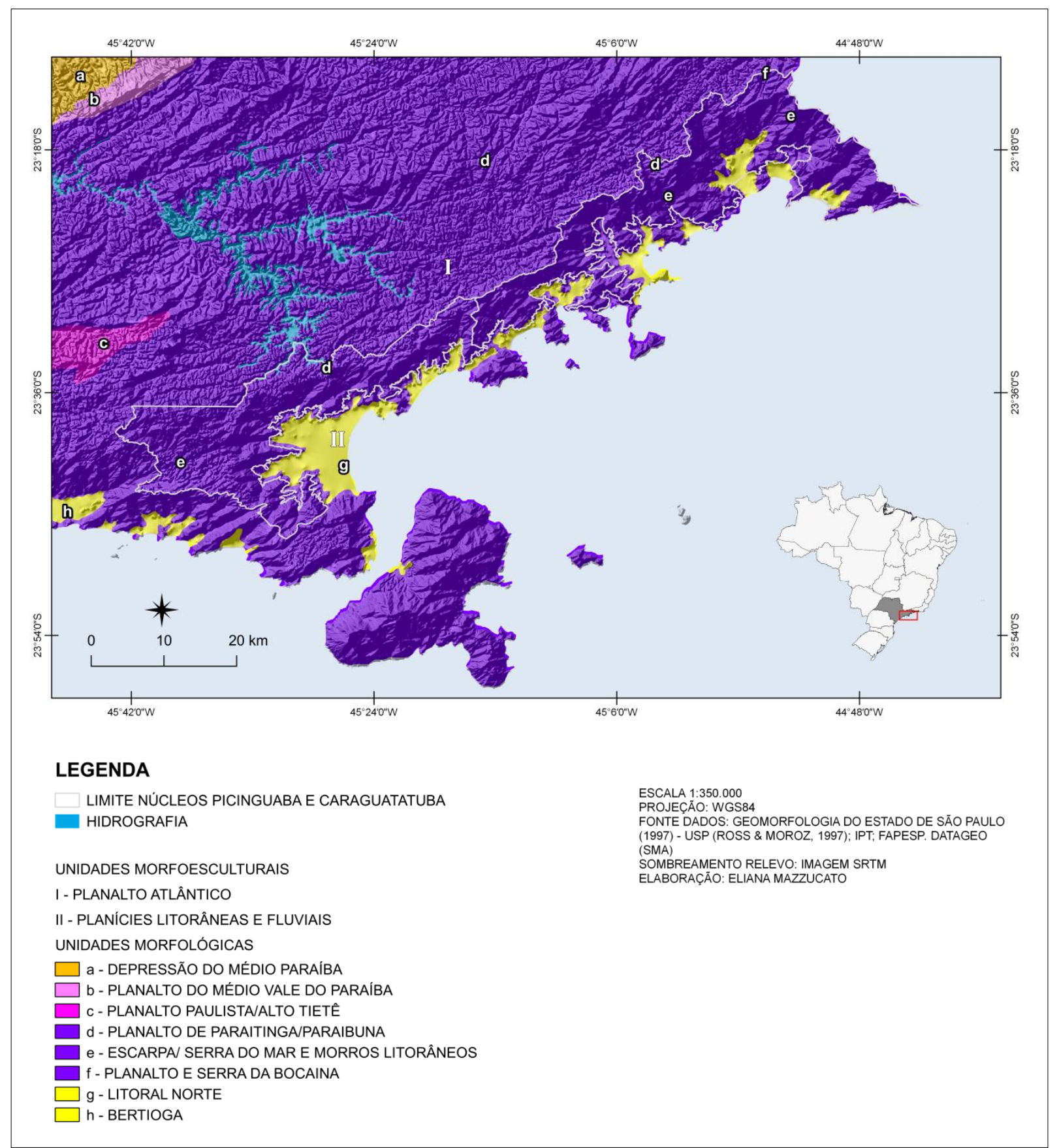

Figura 13 - Mapa Geomorfológico regional contemplando a área de estudo. (Dados: DataGEO, 2017). 
A Serra do Mar no setor norte de São Paulo apresenta-se próxima ao oceano atlântico, composta por escarpas mais íngremes de fácies festonadas. Apresenta frequentemente baías e enseadas intercaladas por esporões (GONTIJO-PASCUTTI et al., 2012). Além disso, é possível verificar o recuo erosivo das escarpas da Serra do Mar, apresentando promontórios e ilhas continentais, que reforçam a concepção de que a Serra do Mar já esteve além da posição em que se situa hoje (ALMEIDA \& CARNEIRO, 1998).

Em relação à geodiversidade e o patrimônio geológico, a região que corresponde ao município de Ubatuba foi inventariado por Santos (2014). A autora identificou os geossítios que apresentam interesse do ponto de vista científico, com base na metodologia de Brilha (2005). Um total de 10 geossítios foram inventariados a fim de recontar a história geológica da evolução do Supercontinente Gondwana. Dessa forma, procurou interpretar as evidências/registros da amalgamação, evolução e fragmentação do Supercontinente Gondwana, considerando ainda aspectos históricos, culturais e turísticos do município.

Os geossítios definidos pela autora foram classificados de acordo com seu interesse geológico principal e sua associação com a história do Gondwana Ocidental, sendo eles:

- Interesse ígneo, metamórfico e tectônico relacionados à fase de aglutinação do Gondwana no Neoproterozoico-Cambriano: "Pedra do Sino de Ubatuba" (Praia Santa Rita), "Charnockito Ubatuba" (Praia do Prumirim), "Praia do Cedro" e "Ponta Aguda";

- Interesse ígneo e tectônico:

a) registros da fase final da aglutinação do Gondwana: "Monzogranito Ilha Anchieta" (Ilha Anchieta);

b) registros relacionados à fase de aglutinação e fragmentação do Gondwana: "Gruta que Chora" (Praia do Sununga);

- Interesse tectônico relativo à fase de fragmentação do Gondwana: "Brecha magmática Ilha Anchieta" (Ilha Anchieta), "Xenólitos do manto e cones de explosão" (Praia Vermelha do Centro), "Pico do Corcovado" (entre Ubatuba e Natividade da Serra);

- Interesse histórico e mineiro: "Mineração Itamambuca" (Praia de Itamambuca).

Em Caraguatatuba o inventário foi realizado por Arruda et al. $(2015,2017)$ sendo catalogados 7 geossítios, agrupados de acordo com seus elementos geológicos: 
- Metamórfico, Mineralógico e Tectono-estrutural: "Praia Brava", "Ilha TabatingaTamanduá", "Milonitos da estrada da Petrobrás";

- Metamórfico, Geomorfológico e Tectono-estrutural: "Megaboudin Lagoa Azul”;

- Metamórfico, Paleoambiental, Sedimentológico, Geomorfológico e Tectonoestrutural: "Morro Santo Antônio";

- Metamórfico e Geomorfológico: "Geoformas de Caraguatatuba";

- Estratigráfico, Geomorfológico e Sedimentológico: "Registros da Catástrofe".

\subsection{Aspectos históricos e Socioculturais}

A caracterização histórica e sociocultural dos núcleos Caraguatatuba e Picinguaba do Parque Estadual da Serra do Mar foi realizada a partir de seus principais municípios que são Ubatuba e Caraguatatuba os quais se enquadram no contexto do litoral norte do Estado de São Paulo.

O litoral norte é composto por quatro municípios: Ubatuba, Caraguatatuba, Ilhabela e São Sebastião, com cerca de $1977 \mathrm{~km}^{2}$. Este setor do litoral paulista foi caracterizado pelo Zoneamento Ecológico-Econômico (ZEE) do litoral norte de São Paulo (SÃO PAULO, 2005) como uma região de potencialidades turísticas, porém com inúmeros problemas ambientais, como especulação imobiliária, pesca predatória, ocupação irregular do solo, dentre outros.

Sua paisagem litorânea possui peculiaridades em decorrência da formação da Serra do Mar e da manutenção da Mata Atlântica, compondo uma costa recortada com inúmeras praias e ilhas, formações rochosas e as escarpas abruptas da Serra do Mar. Sua paisagem revela uma diversidade de culturas que se estabeleceram nesses territórios ao longo dos anos. Portanto cabe aqui compreender a forte interação histórica e cultural que se deu neste ambiente peculiar que é o litoral norte paulista, com ênfase nos municípios de Ubatuba e Caraguatatuba.

A retomada do contexto da ocupação desse território revela os diversos povos que passaram por essas áreas, pois, essa faixa litorânea apresentou condições naturais favoráveis para a sua sobrevivência, com disponibilidade de alimento, água e também abrigos. Neste contexto, a presença da Serra do Mar foi preponderante para a diferenciação de povos que se fixavam na região litorânea dos que se encontravam no planalto. O Plano de Manejo elaborado para o Parque Estadual da Serra do Mar realiza uma síntese das ocupações territoriais que se sucederam à região (SÃO PAULO, 2006). 
O cenário pré-histórico da região planáltica é marcado por habitantes coletorescaçadores, cerca de 6000 anos antes do presente. Em relação à faixa litorânea, os registros em sambaquis, acampamentos conchíferos e abrigos em rochas registram idades mais antigas, entre 8000 e 1000 anos antes do presente, consistindo em grupos de coletores-caçadorespescadores (SÃO PAULO, 2006).

Os povos tupi-guaranis que ocupavam grandes áreas do interior iniciaram um processo de expansão sobre a faixa litorânea, ocupando esses territórios nos séculos XI e XII (SÃO PAULO, 2006). Os tupinambás, ou tamoios, que se concentravam na faixa norte do litoral paulista são descritos como povos guerreiros, que exploravam as potencialidades do mar. Notáveis na pesca utilizavam além de flechas um tipo de rede feita de cipó e possuíam uma agricultura primitiva baseada no pousio e na coivara ${ }^{1}$, com roças de mandioca, apresentando também técnicas de conservação de alimentos (MARCÍLIO, 2006).

A partir do início da colonização portuguesa, o século XVI representou um período de dizimação desses grupos indígenas. Aqueles que resistiram às doenças e permaneceram no território foram dominados e escravizados para a implantação da cana de açúcar, alterando profundamente a sua cultura, sua organização territorial e transformando a paisagem da região (MARCÍLIO, 2006).

Ainda no século XVI algumas vilas e estruturas básicas foram instaladas na região, introduzindo uma arquitetura do tipo colonial, registrada em igrejas, praças e pelourinhos nos dias atuais. Além disso, houve um progressivo adentramento no continente através da construção de passagens para superar a grande barreira da Serra do Mar, geralmente os caminhos consistiam em antigas trilhas dos indígenas. Em 1560 foi aberta a passagem conhecida como o "Caminho do Padre José", em referência ao Padre José de Anchieta. A "Calçada de Lorena" foi aberta no final do século XVIII, sendo construída com rochas locais (SÃO PAULO, 2006).

Segundo Silva (1975), os núcleos urbanos centravam-se em planícies de sedimentação flúvio-marinhas, onde o curso d'água proporcionava condições mínimas para a agricultura e pecuária. A configuração espacial destes núcleos era de "tabuleiro de xadrez", com traços regulares e organizados. Porém, nas periferias via-se um traçado irregular. Marcílio (2006) destaca que em Ubatuba havia uma ocupação dispersa ao longo das praias, e, em relação aos núcleos centrais (cidades), havia uma centralidade para com o porto, a igreja

\footnotetext{
${ }^{1}$ Pousio e coivara - O pousio e a coivara são técnicas agrícolas. A técnica do pousio consiste em deixar determinada área sem plantio por certo período, permitindo que os nutrientes do solo se reconstituam. A coivara que também pode ser denominada de "roça de toco" é uma técnica agrícola de influência indígena caracterizada pela derrubada e queima da mata, utilizando a área para o cultivo (TOFFOLI \& MANSUR, 2014).
} 
matriz e, nas proximidades das vias terrestres de acesso a outras vilas. Ainda segundo a autora iniciam-se neste período as ocupações em direção ao interior, como no "sertão", havendo interligações entre elas por trilhas ou através de cursos d'água.

Durante o ciclo açucareiro e o ciclo do ouro os portos localizados em São Sebastião e em Ubatuba tiveram importante papel para a dinamização econômica da região. Representaram assim centros para a economia regional, com movimentação de embarcações para importação de peças para as fazendas, pipas de vinho ou carne seca e para exportação de aguardente e cana de açúcar, além de produtos como fumo, anil, farinha de mandioca e arroz (SILVA, 1975).

Em contraste com as outras capitanias açucareiras do Brasil, na área abrangida pela Capitania de São Vicente havia uma baixa utilização da mão de obra dos escravos africanos. A Fundação Instituto de Terras do Estado de São Paulo (ITESP, 2002) levantou dados para a região de Ubatuba que demonstram que no século XVIII a região possuía apenas alguns engenhos de açúcar, sendo que a maior parte da sua população vivia da agricultura de subsistência, marcada pela produção de farinha de mandioca, arroz, feijão e da pesca.

Esse quadro econômico do litoral norte ganha novas proporções no início do século XIX, com a introdução da cultura de café na região, cultivada em fazendas que utilizavam a mão de obra escrava em maior escala. Neste período o porto de Ubatuba também se dinamizou, devido ao comércio de escravos e ao escoamento do café proveniente da região do Vale do Paraíba. Além disso, os grupos domésticos menores, dispersos pelo território, também começaram a introduzir o café em suas roças, mantendo a mandioca e o feijão (ITESP, 2002; MARCÍLIO, 2006).

A partir de 1867, esse período de crescimento econômico foi prejudicado pela construção da estrada de ferro Santos-Jundiaí. Assim, a opção pelo transporte ferroviário acabou privilegiando o escoamento dos produtos pelo porto de Santos, ocasionando a estagnação dos portos do litoral norte, situação agravada com a criação da ferrovia entre São Paulo e Rio de Janeiro, em 1977. O litoral norte de São Paulo ficou em situação de isolamento com a diminuição do fluxo de mercadorias na região. Outro fator que influenciou a estagnação da região foi o processo que culminou na abolição da escravatura, sendo que não houve imigração suficiente para a substituição da mão de obra escrava na região (SILVA, 1975).

Nesse período ocorreu o fortalecimento das comunidades tradicionais. Devido à estagnação da economia, as pessoas empregadas no modo de produção anterior viram-se obrigadas a criar uma estratégia de sobrevivência. 
Segundo Esterci (2007, p. 223)

Populações tradicionais é como têm sido chamados aqueles povos ou grupos que, vivendo em áreas periféricas à nossa sociedade, em situação de relativo isolamento face ao mundo ocidental, capitalista, construíram formas de se relacionar entre si e com os seres e coisas da natureza muito diferente das formas vigentes na nossa sociedade.

Assim desenvolveram um modo de vida de subsistência, produzindo gêneros de primeiras necessidades a partir da roça, explorando recursos e realizando também a caça e pesca. Era próprio dessas comunidades o estabelecimento de laços de comunidade e solidariedade, compondo as comunidades tradicionais conhecidas como "caiçaras" (SÃO PAULO, 2006). Silva (1975) ressalta a contribuição da cultura indígena na constituição destas comunidades, além dos mestiços com os africanos e portugueses.

Atribui-se a esse mesmo período a formação das comunidades quilombolas, fruto do processo de alforria e da baixa oferta de emprego para os antigos escravos da região. Ganha destaque nesse processo a generalização da produção de banana, influenciada pelo capital de imigrantes europeus que se instalaram na região, destinando sua produção ao mercado interno e externo (SÃO PAULO, 2006).

Além disso, intensificam-se as atividades pesqueiras e a exploração de recursos com a instalação de pedreiras e exploração de areia, bem como a retirada de madeira para sua comercialização e produção de carvão. A paisagem também foi impactada neste momento pela instalação de usinas hidrelétricas, ferrovias e linhas de transmissão de energia (SÃO PAULO, 2006).

A dinamização proveniente do ciclo da banana na região, das atividades pesqueiras e do crescente interesse no porto de São Sebastião impulsionou novos investimentos que melhoraram a acessibilidade da região. Assim, surgiram importantes vias de acesso como a ligação entre São Sebastião e Caraguatatuba (1938), a rodovia Tamoios (SP-099) com traçado de São José dos Campos a Caraguatatuba (1939), e, a rodovia que liga Caraguatatuba Ubatuba (1950) (SILVA, 1975). Destaca-se também que nesse período houve um crescente interesse turístico sobre a região, favorecido pelas vias de acesso. Grande parte dos turistas que se deslocavam para o litoral norte eram proveniente da elite paulista. Assim, já na década de 50 o turismo na região estava estabelecido, induzindo a instalação de loteamentos, hotéis de luxo e segundas residências para servir ao público mais abastado de São Paulo (SÃO PAULO, 2006). 
Esse processo é verificado em Ubatuba, onde os dados coletados por Marcílio (2006) demonstraram que

\begin{abstract}
Os habitantes da cidade de Ubatuba, no recenseamento geral de 1872, eram ainda tão somente 7.565 pessoas. Em 1940, quando o turismo ainda não havia descoberto Ubatuba, sua população havia regredido para os níveis do final do século XVIII: ou seja, 3.227 no total. Nessa época, Ubatuba conservava-se, ainda, como uma coletividade de roceiros-pescadores, que plantavam para o gasto. Trinta anos depois, já se processava o implacável movimento de destruição da economia caiçara e da expulsão dos posseiros tradicionais, numa ação concertada pelo grande capital paulista de especuladores e das transnacionais do turismo [...] Em 1970, o município já contém uma população, de fato, contada em 15.203 habitantes (MARCÍLIO, 2006, p. 61).
\end{abstract}

Como destacou Silva (1975), a cidade de Ubatuba foi elevada como vila em 1637, consistindo num aglomerado de edificações históricas que se encontram no centro de uma planície flúvio-marinha. O núcleo urbano histórico encontra-se entre os rios Grande de Ubatuba e Tavares ou Lagoa junto à praia de Iperoig. Também fazem parte desta área urbana a região da praia de Itaguá e de Perequê-Açu, concentrando residências e loteamentos turísticos, serviços e comércio. Também apresenta adensamentos urbanos ao longo da rodovia que liga Taubaté a Ubatuba. Porém, o processo de urbanização de Ubatuba foi o mais tardio no contexto do litoral norte. Dessa forma as comunidades caiçaras permaneceram na região norte do município, no entorno de Picinguaba (SILVA, 1975).

A instalação da rodovia Rio-Santos, na década de 70, intensificou e marcou profundamente a dinâmica econômica, social e natural da região, influenciando uma expansão urbanística na faixa litorânea. Tal expansão não obedeceu a qualquer planejamento, gerando, além da degradação ambiental, forte pressão junto às comunidades tradicionais, dando lugar progressivamente a instalação de residências e condomínios de luxos. Tal pressão ocasionou o processo de periferização dessas comunidades, que acabaram instalando suas habitações em áreas de risco, como encostas íngremes e locais sujeitos a enchentes, se caracterizando muitas vezes em loteamentos clandestinos.

O município de Caraguatatuba demarca essa transição, com intensificação de sua urbanização a partir da década de 1950, sendo que sua ampla planície costeira favoreceu este processo. Como relatam Gigliotti e Santos (2012), as vias de acesso favoreceram o setor imobiliário, que promoveu um processo de especulação imobiliária na região. Os caiçaras foram pressionados por esse movimento, muitas vezes coagidos a deixar seus territórios, migrando para bairros periféricos, nas encostas da Serra do Mar, em áreas de risco de 
desabamento. As famílias vendiam suas propriedades a preços baixos ou eram expulsas, pois não possuíam escrituras regularizadas. A partir de dados coletados do Instituto de Pesquisa Econômica Aplicada (IPEA, 2011), os autores supracitados indicam que entre 1970 e 1980 a população de Caraguatatuba cresceu em 124\% (15.073 habitantes em 1970 e 33.802, em 1980), sendo que a população urbana em 1970 era de 87\%, já em 1980 chegava a 98\%, destoando, portanto da década de 1940, quando apenas 38\% dos 4.666 habitantes de Caraguatatuba eram de área urbana.

Segundo Campos (2000) os registros apontam para a fundação da Vila de Santo Antônio de Caraguatatuba em 1664, ou no início de 1665. A vila se tornou o município de Caraguatatuba em 1857. Seu centro histórico limitava-se à planície do rio Santo Antônio, que em 1945 teve seu trecho modificado com a abertura de uma vala de $800 \mathrm{~m}$. Esta estrutura ampliou-se pela erosão fluvial, com contribuição da catástrofe de $1967^{2}$, tornando-se um leito fluvial de cerca de $50 \mathrm{~m}$ de largura. $\mathrm{O}$ antigo curso do rio, próximo à igreja matriz apresentava problemas de inundação. $\mathrm{O}$ autor relata também que poucos prédios históricos foram preservados na cidade, sendo que grande parte foi reurbanizada (SANTOS, 1975). A intensa urbanização do município praticamente desapareceu com os aglomerados de caiçaras que se estendiam na Enseada de Caraguatatuba, principalmente nas praias de Massaguaçu, Cocanha, Mococa e Tabatinga (SANTOS, 1975).

O processo de urbanização que vinha devastando a Mata Atlântica da região foi parcialmente cessado com a criação do Parque Estadual da Serra do Mar em 1977, que privilegiou a conservação da natureza e influenciou as características desses municípios, restringindo seu uso e ocupação, a exploração dos recursos, a implantação do turismo, dentre outros (SÃO PAULO, 1977). Portanto, contextualizar o processo de evolução das formas de uso deste território e culturas correspondentes possibilita uma visão mais aprofundada para compreender as características de preservação e peculiaridades deste território, revelando o contexto dos conflitos socioambientais da região.

\footnotetext{
${ }^{2} \mathrm{O}$ município foi marcado por um grande evento geológico de movimento de massa, conhecido como a grande Catástrofe de 1967, nos dias 17 e 18 de março. O evento ocorreu seguido de um verão bastante chuvoso, que encharcou os solos e materiais coluviais e alimentou o lençol freático (CRUZ, 1990). Cruz (1967) relata ainda que o evento ocorreu após dois dias de chuvas intensas, sendo caracterizado por avalanches de blocos, árvores e lamas que desciam encosta abaixo, principalmente pelo Rio Santo Antônio, ocasionando a obstrução de rodovias, a destruição de pontes, a interdição de ruas e a inundação do centro do município. Segundo dados da prefeitura, cerca de 450 pessoas morreram na ocasião.
} 


\subsection{O Parque Estadual da Serra do Mar}

O Parque Estadual da Serra do Mar (PESM) foi criado por decreto estadual em 1977 $\left(n^{\circ} 10.251\right)$ com base no Novo Código Florestal (Lei no 4771 de 1965), com uma área inicial de cerca de 315 mil hectares.

Fica criado o Parque Estadual da Serra do Mar com a finalidade de assegurar integral proteção à flora, à fauna, às belezas naturais, bem como para garantir sua utilização a objetivos educacionais recreativos e científicos (BRASIL, 1965).

O decreto estadual de criação do Parque Estadual da Serra do Mar consistiu na reunião de diversas áreas protegidas e reservas já existentes, sendo elas o Parque Estadual de Caraguatatuba; as Reservas Estaduais da Serra do Mar, Rio Branco-Cubatão, Curucutu, Itarirú, Pedro de Toledo, São Vicente, Natividade da Serra; as Reservas Florestais de Itanhaém e do Vale do Paraíba (SÃO PAULO, 2006).

Em 2010, sua área foi expandida para 332 mil hectares, incorporando áreas públicas, devolutas ou remanescentes de ações judiciais a partir do decreto $n^{\circ} 56.572$ de 22 de dezembro de 2010. Reconhecido como relevante reduto da Mata Atlântica, já dizimada em 93\% de seu total, é a maior unidade de conservação desse bioma formando um corredor de preservação com 25 municípios, com a função de conectividade entre as florestas da Serra do Mar desde o Paraná ao Rio de Janeiro. O decreto garantiu a conservação desta área, mesmo estando próxima às maiores metrópoles do País (São Paulo e Rio de Janeiro). Destaca-se a preservação do bioma e aspectos físicos de profunda relevância, como a preservação de mananciais, áreas de encosta suscetíveis à erosão e ambientes costeiros (SÃO PAULO, 2006).

Devido à sua abrangência territorial, o PESM foi compartimentado em núcleos (Tabela 1), com objetivo de facilitar a gestão diante de um território com características tão diversas. Assim, a partir de 2006, foram delimitados os seguintes núcleos com autonomia administrativa: Caraguatatuba, Cunha, Curucutu, Itutinga-Pilões, Itarirú, Picinguaba, Santa Virgínia e São Sebastião (SÃO PAULO, 2006). Desde 2011 o núcleo Itutinga-Pilões foi desmembrado, sendo parte deste incorporado ao núcleo Bertioga. A modificação mais recente refere-se ao núcleo Padre Dória. Criado em 2014, foi o décimo núcleo administrativo do Parque, sendo que há registros de um novo núcleo no site institucional do PESM, denominado Caminhos do Mar. 
Desde 2007 a entidade gestora do Parque Estadual da Serra do Mar é a Fundação Florestal, órgão vinculado à Secretaria do Meio Ambiente do Estado de São Paulo. O Instituto Florestal, anteriormente responsável por esta função, passou a acompanhar e monitorar o conhecimento científico desenvolvido nas Unidades de Conservação do Estado.

Tabela 1 - Relação dos núcleos administrativos do PESM em 2017

\begin{tabular}{|c|c|c|c|}
\hline Núcleos & Ano & Extensão (ha) & Municípios \\
\hline Cunha & 1977 & 13.300 & Cunha, Ubatuba \\
\hline Santa Virgínia & 1989 & 17.500 & $\begin{array}{l}\text { São Luiz do Paraitinga, Natividade da } \\
\text { Serra, Cunha, Ubatuba e Caraguatatuba }\end{array}$ \\
\hline Picinguaba & 1979 & 47.500 & Ubatuba \\
\hline Caraguatatuba & 1977 & 35.947 & $\begin{array}{c}\text { Caraguatatuba, Paraibuna, Natividade da } \\
\text { Serra }\end{array}$ \\
\hline São Sebastião & 1998 & 26.268 & São Sebastião \\
\hline Itutinga-Pilões & 1977 & 43.800 & $\begin{array}{c}\text { Praia Grande, São Vicente, Santos, } \\
\text { Cubatão, São Bernardo do Campo, Santo } \\
\text { André, São Paulo e Mogi das Cruzes }\end{array}$ \\
\hline Curucutu & 1977 & 37.518 & Juquitiba, São Paulo, Itanhaém, Mongaguá \\
\hline Bertioga & 2010 & 29.945 & Bertioga, Biriti Mirim \\
\hline Caminhos do Mar & - & - & São Bernardo do Campo \\
\hline Itariru & 1977 & 53.927 & $\begin{array}{c}\text { Itariri, Juquitiba, Peruíbe, Miracatu e } \\
\text { Pedro de Toledo }\end{array}$ \\
\hline Padre Dória & 2014 & $26.154,02$ & $\begin{array}{l}\text { Paraibuna, Salesópolis, Biritiba Mirim, } \\
\text { São Sebastião, Caraguatatuba e Bertioga }\end{array}$ \\
\hline
\end{tabular}

Fonte: Sistema Ambiental Paulista (2017).

O Parque Estadual da Serra do Mar apresenta ainda algumas sobreposições de classificações territoriais, como reservas indígenas, demarcadas pela FUNAI; a Vila de Picinguaba, tombada pelo CONDEPHAAT, em 1983; a Comunidade de Remanescentes de Quilombolas do Cambury, reconhecida em 2005 pelo ITESP, pela Fundação Cultural Palmares em 2006 e pelo Incra em 2008; o Parque Nacional da Bocaina, criado em 1971 (SÃO PAULO, 2006). Tais sobreposições refletem a riqueza socioambiental desta região, que impõe alguns desafios de gestão e compatibilidade aos objetivos e planejamento do PESM.

Em 2000 foi instituído o Sistema Nacional de Unidades de Conservação (SNUC), pela Lei ${ }^{\circ}$ 9.985, determinando as normas vigentes para as áreas protegidas no Brasil. Assim, o PESM passou a se enquadrar em unidade de proteção integral, vinculada à categoria de 
Parque Estadual. Segundo o SNUC, os parques preservam ecossistemas naturais de grande relevância ecológica, associados a paisagens de beleza cênica. Sendo uma unidade de proteção integral, seu território passa a ser de domínio público, permitindo apenas o uso indireto dos recursos naturais, com atividades de educação ambiental e interpretação, turismo ecológico e de recreação (BRASIL, 2000).

No PESM o processo de implementação da unidade e gestão desse território ocorreu de forma progressiva, muitas vezes com poucos recursos, considerando sua abrangência territorial. Nesse histórico, as comunidades tradicionais que estavam inseridas nos limites da unidade foram pressionadas, com base na legislação, sofrendo processo de desapropriação de suas residências. Quase trinta anos depois de sua criação foi elaborado o Plano de Manejo do Parque, tratando dentre outros assuntos, da questão fundiária que ainda hoje é bastante conflituosa na região.

Sendo assim, apesar de uma Unidade de Proteção Integral determinar a desapropriação dos residentes inseridos nessas áreas, em alguns casos especiais esses residentes apresentam o direito à permanência em seus territórios. Esses casos se referem às comunidades tradicionais, remanescentes de quilombolas e tribos indígenas que possuem direitos territoriais garantidos.

Em relação às classificações territoriais, é importante destacar alguns marcos legais que ao longo do histórico do Parque influenciaram o modo de relação e a conciliação entre o Parque e as comunidades.

O decreto $\mathrm{n}^{\circ} 6.040$ de 7 de fevereiro de 2007 que institui a Política Nacional de Desenvolvimento Sustentável dos Povos e Comunidades Tradicionais definem essas populações como

grupos culturalmente diferenciados e que se reconhecem como tais, que possuem formas próprias de organização social, que ocupam e usam territórios e recursos naturais como condição para sua reprodução cultural, social, religiosa, ancestral e econômica, utilizando conhecimentos, inovações e práticas gerados e transmitidos pela tradição (BRASIL, 2007).

Assim, as comunidades e povos tradicionais compõem importante aspecto do patrimônio histórico e cultural brasileiro, além disso, caracterizam-se por manter estreita relação com o patrimônio natural, desenvolvendo algumas práticas de manejo que conservam a natureza, através de seu uso sustentável. 
A relação dessas populações com o território revela-se pela pertença do grupo, com destaque para a singularidade nas relações estabelecidas entre a comunidade que se fortalecem

através de laços de parentesco, compadrio ou vizinhança, de uma vivência histórica e uma memória partilhadas - bases da construção da identidade e da distinção com relação aos de fora (ESTERCI, 2008, p. 223).

A autora segue apresentando que

Os povos e grupos referidos como tradicionais são pequenos produtores familiares que cultivam a terra e/ou praticam atividades extrativistas como a pesca, coleta, caça, utilizando-se de técnicas de exploração que causam poucos danos à natureza. Sua produção é voltada basicamente para o consumo e têm uma fraca relação com os mercados. Sendo sua atividade produtora muito dependente dos ciclos da natureza, eles não criam grandes concentrações, e as áreas que habitam, tendo uma baixa densidade populacional, são as mais preservadas entre as áreas habitadas do Planeta (ESTERCI, 2008, p. 224).

De acordo com essas características, o SNUC também incorpora essa categoria, sendo que no art. $4^{\circ}$, seu objetivo XIII se refere diretamente às comunidades tradicionais, considerando a conservação dos recursos que são necessários à subsistência dessas comunidades, valorizando assim sua cultura. Além disso, determina no Art. $28^{\circ}$ que enquanto o Plano de Manejo não estiver formulado deve-se atentar às comunidades tradicionais inseridas na UC de proteção integral, sendo necessário garantir as condições e os meios para satisfazer suas necessidades básicas materiais, sociais e culturais (SNUC, 2000). O decreto $\mathrm{n}^{\circ}$ 4.340 de 22 de agosto de 2002 que regulamenta alguns artigos do SNUC, reafirma a necessidade de atenção às comunidades tradicionais que ainda não foram reassentadas.

as condições de permanência das populações tradicionais em Unidade de Conservação de Proteção Integral serão reguladas por termo de compromisso, negociado entre o órgão executor e as populações, ouvido o conselho da unidade de conservação (BRASIL, 2002, art. 39%).

Para Diegues (2001), as comunidades tradicionais resultam da miscigenação entre os portugueses, os indígenas e os escravos africanos. Geralmente se caracterizam por comunidades camponesas, como os caiçaras (exemplo no litoral de São Paulo, Rio de Janeiro e Paraná), os caipiras (sul do Brasil), vargeiros (ribeirinhos de rios e várzeas do norte e nordeste), dentre outros. Esterci (2008) complementa esses exemplos, destacando também os 
babaçueiros (que exploram o babaçu na região Norte), caboclos (comunidades rurais de mestiços de negros e índios), seringueiros (extraem o látex das seringueiras, principalmente na região Norte) e quebradeiras de coco (prática de coleta e quebra do coco do Babaçu em reservas extrativistas do Maranhão, Tocantins, Pará e Piauí).

Os caiçaras são apresentados como mestiços de índios e portugueses, compostos por pescadores tradicionais da faixa litorânea de São Paulo, Rio de Janeiro e Paraná, onde se deu início a ocupação dos portugueses (ESTERCI, 2008). Destaca-se que esses povos mantêm um "forte elo entre o homem e seus recursos naturais, gerando um raro exemplo de comunidade harmônica com o seu ambiente" (POLETTE \& SILVA, 2008, p. 197).

Os quilombolas estão relacionados às comunidades rurais de descendentes de escravos, que preservam uma cultura de subsistência e suas manifestações culturais. Sua história está relacionada à formação dos quilombos no século XVII, que, representando um movimento de resistência, formavam núcleos de escravos refugiados em meio à mata (VELASQUEZ, 2008). Seus direitos territoriais são garantidos pela Constituição de 1988, no artigo $216^{\circ}$ que trata do patrimônio cultural brasileiro, definindo no $5^{\circ}$ parágrafo que "Ficam tombados todos os documentos e os sítios detentores de reminiscências históricas dos antigos quilombos". Destaca-se também que de acordo com o art. $68^{\circ}$ dos Atos das Disposições Constitucionais Transitórias da Constituição da República é atribuição do Estado emitir títulos de propriedade definitiva para as comunidades de remanescentes de quilombolas.

Um marco mais recente favorável aos direitos territoriais das comunidades de remanescentes de quilombolas é composto pelo Decreto 4.887 de 20 de novembro de 2003, que regulamenta o procedimento para identificação, reconhecimento, delimitação, demarcação e titulação das terras ocupadas por estas comunidades. Segundo o decreto, as comunidades de remanescentes de quilombolas são compostas por

Os grupos étnico-raciais, segundo critérios de auto-atribuição, com trajetória histórica própria, dotados de relações territoriais específicas, com presunção de ancestralidade negra relacionada com a resistência à opressão histórica sofrida (BRASIL, 2003).

Este decreto vem fortalecer as políticas que valorizam o aspecto histórico e cultural dessas comunidades, reconhecendo a importância do território para sua reprodução física, social econômica e cultural. Assim, cabe ao Instituto Nacional de Colonização e Reforma Agrária (INCRA) a execução dos procedimentos que culminam na titulação de suas terras. $\mathrm{O}$ artigo $11^{\circ}$ trata especificamente das comunidades inseridas em Unidades de Conservação, em 
que deverão ser tomadas medidas com vistas a garantir a sua sustentabilidade, em conciliação com os interesses do Estado.

Portanto, essas comunidades formadas por caiçaras e quilombolas presentes no núcleo Picinguaba recontam o histórico desta região e preservam ainda seus modos de vida em profunda relação com a natureza local. Cabe destacar a territorialidade, a forte integração socioambiental que emerge destas comunidades, culminando em percepções e tradições que podem ser valorizadas em ações educativas, de conservação e de geoconservação.

Assim, segundo Diegues (2001) a referência ao território dessas comunidades se faz em relação ao meio físico e as relações sociais existentes no ambiente. No litoral de São Paulo os caiçaras mantêm estreita relação com a Mata Atlântica, influenciando o tipo de alimento cultivado em suas roças (mandioca, banana), o modo de cultivo baseado do descanso e pousio, a exploração dos recursos como o palmito Juçara, a semente do Juçara, a retirada de madeira para construção de canoas e equipamentos de pesca, instrumentos de trabalho, entre outros.

Em conformidade com essas diretrizes e normatizações, o Plano de Manejo do PESM (2006) incorporou a categoria de comunidades tradicionais, definindo-as

\begin{abstract}
Para efeito deste Plano de Manejo, serão considerados tradicionais os moradores efetivos cujas famílias tenham origem de várias gerações nestas mesmas localidades, e cuja ocupação ou sobrevivência esteja diretamente relacionada às atividades de agricultura de subsistência, pesca artesanal, artesanato e outras tecnologias patrimoniais, bem como atividades que contribuam para o fortalecimento sócio cultural da comunidade ou para alternativas econômicas compatíveis com o seu desenvolvimento sustentável. Um dos subsídios para esta definição são os laudos técnicos das instituições competentes (SÃO PAULO, 2006, p. 278).
\end{abstract}

Em atenção à regularização e ordenamento do território nos limites do PESM, o Plano de Manejo estabeleceu o Zoneamento de seu território. Esse instrumento de gestão tem orientado o manejo e o estabelecimento de normas e objetivos específicos para cada compartimento, considerando graus de conservação e de intervenção humana. Assim os critérios para a delimitação se relacionam com os valores que determinada área possui para a conservação e as que possuem vocação de uso (SÃO PAULO, 2006). 


\subsubsection{Núcleo Picinguaba (NP)}

O núcleo Picinguaba que pode ser observado na Figura 14, localizado no extremo norte do PESM, apresenta paisagens desde a costa até as escarpas da Serra do Mar, protege assim os ambientes de floresta densa das escarpas da Serra do Mar, e os ecossistemas costeiros da cota zero, com costões rochosos, restingas e manguezais. Protege cinco praias do município de Ubatuba: Brava da Almada, Fazenda, Picinguaba, Cambury e Brava do Cambury (SISTEMA AMBIENTAL PAULISTA, 2017).

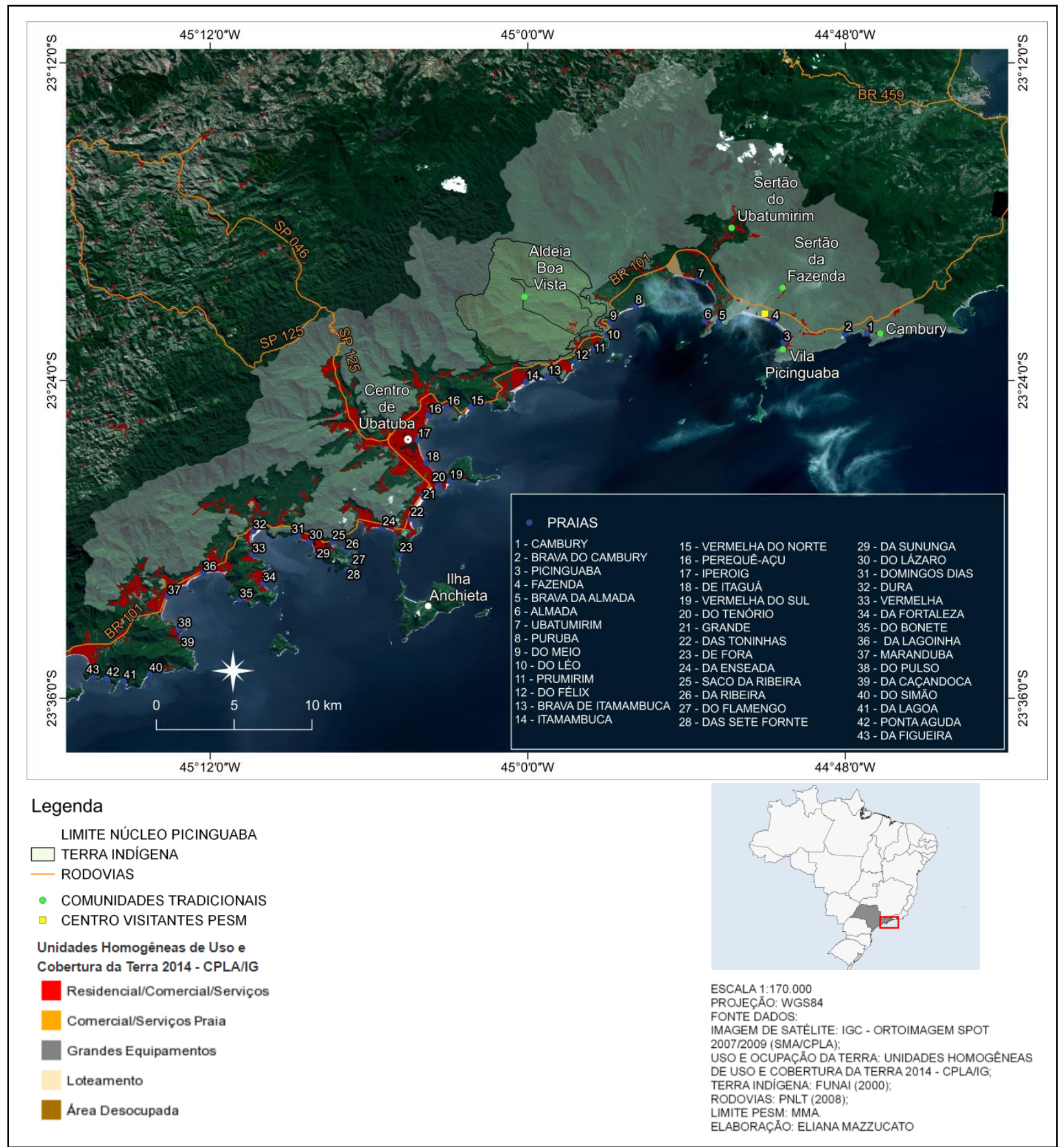

Figura 14 - Mapa de localização do Núcleo Picinguaba do Parque Estadual Serra do Mar. (Dados: DataGEO). 
Em 1979 o PESM incorporou em seus limites a Fazenda Picinguaba, com 7.900 hectares que atualmente estão inseridos no núcleo (decreto nº 13313, 6 março 1979). A região caracterizava-se como área de ocupação de comunidades tradicionais (caiçaras e quilombolas), sujeita a intenso processo de ocupação e especulação imobiliária entre 1974 e 1983 (SIMÕES, 2015). No período de demarcação dos limites da unidade, os critérios não incluíam a preocupação com essas comunidades e seus direitos, e, além disso, a própria criação da UC seguida de uma ausência administrativa atraiu novos moradores (SANSOLO, 2002).

Assim, mesmo criado em 1977, somente em 1985 surgiram as primeiras estratégias para a implementação do Parque. Observa-se que ao longo dos anos, a administração do parque lida constantemente, e de diversas maneiras, com a questão da presença humana na unidade (SIMÕES, 2015). Principalmente os primeiros gestores do núcleo Picinguaba possuíam maior inclinação em desapropriar estas famílias, situação agravada pela falta de diretrizes e normalizações que tratassem dos conflitos entre o parque e as comunidades residentes.

O processo de construção do Plano de Manejo do PESM e as negociações realizadas no NP resultante da existência de residentes em seus limites foram descritos por Simões (2010), pesquisadora que também foi gestora do núcleo de 2002 a 2009, revelando os conflitos e os caminhos escolhidos diante as sobreposições territoriais para compatibilizar os interesses conservacionistas do PESM ao direito de permanência das comunidades tradicionais em seus territórios, garantindo a manutenção de sua cultura e modo de vida.

Assim, como resultado deste processo de diálogo e interação buscou-se a definição de diretrizes, instrumentos e mecanismos de gestão, compatíveis com a legislação socioambiental e as demandas do desenvolvimento humano. Os atores envolvidos no processo eram compostos por instituições, ONGs ambientalistas e defensores de direitos humanos ou entidades de classe, voltados para apoiar as comunidades tradicionais e fortalecer esse grupo através da maior participação e visibilidade (SIMÕES, 2015).

Como destaca Simões (2015) esse processo de negociação culminou na garantia da permanência das comunidades tradicionais no território do NP, a partir da formulação do Plano de Uso Tradicional em conjunto com as Câmaras Técnicas, em 2004, para o bairro do Cambury, e, para o Sertão da Fazenda, em 2005. Posteriormente, o Plano de Manejo adotou as orientações estabelecidas no Plano de Uso Tradicional, delimitando em seu zoneamento a 
Zonas Histórico-Cultural Antropológica (ZHCAn) ${ }^{3}$ destinadas às comunidades tradicionais, incorporando a estratégia de microzoneamento para estas áreas (SIMÕES, 2015).

Em atenção aos residentes que não possuem o estatuto de tradicionais ${ }^{4}$ estabeleceu-se a Zona de Ocupação Temporária $(\mathrm{ZOT})^{5}$. Essa zona é formada por ocupações por posseiros ou titulares de registro imobiliário que serão indenizados em processo de regularização fundiária. As ocupações irregulares, posteriores à criação do parque terão suas casas demolidas (SÃO PAULO, 2006). Neste enquadramento se inserem também os habitantes inseridos na ZHCAn mas que não possuem o estatuto jurídico de tradicional, sendo que as normas vigentes para estes habitantes são correspondentes à ZOT. De modo geral a população residente na ZOT está sujeita à maiores restrições se comparada aos residentes da ZHCAn, como em relação à instalação de energia elétrica, construções e reformas das residências, uso dos recursos, dentre outros (SIMÕES, 2015).

Também é observado nesse núcleo a Zona de Superposição Indígena, composta pela Aldeia Boa Vista de população Guarani, no Bairro do Promirim, ao qual se aplicam as normas vigentes pela Constituição e legislação federal.

\subsubsection{Núcleo Caraguatatuba (NuCar)}

A área que hoje faz parte do NuCar conforme a Figura 15 corresponde a parte da área da Reserva Florestal de Caraguatatuba de 1956 (Decreto Estadual no 26.393), posteriormente recategorizada em Parque Estadual de Caraguatatuba em 1962 (Decreto Estadual $n^{\circ}$ 6.884) com área de 13.969,60 hectares. Em 1977 a área foi incorporada ao PESM tendo seus limites ampliados (SISTEMA AMBIENTAL PAULISTA, 2017).

\footnotetext{
3 A Zona Histórico-Cultural Antropológica (ZHCAn) destina-se a abrigar os territórios pertencentes às comunidades tradicionais de caiçaras e quilombolas presentes nos bairros do Cambury, Sertão da Fazenda, Vila de Picinguaba e Sertão Ubatumirim, que correspondem a 0,37\% do PESM. Essas unidades territoriais estão presentes somente no NP e estão sujeitas a diretrizes estabelecidas no Plano de Manejo, que ordena o uso do território e dos recursos. O Plano de Manejo prevê ainda a necessidade de alteração de categoria de manejo destas áreas para uma UC de uso sustentável, compatível com a ocupação humana (SÃ̃ PAULO, 2006).

${ }^{4}$ Estatuto de tradicionais: O decreto $\mathrm{n}^{\circ}$ 6040, de 7 de fevereiro de 2007 reconhece os povos e comunidades tradicionais como: "grupos culturalmente diferenciados e que se reconhecem como tais, que possuem formas próprias de organização social, que ocupam e usam territórios e recursos naturais como condição para sua reprodução cultural, social, religiosa, ancestral e econômica, utilizando conhecimentos, inovações e práticas gerados e transmitidos pela tradição" (BRASIL, 2007, art. $3^{\circ}$ ).

5 A Zona de Ocupação Temporária (ZOT) foi definida no zoneamento do plano de manejo do PESM (SÃO PAULO, 2006) referente às "áreas ocupadas por posseiros ou titulares de registro imobiliário que ainda não foram indenizados e que se encontram em processo de regularização fundiária. Após a indenização e/ou reassentamento, esta zona será incorporada a outras, conforme suas condições ambientais” (p. 297).
} 
Sua área ocupa predominantemente seções da Serra do Mar, com paisagens exuberantes de matas de encosta, rios e cachoeiras, mananciais da represa de Paraibuna e os cenários observados a partir da Rodovia Tamoios e a estrada do Rio Pardo (SISTEMA AMBIENTAL PAULISTA, 2017).

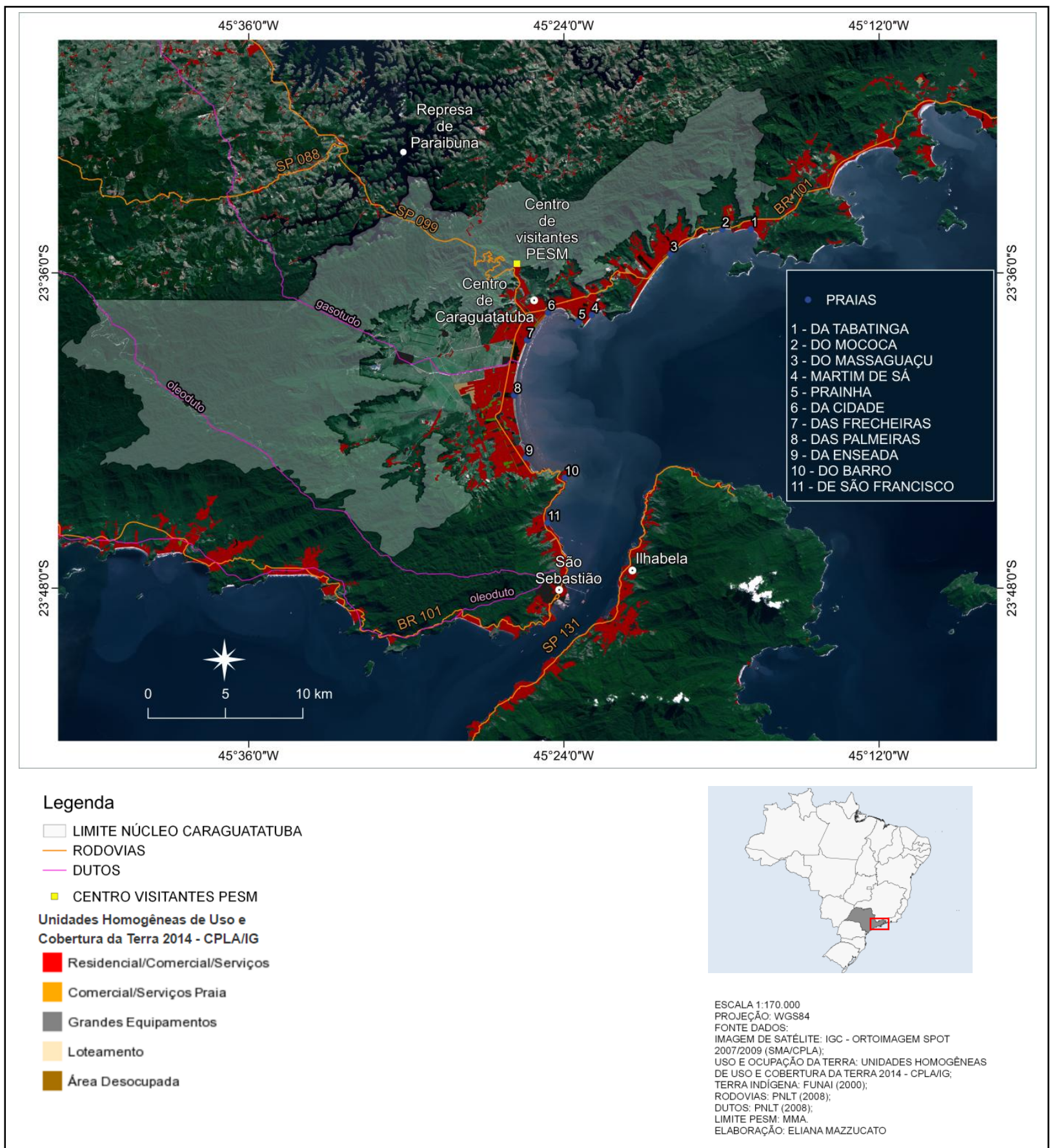

Figura 15 - Mapa de localização do Núcleo Caraguatatuba do Parque Estadual da Serra do Mar. (Dados: DataGEO). 
Inserido numa região de maior adensamento populacional a unidade sofre intensa pressão, sendo que obras de infraestrutura atravessam seu território, como a estrada intermediária, os dutos da Petrobrás e a rodovia Tamoios (DAHER, 2012).

Em relação às ocupações humanas no núcleo, não foram caracterizadas comunidades tradicionais em seu território. Portanto os adensamentos populacionais inseridos em seus limites correspondem às Zonas de Ocupação Temporária, representando residentes que não possuem estatuto de tradicionais, e aqueles que possuem casas de veraneio.

Observa-se trechos do NuCar que tem sofrido maiores pressões por ocupação, como na área de abrangência da Rodovia dos Tamoios (SP-099) que já apresentava ocupações humanas anteriormente a criação da unidade, onde os proprietários de grandes territórios parcelaram suas áreas em loteamentos. Esse setor também presenciou o avanço de ocupações irregulares nas décadas de 1970 e 1980 nas margens da Represa de Paraibuna, sendo destinadas a pontos de caça e extração de produtos florestais (MOTA, 2007). 


\section{CAPÍTULO 4 - REFERENCIAL METODOLÓGICO}

Esta pesquisa foi desenvolvida no contexto da Geoconservação, articulando aspectos teóricos e empíricos para analisar e discutir a participação social e sua contribuição no processo de (re)conhecimento da geodiversidade e do patrimônio geológico, bem como na elaboração de propostas de geoconservação.

Considera-se neste capítulo a abordagem da Geoconservação a partir do diálogo entre as Geociências e a Pesquisa Social, com a análise a partir da visão integrada das relações entre o meio físico e o meio social.

O referencial metodológico da pesquisa foi estabelecido a partir da reflexão sobre a metodologia proposta por Brilha (2005), que se pauta nas estratégias de geoconservação considerando as seguintes etapas sequenciais: inventário, quantificação, conservação, valorização, divulgação e monitoramento.

A pesquisa também se insere no contexto do NAP GeoHereditas dando continuidade, sob novas perspectivas, a uma série de pesquisas e ações já desenvolvidas na área do estudo, que foram essencialmente:

- Inventário e quantificação do patrimônio geológico: inventário e quantificação científico e sistemático do Patrimônio Geológico de Ubatuba (SANTOS, 2014) e Caraguatatuba (ARRUDA et al., 2015, 2017). Compõe também a área de estudo alguns geossítios levantados no inventário do Patrimônio Geológico do Estado de São Paulo (GARCIA et al., 2017);

- Divulgação e valorização da geodiversidade e do patrimônio geológico: realização de cursos de difusão com os monitores do PESM, em Picinguaba (2012) e Caraguatatuba (2014). Em relação aos materiais de divulgação desenvolvidos pelo NAP GeoHereditas destacam-se para a área de estudo os roteiros geointerpretativos e os painéis interpretativos. Os roteiros geointerpretativos foram elaborados a partir do projeto "interpretação geológica em trilhas", propondo dois roteiros para a presente área de estudo, o da Praia Brava da Almada (Ubatuba) e a Trilha do Jequitibá (Caraguatatuba). Em 2016, inserido no projeto "Roteiro Geoturístico: Geossítios ao longo da BR-101" foram elaborados e instalados 12 painéis de interpretação geológica 
ao longo do litoral norte de São Paulo, estando três deles instalados em Ubatuba e três em Caraguatatuba ${ }^{6}$.

Considerando a unidade de conservação como escala de análise da pesquisa, observou-se as orientações apresentadas na publicação do Ministério do Meio Ambiente e o ICMBio de diretrizes para Estratégias Nacional de Comunicação Educação Ambiental em Unidades de Conservação (ENCEA-ICMBIO, 2011) e a publicação desenvolvida em conjunto pelo Ministério do Meio Ambiente, ICMBio e o WWF (BRASIL, 2016) que versam sobre o desenvolvimento de atividades de educação ambiental em unidades de conservação. Este último salienta o papel da UC como "espaço educador", reconhecendo a educação ambiental como instrumento de gestão.

A educação ambiental direcionada aos grupos sociais que convivem diretamente com a realidade das unidades de conservação, sejam os vizinhos, moradores, usuários ou beneficiários desses territórios protegidos, é uma estratégia essencial para o engajamento da sociedade na desafiadora tarefa de conservar as diversidades natural, cultural e histórica desses territórios (BRASIL, 2016, p. 10).

Portanto, as orientações apresentadas no guia para a educação ambiental em UCs foram correlacionadas à abordagem da Geoconservação nos núcleos da área de estudo, considerando a valorização e divulgação da geodiversidade e do patrimônio geológico e a articulação com os atores locais.

Para a definição das estratégias de educação ambiental adotadas pela equipe da UC no seu processo de gestão, alguns aspectos como leitura do contexto, identificação dos principais desafios e conflitos em que a unidade está inserida e quais atores sociais participam ou têm potencial de participação neste processo precisam ser considerados. Do mesmo modo, é fundamental o envolvimento de toda a equipe que trabalha na unidade de conservação (BRASIL, 2016, p. 35).

Insere-se, assim, a relevância das metodologias participativas, tanto na promoção da participação social, quanto na "eficácia da ação educativa que se pretende" (BRASIL, 2016, p. 40).

6 Todos os projetos do NAP GeoHereditas podem ser acessados pelo site $<$ http://www.igc.usp.br/?id=geohereditas>. 
No contexto da área de estudo, o estabelecimento de parceria com a administração do PESM nos núcleos Picinguaba e Caraguatatuba foi primordial na trajetória da pesquisa. Através dessa parceria houve perspectivas para o desenvolvimento das etapas metodológicas que se centraram na valorização e divulgação do patrimônio geológico com o envolvimento dos atores locais. A atuação da equipe administrativa do parque foi fundamental para a promoção, divulgação e desenvolvimento dos cursos realizados no parque, como pode ser observado nas páginas dos núcleos do site institucional do PESM divulgando o curso (ANEXO A).

Na perspectiva de ampliar as parcerias com os atores locais, destaca-se a articulação realizada com a escola municipal de Ubatuba "José Belarmino Sobrinho" e com a ONG Instituto Argonauta ${ }^{7}$ para a Conservação Costeira e Marinha que possui projetos relacionados à preservação dos ambientes marinhos e costeiros. Assim como o PESM, a escola teve papel fundamental na promoção e desenvolvimento do curso para os professores, possibilitando também que fossem apreendidas as percepções desses atores locais. A parceria com a ONG permitiu que os funcionários que realizam o monitoramento das praias de Ubatuba e Caraguatatuba preenchessem os questionários da pesquisa.

Assim, a presente pesquisa inovou nas metodologias amplamente utilizadas na área da Geoconservação, realizando uma releitura da proposta de Brilha (2005), com ênfase nas etapas de divulgação e valorização, propondo sua articulação com as metodologias participativas e de diagnóstico socioambiental do lugar.

Durante toda a pesquisa buscou-se dar voz a mais de um ator social, garantindo assim um processo participativo com múltiplos olhares, interesses e contextos sociais. Essa aproximação e articulação com os moradores locais, monitores ambientais, gestores dos núcleos, professores e outros, embasou os pressupostos dessa pesquisa, ressaltando suas perspectivas em solucionar questões locais para estabelecer estratégias de geoconservação.

A pesquisa na área da Geoconservação é singular no contexto das unidades de conservação, dessa forma, os parceiros e atores locais envolvidos na pesquisa também foram únicos nesse tipo de abordagem, sendo eles:

- Moradores tradicionais, que residem na Zona Histórico Cultural Antropológica do PESM núcleo Picinguaba, e não tradicionais, residentes da Zona de Ocupação Temporária, do PESM núcleo Picinguaba e Caraguatatuba;

\footnotetext{
${ }^{7}$ http://institutoargonauta.org/
} 
- Representantes do poder público sob a figura dos gestores e funcionários dos dois núcleos do Parque Estadual da Serra do Mar;

- Professores da rede municipal de ensino de Ubatuba;

- Monitores ambientais e guias de turismo;

- Funcionários de ONG.

\subsection{Etapas e Procedimentos da Pesquisa}

As etapas metodológicas da pesquisa resultaram da articulação da metodologia para o desenvolvimento de estratégias de geoconservação com as metodologias participativas, de diagnóstico socioambiental e apreensão das percepções ambientais em sua relação com a geodiversidade, considerando uma multiplicidade de atores sociais.

A pesquisa envolveu essencialmente etapas de levantamento e revisão bibliográfica acerca da temática, etapas de campo direcionadas para o reconhecimento e avaliação do potencial educativo dos geossítios, desenvolvimento de cursos de divulgação das Geociências e valorização da geodiversidade e do patrimônio geológico, além da realização de entrevistas e aplicação de questionários com os atores locais. A síntese dos procedimentos metodológicos adotados na pesquisa pode ser observada na Tabela 2 . 
Tabela 2 - Síntese dos procedimentos metodológicos da pesquisa.

\begin{tabular}{|c|c|c|c|}
\hline $\begin{array}{l}\text { Eixos } \\
\text { Temáticos }\end{array}$ & Objetivos específicos & $\begin{array}{l}\text { Metodologias de coleta e } \\
\text { análise dos dados }\end{array}$ & Resultados esperados \\
\hline $\begin{array}{l}\text { Diagnóstico } \\
\text { prévio da área } \\
\text { de estudo }\end{array}$ & $\begin{array}{l}\text { Análise previa da área de } \\
\text { estudo, considerando as } \\
\text { publicações pertinentes e as } \\
\text { pesquisas do NAP } \\
\text { GeoHereditas. Estabelecer } \\
\text { contato com os atores locais. } \\
\text { Avaliar o potencial didático } \\
\text { dos geossítios. }\end{array}$ & $\begin{array}{l}\text { - Levantamento bibliográfico e } \\
\text { cartográfico; } \\
\text { - Análise crítica das referências; } \\
\text { - Trabalhos de campo; } \\
\text { - Aplicação do questionário } \\
\text { piloto. }\end{array}$ & $\begin{array}{l}\text { Adequar a trajetória da pesquisa } \\
\text { a partir do contexto } \\
\text { socioambiental local. Esperou- } \\
\text { se mapear os atores locais e } \\
\text { estabelecer vínculos e parcerias } \\
\text { com os mesmos. Foi previsto } \\
\text { também a elaboração e } \\
\text { aplicação do questionário piloto. }\end{array}$ \\
\hline $\begin{array}{l}\text { Divulgação e } \\
\text { valorização da } \\
\text { geodiversidade } \\
\text { e do patrimônio } \\
\text { geológico do } \\
\text { PESM }\end{array}$ & $\begin{array}{l}\text { Contribuir com o ensino de } \\
\text { Geociências e com o } \\
\text { reconhecimento da relevância } \\
\text { da geodiversidade e do } \\
\text { patrimônio geológico. } \\
\text { Elaborar materiais didáticos } \\
\text { de divulgação. }\end{array}$ & $\begin{array}{l}\text { - Valorização e divulgação do } \\
\text { patrimônio geológico e da } \\
\text { geodiversidade (BRILHA, } \\
\text { 2005); } \\
\text { - Metodologias de ensino com } \\
\text { base na Aprendizagem Social: } \\
\text { Aulas dialogadas, atividades } \\
\text { didático-pedagógicas } \\
\text { participativas, trabalhos de } \\
\text { campo (WALS, 2007; SANTOS } \\
\& \quad \text { BACCI, 2011; JACOBI, } \\
\text { 2013). }\end{array}$ & $\begin{array}{l}\text { Promover a compreensão dos } \\
\text { aspectos relevantes } \\
\text { geodiversidade e do patrimônio } \\
\text { geológico para que os atores } \\
\text { locais possam refletir sobre as } \\
\text { estratégias de geoconservação. }\end{array}$ \\
\hline $\begin{array}{l}\text { Diagnóstico } \\
\text { socioambiental } \\
\text { e levantamento } \\
\text { das percepções } \\
\text { geoambientais }\end{array}$ & $\begin{array}{l}\text { Diagnosticar a dinâmica } \\
\text { socioambiental da área de } \\
\text { estudo, identificando assim os } \\
\text { problemas e conflitos a partir } \\
\text { dos atores locais, } \\
\text { compreendendo também suas } \\
\text { percepções ambientais com } \\
\text { ênfase na geodiversidade. }\end{array}$ & $\begin{array}{l}\text { - } \text { Entrevistas } \text { semiestruturadas } \\
\text { (TRIVIÑOS, 1987; GIL, 2008); } \\
\text { - Questionários (Gil, 2008); } \\
\text { - } \text { Percepção ambiental (DEL } \\
\text { RIO, 1991; DEL RIO \& } \\
\text { OLIVEIRA, } \\
\text { MACHADO, 1996). }\end{array}$ & $\begin{array}{l}\text { Esperou-se realizar } \\
\text { diagnóstico socioambiental da } \\
\text { área de estudo e levantar as } \\
\text { percepções geoambientais com } \\
\text { o intuito de compreender o } \\
\text { contexto local e as percepções } \\
\text { sobre a abordagem da } \\
\text { Geoconservação a partir do } \\
\text { olhar dos atores locais. }\end{array}$ \\
\hline
\end{tabular}

\section{Continua}




\begin{tabular}{|c|c|c|c|}
\hline $\begin{array}{l}\text { Eixos } \\
\text { Temáticos }\end{array}$ & Objetivos & $\begin{array}{l}\text { Metodologias de coleta e } \\
\text { análise dos dados }\end{array}$ & Resultados esperados \\
\hline $\begin{array}{l}\text { Elaboração } \\
\text { participativa de } \\
\text { estratégias de } \\
\text { geoconservação }\end{array}$ & $\begin{array}{l}\text { Definir estratégias de } \\
\text { geoconservação para a área de } \\
\text { estudo }\end{array}$ & $\begin{array}{l}\text { - Estratégias de geoconservação } \\
\text { (BRILHA, 2005); } \\
\text { - Metodologias participativas: a) } \\
\text { Mapeamento Socioambiental } \\
\text { (SANTOS, 2010; SANTOS \& } \\
\text { BACCI, 2011; BACCI \& } \\
\text { SANTOS, 2013a, 2013b); } \\
\text { b) World Café (BROWN, } \\
\text { 2001a, 2001b), (CAMARGO, } \\
\text { 2011; FERNANDES, 2015). }\end{array}$ & $\begin{array}{l}\text { Criar sistema colaborativo e } \\
\text { autônomo para } \\
\text { geoconservação, através da } \\
\text { sensibilização dos atores } \\
\text { locais. Possibilitar a } \\
\text { participação desses atores na } \\
\text { elaboração de estratégias de } \\
\text { geoconservação. }\end{array}$ \\
\hline
\end{tabular}

Conclusão

Nessa seção serão apresentados os eixos temáticos que nortearam a pesquisa, sendo eles:

- Diagnóstico prévio da área de estudo;

- Divulgação e valorização da geodiversidade e do patrimônio geológico do PESM;

- Levantamento das percepções geoambientais e dos conflitos sociais;

- Elaboração participativa de estratégias de geoconservação.

Cada um desses eixos compreendeu a utilização de um ou mais instrumentos de coleta de dados, que, serão apresentados:

- Questionários;

- Entrevistas;

- World Café;

- Mapeamento Socioambiental;

\subsubsection{Diagnóstico prévio da área de estudo}

A pesquisa iniciou-se com a análise da área de estudo a partir da leitura da bibliografia pertinente aos seguintes aspectos: patrimônio geológico e geoconservação, percepção ambiental, metodologias participativas no âmbito da Aprendizagem Social e educação ambiental em unidades de conservação. Além disso, recorreu-se às bibliografias de caracterização do meio biofísico e social, bem como de inventário e quantificação do patrimônio geológico da área de estudo. 
A análise preliminar desses referenciais foi acrescida de trabalho de campo, realizado nos dias 14 e 15 de novembro de 2015 para a observação e contato prévio com os habitantes locais que nortearam os passos metodológicos. Além disso, durante o trabalho de campo foram analisados alguns geossítios presentes nos inventários, observando as possibilidades e a viabilidade de desenvolver estratégias de valorização e divulgação.

Com isso, pôde-se delinear a trajetória da pesquisa, partindo do estabelecimento de parcerias e propostas de valorização e divulgação da geodiversidade e do patrimônio geológico no contexto nos núcleos do PESM no sentido de promover o envolvimento da comunidade local nas propostas de estratégias de geoconservação.

\subsubsection{Valorização e divulgação da geodiversidade e do patrimônio geológico com base na Aprendizagem Social}

A valorização e divulgação da geodiversidade e do patrimônio geológico consistiu no desenvolvimento de uma das etapas das estratégias de geoconservação propostas por Brilha (2005), considerando as características levantadas na etapa anterior.

A proposta foi desenvolvida essencialmente através de cursos formativos em torno do saber geocientífico e da geoconservação, com base na Aprendizagem Social e nas metodologias participativas junto aos atores locais. Essas ações tiveram como objetivo dar suporte ao entendimento e ao (re)conhecimento do patrimônio geológico e da relevância da Geoconservação. Além disso, buscou fortalecer a participação social de diversos atores para a Geoconservação. Essas ações também viabilizaram as coletas dos dados a partir dos questionários e do desenvolvimento de metodologias participativas.

O curso de difusão cadastrado no Instituto de Geociências da USP intitulado "Estratégias de Geoconservação no Parque Estadual da Serra do Mar" foi coordenado pela Professora Dr ${ }^{\mathrm{a}}$ Denise de La Corte Bacci (IGc - USP), e contou com a colaboração da Professora Dr ${ }^{\mathrm{a}}$ Maria da Glória Motta Garcia (IGc - USP), Professora Dr ${ }^{\mathrm{a}}$ Vânia Maria Nunes dos Santos (IG - UNICAMP) e da presente pesquisadora.

A proposta do curso teve como objetivo trazer aos monitores do PESM e professores locais uma visão interdisciplinar sobre as questões ambientais, com foco na temática da Geoconservação e da Aprendizagem Social. As atividades desenvolvidas tiveram o propósito de promover a compreensão da temática, bem como articular a definição de estratégias para conservação do patrimônio natural e geológico. O desenvolvimento do curso se deu a partir de 
diferentes atividades didático-pedagógicas, com aulas dialogadas, dinâmicas de grupo e atividades de campo.

A abordagem do curso teve algumas especificidades de acordo com os atores locais envolvidos, sendo eles os monitores ambientais do PESM e os professores da escola municipal do bairro do Puruba.

a) Monitores Ambientais do PESM - núcleo Caraguatatuba e Picinguaba

O público alvo do curso desenvolvido no centro de visitantes do PESM nos núcleos focalizados foram os monitores ambientais do parque, porém a ação esteve aberta para a comunidade do entorno. A divulgação do curso e toda a infraestrutura para seu desenvolvimento foi promovida a partir da administração dos núcleos da UC.

A presente proposta se baseou no papel que esses monitores exercem nas ações de visitação e de educação ambiental promovidas pelo parque, valorizando seu olhar crítico, conhecimentos e experiências como contributos para a elaboração de estratégias de geoconservação.

A formação continuada de monitores ambientais observou as orientações indicadas para a formação de monitores segundo as diretrizes da unidade de conservação. Os conteúdos e abordagens foram organizados em módulos contemplando os seguintes temas:

- Geodiversidade e Patrimônio Geológico: abordagem das relações entre a unidade de conservação e a questão socioambiental, destacando a contribuição das Geociências para o estudo do ambiente, da conservação, da geodiversidade e do patrimônio natural;

- Propostas de geoconservação para a unidade de conservação: promoção de reflexões sobre as ameaças a que os geossítios estão sujeitos e sua necessidade de conservação, visando à elaboração de propostas de estratégias para conservação do patrimônio geológico, biológico e cultural da região. Tais dinâmicas foram articuladas através da metodologia do World Café.

- Roteiros Geológicos: realização de visitas técnicas em trilhas do parque, observando e refletindo sobre os geossítios que contemplem aspectos geológicos, geomorfológicos, históricos, arqueológicos e culturais de significativa expressão local/regional, visando o (re)conhecimento desses aspectos e a análise crítica do lugar.

O curso foi desenvolvido no centro de visitantes dos dois núcleos da área de estudo, compreendendo atividades presenciais e à distância, totalizando 32h. Em Caraguatatuba o 
curso foi realizado nos dias 12 e 13 de setembro de 2016 (12 participantes), e, em Picinguaba, nos dias 27 e 28 de setembro de 2016 (15 participantes).

No primeiro dia, durante a manhã foi apresentado de forma dialogada a proposta do curso, sendo abordados conceitos básicos relativos às Geociências, com maior enfoque aos conceitos de geodiversidade e patrimônio geológico, utilizando-se de exemplos globais e locais. No período da tarde foi desenvolvida a temática das estratégias de geoconservação, exemplificando e problematizando as estratégias em âmbito local.

No segundo dia do curso, foi proposto o desenvolvimento do trabalho de campo, utilizando-se de roteiros geointerpretativos. Assim, os conteúdos discutidos em aula foram relacionados aos materiais e processos da geodiversidade observados em campo, refletindo também sobre aspectos da realidade socioambiental local. No período da tarde foi proposta a atividade dos valores/ameaças/estratégias de geoconservação de forma participativa, e o World Café. Ao final do curso os participantes apresentaram suas respostas e reflexões sobre as estratégias de geoconservação.

O trabalho de campo no núcleo Picinguaba foi desenvolvido na trilha Saco das Taquaras que é parte da trilha Brava da Almada. O trajeto teve como ponto de partida a sede do núcleo administrativo do PESM em Picinguaba, seguindo em direção à praia, onde foi percorrida a orla da praia da Fazenda, em direção ao costão rochoso localizado a noroeste desta. No costão rochoso iniciou-se a trilha da Praia Brava da Almada, que foi percorrida até o Saco das Taquaras (ou Praia das Conchas). O roteiro geointerpretativo da trilha Brava da Almada encontra-se publicada em Santos (2014, p. 209).

No núcleo Caraguatatuba, o trabalho de campo foi desenvolvido na trilha do Jequitibá, que fica na sede do núcleo. A trilha percorre trecho da Mata Atlântica, até alcançar o rio Santo Antônio. O roteiro geointerpretativo dessa trilha foi desenvolvido pelo NAP GeoHereditas.

b) Professores da Escola Municipal José Belarmino Sobrinho

O curso foi destinado aos professores da escola municipal de Educação Infantil (EI) e Ensino Fundamental (EF) localizada no bairro do Puruba, em Ubatuba. A proposta considera o professor como ator social local, detentor dos conhecimentos didático-pedagógicos, capaz de articular e relacionar os conceitos ambientais à geoconservação no currículo escolar.

A formação de professores proposta teve em atenção às orientações curriculares indicadas nos documentos oficiais para o ensino fundamental. Relacionou assim abordagens 
conceituais através de aulas dialogadas, dinâmicas em grupo e, trabalho de campo, organizados nos seguintes módulos:

- Ensino em Geociências: abordagem das relações entre escola e a questão socioambiental por meio de reflexões sócio-político-pedagógicas, destacando a contribuição das Geociências para o estudo do ambiente, da conservação, da geodiversidade e do patrimônio natural;

- Educação e Aprendizagem Social: promoção de reflexões sobre a importância do desenvolvimento de práticas educativas colaborativas pautadas em princípios de diálogo, participação e co-responsabilização frente à questões socioambientais locais com referência no conceito de aprendizagem social, bem como apresentar diferentes metodologias participativas;

- Roteiros Geológicos: realização de visitas técnicas a geossítios que contemplem aspectos geológicos, geomorfológicos, históricos, arqueológicos e culturais de significativa expressão local/regional, visando o reconhecimento desses, bem como desenvolver a metodologia do mapeamento socioambiental em geossítio selecionado;

- Propostas socioambientais colaborativas: promoção de reflexões sobre a contribuição da escola na educação para a geoconservação e sustentabilidade, visando à elaboração de propostas/projetos com estratégias para conservação do patrimônio geológico, biológico e cultural da região.

O curso foi desenvolvido na escola, localizada cerca de $20 \mathrm{~km}$ a norte do centro de Ubatuba, com uma carga horária de 30h, entre 27 de março de 2017 a 10 de abril de 2017, com a participação de 25 pessoas.

No período de 27 de março a 7 de abril de 2017 foram propostas atividades à distância, com a leitura de textos vinculados à Geoconservação e à Aprendizagem Social. De 7 a 10 de abril o curso foi presencial.

Durante a manhã do primeiro dia foi apresentada a proposta do curso, seguida de aula dialogada com dinâmicas de grupo sobre o ensino de Geociências e a Aprendizagem Social, e introdução aos conceitos da geoconservação no período da tarde.

No segundo dia, durante a manhã foi realizada a apresentação da metodologia do Mapeamento Socioambiental, seguida da realização do trabalho de campo utilizando essa metodologia. O roteiro do trabalho de campo teve como ponto inicial a escola e seguiu a principal via do bairro que culmina na foz dos rios Quiriri e Puruba e na praia do Puruba, de 
acordo com o roteiro no Anexo G. Para essa atividade foi elaborado o roteiro geointerpretativo como apoio para a atividade (Apêndice A).

No terceiro dia prosseguiu-se à elaboração do mapa síntese socioambiental e a apresentação de forma dialogada das estratégias da geoconservação, relacionando os aspectos apreendidos em campo e o papel da escola nesse contexto.

\subsubsection{Diagnóstico socioambiental e levantamento das percepções geoambientais}

Integrar a metodologia da Geoconservação ao diagnóstico socioambiental e ao levantamento das percepções ambientais com ênfase na geodiversidade (geoambientais) foi um dos caminhos escolhidos nessa pesquisa para compreender os diversos olhares e interpretações sobre o ambiente em estudo.

Portanto as etapas de levantamento das percepções geoambientais e de diagnóstico socioambiental objetivaram complementar as estratégias de geoconservação propostas por Brilha (2005), valorizando a contextualização das estratégias de geoconservação no âmbito local.

Essa proposta vai ao encontro das orientações apontadas por Castro et al. (2015) que inclui as comunidades na elaboração das estratégias de geoconservação, priorizando que haja o reconhecimento do patrimônio geológico pelos atores locais. Essas estratégias podem ser traçadas a partir de diagnósticos e análises junto às comunidades, como destacam os autores:

É necessário conhecer e verificar como é a relação das pessoas com elementos da geodiversidade, pois são elas que residem nas proximidades dos afloramentos geológicos e têm contato com eles todos os dias. Essas pessoas devem ser compreendidas como potenciais parceiros na salvaguarda do patrimônio (CASTRO et al., 2015, p. 163).

Reconhecer a percepção da geodiversidade implica em compreender os valores e ameaças a partir do olhar dos atores locais, incidindo em ações significativas para promover a sensibilização sobre a geodiversidade e o patrimônio geológico e mudanças de conduta em relação a esses elementos.

Identificar a geodiversidade a partir da percepção desses moradores contribui com a compreensão da construção de identidade a partir desses elementos, considerando os valores locais atribuídos à geodiversidade. Os estudos de percepção ambiental apontam possíveis trajetórias significativas nas abordagens de valorização e divulgação da geodiversidade local, contribuindo com sua geoconservação. 
A coleta dos dados para o levantamento das percepções geoambientais e do diagnóstico socioambiental ocorreu com base em entrevistas realizadas com os moradores locais e em questionários aplicados aos atores locais envolvidos com o ensino e atividades turísticas.

\subsubsection{Elaboração participativa de estratégias de geoconservação}

A elaboração de estratégias de geoconservação de forma participativa teve em atenção todos os eixos descritos anteriormente, focalizando os resultados obtidos por meio das metodologias participativas. As metodologias participativas são apresentadas como ferramentas que favorecem a aprendizagem e a construção de agendas socioambientais locais, através de diagnósticos participativos e elaboração de planos de intervenção (FRANCO, 2011).

Jacobi e Franco (2011) relacionam a participação como um processo de democratização da vida dos cidadãos. Assim a participação procura reforçar os princípios da democracia, garantindo o "desenvolvimento de objetos de interesse coletivo", reforçando o “tecido associativo" e "a capacidade técnica e administrativa das associações", promovendo também a "participação na definição de programas e projetos de interesse coletivo" (JACOBI \& FRANCO, 2005, p. 12).

De acordo com Bracagioli (2007) as metodologias participativas devem ter como pressuposto a emancipação. Dessa forma, podem ser empregadas no sentido da aprendizagem, valorizando a riqueza de conhecimentos e experiências do grupo e, refletindo sobre a ação de aprender a partir da interação e colaboração entre as pessoas. Além disso, a participação pode vir acompanhada de consulta, informação ou mobilização, esclarecendo os benefícios pessoais, socioambientais ou materiais provenientes dessa participação.

A coleta dos dados referentes às metodologias participativas foi realizada durante os cursos propostos. A aplicação das metodologias participativas através da divulgação e valorização da geodiversidade e do patrimônio geológico, bem como toda a trajetória da pesquisa teve em conta os pressupostos de Jacobi e Franco (2011) que inserem a perspectiva das metodologias participativas no contexto da Aprendizagem Social:

[...] construir espaços pedagógicos como espaços coletivos para a aprendizagem e o exercício da cidadania supõe autonomia, aprendizado da capacidade de autogerenciamento, informação, conhecimento situado e significativo, diálogo, leitura crítica de mundo. [...] A Aprendizagem Social 
é a base para a aprendizagem da cidadania ambiental e, portanto, para a incorporação de atitudes individuais e coletivas para a sustentabilidade. Emerge solicitando metodologias participativas e colaborativas que articulem as dimensões social, ambiental, cultural e afetiva. Envolve processos de informação reflexiva e engajada, sensibilização e a construção de espaços político-educativos de formação cidadã, de diálogos colaborativos, a internalização das questões ambientais, o comprometimento ético e político com novas posturas e sentidos comuns diante das urgências que se apresentam para a construção da sustentabilidade, que com o processo de globalização dos riscos, passa a ser de caráter planetário (JACOBI \& FRANCO, 2011, p. 16).

A análise das estratégias participativas de geoconservação foi realizada de forma qualitativa, considerando os caminhos apontados e sua correlação com propostas presentes da bibliografia pertinente, observando, ainda, as relações estabelecidas com os aspectos de gestão do território e conflitos socioambientais locais.

\subsection{Instrumentos de coleta e análise dados}

$\mathrm{Na}$ etapa de coleta de dados, foram priorizados instrumentos qualitativos, abrangendo de forma inédita diversos atores sociais para a geoconservação do lugar. $\mathrm{Na}$ Tabela 3 pode-se observar os atores locais que fizeram parte do escopo da pesquisa, bem como os instrumentos de coleta de dados utilizados.

Tabela 3 - Relação dos atores locais e os instrumentos de coleta de dados utilizados

\begin{tabular}{|c|c|c|c|c|}
\hline Público-alvo & Questionário & Entrevista & $\begin{array}{c}\text { Mapeamento } \\
\text { Socioambiental }\end{array}$ & World Café \\
\hline Moradores locais & $\mathrm{X}$ & $\mathrm{X}$ & & \\
\hline Poder público & $\mathrm{X}$ & $\mathrm{X}$ & & $\mathrm{x}$ \\
\hline Professores & $\mathrm{X}$ & & $\mathrm{X}$ & \\
\hline Monitores ambientais & $\mathrm{X}$ & $\mathrm{X}$ & & $\mathrm{X}$ \\
\hline Funcionários ONG & $\mathrm{X}$ & & & \\
\hline
\end{tabular}

Entretanto, alguns atores sociais se enquadram em mais de uma dessas categorias, a exemplo, funcionários do parque que são também moradores da comunidade. Destacam-se também aqueles que não estão inseridos nesses grupos, como participantes dos cursos que representam outras categorias sociais, como bombeiros, funcionários do DERSA (Desenvolvimento Rodoviário S/A), gestores de outras UCs, dentre outros. 


\subsubsection{Questionários}

O questionário foi utilizado na presente pesquisa visando alcançar maior parcela de atores sociais tendo como pressuposto a conceituação de Gil (2008) que o define como

técnica de investigação composta por um conjunto de questões que são submetidas a pessoas com o propósito de obter informações sobre conhecimentos, crenças, sentimentos, valores, interesses, expectativas, aspirações, temores, comportamento presente ou passado, etc (GIL, 2008, p.121).

Foram incluídas questões abertas, proporcionando maior liberdade para os atores locais formularem suas respostas, e fechadas, visando aspectos mais objetivos e atribuindo maior uniformidade na análise das respostas. Sua formulação objetivou que eles pudessem ser "auto-aplicados" (GIL, 2008, p. 121), ou seja, possíveis de serem respondidos sem a interferência da pesquisadora.

No caso das questões fechadas, foi definido um amplo leque de alternativas, para garantir maior exaustividade no que concerne ao campo dos elementos em questão. Também foi apresentada a opção "outros", caso o indivíduo identificasse algum elemento que não tenha sido apresentado nas alternativas. O questionário oferecia a possibilidade de seleção de mais de uma alternativa.

Assim, diante o escopo da presente pesquisa, a elaboração do questionário se orientou para a avaliação das concepções e percepções sobre a conservação da natureza na região, a geodiversidade e o patrimônio geológico, a relação de identidade e pertencimento com o lugar e, sobre os conflitos socioambientais locais.

O diagnóstico prévio (Etapa I) orientou a elaboração das questões do questionário e das entrevistas, considerando conhecimentos prévios da área de estudo a partir da revisão da literatura e também de observações de campo e conversa com moradores locais. Inicialmente realizou-se um pré-teste para avaliar a efetividade do questionário. O questionário piloto foi aplicado no contexto das comunidades locais, tendo a participação de quatro pessoas. Observou-se a necessidade da pesquisadora fazer a leitura das perguntas do questionário, explicá-las e assim anotar as respostas.

Além de não se apresentar como um instrumento auto-aplicado, também observou-se que as questões eram limitantes diante do vasto conhecimento e expectativas dos moradores locais em dialogar e contribuir com a pesquisa. Dessa forma, optou-se por readequar os instrumentos de coleta de dados para esse público específico, sendo preferida a entrevista para 
a análise das comunidades locais. Nesse sentido, esse contato prévio permitiu orientar a elaboração do roteiro das entrevistas.

As questões do questionário também foram revisadas, na perspectiva de avaliar concepções e percepções de outros públicos, nomeadamente os participantes dos cursos de formação continuada de professores no bairro do Puruba (Ubatuba), curso de formação continuada de monitores ambientais do PESM, núcleo Caraguatatuba e núcleo Picinguaba, e aos funcionários responsáveis pelo monitoramento das praias de Ubatuba e Caraguatatuba da ONG Instituto Argonauta.

O modelo final do questionário encontra-se no anexo $\mathrm{F}$, contendo 15 questões, sendo 8 abertas e 7 fechadas, apresentando também espaço para observações, caso houvesse a necessidade de complementar ou expressar alguma opinião. Esperou-se com isso ampliar a possibilidade de comunicação do indivíduo.

O desenvolvimento das perguntas propõe o afunilamento das questões, ou seja, cada eixo inicia-se com temas mais gerais e segue para temas mais específicos.

Os eixos temáticos são descritos a seguir:

a) Concepções e percepções sobre a conservação da natureza;

b) Relação com o lugar e apreensão do patrimônio;

c) Conflitos Socioambientais;

d) Concepções e percepções sobre geodiversidade, patrimônio geológico e geoconservação;

e) Proposição de estratégias de geoconservação.

A partir do conteúdo das questões apresentadas por Gil (2008) formulou-se os seguintes grupos de perguntas:

- Questões sobre fatos: abrangem perguntas sobre o perfil dos sujeitos, como nome, idade, sexo, cidade de origem, cidade em que reside atualmente e tempo de residência, escolaridade, profissão/formação e tempo de atuação no PESM;

- Questões sobre atitudes e crenças: questões relativas à compreensão do sujeito sobre unidade de conservação, sobre o que eles consideram mais importante no município, os benefícios mediados pelo PESM, os conflitos socioambientais da região, correlação com o conceito de patrimônio e sua identificação, correlação com conceito de 
geodiversidade, concepção sobre natureza abiótica do Litoral Norte e responsabilização para a conservação do patrimônio;

- Questões sobre comportamentos: questões referentes ao comportamento em relação ao lugar, por exemplo, locais que frequentam para ter momentos de lazer em contato com a natureza;

- Questões sobre sentimentos: questões que se relacionam ao pertencimento do sujeito com o lugar, às sensações referentes a lugares desmatados que já tenha visitado e, identificação do patrimônio geológico;

- Questões sobre padrões de ação: questões desse tipo relacionam, por exemplo, o papel do sujeito em relação à conservação da natureza, postura em relação às ameaças e à conservação do patrimônio geológico.

Os questionários foram aplicados no início dos cursos de formação "Estratégias de Geoconservação no Parque Estadual da Serra do Mar" para os monitores ambientais do parque, núcleos Caraguatatuba e Picinguaba e, para os professores da escola do bairro do Puruba (Escola Municipal José Belarmino Sobrinho). Os questionários também foram aplicados aos Monitores Ambientais de Ubatuba e Caraguatatuba da ONG.

A aplicação desse instrumento de pesquisa no início dos cursos foi importante para evitar a exposição dos sujeitos às influências da pesquisadora e do conteúdo do curso, garantindo dados que apresentem as concepções prévias dos participantes sobre os conceitos estruturantes na área da Geoconservação. Assim, além de oferecer um diagnóstico anterior ao curso, foi possível realizar comparações com os diálogos e atividades desenvolvidas durante o curso.

Os questionários foram aplicados nas seguintes datas:

- Monitores de Caraguatatuba: 12 de setembro de 2016;

- Monitores ambientais de Picinguaba: 27 de setembro de 2016;

- Professores: 7 de abril de 2017;

- Funcionários da ONG: 10 de abril de 2017.

Os dados levantados em campo foram digitados, tabulados e sistematizados no programa Excell para posteriormente serem analisados. 


\subsubsection{Entrevista}

A entrevista foi utilizada como metodologia na pesquisa, pois, segundo Gil (2008), além de possibilitar a coleta de dados, volta-se para a realização de diagnósticos e orientação dos objetivos da pesquisa. Assim, a entrevista consiste em

técnica em que o investigador se apresenta frente ao investigado e the formula perguntas, com o objetivo de obtenção dos dados que interessam à investigação. A entrevista é, portanto, uma forma de interação social. Mais especificamente, é uma forma de diálogo assimétrico, em que uma das partes busca coletar dados e a outra se apresenta como fonte de informação (GIL, 2008, p. 109).

Com base nas orientações de Gil (2008), essa metodologia concentrou-se nas comunidades tradicionais e mostrou-se efetiva e inclusiva, pois não é restrita aos sujeitos que sabiam ler e escrever, sendo positiva em um contexto de público com diversas formações escolares, permitindo também o esclarecimento e adaptação das questões em relação às circunstâncias reveladas durante a entrevista. Além disso, garante a coleta de dados de diversos aspectos em maior profundidade, principalmente no que concerne o comportamento.

Essa técnica também foi realizada junto aos gestores dos núcleos da área de estudo do PESM, considerando os mesmos pressupostos de explorar em maior profundidade os conhecimentos, experiências e expectativas desses sujeitos na conservação do patrimônio natural e na mediação de conflitos socioambientais.

Em relação ao nível de estruturação das entrevistas, optou-se pela entrevista por pautas (GIL, 2008), referenciada também como entrevista semiestruturada (TRIVIÑOS, 1987)

Podemos entender por entrevista semi-estruturada, em geral, aquela que parte de certos questionamentos básicos, apoiados em teorias e hipóteses, que interessam à pesquisa, e que, em seguida, oferecem amplo campo de interrogativas, fruto de novas hipóteses que vão surgindo à medida que se recebem as respostas do informante. Desta maneira, o informante, seguindo espontaneamente a linha de seu pensamento e de suas experiências dentro do foco principal colocado pelo investigador, começa a participar na elaboração do conteúdo da pesquisa (TRIVIÑOS, 1987, p. 146).

Assim, elaborou-se um roteiro prévio com questões pré-definidas, porém passíveis de adaptações de acordo com o discurso do sujeito. Essa categoria permitiu uma maior 
flexibilidade, fugindo de questões rígidas e diretas, uma vez que o público entrevistado poderia se sentir inseguro ou pressionado para corresponder às expectativas do entrevistador.

Todas as entrevistas foram realizadas de forma presencial e individual, em ambiente familiar aos entrevistados, preferencialmente reservado, conduzidas pela pesquisadora. No caso dos gestores, as entrevistas foram agendadas previamente e realizadas nos respectivos locais de trabalho. Já as entrevistas com os moradores foram realizadas sem agendamento prévio. A escolha desses sujeitos ocorreu a partir da indicação pelos moradores locais de lideranças comunitárias, membros de associações de moradores, ou pessoas mais engajadas na história de luta dessas comunidades.

O contato prévio se deu de forma amistosa como sugere Gil (2008), reforçando o rapport (TRIVIÑOS, 1987, p. 149) entre pesquisadora e entrevistado objetivando estabelecer uma relação de confiança e receptividade.

Assim, as entrevistas foram iniciadas através da apresentação da entrevistadora, explicação do motivo da entrevista, a apresentação da pesquisa com seus objetivos e instituição de origem, explicação da relevância dos temas que serão tratados e a garantia de anonimato ao sujeito.

A elaboração do roteiro teve em atenção às particularidades dos públicos envolvidos nessa etapa da pesquisa, sendo eles os gestores dos núcleos do PESM e os moradores locais.

Os gestores dos núcleos administrativos de Picinguaba e Caraguatatuba foram selecionados para a realização de entrevistas por possuir profundo conhecimento e experiência a respeito da gestão do patrimônio natural e dos conflitos socioambientais locais.

O roteiro definido para os gestores dos núcleos em estudo teve em atenção a visão desses atores sobre a inserção das estratégias de geoconservação do PESM. O roteiro, que pode ser verificado no Anexo E, foi elaborado e conduzido observando os seguintes eixos norteadores:

- Compreender o histórico de criação do PESM;

- Compreender como tem sido a inserção da geoconservação no âmbito da gestão do patrimônio natural pelos gestores nos núcleos Picinguaba e Caraguatatuba;

- Entender a participação das comunidades na gestão do patrimônio natural;

- Diagnosticar possíveis conflitos entre o PESM e as comunidades em relação à conservação do patrimônio natural; 
- Entender os projetos educativos do parque e a possibilidade de inserção de conteúdos geocientíficos.

No caso dos moradores locais, teve-se em conta a vivência e experiência desses atores na perspectiva histórica e sociocultural. O roteiro elaborado para as entrevistas foi embasado a partir do pré-teste do questionário realizado junto às comunidades tradicionais, considerando as readequações sofridas no pré-teste, a partir dos seguintes eixos temáticos:

- Perfil do sujeito: os dados pertinentes para delinear o perfil dos entrevistados tiveram como pressuposto não ferir a privacidade do entrevistado, portanto somente se questionou o nome, idade, o sexo, profissão, naturalidade e tempo de vida na cidade atual;

- Dinâmica socioambiental e a UC: neste eixo temático a abordagem direcionou-se para a relação do indivíduo com o histórico de implantação do parque. Portanto neste momento é importante destacar o conhecimento sobre o histórico de luta e conflito que decorreu de uma postura mais preservacionista em relação às ocupações humanas no território. Além disso, achou-se importante inquirir sobre as percepções pessoais a respeito da necessidade ou não da conservação ambiental, o papel do parque e das comunidades em relação a essa conservação, e as transformações recentes, impulsionadas pelo turismo e interesse do setor imobiliário na região;

- Relação com o lugar e percepções geoambientais: a relação do indivíduo com o lugar foi investigada através dos pontos que consideram como lugares de lazer e apreciação da natureza, e, quais os sentimentos ao se pensar em um ambiente não preservado. $\mathrm{O}$ objetivo era apontar a relação direta da comunidade com a geodiversidade, observando-se também os fatores de ameaça e de pressão sobre esses ambientes ainda preservados, o qual mantém profunda relação de pertencimento. Assim, sua vivência e relação com o lugar são priorizadas para se pensar em estratégias de geoconservação.

A realização das entrevistas decorreu em três trabalhos de campo realizados em: 24 a 28 de maio de 2016, 4 julho de 2016 e 10 a 12 de fevereiro de 2017.

A transcrição das entrevistas teve como base a proposta de Manzini (2008) e Duarte (2004), sendo realizada pela autora logo depois das entrevistas. Procurou-se manter ao máximo as falas originais dos entrevistados, considerando que a fala também faz parte de seu 
contexto sociocultural. Porém algumas edições foram realizadas, principalmente no que concerne às “[...] interjeições, repetições, frases incompletas, vícios de linguagem, cacoetes, [...]" (DUARTE, 2004, p. 221).

Com adaptações a partir de Preti (1999) foram adotadas as seguintes normas para transcrição:

- Uso de Itálico

- ? Interrogação;

- , pausas;

- ... pausa prolongada;

- ((minúscula)) Comentários descritivos;

- -- -- Comentários que quebram a sequência temática da exposição

- [...] Indicação de que a fala foi tomada ou interrompida em determinado ponto.

- “ " Citações literais de textos e narração da fala de outra pessoa.

A transcrição consistiu em uma pré-análise do texto, e posteriormente realizou-se os seguintes procedimentos, com base na proposta de Alves e Silva (1992):

a) Realização de leituras atentas de todo o material transcrito, estabelecendo-se análises dos conteúdos expressos nos discursos e suas relações;

b) Identificação de relações de convergências e divergências entre esses discursos, sendo realizadas anotações de interpretações atribuindo-se significados para os pontos considerados relevantes para o lugar e para a pesquisa como um todo. Nesse momento também se procurou estabelecer relações com materiais bibliográficos já publicados sobre o assunto;

c) De acordo com as regularidades e diferenças ressaltadas nos discursos realizou-se uma discriminação do material, fragmentando-o em temas pertinentes à pesquisa;

d) Seguiu-se à análise e interpretação desses materiais em maior profundidade de acordo com a delimitação dos subtemas.

Tanto os questionários quanto as entrevistas semiestruturadas serviram de base para análise da percepção geoambiental, tendo em conta que o estudo da percepção ambiental traz uma abordagem inovadora no contexto da geodiversidade. Estudos de Del Rio (1991), Del 
Rio e Oliveira (1996) e Machado (1996) foram utilizados como orientadores para a coleta e análise de dados nesse contexto.

Com base no referencial teórico, a análise da percepção ambiental dos atores locais considerou os seguintes aspectos do processo perceptivo:

a) Sensações: como o sujeito sente o ambiente, a partir dos estímulos externos e da captação (seletiva ou instantânea) desses estímulos através dos órgãos sensoriais;

b) Motivação: qual o interesse (consciente ou inconsciente) do sujeito de interagir com o ambiente;

c) Cognição: Como o sujeito compreende o meio, ou seja, atribui um significado às informações recebidas, considerando sua memória, e a organização e construção de imagens;

d) Avaliação: Como o sujeito avalia os aspectos percebidos do ambiente, ou seja, de que maneira, o sujeito envolto de uma série de valores culturais, sociais e do grupo julga os aspectos percebidos;

e) Conduta: Qual a implicação desse processo perceptivo em alterar ou não o comportamento do sujeito?

A análise exploratória da percepção geoambiental teve como objetivo reconhecer a presença ou não dos elementos da geodiversidade em cada um dos cinco processos descritos acima, apreendendo também as interpretações e condutas em relação à conservação da geodiversidade e do patrimônio geológico.

\subsubsection{World café}

A metodologia do World Café se mostrou pertinente aos objetivos dessa dissertação, pois consiste em uma metodologia que fortalece o sentido de comunidade e de diálogo significativo entre os membros da comunidade para resolução de problemas locais.

Essa denominação remete a uma conversa próxima ao que ocorre nos momentos de intervalo ou coffe break, que pode se tornar significativa quando orientada a partir da metodologia proposta, reforçando a colaboração e a criatividade entre indivíduos, mobilizados para a reflexão e resolução de uma problemática local.

A metodologia foi desenvolvida na década de 1990 por Juanita Brown e David Issac. 
O que é o World Café? É uma metodologia inovadora que aumenta a capacidade colaborativa sobre questões críticas ligando as conversas de grupos pequenos e grandes grupos. No processo, o conhecimento cresce, um sentido do todo torna-se real, e novas possibilidades tornam-se visíveis. $\mathrm{O}$ World Café utiliza os princípios de redes dinâmicas e sistemas vivos para acessar uma fonte de criatividade mais profunda e conhecimento compartilhado que pode não estar disponível através de abordagens mais tradicionais para o trabalho colaborativo (BROWN, 2001b, tradução nossa).

A partir dos pressupostos de Brown (2001b), Fernandes (2015) destaca que o World Café apresenta uma multiplicidade de possibilidades investigativas, reforçando também o resgate da conversa entre membros de uma comunidade como processo central.

O World Café (Café Mundial) é tanto um método para conversas significativas sobre questões complexas, ancorado num conjunto de princípios para criar um ambiente seguro para as pessoas falarem o que realmente importa, quanto uma "metáfora" do cultivo da conversa como um processo central (FERNANDES, 2015)

A Metodologia do Word Café consiste, portanto na reunião de um grupo composto por diversos atores sociais de determinado ambiente, conversando e dialogando acerca de uma problemática local com o objetivo de delimitar caminhos e proposições para a resolução dessa problemática. Segundo Camargo (2011), a organização do World Café deve seguir os seguintes princípios:

- Criar um ambiente acolhedor;

- Explorar questões que realmente importam;

- Estimular a contribuição de todos;

- Estabelecer ligações e conexões entre pessoas e ideias;

- Escutar juntos para perceber os "insights" e questões relevantes

- Tornar o conhecimento coletivo visível

Ressalta-se que essa metodologia não trata apenas da promoção de uma conversa, mas sim, de uma conversa significativa e propositiva, como destaca Brown (2001b), a conversa pode ser "trabalho real", possibilitando avaliar questões pertinentes às pessoas envolvidas nesse processo, refletindo sobre as responsabilidades de cada indivíduo e os passos necessários para resolver determinada questão ou conflito.

O desenvolvimento da atividade seguiu o seguinte roteiro: 
a) Elaboração das questões significativas para o escopo da pesquisa e para os sujeitos participantes

As questões foram elaboradas dando sentido aos objetivos dessa pesquisa de refletir sobre estratégias de geoconservação no PESM, valorizando nesse caso a experiência de vida e profissional desses atores locais. Foram definidas quatro questões apresentadas na Tabela 4:

Tabela 4 - Questões realizadas na aplicação da metodologia do World Café durante o curso "Estratégias de Geoconservação no PEM" nos núcleos Picinguaba e Caraguatatuba

\begin{tabular}{|l|l|}
\hline Questão 1 & $\begin{array}{l}\text { Há necessidade da geoconservação na região? } \\
\text { Por quê? Se sim, o que precisa ser feito? }\end{array}$ \\
\hline Questão 2 & $\begin{array}{l}\text { O Plano de Manejo abrange a geodiversidade? O que você } \\
\text { incluiria ou acrescentaria ao plano de manejo? }\end{array}$ \\
\hline Questão 3 & $\begin{array}{l}\text { Quais caminhos devem ser seguidos para a geoconservação nos } \\
\text { programas de Educação Ambiental e Educação Patrimonial? }\end{array}$ \\
\hline Questão 4 & $\begin{array}{l}\text { Quais locais podem ser considerados importantes para a } \\
\text { geoconservação? Por quê? Como valorizá-los? }\end{array}$ \\
\hline
\end{tabular}

b) Reunião dos atores locais a partir da proposição do curso "Estratégias de Geoconservação no Parque Estadual da Serra do Mar”, nos núcleos Picinguaba e Caraguatatuba

O World Café foi desenvolvido nessa pesquisa durante o curso proposto. Sua aplicação se deu no final do curso, após a apresentação dos conceitos geocientíficos, no âmbito da geoconservação, e de sua contextualização socioambiental. Optou-se por aplicar essa metodologia ao final do curso garantindo assim certa equiparação quanto aos conhecimentos sobre os conteúdos abordados.

c) Criação de um ambiente acolhedor, tanto físico, quanto da receptividade e do trabalho em grupo

Durante as dinâmicas desenvolvidas no curso, os participantes já puderam se sentir mais à vontade para a participação, estabelecendo um ambiente amistoso, de reciprocidade e troca, onde o grupo tinha muito a contribuir com o desenvolvimento da geoconservação na região. Além disso, a infraestrutura proporcionada pelos núcleos administrativos do PESM 
garantiu seu desenvolvimento em um ambiente agradável e acolhedor, sendo local de trabalho de parte dos participantes.

\section{d) Apresentação da metodologia do World Café}

Antes do início da atividade, realizou-se uma apresentação sobre o World Café, contendo informações de seu histórico, objetivos e metodologias. Os procedimentos sugeridos foram que os participantes se reunissem em grupos de 4 a 5 pessoas, sendo que no decorrer do diálogo os participantes poderiam trocar de grupos quantas vezes achassem necessário. Cada grupo teria que possuir pelo menos uma pessoa fixa, o anfitrião do grupo, responsável por mediar o diálogo e relatar aos participantes as discussões anteriores.

As respostas anotadas deveriam representar as diferentes opiniões sobre a pergunta ou consenso, reforçando a relevância do diálogo e da participação de todos. As respostas poderiam ser representadas de forma escrita ou por desenhos e esquemas, sendo que o preenchimento poderia ser realizado apenas pelo anfitrião ou por todos os participantes. Foram distribuídas folhas A2 para os grupos, além de diversas canetinhas coloridas e lápis de cor. O tempo para as respostas variaram de 30 a 60 minutos. Ao final da atividade todos os grupos fizeram uma breve síntese sobre as respostas apontadas em cada questão, que foram gravadas para serem analisadas posteriormente.

A análise do World Café se deu através da observação durante as atividades, da análise dos materiais elaborados pelos participantes, e da gravação das apresentações dos grupos ao final da atividade. Teve-se em atenção a percepção e concepção da geodiversidade e do patrimônio geológico e as proposições de geoconservação relacionadas com o contexto socioambiental.

\subsubsection{Mapeamento Socioambiental}

O mapeamento socioambiental tem como pressuposto a participação social buscando a integração dos processos e métodos oriundos da espacialização e da cartografia às percepções, representações e experiências relacionadas aos indivíduos participantes do processo de mapeamento (OLIVATO, 2013, p. 50).

Assim, de acordo com Tassara e Ardans (2007), um processo que envolve a mobilização social para representar a paisagem tem como pressuposto uma "polifonia de visões" (p. 222), ou seja, cada indivíduo terá um olhar sobre a realidade, influenciando na 
maneira de representar essa realidade. $\mathrm{O}$ mapeamento socioambiental participativo demanda assim um processo de estabelecimento de critérios para definir de forma consensual a representação dessa paisagem. Segundo os autores:

\begin{abstract}
Descrever coletivamente, então, uma paisagem significa escolher, de forma participativa, os atributos que melhor a representam, para o coletivo, em função do conjunto de olhares que o mesmo produziu sobre ela. Significa, também, relacionar, na linguagem, atributos característicos das paisagens: como elas são, como elas estão, o que há nelas, o que elas têm, qual a permanência ou mudança no tempo de atributos nelas identificados, quais atributos estão ausentes, entre outros. Esta descrição pode ser definida como mapeamento participativo do território (paisagem) ou mapeamento socioambiental participativo (TASSARA \& ARDANS, 2007, p. 222).
\end{abstract}

Em sua revisão, Olivato (2013) aponta a singularidade dessa metodologia para os estudos de riscos ambientais e para a percepção da paisagem e do ambiente, envolvendo projetos de educação ambiental e alfabetização cartográfica. Dessa forma essa metodologia contribui no âmbito da pesquisa científica e da gestão, uma vez que pode apresentar fatos que não eram do conhecimento do pesquisador ou do profissional, podendo também favorecer um processo educativo. Nota-se o relato de uma professora de geografia que coordenou projetos de mapeamento participativo no ensino não formal no litoral norte de São Paulo observando que

É uma ferramenta participativa, que permite o grupo pensar sobre si e trabalhar sobre uma mesma base. Com isso [...] as pessoas fazem uma reflexão sobre o espaço, o lugar onde elas vivem. Dependendo do objetivo do mapa, busca-se identificar temáticas específicas (por exemplo: problemas do bairro ou pontos positivos), permitindo uma discussão entre o grupo, e há complementação das informações. Cada um vai lembrando um pouquinho e vai colocando na ferramenta. [...] Elas vão tendo a noção de onde as coisas estão na comunidade (NUNES, 2012 apud OLIVATO, 2013, p. 53).

Franco (2014) realizou pesquisa junto às comunidades tradicionais de artesãos em pedra-sabão (esteatito) no Quadrilátero Ferrífero (MG), se apoiando na etnocartografia e nos valores da geodiversidade apreendidos por essas comunidades. A etnocartografia consiste em mapeamento participativo com enfoque no conhecimento tradicional. A partir dos etnomapas, o autor fez uma análise exploratória dos valores da geodiversidade, considerando o vínculo histórico-cultural e econômico que os artesãos possuem com a pedra-sabão, apreendendo assim os valores culturais e econômicos, e também, o valor estético, devido a sua utilização como rocha ornamental na região. 
No âmbito da percepção ambiental e da análise crítica socioambiental local, Santos (2006) indica que a metodologia do mapeamento participativo é própria para o (re)conhecimento do lugar, subsidiando reflexões e podendo ser utilizada como forma de diagnósticos socioambientais.

A autora aponta que o (re)conhecimento do lugar se deve ao fato de que muitas vezes a atividade decorre em locais já conhecidos pelos participante. Com o desenvolvimento da atividade no ambiente os participantes se posicionam como pesquisadores, favorecendo a tomada de consciência e a apreensão crítica do ambiente, superando assim posturas passivas frente aos conflitos socioambientais.

Como o meio ambiente está em processo contínuo e dinâmico de transformação a situação real dos bairros e ou cidades é, com frequência, percebida de modo aparente como consequência dessa dinâmica, sendo, portanto, pouco conhecida e, sobretudo questionada. [...] Realizar esse mapeamento significa fazer um levantamento de dados socioambientais do bairro ou região de estudo em seus múltiplos aspectos, visando à elaboração de um diagnóstico da realidade local (SANTOS, 2006, p. 21).

Assim, Santos (2002, 2006) e, Santos e Bacci (2011) ressaltam o caráter participativo dessa metodologia relacionando-a à Aprendizagem Social, que vai ao encontro dos princípios apresentados por Wals (2007) de participação, diálogo e co-responsabilização. Assim a metodologia do mapeamento socioambiental se compõe em um

recurso didático-pedagógico de diagnóstico, planejamento e ação que promove a participação da comunidade local no levantamento de diferentes informações sobre o lugar, com o uso de mapas, fotografias aéreas ou imagens de satélite e saídas a campo. Sua realização possibilita o (re)conhecimento do lugar e seus problemas, bem como o compartilhamento de conhecimentos, vivências e percepções sobre a realidade socioambiental (SANTOS \& BACCI, 2011, p. 61).

Em síntese, a metodologia do mapeamento socioambiental consiste na reunião de um grupo de atores locais com o objetivo de (re)conhecimento do lugar. É desenvolvido em um determinado espaço, que deve ser percorrido e analisado pelos participantes para a identificação e localização dos aspectos observados e discutidos em campo em uma base cartográfica. Durante a atividade, torna-se importante o diálogo entre os participantes, que passam a observar o ambiente com maior atenção e sensibilidade e que compartilham entre si conhecimentos e experiências acerca do contexto social e histórico daquele ambiente, dando ênfase aos aspectos biofísicos e socioculturais. À medida que ocorre esse (re)conhecimento do 
ambiente, emergem também diversas reflexões e questionamentos sobre a realidade observada e as responsabilidades em relação aos conflitos e problemas identificados.

Segundo Santos (2010) e Santos e Bacci (2011) as etapas necessárias ao desenvolvimento dos mapas socioambientais são:

a) Elaboração mapa mental: deve ser realizado previamente à saída de campo, considerando a representação do trajeto de acordo com a vivência e memória que os atores possuem sobre esse lugar;

b) Elaboração mapa socioambiental local: Consiste no mapa realizado durante a saída de campo, em que os participantes devem observar os aspectos socioambientais locais, como cursos d'água, tipos de vegetação, animais, habitações, resíduos sólidos, etc;

c) Elaboração do mapa síntese: o mapa síntese é elaborado na etapa pós-campo, a partir da reflexão e diálogo entre os grupos sobre os problemas/conflitos locais identificados;

d) Elaboração do mapa propositivo: deve ser elaborado através do consenso do grupo em relação às ações e responsabilidades necessárias para a melhoria da qualidade de vida do lugar.

Assim, sugere-se que a atividade seja organizada em oficinas para realização de cada uma dessas etapas separadamente, variando de uma semana a quinze dias entre cada encontro. Ressalta-se a importância da participação de diferentes atores sociais, representativos de diferentes segmentos da sociedade. Inicialmente é necessário realizar a apresentação da metodologia para os participantes, reforçando a relevância do diálogo e da participação sobre os problemas e conflitos socioambientais locais para o (re)conhecimento do lugar e a reflexão para a co-responsabilização (SANTOS \& BACCI, 2011).

O local de realização do mapeamento deve ser definido de forma consensual entre os participantes, observando que deve apresentar fácil acessibilidade para o desenvolvimento da atividade. O material de base utilizado consiste em mapas com escala compatível (SANTOS \& BACCI, 2011). As principais diretrizes para a realização do mapeamento de acordo com Bacci e Santos (2013b) são:

a) Análise de imagens de satélites e mapas da área;

b) Localização do percurso definido, a partir de fotografias aéreas e mapas;

c) Observação durante o campo dos "elementos ambientais locais";

d) Elaboração do mapa socioambiental local; 
e) Criação de legenda representativa dos aspectos observados;

f) Descrição das observações;

g) Explicação do significado dos aspectos levantados durante a atividade.

Os "elementos ambientais locais" foram utilizados por Santos (2006) para o cadastro de elementos ambientais de microbacias urbanas, elaborado a partir de grupos temáticos denominados de V.E.R.A.H (Vegetação, Erosão, Resíduos Sólidos, Água, Habitação e Ocupação).

Para Oliveira (2016), a utilização de tais componentes como base para a representação do ambiente a partir dos aspectos físicos, biológicos e antrópicos reforça a apreensão das conexões e interligações entre eles. $\mathrm{O}$ autor destaque que

o VERAH visa ao conhecimento de um determinado meio ambiente urbano, criteriosamente delimitado, com o propósito de detectar os problemas ambientais gerados pelo uso do solo e valorizar o bem-estar humano. Os problemas diagnosticados passam a ser analisado para serem corrigidos e evitados [...] O ambiente de aplicação do método é participativo, pois é feito em grupo, devido à necessidade dos alunos diagnosticarem o meio ambiente local, é estimulado o contato e a participação da comunidade que convive com os problemas ambientais que estão sendo diagnosticados (OLIVEIRA, 2016, p. 21).

A partir desses pressupostos metodológicos, o mapeamento socioambiental foi realizado na presente pesquisa durante o curso de formação continuada de professores na Escola Municipal José Belarmino Sobrinho. Como o curso foi realizado de forma concentrada, não foi possível realizar a atividade em módulos separados como sugerido por Santos e Bacci (2011).

O mapeamento socioambiental foi realizado no segundo dia do curso, com duração de 4 horas e a participação de 18 professores. Primeiramente foi apresentada a metodologia aos participantes, iniciando uma pré-reflexão sobre o lugar onde se localiza a escola, e sobre as concepções e percepções que os participantes possuíam. A partir disso foi definido junto com os participantes o percurso a ser realizado, que basicamente teve a escola como ponto de partida, seguindo as áreas de floresta e de habitações do bairro até a foz dos rios Quiriri e Puruba. Nesse ponto seria realizada a travessia do rio para alcançar a praia do Puruba.

Foi entregue aos participantes um roteiro geointerpretativo (Apêndice A), contendo mapa de localização, imagens de satélite e mapa hipsométrico. Além desse material, no primeiro dia do curso foram utilizadas algumas imagens obtidas na internet de sobrevoo de 
drone $^{8}$, contribuindo com a interpretação e análise desse material. Foram formados quatro grupos, de quatro a cinco pessoas, sendo entregue mapas bases elaborados a partir do Google Maps, canetas e lápis coloridos, prancheta e folhas em branco para anotações.

Os grupos foram orientados para preencher o mapa, representando os aspectos observados com base nos grupos temáticos propostos pelo V.E.R.A.H., sugerindo que fossem apontados também os elementos da geodiversidade. Cada grupo criaria legenda própria para a representação desses aspectos. A proposta teve como objetivo promover o (re)conhecimento do lugar, observando a dimensão da geodiversidade e, tecendo relações entre os conflitos socioambientais locais e a geoconservação.

A atividade foi finalizada com a elaboração do mapa síntese contendo esses aspectos levantados pelos grupos. Para isso, inicialmente os grupos retomaram as observações e reflexões entre si para posteriormente discutir coletivamente, sintetizando as contribuições dos grupos para compor um mapa representativo do lugar.

A análise do mapeamento socioambiental teve como base os mapas elaborados pelos grupos durante a atividade e o mapa síntese, considerando ainda as anotações realizadas em campo. Desse modo, teve-se em atenção a proposta de Bacci e Santos (2013a) para a análise a partir das seguintes categorias:

- Mapeamento da percepção visual direta: representa os aspectos observacionais, relativos ao ambiente biofísico e social;

- Momento de reflexão: apresenta reflexões sobre os aspectos observando, relacionando-os com o real com base nas questões norteadoras. Observa-se os indicadores dessa categoria nos mapas a partir da problematização da percepção visual direta;

- Momento de transformação: revela a percepção crítica do lugar e as sugestões de mudanças a partir dos diálogos levantados. Pode-se aferir seus indicadores a partir das propostas para a sustentabilidade do lugar.

\footnotetext{
${ }^{88}$ Disponível em: 〈https://www.youtube.com/watch?v=KTUerH5nARw>
} 


\section{CAPítulo 5 - ESTRATÉgias PARA A GEOCONSERVAÇÃo NOS NÚCleOS PICINGUABA E CARAGUATATUBA}

Neste capítulo serão apresentados os resultados da pesquisa sobre as estratégias de geoconservação nos núcleos Caraguatatuba e Picinguaba do PESM.

A reflexão e definição sobre estratégias de geoconservação no PESM delineou-se a partir de uma trajetória iniciada com o inventário e a quantificação do patrimônio geológico realizados por estudos prévios no NAP GeoHereditas. Tais estudos proporcionaram articular com os atores locais as informações obtidas de levantamento do patrimônio geológico. Assim, visando o envolvimento da comunidade local e na Geoconservação, as etapas definidas nessa pesquisa se pautaram nos seguintes pressupostos: diagnóstico socioambiental local, percepção geoambiental, e, elaboração de estratégias de geoconservação.

\subsection{Os atores locais}

O conjunto de atores locais que fez parte do universo da pesquisa pode ser agrupado a partir das seguintes categorias: moradores locais (tradicionais - quilombolas e caiçaras; e não tradicionais - moradores antigos em áreas do parque e, moradores da zona de amortecimento do parque) (Figura 16), gestores do PESM (núcleo Picinguaba e Caraguatatuba), monitores ambientais do PESM, professores da rede municipal do entorno do parque e funcionários de ONG.

No âmbito dos moradores locais foram realizadas 18 entrevistas, sendo que 14 pessoas residiam na ZHCAn, 2 na ZOT e 2 na área de amortecimento do parque. Dos 14 entrevistados 50\% era do sexo feminino e 50\% do sexo masculino. Daqueles que indicaram a idade, aproximadamente $46 \%$ ( 6 pessoas) possuíam faixa etária entre 30 e 60 anos, $46 \%$ com mais de 60 anos (6 pessoas) e cerca de $8 \%$ (1 pessoa) com menos de 30 anos (Tabela 12, Anexo B).

As comunidades tradicionais entrevistadas correspondem a todos os bairros inseridos na ZHCAn de Picinguaba. 4 das pessoas entrevistadas eram residentes do bairro do Cambury, dois deles localizados na seção onde se concentram os Remanescentes de Quilombolas do Cambury (Jambeiro) e dois na seção da praia, formado predominantemente pelos caiçaras. No Sertão da Fazenda foram realizadas 8 entrevistas. Já na Vila de Picinguaba e no Sertão do Ubatumirim foram entrevistados uma pessoa em cada um dos bairros. As características gerais desses bairros podem ser visualizadas nas Figura 17 e 18. 
As entrevistas realizadas na ZOT decorreram no Bairro Rio do Ouro, onde fica o centro de visitantes do núcleo Caraguatatuba, com a participação de duas pessoas. Por fim, as entrevistas realizadas na Zona de Amortecimento se concentraram no bairro do Puruba (Ubatuba), com a participação de dois moradores antigos do bairro.

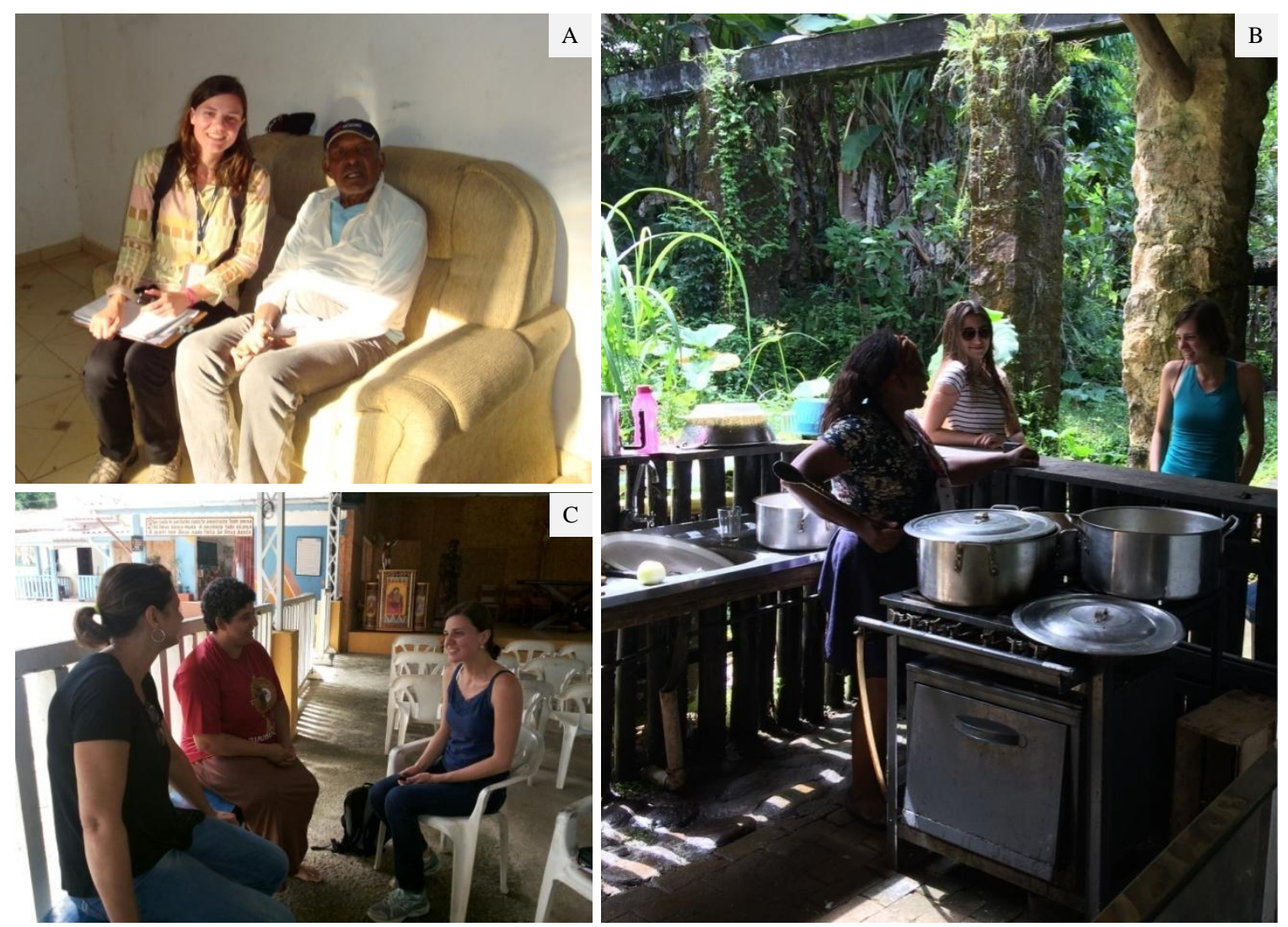

Figura 16 - Imagens dos diálogos estabelecidos com os moradores locais da região (Fotos: A) Eliana Mazzucato, B) Denise de La Corte Bacci, C) Vânia Maria Nunes dos Santos). 

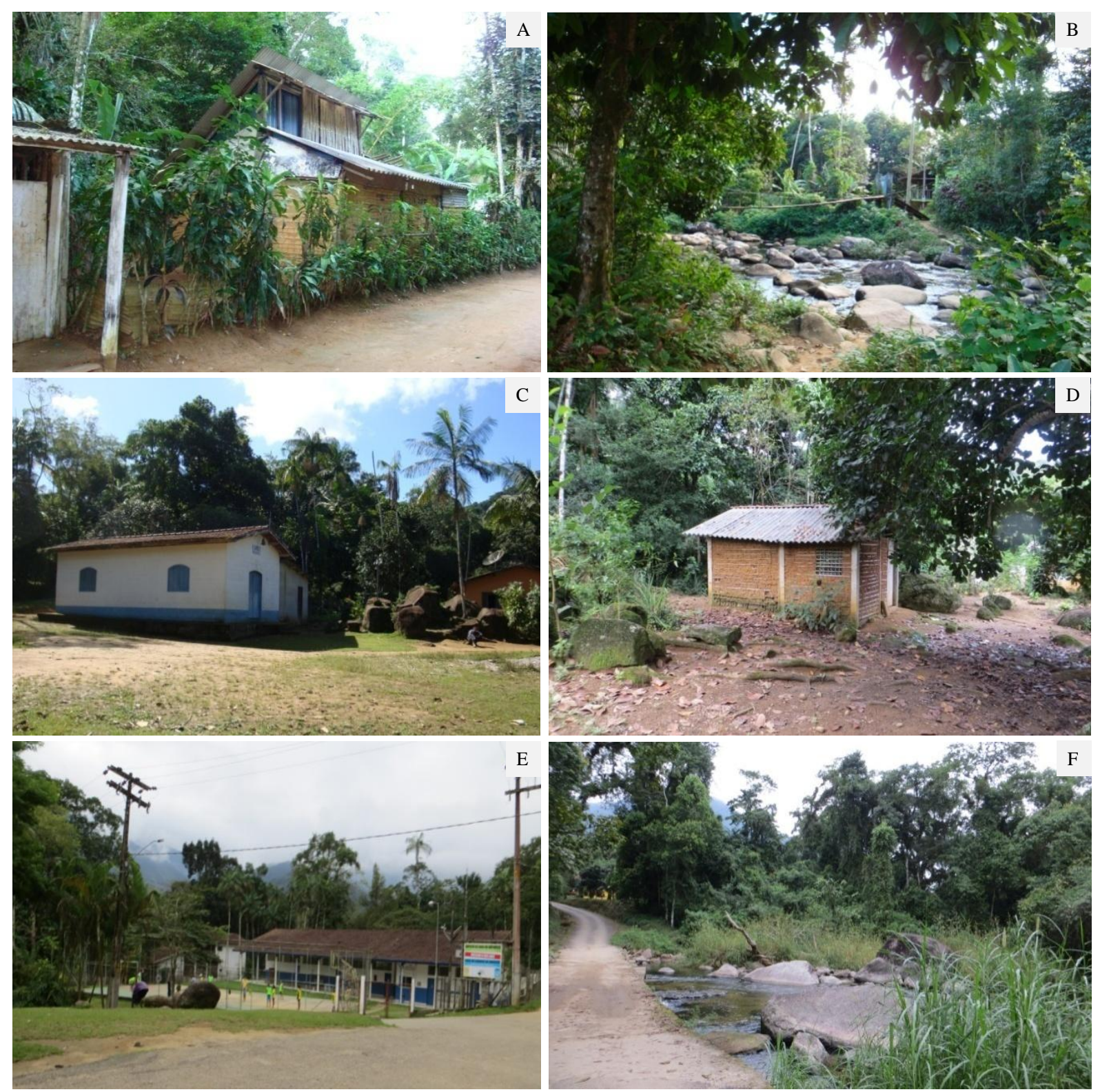

Figura 17 - Imagens das comunidades tradicionais dos sertões de Ubatuba inseridas na ZHCAn. A) casa de pau a pique e via sem asfalto do Remanescente de Quilombolas do Cambury - Jambeiro; B) ponte de pedestres sobre o rio do Cedro no Cambury - Jambeiro; C) igreja de São Pedro na entrada do Sertão da Fazenda; D) casa de pau a pique no Sertão da Fazenda; E) Escola Municipal no Sertão do Ubatumirim com vista para rua asfaltada; F) estrada de acesso ao Sertão do Ubatumirim (Fotos: Eliana Mazzucato). 

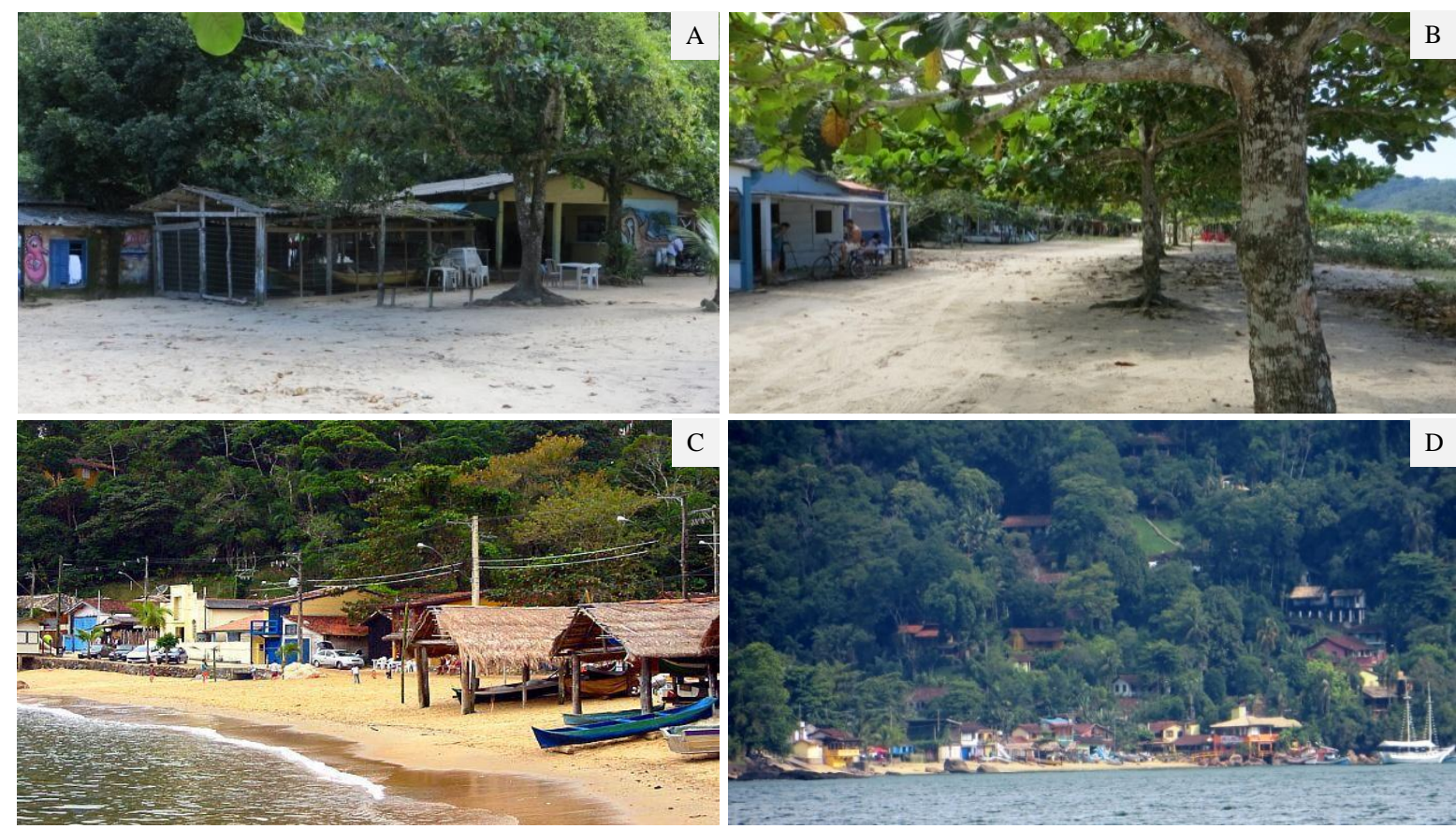

Figura 18 - Imagens das comunidades tradicionais nas praias de Ubatuba inseridas na ZHCAn, observando o avanço de comércios e serviços ao turismo nessas áreas. A e B) comércio e serviços disponíveis na praia do Cambury; C) e D) aspectos gerais da Vila Picinguaba (Fotos: A, B e D Eliana Mazzucato; C) guiadolitoral.uol.br).

As entrevistas com os gestores dos núcleos também deram suporte para o entendimento e descrição da realidade socioambiental local, fornecendo dados importantes para a elaboração de estratégias de geoconservação, centradas principalmente na divulgação da geodiversidade e patrimônio geológico a partir do olhar e experiência desses atores locais. Esses atores são do sexo masculino, com idade entre 20 e 40 anos, e formação em Geografia e Engenharia Florestal. Sendo que um trabalha como gestor na unidade a 4 anos, e o outro a 8 anos, como verificado na Tabela 13 (Anexo B). ${ }^{9}$

A análise da percepção dos monitores ambientais e professores foi realizada por meio dos questionários, preenchidos pelos funcionários de $\mathrm{ONG}$ e pelos professores e monitores ambientais antes do desenvolvimento do curso "Estratégias de Geoconservação no Parque Estadual da Serra do Mar" (Figura 19). O perfil dos participantes do curso pode ser observado nas Tabelas 14 e 15 (Anexo B). Já o perfil dos funcionários da ONG pode ser observado na Tabela 16 (Anexo B).

\footnotetext{
${ }^{9}$ Em 2017 houve mudança na gestão do núcleo Picinguaba, não sendo possível realizar nova entrevista utilizouse os dados realizados a partir da entrevista com o antigo gestor.
} 

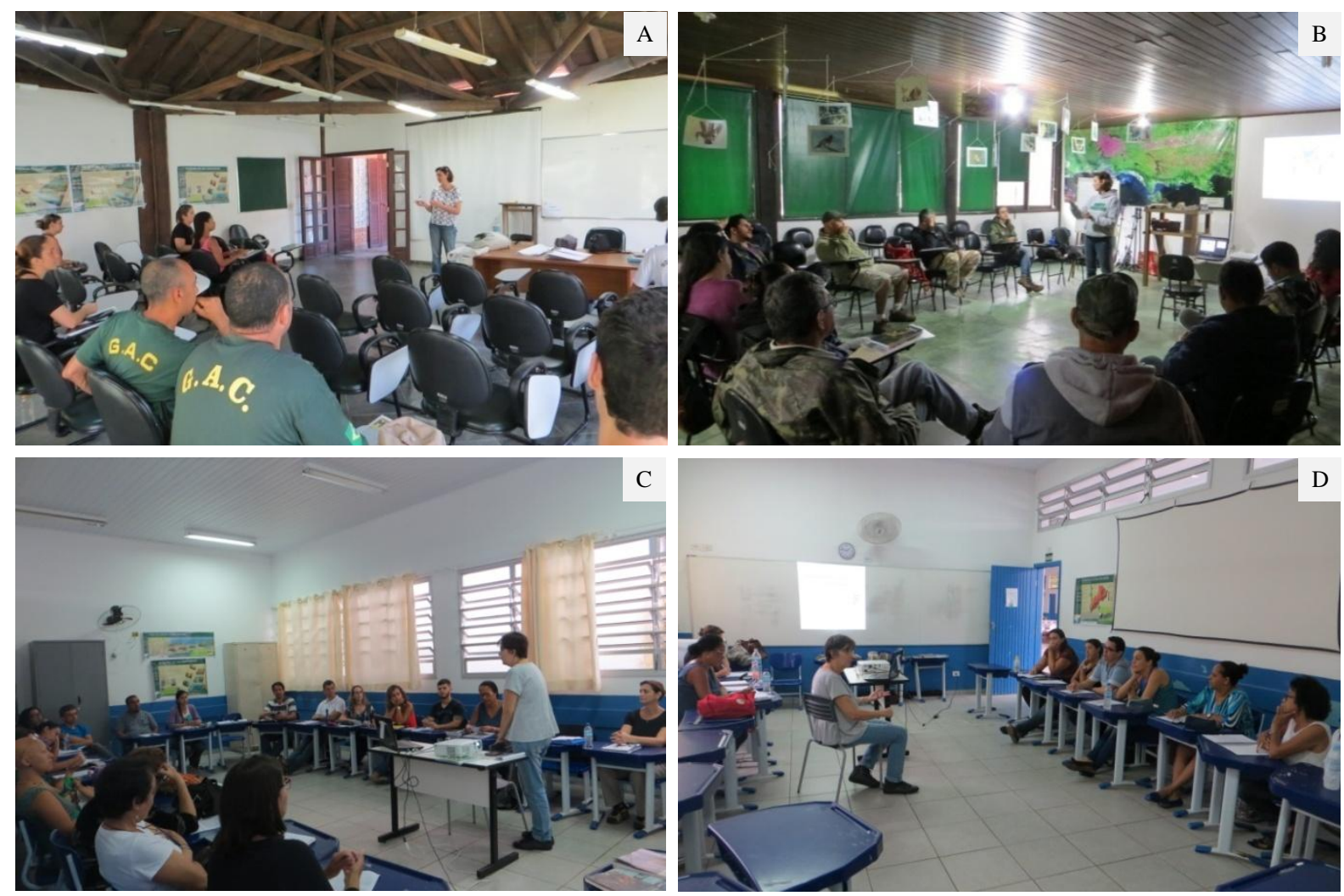

Figura 19 - Desenvolvimento do curso "Estratégias de geoconservação no Parque Estadual da Serra do Mar". A) realização do curso no núcleo Caraguatatuba; B) realização do curso no núcleo Picinguaba; C) e D) curso com os professores na escola da Rede Municipal de Ensino de Ubatuba - turma manhã e turma da tarde (Fotos: Eliana Mazzucato).

Na Tabela 5 observa-se o perfil dos indivíduos que responderam aos questionários, com relação ao sexo, idade, o município que residem atualmente, o tempo em que residem nesse município, e sua escolaridade. Ressalta-se que a composição da tabela levou em conta somente aqueles que preencheram os questionários, pois, no caso dos monitores, dos 30 participantes do curso, quatro deixaram de responder o questionário. 
Tabela 5 - Perfil dos indivíduos que responderam ao questionário

*A categoria "Tempo de residência" se refere ao tempo que o indivíduo habita na cidade identificada. Nesse caso, três pessoas do grupo de monitores e dois de professores não preencheram essa opção.

\begin{tabular}{|c|c|c|c|c|c|c|}
\hline & & Monitores & Professores & $\begin{array}{c}\text { Funcionários } \\
\text { ONG }\end{array}$ & Total & $\begin{array}{c}\text { Total } \\
\text { aprox. }(\%)\end{array}$ \\
\hline Sexo & Feminino & 10 & 18 & 3 & 31 & $44 \%$ \\
\hline & Masculino & 16 & 7 & 16 & 39 & $56 \%$ \\
\hline Idade (anos) (i) & $\mathrm{i} \leq 20$ & 1 & - & 1 & 2 & $3 \%$ \\
\hline & $40 \leq \mathrm{i}>20$ & 17 & 13 & 13 & 43 & $61 \%$ \\
\hline & $\mathrm{i}>40$ & 8 & 12 & 5 & 25 & $36 \%$ \\
\hline Residência & Paraty & - & 6 & - & 6 & $9 \%$ \\
\hline atual & Ubatuba & 13 & 19 & 19 & 51 & $73 \%$ \\
\hline & Caraguatatuba & 8 & - & - & 8 & $11 \%$ \\
\hline & São Sebastião & 2 & - & - & 2 & $3 \%$ \\
\hline & São José dos & 1 & - & - & 1 & \\
\hline & Campos & & & & & $1 \%$ \\
\hline & São Paulo & 2 & - & - & 2 & $3 \%$ \\
\hline Tempo de & $\mathrm{t} \leq 20$ & 14 & 8 & 12 & 34 & $49 \%$ \\
\hline residência & $40 \leq t>20$ & 6 & 11 & 5 & 22 & $31 \%$ \\
\hline$(\operatorname{anos})(t) *$ & $t>40$ & 2 & 4 & 2 & 8 & $11 \%$ \\
\hline Escolaridade & Pós Graduação & 1 & 6 & 4 & 11 & $16 \%$ \\
\hline & Especialização & - & - & 1 & 1 & $1 \%$ \\
\hline & Técnico & 2 & - & - & 2 & $3 \%$ \\
\hline & Superior & 15 & 17 & 9 & 41 & $59 \%$ \\
\hline & Magistério & - & 1 & - & 1 & $1 \%$ \\
\hline & Ensino Médio & 7 & 1 & 5 & 13 & $19 \%$ \\
\hline & Ensino & 1 & - & - & 1 & $1 \%$ \\
\hline & Fundamental & & & & & \\
\hline & Incompleto & & & & & \\
\hline Total & & 26 & 25 & 19 & 70 & \\
\hline
\end{tabular}

Observa-se que um total de 70 pessoas compõe o grupo de coleta de dados através dos questionários. O perfil desses grupos mostra que os indivíduos do sexo masculino foram mais numerosos que do sexo feminino, com cerca de $56 \%$ do total. A idade predominante dos grupos variou de 21 e 40 anos ( 61\%), sendo que aproximadamente $36 \%$ dos indivíduos possuíam mais de 40 anos.

Identificou-se que esses atores locais residem em municípios do litoral norte (Ubatuba, Caraguatatuba e São Sebastião), além de Paraty - RJ, São Paulo e São José dos Campos. Foram predominantes os municípios de Ubatuba (72\%), seguido de Caraguatatuba 
(11\%) e Paraty (9\%). Nesse sentido, a maioria dos indivíduos reside nesses municípios indicados a menos de 20 anos (49\%), e parcela significativa reside entre 21 e 40 anos (31\%).

Em relação à escolaridade dos grupos, predominaram aqueles com formação de nível superior, correspondendo a 58\%, seguidos daqueles com ensino médio completo (18\%) e pósgraduados $(16 \%)$.

No âmbito do cargo ou função que exercem, observa-se as peculiaridades em relação a cada grupo:

\section{a) Monitores Ambientais}

Como o curso foi aberto à comunidade, além dos monitores, participaram também do curso pessoas com outras funções, a seguir são apresentadas as principais funções dos participantes do curso:

- Funcionários do PESM: 11 pessoas eram funcionárias do PESM, ou prestavam serviços ao parque, ou ainda tinham vínculo de voluntariado. Sendo que 6 se apresentaram como monitores ou guias ambientais; 3 possuíam funções administrativas; e, os outros 2 eram agente de recursos ambientais e técnico de apoio à pesquisa;

- Parceiros do PESM: 15 pessoas não eram parte da equipe do PESM sendo que 2 trabalhavam como bombeiros civis, além de exercer outras funções; 2 eram estudantes sendo um de ensino médio e outro de curso superior em Biologia; 5 eram biólogos, e um deles exercia função na Área de Proteção Ambiental (APA) Marinha do Litoral Norte, e o outro supervisor de meio ambiente da Concessionária Rodovia dos Tamoios; 2 estavam ligados à instituições públicas, sendo que um deles se especificou como gestor de outra unidade de conservação; 3 eram da área de turismo e trabalhavam como guias; 1 pessoa se declarou como marinheiro da Associação de Preservação e Recuperação da Mata Atlântica (PROMATA) que se constitui em uma associação de base comunitária.

\section{b) Professores}

No módulo do curso de formação desenvolvido na escola municipal do bairro do Puruba participaram 25 professores. Dentre eles: 8 lecionavam no Ensino Básico I (PEB I), da área de pedagogia ou letras; 17 lecionavam no Ensino Básico II (PEB II), sendo 6 Professores de Língua Portuguesa; 3 de Matemática; e outros 6 que lecionam cada um as disciplinas de 
Biologia, Geografia, História, Artes, Inglês e Educação Física; e 1 Professor não identificou a disciplina.

c) Funcionários ONG

Os funcionários da ONG que compõem o terceiro grupo de coleta de dados correspondem a 19 pessoas, que monitoram as praias dos municípios de Ubatuba e Caraguatatuba. 15 pessoas indicaram sua área de atuação, sendo 7 da biologia; 4 oceanógrafos, 1 gestor ambiental e 1 educador físico.

As análises tiveram como base as questões abertas e fechadas, compondo dados qualitativos e quantitativos. A interpretação dos dados foi realizada a partir da definição dos elementos chave presentes nos questionários e que representam as concepções e percepções relacionadas com a conservação da natureza, a relação com o lugar, o patrimônio e a geodiversidade. Além disso, estabelecem relações com a identificação do patrimônio geológico e das estratégias de geoconservação.

\section{2 Diagnóstico socioambiental a partir do olhar histórico dos atores locais}

A análise das entrevistas se deu de forma qualitativa, a partir das anotações de campo, das análises das transcrições e dos questionários. Esses dados foram correlacionados à literatura a fim de identificar a relação dos habitantes com o ambiente natural e construído e os conflitos socioambientais locais que influenciam na elaboração das propostas de geoconservação da região.

O diagnóstico socioambiental de determinado lugar integra os aspectos sociais, culturais e históricos aos elementos da paisagem natural, incluindo a biodiversidade, a geodiversidade e as transformações do espaço.

Essa análise foi realizada a partir de eixos temáticos descritos na metodologia, que são pertinentes para compor o diagnóstico socioambiental da área de estudo, considerando o histórico de implantação do PESM, implicações territoriais e culturais para as comunidades locais, transformações na paisagem, e identificação dos atores sociais locais envolvidos nos conflitos socioambientais.

\subsubsection{A perspectiva dos moradores locais (tradicionais e não tradicionais)}


A descrição dos aspectos socioambientais da região incide em uma perspectiva histórica, levantando características de uma comunidade tradicional que desenvolveu profunda relação com o ambiente e que vivenciou transformações nesse espaço, decorrentes de implicações territoriais e normativas da criação de Unidades de Conservação e, das convergências com outros atores e regularizações para o gerenciamento desse território.

Os relatos apontam que desde a criação do PESM em 1977 até sua implementação, principalmente a partir de 1985, e as atuais estratégias de planejamento e gestão, a vivência e os modos de vidas das comunidades residentes nessas áreas sofreram transformações. Apresentam-se, assim, diversas fases que caracterizam o socioambiente dessa região.

De um modo geral, no início do século XIX, e anteriormente à criação do PESM a região era ocupada por pequenas comunidades de agricultores e pescadores descendentes de escravos e indígenas que mantinham forte vínculo com a natureza da região. As características dessas comunidades remetem a um período de estagnação econômica dos municípios do litoral norte, onde eles se organizaram em núcleos, reconhecendo a importância da terra como local de sobrevivência, não como recurso, como se observa em Marcílio (2006, p. 49) para os tradicionais: "a Terra é do trabalho, e não de exploração".

A paisagem daquele período remetia a uma natureza pouco modificada, segundo Marcílio (2006), com povoações dispersas no território, ocupando áreas de "praias, ilhas e enseadas e invadindo o mato adentro" (p. 53), considerando dessa forma a ocupação litorânea e dos "sertões".

Essa configuração em Ubatuba resulta em uma paisagem de natureza preservada, onde era possível observar as plantações em meio a Mata Atlântica e a presença de alguns núcleos habitacionais, ou bairros rurais. Nesses pontos, as plantações ocorriam nas encostas da Serra e nas áreas de planície. As comunidades que formavam núcleos afastados e isolados do centro urbano mantinham forte interação com o ambiente, desenvolvendo técnicas tradicionais para sua sobrevivência, através da pesca e da agricultura, criando condições de deslocamento e de construção de residências:

"[...] caçava os peixe pra comida, todo mundo ia pra lavoura. Aonde o senhor tá hoje, era tudo um lugar rico, não de prata nem ouro, mas de mantimentos. De criação de porcos, criação de galinha, de patos, não de boi. Criação de animal grande não, mas a plantação, a plantação, era a mandioca pra farinha, era a batata doce, era o cará, era o inhame, era a taioba, era o milho, era o feijão. Isso o senhor eu criava uns porco, cevada, ia matar, aí eu ia pro vizinho, meu pai dizia, [...], meu filho vai oferecer quem quer comprar, quem interessa comprar uns quilos de carne de porco que eu quero matar. [...] ai eu saia de manhã, saia cedo, casa por casa, 
vizinha por vizinha, oferecer... O que eles falavam pra mim? Dizia assim [...], "fala pro teu pai que eu também to com dois aqui pra matar", meu colega, todo mundo criava" (M4).

No contexto da expansão da malha rodoviária na região (a partir da década de 1930) houve a ampliação do turismo, provenientes principalmente do Vale do Paraíba e da capital Paulista. Nesse sentido, pode-se destacar a precária infraestrutura para receber esse novo público, transformando e impactando as condições ambientais locais (aumento resíduos, fluxo viário, construção de novas habitações e/ou estruturas de recebimento de turistas, como hotéis, pousadas, etc.). Além disso, soma-se um ator social na dinâmica socioambiental local, com culturas e interesses divergentes daqueles característicos dos tradicionais.

Esse turismo emergente no território caracteriza-se por certa sazonalidade, concentrando-se principalmente nos períodos de verão. Nesse contexto, crescia também outro tipo de turismo, aquele que buscava adquirir propriedades na região construindo casas de veraneio. Nesse processo, muitos tradicionais acabaram vendendo suas propriedades, comercializando seus espaços e se deslocando para áreas mais periféricas.

Essa nova dinâmica presente no litoral norte, que já impunha marcas na paisagem natural, influenciou a criação de uma unidade de conservação na área, pois havia um crescente processo de pressão sobre a floresta. Além disso, a política nacional e estadual nesse período já vinha deliberando sobre criação de Unidades de Conservação no sentido de garantir a preservação dos principais ecossistemas brasileiros.

A criação do PESM teve, portanto essa perspectiva de interromper esse processo, sendo um marco para o território e a paisagem local, que passou a ser gerida por concepções preservacionistas e restritivas em relação ao uso e ocupação do território. A criação do PESM representou um marco para a dinâmica socioambiental da região, pois intermediou restrições quanto aos deslocamentos populacionais para a região à medida que impediu legalmente a aquisição e construção de casas de veraneio e outros empreendimentos, e estabeleceu novas condições de vida para os tradicionais residentes na área. Além disso, no âmbito físico e biológico, procurou cessar as atividades de uso e exploração dos recursos naturais, sistematizando estratégias de recuperação e reflorestamento.

Dessa forma, num primeiro momento, sua criação representou uma ameaça aos moradores da região por tratar-se de uma unidade de Conservação de Proteção Integral. Na fase de criação e implementação do PESM não se deu prioridade à questão dos residentes do território. Apesar do decreto de criação da unidade ter reflexos diretos no uso e ocupação da região, prevendo a retirada de todos os moradores, as populações residentes não foram 
apresentadas a essa nova realidade, sem compreender o que é uma unidade de conservação, quais seus objetivos e principalmente quais as implicações para os moradores.

"quando o parque chegou, a relação não foi muito boa né, é, parque e comunidade, porque eles não, eles não reuniram ninguém né... pra explicar pra eles que a partir dessa data ia criar o parque né... então ninguém sabia o que que era um parque, entendeu, então ele veio como assim, como um balde de água fria na cabeça das pessoas" (M6).

Pode-se considerar que na perspectiva preservacionista da década de 1970, a dinâmica sociocultural do ambiente não foi considerada na determinação da tipologia da UC. No momento da implementação da unidade a postura gestora amparada na legislação ambiental vigente centrou-se na retirada dos moradores. O quadro normativo ambiental para aquela região tinha como principais norteadores o Código Florestal (Lei 4771, de 15 de setembro de 1965) e o decreto de criação do Parque Estadual da Serra do Mar (Decreto 10.251, de 30 de agosto de 1977), determinando que: "ficam declaradas de utilidade pública, para fins de desapropriação, por via amigável ou judicial, as terras de domínio particular abrangidas pelo Parque ora criado" (SÃO PAULO, 1977, artigo $6^{\circ}$ ).

Alguns relatos no núcleo Picinguaba anunciam a arbitrariedade com que decorreram as desapropriações, pois muitos residentes não possuíam documentos sobre a propriedade de suas terras e assim foram obrigados a sair de suas casas sem o recebimento de indenizações. Além disso, as indenizações foram consideradas injustas em relação ao valor definido para as propriedades, principalmente no que se refere à relação de identidade e pertencimento que o morador possui com o lugar.

No âmbito cultural, essas comunidades foram prejudicadas, pois a perda do território vai além de uma perda material. Ou seja, existe nesse lugar uma relação construída historicamente, que revela um pertencimento, uma identificação afetiva e de memória, remontando a história de seus antepassados e os usos tradicionais do território. Para muitas famílias, deslocar-se de um espaço a outro implica na perda afetiva de seu lugar. Lugar onde estabeleceu e reconhece sua cultural e seu modo de vida, compreendendo percepções e relações apreendidas no universo da memória do indivíduo.

"[...] foi levantado o Parque Estadual da Serra do Mar, por volta de 84, foi nessa época que eles não trouxeram nenhum é, é, nenhuma educação ambiental, a gente nem sabia que que era meio ambiente... ah meio ambiente, o que é meio ambiente? né, e aí a gente não sabia nada e eles caíram de paraqueda em cima da gente... e aí foi um baque muito grande... ah, "o parque agora é Parque Estadual da Serra do Mar", o que eles 
passavam na porta das pessoas e diziam, "e vocês tem que sair, e ir embora, ceis não podem mais ficar aqui"... tá, mais o que é parque?" (M5).

Simões (2015) argumenta ainda que desde a legislação vigente do período de implementação do Parque (1985) até 2004, as comunidades não puderam manter suas atividades econômicas tradicionais. Diante as pressões da especulação imobiliária na região, muitos caiçaras venderam suas propriedades, vislumbrando uma renda alternativa. Assim, muitos tradicionais se deslocaram para zonas marginalizadas e áreas de encosta, que apresentavam riscos de escorregamento (SIMÕES, 2015, p. 81).

Nos relatos há indicações das mudanças em relação às primeiras décadas da implementação do Parque, no qual prevalecia uma postura preservacionista e de resolução dos conflitos através do cumprimento de desapropriações. Porém, tornou-se claro a impossibilidade de colocar em curso uma total desocupação desse território, tanto no âmbito legal, já que várias comunidades se muniam da legislação para garantir sua permanência, nomeadamente os indígenas, quilombolas e caiçaras, e também, do ponto de vista de recursos, dado o montante necessário para as indenizações.

As estratégias definidas pela administração do PESM convergiam para a conservação ambiental, portanto, as comunidades que permaneceram no território estiveram sujeitas a diversas normas restritivas no uso e ocupação. Essa estratégia resultou em diversas transformações culturais, econômicas e políticas na perspectiva social, mas também transformações paisagísticas em relação ao ambiente natural e construído. O modo de vida baseado na agricultura de subsistência e na pesca artesanal era percebido pela gestão da UC como fator de pressão para a biodiversidade, principalmente tendo em conta que as suas plantações ocupavam áreas em meio a floresta, utilizando técnicas tradicionais e voltadas para o consumo local como o sistema de pousio e a coivara, o extrativismo, a caça e a pesca.

"eles tão barrando o parque em cima da comunidade, entendeu? quando tombou o parque em 77 eles num, eles já não retiraro a comunidade, eles simplesmente montaro o parque em cima. Aí começaram a proibir roça, proibir isso, proibir aquilo e ficou até hoje. Hoje não pode, isso não pode, não pode, não pode, isso não pode, a comunidade ficou presa, então muitos foram embora, né? e muitos continuaram, mas a pressão continua, o conflito continua, a pressão continua, né?" (M7).

Nota-se nesse relato o aspecto restritivo e punitivo adotado pelo parque em relação às comunidades, forçando a saída de indivíduos em busca de melhores condições de vida, já que 
era impedido de realizar suas atividades de pesca e agricultura, que consistiam na base de sua sobrevivência.

"hoje é uma área florestal, não pode mais fazer a plantação, não [...] pode mais fazer o plantio na terra, então as pessoa sentiu, as pessoa passou até fome, o povo que tá dentro da floresta [...]" (M4).

As restrições sofridas por esses moradores geraram diversos momentos de conflito e de insatisfação dos residentes com o parque. As comunidades não possuíam orientações quanto à regularização das atividades de subsistência, além disso, não possuíam acesso a serviços básicos, como energia elétrica, transporte público, educação e saúde. Nesse sentido, relatos sobre ocupações da sede do Parque no núcleo Picinguaba chamam a atenção para a relação conflituosa entre a administração da unidade e a comunidade, requerendo acesso à energia elétrica e melhorias nas estradas de acesso.

Em relação à energia elétrica, a população constatou que o embargo para a chegada da energia era de responsabilidade do parque, o que estimulou manifestações em meados de 2005

"[...] o parque que não deixava aí peguemo e fizemo manifestação lá de uns quatro dia, no parque, aí conseguimo a liberação da energia” (M1).

Devido às precárias condições de acesso para os núcleos comunitários, a população também precisou se manifestar para ter melhorias nesse sentido:

"[...] depois a gente também viu que o acesso tava ruim aí a gente fez outra invasão no parque, por causa do acesso. Aí a gente conseguiu só os pedaço crítico asfaltado, mas agora já tá pior de novo, né” (M1).

No contexto dessas manifestações, o relato de uma moradora do bairro do Ubatumirim revelou que os protestos se deram em um momento generalizado de insatisfações dos moradores em relação ao parque em busca de condições básicas de sobrevivência, mas também, contrários às sanções que vinham sofrendo

"A gente fizemo uma invasão no parque uma fez, Ubatumirim, Fazenda e Cambury, porque assim, teve um mês aqui, [...] em 2009, nós recebemos 23 multa, só aqui no sertão do Ubatumirim. Daí as coisas já não tavam caminhando muito bem, ai a gente pegou e resolvemos invadir o parque, ficamos lá por 3 dias lá, fazendo manifestação" (M14). 
Esses relatos consistem em indicadores para a organização social da região, sendo presente principalmente nas comunidades tradicionais, através das associações de bairro.

O cargo de gestor dos núcleos do PESM é apresentado pelo Manual de Gestão das Unidades de Conservação do Estado de São Paulo como "um dos principais agentes para o cumprimento da missão institucional da conservação e sustentabilidade dessas áreas naturais protegidas" (FUNDAÇÃO FLORESTAL, 2014, p. 24). Sua designação é, portanto cargo de confiança, definida pela Secretaria de Meio Ambiente do Estado de São Paulo. Assim, a formação, experiência e orientação de cada gestor é fator condicionante sobre a vida dos habitantes desse território. Nota-se que o empenho pessoal do gestor, que de certa forma converge com as exigências da Fundação Florestal e a Secretaria de Meio Ambiente, define as estratégias e prosseguimentos, ordenando a forma como os conflitos são solucionados.

A administração do PESM - Núcleo Picinguaba buscou de forma progressiva regulamentar o uso e ocupação do território do PESM pelas comunidades tradicionais, como medida emergencial enquanto o Plano de Manejo ainda não estivesse concluído. Inicialmente, e incorporando a perspectiva da participação social e do diálogo para a resolução de conflitos, foi elaborado o Plano de Uso Tradicional para o bairro do Cambury ${ }^{10}$. Essa participação se deu através de uma Câmara Técnica estabelecida a partir do Conselho Consultivo do núcleo Picinguaba (SIMÕES, 2015).

A forma dialogada e participativa com que se deu esse processo pôde ser verificada em campo, a partir do relato de uma moradora tradicional e atuante na Associação de Moradores e Amigos do Cambury. A entrevistada revela os benefícios decorrentes dessa organização, condicionando o ordenamento de suas atividades através do microzoneamento do bairro, garantindo um manejo sustentável e condizente com os objetivos do PESM:

"[...] depois que a gente montou esse plano de uso tradicional aqui dentro
da comunidade, ele melhorou muito pra gente né, o gestor veio, conversou,
a gente sempre participa de câmara técnica, com o gestor do parque,
reunião com o parque, reunião com outros órgão. Aí assim, foi melhorando
mais. Os caiçara não podia construir, não podia reformar, não podia fazer
plantação, né, outros, outros projeto que vinha as veis não era aceitado... aí
esses fizero cronograma e [...] montaro o prano de uso tradicional que
favorece nóis, ai melhorou, entendeu... aí hoje em dia se um caiçara casa,

${ }^{10}$ O Plano de Uso Tradicional do Cambury foi implantando em 2004, decorrente de reuniões técnicas com a comunidade para a elaboração do Plano de Gestão para a Comunidade de Cambury, que consistia em um plano emergencial para o manejo nessa região. Houve assim o esboço do microzoneamento do bairro, elaborado em conjunto com a comunidade. A partir do microzoneamento o bairro foi dividido em: acessos, apoio à pesca $\mathrm{e}$ lazer, uso público e institucional, uso residencial caiçara e quilombola, subsistência e uso sustentável de reursos florestais, uso sustentável de recursos florestais proteção permanente. Posteriormente o Plano de Uso tradicional serviu como referência para o Plano de Manejo do Parque em 2006 (SIMÕES, 2015). 
quer construir uma casa, aí vai lá e eles tem um relatório que que pode, que que não pode, o que que o cê vai fazê, aí cê escreve tudo, aí passa pela nossa associação" (M1).

Também fica evidente nesse relato a gestão compartilhada entre Associação de moradores e parque, sendo parte do processo de liberação de pedidos (exemplo de construção ou reforma de residências, espaço para horta, etc.) o parecer, tanto da administração do PESM, quanto da associação de moradores.

Essa proposta incidiu na melhoria da relação entre comunidade e parque, sendo utilizada como referência para a elaboração do Plano de Uso Tradicional do Sertão da Fazenda. Além disso, indica caminhos para a proposição de soluções conjuntas, partindo do princípio do diálogo e da conciliação de diversos atores sociais, num movimento de conscientização da importância do parque e da comunidade tradicional convergindo para a conservação da natureza. Esses Planos também serviram de base para a elaboração do Plano de Manejo no que toca à regulamentação do uso e ocupação da Zona Histórico Cultural Antropológica.

\begin{abstract}
"Então, é o senhor vê que miorou nessa parte aí. A casa, o senhor pode ter uma casa, aí o senhor pode fazer, aqui. Agora, só que em parte da floresta não, porque o senhor tem que procurar o tipo de lugar pra fazer sua roça, fazer seu plantio... beira de rio, cabeceira de morro, não pode. Então [...], miorou, hoje a gente fica, o senhor vê que há muitos anos, passados, vinham muitos compradores, compravam, naquele tempo tinha de mil reis, tinha de duzentos, o terreno, hoje acabou [...]" (M4).
\end{abstract}

Vê-se que a partir dos anos 2000 a postura adotada pela administração do núcleo Picinguaba implementou um crescente processo de diálogo e busca de conciliação a partir das Câmaras Técnicas e dos Conselhos Consultivos para ordenar as sobreposições territoriais existentes. Isso se deve em partes pela evolução da legislação ambiental, que passou a tomar a questão das sobreposições territoriais como fatores centrais na gestão e no planejamento da conservação em UCs. Nesse sentido, destaca-se a criação do Sistema Nacional de Unidades de Conservação (Lei 9985, de 18 de julho de 2000), o decreto n $^{\circ} 4340$ de 22 de agosto de 2002 que regulamenta os artigos da lei 9985 do SNUC e a Política Nacional de Desenvolvimento de Povos Tradicionais (decreto $n^{\circ}$ 6.040, de 7 de fevereiro de 2007).

Somente no Plano de Manejo finalizado em 2006 as normas e diretrizes de uso e ocupação do território foram estabelecidas. A partir do zoneamento foram definidas as áreas destinadas à permanência de populações tradicionais que possuem o direito legal ao território (Zona Histórico Cultural Antropológica e Zona de Superposição Indígena) e, áreas em que o 
parque está em processo de regularização fundiária, sendo que seus residentes permanecem temporariamente no território (Zona de Ocupação Temporária). Além da Zona de Amortecimento, que corresponde ao entorno da área do Parque, em um raio de aproximadamente $10 \mathrm{~km}$, os quais foram definidos normas e restrições para minimizar os impactos no parque.

"hoje miorou um pouco [...], hoje nós plantamo, a capoeira, adubo, adubá a terra, antes não podia" (M4).

Entretanto, muitos conflitos permanecem no território, e outros surgem à medida que as estratégias e propostas são implementadas. Inseridos em uma realidade peculiar, com diversidade de atores e interesses, o benefício a uma comunidade tradicional específica pode gerar o questionamento sobre como se deu a classificação de outras comunidades em Zona de Ocupação Temporária. Além disso, o enquadramento da Zona Histórico Cultural Antropológica pressupõe a recategorização dessa área, gerando inseguranças sobre a conservação dessas regiões.

Num relato sobre conflitos atuais, uma moradora do Sertão da Fazenda retoma as consequências que a construção da BR - 101 gerou sobre sua comunidade, que somadas às restrições do parque acabam dificultando o desenvolvimento de atividades agrícolas em seu território.

\footnotetext{
"Então se você ver, você olha assim, aquela mata enorme linda, mas a comunidade sofre porque não tem espaço, a água tomou conta, o alagamento por causa da BR, então, as vezes, até tenta plantar, mas o lugar é pequeno... em outras áreas o parque não deixa, abri né, porque, com o tempo as árvores cresce, e pra você planta mandioca, pra você fazer farinha, tudo, tem que ter um lugar descampado grande, e aqui não tem" (M7, grifo nosso).
}

Esses conflitos se tornam evidentes no levantamento da atual situação fundiária do PESM. Segundo dados do Plano de Manejo de 2006, a porcentagem das zonas no PESM que comportam a ocupação humana soma um total de 12,34\%, que corresponde a 37.862 hectares (Zona Histórico Cultural Antropológica - 0,37\%; Zona de Ocupação Temporária - 5,26\%; Zona de Superposição Indígena - 6,71\%). No extremo norte do PESM onde se encontra o núcleo Picinguaba é a região com maior ocupação humana do Parque. De acordo com Simões (2015), os dados do ITESP para 2008 apontaram 985 edificações no núcleo 
Picinguaba, sendo que cerca de 485 são utilizadas como segunda residência ou casas de veraneio.

Na perspectiva dos residentes tradicionais de Picinguaba, há uma ponderação quanto ao papel do parque em conservar a natureza, mesmo que nessa trajetória seus direitos tenham sido cerceados. Seu questionamento centraliza-se no fato de que seus usos sobre aquele território não implicaram na degradação ambiental, pelo contrário, muitas de suas técnicas previam um uso consciente, à medida que consumiam algum produto da floresta, tinham a preocupação com que esse recurso continuasse a existir. Porém, mesmo com toda essa prática sustentável, a comunidade reconhece que diante o processo de avanço da especulação imobiliária, relacionada com os interesses turísticos e casas de veraneio, seu território estaria sujeito a essa nova realidade.

"então nesse caso aí da conservação mesmo, é graças ao parque né, que, o parque tá aqui ainda, porque, eu, na minha opinião, porque se o parque num existisse nossa isso aí num existia mais mato, tava tudo no chão desmatado, entendeu, então o parque ainda tá em cima indo, então graças a ele que tem essas mata aí, então ainda tá conservado porque é do parque né, que se não fosse pelo parque imagina" (M3, grifo nosso).

Esse novo olhar advém das estratégias participativas adotadas pelo parque, em estabelecer maior comunicação, almejando o entendimento das pessoas sobre os objetivos da criação da unidade e as consequências normativas para o território. Há também uma ampliação do canal de diálogo entre comunidade e parque, no sentido de ouvir as considerações da comunidade. Esse momento de maior conciliação também é fruto do amparo legal, que evoluiu no sentido de garantir os direitos territoriais de comunidades tradicionais, mesmo inseridas em Unidades de Conservação de Proteção Integral (Constituição de 1988; SNUC, 2000; decreto $\mathrm{n}^{\circ}$ 6.040, de 7 de fevereiro de 2007; decreto $\mathrm{n}^{\circ} 4.340$, de 22 de agosto de 2002).

Entretanto essa comunicação não é reconhecida por todos como um canal eficiente e constante. No caso de Caraguatatuba, a entrevistada de uma área de entorno do parque relatou que nunca foi conhecer o centro de visitantes do parque, apontando que muitas vezes a divulgação e comunicação do parque é destinada para os turistas, ou pessoas que não são do entorno

"Por exemplo, se faz alguma campanha dentro do parque, por exemplo, aonde é que essa campanha alcança e aonde é que é o alvo dela? né a quem ela quer? não é, primeiro eu acho que deveria passar por aqui, pra depois 
chegar lá, né. Os primeiro deveriam ser alcançados, os moradores do bairro né, então, depois lá" (M18).

Nesse caso, por estar delimitado como Zona de Ocupação Temporária, há ainda uma insegurança quanto aos direitos de permanência no território, mesmo que as propriedades sejam mais antigas que a chegada do parque.

\footnotetext{
"Eu na verdade me sinto privilegiada, ao mesmo tempo sinto privilegiada por morar bem próximo daqui, bem pertinho, e ao mesmo tempo, bem preocupada, os sentimentos se dividem" (M18).
}

Apesar disso reconhece as singularidades do ambiente em que vive, relacionadas com as características naturais preservadas:

"Então é como se tivesse dentro do horto aqui, né, então essa, essa calmaria né, esse ouvir dos pássaros, [...] a gente ter as águas correntes aqui próximo, isso é maravilhoso... então, quando a gente tá mais agitado você pode ir um pouco mais ali na beira do lago, então isso é muito bom, te ajuda a relaxar né, te ajuda a acalmar [ ..]" (M 18).

No contexto da Zona de Amortecimento, as considerações se assemelham às da ZOT. No caso das entrevistas realizadas no bairro da praia do Puruba, há o reconhecimento de certa influência do parque e da APA marinha do litoral norte nas restrições quanto à atividade pesqueira que antes era feita com rede, de acordo com as espécies de cada época, principalmente a época da tainha, do robalo, do bagre, dentre outros.

A partir dessa diversidade de comunidades presentes no parque e no seu entorno, o Plano de Manejo (SÃO PAULO, 2006) adotou o procedimento de definir comunidades tradicionais a partir de laudos técnicos de instituições competentes. Até o momento, o núcleo Picinguaba é o único no PESM que possui comunidades tradicionais, sendo a Fundação Instituto de Terras do Estado de São Paulo (ITESP) responsável pela elaboração de Relatório Técnico-Científico para o reconhecimento de comunidades quilombolas. Esse reconhecimento implica no direito à terra que essas comunidades possuem.

No núcleo Picinguaba, os moradores do bairro do Cambury foram reconhecidos como comunidade de remanescentes de quilombolas, tanto pelo ITESP (2005) quanto pela Fundação Cultural Palmares (2006) e pelo INCRA (2008). Em relação à comunidade da Fazenda, o Relatório Técnico-Científico do ITESP foi realizado em 2006, porém até o momento só houve o reconhecimento por parte da Fundação Cultural Palmares (2006), não implicando em ações necessárias à titulação da Terra. 
Os conflitos decorrentes da morosidade no reconhecimento dessas comunidades, e mesmo nos encaminhamentos necessários à regularização das terras daquelas já reconhecidas geram incertezas e instabilidades nos residentes.

\begin{abstract}
"e agora a gente tem uma parceria melhor com o parque depois de tantos anos. Mas assim, sempre, sabe, sede aqui, abre ali, é negociando, é sempre assim, por isso que tá difícil realmente o reconhecimento quilombola né, o título da terra né... porque o interessante é o território pra nóis, mais o território ainda tá bem dificil” (M7, grifo nosso).
\end{abstract}

Nesses relatos também pode-se verificar preocupações com relação à política de concessões e parcerias adotadas pelo Governo do Estado de São Paulo, principalmente a partir da Lei $n^{0}$ 16.260, de 29 de Junho de 2016 que "autoriza a Fazenda do Estado a conceder a exploração de serviços ou o uso, total ou parcial de áreas em próprios estaduais”. Dentre esses próprios estaduais encontram-se treze Parques Estaduais, no qual o PESM está integrado com os núcleos Santa Virgínia e São Paulo. A insegurança desses residentes relaciona-se com a morosidade em resolver os problemas fundiários, assim, a moradora do Sertão da Fazenda entrevistada relata que:

"eles tão querendo terceirizar [...] a gente não sabe como é que vai ficar o futuro, se a gente não consegue o território, a regularização do território, como é que vai ficar? então é incerto, é o futuro incerto... infelizmente" (M7, grifo nosso).

Diante de tantas transformações socioculturais recentes, o fortalecimento da identidade dessas comunidades tem relação direta com seus direitos territoriais. Numa situação de desapropriação e avanços imobiliários, o conhecimento de seus direitos e a própria autoidentificação com sua cultura tradicional representou passo importante para a permanência no território e a manutenção de muitos aspectos de sua cultura, mesmo inseridos em um novo contexto político, econômico e social. O papel do parque torna-se conciliador nesse processo, no sentido de garantir a conservação ambiental e da paisagem através de uma gestão integradora, mas também de criar condições para a sobrevivência e manutenção da cultura representativa desse lugar.

Interessante notar as visões sobre o parque, que representa papéis diversos na gestão do território. Do ponto de vista natural, é reconhecido seu papel em preservar a natureza local, embora com ressalvas em relação ao próprio papel das comunidades em ter conservado a partir de seu uso tradicional, no passado e no presente. Em relação à cultura, também há 
controvérsias, pois, de um modo em geral, as medidas conservacionistas impõem restrições ao modo de vida tradicional dessas comunidades, porém garante a manutenção da paisagem na região, percebida inclusive, com transformações no sentido de possuir maiores áreas preservadas. Porém, apesar de tais restrições, o parque também impediu e impede o processo de expulsão dessas comunidades para a periferia ou para outras regiões em substituição a instalação de grandes empreendimentos imobiliários e turísticos.

O modo de vida, apesar de ter sido transformado principalmente em relação às práticas de agricultura e de caça, permanece nas comunidades da região, com características muito similares às vivenciadas historicamente.

“Continua essa mesma visão do parque né, o parque é bom pro lado que também ajuda a proteger a pessoa que não tem é, grandes empreendimentos aqui, não tem né, é, mas pro outro lado pra comunidade já sufoca um pouco né, ela não tem aquela liberdade que tinha antes" (M7).

Mesmo diante de tantas restrições, a comparação desse território com o contexto regional de urbanização e degradação ambiental proporciona um autoquestionamento do caiçara/quilombola, em avaliar se a região não teria sido alvo do grande investidor imobiliário e turístico caso o parque não tivesse sido criado, mantendo assim, a paisagem que em parte havia sido preservada por eles.

\footnotetext{
"o papel do parque no começo foi ruim, de querer tirar as pessoas do seu local, mas essas coisas dele está aqui é importante, porque se o parque não tivesse, comunidade não conseguiria segurar os grilheiros, com certeza isso aqui já tinha virado um condomínio, um resort, porque a gente não ia ter perna pra isso, então esse papel do parque de tá aí junto com a gente é muito importante, é muito bacana, entendeu? então a gente não se vê semo parque mais, foi ruim no começo? foi, mas agora melhorou. Mas também melhorou devido à nossa luta, porque a gente não deixou eles fazer o que eles queriam fazer com a gente" (M5, grifo nosso).
}

Notam-se iniciativas no sentido de valorizar a cultura local através da elaboração de roteiros e propostas didáticas que incorporam o aspecto sociocultural da região de Picinguaba pelo parque. Exemplo disso são os atrativos apresentados pelo parque aos visitantes, que incluem no núcleo Picinguaba aspectos naturais, socioculturais e históricos. Assim, apresentam-se roteiros que incluem a Casa de Farinha (Sertão da Fazenda) onde são realizadas rodas de conversa com moradores antigos do bairro, como observado na Figura 20, a visitação de agroflorestas, que se localizam nos remanescentes de quilombos do Cambury e 
da Fazenda. Essa visitação é regulada pelo Parque que agenda e acompanha as atividades através de monitores ambientais.

"a gente trabalha com muito grupo de faculdade, escola que já é agendado pelo, pelo parque, [...] então, a gente assim é... trabalha com eles, eles trazem a escola, falcudade, aí faz, trabalha aqui dentro da comunidade, [...] tem roda de conversa. A roda de conversa é a pessoa mais antiga contando a história como que era o camburi antigamente. Aí vinha essas pessoas pa fazer os estudo, e aí leva pas faculdade deles, entendeu, e aí o parque ele assim tem um trabalho junto com a comunidade, e aí nessa parte é bem melhor" (M1, grifo nosso).

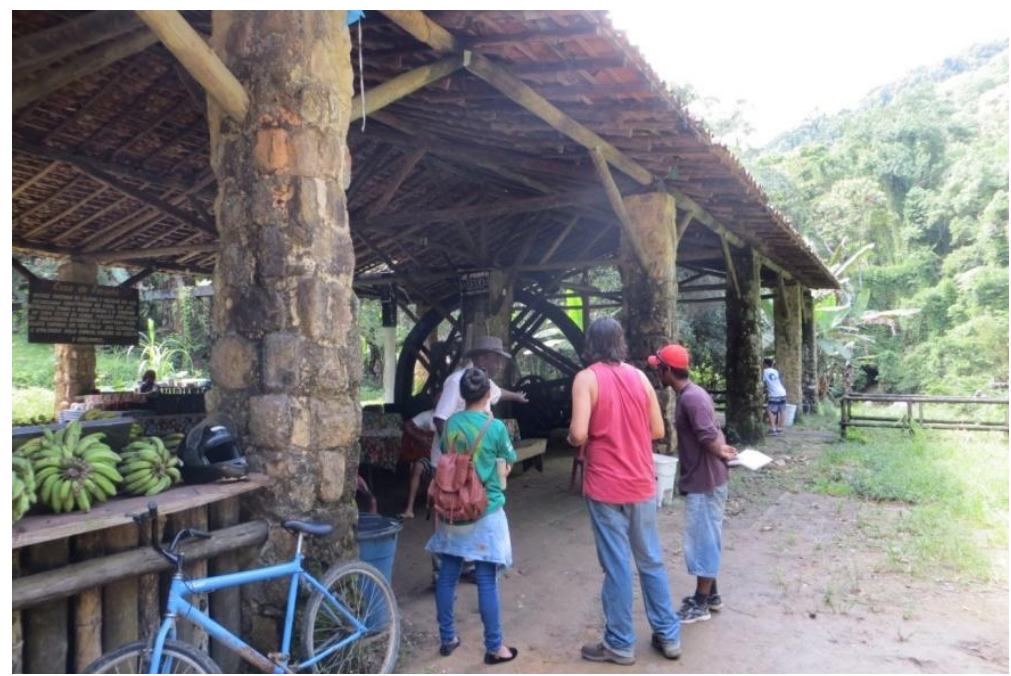

Figura 20 - Imagem de um grupo de visitantes na Casa da Farinha (Sertão da Fazenda) em interação com o líder comunitário e morador antigo da região (Senhor Zé Pedro) (Foto: Eliana Mazzucato).

De acordo com a Resolução da Secretaria do Estado do Meio Ambiente (Resolução SMA/SP 32, de 31 de março de 1998) as atividades guiadas no Parque são feitas por pessoal especializado, incluindo funcionários da UC, monitores ambientais e outros profissionais credenciados. Observa-se que as atividades que fomentam a formação e credenciamento dos monitores ambientais das comunidades locais no parque tem sido uma estratégia positiva no sentido de valorizar a cultura tradicional local. Esses monitores ambientais das comunidades locais formados pelo parque podem proporcionar uma visita que incorpore as características socioculturais às atividades na natureza.

"a gente brigava muito também porque os monitores eram de fora, e a gente quer que eles envolvam os jovens da comunidade, já que as trilhas estão localizadas dentro do quilombo, então usa as pessoas dentro da comunidade... então hoje já tem quatro, foi feito um curso, ah tem mais, [...] são cinco pessoas hoje que já são monitores da comunidade, entendeu, e a gente quer envolver muito mais, vai ter mais um curso agora de novo" (M5, grifo nosso). 
Observa-se nessa resolução que o credenciamento exige uma grade curricular mínima de curso de formação, oferecido geralmente pela UC. Portanto, vê-se o papel do parque em articular esses cursos de capacitação, promovendo uma valorização das comunidades, beneficiando tanto a instituição quanto as comunidades

“[...] aqui vem mais grupos organizados de colégio que o parque traz, né, e
aí vão conhecer a comunidade. É eles fazem trabalho de pesquisa dentro da
comunidade, tem bastante. É pouco, não é muito turismo, por ser um lugar
mais longe né, mas vem, vem, o turismo vem, e, tem a casa da farinha aonde
tem roda de conversa, [...] eles fazem roda de conversa com os grupos
organizados [...]" (M7).

Outra iniciativa importante que vem sendo desenvolvidas nas Zonas Histórico Cultural Antropológicas do NP é o "Projeto Juçara"11 (Figura 21). Esse projeto foi proposto pelo Instituto de Permacultura e Ecovilas da Mata Atlântica (IPEMA) com parceria da Associação para Cultura, Cidadania e Meio Ambiente (AKARUI) e apoio da Fundação Florestal. A Juçara é uma palmeira típica dessa área de Mata Atlântica, porém, vem sendo explorada há séculos devido ao alto valor comercial do palmito. Essa atividade gerou grande impacto na região, pois é através do corte da planta que se dá a exploração do palmito.

11 Mais informações sobre o Projeto Juçara no Sertão do Ubatumirim estão no wbsite: <http://www.projetojucara.org.br/projeto-jucara/> 

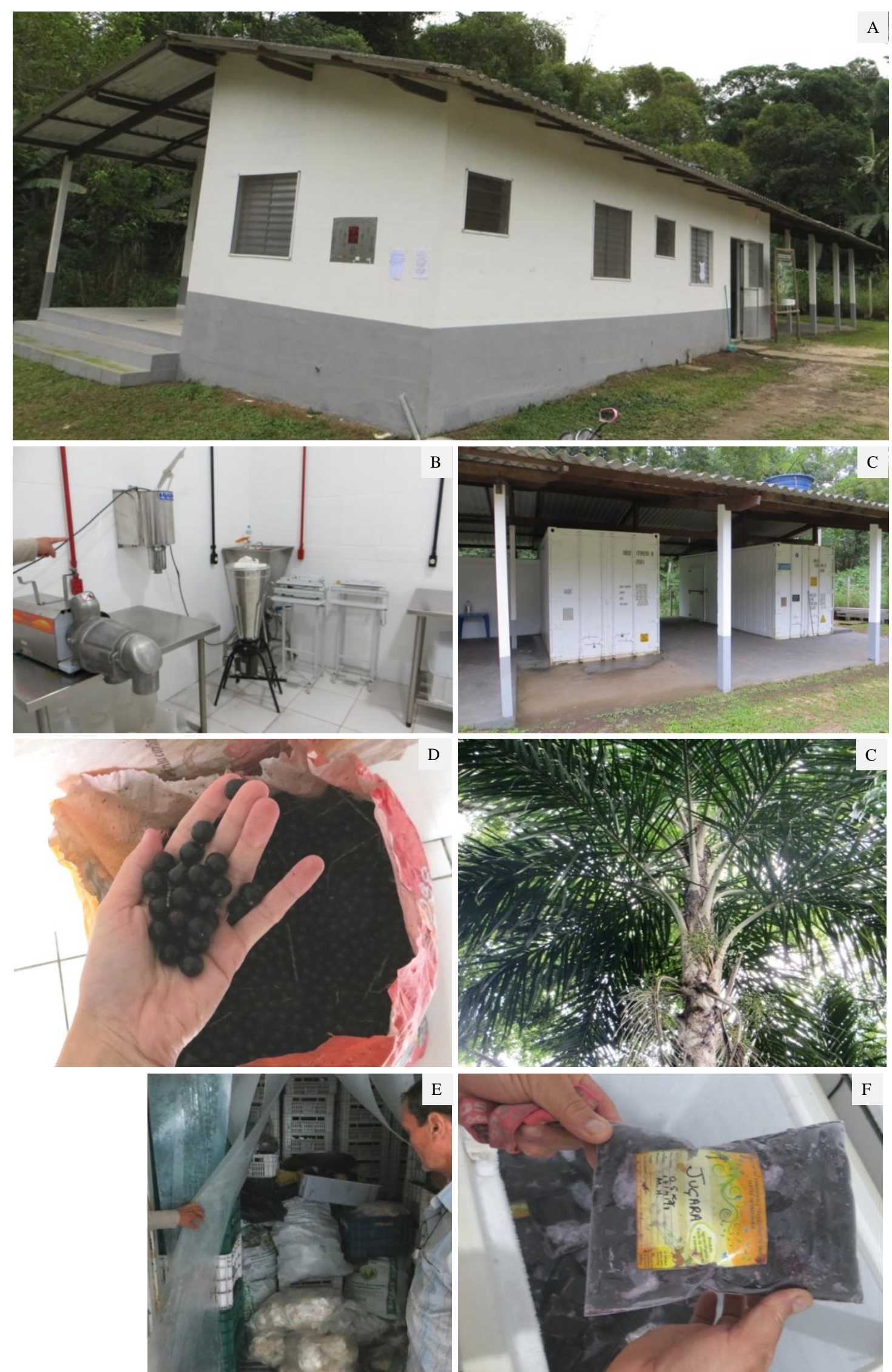

Figura 21 - A) Cozinha comunitária do projeto Juçara no Sertão do Ubatumirim, Ubatuba (SP); B) Maquinário para preparação polpa do juçara; C) câmaras frias da cozinha; D) Fruto do Juçara; E) Polpa do Juçara; F) interior da câmara fria, que armazena produtos diversos, como juçara, mandioca e cambuci; G) Fruto do Cambuci (Fotos: Eliana Mazzucato). 
Nesse projeto, o foco das atividades está na utilização sustentável do fruto do Juçara para produção de polpa, que se assemelha ao açaí. O relato de uma moradora do bairro do Ubatumirim, que é caracterizado essencialmente pela agricultura, aponta para os benefícios que esse projeto proporcionou para a comunidade e também para o próprio manejo da espécie, que tem se restabelecido.

“[...]então isso aí é muito rico né, a juçara aqui... a gente, nossos pais preservaram, hoje a gente produz 30 tonelada de Juçara aí porque a gente preservou né. Então, um patrimônio. E a gente tem muita juçara" (M14).

"[...] você pode ver, aonde é parque não tem um palmito, e aonde é propriedade que é da gente a gente cuida, para poder se beneficiar depois, entendeu” (M14).

Além do manejo do Juçara, essa comunidade vem realizando o manejo de outros produtos, como o cambuci (Figura 22), proporcionando uma maior dinamicidade econômica e consequente melhorias nas condições de vida, na Figura 23 é possível observar o local onde é realizada a festa do Juçara.

"[...] a gente trabalha com o juçara, trabalha com a mandioca, trabalha com o cambuci, polpa de fruta... a gente trabalha com merenda escolar né, a gente vende pras casa de suco em Ubatuba, restaurante, e até pessoas de fora mesmo vem comprar com a gente aqui, época de feriado quando eles tão por aí. Eles procuram vim em ubatumirim, comprar as coisas que a gente produz aqui pra vender. [...] A gente tem uma cozinha ali, a gente tem duas câmara fria, a gente processa um monte de alimento e congela, e daí mais pra frente a gente vende né" (M14).

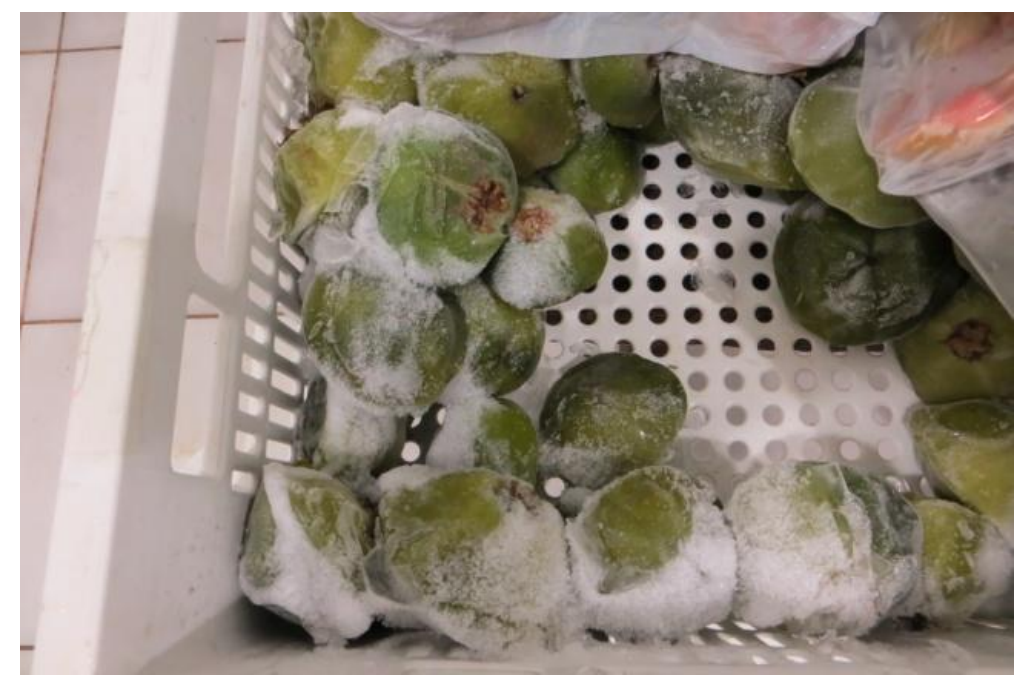

Figura 22 - Imagem do fruto do Cambuci que também é um produzido de forma sustentável no Sertão do Ubatumirim (Foto: Eliana Mazzucato). 


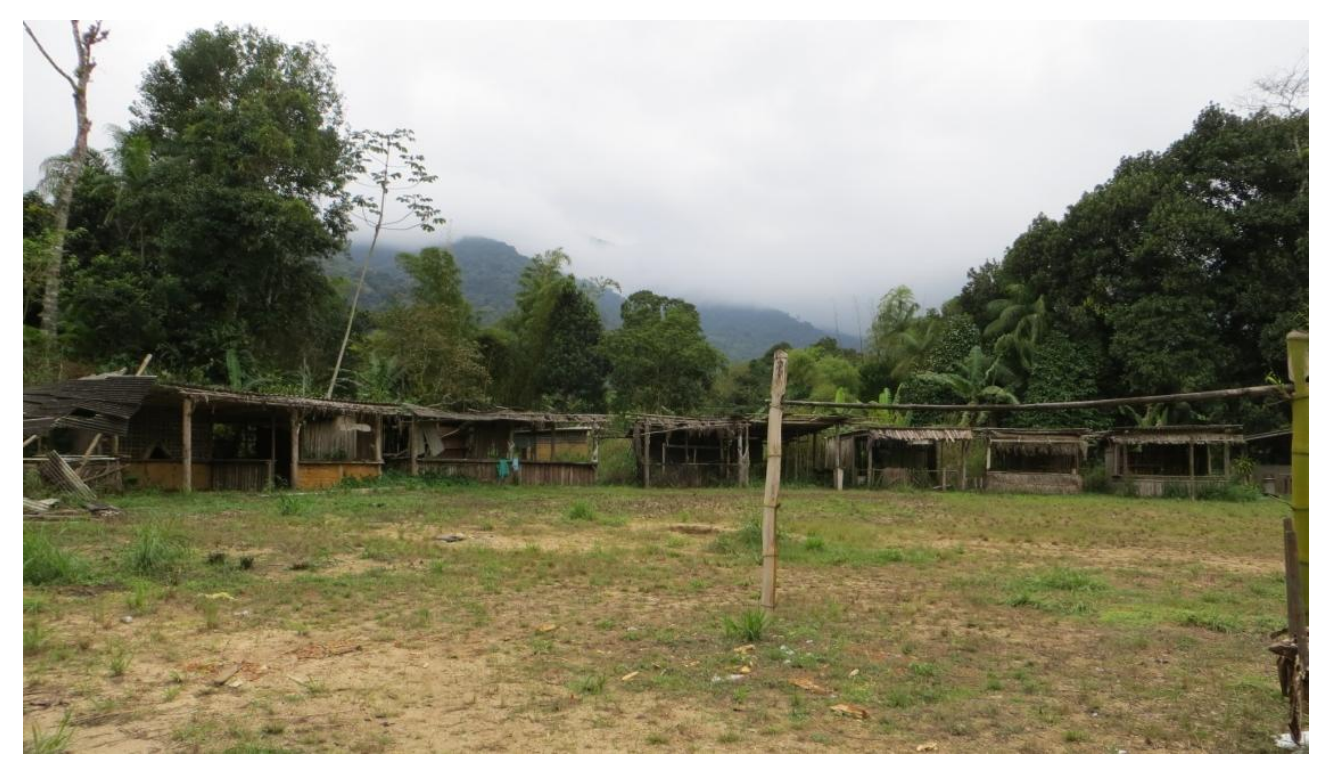

Figura 23 - Local onde é realizada a festa do Juçara em Ubatumirim (Foto: Eliana Mazzucato).

Esse projeto também abrange outras comunidades da região, como a do Sertão da Fazenda. As moradoras entrevistadas dessa localidade também destacaram os benefícios desse projeto para as comunidades, proporcionando novas perspectivas na relação dos tradicionais com o parque

"hoje a gente não tira, a gente planta o palmito né, o juçara hoje é o nosso carro forte, da polpa do juçara entendeu, hoje do juçara a gente faz todo tipo de bolo, geleia, comida, tudo com o fruto da juçara, então além de plantar pra gente ter, a gente colhe o fruto" (M7).

“[...], tem uns pratos também que nós criamos, do juçara, o suco juçara, eu criei alguns pratos também, nós fazemos alguns pratos né, estrogonofe de lula com juçara, a moqueca de lula com, a moqueca de juçara, minha filha faz trufa, fazemo doce, licores, tudo de juçara... e o povo vem mesmo porque o povo gosta" (M5).

A melhoria na condição de vida da comunidade fica evidente quando uma entrevistada chama a atenção sobre a importância desse projeto para criar oportunidades para os jovens. De modo geral, vários relatos trouxeram informações sobre o movimento de deslocamento dos jovens da comunidade que procuram melhores condições de vida. Nesse sentido, a partir do projeto Juçara vislumbra-se a permanência ou o retorno dos jovens da comunidade

"uma forma da gente conseguir trazer os jovens pra essas atividades, porque hoje a gente tem o manejo da juçara, que nós temos né, a gente fez o projeto da juçara que hoje nós temos o suco da juçara, então dá pra envolver bastante jovem na juçara" (M5). 
Esse processo de transformações culturais devido ao afastamento dos jovens dessas tradições também é sentido pelos moradores do entorno

\begin{abstract}
"só o que tá tendo continuidade só o da folia do divino, que é uma coisa que a gente tinha todo ano, ainda tá tendo, a folia de reis que vinha, agora não tá vindo mais. A festa que a gente fazia não tá conseguindo. Tá fazendo assim no dia, mas não de azul marinho, de barracas, não tão mais, porque os velho não tão aguentando mais enfrenta. Mas ainda tem alguma coisa ainda" (M15).
\end{abstract}

Para essas comunidades, esse processo resulta da dificuldade de manter condições de vida no ambiente e também das poucas oportunidades para a estruturação de uma carreira profissional almejada pelos mais jovens

\begin{abstract}
"assim, hoje pra falar a verdade, os caiçara, eles não é que eles perderam essa cultura, eu acho que veio o progresso e ai os jovens foram se afastando né, foram assim esquecendo um pouco das festas que tinha mesmo né, que nem dança catira, ciranda, folia do reis, a congada, então não tem interesse em aprender com o velhos pra dar continuidade, e aí foi se perdendo" (M16).

"Acho que pela situação hoje, primeiro você tem que estudar, quando você estuda você tem que procurar um serviço, aí se você ficar aqui, aqui mesmo no município de Ubatuba, se você não sair pra outra cidade aqui da região, você vai ficar, sabe, à mercê de um salário bem baixo, e se você vai pra faculdade essas coisa também não tem campo pra você vencer aquilo. [...] complicado né, aí você vai pra cidade maior assim pra você poder ter uma melhor condição de vida né" (M16).
\end{abstract}

No caso das ações promovidas pelo parque, para fortalecer a cultura local, observa-se uma relação positiva entre comunidade e parque. Exemplo disso é a articulação do parque em formar monitores ambientais das comunidades tradicionais e o desenvolvimento do Projeto Juçara já citado. Considera-se que essas propostas valorizam os saberes locais e possibilitam o desenvolvimento de atividades econômicas compatíveis com a conservação da natureza local. Essa conciliação gera resultados positivos para ambos os lados, superando a visão dicotômica de uso e exploração dos recursos e conservação da natureza.

No âmbito de uma maior dinamização econômica dessas comunidades, que leve em conta a manutenção das características culturais e sociais que determinam sua condição de tradicionais, há muito ainda para ser dialogado, proposto e monitorado. Em síntese, os caminhos apontados por esses atores locais no sentido de melhorar suas condições de vida e a relação com o parque foram: 
- Maior estabilidade para os moradores;

- Possibilidade de renda através do turismo sustentável (que valoriza sua comunidade e gera renda), destacando nesse âmbito o turismo de base comunitária e o ecoturismo;

- Desenvolvimento de projetos baseados no manejo sustentável dos recursos;

- Repensar a classificação das comunidades tradicionais que gerou fragmentação do território e enfraquecimento das comunidades;

- Possibilitar caminhos para o envolvimento dos jovens na participação social;

- Ampliar restrições aos grandes investidores;

- Ampliar canais de participação e valorização do papel das comunidades na conservação socioambiental.

Portanto, de modo em geral, a relação do parque com as comunidades é marcada por períodos conflituosos em maior ou menor amplitude, em decorrência de uma perspectiva preservacionista predominante que percebe a natureza de forma desvinculada do meio social, mesmo considerando as comunidades tradicionais. A implementação do Parque Estadual da Serra do Mar gerou instabilidade aos habitantes da região, porém barrou o avanço de novos residentes, e, principalmente o avanço de grandes investidores imobiliários e turísticos na região.

\subsubsection{A perspectiva dos gestores dos núcleos Picinguaba e Caraguatatuba}

O parque possui papel de referência para a conservação da natureza local, dando manutenção à paisagem vivenciada pelos moradores locais e pelos indivíduos que frequentam esses municípios.

No contexto do lugar, verifica-se que o parque é amplamente reconhecido por aqueles que tiveram seus direitos limitados, e transformações no modo de vida determinados pela dinâmica conservacionista intrínseca à implantação do parque. Nesse sentido, percebe-se que a interação do parque com a comunidade muitas vezes se restringe à gestão territorial, correspondendo ao ordenamento das atividades no parque e em seu entorno.

A ampliação da interação do parque com a sociedade e sua afirmação como área pública centram-se na gestão do uso público do parque. O uso público reúne as atividades de normatização e ordenamento de áreas para a visitação pública, a prática de esportes de aventura, desenvolvimento de programas de educação ambiental, ecoturismo, programas de 
comunicação e divulgação, realização de eventos e desenvolvimento de pesquisas (SÃO PAULO, 2014).

Assim, busca-se promover o acesso e envolvimento da sociedade com esse lugar, considerando os moradores da unidade e seus usuários diretos, os visitantes e beneficiários externos à UC e os moradores da Zona de Amortecimento (SÃO PAULO, 2014).

Em acordo com essas orientações, os gestores apresentaram diversos programas que vêm desenvolvendo através da gestão do uso público, considerando a potencialidade da UC em ampliar a vivência da sociedade com áreas naturais e as possibilidades de aprendizado nesse ambiente.

Observam-se indicativos dessa abordagem nos projetos relatados pelos gestores que o parque vem desenvolvendo junto com escolas do entorno, destacando a relevância das parcerias com a Diretoria Regional de Ensino (DRE), ou a Secretaria Municipal de Ensino (SME), que proporcionam o deslocamento dos alunos para a unidade.

Através dessa disponibilidade de recursos as unidades organizam a atividade, através de ações de educação ambiental e trilhas monitoradas. As atividades propostas têm como objetivo proporcionar aos alunos uma maior interação com o ambiente preservado, além de desenvolver atividades visando o aprendizado nesse meio, relacionando conteúdos escolares às observações de campo. Nesse contexto, o aluno como ator local vivencia esse ambiente e, através da sua sensibilização cria vínculos e novas atitudes quanto à importância da conservação.

Em Caraguatatuba há ainda pouca identificação do parque como parte do município. A área preservada pelo PESM é identificada como Horto Florestal por muitos moradores, como relatou o gestor do núcleo. O Horto Florestal correspondia a grande parte da área atual do parque antes de 1977. Essa concepção vem sendo modificada, partindo principalmente de projetos de divulgação e comunicação promovidos pela unidade, bem como com a promoção de atividades de turismo, lazer e de educação ambiental.

O núcleo de Caraguatatuba também já desenvolveu projetos relacionados à prática de observação de aves com as escolas, sendo um diferencial para as escolas da região. A atividade foi desenvolvida nas trilhas do núcleo, na perspectiva da educação ambiental, proporcionando o contato dos alunos com a diversidade de espécies de aves e sensibilizandoos quanto à problemática da captura de aves na região.

Nesse contexto, a unidade preocupa-se também com a ampliação do acesso das trilhas para os mais diversos públicos, estando em construção uma trilha acessível para aqueles que possuem maiores restrições físicas e motoras, ou com necessidades especiais. 
Em Caraguatatuba a interação com os moradores locais é ampliada a partir do livre acesso que os moradores do entorno do parque possuem, decorrente de um cadastro prévio de acordo com a regularização definida. Dessa forma os moradores do entorno podem ter acesso ao parque de forma gratuita, já que o núcleo possui uma taxa de ingresso de 13,00 R \$ para os visitantes.

Em Picinguaba, também foram relatadas atividades com as escolas locais, em situações que os alunos se deslocam até o parque, ou que os monitores vão até as escolas. Essa abordagem visa aproximar as pessoas do núcleo, valorizando também o potencial da unidade em favorecer o aprendizado e a sensibilização da sociedade num contexto de ambiente natural. Nesse sentido, a unidade também pode apresentar uma ação de acolhimento, quando há apoio de projetos e parcerias, proporcionando o deslocamento dos alunos para esse ambiente, pois muitos desses alunos não possuem condições ou possibilidade de se deslocar para o núcleo e vivenciar esse lugar, já que o centro de visitantes encontra-se no extremo norte do município.

De um modo geral as atividades do parque estimulam o reconhecimento da importância da unidade, abrindo também outras possibilidades, correlacionando os materiais e conteúdos propostos pelas escolas e pelos materiais didáticos às observações no campo, em que a experiência e conhecimento de monitores locais, outros funcionários, e até mesmo dos moradores tradicionais enriquecem a atividade.

Outros instrumentos de interação têm sido valorizados, no sentido de fortalecer a participação dos residentes nos Conselhos Consultivos do parque, que é presidido pelo órgão administrador da unidade e composto por representantes dos órgãos públicos e organizações da sociedade civil. Observa-se que a garantia da representatividade da sociedade civil perpassa pela organização das comunidades, através das associações de moradores dos bairros. Os relatos do núcleo Picinguaba em conjunto com a análise de Simões (2015) indicam uma maior participação e envolvimento das comunidades no Conselho Consultivo.

No âmbito dos conflitos socioambientais percebidos pelos gestores do núcleo observa-se em seus relatos que os maiores conflitos estão associados às invasões por moradores e outras pressões provenientes de grandes empreendimentos e novos loteamentos.

Em Caraguatatuba, o núcleo do PESM é marcado pela passagem da rodovia Tamoios (SP-099), transpassando seções da zona intangível, que é um fator facilitador da prática de crimes ambientais como caça, exploração da flora (exemplo: captura de orquídeas e bromélias), corte palmito, despejo inadequado de lixo, dentre outros. Além disso, são descritos fatores como a intensa urbanização do município, proporcionando a expansão da 
ocupação nas áreas do parque e na Zona de Amortecimento, os dutos (aeroduto e gasotudo) que também percorrem o território do núcleo, a construção de grandes empreendimentos, as atividades mineradoras e a coleta e tratamento inadequados dos resíduos.

No caso de Picinguaba, também ocorre a facilitação da prática de crimes ambientais e da ocupação através da rodovia Oswaldo Cruz (SP-125) e da rodovia Rio-Santos (BR-101). Os conflitos nesse território também se relacionam às ocupações anteriores à criação do PESM, por tradicionais e não tradicionais.

\subsubsection{A identificação dos conflitos socioambientais na perspectiva dos monitores, professores e funcionários de ONG}

As apreensões dos conflitos socioambientais que se inserem no diagnóstico proposto a partir do olhar desses atores locais foram identificadas através da questão 6 do questionário que trata dos conflitos socioambientais (Para você, quais seriam os principais conflitos socioambientais da região?).

Três indivíduos declararam não saber quais os conflitos socioambientais dos municípios, e seis pessoas deixaram a resposta em branco. Os demais atores locais apresentaram os principais conflitos/problemas da região, que foram agrupados em:

\section{a) Deficiências nos serviços básicos dos municípios}

Os serviços de coleta e tratamento dos resíduos sólidos dos municípios que compreendem a área de estudo foram apontados como problemas relevantes (Figura 24), pois, não há coleta seletiva de lixo, nem a existência de aterro sanitário. A partir da proibição do funcionamento de lixões que existiam nesses municípios (o lixão de Caraguatatuba, localizado na Fazenda Serramar foi fechado em 2007, e o de Ubatuba, em 2009, no bairro Ipiranguinha), as prefeituras realizam o transbordo do material para municípios vizinhos, no Vale do Paraíba. 

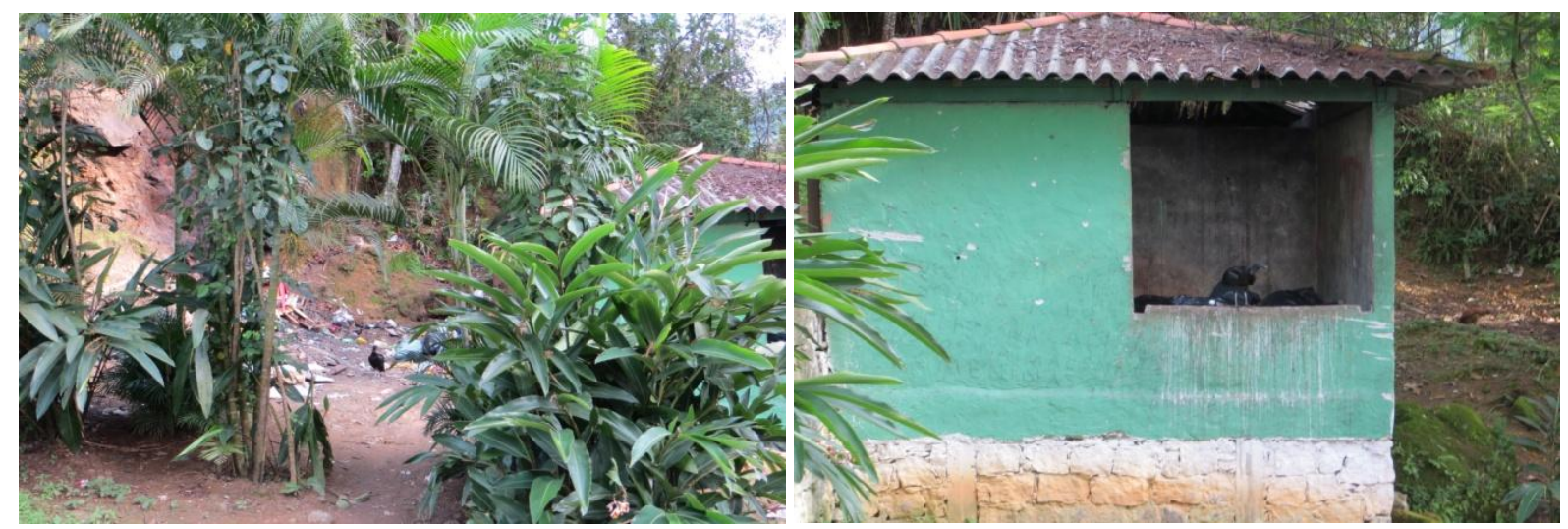

Figura 24 - Posto de coleta de lixo em más condições e sobrecarregado na entrada da Vila de Picinguaba, Ubatuba (SP) (Fotos: Eliana Mazzucato).

Foi destacado também os baixos índices de tratamento de esgoto nesses municípios. Dados do Sistema Nacional de Informações sobre Saneamento (SNIS) ${ }^{12}$ de 2015 apresentam a situação desses municípios. Em Caraguatatuba, que possuía população estimada de 108.998 habitantes segundo a Fundação Sistema Estadual de Análise de Dados (SEADE, 2015) ${ }^{13}$, teve, nesse mesmo ano 73.230 habitantes atendidos pelo sistema de esgotamento sanitário. Foram coletados 6.600,16 $\mathrm{m}^{3}$ /ano de esgoto, com $100 \%$ desse volume tratado. Portanto, $67 \%$ da população de Caraguatatuba foi atendida. Em Ubatuba, com população estimada de 83.890 habitantes (SEADE, 2015), apresentou 25.644 habitantes atendidos pelo sistema de esgotamento sanitário. Coletou-se 2.523,68 $\mathrm{m}^{3} / \mathrm{ano}$ de esgoto, dos quais, 99,96\% foram tratados. Assim, cerca de $31 \%$ da população de Ubatuba foi atendida pelo sistema.

\section{b) Conflitos de interesses versus preservação}

Percebe-se que muitos conflitos são identificados a partir da atuação antrópica na exploração dos recursos naturais, sendo descritos como "conflitos de interesse econômico versus preservação", e segundo outro participante "O homem que não consegue o equilíbrio entre ele e a natureza. Tem que desmatar para construir, para plantar, para se divertir. Ele não tem a consciência que sempre será o invasor". Nesse sentido, apreende-se que os conflitos socioambientais identificados por esses atores se relacionam aos conflitos entre uso e conservação da natureza, provocando a degradação ambiental: "poluição dos rios e águas", "poluição do ar" e "corte de barrancos".

\footnotetext{
${ }^{12} \mathrm{http} / / /$ app.cidades.gov.br/serieHistorica/\#

${ }^{13} \mathrm{http} / / /$ produtos.seade.gov.br/
} 
Destacam-se também as incidências do uso dos recursos naturais de forma exploratória, como "desmatamento", “caça”, "exploração hídrica”, "caça e pesca ilegais/predatórias" e "extração de madeira e da palmeira juçara, tráfico de animais silvestres".

\section{c) Sobreposições territoriais em área de UC}

A presença de populações na área do parque também foi recorrente dentre as respostas apresentadas, evidenciando diferenciações quanto às comunidades de tradicionais, moradores antigos, agricultores e outros. Os conflitos emergem assim da situação que esses atores locais se encontram diante a criação da unidade: “A falta de respeito e consideração (mínima) para com as comunidades tradicionais que já existem dentro do Parque, quando o mesmo foi criado pelo governo". Outro respondendo acrescenta: "O maior conflito é que não levaram em conta que as comunidades locais sobreviveram por dezenas de anos nas respectivas áreas, se alimentando do que a natureza servia, e de repente sem serem adaptados a nova realidade, foram forçados a mudarem suas vidas, sem nenhum trabalho de adaptação à nova realidade”.

Nesse sentido, o relato a seguir reforça o papel de luta histórica dessas comunidades para garantir o direito ao seu território, constituindo um dos conflitos socioambientais mais perceptíveis do território: "A região tem um histórico forte de luta das comunidades, principalmente quilombolas e caiçaras, que conquistou a desafetação de algumas áreas do Parque, mostrando que suas práticas podem ser compatíveis com os princípios de conservação do Parque”.

\section{d) Transformações recentes}

As transformações recentes que tem influenciado os conflitos socioambientais da região aos olhos desses atores estão relacionadas ao crescimento desordenado dos municípios, à especulação imobiliária, e ao turismo predatório de massa.

Esses municípios atraem historicamente o olhar de novos moradores e de empresários que reconhecem o potencial econômico e turístico centralizados no litoral norte como um todo. A evolução do crescimento populacional (Tabela 6) de Caraguatatuba e Ubatuba pode ser um dos indicadores dessa nova dinâmica. 
Tabela 6 - Número de habitantes em Caraguatatuba e Ubatuba nos anos de 1970, 1980, 1996, 2000, 2007 e 2010

\begin{tabular}{|l|l|l|l|l|l|l|}
\hline \multirow{2}{*}{ Municípios } & \multicolumn{6}{l|}{ Censo demográfico (IBGE) - Ano } \\
\cline { 2 - 7 } & $\mathbf{1 9 7 0}$ & $\mathbf{1 9 8 0}$ & $\mathbf{1 9 9 6}$ & $\mathbf{2 0 0 0}$ & $\mathbf{2 0 0 7}$ & $\mathbf{2 0 1 0}$ \\
\hline Caraguatatuba & 15.073 & 33.802 & 66.669 & 78.921 & 88.815 & 100.840 \\
\hline Ubatuba & 15.203 & 27.139 & 54.196 & 66.861 & 75.008 & 78.801 \\
& & & & & & \\
\hline
\end{tabular}

Fonte - Censos demográficos IBGE

Segundo o Instituto Pólis (2013a), Caraguatatuba é considerada polo de comércio e serviços no litoral norte de São Paulo: "Caraguatatuba sofreu gradualmente, ao longo dos anos, um deslocamento progressivo de sua vocação econômica, antes pautada pelo turismo em larga medida, tornando-se um polo regional de comércio e de serviços consolidado" (INTITUTO PÓLIS, 2013a, p. 70). Segundo essa mesma referência, a população do município duplica e até mesmo triplica na época de alta temporada para o turismo.

A partir do exposto nas respostas, pode-se observar essa dinâmica no município, constituindo os conflitos socioambientais a partir de empreendimentos significativos, como as construções da Petrobrás de gasoduto e oleoduto, o porto de Santos (previsão de ampliação) e a duplicação da Tamoios (Figura 25).

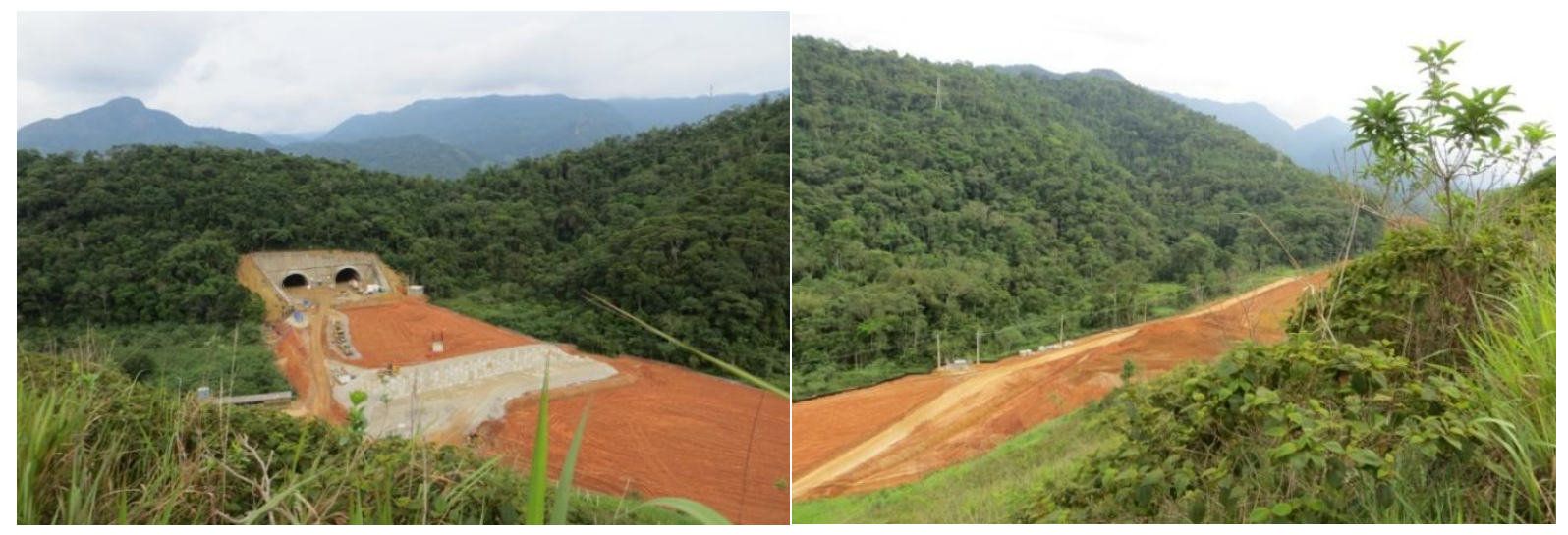

Figura 25 - Obras de duplicação da Rodovia Tamoios no entorno de Caraguatatuba (Fotos: Eliana Mazzucato)

No caso de Ubatuba, vê-se que o município apresenta maior influência do turismo na sua dinâmica "A vocação turística de Ubatuba é apontada como a característica mais importante do município entre todos os segmentos entrevistados, tanto na sociedade civil organizada como nos grupos de pesquisa" (INSTITUTO PÓLIS, 2013b, p. 83). Nesse sentido, 
as respostas obtidas nessa pesquisa corroboram as infraestruturas conflitantes, como a construção e ampliação de marinas.

Em ambos os casos foram relatadas preocupações quanto à "urbanização de áreas próximas das unidades de conservação", "Uso e ocupação do solo", "construções irregulares", "construções inadequadas" e "construção civil desorganizada",

Além disso, representam conflitos no sentido da degradação ambiental: "órgãos privados tentam através de todo poder aquisitivo, comprar locais de proteção ambiental", "A exploração imobiliária também ameaça o ambiente pois grandes construtoras compram grandes áreas e constroem condomínios de alto padrão degradando e privatizando as áreas de reserva natural", "detrimento de áreas naturais para empreendimentos imobiliários desordenados".

Provocando alterações paisagísticas e no modo de vida: "por conta da especulação imobiliária em épocas passadas e atuais, a cidade perdeu um pouco de suas referências, e com, ainda, construções e interesses em áreas cuja beleza atrai cada vez mais construtoras e condomínios de luxo".

E, afetando as populações mais carentes e comunidades tradicionais "perda de locais dos povos tradicionais, os quais perderam, e muito suas terras para grandes especuladores" e, "Perda de território das comunidades tradicionais (indígenas, quilombolas e caiçaras) para especulação imobiliária e grandes empreendimentos (rodovias, portos, atividades de petróleo e gás, etc)".

Em relação ao turismo, ficam claras as pressões que vem causando na paisagem natural e na infraestrutura desses municípios, ocasionando intensificação do trânsito, poluição das praias, maior demanda por residências, melhorias na coleta de lixo, abastecimento de água e na coleta e tratamento de esgoto, dentre outros. Dessa forma, as descrições salientam que: "A visitação massiva nos feriados e férias desordenada faz a degradação e poluição deste meio ambiente".

\section{e) Legislação e gestão pública}

Nesta perspectiva, as considerações se voltam para a fragilidade das leis ambientais e do município, bem como na forma com que o território é gerido. Segundo os respondentes, ocorre "o desrespeito às leis ambientais", "conflito de interesse quanto ao plano estratégico do estado e o interesse da comunidade para o crescimento logístico dos municípios do litoral norte", "As políticas públicas estaduais que tem se esforçado em fragilizar as leis de 
preservação e dificultando o acesso da população nas discussões da gestão das áreas protegidas", "falta de valorização da Fundação Florestal", "troca da gestão municipal da cidade (prefeito) não seguindo e valorizando a legislação ambiental”, "a falta de vontade de algumas autoridades de querer ajudar a preservar o meio ambiente", "falta de recursos da Fundação Florestal para fiscalização”. Nesse sentido, alguns respondentes apontaram demandas como a necessidade de "fiscalização e novas leis mais rigorosas em relação a pesca, principalmente com redes e aumento do defeso ${ }^{14}$,.

Também foram apontados os conflitos decorrentes do processo em curso de revisão do Zoneamento Ecológico Econômico do litoral norte de São Paulo e dos licenciamentos ambientais.

\section{f) Falta de conhecimento}

Para muitos dos respondentes, os conflitos socioambientais dessas áreas se relacionam ao baixo conhecimento ou falta de informação por parte dos moradores da região sobre a condição especial desses municípios por abrangerem área de conservação: "a falta de esclarecimento das pessoas que moram no entorno do parque em contrapartida com uma necessidade de uma política sustentável voltada para a melhoria de vida dessas pessoas e que seria o papel do Estado. É necessário uma maior valorização da cultura e apoio do Estado”, "Conscientizar o morador local da preservação do local, caça, pesca fora de época, desmatamento por não saber da importância de cada espécie”,

Observa-se, portanto, a ausência de maior articulação e envolvimento dos moradores do entorno para compreenderem as especificidades da unidade de conservação, não apenas no sentido de suas restrições, mas, em como isso afeta e proporciona uma melhor qualidade de vida para essas pessoas: "Pescadores são levados a acreditar que as leis só os prejudicam, assim como áreas de exclusão à pesca, quando na verdade são os beneficiados",

\subsection{A Percepção Geoambiental}

A percepção ambiental dos habitantes dos núcleos Picinguaba e Caraguatatuba emerge das relações construídas a partir de suas vivências e experiências com o lugar, sendo possível correlacionar os aspectos da geodiversidade para a construção dessa percepção.

\footnotetext{
${ }^{14} \mathrm{O}$ defeso consiste numa medida de paralisação temporária da pesca durante o período de reprodução ou recrutamento, podendo ainda ser adotado em decorrência de fenômenos naturais ou acidentes, visando a preservação das espécies (BRASIL, 2009).
} 
Dessa forma, buscou-se realizar o levantamento das percepções ambientais com ênfase na geodiversidade (percepções geoambientais) dos diversos atores envolvidos na conservação do patrimônio natural local, trazendo sentido amplo na compreensão das percepções, significados e interpretações, estabelecendo relações e identificação da geodiversidade e do patrimônio geológico.

Identificar a geodiversidade a partir da percepção desses moradores contribui com a compreensão da construção de identidade a partir desses elementos, considerando os valores locais atribuídos à geodiversidade. Os estudos de percepção ambiental apontam possíveis trajetórias significativas nas abordagens de valorização e divulgação da geodiversidade local, contribuindo com sua geoconservação.

\subsubsection{O olhar do morador tradicional}

No conjunto dos aspectos perceptivos nos núcleos Picinguaba e Caraguatatuba destaca-se a formação da Serra do Mar. Visualmente exuberante, essa feição geomorfológica marca a paisagem pelo olhar dos moradores tradicionais, e remete à integração entre geodiversidade e biodiversidade à medida que as áreas de Serra possuem uma mata atlântica mais densa e preservada.

Nessa paisagem retratada pelos moradores surge também o litoral, como lugar de contemplação e de tranquilidade. Portanto a paisagem é apresentada a partir da interação da geodiversidade e biodiversidade, uma apreensão integrada e interdependente. Nesse sentido, os moradores estão sensíveis e atuantes na conservação dessa paisagem. No relato apresentado abaixo, há a exposição de uma percepção contemplativa, apresentando a imagem de um local preservado, sendo destacado um sentimento de pertencimento que apresenta uma sensibilidade do indivíduo para com a questão ambiental do lugar. No resgate de sua memória, a paisagem do lugar se apresenta preservada e exuberante, tendo sentido assim em promover sua conservação.

"eu acho que a nossa serra do mar ela tá bem protegida né, porque um espaço melhor que a gente tem é esse aqui, né, de toda essa costa aqui que tem lugares aí que já tá muito detonado também mas eu acho muito bonito, nossa, eu acho que isso aqui, eu acho que não é só eu não, todo mundo que vem, que olha pra lá, pra cá, que vê essa montanha, isso é tudo de bom né, por isso que a gente quer conservar" (M7, grifo nosso). 
A relação com o lugar também pode ser descrita a partir da construção cultural, na qual os moradores locais estabeleceram as comunidades tradicionais do litoral norte em interação com o ambiente. O lugar é base para o desenvolvimento das culturas tradicionais, de fonte de recursos para sua sobrevivência, e onde decorreu um longo histórico de lutas e conflitos pelo direito a esse território. Assim, as marcas desse histórico de ocupação podem ser percebidas, através de ruínas, casas, comércio, igrejas, antigas fazendas de beneficiamento de cana e de açúcar (Figura 26), caminhos e trilhas por entre a serra, dentre outros. 

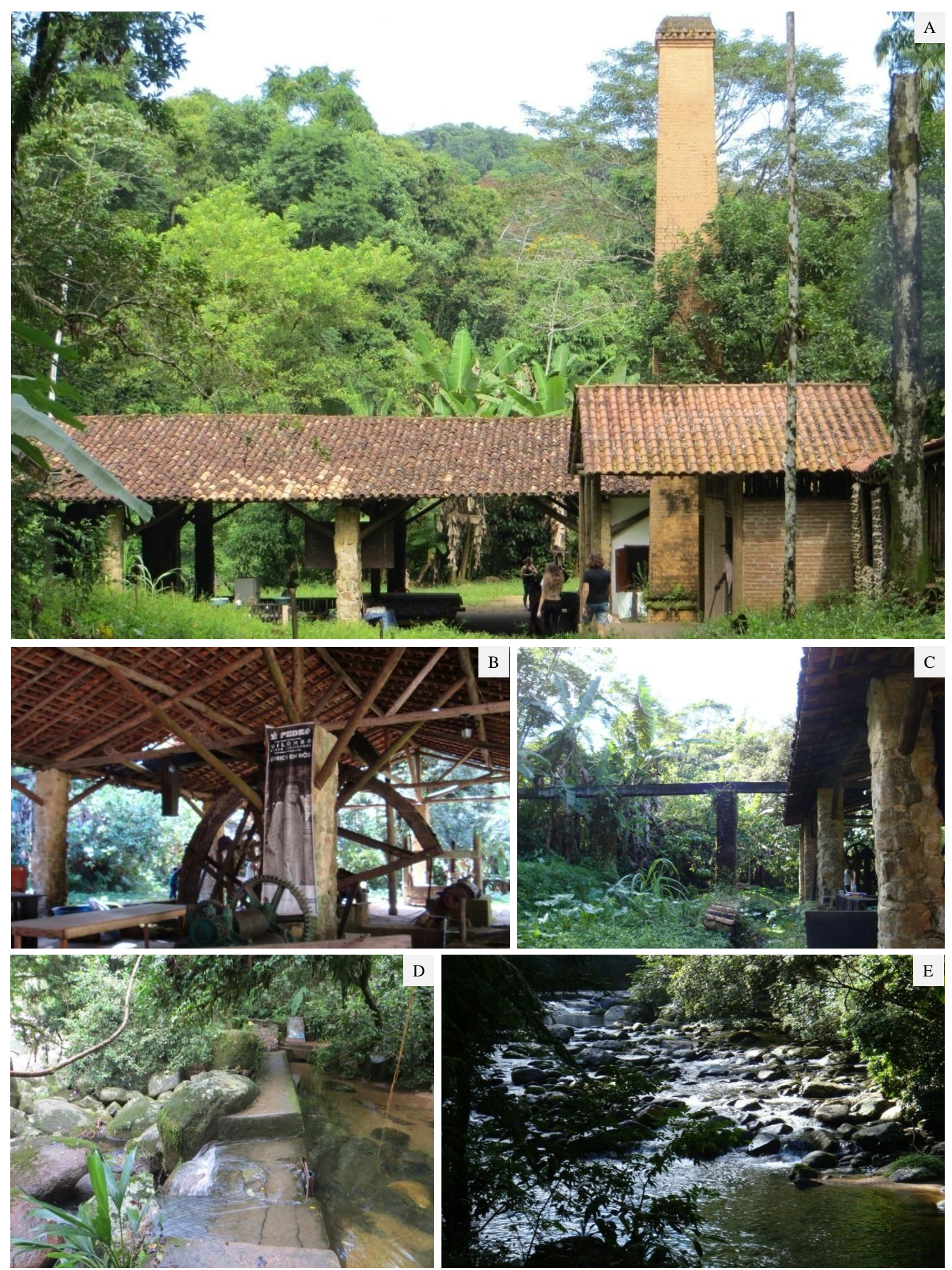

Figura 26 - Casa da Farinha no Sertão da Fazenda. A) engenho de álcool e açúcar do século XVIII; B) roda d'água e outras ferramentas do engenho, com destaque para o poster com a figura do Seu Zé Pedro, líder comunitário e morador antigo que recebe grupos para rodas de conversa; C) sistema de canalização do rio Fazenda; D) pequena barragem par a canalização da água do rio Fazenda; D) vista do rio Fazenda à juzante da barragem (Fotos: Eliana Mazzucato). 
Mas as marcas também estão registradas no imaginário, nas histórias de luta dos antepassados e dos conflitos atuais, nas perdas territoriais que condicionaram mudanças em seus modos de vida.

"por trás dessa natureza, dessa coisa linda, dessa paisagem, dessa mata maravilhosa, tem um pouco de sofrimento também né, então tem o sofrimento" (M5).

A relação do morador tradicional com o lugar revela uma interdependência entre a disponibilidade de recursos e seus modos de vida. Nesse caso, destaca-se a tradição alimentar, baseada em produtos típicos mediante as características do solo e do relevo local. Nota-se nas falas dos moradores tradicionais apresentadas no diagnóstico socioambiental a riqueza da agricultura local, onde áreas de vale e de encosta eram utilizadas para o plantio de produtos típicos (mandioca, inhame, cará, batata doce, taioba, milho, abóbora, banana, cana de açúcar, além da criação de animais de pequeno porte, como galinha e porco).

Tais produtos compunham a dieta alimentar do caiçara e do quilombola, e nessa região também se usava muitos recursos da floresta para a medicina tradicional, num local onde a geodiversidade também serviu de base para a diversidade de espécies de plantas benéficas para a saúde. Nesse trecho, a moradora do Sertão da Fazenda revela que atualmente o plantio é realizado no quintal das casas (Figura 27), como agricultura de subsistência:

"todo mundo tem suas rocinhas assim, todas as pessoas tem no fundo do quintal, a sua banana, a sua cana, seu tempero, principalmente ervas medicinais. [...] todos tem sua erva medicinal no quintal, porque isso é raiz $\underline{n e ́, ~ i s s o ~ j a ́ ~ v e m ~ d e ~ a n t e s ~ n e ́ " ~(M 7, ~ g r i f o ~ n o s s o) . ~}$
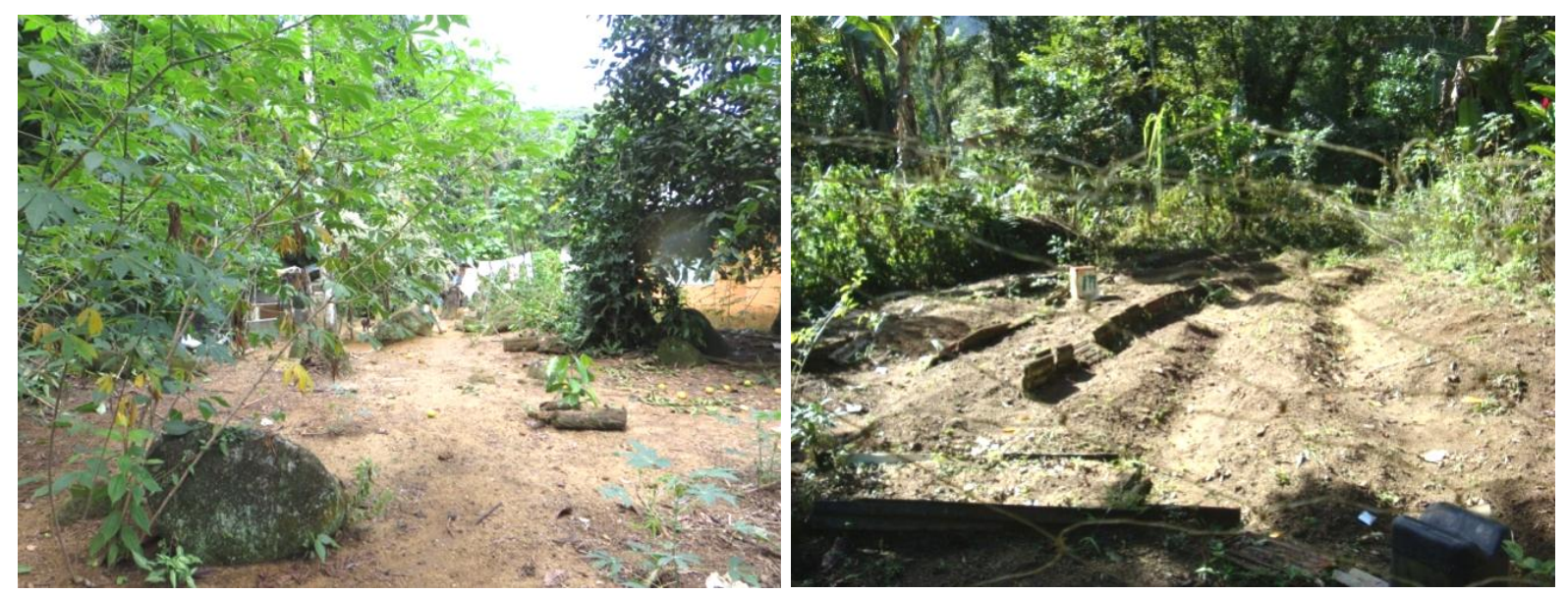

Figura 27 - Hortas nos quintais das residências do Sertão da Fazenda, cultivando algumas hortaliças, mandioca, frutas, além de apresentar criação de galinha (Fotos: Eliana Mazzucato). 
Esses indicadores revelam os usos e valores da geodiversidade e o estabelecimento de um saber popular e tradicional para com esses usos, mesmo que essa não seja compreendida de forma explícita. Nesse sentido, há um saber popular importante a respeito da dinâmica física do ambiente, sobre seus materiais e processos. O saber popular é revelado no trecho abaixo em que a entrevistada indica um respeito e reconhecimento em preocupar-se com o uso dos recursos de forma planejada, seguindo manejo específico para garantir a manutenção de determinado recurso.

\begin{abstract}
Eu costumo dizer que os antigos, os mais velhos, pessoas que muitos já morreram, outros estão aí, que eram os contadores de história, que era as pessoas que é manejava, trabalhava com as plantas medicinais [...] eles tinham todo um conhecimento, eles sabiam fazer o manejo de tudo, eles caçavam, mas não na época que a caça tava com cria, eles sabiam a época de pescar também, eles sabiam como manejar uma moita de cipó, então eles sabia qual cipó que ele tinham que tira pra não matá a moita, eles sabiam como manejar a palha, tudo, tudo era com manejo, tudo, então eles tinha essa sabedoria, e por isso que nada a gente destruía, então a gente preservava" (M5, grifo nosso).
\end{abstract}

Esse saber popular também é revelado nos conhecimentos para a atividade da pesca, em que os tradicionais conhecem os locais de maior disponibilidade de peixes, condicionados por fatores relacionados à dinâmica costeira, correntes marinhas, desenho da costa, direção dos ventos. Além disso, as embarcações típicas dessa região são confeccionadas a partir de uma técnica tradicional que para sua fabricação utiliza apenas um tronco de árvore nativa da região, que pode ser observada na Figura 28. Um morador caiçara entrevistado no Cambury relatou que as principais espécies utilizadas para a construção da canoa caiçara na região são: cedro, timbuíba, ingá, loro, guapuruvu, guapeva, canela, figueira, aricurana, dentre outras. 


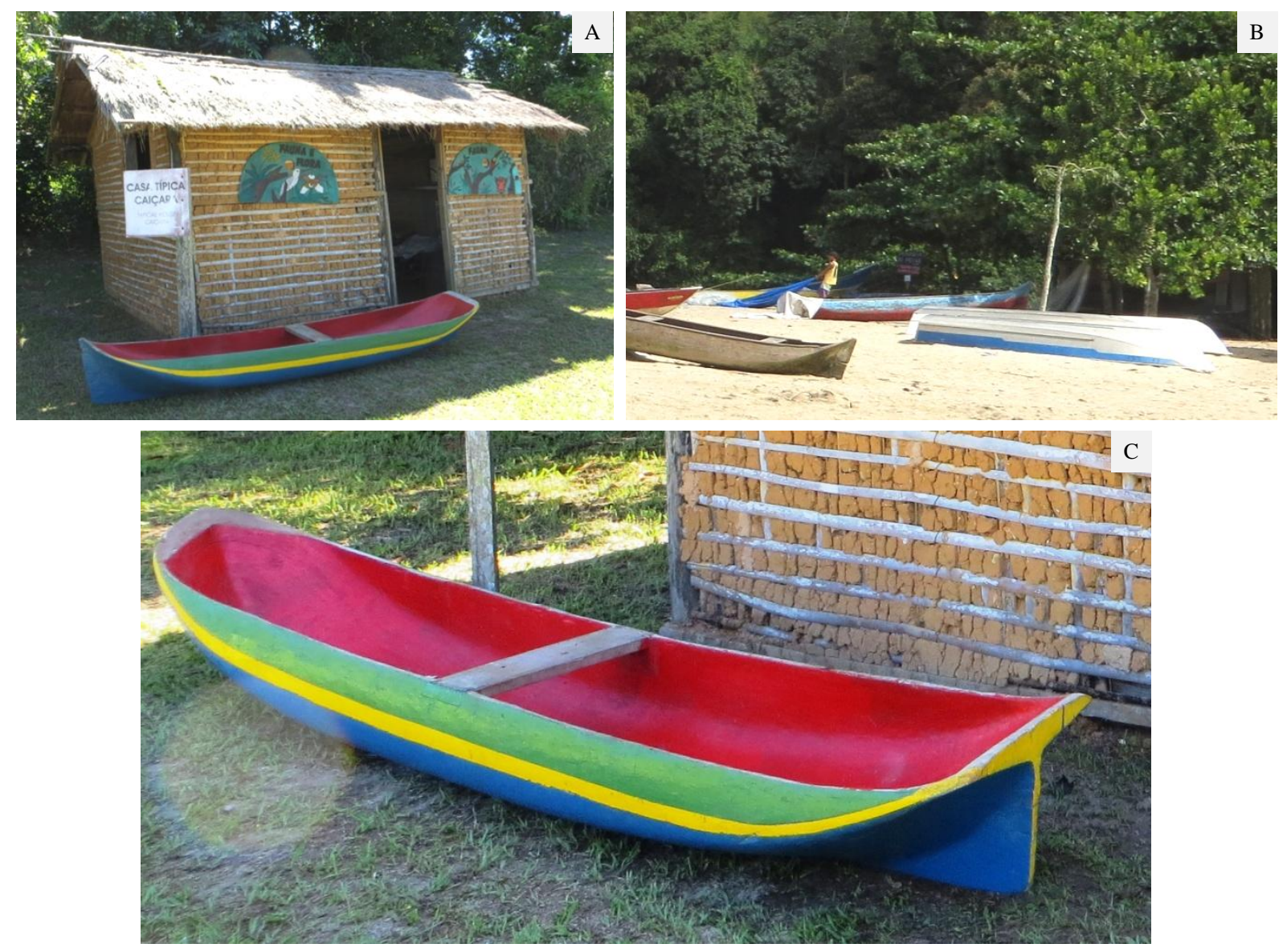

Figura 28 - Imagens de canoas utilizadas na região, construídas a partir de técnicas tradicionais de um tronco só, e outras canoas e embarcações modernas. A) representação casa de pau a pique e canoa caiçara no centro de visitantes do Parque Estadual Serra do Mar, núcleo Picinguaba; B) canoas caiçaras tradicionais e embarcações modernas na praia do Cambury. C) detalhe da canoa apresentada no centro de visitantes do núcleo Picinguaba (Fotos: Eliana Mazzucato).

Além disso, os caiçaras da região que possuem autorização para a prática da pesca utilizam a técnica do cerco flutuante (Figura 29) considerada técnica tradicional dos pescadores artesanais da região. O cerco flutuante possui a singularidade de manter indivíduos capturados vivos, assim, durante a despesca pode-se selecionar os pescados de maior valor comercial ou de maior tamanho, ou ainda, apenas as espécies permitidas, liberando assim as outras espécies (BLANK et al., 2009). 


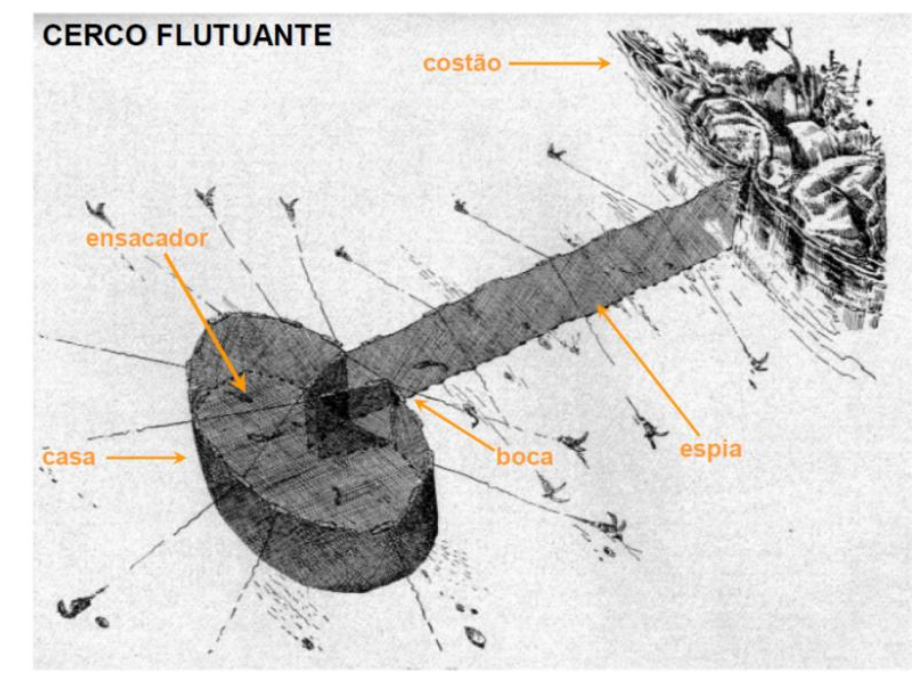

Figura 29 - Modelo esquemático do cerco flutuante. Detalhe para as indicações do "costão rochoso", local onde geralmente é armado o cerco; a "espia", formada por uma malha que barra a passagem dos peixes e os orienta para entrarem na estrutura através da "boca"; a "casa" se assenta no fundo por âncoras e é sustentada por flutuantes, como boias ou canos de PVC, tem a função de armazenar os peixes; o "ensacador", na lateral da casa, possui malhas finas e mais resistentes para sustentar o peso durante a despesca" (VIEIRA et al. 1945 apud BLANK et al., 2009).

Segundo relatos de caiçaras do Cambury, há uma rede de cerco flutuante armada no costão rochoso da praia (Figura 30). A retirada dos pescados é feita de duas a três vezes por dias, e, nesses momentos é possível retirar as tartarugas que tenham sido capturadas, atuando, portanto em conjunto com o Projeto Tamar.

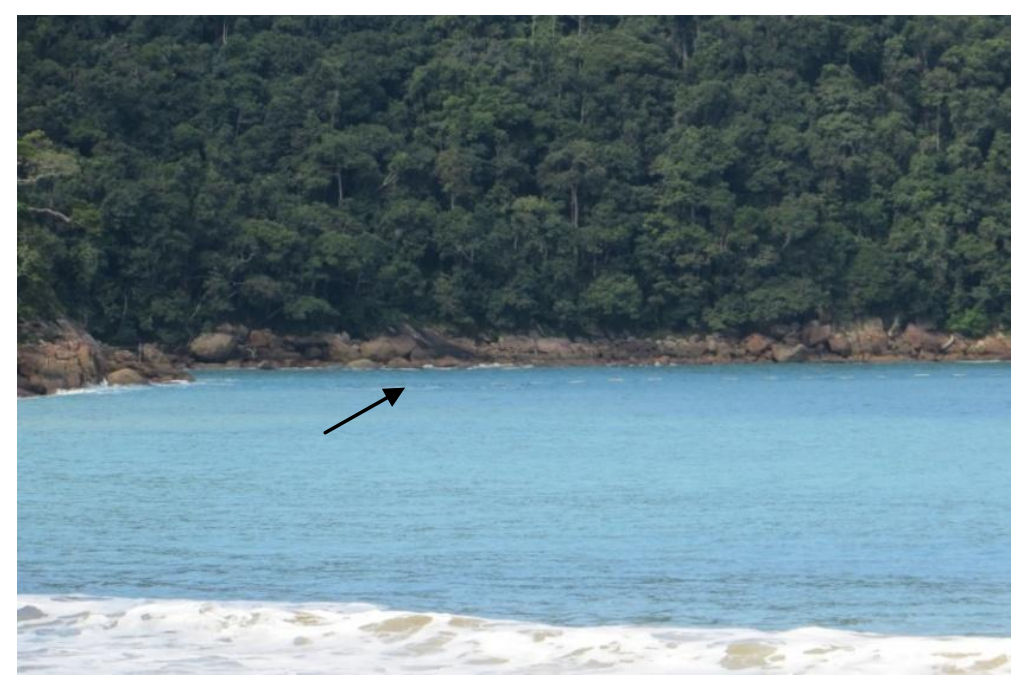

Figura 30 - Detalhe das boias flutuantes da rede de cerco flutuante próximo ao costão rochoso da Praia do Cambury, Ubatuba (SP) (Foto: Eliana Mazzucato).

O sentimento de pertencimento também possui relação com a diversidade de paisagens e recursos, como observados nas Figuras 31 e 32, como solo fértil; diversidade de ambientes de relevo acidentado, vales fluviais e planícies litorâneas; clima tropical de altitude, 
com influência da Serra do Mar na incidência de chuvas em todo o ano; disponibilidade de materiais para a construção de casas de pau-a-pique (solo argiloso), construções que utilizam rochas locais (granitos e gnaisses, principalmente), como escadas, fundação de casas, etc.
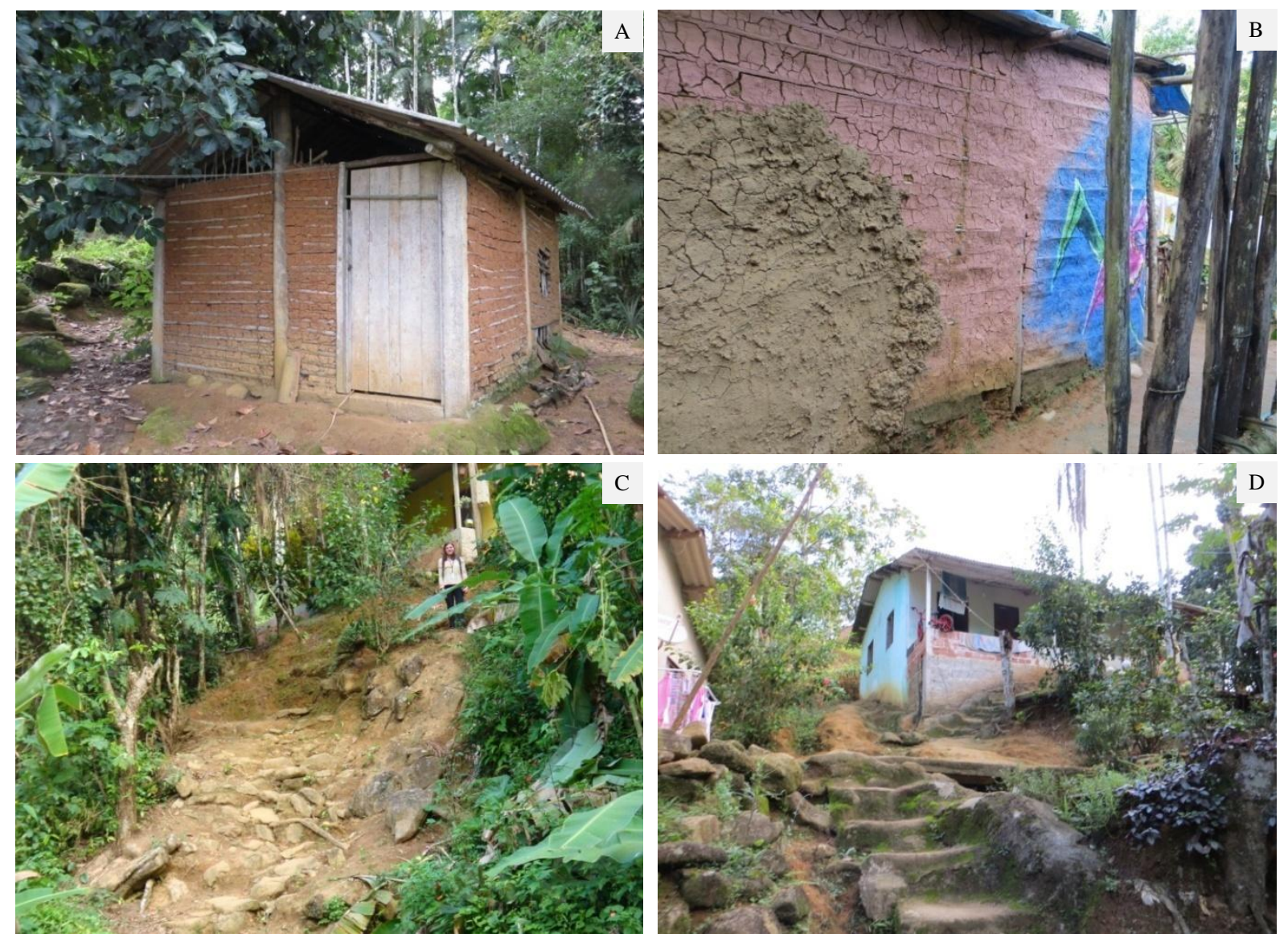

Figura 31 - A) casa tradicional de pau a pique no Sertão da Fazenda; B) casa tradicional de pau a pique no Cambury; C) relevo acidentado no Cambury, e utilização blocos rochosos para assentamento do terreno; D) construção de escadas de acesso no afloramento (Fotos: Eliana Mazzucato).
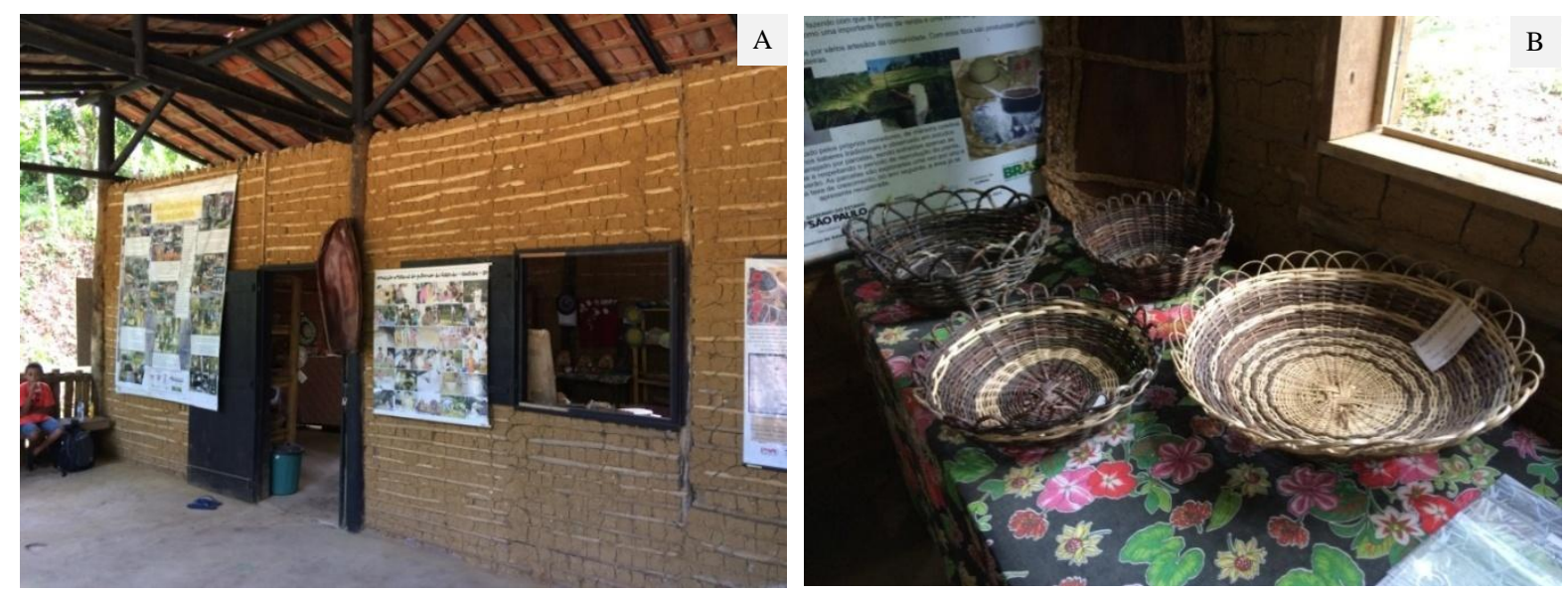

Figura 32 - A) loja de artesanato tradicional no Sertão da Fazenda; B) artesanato tradicional do Sertão da Fazenda (Fotos: Denise de La Corte Bacci). 
Também existem associações com os aspectos da geodiversidade que estão presentes nos monumentos históricos dos municípios, como os exemplos identificados em Ubatuba (Figura 33).

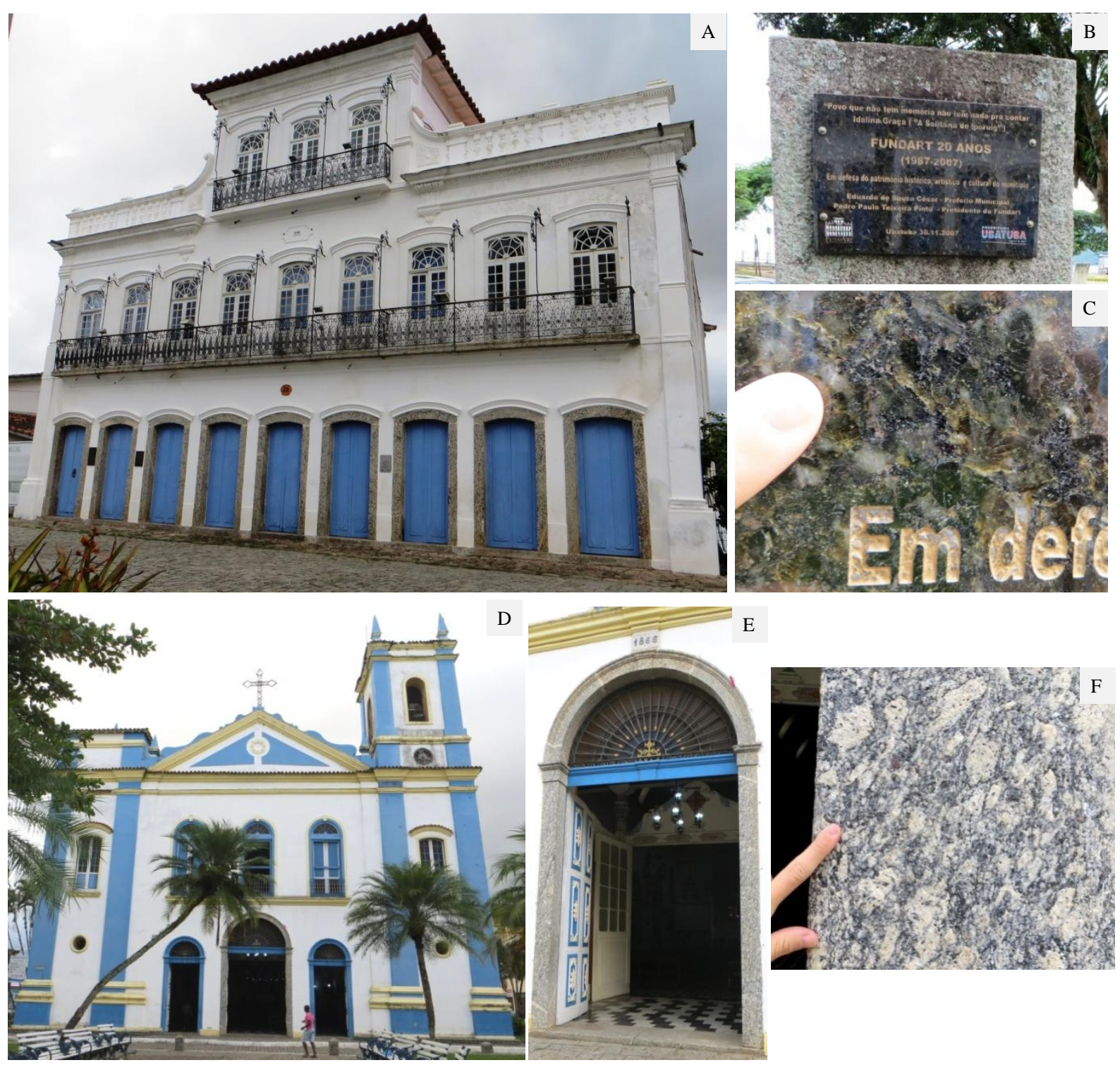

Figura 33 - Elementos da geodiversidade presentes na arquitetura de monumentos históricos em Ubatuba (SP). A) Casarão do Porto, apresentado rochas nos batentes das portas; B) placa em frente ao Casarão do Porto, em comemoração aos 20 anos da Fundart (1987 - 2007); C) detalhe da constituição da placa de "Granito Verde Ubatuba"; D) Igreja exaltação de Santa Cruz em Ubatuba; E) detalhe das portas revestidas de rochas G) detalhe da gnaisse no batente da porta (Fotos: Eliana Mazzucato). 
No trecho a seguir, uma moradora revela a relação da comunidade com o rio, interpretando o lugar no seu conjunto físico e imagético, como lugar que fornece água para diferentes tipos de atividade, e um lugar de vivência, porém sujeito a transformações recentes de modernização e mudanças culturais da comunidade:

\begin{abstract}
"A gente tomava banho no rio, e por isso que as casas eram feitas mais na beira do rio pra ter, é, pra ser, pra ter facilidade né, porque a roupa era lavada no rio, e, a gente pegava água...e a água pra gente tomar, a gente então era tirado de um espaço onde ninguém mexia, onde não tinha ninguém, onde não tinha nenhum tipo de atividade, que daí era água limpa né, então, a gente fazia todas essas coisas na água que descia. [...] aî hoje ninguém vai mais pra cachoeira lavar roupa, agora as comadres da vida né... ué, você vai lavar a roupa como? ah eu vou lavar na quarta, então também vou lavar a minha na quarta pra gente se juntar, lá nas pedra né, e aí, lá elas eram feliz, porque elas conversavam, cantavam lá, lavando a roupinha delas, hoje todo mundo tem máquina, tanquinho, hoje ninguém mais vai pra beira do rio, hoje tá tudo mais moderno, água encanada, que é uma coisa boa também, porque era muito sofrido né, era sofrido, era uma coisa assim” (M5).
\end{abstract}

Pode-se observar que para além do uso material desses elementos da geodiversidade, existe também uma afeição, uma ligação entre esses materiais e processos com a história e o modo de vida dessas comunidades. Nesse ponto podemos destacar que para a percepção local, os aspectos da geodiversidade contribuem com o sentimento de pertencimento, de constituição e manutenção de sua cultura tradicional, e onde se vivencia atualmente as transformações socioambientais do lugar. Exemplo disso é que no passado, as casas eram construídas próximas ao rio, facilitando o uso e o desenvolvimento de atividades básicas que dependem da água. Assim o conhecimento acerca da dinâmica do rio era imprescindível, ordenando o desenvolvimento de atividades ao longo de seu curso, com captação de água na montante do rio, garantindo uma água limpa para o consumo, e, na jusante o uso da água através de atividades que causavam maiores impactos, como se banhar e lavar roupa. Nesse espaço havia também uma relação sentimental, era o lugar onde as mulheres se reuniam para lavar as roupas e construir ali um ambiente de troca em comunidade.

A percepção dos processos relacionados à geodiversidade pelos moradores incide nas recentes transformações do ambiente e dos impactos decorrentes da construção da BR - 101 (Rodovia Rio-Santos). Para os moradores, com a chegada da rodovia, o curso d'água teve sua dinâmica modificada, causando o assoreamento dos rios e alagamento de suas áreas de plantio, denunciando a negligência nos procedimentos de implantação da rodovia em relação aos impactos socioambientais decorrentes: 


\begin{abstract}
"quando saiu a BR, essa Rio-Santos, o que aconteceu com as comunidades, eles fizeram a estrada e não pensaram no futuro das cachoeira, porque o que aconteceu, assoreo os rio, hoje a maior parte das terra baixa tá tudo alagada, entendeu... então se você for na fazenda, você olha pro lado de cima, que aquilo virou um lago, então aonde tinha os cafezais dos imigrante italiano, do pessoal antigo, hoje é mata enorme porque tá tudo debaixo da água. Quando chove, aquilo alaga tudo. [...] com a BR ele represou os rio, os braço de rio, aí não tem pra onde a água saí então a água se expande pelo lugar mais baixo... então a comunidade, ela ficou num espaço aonde era mais alto, porque os mais baixo alagaram tudo. E foi a BR, entendeu, então a BR, veio o progresso? veio o progresso, mas pras comunidade atrasou muito, porque aonde tinha as grande roça não tem mais, uma porque o parque já não deixava mais, e duas que a BR soreou os rio, alagou tudo" (M7).
\end{abstract}

A percepção dos processos na perspectiva da geodiversidade revela o saber popular em relação ao ambiente físico, incluindo aspectos sobre a dinâmica dos rios e da paisagem, em transformações recentes advindas das alterações antrópicas à medida que essas transformações são sentidas, de forma sensorial (imagens, sensações e memórias) e prática (alagamento das áreas de moradia e de plantio). O impacto da construção da BR sobre a dinâmica dos rios é percebido pelos moradores, que também foram atingidos por esses impactos. Aqui se observa que os moradores estão apropriados do conhecimento acerca da dinâmica física do rio, com alguns conceitos específicos das Geociências, quando utiliza termos como assoreamento, alagamento, represamento, braço de rio, direção do curso, e, sua capacidade em apontar os impactos socioambientais decorrentes dessa obra, como mudança no curso do rio represando novas áreas, redução dos espaços produtivos em zonas de planície.

Observou-se que para esses residentes tradicionais, há pouca separação entre natureza biótica e abiótica, bem como a natureza construída.

"[...] eu acho que eles vive muito bem o home e a natureza, aqui, vive muito bem" (M7).

"[...] os quilombo eles tem isso da natureza, de preservar a própria natureza. Então a natureza...ela ((a comunidade)) não tem que mexer naquilo ((na natureza))... que, eu acho que todo mundo tem o direito de viver bem, né?, mas bem com a natureza, e dá pra viver, dá pra viver tranquilo" (M7).

"eles ((administração do parque)) entenderam que aqui é o nosso espaço ((comunidades tradicionais $)$ ), então vai ter que trabalhar mata com gente, não tem como tirar todo mundo e deixar só a mata" (M5).

"acho que dá pra ter as duas coisas dentro dum parque, o parque e a comunidade né, uma coisa compensa a outra né” (M14). 
Percebe-se que a comunidade não faz separação entre a dinâmica antrópica e natural, com implicações no comportamento que mantêm em relação ao lugar, compreendendo a necessidade de conservação e afirmando uma conduta condizente com essa percepção. Entretanto, há uma diferenciação entre o uso estabelecido pelos tradicionais, e outros usos, que exploram os recursos naturais indistintamente, geralmente relacionados aos grandes empresários do setor turístico e imobiliário, sendo que em relação a esse tipo de uso, a dualidade torna-se maior, à medida que fica claro que o interesse dos empresários se pauta na exploração comercial do território, e como esse interesse guia sua conduta no sentido de devastar a paisagem natural.

As percepções sobre o lugar também se revelam nos relatos que inserem sensações e sentimentos, relacionados à paisagem preservada vivenciada por eles e pelas suas comunidades. Assim, sua relação com o lugar se dá muitas vezes pelos benefícios provenientes dessa paisagem preservada, e da cultura construída pela comunidade.

"a porque onde a gente mora assim é um lugar tranquilo, não tem violência né, é bem sossegado, tem natureza, não tem poluição né, então assim, bem dizer assim né, quase todo mundo é uma família só. Então assim né, eu nunca sairia daqui” (M1, grifo nosso).

[...] meus bisavós, meus avós, meu pai, é... eles nasceram aqui né, e aí meu pai foi pra Santos... e ai foram morrendo os tronco, foram morrendo... e aí meu tio ficou aqui na fazenda na Picinguaba, os meus outros tios né, e aí a gente vinha passear pra cá, meu pai vinha prá cá, então noi nunca deixamo de vim né. e depois eu vim de vez (risos)" (M7, grifo nosso).

"Porque todo mundo que tá aqui, ninguém quer sair daqui, principalmente as pessoas que são nativa, que nem eu não consigo morar na cidade, se me tirar... tirar nóis daqui falar assim - não, não, você vai morar agora. como que é, "CDHU - que fala, que os cara constrói aquelas casa que você [...] nem respira um ar puro, porque você tem, você olha aqui, cê tem uma parede, cê olha ali cê tem uma parede, cê tá preso [...] você não tem nem um quintal, cê não tá acostumado com aquilo ali, cê tá acostumado nisso aqui... ar, ir lá no rio e nadar, [...] andar nas trilha, andar por aí tudo, agora bota eu lá dentro, cê vai morrer. Cê vai ficar preso, mesma coisa que cê tá na cadeia" (M6, grifo nosso).

Eu sei porque meu pai [...], meu avô [...] eles viviam na natureza, eles vinham daqui da roça, então eles eram os grandes doutores, e isso, não se perdeu ainda porque ele foi passando pra gente, né, pras criança que foro, nós fomo crescendo, tanto que hoje ninguém quase da minha família vive mais no mato, eles mora na cidade assim, mas essas cidade assim mais pra cá, por que? por causa do costume, né, tem que ter um mato, tem que ter um, não dá pa você viver dentro de um apartamento, por que? porque não consegue isso, porque já é da natureza da própria pessoa, né, tá acostumado $n e ́$, se você nasceu na grande cidade, você se acostuma, vendo aqueles prédio, vendo aqueles negócio, mas se você nasceu no meio do mato, no 
meio do mato entre aspas dizer né, mas você tem um convívio maior com a natureza, você respira aquilo, você acaba cuidando daquilo, [...] então na época dos escravos isso aqui era, como eu posso dizer, era o caminho deles né, é, e meu avô, meus bisavô, eles tinha esse caminho, e eles tinham essa ((relação)) ca natureza. Então... e a gente acaba pegando isso pra gente porque é gostoso né, porque se fosse ruim a gente não ficava” (M7, grifo nosso).

Retomando os aspectos relacionados ao processo perceptivo, serão indicadas algumas convergências observadas nos discursos que colaboram com a construção da percepção ambiental dessas comunidades tradicionais, e sua relação com a geodiversidade.

a) No campo das sensações, fica evidente que salta aos sentidos desses indivíduos aspectos da geodiversidade e da natureza preservada, além de inserir aspectos culturais de sua comunidade, que contribuem com a construção da sua identidade com o lugar:

- Aspectos visuais: "tem natureza", "montanha", "pedra”, "costa”, "vegetação", “o mato”, “jundu da praia”, “a juçara”, “água, muita água”, “cachoeira”, “a trilha do rio”, “a nossa serra do mar ela tá bem protegida”, "rocinhas assim, todas as pessoas tem no fundo do quintal, a sua banana, a sua cana, seu tempero, principalmente ervas medicinais", "casas humilde", "tem um postinho, tem luz, tem o telecentro";

- Aspectos olfativos: "não tem poluição", "espaço onde você respira”, "O ar puro".

b) Em relação à motivação, emergem fatores relacionados aos familiares e descendentes, que se estabeleceram no território e criaram os modos de vida, sendo que desenvolveram assim profundo conhecimento sobre o lugar, um saber voltado para o uso e manejo dos recursos. Além disso, a relação estabelecida com o lugar é direcionada pela produtividade da terra, a possibilidade de cultivar a terra, de estabelecer suas residências, de se deslocarem por esse território, de terem a fartura do mar. Ou seja, uma motivação de sobrevivência ganha destaque nesse território, além de todo o significado revelado pela memória, pelo sentimento de pertencimento, e pelo papel que possuem em dar continuidade a essa cultura:

- Interesses: "quase todo mundo é uma família só”, "eu gosto de cria a galinha no quintal”, “isso aqui é tudo pra ele”; 
- Necessidades: "onde você tira seu, hoje a gente não tira, a gente planta”, "a gente vivia da roça, o arroz, o feijão”, "tem o que comer, ele quer viver, ele precisa disso”, “não podemos viver sem ela ((natureza))”, "a gente sabe que precisa dela”, "tudo que está em nossa volta nós precisamos muito de ter uma água limpa, nós precisamos de cuidar da natureza".

c) No processo cognitivo, emergem relatos sobre os saberes dos tradicionais, com aspectos referentes ao campo da memória, da organização das informações, e das imagens, ou seja, apresentam aspectos de como eles interpretam e dão significado aos elementos/ informações presentes nesse lugar:

- Apropriação do lugar: "aqui é tudo meu lugar”, "nós somo quilombola, nós somo isso, nós vivemo assim”, "nosso espaço", "nosso território”, "nossa cultura, nosso modo de vida”, "nossa história”;

- Interpretações sobre o lugar: "aqui você vê que é diferenciado porque não é tocado", "o melhor patrimônio que a gente tem é a natureza, é viver nisso que a gente vive”, "tem que ter um mato”, "eu não me vejo morando na cidade”;

- Saberes tradicionais: "eles tem esse dom com a natureza, por isso que não tá detonado", "tem a mente diferenciada das pessoas da cidade”, "já é da natureza da própria pessoa”, "tá acostumado né”, "um convívio maior com a natureza”, "você respira aquilo", "foi sentido na pele pelos meus bisavós”, "você acaba guardando aquilo”, "já é costume”, “isso é raiz né”, "eles sabiam fazer o manejo de tudo”, "eles sabiam a época de pescar", "sabiam como manejar", "eles tinha essa sabedoria”, "toda essa geração ela vem, adquirindo conhecimento dos mais velhos e seguindo sempre aquilo que eles faziam”, "uma coisa dos nossos antepassados, guardar a semente, saber a lua”, "eles sabe trabalhar com a natureza”, "nóis comia o que plantava então hoje cê tem que dar valor, dar valor", "porque você tem que pensar no futuro, e as criança?".

d) No campo da avaliação se expressam diversos valores ao ambiente vivenciado, que no geral são positivos, associados ao seu modo de vida e a manutenção da área preservada. Em contrapartida esse sistema de julgamentos irá orientar os relatos sobre regiões que já visitaram, como grandes centros urbanos ou áreas degradadas: 
- "lugar tranquilo”, "bem sossegado”, "não tem violência”, "ando por isso aí tudo, não tenho medo de nada", "eu acho muito bonito", "isso é tudo de bom”, "é gostoso né, porque se fosse ruim a gente não ficava”, "era muito bonito”, "nós gostamo disso", "ele gosta da natureza", "ele gosta é de fazer as trilha”, "ele gosta de surfar", "mata atlântica exuberante ai linda, maravilhosa”, "água do rio limpíssima”, "era muito sofrido ((no passado))”;

e) Em relação à Conduta permanece um olhar de valorização do ambiente e de forte enraizamento, configurando em ações positivas para com o lugar:

- "não pode desmatá”, "eu nunca sairia daqui”, "a gente que conservar isso mesmo, não quer que mude", "você acaba cuidando daquilo", "se tirar ele daqui, com certeza ele vai, não vai se adaptar”, "nós não somos destruidores”, "nada a gente destruía”.

A construção dessa percepção também pôde ser apreendida a partir das referências a outros lugares visitados, que associam como área desmatada ou grandes centros urbanos:

\section{a) Sensações:}

- Visuais: "não tem um verde perto de você", "aonde era mangue não tem mais", "lá é só pasto, boi”, “casa”, “barraco”, "tem um pouquinho de mata atlântica”, "lá é mais aquele pinhão”, "não tinha uma planta”, "cê só via cimento na sua frente, não tinha mais nada nada";

- Auditivos: "barulho";

- Olfativo: "muita poluição”, "não tem como respirar".

\section{b) Cognição:}

- Memória: "não conhecia nada lá", "aonde a gente tomava banho, aonde a gente catava o caranguejo, [...] não tem mais nada”, "eu cheguei lá me sufocou”, “detonaro com aquele negócio tudo”, “como que vive aqui? [...] eu me senti um preso ali dentro".

\section{c) Avaliação}


- "é triste”, "não tem mais graça”, "detonaro tudo”, “outro clima”, "clima era diferente".

\section{d) Conduta}

- “eu chorava”, "não me acostumei com São Paulo”, “eu não tenho mais vontade de ir", "eu quero voltar pra cá, e ficar no meu cantinho”, "eu levo pra eles isso de plantar".

Em síntese, a partir da reflexão sobre o lugar da geodiversidade na percepção do ambiente pelos moradores locais, esta se apresenta em diversas faces, entretanto o conceito de geodiversidade não foi relevante para a construção dessa análise. Dessa forma, as percepções geoambientais identificadas se relacionam com os valores associados aos elementos da geodiversidade como fonte de recursos e base para a sobrevivência e, o valor da geodiversidade como contribuição para o estabelecimento de vínculos com o lugar, relacionada, portanto ao valor cultural.

Geodiversidade como base de sobrevivência: aquela em que a geodiversidade se relaciona com o sustento/base da sobrevivência desses moradores. É expressa principalmente através do uso dos elementos geológicos pelas comunidades tradicionais no contexto socioambiental local, se relacionando, portanto ao valor funcional da geodiversidade. Esses elementos da geodiversidade são:

- Solo: substrato para o desenvolvimento da agricultura de subsistência, possibilitando o estabelecimento de roças de mandioca, café, arroz, feijão, cana de açúcar, juçara, dentre outros. Além disso, localmente o solo argiloso também era e ainda é utilizado para as construções das casas de pau-a-pique;

- Rochas: as rochas também eram muito utilizadas para a fundação das casas, revestimento e outros. É possível observar a presença dessas rochas nas casas das comunidades tradicionais e também nos monumentos do centro histórico, com destaque para o Charnockito Ubatuba;

- Relevo: o relevo está relacionado ao estabelecimento dos núcleos comunitários, nas planícies costeiras e nas áreas dos sertões, no sopé da Serra do Mar; 
- Hidrologia - o uso dos recursos hídricos marca essas comunidades, sendo os rios locais a principal fonte de água potável no passado, água que também era utilizada para o cozimento de alimentos, banho, lavagem de roupa, e outros.

Geodiversidade na construção do vínculo com o lugar que se relaciona com a relação construída com o ambiente no campo imagético, sensorial, compondo elementos de referência para a relação de pertencimento e identificação com o lugar. A geodiversidade como fator da construção do vínculo com o lugar é observada nos aspectos que revelam afetividade e familiaridade a partir da relação do individuo e da comunidade com o ambiente, apresentando relação com o valor cultural da geodiversidade.

Nesse sentido somam-se as dimensões visíveis da geodiversidade, condicionando diversidade de paisagens na região (Serra do Mar, Planície Costeira, costões rochosos, ilhas), as memórias e sensações positivas relacionadas com os aspectos da geodiversidade que fazem desse ambiente um lugar único para esses moradores, locais onde aprenderam a cultura de seus antepassados, nadavam nos rios da comunidade, caminhavam em meio às trilhas, tinham o rio como local de convivência durante a lavagem das roupas, as experiências trocadas nas atividades de pesca desenvolvidas nas praias da região. Estão assim presentes a satisfação e orgulho em viver numa área preservada, com a interação da geodiversidade e biodiversidade em todos os aspectos que compõem a relação do indivíduo e da comunidade com o lugar.

\subsubsection{O olhar do Gestor}

A perspectiva da gestão sobre os elementos da geodiversidade centrou-se na própria identificação, por parte desses atores locais, de o que é a geodiversidade e o patrimônio geológico. Mas, devido ao papel de gestor do território, apreendeu-se também um olhar mais estratégico, considerando a relevância da geodiversidade do ponto de vista técnico, no âmbito da gestão do território, e, no âmbito do uso público, valorizando a geodiversidade nos programas de educação ambiental e de visitação dos núcleos.

Quanto à percepção da geodiversidade, observa-se que os gestores já estão mais familiarizados com o conceito, o que pode ser atribuído ao trabalho de divulgação promovido pelo NAP GeoHereditas, em que esses núcleos sempre receberam e articularam as ações propostas. Portanto, o contato que esses atores locais possuem com esse campo de pesquisas é de longo prazo, e permitiu a compreensão das terminologias, além de estabelecer relações com a experiência e vivência desses gestores no lugar. 
A identificação do patrimônio geológico por esses atores locais está relacionada aos pontos extremos da Serra do Mar (Figura 34), ou seja, os cumes e picos que marcam a paisagem da região (exemplificando com o pico do corcovado e pico do cuscuzeiro), e os paredões rochosos observados nas encostas.
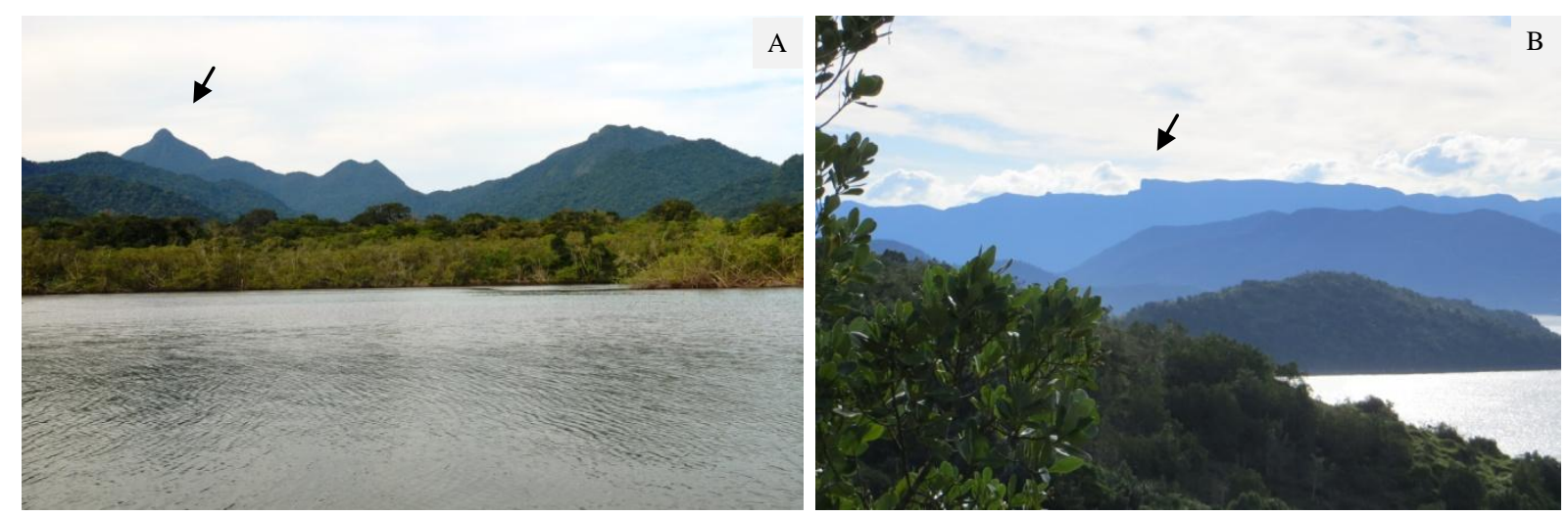

Figura 34 - Formas de relevo destacadas na Serra do Mar em Ubatuba. A) Morro do Cuscuzeiro (Foto: Maria da Gloria Motta Garcia; B) Morro do Corcovado (Foto: Eliana Mazzucato).

Nesse sentido, a relevância da geodiversidade presente nas encostas da Serra do Mar foi apresentada do ponto de vista paisagístico e cênico, porém, também foi reconhecida a relevância da Serra para a própria conservação da Mata Atlântica, uma vez que a Zona Intangível $^{15}$ dos núcleos corresponde em grande parte às Escarpas da Serra do Mar, que compõem uma barreira natural às ameaças antrópicas da Mata Atlântica, impondo condições de difícil acesso e de ocupação.

Além disso, atribui-se a relevância da paisagem litorânea, considerando também os matacões e costões rochosos das enseadas e da diversidade hídrica com os cursos d'água, os grandes rios e os materiais rochosos presentes nesses rios.

Quanto à visão estratégica desses atores, os relatos apontaram considerações que destacam a relevância da geodiversidade para a gestão do território e para a inserção dessa dimensão no programa de uso público da unidade.

A perspectiva técnica está relacionada aos aspectos de planejamento do território, ou seja, a necessidade de compreender e mapear os aspectos da geodiversidade para orientar a gestão do território. Considerando os mapeamentos de área de risco, estudos de impacto ambiental e licenciamentos, estabilização de encostas em áreas de rodovias, etc. Dessa forma, reconhecem que a geodiversidade precisa ser observada nos relatórios técnicos, na aprovação

\footnotetext{
${ }^{15}$ A Zona Intangível é aquela que possui pouco ou nenhum grau de intervenção, ou seja, a natureza permanece mais próxima de seu estado primitivo. Essa zona tem como objetivo principal a proteção integral dos ecossistemas e processos ecológicos (SÃO PAULO, 2006).
} 
de instalação de grandes empreendimentos, no uso e ocupação do território, além de ser necessária na delimitação do zoneamento do parque.

Em relação às propostas de inserção da geodiversidade no Programa de Uso Público, observa-se o sentido da geodiversidade nos programas de educação ambiental, considerando uma perspectiva interdisciplinar, além de proporcionar uma nova visão a partir da visitação na unidade.

\subsubsection{O olhar dos monitores, professores e funcionários da ONG}

A construção da percepção ambiental com ênfase na geodiversidade a partir desses atores locais se deu a partir dos questionários, portanto, foram organizados de acordo com as questões formuladas nos seguintes eixos temáticos: conservação da natureza, relação com o lugar, e, ênfase na geodiversidade.

\subsubsection{Conservação da natureza}

A apreensão sobre a Conservação da Natureza foi relacionada com as questões 1, 4 e 5 do questionário (Anexo F). Considerou-se para a interpretação que esses atores locais estão em grande parte envolvidos com a concepção conservacionista, percebem, portanto, a importância da conservação da natureza na região, e toda a inter-relação socioambiental presente no território.

De modo geral as questões utilizadas nesse eixo temático abordam a conceituação de Unidades de Conservação, questionando também se é um privilégio ou não viver em área de influência do parque, refletindo sobre o papel do indivíduo nesse contexto. Dessa forma, também foi explorada a percepção desses atores sobre o alcance do parque em trazer benefício para a região.

\section{Definição de Unidade de Conservação}

A primeira pergunta do questionário refere-se ao entendimento do conceito de Unidade de Conservação já que a questão do estabelecimento de áreas protegidas marca de diversas formas a paisagem e a vida dos habitantes de Ubatuba e de Caraguatatuba, subsidiando as reflexões sobre a perspectiva da conservação da natureza. 
De um modo geral nota-se que as concepções relacionadas à conservação da natureza apreendidas apresentam aspectos relativos à própria delimitação da unidade, ou seja, seu contexto espacial, como ela é criada e regulamentada, os motivos relacionados à sua criação e estabelecimento, e, as responsabilidades para a efetiva conservação da natureza.

Para se referir aos limites que compõem a unidade de conservação, os atores locais utilizaram conceitos como "área”, "espaço”, "território", "organização", "lugar”, "região" ou "ambiente”. No geral esses conceitos denotam limites físicos, apresentando certa neutralidade (área, espaço) ou, valoriza atributos socioambientais (território, lugar, região e ambiente). Também foram identificadas atribuições relativas à gestão e planejamento da unidade como: "organização”, "órgão” ou "instituição". E, apenas um indivíduo identificou a unidade de conservação como uma ação, sendo apresentada como uma "atitude de todos para com a conservação".

O papel do governo estadual e federal na regulamentação e conservação dessas áreas foi destacado em diversos momentos, sendo que também foram atribuídas responsabilidades a outros órgãos ambientais e empresas privadas.

Algumas observações foram feitas em relação aos aspectos a serem conservados, que foram organizados através dos seguintes itens:

- Natureza pouco alterada: "natureza”, “o meio ambiente” e "meio natural”;

- Locais relevantes: "características especiais";

- Locais ameaçados: "área ameaçada”;

- Aspectos do meio biótico: "fauna e flora", "biodiversidade", "mata”, "biomas", "espécies animais e vegetais", "locais de grande relevância biológica”, "animais endêmicos", "pássaros", "ecossistemas" e "processos ecológicos”;

- Aspectos do meio físico: "solo”, “água”, "bacias hidrográficas”, "costões rochosos", "belezas paisagísticas", "recursos naturais" e "geodiversidade”;

- Aspectos socioambientais: "patrimônio cultural”, "patrimônio ambiental”, "patrimônio histórico”, “sociodiversidade”, “patrimônio paisagístico” e “comunidades tradicionais como os caiçaras, quilombolas, índios e povos ribeirinhos".

No sentido da motivação para a conservação de determinadas áreas aparecem aspectos mais naturalistas, em que a ação da conservação centra-se na própria manutenção da 
natureza intocada, para a vida das espécies animais e vegetais que habitam esses locais. Porém, numa perspectiva pragmática, destaca-se o uso dessas áreas para o desenvolvimento de pesquisas, prevendo a sustentabilidade dos recursos para a sobrevivência da humanidade. Além disso, muitas concepções vão ao encontro do aspecto socioambiental, refletindo sobre o uso desse ambiente pelas comunidades do entorno, para o desenvolvimento de atividades de educação ambiental, recreação e lazer.

De um modo geral, as representações sobre Unidades de Conservação remetem à própria legislação e à postura governamental frente às estratégias de conservação, ou seja, uma postura mais restritiva e que reforça a separação do meio social do natural.

\section{$\underline{\text { A opinião sobre o lugar e seu papel diante a conservação da natureza }}$}

$\mathrm{Na}$ quarta questão, foi solicitado que eles apresentassem sua opinião quanto a se sentirem privilegiados ou não em viver ou trabalhar em área de conservação, questionando também suas considerações em relação ao seu papel nesse contexto.

Em todas as respostas os atores locais se consideraram privilegiados por viver ou trabalhar na área e no entorno da UC, assimilando a singularidade desse ambiente num contexto regional e até mesmo global. Assim, os aspectos destacados do lugar, que fazem parte do processo perceptivo foram:

- Aspectos sensoriais:

- Visuais: "verde da mata”, "lindas praias", “recursos naturais”, "fauna e flora”, "ambiente natural" e "bichos";

- Olfativos: "ar puro” e "ar menos poluído”;

- Auditivos: "o som das aves".

- Motivação: "viver natural”, "viver em contato com a natureza”, "contato com a natureza”, "desfrutar dos recursos naturais", "áreas de lazer - praias, rios, trilhas”, "saúde fisica quanto mental” e "o lugar onde gosto de estar";

- Cognição: "patrimônio", "serviços ecossistêmicos", "o ser humano como parte da natureza" e "nascer, crescer e se desenvolver como cidadão ubatubense é um presente da vida";

- Avaliação: "qualidade de vida”, "manter a saúde”, "tranquilidade”, "lugar onde não tem desmatamento", "iluminado”, "paz e esperança”, "equilíbrio de relacionamento entre homem e natureza”, "beleza”, "beleza natural”, "bem-estar e 
saúde física e mental", "riqueza”, "vida saudável e rica em se estar”, "o clima é muito bom”, "lugar tão lindo”, “ambientes preservados", "povo acolhedor” e "bem tão precioso".

- Conduta:

- Ações pontuais e naturalistas: "preservação trilhas", "precisam de cuidados para que não perdemos o ambiente natural", "ensinar os alunos a cuidar do lixo, não permitir o tráfico de animais", "conscientização da preservação", "Eu me sinto importante podendo conservar e principalmente incentivando outros a agirem da mesma maneira", "abordar o meio ambiente em aula" e "participar de projetos relacionados à temática do meio ambiente”;

- Ações socioambientais: "trabalhar com alunos desta região, pois são oriundos em sua maioria, de famílias tradicionais caiçaras. São pessoas que possuem aspectos importantes da cultura local e da história do município", "resgate da nossa cultura tradicional, manutenção da mata atlântica, conscientização ambiental com crianças”, "o meu papel enquanto filho desta terra é poder contribuir de maneira efetiva e continua, os usos e costumes deste modo de vida tradicional em meio ao advento da pós modernidade trabalhando a resiliência como elemento fundamental em momentos de transição cultural”, "atuo como pesquisadora na área dos impactos globalizantes nas comunidades tradicionais, [...], sou atuante tanto em sala de aula quanto socialmente no que concerne aos discursos e preservação, respeito, tolerância e não silenciamento", "posso ajudar no trabalho de preservação da cultura e das áreas onde meus antepassados povoaram e lutaram para manter como fonte de subsistência em um equilíbrio saudável com a natureza", "é necessário uma mediação entre os órgãos ambientais de proteção e as comunidades tradicionais" e "sou um entusiasta na politica preservacionista";

- Educação: "realizar oficinas e vivência que eduquem a comunidade a qual estou inserida. Enquanto educadora procuro trazer para esse educando o nosso papel de cidadania na sustentabilidade do planeta", "trabalho junto aos alunos aprendendo com eles e trocando conhecimentos/saberes", "responsabilidade moral e ética de colaborar com a conservação da natureza”, "responsabilidade é com a informação, colaborando com a compreensão da importância da preservação ambiental”, "contribuirmos para preservação direta e indiretamente através da Educação Ambiental e conscientização", "Esta experiência me proporciona aprender coisas novas e conhecer diversas pessoas que tem este interesse em comum com a Unidade 
de Conservação, seja através do ecoturismo ou pesquisa científica. Fico feliz em trocar experiências" e "Eu, como parte integrante do meio ambiente, tenho obrigação de atuar na conservação da natureza, portanto, me sinto responsável individual e coletivamente".

Nesse âmbito, observa-se que no processo perceptivo há sedimentação da valorização do ambiente a partir dos atributos naturais conservados, influenciando em grande parte a qualidade de vida na região e influenciando condutas positivas. Em relação às condutas, veem-se posicionamentos bastante amplos, refletindo sobre caminhos através de sua atuação profissional, mediando a divulgação da informação, promovendo a educação, valorizando os aspectos socioambientais, fortalecendo sentimento de participação e de atuação política, dentre outros.

\section{Benefícios que o parque promove para a região}

A quinta questão apresenta alternativas que os indivíduos poderiam selecionar para se referir aos benefícios que o parque traz para a região.

Nesse sentido, a apreensão do papel do parque pode perpassar por diversos fatores, mas ficam claros os condicionantes em relação ao uso e ocupação do território e em relação ao meio de vida dos moradores locais. Nesse sentido, as alternativas apresentadas aos atores locais podem ser divididas em:

- Meio biótico: "preservação de espécies nativas (animais e vegetais)";

- Meio abiótico: "preservação de fontes e nascentes de água" e "preservação da paisagem natural";

- Meio social: "melhoria qualidade de vida", "aumento pesquisas", "programas educativos", "desenvolvimento do turismo", "preservação cultura tradicional", "oportunidades de empregos no parque", "valorização dos terrenos no entorno do parque", "maior segurança", “oferta de empregos" e "presença de novos loteamentos".

A partir dessas alternativas têm-se indicativos sobre a atuação do parque em relação à preservação dos aspectos geoambientais, mas também do seu papel junto à sociedade, valorizando o acesso à pesquisa e aos programas educativos, influenciando o uso e ocupação do espaço, a qualidade de vida dos moradores do entorno e a dinamização da economia local. 
Os dados relativos à seleção de cada uma dessas categorias foram organizados no Gráfico 1, considerando que cada participante poderia selecionar mais de uma alternativa.

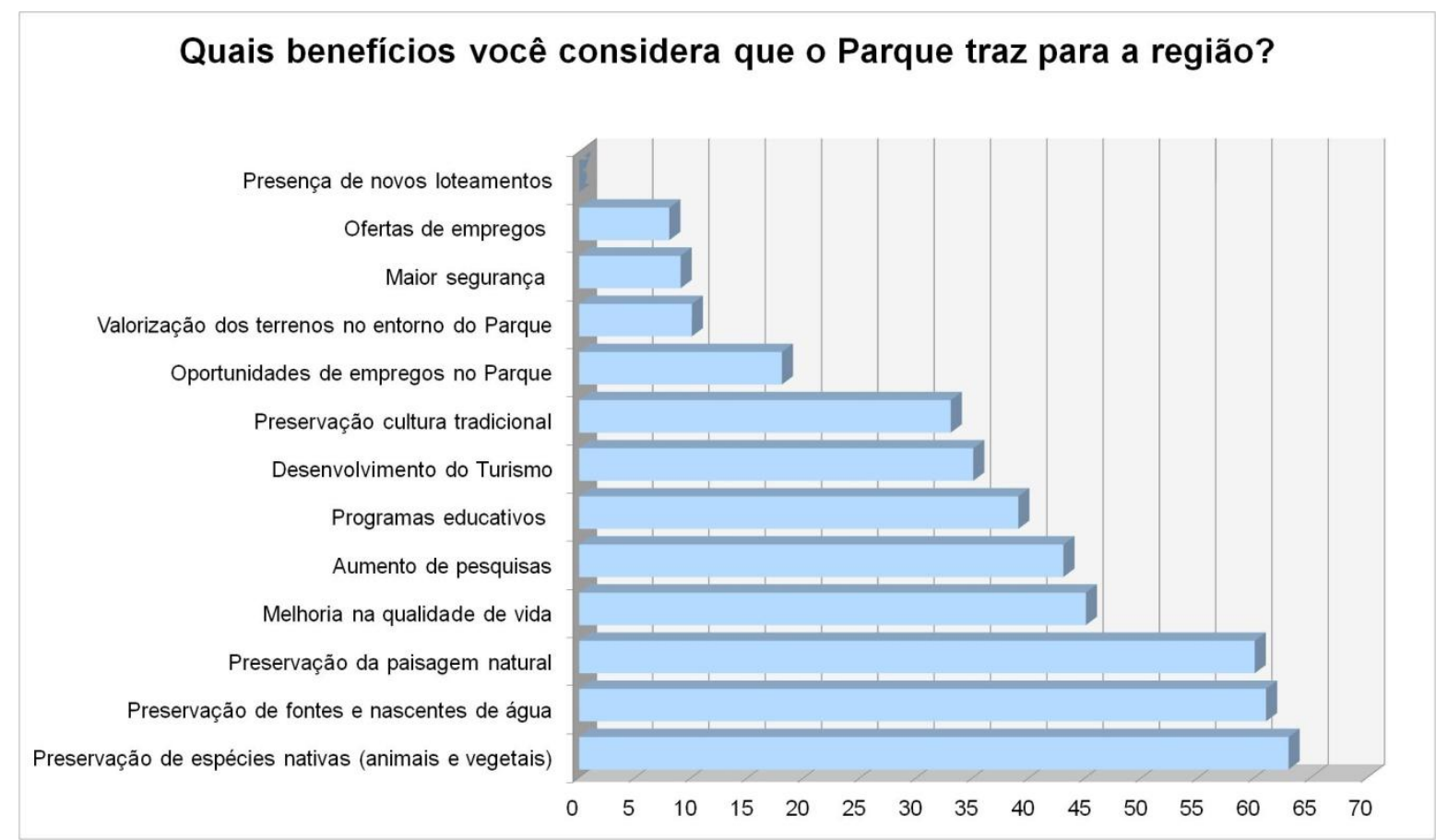

Gráfico 1 - Total de indicações na questão 5: Quais benefícios você considera que o Parque traz para a região?

As categorias de preservação de espécies nativas (90\%), de fontes e nascentes de água (87\%) e da paisagem natural (86\%) tiveram maior destaque. Nessa sequência, apreendese que de acordo com a percepção local, o papel do parque centra-se na preservação da biodiversidade, dos recursos hídricos e da paisagem natural. Nota-se o maior destaque à biodiversidade (espécies nativas), seguidos dos aspectos da geodiversidade (fontes e nascentes de água e paisagem natural). Esses dados ressaltam o papel conservacionista do parque, em atenção ao meio biofísico.

Seguido desse primeiro grupo de opções voltadas para a conservação da natureza, destacou-se também categorias que se referem ao papel do parque para a sociedade, sobre a qualidade de vida (64\%), o aumento de pesquisas (61\%), os programas educativos (56\%), o desenvolvimento do turismo (50\%) e a preservação da cultura tradicional (47\%).

A categoria de qualidade de vida foi incluída, pois apreende a relação dos indivíduos com esse ambiente à medida que versa sobre as qualificações do lugar. Como destacou Forattini (1991), baseado nos estudos de Hörnquist (1990) e Papageorgiou (1976), essa categoria apresenta elementos individuais e sociais que determinam a percepção de qualidade de vida dos indivíduos, sendo que mensurar os aspectos relacionados à concepção social 
permite uma avaliação mais concreta a partir de indicadores do ambiente, como aspectos habitacionais, urbanos, sanitários e sociais.

Para avaliar a qualidade de vida, o IBGE baseou-se no relatório Report by the Commission on the Measurement of Economic Performance and Social Progress (STIGLITZ, SEM \& FITOUSSI, 2009), indicando que o tema qualidade de vida inclui aspectos que vão além dos materiais, mas também o bem estar dos indivíduos. Assim, os indicadores selecionados relacionam-se com a saúde (saneamento básico e direitos humanos), educação, atividades pessoais (trabalho e uso do tempo), direitos humanos (participação política e governança), famílias e redes sociais (relações e conexões sociais), habitação e entorno (meio ambiente), segurança física e econômica, padrão de vida material e distribuição de renda (IBGE, 2012).

Diante o exposto, a categoria que atribui a capacidade do parque em garantir uma melhor qualidade de vida para os moradores locais pode estar relacionada com seu papel de preservação do meio ambiente, garantindo melhores condições de vida relacionadas à uma natureza preservada para as populações do entorno do parque. Os impactos imediatos na qualidade de vida das pessoas a partir das condições ambientais destacados por Stiglitz, Sem e Fitoussi (2009) podem ser:

- Interferências na saúde humana: a saúde humana pode ser afetada de forma direta (poluição do ar e da água, substâncias perigosas e ruído), e indireta (alterações climáticas, transformações no ciclo do carbono e da água, perda de biodiversidade e desastres naturais que afetam a saúde dos ecossistemas);

- Benefícios dos serviços ambientais: acesso a água potável e áreas de recreação, direitos no campo ambiental (por exemplo, o acesso às informações ambientais);

- Qualidade ambiental: a avaliação da qualidade ambiental pela população pode influenciar nas suas escolhas, por exemplo, aonde viver.

Sendo assim, a mediação do parque em proporcionar uma boa qualidade de vida aos olhos desses atores se relaciona fortemente com o ambiente que ele está inserido, apresentando indicadores de um ambiente preservado, com extensas áreas de floresta, boa qualidade do ar, da água, do solo, diversas áreas para o lazer e a recreação, dentre outros. As sensações positivas em relação às condições de vida determinadas pela qualidade ambiental se sobressaem em relação aos indicadores habitacionais, urbanos, sanitários e sociais da região que apresentam diversos problemas, percebidos a partir dos diversos relatos durante a 
pesquisa, como ocupação de áreas de risco, baixa disponibilidade de transporte público, precarização das vias de acesso, ausência de coleta seletiva de lixo, ausência de tratamento de lixo, baixas taxas de tratamento de esgoto, dentre outros, que estão relacionados com a administração pública.

Em relação às pesquisas científicas, programas educativos e ao turismo, vê-se a importância do papel do parque em mediar e fortalecer esses aspectos. Corrobora assim com os próprios objetivos da UC, que possui a finalidade de "assegurar integral proteção à flora, à fauna, às belezas naturais, bem como para garantir sua utilização a objetivos educacionais recreativos e científicos". Assim, o plano de manejo do PESM (SÃO PAULO, 2006) tem em atenção os programas de manejo voltados para a administração, uso público, fiscalização e proteção, pesquisa científica e interação socioambiental, que ordenam e promovem as atividades relacionadas aos programas educativos e pesquisas científicas.

A atribuição do parque em promover a preservação da cultura tradicional foi indicativo relevante nesse contexto, o que fornece subsídios para perceber um período de maior estabilidade na relação comunidade tradicional e parque. Dessa forma, é positivo o fato de que $47 \%$ dos indivíduos reconheceram o papel do parque em garantir as condições de sobrevivência dos habitantes tradicionais inseridos na unidade, fortalecendo essa cultura tradicional na região.

As categorias que tiveram menor referência foram: oportunidades de empregos no parque (26\%), valorização dos terrenos no entorno do parque (14\%), maior segurança (13\%), oferta de empregos $(11 \%)$ e presença de novos loteamentos $(0 \%)$.

A baixa referência às opções de oportunidades de emprego no parque e oferta de empregos indica que ainda há um longo caminho a ser percorrido pela gestão para beneficiar as comunidades locais através da dinamização da economia pelo turismo e visitação das Unidades de Conservação.

Já a baixa aceitação das categorias valorização dos terrenos no entorno e presença de novos loteamentos representa um bom resultado para a gestão do parque em impedir a expansão de loteamentos e da especulação imobiliária.

A categoria de segurança obteve menor expressão, revelando transformações recentes da localidade, com crescentes relatos de roubos, homicídios e tráfico de drogas. Salienta-se que a segurança pública não é de responsabilidade dessa instituição, porém, o parque possui atribuições que conferem maior estabilidade relacionada às suas influências políticas e sociais. Além disso, possui funcionários específicos como guarda parques e agentes de fiscalização que podem garantir maior segurança. Entretanto, observa-se que o 
quadro de funcionários é desproporcional diante as dimensões do PESM, segundo dados do plano de manejo de 2006, 26 funcionários possuíam a designação Guarda-Parque e agentes de fiscalização (SÃO PAULO, 2006).

O Gráfico 2 apresenta as porcentagens referentes às indicações de acordo com os grupos de respondentes. Na Tabela 17 (Apêndice B) são apresentados os valores totais de indicações para cada grupo de respondentes.

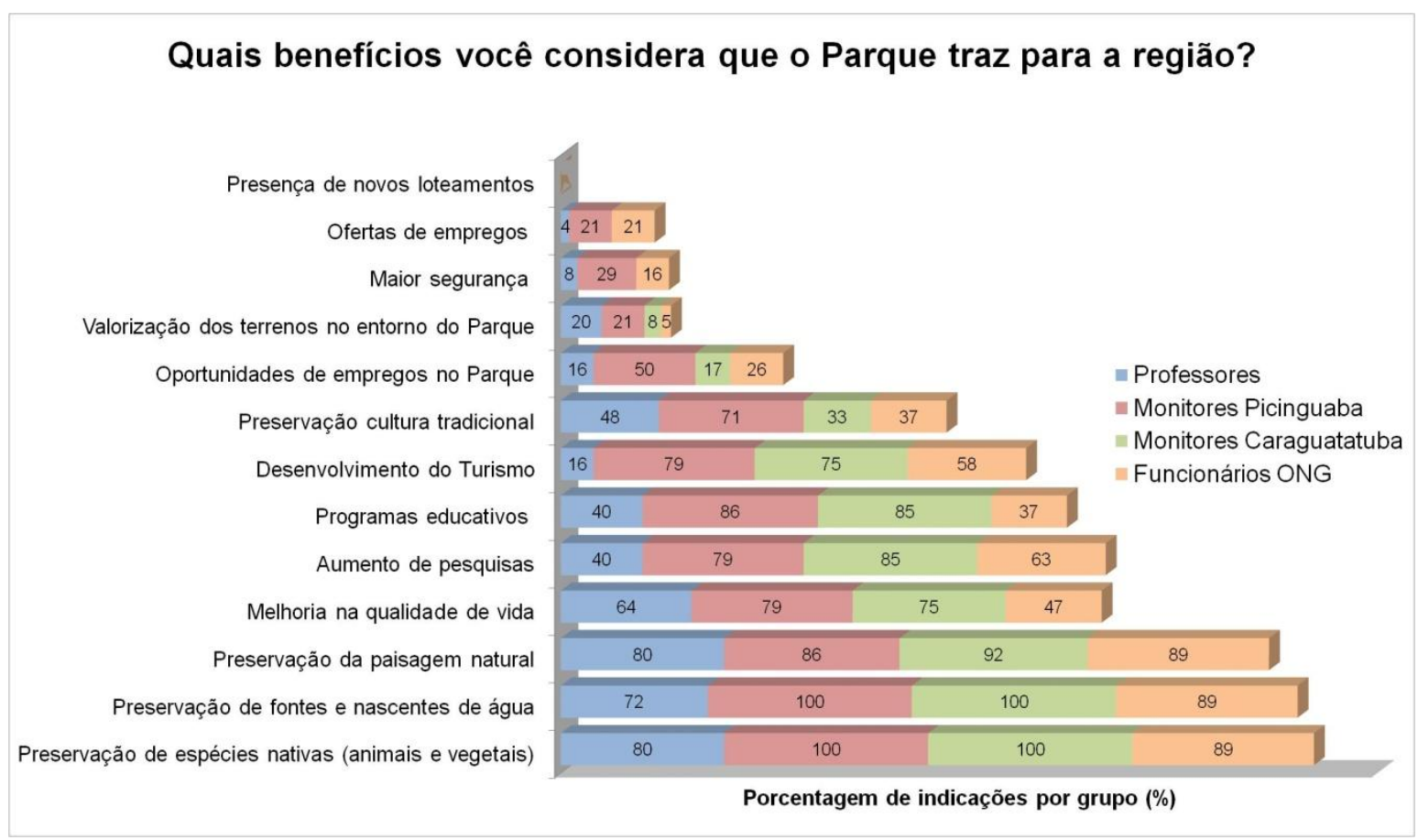

Gráfico 2 - Porcentagem de indicações por grupos de atores sociais para a questão 5: Quais benefícios você considera que o Parque traz para a região?

O desenvolvimento do turismo foi mais destacado pelos monitores ambientais (Picinguaba - 79\%; Caraguatatuba 75\%) do que pelos funcionários de ONG (58\%) e professores (16\%), chamando atenção para a abertura que a unidade proporciona aos guias e monitores ambientais que se beneficiam com os turistas nesse território.

No caso dos programas educativos, os funcionários da ONG (37\%) e os professores (40\%) dão menor destaque do que o grupo dos monitores (Picinguaba - 86\%; Caraguatatuba - 83\%). Isso pode estar relacionado ao papel educador centrado na escola, portanto, no espaço formal de educação, em contraposição aos programas pontuais e não formais promovidos pelo parque.

Quanto às pesquisas, os professores (40\%) e funcionários de ONG (63\%) também dão menor destaque do que os monitores de Caraguatatuba (83\%) e os monitores de Picinguaba (79\%). Considera-se para a interpretação desse dado o maior acesso que os monitores tem com o desenvolvimento das pesquisas, guiando os pesquisadores em campo, 
além de participarem de ações de divulgação das pesquisas científicas promovidas pelo parque.

Em relação à preservação da cultura tradicional, os monitores de Picinguaba (71\%) dão maior destaque que os professores (48\%), funcionários de ONG (37\%) e monitores de Caraguatatuba (33\%). O núcleo Picinguaba se destaca em relação à presença de comunidades tradicionais, sendo referência também o processo de conciliação entre a permanência dessas comunidades e gestão do parque, provavelmente influenciando a resposta dos monitores desse núcleo, o qual promove ainda visitação nas comunidades tradicionais como parte das atividades do parque.

Nenhum dos respondentes selecionou a opção "presença de novos loteamentos" e, poucos apontaram a opção "valorização dos terrenos no entorno do parque" (funcionários ONG $-5 \%$, monitores Caraguatatuba $-8 \%$, professores $-20 \%$, e, monitores Picinguaba 21\%), o que reforça o papel do parque em preservar a região e impedir o avanço das ocupações e especulação imobiliária.

Ainda nessa direção, em relação à "preservação da paisagem natural”, há concordância entre os atores locais (monitores Caraguatatuba - 92\%, funcionários ONG $89 \%$, monitores Picinguaba $-86 \%$, professores $-80 \%$ ) sobre a importância da atuação do parque e os benefícios que ele traz para a região.

\subsubsection{Relações com o lugar}

A apreensão sobre as relações desses atores com o lugar se deu através da análise das respostas para as questões 2, 3 e 7 do questionário. As interpretações sobre a relação com o lugar foram baseadas nos valores atribuídos aos aspectos presentes no ambiente, considerando a contribuição da geodiversidade. Observa-se que a relação com o lugar é construída a partir da vivência dos indivíduos, seus sentimentos de identificação e pertencimento.

As questões apresentadas nesse eixo temático reúnem informações sobre quais os locais que esses atores frequentam, qual sua relação de pertencimento, e, o que eles consideram mais importante nos seus respectivos municípios, além de sensações que têm em relação aos ambientes degradados.

Em relação à segunda questão, o objetivo foi identificar os locais de lazer que são frequentados pelos atores e qual sua relação de pertencimento com o lugar. 
Quatro pessoas deixaram as respostas em branco, 12 pessoas identificaram os locais que costumam frequentar, 53 identificaram os locais e explicaram qual sua relação de pertencimento, e, apenas uma pessoa não se considerou pertencente ao lugar.

Os locais que foram apontados têm forte relação com a geodiversidade, consistindo principalmente em: "praias", "cachoeiras", "sitios", "trilhas”, "praças”, "rios”, "montanhas", "ilhas", "costões rochosos", "mar" e "picos”. No âmbito dos aspectos da biodiversidade têm-se: "matas", "vegetação", "matas do sertão", "mata atlântica" e "áreas rurais". Os aspectos socioculturais também foram referenciados como: "restaurantes", “comunidades tradicionais" e "centros urbanos".

Os aspectos apontados para justificar a relação de pertencimento variaram nas relações de trabalho, de vivência, de nascimento e morada, de lazer, de reconhecimento cultural, valorização do contato com a natureza, do papel em contribuir com a conservação, como parte da natureza, de satisfação com o lugar, de admiração, relação de familiaridade com o ambiente, de práticas esportivas e de estudo. Algumas respostas exemplificam esses aspectos:

- "Sou monitor ambiental em UC e guia de turismo, tendo trabalhado em todos os atrativos naturais e culturais da região. Me sinto bem em trilhas, praias, comunidades tradicionais me relacionando intensamente com meu entorno. $\underline{\text { Meu local de lazer é }}$ meu local de trabalho" (grifo nosso);

- "Praias, trilhas, ilhas, restaurantes. Pertenço aonde eu trabalho, tendo uma relação referente a preservação ambiental" (grifo nosso);

- "Nas praias, pois é um local de tranquilidade, onde podemos relaxar e renovar as energias, além de ser uma paisagem muito agradável de se ver e estar" (grifo nosso);

- "Frequento as praias de Ubatuba. Sim, sinto que pertenço à elas, pois fazem parte de minha cultura e tradição" (grifo nosso);

- "As matas, as quais observo a liberdade dos pássaros; manejo de plantas nativas da Mata Atlântica de forma especial a Palmeira Juçara; sinto-me parte dela, respeitando-a e praticando a sustentabilidade" (grifo nosso);

- "Normalmente vamos na praia, acampar em montanhas, tomar banho de cachoeira. Sim, sinto-me parte deste lugar pois compreendo a natureza como parte de minha vida, parte de mim mesma. E compreendo a natureza como fonte da vida. Trabalho 
com plantas medicinais e minha relação com as plantas dos locais que frequento são de estudo" (grifo nosso);

- "Em Ubatuba são vários os locais, Parque Estadual da Ilha Anchieta, Ilha das Couves e frequentemente na praia vermelha do norte onde vou diariamente para a prática do surf local onde vejo os amigos, praia que replantamos o jundú para contribuir em sua preservação e aonde sempre que podemos desenvolvemos um trabalho de limpeza e colocação de placas para a sua preservação [...]” (grifo nosso).

A questão das percepções pessoais sobre os elementos mais importantes nos municípios (questão 3) teve como objetivo entender a relação dos indivíduos com o lugar. Considerando aspectos da vivência, dos objetivos pessoais e do contexto sociocultural.

Nota-se que os parâmetros apresentados se dividem em aspectos relativos ao meio natural (biodiversidade e geodiversidade), e o social (cultura, história, tradição e contemporaneidades).

- Meio biótico: biodiversidade;

- Meio abiótico (geodiversidade): paisagem, rochas, rios, recursos hídricos e montanhas;

- Meio sociocultural: No aspecto sociocultural, apresentou-se opções de cultura, história, pessoas, beleza e qualidade de vida. Também foram apresentados elementos da cultura tradicional e contemporânea como artesanato, alimentação, festas tradicionais, igrejas, arquitetura, museus, monumentos, casas, praças, obras de arte, bares, prédios e shoppings.

O Gráfico 3 apresenta em ordem decrescente o total de indicações para cada categoria apresentada no questionário. 


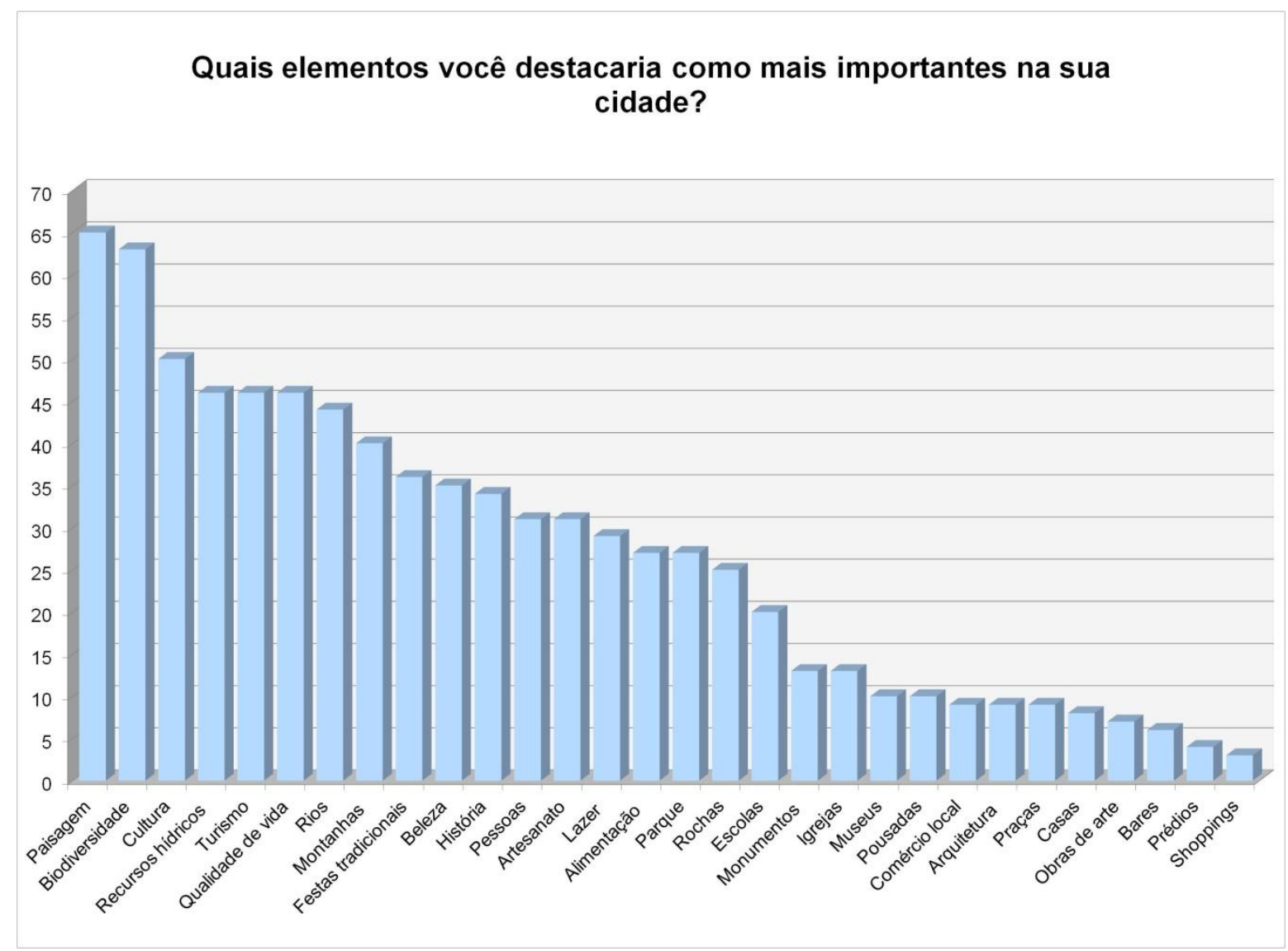

Gráfico 3 - Total de indicações na questão 3: Quais elementos você destacaria como mais importantes na sua cidade?

Segundo o gráfico 3, quatro grupos de elementos são identificados:

I) Paisagem e biodiversidade (93\% a 90\%);

II) Cultura, recursos hídricos, turismo, qualidade de vida e rios ( $71 \%$ a $63 \%)$;

III) Montanhas, festas tradicionais, beleza, história, pessoas, artesanato, lazer, alimentação, parque, rochas e escola (57\% a 29\%);

IV) Monumentos, igrejas, museus, pousadas, comércio local, arquitetura, praças, casas, obras de arte, bares, prédios e shoppings (19\% a 4\%).

O destaque dado à categoria "paisagem" (93\%) chama atenção por consistir em um elemento da geodiversidade, mas que também possui uma série de interpretações, remetendo às imagens observadas no ambiente. Nesse sentido, tem-se que na imagem desses núcleos, a presença marcante da Serra do Mar é um grande contributo para a configuração da paisagem local.

Por isso, olhar para as categorias seguintes que foram selecionadas contribuem para compreender como se dá a composição dessa paisagem. Os aspectos apontados como mais 
relevantes foram a "biodiversidade" (90\% das indicações) e a "cultura", com 71\%. Percebe-se a interação da paisagem com os aspectos bióticos e sociais.

Nesse contexto da geodiversidade, outras categorias obtiveram maior visibilidade como os "recursos hídricos" (66\%), os "rios" (63\%), as "montanhas" (57\%), sendo as taxas mais baixas referentes às "rochas" $(36 \%)$, talvez pela falta de conhecimentos específicos.

$\mathrm{O}$ reconhecimento dos atributos hidrológicos no ambiente pode estar relacionado à grande divulgação que o parque promove na conservação dos rios e nascentes inseridos na unidade, fundamental para o abastecimento de água dos municípios do litoral norte, e também contribuindo com as bacias hidrográficas da região. Além disso, os rios apresentam relação direta com os modos de vida dos moradores do litoral norte, fortemente relacionados com a atividade da pesca, que constitui também importante base alimentar. A relação e vivência nos rios e no mar ocorrem a partir da consciência de sua importância no contexto local, pelo uso da água para abastecimento dos municípios, pela fonte de alimento e manutenção da cultura tradicional, e, a partir do próprio reconhecimento dos ambientes hídricos como local de lazer.

Apesar das formas de relevo terem sido indicadas como relevantes na cidade, a partir das categorias de paisagem e montanhas, a atribuição de importância para a categoria das rochas foi menor, porém considerável nesse contexto. De modo geral, a apreensão das formas de relevo é mais perceptível visualmente que as formações e litologias que condicionam essa feição. Porém, a indicação das rochas por $36 \%$ dos atores locais pode ser devido à presença marcante de blocos rochosos nos rios e dos costões rochosos das praias do litoral norte.

De forma expressiva a biodiversidade é tão valorizada quanto a paisagem, sendo categoria importante na apreensão do lugar. Esses elementos se tornam referência para os habitantes locais, que ressaltam o caráter preservado da região. Na paisagem observa-se uma densa mata sobreposta às vertentes da Serra do Mar, indicando que a biodiversidade se sobrepõe em termos de percepção à geodiversidade.

No tocante aos aspectos socioculturais, as principais categorias selecionadas foram: cultura $(71 \%)$, festas tradicionais $(51 \%)$, história (49\%), artesanato $(44 \%)$, pessoas $(44 \%)$ e alimentação (39\%). Nota-se que a prioridade foi dada aos aspectos da cultura tradicional dos municípios. O destaque à categoria cultura chama a atenção por ser a terceira opção mais selecionada. Nesse sentido, temos a paisagem, a biodiversidade e a cultura como principais aspectos da apreensão socioambiental do lugar.

As categorias de beleza (50\%), qualidade de vida (66\%), turismo (66\%) e lazer (41\%) convergem para a percepção desse lugar como agradável e positivo. Atribuindo a 
relevância da beleza observada, da qualidade de vida que esse ambiente proporciona, contribuindo para o turismo e com possibilidades inúmeras de lazer.

As categorias menos indicadas se relacionam aos aspectos sociais contemporâneos, como shoppings, prédios, bares, casas, praças, arquitetura, comércio local e pousadas.

No Gráfico 4, pode-se observar as porcentagens de indicações segundo os atores sociais, considerando ainda a Tabela 18 (Apêndice B) que apresenta o total de indicações por grupo.

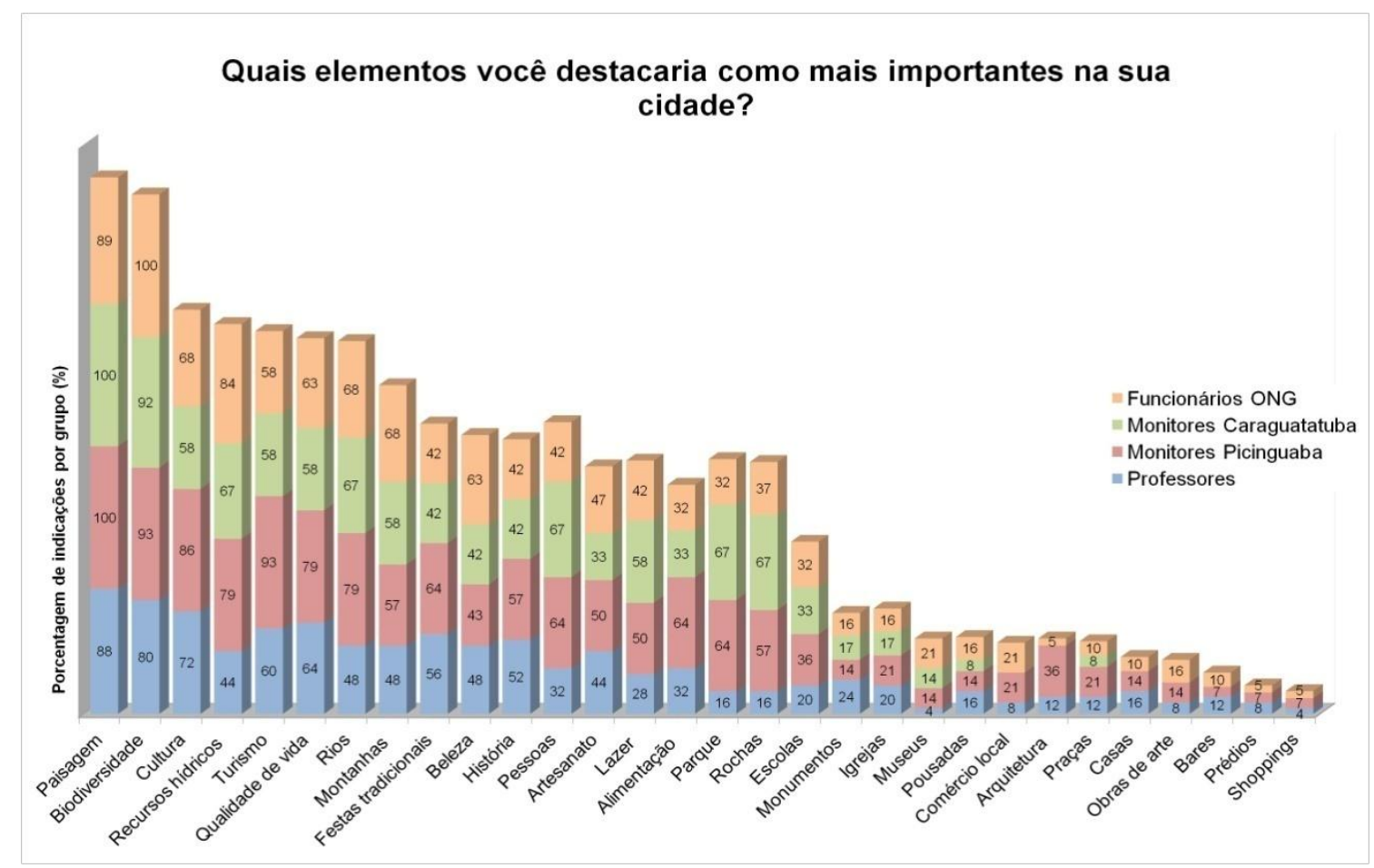

Gráfico 4 - Porcentagem de indicações por grupos de atores sociais para a questão 3: Quais elementos você destacaria como mais importantes na sua cidade?

Foram observadas grandes divergências entre os grupos nas categorias de parque, rochas e recursos hídricos.

No primeiro caso, destaca-se a diferença entre os monitores de Caraguatatuba (67\%) e de Picinguaba (64\%) em relação aos Professores (16\%) e Funcionários da ONG (32\%). A atribuição de maior relevância para o parques pelos monitores pode ser interpretado pelo fato de fazerem parte de seu quadro de funcionários e vivenciar diariamente esse ambiente.

No caso das rochas, as maiores diferenças observadas também foram entre os monitores, que deram maior relevância para essa categoria (Picinguaba - 57\%; Caraguatatuba - 50\%) e os Professores e Funcionários da ONG (16\% e 37\%, respectivamente).

Os recursos hídricos foram marcados em destaque pelo grupo dos funcionários da ONG, seguidos dos monitores de Picinguaba (79\%), de Caraguatatuba (67\%), e, em menor 
quantidade pelos professores (44\%). Essa diferenciação confirma a ideia de que a divulgação do PESM e o saber técnico dos monitores e funcionário da ONG atribuem maior valor aos recursos hídricos da região.

A arquitetura foi destacada pelos monitores de Picinguaba (36\%), em contraposição aos grupos dos professores (12\%), funcionários da ONG (5\%) e monitores de Caraguatatuba $(0 \%)$. Nesse sentido, o destaque dado pelo grupo dos monitores indica que eles podem ter sido influenciados pelo aspecto histórico mais preservado de Ubatuba, associado aos elementos arquitetônicos presentes nos monumentos do patrimônio histórico. Pode-se considerar também a influência da arquitetura presente nas comunidades tradicionais, observada nas casas de pau a pique.

Nas categorias relativas às dinâmicas atuais no município, considerando as pessoas, alimentação e casas houveram diferenciações principalmente entre os professores na categoria de pessoas (32\%), alimentação (32\%) e casas (16\%) em contraposição aos monitores de Picinguaba, com (64\%) na categoria pessoas, (64\%) na categoria alimentação, e, aos monitores de Caraguatatuba na categoria casas $(0 \%)$.

Em relação às categorias que tiveram baixas porcentagens de indicações destacam-se as igrejas, os shoppings, os prédios e os museus (11\%).

As categorias igrejas e museus que denotam elementos antigos do município foram selecionadas por menos da metade dos atores locais de cada grupo. No caso das igrejas foram $20 \%$ dos professores, $21 \%$ dos monitores de Picinguaba, 17\% dos monitores de Caraguatatuba e 16\% dos funcionários da ONG. Pode-se considerar a influência de diferentes religiões presentes para a baixa seleção desse atributo. A categoria de museus foi selecionada por $4 \%$ dos professores, $14 \%$ dos monitores de Picinguaba, 25\% dos monitores de Caraguatatuba e $21 \%$ dos funcionários de ONG. Esse valor pode ser atribuído à escassez de museus nos municípios, ou à baixa divulgação, o difícil acesso para aqueles que residem distantes do centro dos municípios e também, à maior valorização dos atributos naturais locais.

As categorias de shoppings e prédios referem-se a elementos contemporâneos na paisagem desses municípios, e tiveram poucas indicações por parte dos atores locais, com $4 \%$ e $8 \%$ em cada categoria pelos professores, $7 \%$ e $7 \%$ pelos monitores de Picinguaba, $0 \%$ e $0 \%$ pelos monitores de Caraguatatuba, e, 5\% e 5\% no caso dos funcionários da ONG. Pode-se considerar a pouca presença desses empreendimentos nos municípios, bem como o baixo valor que os atores locais atribuem a essas categorias, uma vez que representam profundas transformações na paisagem e no próprio modo de vida típico desses municípios. 
$\underline{\text { Observações e sensações sobre locais desmatados ou com problemas ambientais }}$

A questão 7 aborda a sensação diante da degradação ambiental. 12 pessoas responderam que nunca tinham visitado um local degradado e 5 pessoas deixaram as respostam em branco. Dentre os respondentes, sensações de repulsa e de pesar foram relatadas quando comparavam a paisagem preservada em que vivem com paisagens degradadas. Nesse sentido apresentaram os seguintes aspectos:

- Sensações: "lugar vazio (sem mata - fauna e flora)", "pouca variedade de animais", "aridez”, “ausência flora e fauna”, "poluição”, “drogas”, “crimes”, "calor”, "frio", "aumento da temperatura", "ar seco" e "ar comprometido".

- Cognição: "outras necessidades", "perda de biodiversidade, de serviços ambientais e da vida", "falta de informação" e "ausência de práticas de manejo".

- Avaliação: "impunidade”, "falta de respeito", "baixa qualidade de vida”, "lugar desconectado da natureza”, "ineficiência de prestação de serviços pelos órgãos públicos”, "vazio sem vida”, "vazio", "vácuo” e "violência”.

- Conduta: "fragilidade”, "tristeza”, "raiva”, "dor no coração”, "não gostei”, "deprimente”, “desgosto”, "desesperança na humanidade”, "desolação”, "indignação”, "vergonha”, “angústia e frustração”, "nojo”, “dor”, “mal estar”, "pena”, "lamentação”, "falta de amor", "incapacidade" e "impotência".

Portanto, vale destacar que a referência que os atores locais possuem é de um ambiente conservado e que no geral, associam os ambientes degradados aos grandes centros urbanos.

\subsubsection{Geodiversidade}

A percepção ambiental da geodiversidade foi analisada a partir das questões que tratam do patrimônio (questões 8, 9, 14 e 15), da geodiversidade (questões 10 e 11) e do patrimônio geológico (questão 12 e 13).

\section{a) Concepção Patrimônio}


A palavra patrimônio permite compreender as diversas esferas (naturais e construídas) que são significativas para a apreensão e identificação desses elementos em termos locais.

A identidade da população com seu território pode criar e reforçar valores comuns para a conservação dos atributos naturais e culturais, presentes na paisagem, possibilitando a apropriação do ambiente. A percepção e o reconhecimento dos atributos na paisagem se assentam em marcos naturais e construídos, que funcionam como pontos de orientação espacial e repositórios de lembranças. Esses signos, heranças materiais e imateriais, culturais e naturais configuram o que se designa patrimônio (MISATO \& ZANIRATO, 2013).

Diagnosticar as concepções dos atores locais de patrimônio pode subsidiar ações de educação patrimonial e de valorização do patrimônio geológico. Assim, o reconhecimento do patrimônio toma sentido no lugar, revelando os olhares sobre os elementos naturais e culturais e de que forma são valorizados.

A questão 8 trata das percepções sobre o patrimônio. As alternativas definidas relacionam-se às esferas natural e construída, abrangendo também concepções relativas à dinâmica temporal e aspectos de sua valorização. As opções podem ser agrupadas da seguinte forma:

- Patrimônio Natural: "algo da natureza";

- Patrimônio Cultural: "algo cultural", "algo que tenha valor para a história", e "um conhecimento";

- Perspectiva temporal do patrimônio: "uma herança", "algo em ruína" e "algo antigo".

- Importância/valor: "algo que tenha valor para a ciência e para a tecnologia", "algo importante para a humanidade" e "algo importante para você". 


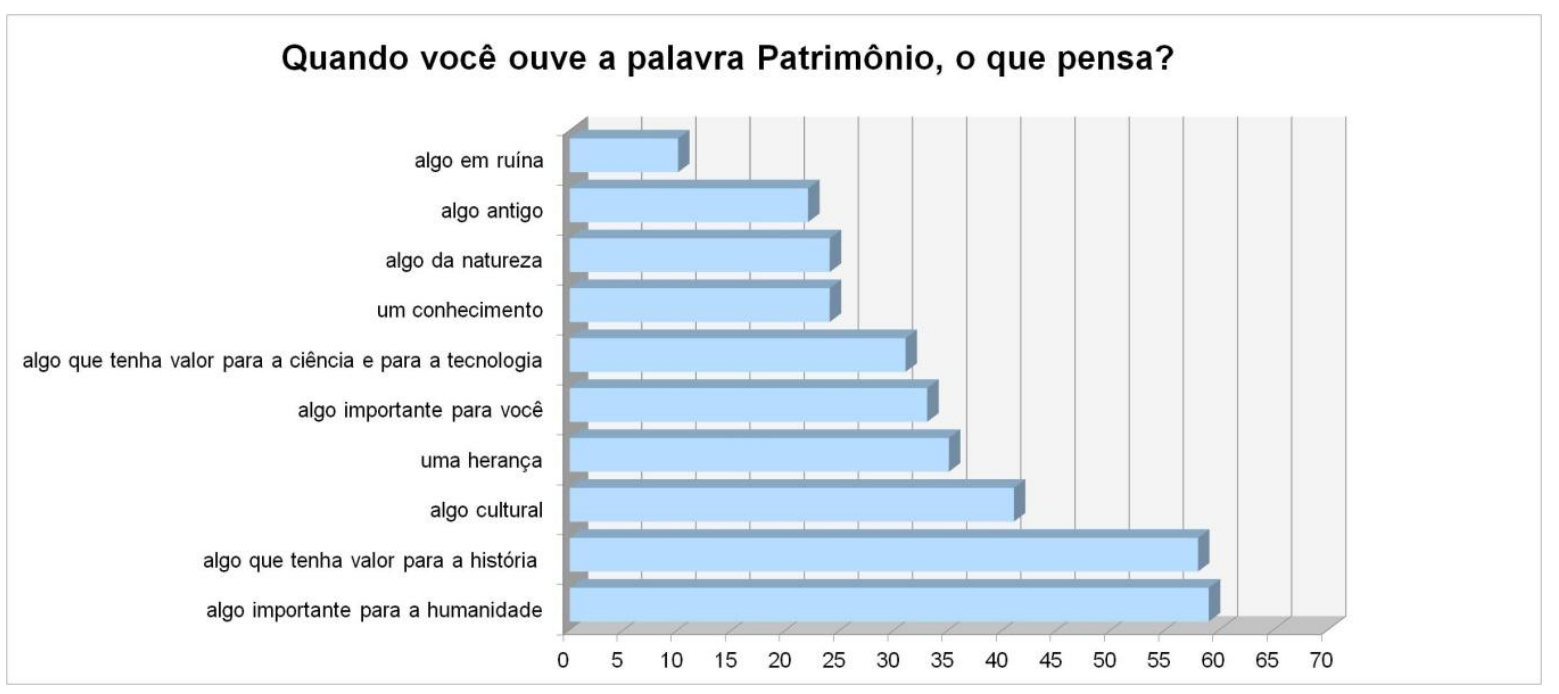

Gráfico 5 - Total de indicações relativas à questão 8: Quando você ouve a palavra Patrimônio, o que pensa?

Segundo o Gráfico 5, quatro conjuntos de elementos são identificados:

I) Algo importante para a humanidade e algo que tenha valor para a histórica ( $84 \%$ e $83 \%)$

II) Algo cultural, uma herança, algo importante para você, algo que tenha valor para a ciência e para a tecnologia (59\% a 44\%);

III) Um conhecimento, algo da natureza, algo antigo (34\% a $31 \%$ )

IV) Algo em ruína (14\%)

Entende-se que as convergências de indicações nas categorias "algo importante para a humanidade" e "algo que tenha valor para a história" representam o imaginário desses habitantes que identificam o valor cultural do patrimônio, ou seja, a definição de patrimônio perpassa pela significação humana e é destinado para esse coletivo. Pode-se correlacionar assim a importância do patrimônio cultural na dimensão histórica, ou seja, sua importância/valor possui relação com os testemunhos da história da humanidade.

Os aspectos indicados em seguida (algo cultural - 59\%, uma herança - 50\%, algo importante para você - $47 \%$, e algo que tenha valor para a ciência e para a tecnologia - 44\%) concordam com essa centralidade no patrimônio histórico. A relação estabelecida entre patrimônio e herança é clara nesse sentido, remontando aos elementos materiais e imateriais herdados das gerações e civilizações passadas.

Já a categoria algo da natureza obteve poucas indicações (34\%), apesar da região se tratar de uma área natural preservada, incluindo a área tombada como patrimônio na Serra do 
Mar. Apreende-se que a atribuição de valor patrimonial aos aspectos naturais ainda é pouco usual se comparada aos aspectos históricos.

Em sua revisão à respeito da evolução da noção de preservação do patrimônio, Anjos (2016), destaca que etimologicamente a palavra se refere à herança, ou seja bens materiais que os indivíduos herdam de seus antepassados, consistindo também em conhecimentos, hábitos, culturas, crenças e valores. Segundo a autora, a ampliação da noção de patrimônio decorreu nas três últimas décadas, vinculando os elementos construídos pelo homem (habitações, artefatos, artesanatos, dentre outros) às condições ambientais, históricas, socioeconômicas e étnicas.

Portanto a própria noção de patrimônio natural surgiu em um segundo momento em relação à noção de preservação do patrimônio, como destaca Anjos (2016). No Brasil, o Decreto Lei $\mathrm{n}^{\mathrm{o}} 25$ de 30 de novembro de 1937 ampliou a perspectiva de monumentos como parte do patrimônio histórico e artístico nacional os aspectos históricos, naturais, os sítios e paisagens de valor artístico, histórico e arqueológico. No entanto, somente a partir da Recomendação de Paris que o tombamento do patrimônio natural e paisagístico cresceu no Brasil (ANJOS, 2016).

Nota-se que a partir das discussões sobre o patrimônio brasileiro nos anos de 1979 centralizadas no Instituto do Patrimônio Histórico Artístico e Nacional (IPHAN), o conceito de patrimônio histórico passou a ser concebido por patrimônio cultural, e o patrimônio natural como referências culturais, dando suporte assim para a definição de patrimônio cultural abarcando tanto os elementos culturais como naturais (FONSECA, 2005 apud ANJOS, 2016).

Dessa forma, a baixa indicação da categoria algo da natureza concorda com essa evolução da noção de patrimônio, sendo ainda para muitos, desvinculada do natural.

As categorias que apresentaram menores valores foram: "um conhecimento" (34\%), “algo da natureza" (34\%), "algo antigo" (31\%) e "algo em ruína” (14\%).

Observa-se que a opção "um conhecimento" foi pouco selecionado, permitindo fazer um paralelo com a dificuldade em se reconhecer o patrimônio imaterial e os saberes tradicionais.

As categorias que remontam ao aspecto temporal do patrimônio (algo antigo e algo em ruína) obtiveram menos indicações. Portanto, para esses atores, as condições físicas e o aspecto temporal do elemento não são atributos essenciais para qualificar o patrimônio.

As singularidades de acordo com os grupos de atores locais pode ser observadas no Gráfico 6 e na Tabela 19 (Apêndice B). 


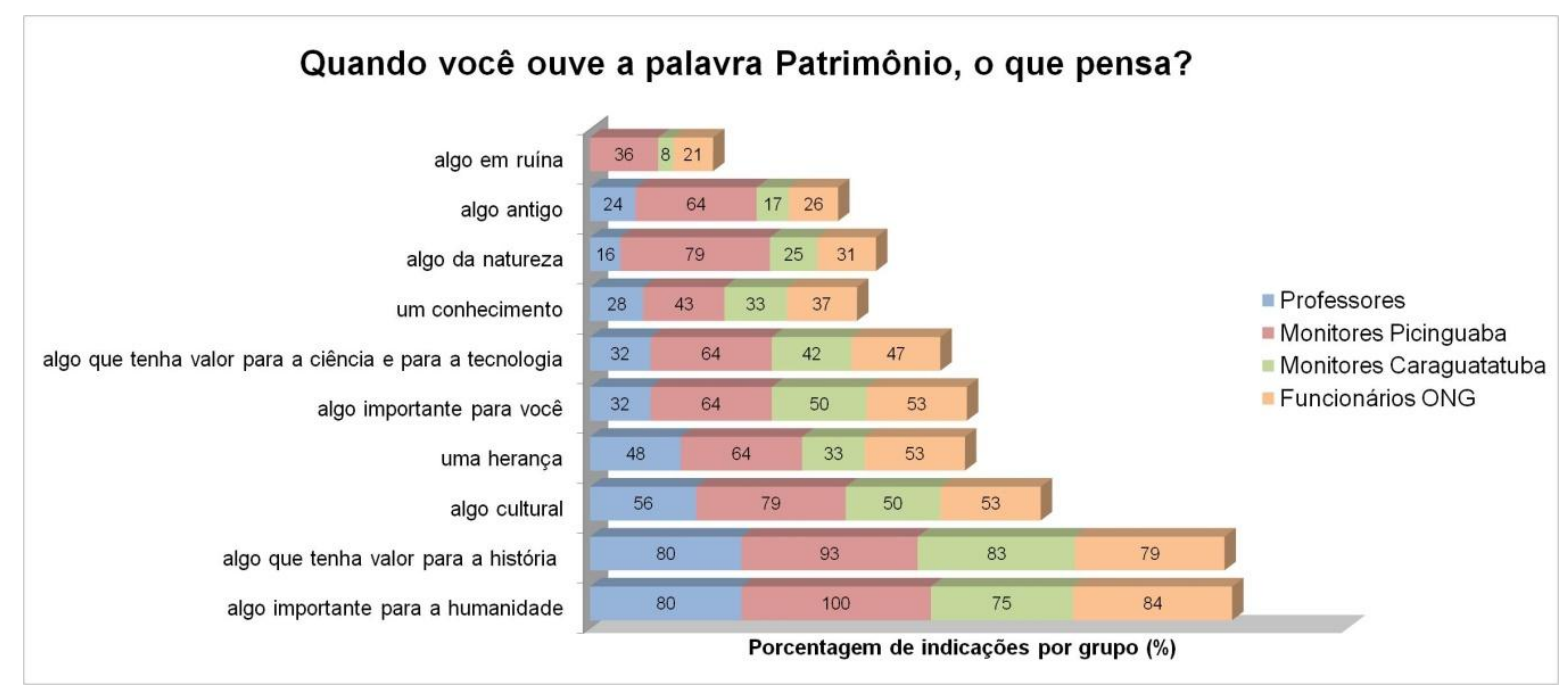

Gráfico 6 - Porcentagem de indicações por grupos de atores sociais para a questão 8: Quando você ouve a palavra Patrimônio, o que pensa?

Observa-se que para todos os grupos de respondentes, as categorias mais indicadas foram "algo que tenha valor para a humanidade" e "algo que tenha valor para a história".

Os monitores de Picinguaba atribuíram maior valor à categoria "algo da natureza" relativamente aos outros grupos, com $79 \%$ de indicações.

Complementando a perspectiva patrimonial, o Gráfico 7 relativo à questão 9, enfatiza os aspectos naturais e construídos do patrimônio:

- Meio biótico: florestas e animais;

- Meio abiótico (geodiversidade): paisagem, recursos hídricos, rios, montanhas e rochas; praias, rios, fósseis, cachoeiras, rochas (pedras) e relevo;

- Meio sociocultural: No aspecto sociocultural, apresentaram-se opções de aspectos gerais como construções históricas, cultura, artefatos arqueológicos, festas tradicionais, monumentos, e igrejas. Também foram apresentados elementos da cultura tradicional e contemporânea como festas tradicionais, tradições, línguas, pessoas, comidas, artesanatos e ruas. 


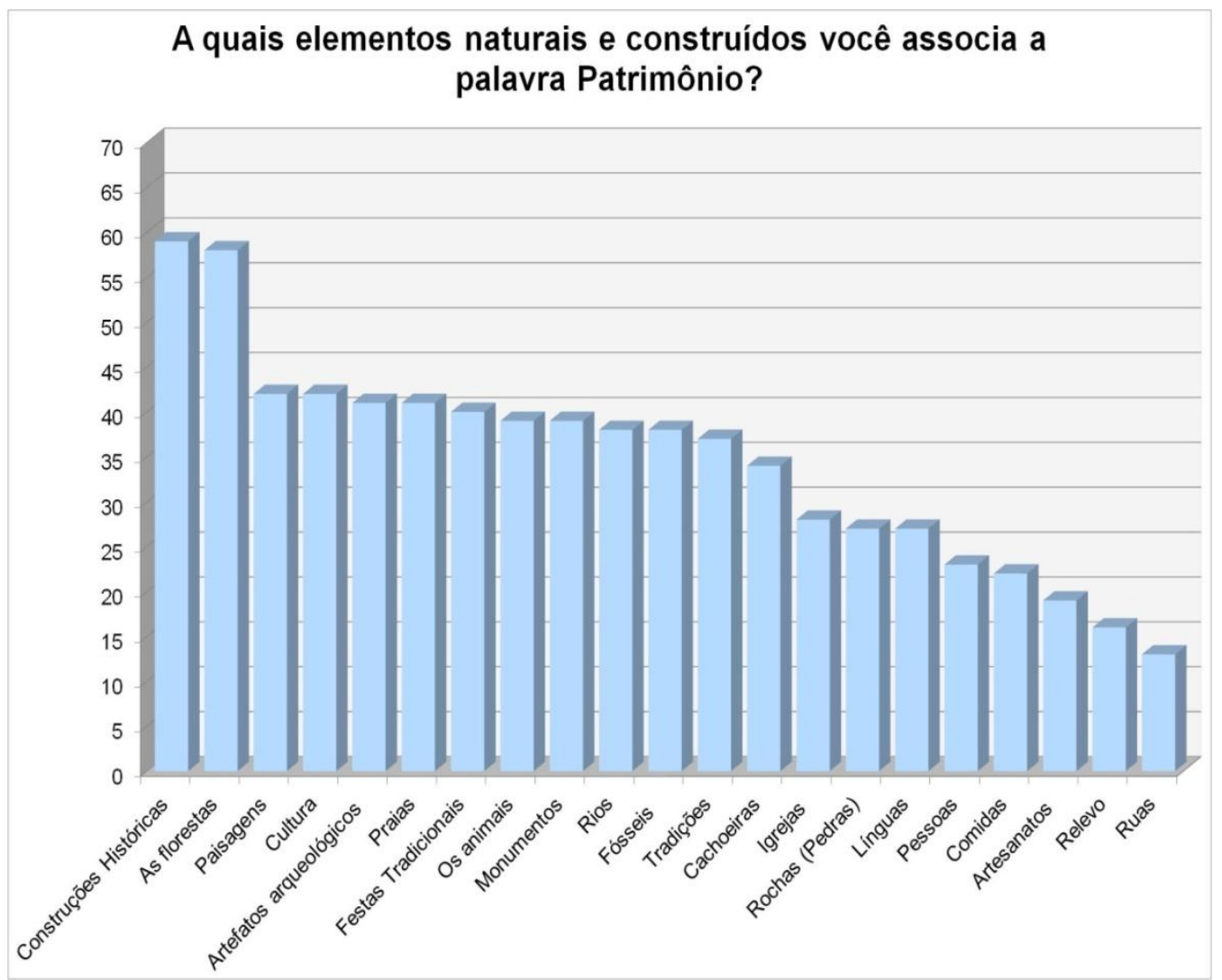

Gráfico 7 - Total de indicações relativas à questão 9: A quais elementos naturais e construídos você associa a palavra patrimônio?

Segundo o Gráfico 7, três grupos de indicações são identificados:

I) Construções históricas e florestas obtiveram as maiores porcentagens de indicações $(84 \%$ e $83 \%)$;

II) Paisagens, cultura, artefatos arqueológicos, praias, festas tradicionais, animais, monumentos, rios, fósseis, tradições e cachoeiras (60\% a 49\%);

III) Igrejas, rochas (pedras), línguas, pessoas, comidas, artesanatos, relevo, ruas (40\% a $19 \%)$.

As categorias mais indicadas representam o patrimônio construído (construções históricas) e o patrimônio natural, percebido através da biodiversidade (florestas). A geodiversidade também apresentou indicações nos três grupos, com destaque para a paisagem, as praias, os rios, fósseis e cachoeiras.

Quanto aos aspectos socioculturais, salienta-se a prioridade dada aos elementos históricos, o que concorda com o Gráfico 5, valorizando também a cultura e os artefatos 
arqueológicos. As indicações de festas tradicionais e tradições valorizam a cultura tradicional local.

Como lembra Scifoni (2006), a visão de um passado histórico nacional é expressa através da monumentalidade dos elementos construídos pelos protagonistas dessa história, perceptível através dos monumentos grandiosos e de valor estético. Nessa mesma perspectiva, a monumentalidade do natural também se relaciona a uma natureza "espetacular, grandiosa, quase sempre ausente de condição humana, intocável e disponível apenas para a fruição visual" (SCIFONI, 2006, p. 28).

A indicação dos elementos cênicos da geodiversidade (paisagens, praias e rios) corresponde a essa perspectiva de monumentalidade do patrimônio natural.

A visão patrimonial a partir do cotidiano valoriza "a experiência pessoal e coletiva dos diversos grupos sociais, constituindo o patrimônio como a representação da diversidade cultural presente em uma sociedade nacional" (SCIFONI, 2006, p. 28), em relação ao patrimônio natural, essa perspectiva "evidencia outras naturezas, apropriadas socialmente e vividas intensamente: a natureza como parte da memória coletiva, das históricas de vida, a natureza como componente das práticas sócio-espaciais” (SCIFONI, 2006, p.28).

Essa visão patrimonial a partir do cotidiano foi expressa no segundo e terceiro grupo de indicações culturais (cultura, festas tradicionais, tradições, línguas, pessoas, comidas, artesanatos e ruas).

O Gráfico 8 apresenta as porcentagens de indicações por grupo de atores sociais, junto com a Tabela 20 (Apêndice B) de valores totais de indicações. 


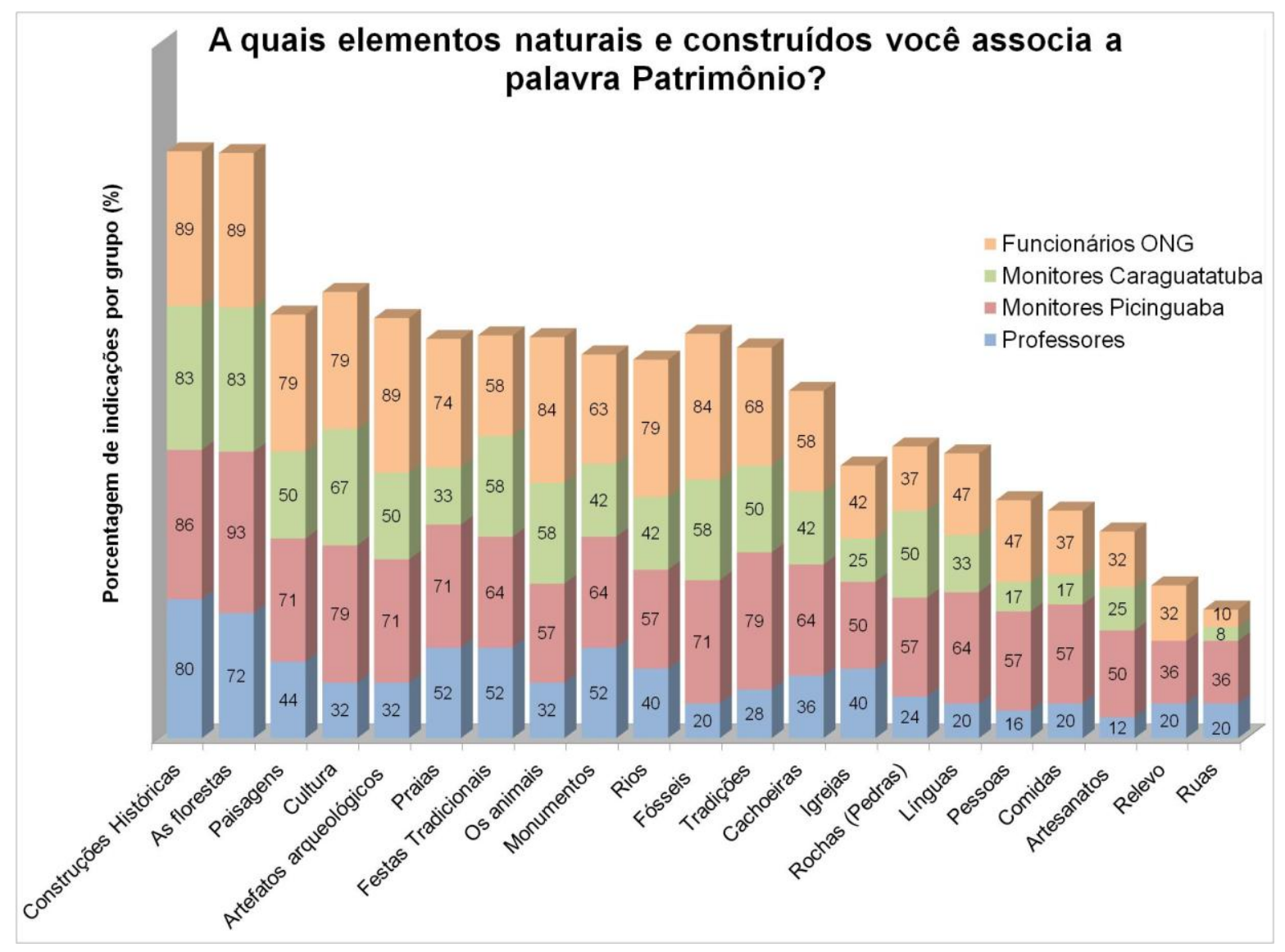

Gráfico 8 - Porcentagem de indicações por grupos de atores sociais para a questão 9: A quais elementos naturais e construídos você associa a palavra patrimônio?

A partir do Gráfico 8, observa-se que as categorias mais indicadas de acordo com os grupos foram:

- Professores - construções históricas (80\%), florestas (72\%), monumentos $(52 \%)$ e festas tradicionais $(52 \%)$

- Monitores ambientais de Picinguaba - florestas (93\%), construções históricas (86\%), tradições $(79 \%)$ e cultura $(79 \%)$.

- Monitores ambientais de Caraguatatuba - construções históricas (83\%), florestas $(83 \%)$ e cultura $(67 \%)$.

- Funcionários da ONG - construções históricas (89\%), florestas (89\%), artefatos arqueológicos (89\%), animais (84\%) e fósseis (84\%).

Nota-se que os grupos dos monitores de Picinguaba deram destaque às categorias tradições e cultura, assim como os monitores de Caraguatatuba deram destaque à cultura, vinculando esse fato à valorização das comunidades tradicionais como patrimônio no lugar. 
O grupo dos funcionários da ONG deu relevância às categorias artefatos arqueológicos, animais e fósseis, relacionando o valor patrimonial ao aspecto histórico da humanidade, e aos elementos da biodiversidade como animais e fósseis, nesse último caso relacionado também à geodiversidade.

Os Gráfico 9 e 10 (questões 14 e 15) referem-se à responsabilidade pela proteção do patrimônio, em relação ao que ocorre atualmente e quais as expectativas desses atores locais sobre como deveria ser esse processo.

Pode-se reunir as categorias disponibilizadas entre:

- Proteção institucional - Que poderiam estar relacionadas às diversas esferas do governo, bem como instituições específicas de proteção da natureza e do patrimônio que são: Governo Estadual, Governo Federal, Prefeituras, Instituto Florestal e ICMBio, polícia, CONDEPHAAT e IPHAN;

- Proteção no âmbito da sociedade - moradores, escolas, monitores ambientais, pescadores, lideranças comunitárias, ONGs e turistas;

- Proteção no âmbito do comércio e indústrias - agências de turismo, comerciantes e indústrias.

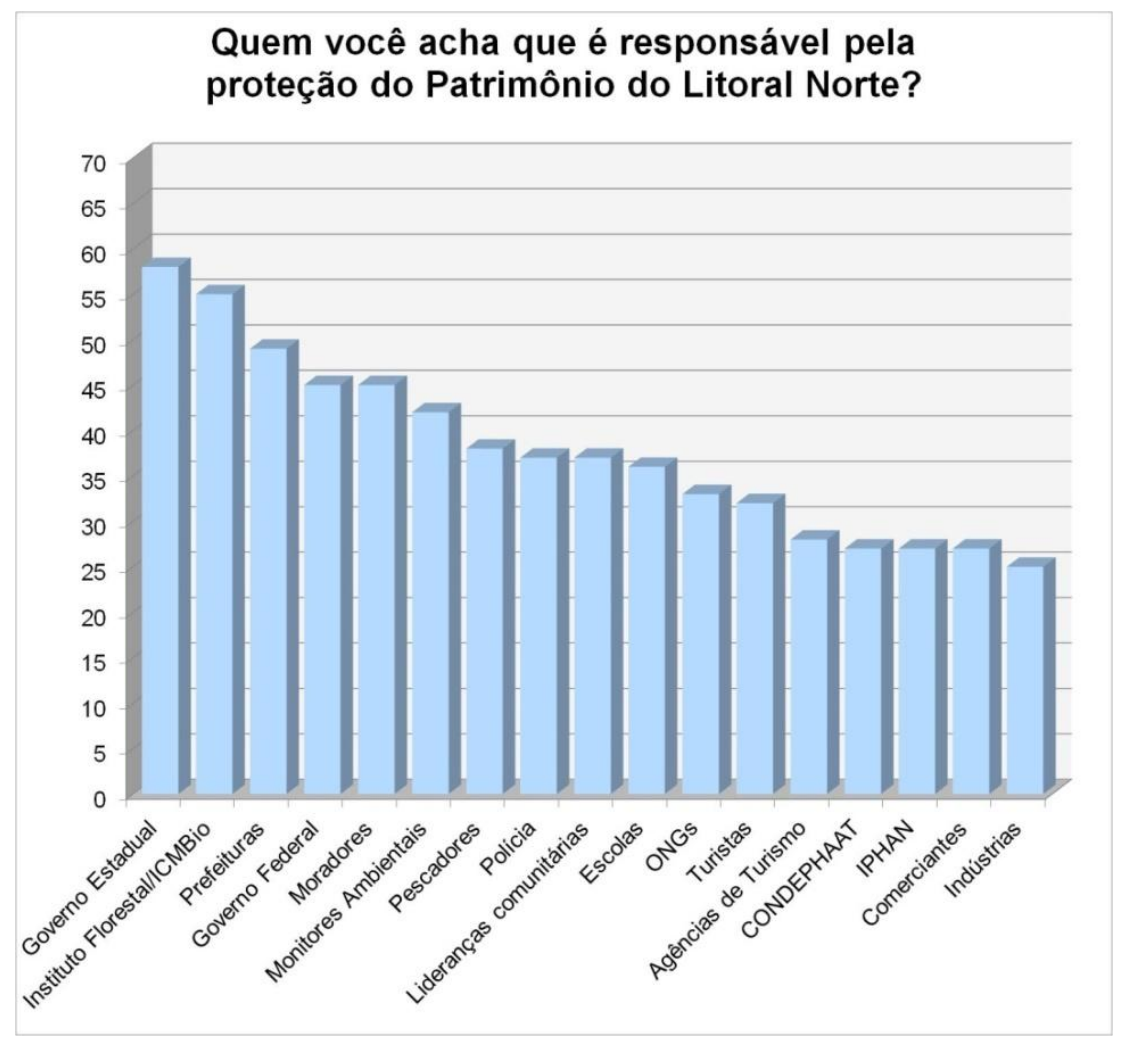

Gráfico 9 - Total de indicações relativas à questão 14: Quem você acha que é responsável peça proteção do patrimônio do Litoral Norte? 


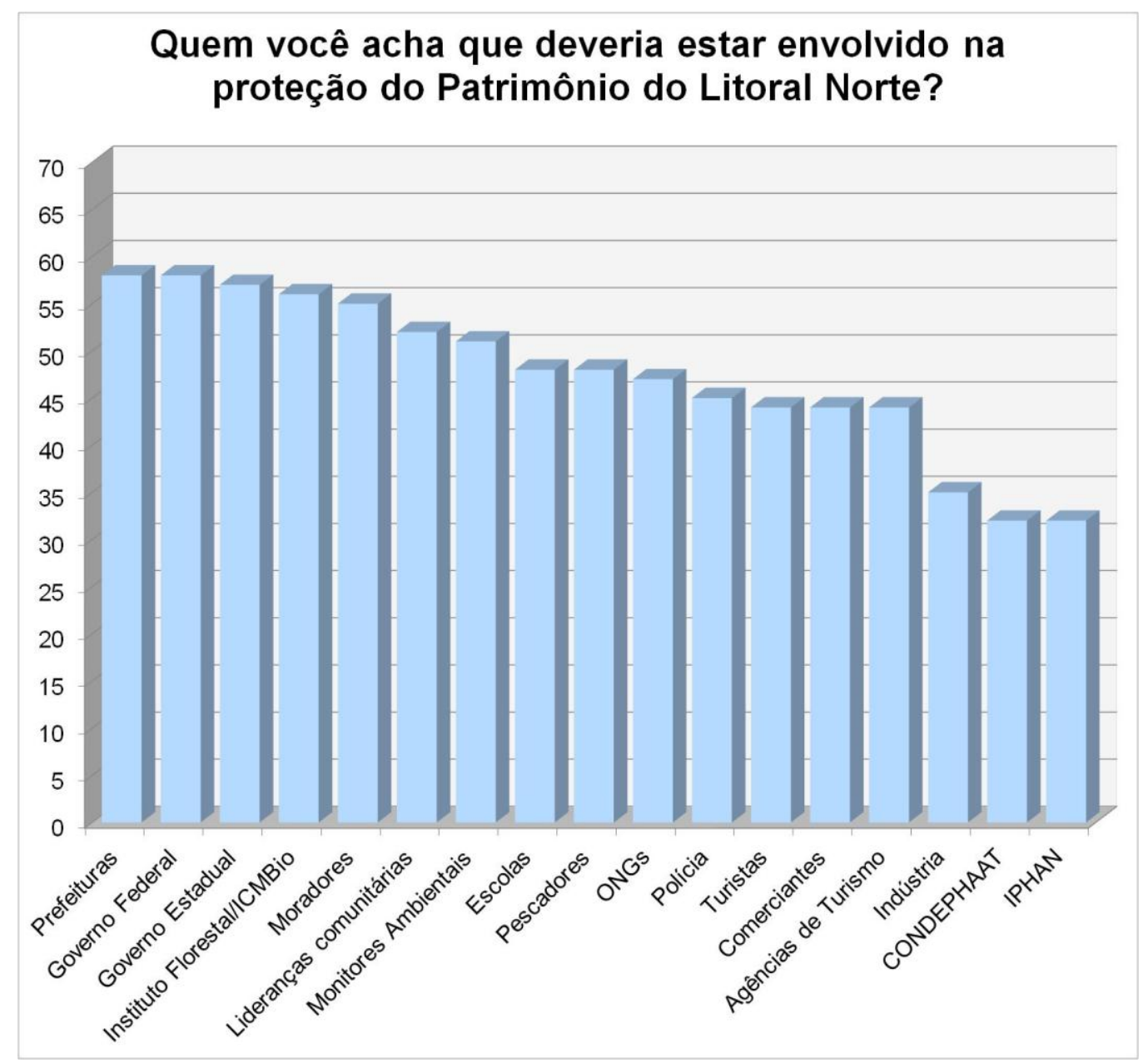

Gráfico 10 - Total de indicações relativas à questão 15: Quem você acha que deveria estar envolvido na proteção do patrimônio do Litoral Norte?

De acordo com o Gráfico 9, o principal indicado foi o governo estadual (83\%), seguido do Instituto Florestal/ICMBio (79\%) e da prefeitura (70\%). Na sequência, variando de $64 \%$ a $46 \%$, os responsáveis seriam o governo federal, os moradores, monitores ambientais, pescadores, polícia, lideranças comunitárias, escolas, ONGs e turistas. Os que aparecem com menor responsabilidade em relação à proteção do patrimônio (40\% a 36\%) foram as agências de turismo, o CONDEPHAAT, o IPHAN, os comerciantes e as indústrias.

No Gráfico 10 as atribuições em relação à proteção do patrimônio do litoral norte seriam das prefeituras (83\%), governo federal (82\%), governo estadual (81\%) e Instituto Florestal/ICMBio (80\%). Na sequência (79\% a 63\%) foram elencados: moradores, lideranças comunitárias, monitores ambientais, escolas, pescadores, ONGs, polícia, turistas, comerciantes e agências de turismo. Por fim, as categorias indústria, CONDEPHAAT e IPHAN obtiveram as menores indicações (50\% a 46\%).

Portanto, percebe-se que, as categorias que representam tanto a proteção atual, quanto a proteção almejada do patrimônio estão prioritariamente associadas à proteção 
governamental. Nesse sentido, a proteção proviria do governo, bem como de instituições de conservação da natureza de São Paulo (Instituto Florestal) e do Brasil (ICMBio).

A proteção governamental constitui em uma referência para esses atores locais, a partir da política centralizada e institucionalizada, que mantêm forte aspecto normativo sobre a proteção do patrimônio. Entretanto, o IPHAN e o CONDEPHAAT que estão propriamente relacionados com a proteção do patrimônio obtiveram menores taxas de indicações, denotando o baixo conhecimento da população em relação ao papel dessas institutições ou, uma baixa atuação na conservação do patrimônio local.

Por outro lado, há o reconhecimento da relevância da participação social e da sua responsabilidade na proteção do patrimônio.

Os Gráficos 11 e 12 e Tabelas 21 e 22 (Apêndice B) apresentam as porcentagens e os valores de indicações das responsabilidades de proteção ambiental segundo os grupos de respondentes.

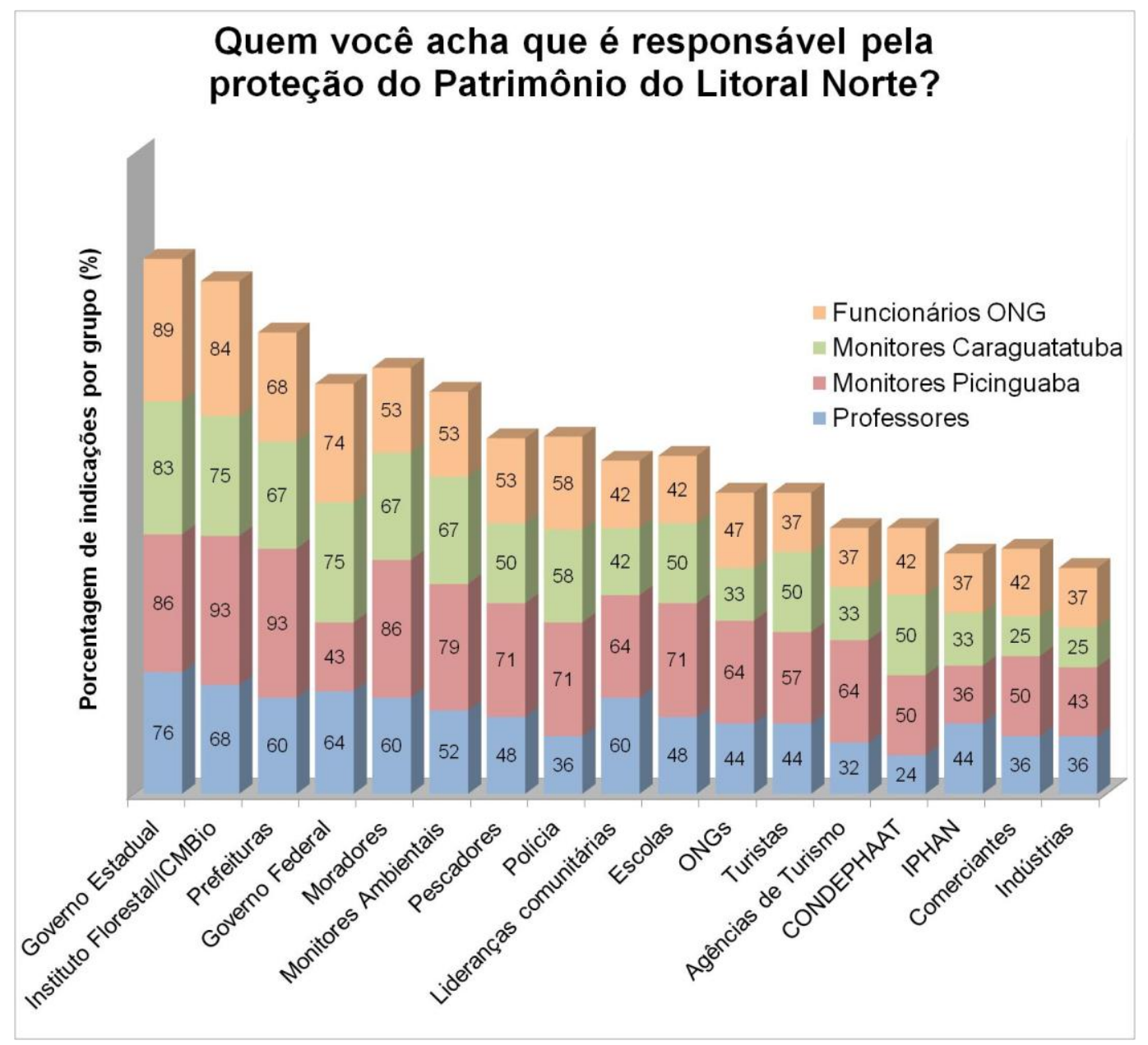

Gráfico 11 - Porcentagens de indicações por grupos de atores sociais para questão 14: Quem você acha que é responsável pela proteção do patrimônio do Litoral Norte. 


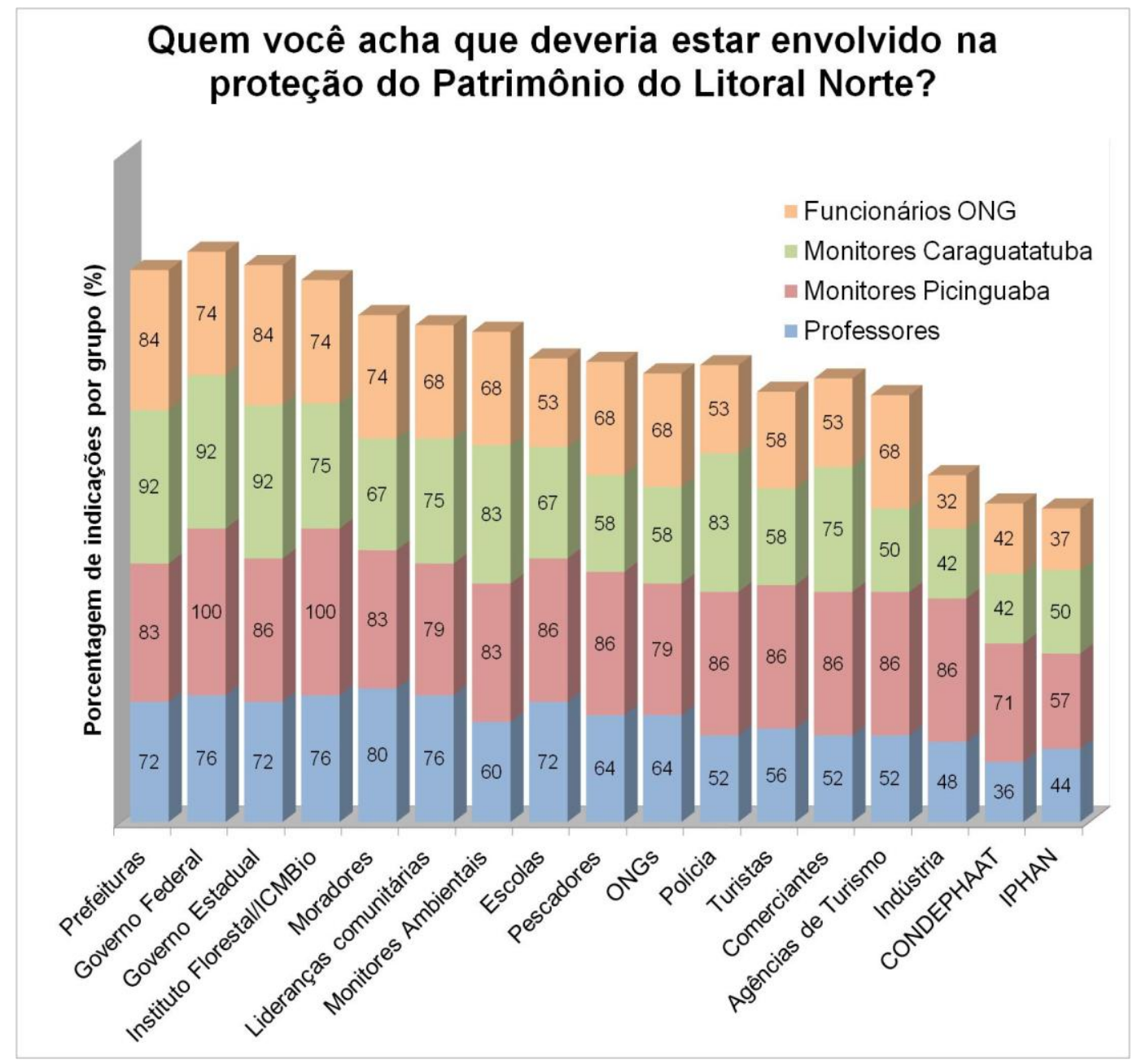

Gráfico 12 - Porcentagem de indicações por grupos de atores sociais para questão 15: Quem você acha que deveria estar envolvido na proteção do patrimônio do Litoral Norte?

As peculiaridades de acordo com os grupos de respondentes podem ser observadas na tabela 7 .

Tabela 7 - Síntese das principais indicações dos grupos para a questão 14 e 15.

\begin{tabular}{|c|c|c|}
\hline $\begin{array}{l}\text { Grupo de } \\
\text { respondentes }\end{array}$ & Principais indicações - questão 14 & Principais indicações - questão 15 \\
\hline Professores & $\begin{array}{l}\text { (76\%) Governo Estadual, } \\
(68 \%) \text { Instituto Florestal/ICMBio, } \\
(60 \%) \text { Moradores, prefeituras e } \\
\text { lideranças comunitárias. }\end{array}$ & $\begin{array}{l}\text { (80\%) Moradores; } \\
(76 \%) \text { Instituto Florestal/ICMBio, } \\
\text { Lideranças comunitárias e Governo } \\
\text { Federal; } \\
(72 \%) \text { Governo Estadual e Escolas. }\end{array}$ \\
\hline $\begin{array}{ll}\text { Monitores } & \text { de } \\
\text { Picinguaba } & \end{array}$ & $\begin{array}{l}\text { (93\%) Instituto Florestal/ICMBio e } \\
\text { prefeituras; } \\
(86 \%) \text { Governo Estadual e } \\
\text { moradores; } \\
(79 \%) \text { Monitores Ambientais. }\end{array}$ & $\begin{array}{l}\text { (100\%) Governo Federal e } \text { Instituto } \\
\text { Florestal/ICMBio; } \\
\text { (93\%) Prefeituras, Moradores e Monitores } \\
\text { Ambientais; } \\
(86 \%) \text { Governo Estadual, Escolas, } \\
\begin{array}{l}\text { Pescadores, Polícia, } \\
\text { Comerciantes, Agências de turismo e } \\
\text { Indústrias. }\end{array}\end{array}$ \\
\hline
\end{tabular}




\begin{tabular}{|l|l|l|}
\hline $\begin{array}{l}\text { Grupo de } \\
\text { respondentes }\end{array}$ & Principais indicações - questão 14 & Principais indicações - questão 15 \\
\hline $\begin{array}{l}\text { Monitores } \\
\text { ambientais de } \\
\text { Caraguatatuba }\end{array}$ & $\begin{array}{l}\text { (83\%) Governo Estadual; } \\
(75 \%) \text { Instituto Florestal/ICMBio e e } \\
\text { Governo Federal; } \\
(67 \%) \text { Prefeitura, Moradores e e } \\
\text { Monitores Ambientais. }\end{array}$ & $\begin{array}{l}\text { (92\%) Prefeituras, Governo Federal e } \\
\text { Governo Estadual; } \\
(83 \%) \text { Monitores Ambientais e Polícia; } \\
(75 \%) \quad \text { Instituto Florestal/ICMBio, } \\
\text { Lideranças Comunitárias e Comerciantes. }\end{array}$ \\
\hline $\begin{array}{l}\text { Funcionários } \\
\text { ONG }\end{array}$ & $\begin{array}{l}\text { (89\%) Governo Estadual; } \\
(84 \%) \text { Instituto Florestal/ICMBio; } ;\end{array}$ & $\begin{array}{l}\text { (74\%) Grefeituras G Governo Estadual; } \\
\text { Florestal/ICMBio e Moradores; Instituto } \\
(68 \%) \text { Lideranças Comunitárias, Monitores } \\
\text { Ambientais, Pescadores, ONGs e Âgências } \\
\text { de turismo. }\end{array}$ \\
\hline
\end{tabular}

Conclusão

b) Concepções de geodiversidade

A apreensão da geodiversidade a partir da seleção dos atributos formulados no questionário foi interpretada de acordo com as seguintes concepções:

- Generalista - reforça a integração dos aspectos: tudo que nos rodeia, onde a humanidade se desenvolve, onde a biodiversidade se desenvolve, ecossistemas, Terra, algo da natureza e recursos naturais;

- Específica - conceitos estritamente relacionados à geodiversidade: diversidade geológica, natureza abiótica, pedras preciosas, rios, fósseis, paisagem, minerais, processos geológicos, montanhas, substrato rochoso e solo.

O Gráfico 13 mostra os resultados da questão 10: “Geodiversidade é?”. Vale ressaltar que os questionários foram respondidos antes que os cursos de formação fossem ministrados, portanto, os respondentes não foram influenciados pelos conceitos abordados no curso. 


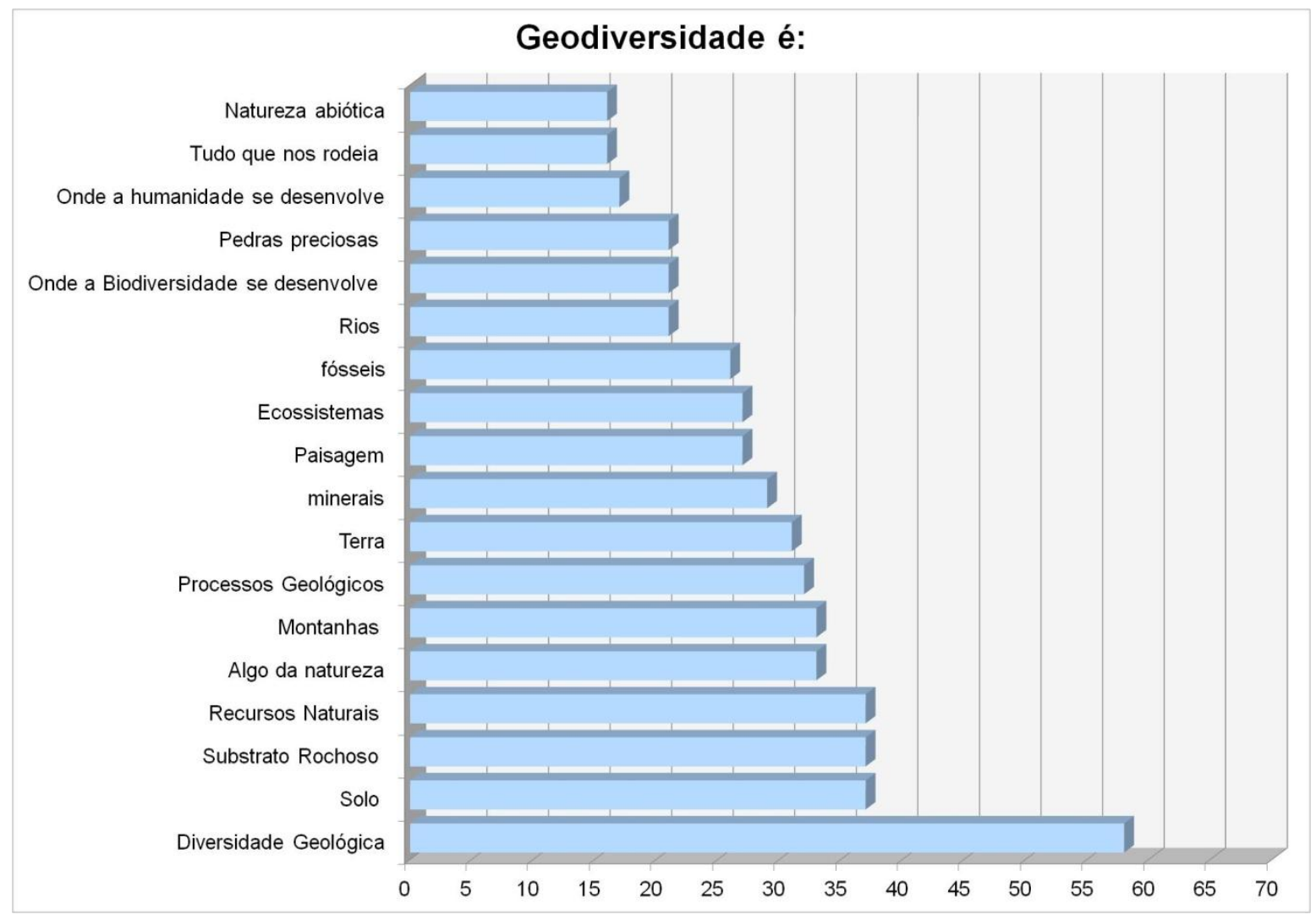

Gráfico 13 - Total de indicações na questão 10: Geodiversidade é:

A geodiversidade é entendida pela maioria dos respondentes como "diversidade geológica" (83\% de indicações). Os elementos da geodiversidade (solo, substrato rochoso, recursos naturais, algo da natureza, montanhas, processos geológicos, Terra, minerais, paisagem, ecossistemas e fósseis) foram apontados entre 53 e $37 \%$ dos respondentes. Também foram indicadas como elementos relacionados à geodiversidade as categorias: rios, biodiversidade, pedras preciosas, humanidade, tudo e natureza abiótica (30\% a 23\%).

O destaque atribuído à categoria "diversidade geológica" revela a apreensão da geodiversidade a partir da etimologia da palavra, ou seja, a "diversidade" do "geo", associado à geologia. Observa-se que o primeiro contato com o conceito os remeteu à uma abordagem específica sobre a geodiversidade, abrangendo toda a diversidade relacionada à geologia.

Pode-se inferir também que tenham feito relação com o termo "biodiversidade" que se refere à diversidade biológica, e que é mais comum no vocabulário desses atores locais.

As diferenças de indicação em relação aos demais elementos da geodiversidade podem estar associadas à confusão ou incertezas quanto ao conhecimento dos processos geológicos, ou, quais elementos da natureza fazem parte dessa dinâmica.

A seleção de aspectos genéricos reforça que esses atores locais não diferenciam exatamente o que é geológico, biológico e social, mas que concebem essa natureza integrada, 
como visto nas categorias "algo da natureza" (47\%), "Terra" (44\%), "Ecossistemas" (39\%), "onde a biodiversidade se desenvolve" (30\%), "onde a humanidade se desenvolve" $(24 \%)$ e "tudo que nos rodeia" (23\%). Sendo que as categorias "Ecossistemas" e "onde a biodiversidade se desenvolve" reforçam a valorização da biodiversidade na natureza.

A visão genérica do ambiente também indica dificuldade de entendimento conceitual.

Nesse sentido, a visão mais específica se relaciona às conceituações que definem quais os elementos que compõem a geodiversidade, a exemplo a definição apresentada por Stanley (2000, p. 15): "variedade de ambientes geológicos, fenômenos e processos ativos que dão origem a paisagens, rochas, minerais, fósseis, solos e outros depósitos superficiais que fornece a estrutura para a vida na Terra".

Enquanto que outras conceituações, compreendidas como mais genéricas e abrangentes buscam apresentar a relação da geodiversidade com outros aspectos, como a definição da CPRM que apresenta a geodiversidade como base para o desenvolvimento da vida na Terra, sendo composta pela "variedade de ambientes, fenômenos e processos geológicos que dão origem às paisagens, rochas, minerais, águas, solos, fósseis e outros depósitos superficiais" (CPRM, 2006 apud SILVA, 2008, p. 12).

Apresenta-se no Gráfico 14 a relação das porcentagens de indicações por grupos. 


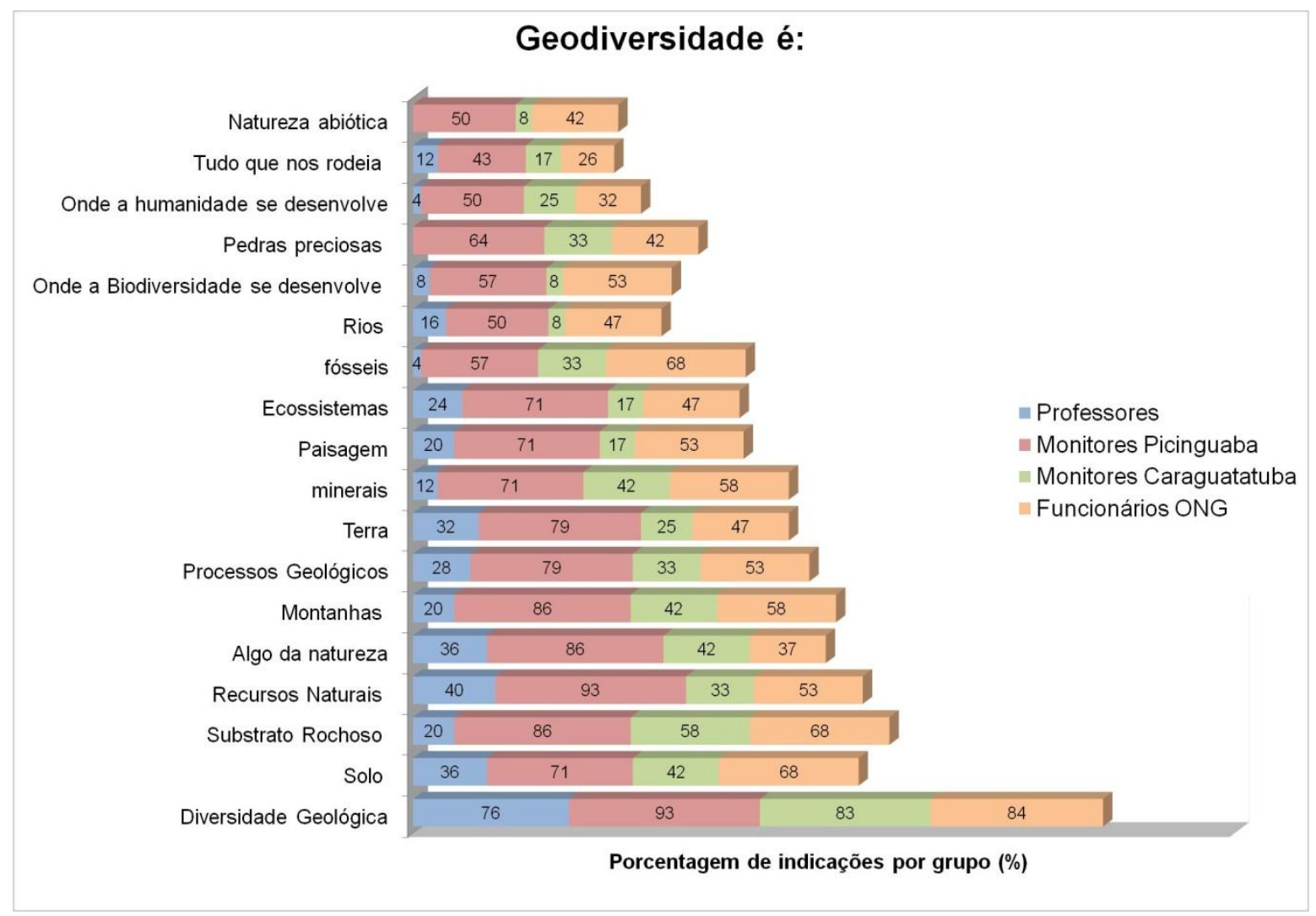

Gráfico 14 - Porcentagem de indicações por grupo de atores sociais para questão 10: Geodiversidade é:

A partir do Gráfico 14 e da Tabela 23 (Apêndice B), observa-se que as maiores indicações para cada um dos grupos foram:

- Professores: diversidade geológica (76\%); recursos naturais (40\%); algo da natureza e solo $(36 \%)$.

- Monitores ambientais de Picinguaba: diversidade geológica e recursos naturais (93\%); montanhas, substrato rochoso e algo da natureza (86\%).

- Monitores ambientais de Caraguatatuba: diversidade geológica (83\%); substrato rochoso (58\%), montanhas, minerais, algo da natureza e solo (42\%).

- Funcionários da ONG: diversidade geológica (84\%), substrato rochoso, solo e fósseis (68\%), montanhas e minerais (58\%).

A indicação da categoria diversidade geológica foi a principal dentre todos os grupos de respondentes. Somente o grupo dos monitores de Picinguaba equiparou a diversidade geológica aos recursos naturais. Na sequência, foram indicadas categorias mais específicas que consistem propriamente nos elementos da geodiversidade como substrato rochoso, solo, 
fósseis, montanhas e minerais. Exceto a categoria generalista de algo da natureza que foi indicada em maior relevância pelos professores, monitores de Picinguaba e de Caraguatatuba.

$\mathrm{Na}$ questão 11, foi proposto que as pessoas inserissem seus pensamentos a respeito da natureza abiótica do litoral norte. Nessa questão, 18 pessoas disseram não saber do que se trata a natureza abiótica, e 11 pessoas deixaram a resposta em branco.

Em relação às respostas obtidas, pode-se agrupá-las entre aquelas que descrevem a natureza abiótica a partir dos aspectos da geodiversidade local, que a relacionam aos aspectos da natureza sem vida, aos aspectos físicos e químicos, além de outras explanações mais gerais.

Geodiversidade - A identificação da natureza abiótica a partir dos aspectos da geodiversidade local foi encontrada em 21 respostas, com destaque para o relevo, as montanhas, a Serra do Mar e a paisagem, as rochas, os recursos hídricos, as praias, o solo, as cachoeiras, formações geológicas e recursos minerais, costões rochosos e a própria geodiversidade. Nesse sentido, muitas vezes é estabelecida uma associação entre os aspectos da geodiversidade e da biodiversidade, como nos seguinte excerto:

- "Penso no relevo. Os grandes desníveis de altitude, com o paredão da encosta atlântica muito próximo ao litoral determinando um altíssimo volume pluviométrico que favorece uma intensa e diversificada floresta, com centenas de espécies de fauna e flora endêmicas" (grifo nosso);

- "Você tem a Serra com todas suas ricas características, mergulhando no mar das mais variadas maneiras, formando baías, enseadas, rios das mais variadas características e muito numerosos pela alta precipitação pluviométrica, praias com variadas características desde abrigadas a expostas, dissipativas, reflexivas, com granulometrias diferentes, composição granulométrica variada. Temos muito a explorar, costões rochosos com diversas formações, e toda vida que se faz presente por todas essas características, basicamente quanto maior a geodiversidade, maior a biodiversidade" (grifo nosso);

- "No nosso litoral existe uma grande troca! Entre o biótico e o abiótico o que nos permite ter uma grande biodiversidade. O abiótico nosso está em constante renovação graças a ação da natureza nosso solo arenoso mas ainda fértil graças a grande decomposição do material biótico. Possibilita o crescimento de vida nos solos, nas pedras, que por sua vez sofre erosão". 


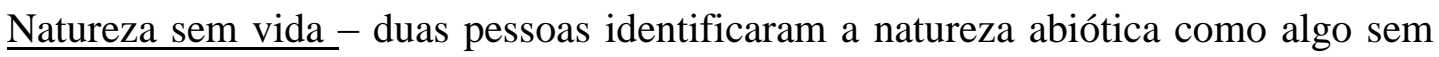
vida: "natureza sem vida, ou perdendo a vida"; "Tudo que é sem vida, em meio a natureza".

$\underline{\text { Aspectos químicos e físicos }}-6$ pessoas relacionaram a natureza abiótica aos indicadores físicos e químicos da natureza, e alguns elementos de sua dinâmica como temperatura, clima, umidade, luz, ph, vento, salinidade, nutrientes e compostos orgânicos.

Outras relações - um conjunto de 12 pessoas fizeram relações diversas, por exemplo, identificando a natureza abiótica como: ecossistema: "Influência que os seres recebem de um ecossistema"; patrimônio histórico cultural; aspectos que possuem vida: "formar parte dum todo com "natureza" pois a parte abiótica tem vida e se transforma constantemente. Cresce se transforma; Ainda - evolui; grita - da vida. Tudo o que gera vida, tem vida”. Ou ainda, chamando atenção de sua relevância para a natureza e o ser humano.

\section{c) Percepções Patrimônio Geológico}

O patrimônio Geológico foi identificado pelos atores na questão 12. A questão 13 aborda a conservação do patrimônio geológico e como deveria promover ser promovida.

$\mathrm{Na}$ análise da questão 12 , três pessoas disseram não saber do que se tratava o patrimônio geológico, ou que não sabiam identificar o patrimônio geológico. 12 pessoas deixaram a resposta em branco.

Dos 55 respondentes, os seguintes elementos que constituem o patrimônio geológico foram identificados:

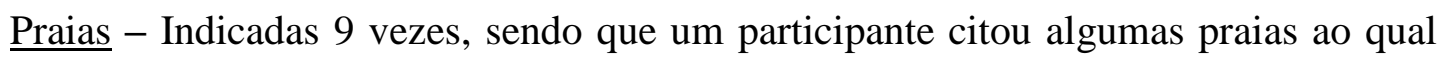
considera patrimônio geológico: "As praias com restinga preservada de diferentes tipos de praias (Fazenda, Brava da Almada e Brava do Camburi dentro do Parque, e outras fora como a praia do costa, Cedro do Sul, Cedro do Centro, Prumirim, Puruba. E no Puruba, em especial a "separando" a praia com formação única".

Zona Costeira - Citada por quatro participantes, sendo que em um dos casos o respondente acrescentou o valor que atribui à zona costeira, “As costeiras, planícies costeiras podem ser considerados Patrimônio Geológico, tanto por sua formação, quanto pela importância dos ecossistemas, biodiversidade e cultura que se desenvolvem sobre ele e em sinergia", e outro inclui as "belezas dos recortes do litoral".

Costão rochoso -5 pessoas.

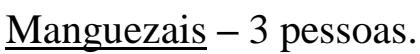


Biodiversidade -8 pessoas relacionaram o patrimônio geológico com a floresta da Mata Atlântica presente na região, considerando sua fauna e flora. 1 pessoa identificou a vegetação do tipo Jundu da praia.

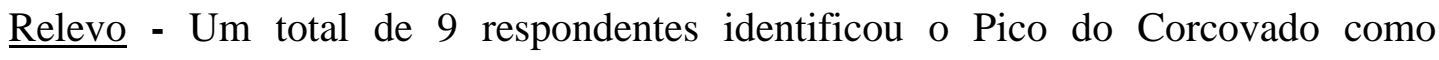
patrimônio geológico, sendo que um deles acrescenta "Gosto muito do Corcovado, por sua formação e por seu visual”. Ainda na categoria do relevo, aparece uma referência ao Pico do Cuscuzeiro, e uma ao Bico do Papagaio. Também se inserem nessa categoria as 12 indicações à Serra do Mar, 8 às montanhas e morros, 2 ao relevo e 1 aos promontórios.

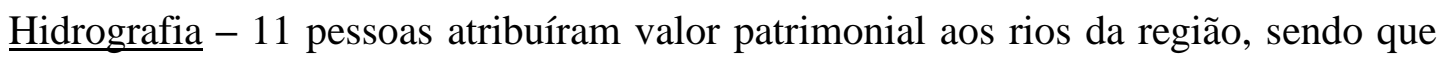
um deles especificou os rios Itamambuca e Prumirim, 11 pessoas se referiram às cachoeiras, sendo a cachoeira da Água Branca indicada por duas pessoas, 1 pessoa identificou as nascentes de água pura, e, por fim, 1 pessoa se referiu aos mares.

$\underline{\text { Rochas }}-11$ pessoas identificaram as rochas da região como patrimônio geológico, sendo que O "Granito Verde Ubatuba" foi especificado entre três delas, considerando também a atribuição dos "cortes de rocha na rodovia" por uma pessoa. Além disso, o substrato marinho foi identificado, acrescentando que este é: "diariamente degradado $e$ impactado pelos arrastos de camarão na região”.

Grutas, Fósseis, solos e sedimentos - Cada um desses elementos foi considerado por um participante.

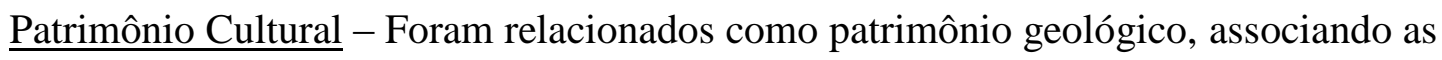
rochas presentes aos bens materiais, como no caso das 2 pessoas que se referiram aos artefatos arqueológicos de pedras que foram trabalhadas pelos homens pré colombianos, identificando inclusive as rochas presentes na vila de Picinguaba. 1 Pessoa identificou o "Parque Arqueológico" de São Sebastião. Além disso, 3 pessoas reconheceram o patrimônio geológico presente nas ruínas da lagoinha, em Ubatuba.

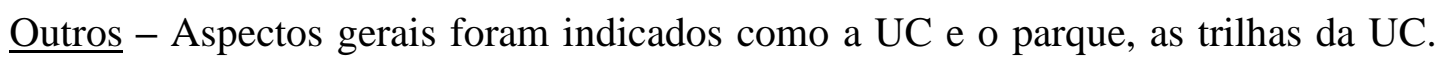
Atribuições quanto à formação geológica da região, aos atrativos turísticos, patrimônios históricos (como culturas e tradições), a interação entre o meio biótico e o abiótico.

Na questão 13, 1 pessoa declarou não saber identificar o patrimônio geológico e 15 pessoas deixaram a resposta em branco. Das 54 pessoas que responderam, foram identificados os seguintes grupos: aquelas que consideram que o patrimônio geológico está ameaçado e indicam as causas das ameaças; aquelas que consideram que está ameaçado e indicam caminhos para sua conservação; aquelas que não o consideram ameaçado, porém indicam caminhos para sua conservação; e aqueles que não consideram as ameaças. 
O patrimônio geológico está ameaçado -12 das 54 pessoas acreditam que o patrimônio está ameaçado ou parcialmente ameaçado, reconhecendo isso nas mudanças dos rios, por exemplo, e atribuindo os fatores de ameaças à atuação do homem, ao descumprimento da lei, ocupação por casas em áreas irregulares, construções nos costões rochosos, má gestão em relação às áreas de risco, desmatamento, poluição, erosão costeira, queimadas e atividades mineradoras.

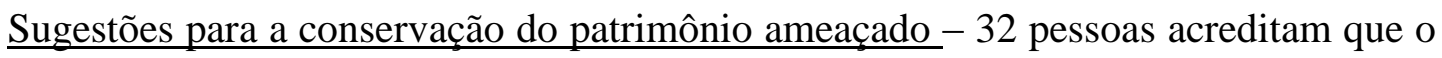
patrimônio geológico está ameaçado e indicam caminhos para sua conservação apontando como fatores de ameaça a especulação imobiliária, o turismo, a revisão do zoneamento ecológico econômico, a falta de conhecimento a respeito do tema, a duplicação da rodovia Mário Covas e fragilidade na gestão da UC. Dessa forma, os caminhos sugeridos se relacionam à conscientização e sensibilização da comunidade e dos turistas, considerando também a inserção dessa temática nas escolas e nos programas de educação ambiental, como forma de valorizar e divulgar essas informações. Outros caminhos apontam o viés normativo e fiscalizatório, sugerindo contratação de pessoas para realizar a proteção desses elementos, a criação de leis mais rígidas, a constante fiscalização dessas áreas, o congelamento de áreas contra a chegada de novas pessoas e retirada de pessoas irregulares. Acrescenta-se também às sugestões o diálogo mais participativo, considerando a participação em reuniões públicas, a exemplo, reuniões municipais para deliberação de empreendimentos, e o fortalecimento do conselho gestor da UC.

O patrimônio geológico não está ameaçado, porém há indicações de caminhos para $\underline{\text { sua conservação }}$ - 4 pessoas disseram que o patrimônio geológico não está ameaçado, entretanto indicaram a criação de políticas de manejo, aumento de guardas parque para o controle dos turistas e, a prática de denúncias por parte dos cidadãos.

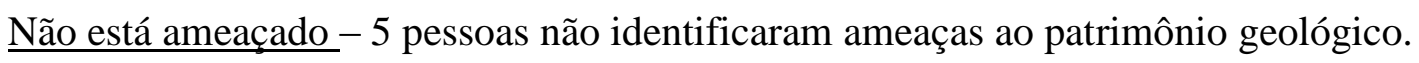

\subsection{Ensino de Geociências e Estratégias de Geoconservação - Aprendizagem Social}

\subsubsection{Ensino de Geociências}

As propostas de ensino de Geociências e, valorização e divulgação da geodiversidade com base na Aprendizagem Social, por meio dos cursos de formação de monitores do PESM e de professores da rede pública, tiveram como objetivo proporcionar o reconhecimento da 
geodiversidade local e possibilitar a participação desses atores na elaboração de estratégias de geoconservação.

O curso consistiu em um processo de ensino e divulgação, e também, em etapa de coleta de dados da pesquisa. Da forma com que foi organizado e ministrado e, as pessoas que envolveu, possibilitou criar processo voltado para a Aprendizagem Social.

Algumas análises foram realizadas no sentido de perceber qual foi a contribuição do curso para o ensino das Geociências, e, em que medida houve reconhecimento da geodiversidade e do patrimônio geológico local. Destacam-se a seguir alguns elementos importantes analisados durante o curso:

\section{Conteúdos de Geociências}

A organização dos conteúdos abordados durante o curso teve como base uma abordagem inicial dos conhecimentos em Geociências além de analisar de forma crítica os conflitos socioambientais e construir coletivamente as estratégias de geoconservação. Os objetivos norteadores foram: promover o entendimento dos conceitos de geodiversidade, patrimônio geológico e geoconservação; promover a valorização e divulgação da geodiversidade e do patrimônio geológico local; relacionar o patrimônio natural, histórico e sociocultural da região.

Dessa forma, considerando os elementos da geodiversidade, foram abordados os seguintes aspectos:

- A conservação da natureza;

- Principais referências na área da Geoconservação;

- Definição de geodiversidade (abordando individualmente o que são minerais, rochas (ígneas, sedimentares e metamórficas), fósseis, solo e processos de intemperismo, erosão e transporte, e, gênese e evolução da paisagem);

- Relação com os elementos da geodiversidade no ambiente local, considerando também as interações socioambientais e ecológicas;

- Valores da geodiversidade (abordando individualmente os valores intrínseco, educativo e científico, cultural, estético, econômico e funcional);

- Ameaças à geodiversidade;

- Definição de patrimônio geológico (exemplificando localmente);

- Estratégias de geoconservação. 
Os trabalhos de campo foram realizados nos curso contribuindo com a apropriação dos conceitos apresentados durante as aulas dialogadas. Como etapa pré-campo ocorreu o reconhecimento das trilhas e percursos identificando suas potencialidades didáticas e a acessibilidade. Essa etapa proporcionou identificar no local as relações que seriam estabelecidas com os conteúdos das Geociências.

As Figuras 35, 36 e 50 ilustram os trabalhos de campo realizados nos cursos com os monitores ambientais e com os professores. Essa atividade proporcionou maior motivação para a compreensão e reconhecimento da geodiversidade e do patrimônio geológico, emergindo diversos questionamentos e reflexões ao longo do percurso.

A atividade promoveu também maior interação entre pesquisadores e participantes do curso, favorecendo as articulações entre a formação teórica proporcionada durante as aulas dialogadas e os aspectos observados em campo. Assim, a resposta à atividade foi positiva, observando as problematizações e reflexões cultivadas durante a atividade, integrando o olhar geocientífico à experiência dos participantes.

Através da abordagem interdisciplinar e integradora, os principais temas abordados durante os trabalhos de campo foram:

- Interação biodiversidade/geodiversidade (ecossistemas, costões rochosos, densidade e características da Mata Atlântica na Serra do Mar);

- Tipos de solo;

- Dinâmica fluvial e marinha;

- Formação da areia da praia;

- Capacidade de transporte dos rios;

- Formação das ilhas

- Abertura e fragmentação do Gondwana e colocação diques

- Formação da Serra do Mar

- Interações socioambientais e possíveis conflitos sociais.

A atividade de campo possibilitou aos participantes estabelecer conexões entre teoria e prática, considerando os conhecimentos dos atores locais sobre o ambiente.

A preparação para o campo também contou com o auxílio do material elaborado pelo NAP GeoHereditas, como painéis interpretativos do roteiro geoturístico do litoral norte. No centro de visitantes de Picinguaba encontra-se o painel "Das Rochas aos Grãos de Areia", e 
no centro de visitantes de Caraguatatuba, "Como as Pedras Rolam". A ludicidade e interatividade presente nos painéis, representadas em suas figuras, ilustrações, esquemas e textos explicativos, proporcionaram melhor compreensão dos conceitos, considerando também a abordagem e interpretação dos aspectos da geodiversidade observados em campo.

Do ponto de vista da divulgação, o curso reconheceu a importância da formação desses atores locais como uma etapa das estratégias de geoconservação, considerando também o papel desses atores sociais na difusão desses conhecimentos.

No caso dos monitores ambientais, teve-se em atenção às possibilidades de inclusão dos conteúdos das Geociências e dos aspectos da geodiversidade na sua prática (monitoramento das trilhas e visitas guiadas, principalmente), que mantém forte interação com o ecoturismo e a Educação Ambiental. Em relação aos professores, as atividades foram orientadas tendo em vista a possibilidade da inserção dessa temática nos projetos escolares.

No caso dos gestores que participaram do curso e outros atores relacionados com a gestão ambiental, teve-se em atenção o alcance dessas informações em influenciar na postura gestora desses atores, considerando ainda que participam de processos de licenciamento ambiental, de renovações no plano de manejo e no zoneamento do parque. 

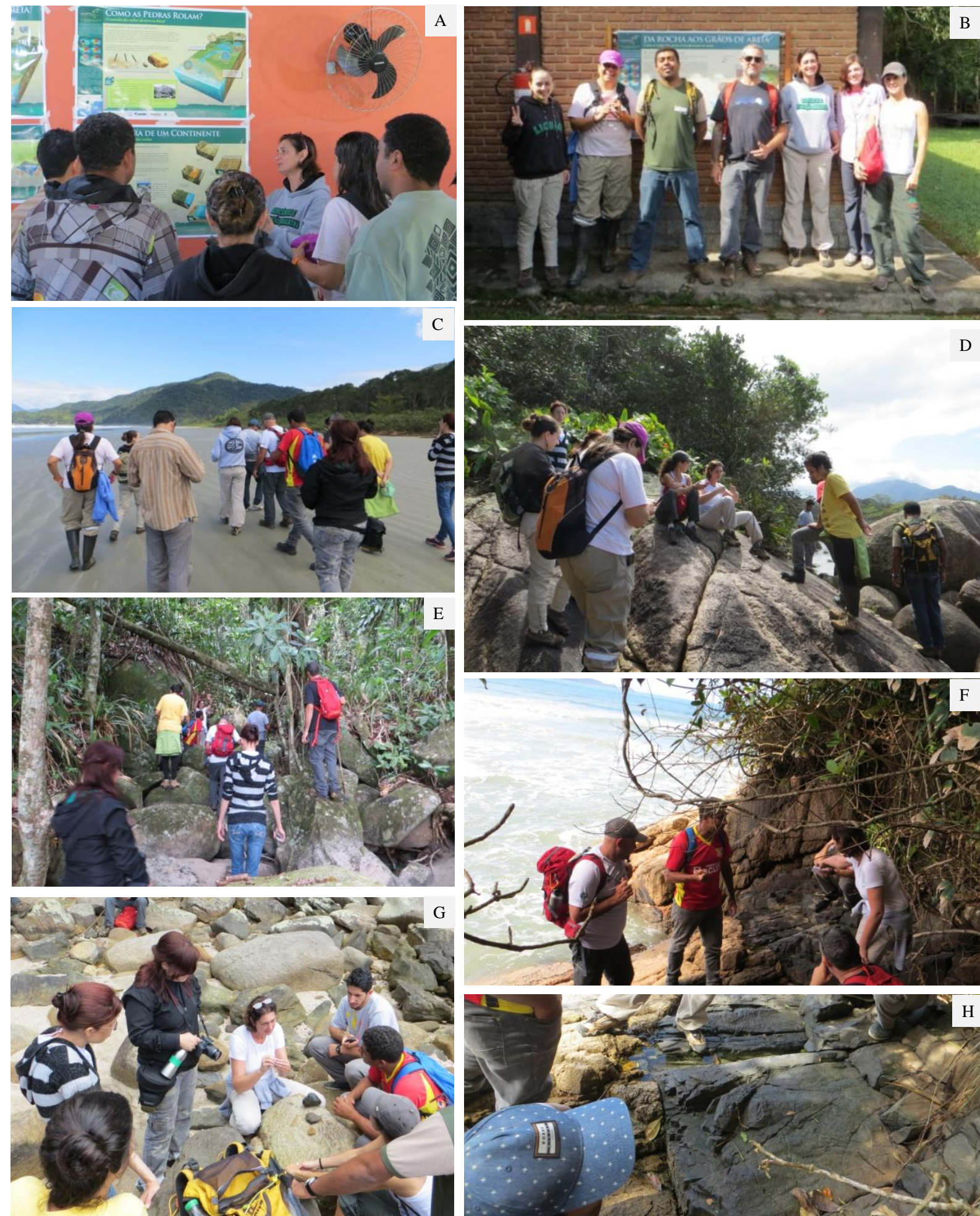

Figura 35 - Trabalho de campo do curso "Estratégias de Geoconservação no PESM" no núcleo Picinguaba. A) preparação do trabalho de campo utilizando os painéis interpretativos; B) participantes do curso; C) trecho do percurso na praia da Fazenda, com detalhe para as marcas de ondulações na areia, e a paisagem das escarpas da Serra do Mar; D) explanação sobre as fraturas observadas no costão rochoso a noroeste da praia da Fazenda; E) abordagem sobre a dinâmica fluvial e o transporte de blocos rochosos; F e H) explanação sobre a colocação dos diques máficos na região; G) grupo durante atividade no Saco das Taquaras (Praia das Conchas) (Fotos: Eliana Mazzucato). 

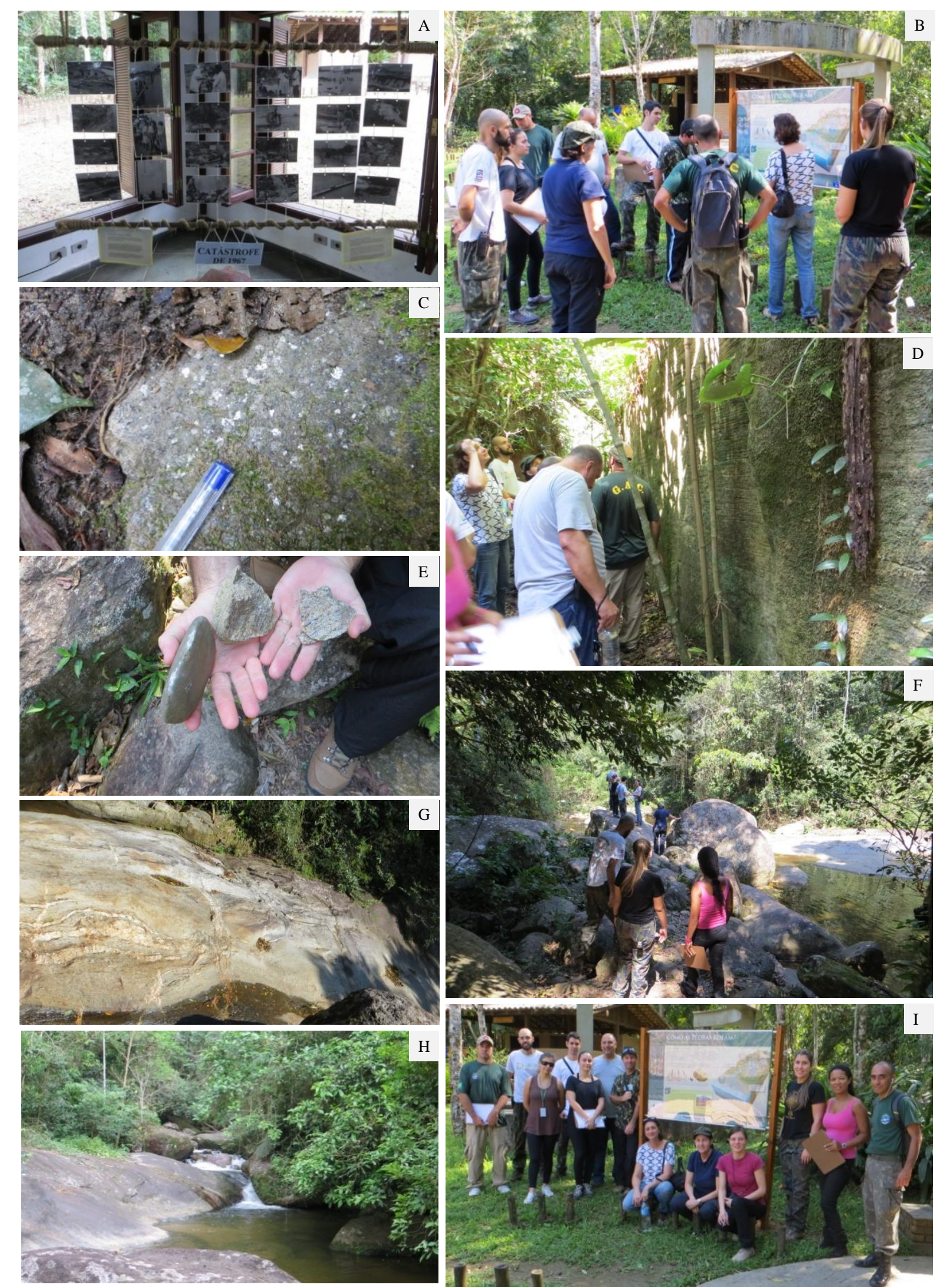

Figura 36 - Trabalho de campo do curso "Estratégias de Geoconservação no PESM" no núcleo Caraguatatuba. A) fotos da "Catástrofe de 1967" no centro de visitantes do núcleo Caraguatatuba; B) explanação utilizando o painel interpretativo; C) minerais de mica observados nos afloramentos ao longo da trilha; D) explanação da relação geodiversidade e biodiversidade; E) análise dos diferentes tipos de rochas e estágios de alteração; F) explanação sobre a "Catástrofe de 1967" através dos blocos rochosos transportados pelo rio Santo Antônio; G) detalhe veios de quartzo presentes no leito rochoso do rio; H) blocos heterogêneos no rio Santo Antônio; I) grupo de participantes (Fotos: Eliana Mazzucato). 


\subsubsection{Aprendizagem Social}

O referencial teórico da Aprendizagem Social e as metodologias utilizadas no curso tiveram importante contribuição para a participação social. Como destacou Jacobi (2011) pensar a participação requer num primeiro momento o "acesso à informação e sua difusão com o objetivo de ampliar o envolvimento do cidadão" (JACOBI, 2011, p. 13).

O fortalecimento da participação decorreu das informações articuladas nas aulas e também das atividades didático pedagógicas desenvolvidas, utilizando as metodologias participativas para a elaboração de estratégias de geoconservação. A análise desses elementos será realizada a seguir.

\subsubsection{Metodologias participativas na elaboração de estratégias de geoconservação}

Nessa sessão serão analisados os dados produzidos através das metodologias participativas desenvolvidas durante os cursos. As metodologias participativas foram abordadas no contexto da Aprendizagem Social e influenciaram o processo formativo promovendo a participação das pessoas em torno da questão da geoconservação. As ferramentas apresentadas trazem reflexões sobre os referenciais teóricos e sua aplicação na realidade local, como: a) aperfeiçoar a compreensão dos problemas inter-relacionados e complexos em diferentes espaços e contextos (CRAPS, 2003); (b) contribuir para que diferentes atores compreendam melhor as percepções dos outros (WALS, 2007) sobre os problemas socioambientais (BACCI et al., 2013).

Ao abordar o conceito de Aprendizagem Social para a elaboração de estratégias de geoconservação buscou-se contribuir para que os participantes dos cursos, a partir da aplicação das ferramentas participativas, pudessem: aprofundar seus conhecimentos e ampliar caminhos de diálogo; estabelecer laços de confiança e cooperação; administrar e resolver conflitos e buscar soluções conjuntas, que sejam técnica e socialmente adequadas (HARMONICOP, 2003).

Assim, a análise focou na compreensão que os participantes tiveram em relação à temática e às questões levantadas, bem como sua interação, a partir do reconhecimento e identificação da geodiversidade e do patrimônio geológico local. A partir disso, foram elaboradas estratégias de geoconservação por meio de conexões entre a formação teórica do curso e a vivência de cada um, atentando para as especificidades socioambientais locais. 
A análise exploratória foi realizada a partir das seguintes atividades: a) Valores/ameaças/estratégias de geoconservação, b) World Café e c) Mapeamento Socioambiental.

\section{a) Atividade - Valores/Ameaças/Estratégias}

Essa atividade teve como proposta a reflexão sobre os valores, ameaças e estratégias a partir da abordagem teórica para a geoconservação. A atividade se desenvolveu a partir da escolha ou indicação de um local (possível geossítio) na região, e, a partir desse local, identificar seus valores e ameaças, no sentido de propor estratégias de geoconservação. A atividade foi realizada em grupos, valorizando o diálogo, as experiências individuais e a participação.

Em Caraguatatuba, a atividade foi realizada em um único grupo com todos os participantes. Todos contribuíram para o levantamento e definição dos valores, ameaças e estratégias. Os locais escolhidos pelos participantes foram os geossítios: "Gruta que Chora" (localizado na Praia da Sununga em Ubatuba) e "Piscina Natural" (localizado ao final da trilha do Jequitibá, em Caraguatatuba).

Em Picinguaba, os participantes se dividiram em três grupos, sendo que cada grupo desenvolveu a atividade separadamente. Os grupos poderiam utilizar os dados do inventário realizado em Ubatuba (SANTOS, 2014) e selecionar os locais a partir de uma lista já existente, ou poderiam escolher um geossítio de acordo com a percepção do próprio grupo. Dessa forma, os geossítios identificados foram: "Gruta que Chora", "Gruta do Pirata", "Cachoeira do Véu de Noiva" (Ruínas da Lagoinha), "Pico do Massaguaçu”, "Costão Rochoso da Brava de Itamambuca" e "Pico do Caxambu" (Itamambuca).

Essa atividade foi importante para a sistematização dos conteúdos desenvolvidos durante o curso, contribuindo também para a avaliação por parte dos pesquisadores da proposta de formação. Assim, o aprendizado e a apropriação dos conhecimentos pelos participantes foram percebidos à medida que se expressavam com novo vocabulário adquirido e relatavam locais conhecidos a partir de suas experiências no lugar. Nesse sentido, os participantes relacionaram os conteúdos do curso à sua realidade local, selecionando de forma consensual os pontos que reconheceram como geossítios, atribuindo assim valor patrimonial a esses locais.

O geossítio "Gruta que Chora" (Figura 37) foi o primeiro a ser selecionado pelos participantes do curso em Caraguatatuba. Esse geossítio está inserido no Inventário do 
Patrimônio Geológico de Ubatuba (SANTOS, 2014), localizado na Praia da Sununga, a 15 km ao Sul do centro de Ubatuba.

Segundo Santos (2014) a gruta que chora é uma caverna com cerca de $1 \mathrm{~m}$ de abertura, formada em costão rochoso cujo material predominante é um granito foliado porfirítico. Sua origem está associada à queda de blocos a partir da fratura principal de orientação N45, que posteriormente foi preenchida por dique basáltico de aproximadamente $3 \mathrm{~m}$ de altura. A autora destaca que a caverna está sujeita à ação do intemperismo e dos processos erosivos que contribuem para a formação dessas feições, bem como favorecem o aumento e preenchimento da caverna.
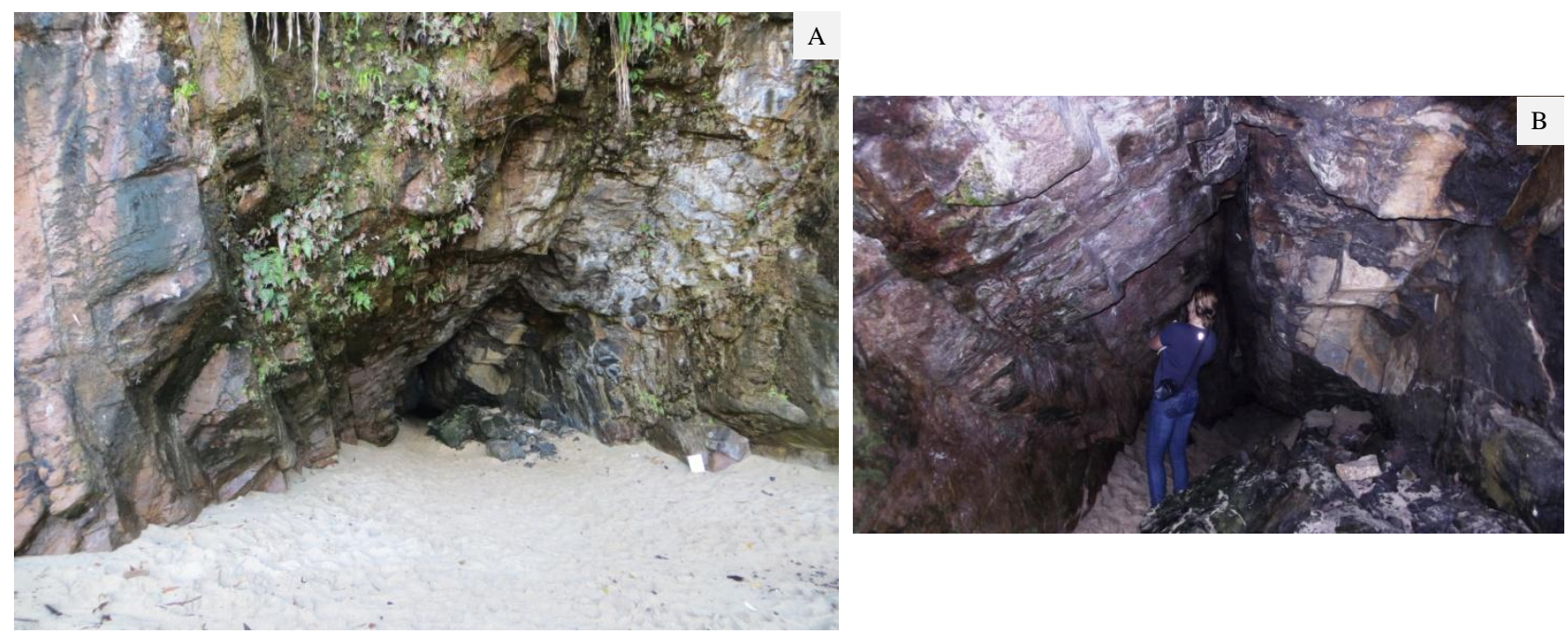

Figura 37 - Gruta que Chora na praia da Sununga, Ubatuba (SP). A) entrada da Gruta que Chora (Foto: Fernanda Reverte); B) interior da gruta que chora, com destaque para o fenômeno de gotejamento e das fraturas presentes na gruta (Foto: Vanessa Costa Mucivuna).

Os participantes já haviam demonstrado interesse nesse geossítio durante as aulas, demandando a apresentação prévia de como a caverna foi formada. Tal interesse relaciona-se à existência de uma lenda em torno da gruta, que conta que quando as pessoas se aproximam da entrada da gruta, gotas começam a cair de suas paredes como se ela estivesse chorando (Anexo H). É um ponto turístico bastante conhecido em Ubatuba.

Os valores, ameaças e estratégias identificados para o geossítio podem ser observados na Figura 38. 


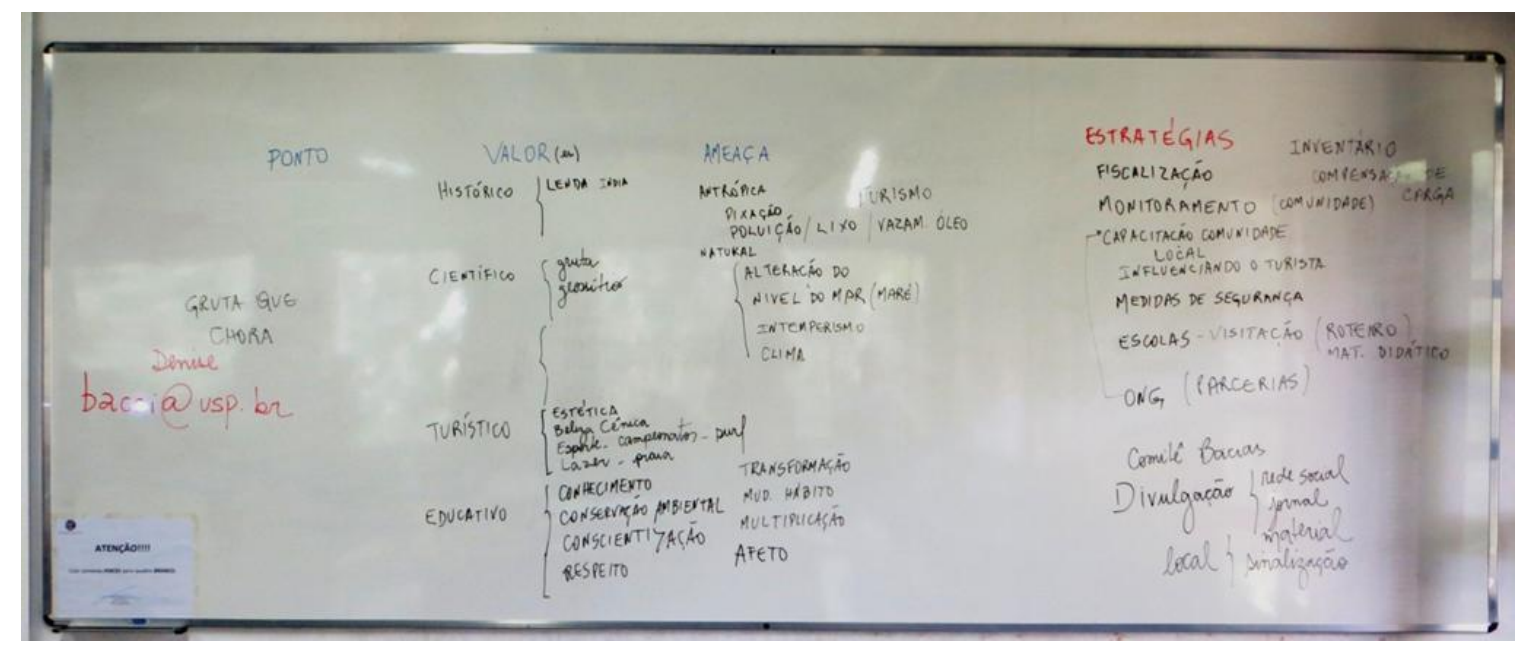

Figura 38 - Atividade valores/ameaças/estratégias de geoconservação para o geossítio "Gruta que Chora" realizada no núcleo Caraguatatuba.

Os valores apresentados para o geossítio remetem ao aspecto histórico, relacionado à lenda da gruta, que representa um sentido cultural e de identificação para com o lugar. A lenda faz parte do imaginário desses habitantes, que a consideram como parte da história do lugar. Através da lenda contada por seus familiares e amigos esses indivíduos dão significado ao fenômeno geológico de gotejamento, que na realidade ocorre devido à percolação da água nas fraturas da rocha (Figura 37B).

Para além do fator histórico-cultural, os participantes ressaltaram seu valor científico, pois se constitui em um geossítio do inventário do patrimônio geológico devido à formação da caverna em rocha granítica. Foi reconhecido que a lenda associada ao fenômeno geológico contribui para o grande interesse turístico, possuindo também valor estético, além de ser um local para a prática de esportes, como campeonatos de surf.

Além disso, os participantes destacaram o valor educativo, identificando os conteúdos relacionados à esse geossítio, com alto potencial para o desenvolvimento de atividades de ensino. Nesse sentido, uma abordagem educativa na gruta pode favorecer a sensibilização e conscientização quanto à relevância do patrimônio geológico.

As ameaças apontadas convergem para a identificação dos aspectos naturais e antrópicos, como as mudanças do nível do mar relacionadas às marés e a própria ação do intemperismo. Já em relação aos aspectos antrópicos, as ameaças são associadas com o turismo desordenado, a ocorrência de pichação de afloramentos, a poluição da praia, principalmente relacionada com o despejo inadequado de resíduos e as ocorrências de vazamentos de óleo.

As estratégias de geoconservação foram elaboradas a partir desses fatores levantados, de valores e ameaças ao geossítio. Os participantes identificaram a necessidade de realizar o 
inventário, ou de atualizá-lo, em seguida foi considerada a perspectiva institucional para a geoconservação através do fortalecimento da fiscalização e do monitoramento, porém, com a inclusão da participação da comunidade nessas etapas. Nesse sentido, as comunidades locais também foram destacadas, com os quais seria ideal divulgar essas informações, e também, estabelecer e fortalecer parcerias com ONGs e com o comitê de bacias hidrográficas para a conservação do patrimônio e para atuar com os turistas.

Também foi apontada a necessidade de criar medidas de segurança, para o ordenamento do turismo e garantia da sustentabilidade do geossítio. Destacaram-se a necessidade de aproximar essa temática das escolas, favorecendo a visitação dos geossítios e criando roteiros e materiais didáticos, considerando também medidas de divulgação a partir de redes sociais, jornais e outros materiais e a instalação de sinalizações nesses geossítios.

Observa-se que os principais eixos norteadores das estratégias de geoconservação foram a realização do inventário, a proteção institucional, a proteção física que ordene a visitação, e, o desenvolvimento de medidas de valorização e divulgação que atuem junto com as escolas. Nesse sentido, os participantes ressaltaram o papel das comunidades locais e o fortalecimento das parcerias, sendo importante o reconhecimento desse patrimônio pelas comunidades locais que podem atuar na geoconservação associada às atividades de turismo, com destaque para o turismo de base comunitária.

As reflexões estiveram centralizadas na questão educativa, visto que o PESM possui alto potencial didático, congregando elementos importantes para as diversas áreas do ensino (Ciências Humanas, Biológicas e da Terra). As estratégias educativas apontadas se baseiam na educação ambiental, situando as atividades educativas em um contexto de conscientização, sensibilização e transformação do indivíduo, com mudanças de hábitos e posturas.

Seguido da "Gruta que Chora", os participantes do curso de Caraguatatuba indicaram a "Piscina Natural" como geossítio, que pode ser observada na Figura 39. A piscina natural é o ponto final da trilha do Jequitibá, localizada na sede do NuCar. A piscina natural corresponde ao curso médio do rio Santo Antônio, que contém blocos rochosos de tamanhos heterogêneos. 

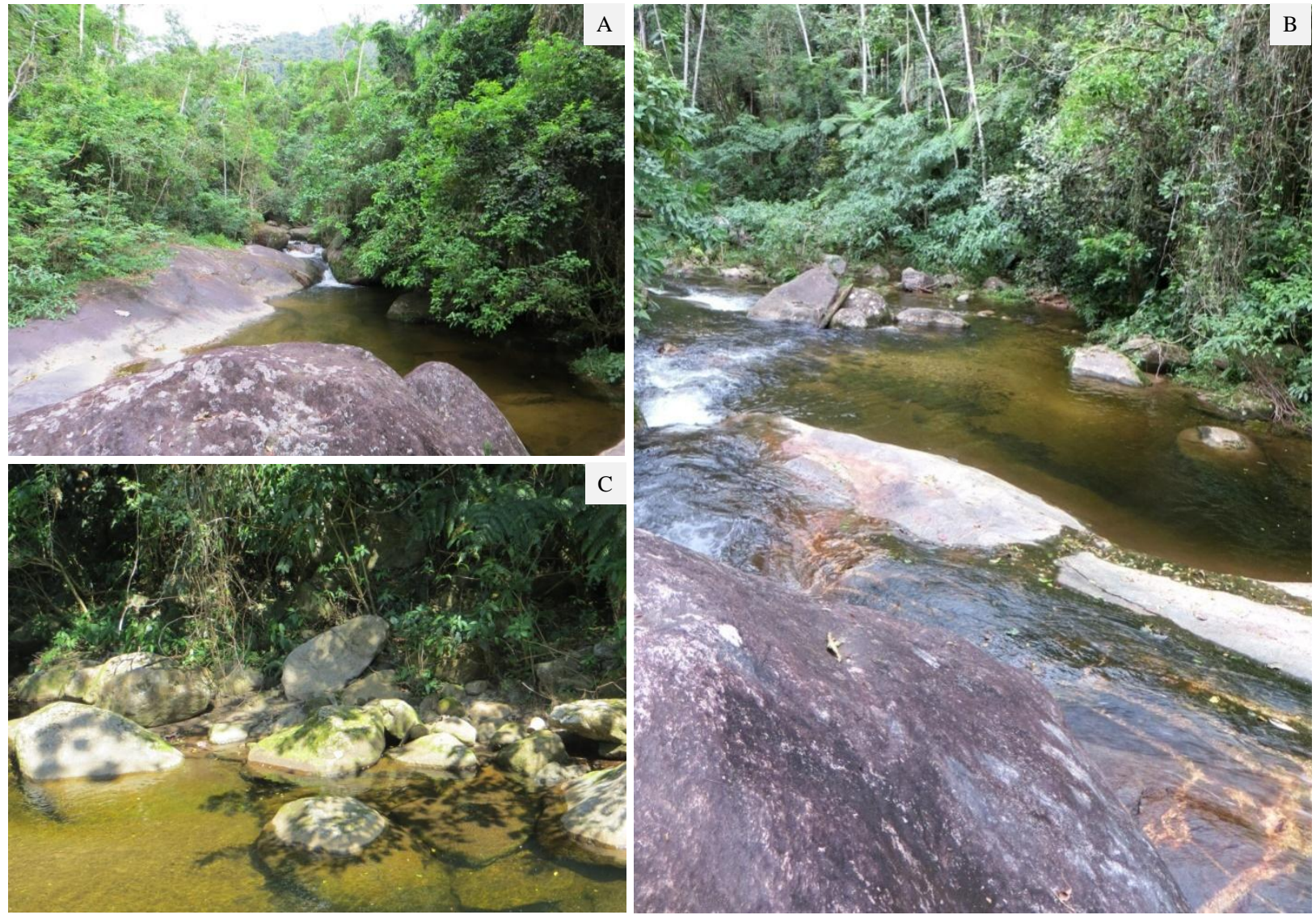

Figura 39 - Geossíto "Piscina Natural" localizado na trilha do Jequitibá, do núcleo Caraguatatuba do PESM. A) rio Santo Antônio, B) detalhe dos veios de quartzo no leito rochoso do rio Santo Antônio; C) detalhe blocos heterogêneos no leito do rio Santo Antônio (Fotos: Eliana Mazzucato).

A diversidade de tamanhos e formas para os blocos rochosos no rio Santo Antônio está associada ao grande evento erosivo que marcou o município de Caraguatatuba em 1967, chamado de "Catástrofe de 1967". Naquela época, houve uma chuva bastante intensa e recorrente, ocasionando os movimentos de massa e escorregamentos nas encostas da Serra do Mar que acabaram provocando inundações no município.

A intensidade desse processo ocasionou o transporte de todo tipo de material presente na Serra como camadas de solo, blocos rochosos menores e blocos de grandes extensões observados no leito do rio. Esse ponto possui relevância científica por representar os movimentos de massa que marcaram a cidade, além disso, é possível observar o leito rochoso do rio, composto principalmente por gnaisses, apresentando veios de quartzo.

Os participantes reconhecem a importância do lugar, sendo já parte de roteiros educativos promovidos pelo PESM. As ações do núcleo GeoHereditas promoveram a divulgação da relevância geocientífica do local através de cursos de capacitação para os monitores ambientais em 2014. Além disso, o GeoHereditas elaborou um roteiro geointerpretativo para a trilha do Jequitibá que foi disponibilizado para os participantes, como 
forma de orientá-los na abordagem sobre a geodiversidade e o patrimônio geológico durante as visitas monitoradas na trilha.

O reconhecimento desse local como geossítio reafirma a importância dessas ações prévias, promovendo mudanças na visão dos monitores em relação ao lugar. A síntese dos valores, ameaças e estratégias para esse geossítio pode ser observados na Figura 40.

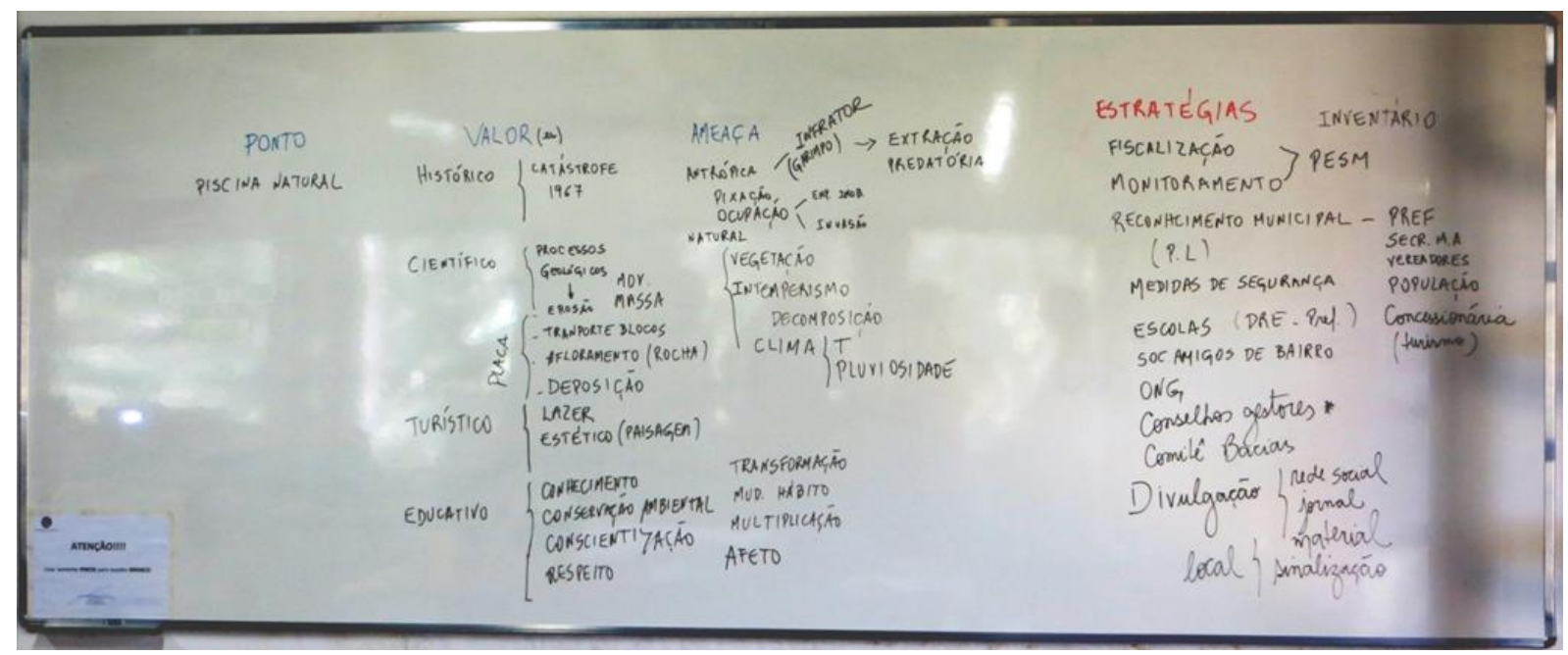

Figura 40 - Atividade valores/ameaças/estratégias de geoconservação para o geossítio "Piscina Natural" realizada no núcleo Caraguatatuba (Foto: Eliana Mazzucato).

O valor apresentado para o geossítio refere-se principalmente ao seu aspecto histórico, da "Catástrofe de 1967", fato que esteve muito presente nas reflexões durante o curso e durante o desenvolvimento do roteiro geointerpretativo. Para o valor científico, os monitores se referiram aos processos geológicos, sendo eles os movimentos de massa, a erosão, transporte e deposição de materiais. Além disso, foram exploradas as características litológicas dos afloramentos e blocos rochosos no leito do rio. $\mathrm{O}$ valor turístico apresentado estava associado às atividades de lazer, relacionadas à alta visitação, como a possibilidade de se banhar no rio, e ao valor estético (paisagístico) do lugar.

Os valores educativos foram similares aos apontados no geossítio "Gruta que Chora", com possibilidades de relacionar os aspectos observados em campo aos conteúdos abordados pelas Geociências e sua interação com a biodiversidade.

As ameaças são também muito similares, com ressalvas ao modo de ocupação da região que sofre um processo de expansão imobiliária, além da crescente ocupação de áreas de risco. Também foram relatadas atividades de uso e exploração de materiais geológicos, como extração de areia e exploração de rochas para revestimento. 
No âmbito das estratégias alguns aspectos novos emergiram, relacionados ao fato de se tratar de um geossítio que faz parte do trabalho e vivência da maioria dos participantes, além de se localizar no município de Caraguatatuba. No sentido institucional, os participantes chamaram a atenção para a necessidade de reconhecimento, por parte da prefeitura, da secretaria do meio ambiente, dos políticos e da população, considerando também as concessionárias de turismo. Além disso, salientou o papel do PESM nas etapas de fiscalização e monitoramento.

O grupo 3 do curso em Picinguaba também selecionou a "Gruta que Chora" como geossítio, contribuindo, portanto, com os aspectos observados em Caraguatatuba. Esse grupo utilizou uma representação mais esquemática como pode ser observado na Figura 41 para considerar os valores, ameaças e estratégias desse geossítio.

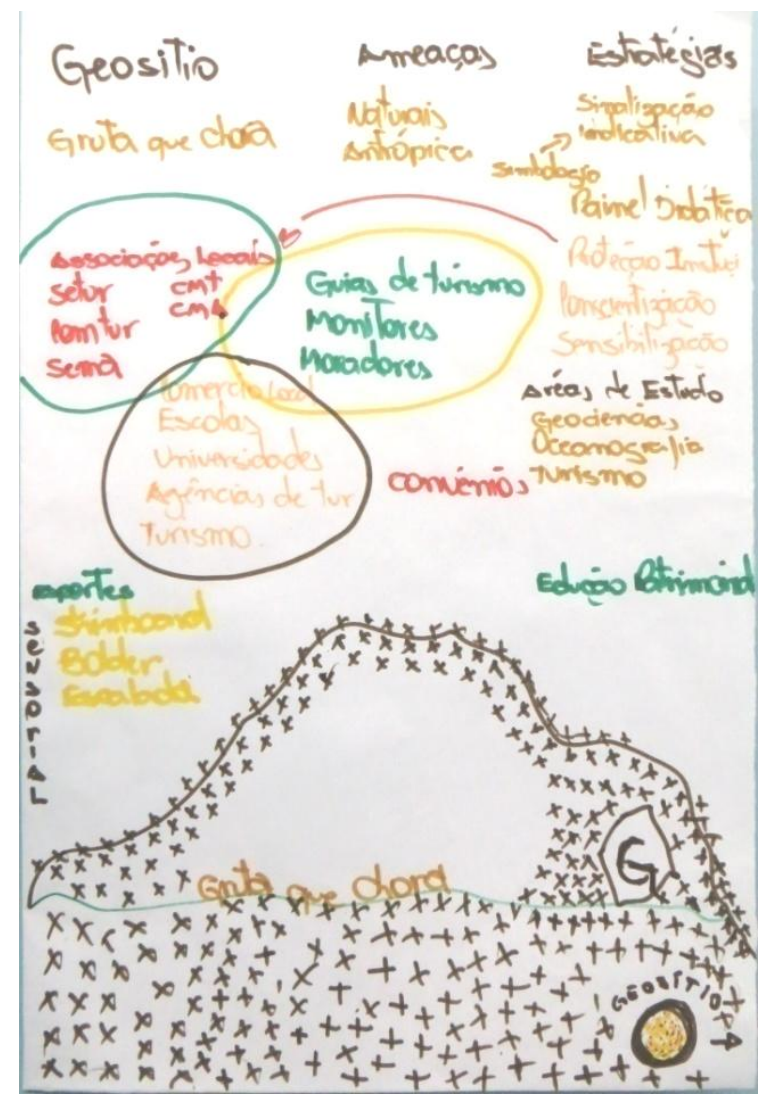

Figura 41 - Atividade valores/ameaças/estratégias realizada pelo grupo 3 em Picinguaba (Ubatuba - SP) para o geossítio "Gruta que Chora".

No esquema apresentado pelo grupo, é considerada a união entre Instituições relacionadas à gestão do território (associações locais, Secretaria de Turismo de Ubatuba (Setur), Companhia Municipal de Turismo de Ubatuba (Comtur), Secretaria de Meio Ambiente de Ubatuba (Sema), Conselho Municipal de Turismo de Ubatuba (CMT)), 
atividades de educação e turismo (comércio local, escolas, universidades, agências de turismo e turismo) e os atores locais (guias de turismo, monitores e moradores). Nota-se que há valorização da gestão integrada e participativa do território para a conservação do patrimônio geológico.

Observa-se também que houve uma preocupação em representar a geodiversidade local, como o material geológico da gruta e a litologia presente em subsuperfície.

No âmbito dos valores e ameaças, os aspectos levantados se assemelham àqueles indicados durante a atividade em Caraguatatuba. Entretanto, em relação às estratégias, destacou-se a gestão integrada supracitada, além de apontar as necessidades de fortalecer o estudo desses locais nas áreas de Geociências, Oceanografia e Turismo; instalar painéis didáticos; promover a sensibilização e conscientização do público; e, promover a educação patrimonial.

O grupo inovou também ao propor a criação de uma simbologia própria como indicativo dos geossítios. Essa questão surgiu pela observação dos participantes em relação às sinalizações de patrimônio cultural e patrimônio natural, que poderiam ser consideradas para a criação de uma sinalização para o patrimônio geológico.

O Grupo 4 apresentou a "Gruta do Pirata" como geossítio (Figura 42). A Gruta do Pirata localiza-se próximo à Praia das Sete Fontes, na Ponta Grande, cerca de 16 km a sul do centro de Ubatuba. A unidade geológica descrita para esse ponto de acordo com o mapa geológico (Figura 10) é o Charnockito Ubatuba. A síntese das propostas para esse geossítio pode ser observado na Figura 43. 

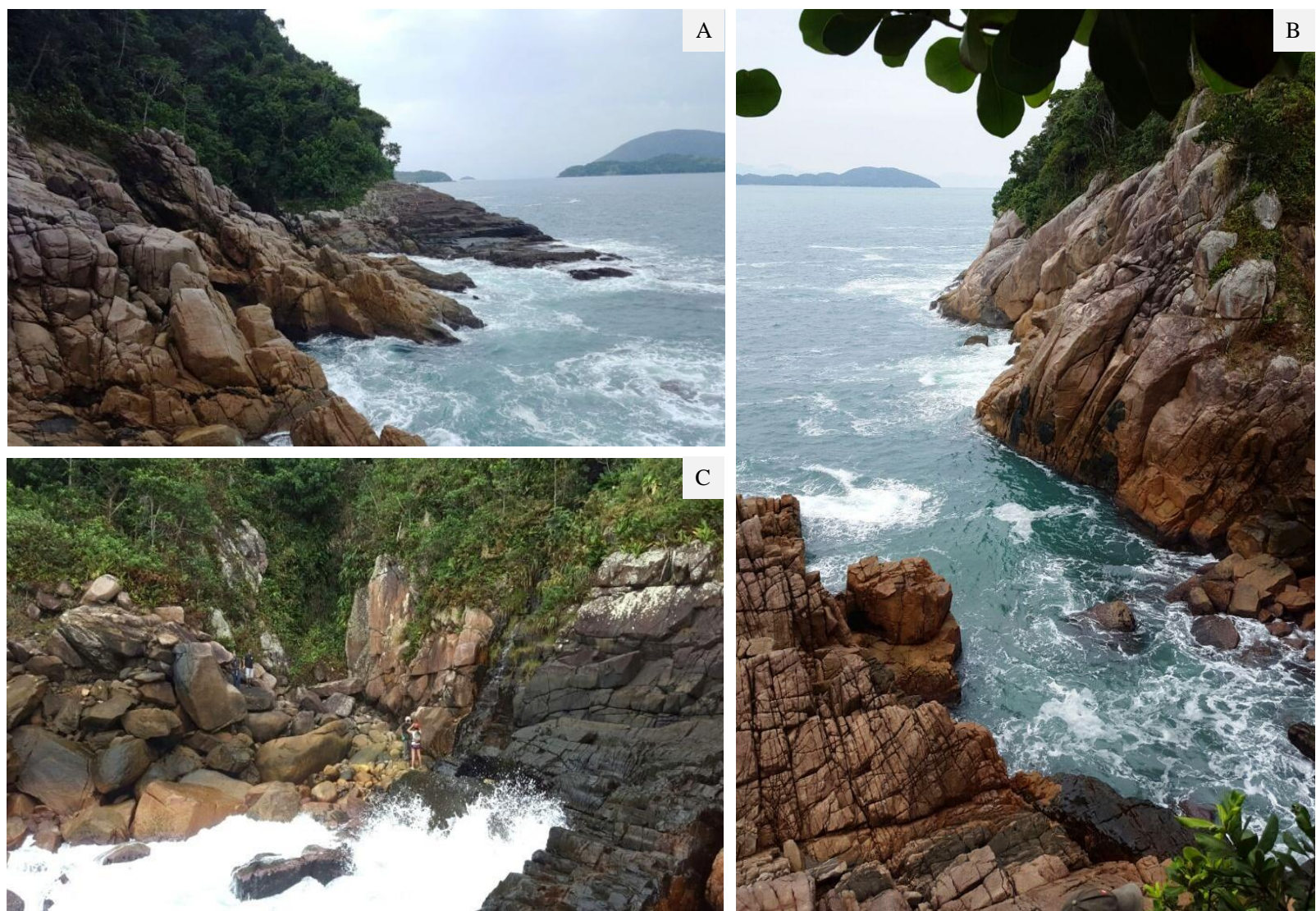

Figura 42 - Geossítio "Gruta do Pirata" identificado pelos participantes do curso, localizado próximo à Praia das Sete Fontes (Ubatuba - SP). A) vista lateral do local conhecido como "Gruta do Pirata"; B) vista de cima da "Gruta do Pirata", com destaque para o conjunto de fraturas C) entrada da gruta do Pirata com destaque para o dique (Fotos: Roberto Peres).

\begin{tabular}{|c|c|c|}
\hline GEOSSITTIO & AMEACAS & ESTRATÉGIAS \\
\hline 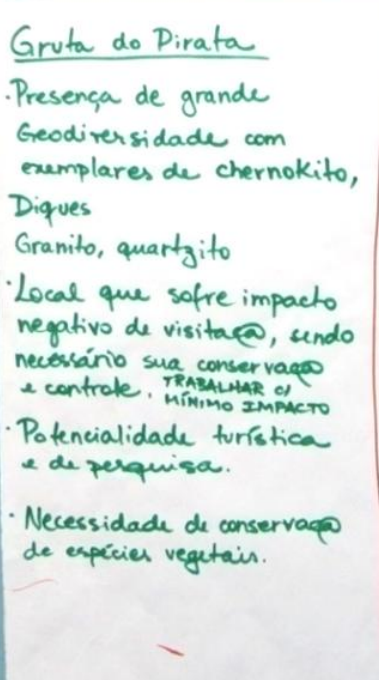 & $\begin{array}{l}\text { - Degradaca do local e } \\
\text { acessos por turismo desordena- } \\
\text { do de massa } \\
\text { - Lixo } \\
\text { - pisoteamento } \\
\text { - Local isolado de difíil } \\
\text { acesso: risco de acidentes } \\
\text { - Propriedade particular } \\
\text { Ameaca de fechamento } \\
\text { dos acessos. }\end{array}$ & 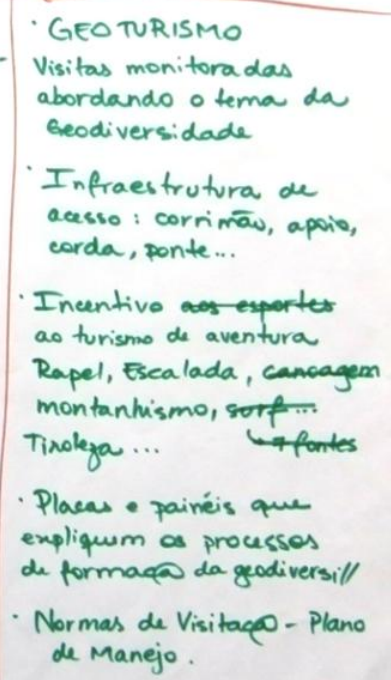 \\
\hline
\end{tabular}

Figura 43 - Atividade valores, ameaças e estratégias do grupo 4 em Picinguaba (Ubatuba - SP) para o geossítio "Gruta do Pirata". 
A escolha de um local que não está presente no inventário do Patrimônio Geológico de Ubatuba demandou uma maior descrição da importância do geossítio por parte dos participantes, realizando essa interpretação sem o auxílio de referências sobre o local ${ }^{16}$. Verificou-se que a unidade litológica presente nesse geossítio é o Charnockito Ubatuba (Figura 10).

Os valores para esse geossítio de acordo com os participantes foram:

- Científicos: Presença de grande geodiversidade, com exemplares de Charnockito Ubatuba, além disso, apontaram a presença de diques, rochas graníticas e quartzito. Foi reconhecido assim como potencial ponto para a realização de pesquisas científicas;

- Turístico: Grande potencial para visitação, em um roteiro que associa praia, trilhas em meio à mata e a formação da gruta;

- Suporte para a biodiversidade: presença de rica biodiversidade associada aos costões rochosos.

As ameaças encontradas se relacionam a visitação do geossítio de forma desordenada, ou ao turismo de massa, que promove o descarte inadequado de lixo, além de favorecer a movimentação dos blocos pelo pisoteamento. Além disso, por ser um local de difícil acesso, possui risco de acidentes. Esse grupo observou que o local é uma propriedade privada, portanto, a possível limitação de acesso para a região foi percebida pelo grupo como uma ameaça ao patrimônio geológico.

As estratégias delineadas foram:

- Geoturismo: Possibilidade de ordenar o turismo na região, acrescentando a perspectiva da geodiversidade nas visitas monitoradas;

- Infraestrutura de acesso e normas de visitação: As melhorias nas condições de acesso proporcionam uma atividade turística planejada, no sentido de garantir a segurança dos visitantes e o mínimo impacto ao geossítio;

- Incentivo ao turismo de aventura: associar a valorização do geossítio à prática de atividades como rapel, escalada, montanhismo e tirolesa;

- Placas e painéis: proporcionando a explicação dos aspectos da geodiversidade.

\footnotetext{
${ }^{16}$ A descrição realizada pelos participantes do geossítio "Gruta do Pirata" não pôde ser verificada, pois não foram encontradas referências bibliográficas sobre o local indicado.
} 
Na Figura 44 apresenta-se a síntese das propostas do grupo 5, que selecionou mais de um geossítio, sendo eles: "Cachoeira do Véu de Noiva” (Ruínas da Lagoinha), "Pico do Massaguaçu", "Costão Rochoso da Brava de Itamambuca", "Pico do Caxambu" (Itamambuca) (Figura 45).

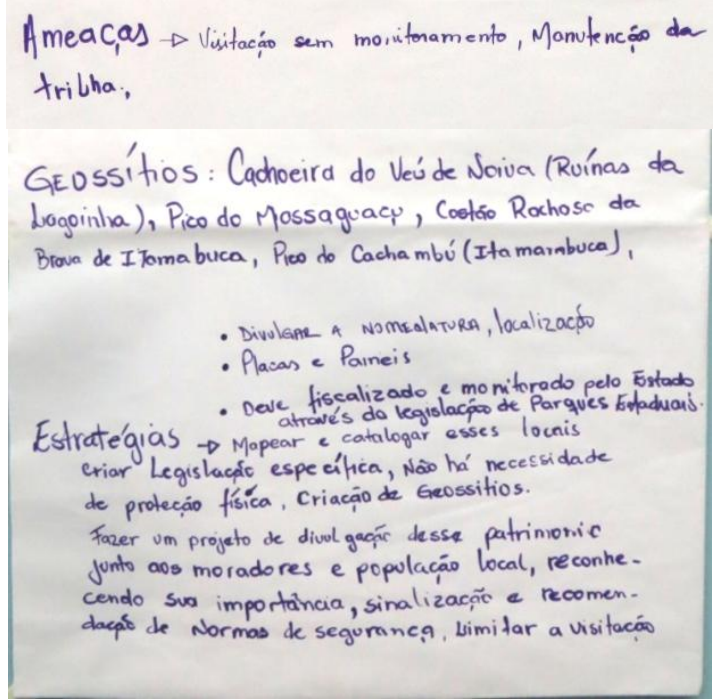

Figura 44 - Atividade valores, ameaças e estratégias do grupo 5 em Picinguaba (Ubatuba - SP) considerando os geossítio "Cachoeira do Véu de Noiva (Ruínas da Lagoinha)", "Costão Rochoso da Praia Brava de Itamambuca", "Pico do Caxambú".
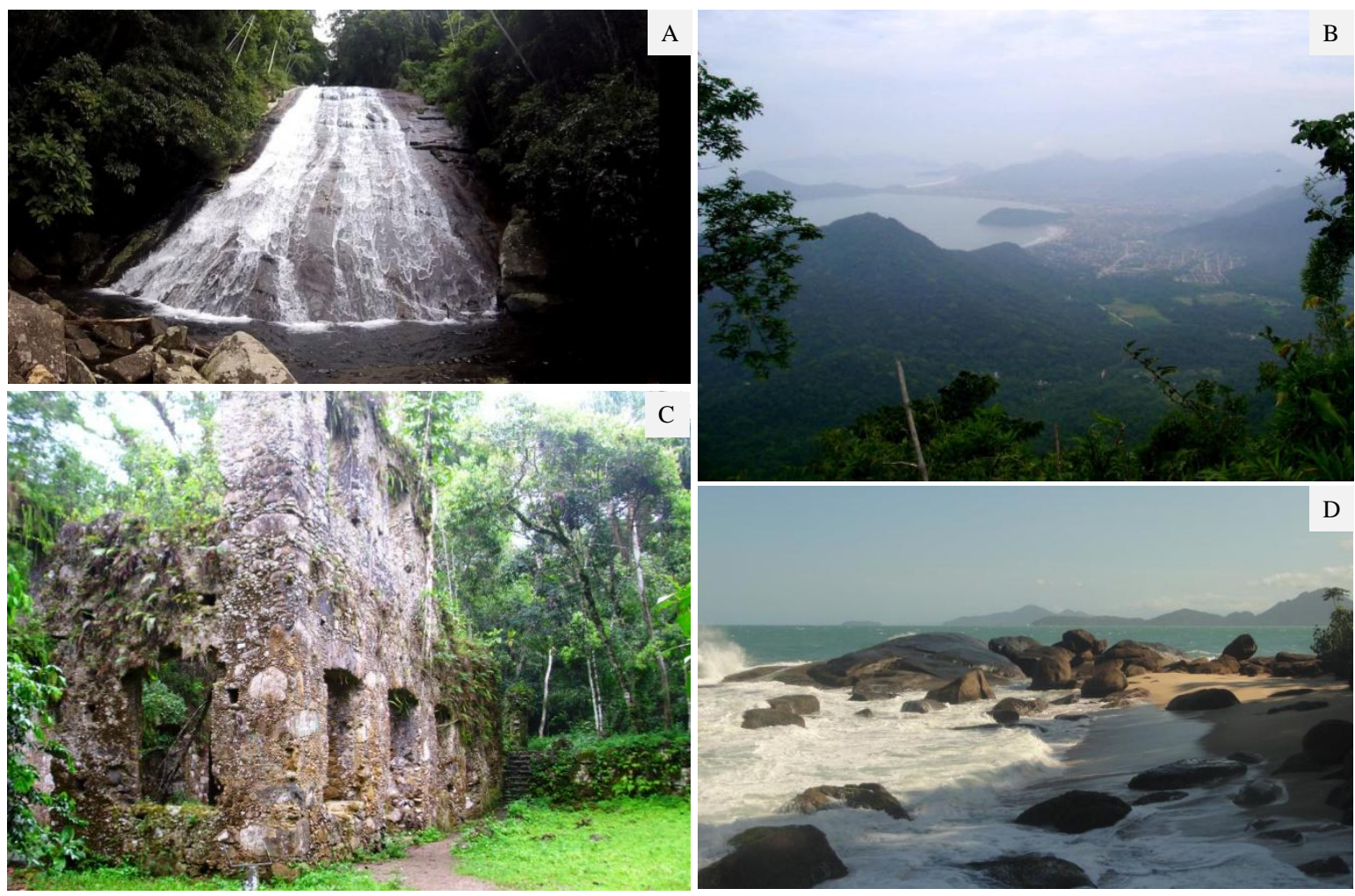

Figura 45 - Geossítios identificados pelos participantes do curso. A) Cachoeira Véu de Noiva (Foto: http://curiosidadesdeubatuba.com.br/cachoeira-veu-da-noiva/); B) Pico do Caxambu (Fonte: ITESP, 2007); C) Ruínas da Lagoinha (Foto: Vanessa Costa Mucivuna); D) Costão Rochoso Praia Brava de Itamambuca (Fonte: https://www.vivaubatuba.com.br/praias/praia-brava-de-itamambuca/) 


\section{Geossítio "Cachoeira Véu de Noiva"}

A Cachoeira do Véu de Noiva (Figura 45A) localiza-se próxima às ruínas da Lagoinha (Figura 45C). Para ter acesso à cachoeira Véu da Noiva é necessário realizar uma trilha em direção a Serra do Mar para alcançar essa queda d'água que apresenta cerca de $60 \mathrm{~m}$ de altura. O percurso é de aproximadamente $870 \mathrm{~m}$, com duração média de 30 minutos $^{17}$. No mapa geológico (Figura 10) pode-se observar que a cachoeira está entre as unidades Charnockito Ubatuba, cujas litologias são o charnockito, monzogranito e mangerito; e o Complexo Pico do Papagaio, composto por biotita-granito.

Os valores apresentados pelos participantes para o geossítio Cachoeira Véu de Noiva se revelam a partir da singularidade observada na cachoeira, composta por um paredão rochoso fraturado. Assim, a formação rochosa e os processos associados a essa feição contribuíram para a seleção desse ponto pelos participantes, que a reconhecem como local de práticas de lazer e turismo de aventura, principalmente a escalada.

Os participantes também chamaram a atenção para o fato de a cachoeira se localizar próxima ao patrimônio histórico das "Ruínas da Lagoinha", que também apresenta interesse geológico devido aos tipos de materiais usados na sua construção, como os blocos rochosos típicos da região e conchas trituradas.

As Ruínas da Lagoinha (Figura 45C) encontram-se próximas à Praia da Lagoinha, cerca de $20 \mathrm{~km}$ a sul de Ubatuba. Este cenário é formado por ruínas da antiga fazenda Bom Retiro, construída em 1828. Essa estrutura foi tombada como patrimônio histórico pelo CONDEPHAAT em 1985, e em 1989 passou a ser administrado pela Fundart ${ }^{18}$. Atualmente observa-se na paisagem três paredões com aproximadamente $8 \mathrm{~m}$ de altura, construídos com blocos rochosos da região. Esse patrimônio encontra-se recoberto por vegetação, com intenso processo de degradação influenciado pelo clima tropical úmido, sendo visíveis fungos, musgos e vários tipos de arbustos e outras plantas se desenvolvendo em meio aos paredões.

\section{Geossítio "Costão Rochoso da Praia Brava de Itamambuca"}

O Costão Rochoso da Praia Brava de Itamambuca (Figura 45C) localiza-se em Ubatuba, a cerca de $16 \mathrm{~km}$ à norte do centro do município. Encontra-se na seção noroeste da Praia de Itamambuca estando próximo ao Geossítio "Pedreira de Itamambuca" que consta no inventário do Patrimônio Geológico de Ubatuba (SANTOS, 2014). A autora destaca que o costão rochoso da praia de Itamambuca é composto pelo Charnockito Ubatuba.

\footnotetext{
${ }^{17}$ curiosidadesdeubatuba.com.br/cachoeira-veu-da-noiva/

${ }^{18}$ fundart.com.br e vivaubatuba.com.br
} 
O Costão Rochoso da Praia Brava de Itamambuca foi destacado a partir da beleza do local, sendo referido como um ambiente ainda muito preservado e que os moradores têm o hábito de pescar.

\section{Geossítio "Pico do Caxambu"}

O Pico do Caxambu ou Morro do Caxambu (Itamambuca) (Figura 45B) localiza-se em Ubatuba, a noroeste da foz do Rio Itamambuca e possui cota máxima de $655 \mathrm{~m}$. De acordo com o ITESP (2007) é o morro mais alto da região, permitindo avistar as praias Itamambuca, Perequê-Açu e Grande. Essa feição é o divisor de águas dos rios Itamambuca que desagua na praia de mesmo nome, e do Ribeirão Capim Melado, que deságua na Praia do Perequê-Açu (IBGE, 1981). As unidades litológicas correspondentes à essa feição são o Charnockito Ubatuba e o Complexo Pico do Papagaio (Figura 10).

A visão panorâmica foi apresentada como fator relevante para esse geossítio, sendo também referência cultural para os Remanescentes de Quilombola do Sertão de Itamambuca, ou Cazanga.

\section{Geossítio "Pico do Massaguaçu"}

O Geossítio "Pico do Massaguaçu” foi descrito pelos participantes do curso como divisor dos municípios de Ubatuba e Caraguatatuba, como forma acentuada na paisagem devido à formação da Serra do Mar, a qual margeia toda a paisagem da planície do rio Massaguaçu.

A praia do Massaguaçu localiza-se no município de Caraguatatuba, cerca de $11 \mathrm{~km}$ de distância do centro do município. De acordo com a carta topográfica do município (IBGE, 1974), observa-se que o rio Massaguaçu possui nascentes de cotas mais altas à 500m. A carta supracitada possui referência apenas ao morro do Cantagalo, que possui altitude de $459 \mathrm{~m}$, divisor dos rios Massaguaçu e Guaxinduba.

De acordo com os participantes, os valores atribuídos à esse morro estão associados à beleza cênica que compõe a paisagem das escarpas da Serra do Mar do litoral norte de São Paulo. Sua singularidade relaciona-se ao fato de ser limitante físico entre os municípios de Ubatuba e Caraguatatuba.

\section{$\underline{\text { Ameaças e estratégias }}$}

Os grupos de participantes identificaram as ameaças e apontaram estratégias de geoconservação para todos os geossítios indicados. 
Segundo os participantes, os geossítios encontram-se ameaçados, principalmente devido à visitação desses locais sem o devido ordenamento das atividades e monitoramento. Por isso, vem sofrendo ameaças muito sérias, com destaque para a Cachoeira Véu de Noiva, ponto que possui grande facilidade de acesso. As ameaças ao costão rochoso da praia Brava de Itamambuca foram relacionadas à prática de pesca e retirada de marisco que podem provocar a degradação do costão rochoso. Ainda foram relatados que são lançados resíduos sólidos e regularmente os frequentadores ascendem fogueiras no local. Os picos Caxambu e Massagaçu foram identificados com menores ameaças, pois são de difícil acesso, além de estarem dentro da unidade de conservação.

As estratégias apontadas convergem para a emergência do mapeamento e catalogação do patrimônio geológico, apoiados pela criação de legislação própria para os geossítios no âmbito estadual. No caso da Cachoeira Véu de Noiva, sua proximidade com as Ruínas da Lagoinha poderia favorecer a gestão do geossítio pela Fundart, sendo, portanto de responsabilidade municipal. Assim, essa legislação também teria que prever a fiscalização e o monitoramento desses pontos. Destacou-se também a necessidade de planejar e ordenar as atividades turísticas, estabelecendo normas e, quando necessário, restrições de acesso.

A contribuição das comunidades locais foi valorizada no sentido de conscientizar essa população para reconhecer o patrimônio geológico em ações de valorização e divulgação, e participar da instalação de sinalização e placas explicativas para esses geossítios.

\section{b) World Café}

A atividade do World Café decorreu a partir das questões elaboradas previamente, de acordo com a Tabela 4. Em Caraguatatuba foram organizados dois grupo e, em Picinguaba, permaneceram os três grupos que realizaram a atividade valores/ameaças/estratégias.

As análises foram realizadas a partir das questões elaboradas.

Questão 1: Há necessidade de Geoconservação na região? Por quê? Se sim, o que precisa ser feito?

Nessa questão, os participantes foram instigados a analisar a necessidade e viabilidade da geoconservação na região, tendo como pressuposto os conhecimentos que possuíam dos geossítios, e a realidade socioambiental local, as quais norteiam as estratégias definidas para a geoconservação.

As respostas elaboradas para a questão 1 podem ser observadas na Figura 46. 


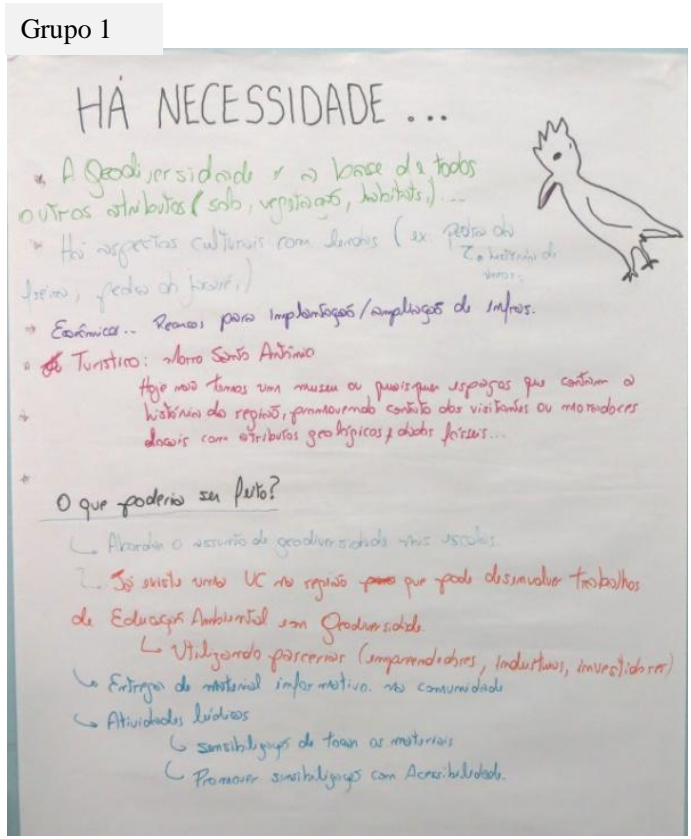

Grupo 3

1 Há necessidode da Gecconservacão na regiâo?

2 Brquê? Se Sim o que precisa ser fito?

(1) Sim. Devido ao valor intrineeo

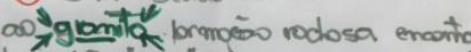
a resjão. rama".

Atualizacáo des inventoría de

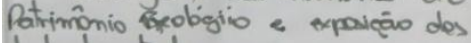
dados levomtados para promoxáo de estudas locando cortecimento, consonim lizacaio.

Grupo 4

werd Cofe'

Há necessida de da Geoconservacão na regiăo?

Forguè se sim, o que precisa sor fato?

Sim, Fais emlora para a nossa sobre -

Vivencra precisamos explorar of reair sas Naturais, faz-se necessarior um

Eoneamento da extracóo das recursos.

Eoneamento da ertrocesso de preserDem como um pracáo de area degradacas

dadas pacóes que causam um grande impacto no Mero Ambiente.

Lixo - segue para cidade Vizinha

Moradures - tem um papel importan

Hissimu, é necessário sya consienti-

2000 o para a preservacau para

as 'futuras geracoes
Grupo 5

1. Há necessidade de geoconservaçāo na Regiāo.

$\rightarrow$ Geoconservaçāo do Património. ex: Pico Corcovado

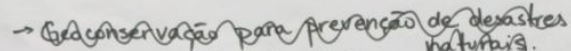

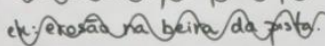

0 que pode ser feito?

Educaco para as pesseas do local pl entender a impor Conscientrzace / Sensibilizaco

- Montoramento

Cálculo capacidade supete

- Mudanca de hábitos

Manejo da TRilha - planejamento

- Manutençāo da Trilha - arrumar infraestrutura

Figura 46 - Respostas da Questão 1 do World Café: Há necessidade de Geoconservação na região? Por quê? Se sim, o que precisa ser feito? 
A necessidade de conservação da geodiversidade foi verificada por todos os participantes, sendo que os fatores destacados para a geoconservação tem maior relação com seus valores do que com suas ameaças. Assim, os valores identificados foram:

- Geodiversidade rica com relação aos seus valores turísticos, cênicos, econômicos, culturais, estéticos, dentre outros.

- A geodiversidade como base de todos os outros atributos (solo, vegetação, habitats). Nesse sentido deu-se relevância a interação da geodiversidade com a biodiversidade. Os valores apontados foram: valores culturais (exemplo pedra da freira); econômicos fornece recursos naturais para implantação e ampliação de infraestrutura; turísticos (exemplo Morro do Santo Antônio).

- Valor intrínseco do "Granito Verde Ubatuba", se apresentando como um elemento raro.

Em relação às ameaças destacam-se:

- Falta de conhecimento e de valorização: a ausência de museus ou espaços apresentem informações sobre os atributos geológicos.

- Ocupações antrópicas que causam um grande impacto ao meio ambiente;

- Questão dos resíduos sólidos produzidos nos municípios, que atualmente são transportados para aterros em cidades vizinhas.

- Uso dos recursos naturais

As estratégias de geoconservação apontadas pelos participantes foram:

- Zoneamento da extração dos recursos naturais bem como um processo de preservação e recuperação de áreas degradadas;

- Inserção do tema na Educação Básica, criação de roteiros turísticos e trilhas interpretativas, aumentar a acessibilidade aos geossítios, promoção de estudos nas áreas de arqueologia e paleontologia, criação de cursos na área, envolvimento do poder público, desenvolver estratégias de comunicação visual, divulgação nos meios de comunicação de massa (TV, rádio, folders, jornais, rede social, oficinas) e criação de geoparques; 
- Implementar a temática da geodiversidade nos programas de Educação Ambiental desenvolvidos pela UC; fortalecer as parcerias (empreendedores, indústrias, investidores); abordar o assunto da geodiversidade nas escolas; utilizar materiais informativoa nas comunidades; desenvolver atividades lúdicas através da sensibilização sobre todos os elementos da natureza; promover a sensibilização com acessibilidade;

- Atualização dos inventários de patrimônio geológico e exposição dos dados levantados para promoção de estudos visando maior conhecimento e sensibilização;

- Educação para as pessoas do local para entender a importância da conservação; Conscientização e sensibilização; monitoramento; mudanças de hábitos; cálculo da capacidade de suporte de visitação dos locais; planejamento para o manejo e manutenção da trilha, incluindo a infraestrutura;

- Conscientização dos moradores locais tendo em vista seu papel, proporcionando a conservação para as futuras gerações.

Questão 2: O plano de manejo abrange a geodiversidade? O que você incluiria ou acrescentaria ao plano de manejo?

Nessa questão a abordagem foi direcionada para o Plano de Manejo do PESM em relação à presença ou não dos aspectos relacionados à geodiversidade. Assim, considerando o conceito abrangente da geodiversidade, a expectativa dos pesquisadores não era encontrar esses conceitos específicos, mas sim, uma perspectiva conservacionista em relação aos elementos físicos do ambiente, bem como sua importância. Além disso, esperava-se reconhecer no Plano de Manejo algumas estratégias de geoconservação de locais já conhecidos como de relevância turística ou científica.

Essa questão demonstrou que os conceitos específicos de patrimônio geológico, geodiversidade e geoconservação não estão presentes no Plano de Manejo. Isso foi evidenciado pela percepção de todos os grupos, que afirmaram que a geodiversidade não faz parte do Plano de Manejo, mas, indicaram que os aspectos da natureza física estão presentes, mesmo que em segundo plano, uma vez que a ênfase da conservação é na biodiversidade.

A Figura 47 ilustra as respostas para essa questão. 


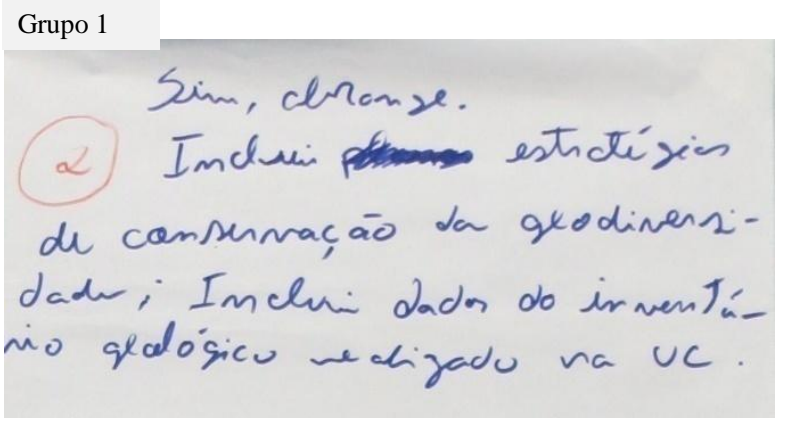

Grupo 3

0 plomo de mamjo abaunge a geadiversidade? Oque voce indinia ou acresentario as plano de momjo? Sim, contudo como aspecto direcionado a biodiversidadel podendo contemplar um dhar en pateilormas multi ilas tais como Geodiversidade/siockuersido de/seciodiverield

Grupo 2

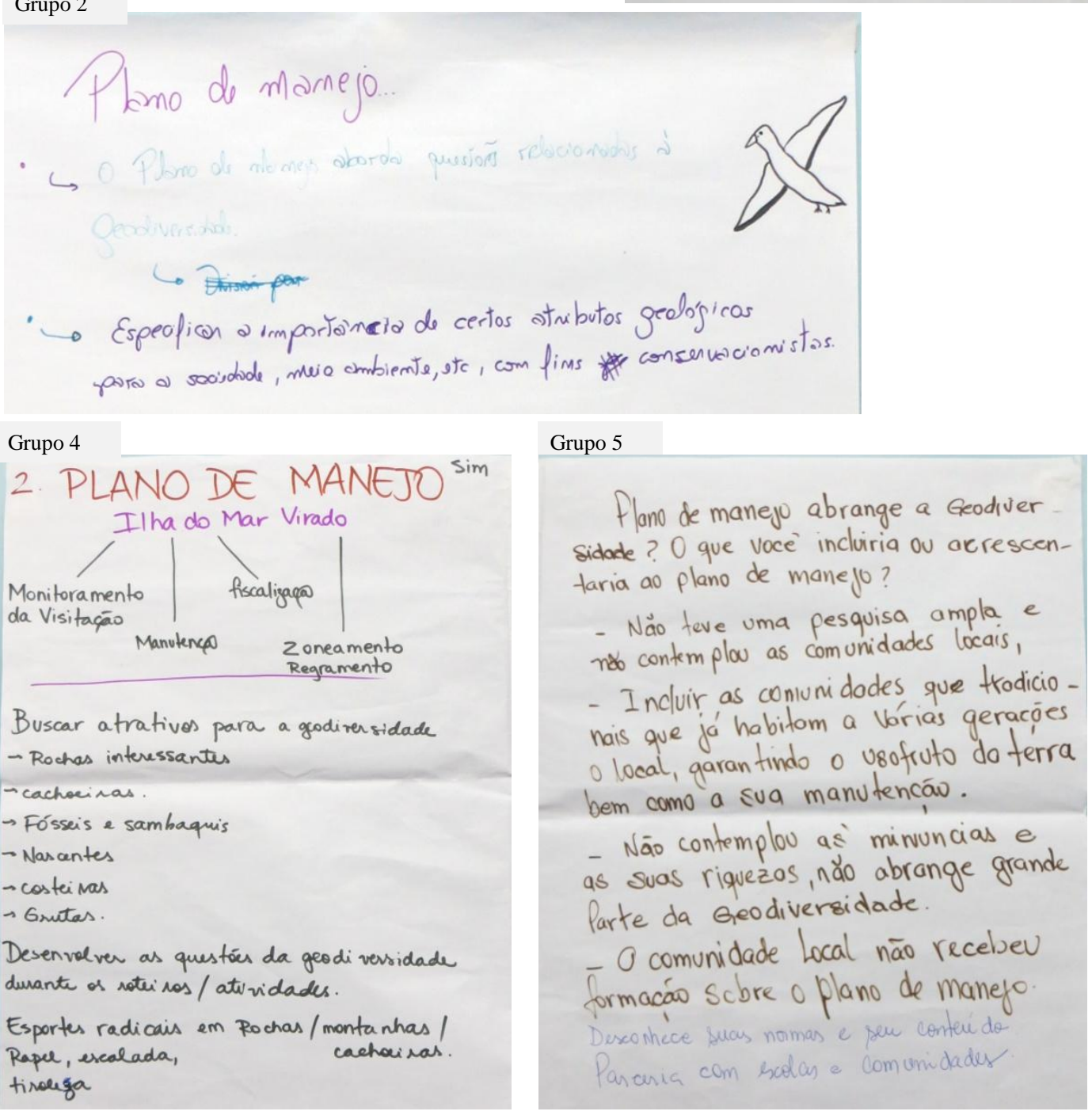

Figura 47 - Respostas da Questão 2 do World Café: O plano de manejo abrange a geodiversidade? O que você incluiria ou acrescentaria ao plano de manejo? 
Assim, os caminhos sugeridos para inserir a geodiversidade no Plano de Manejo de forma mais concisa foram:

- Incluir dados do inventário do patrimônio geológico realizado na UC e as estratégias de conservação da geodiversidade;

- Especificar a importância de certos atributos geológicos para a sociedade e para o meio ambiente com fins conservacionistas;

- Contemplar um olhar em plataformas múltiplas tais como geodiversidade, biodiversidade e sociobiodiversidade.

- As ações em geoconservação no Plano de Manejo devem proceder de forma similar às ações desenvolvidas na Ilha do Mar Virado, reconhecido como um sítio arqueológico, onde há monitoramento da visitação, manutenção, fiscalização e zoneamento específico. Assim deve-se buscar pelo reconhecimento dos atrativos da geodiversidade (considerando as rochas, cachoeiras, fósseis e sambaquis, nascentes, regiões costeiras, grutas), desenvolver as questões da geodiversidade durante os roteiros/atividade e associar os esportes radicais em rochas, montanhas e cachoeiras, rapel, escalada e tirolesa;

- Por não ter contemplado de forma minuciosa as riquezas do lugar, também não abrange grande parte da geodiversidade, assim, um caminho seria a inclusão das comunidades tradicionais que já habitam há várias gerações o local, garantindo o usufruto da terra, bem como sua manutenção. A informação da comunidade local sobre o plano de manejo seria, portanto uma estratégia, proporcionando o conhecimento de suas normas e conteúdos, além disso, destaca-se o estabelecimento de parcerias com escolas e comunidades.

Questão 3: Quais caminhos devem ser seguidos para a Geoconservação nos programas de Educação Ambiental e Educação Patrimonial?

O questionamento sobre a incorporação da geoconservação nos programas de Educação Ambiental e Educação Patrimonial visou aprofundar a discussão sobre essas categorias. As respostas para essa questão podem ser observadas na Figura 47. 
Grupo 1

- Inclusăo da tematica nos

Conselmos gestores das UCs

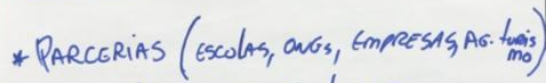

* capacitacáo dos Gestores

* Revisau do Planu de educaciăo

* Museu geologico na Regiăo

Grupo 3

Quais commentos dovem ser seguidas para a geoconsmactio na programas de Edecocioso Ambiental e Edocopor.

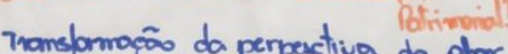
do meio ambiente. imarmogeso e dardagem no tempo ereologico.

Criacoso e propogacīo da imprmasão.

Grupo 4

3. Conquistar as pessoas para ter sua atences em relaco is questäer de geodiressill e educa@ ambiental.

Deve-se abordar as pessoas de forma lídica e divertida.

As questóes ugadas à geodiversidade já sāo abondadas durante os voteiros. Agra será dada maia atenca aos manentos em que as elementos da goodiversidade sugem.

Grupo 2
Caminhos pRra geoconsrruagrón. (E.A).

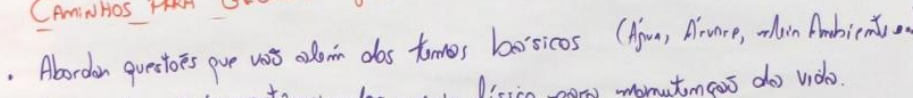

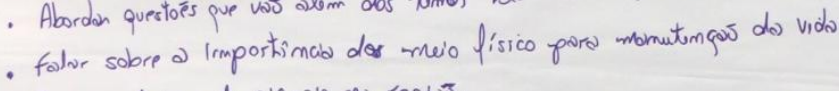

- Promover felens de ciómcia na reglaso.

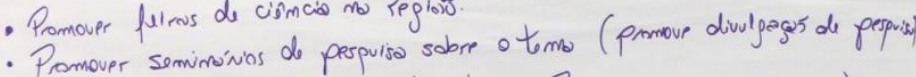

- Compecer e valarizar os pontos turísticos. Proporciomono pertancimento.

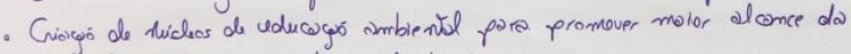

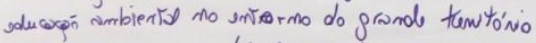

- Copactagara / Volumérinado.

- Acumintas a diculagaso.

$\leftrightarrow$ Palestrar

$C$ Folhoros

Lo Poñis trienant.

C. Situs de rehucioma mperta

C. Dirnimuir or conflitos com o seton de cormuniogese do (Funeses florestal (allimhamemvo)

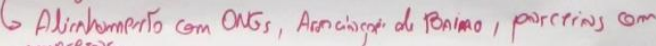

Grupo 5

Guars os Caminlwos deven ser sequidos para a Geoconsevacá nos Programas de Educacáo A mbiental e Educacóo Patrimonial?

10- Pesquisa ampla, entendendo catalogando e formulando questóes e debates

20- Programa de insentivo eficaz para que as novas geracies connecam e possam preservar cóm o sentimento. de Pertencer, fazer parte integrante do local.

30. Incentivar o projeto de Vida das Novas geracóes, contem plan do 0 processo de formacoi a realidade local.

Figura 48 - Respostas da Questão 3 do World Café: Quais caminhos devem ser seguidos para a Geoconservação nos programas de Educação Ambiental e Educação Patrimonial? 
Nesse sentido também foram apresentadas estratégias a partir do olhar dos monitores, que podem sem sintetizadas da seguinte forma:

- Inclusão da temática nos conselhos gestores da UC; capacitação dos gestores, revisão do Plano de Educação do Parque; criação de um Museu Geológico na região;

- Abordar questões que vão além dos temas básicos (como exemplo da água, árvore e meio ambiente) nos programas de Educação Ambiental; refletir sobre a importância do meio físico para a manutenção da vida; promover feiras de ciências na região; promover seminários de pesquisa sobre o tema e a divulgação das pesquisas; conhecer e valorizar os pontos turísticos, e, proporcionar o pertencimento; criação de núcleos de educação ambiental para promover maior alcance dessas ações no entorno; capacitação/voluntariado; aumento da divulgação através de palestras, folhetos, portais na internet, sites de relacionamento; alinhamento com ONGs, associação de bairros e parcerias com empresas;

- Transformação da perspectiva de olhar para o meio ambiente, informação e abordagem do tempo geológico. Criação e propagação da informação;

- Conquistar pessoas para ter sua atenção em relação às questões de geodiversidade e Educação Ambiental. Deve-se abordar as pessoas de forma lúdica e divertida. As questões ligadas à geodiversidade já são abordadas durante os roteiros. Agora será dada maior atenção aos momentos em que os elementos da geodiversidade surgem;

- Realizar pesquisa ampla, entendendo, catalogando e formulando questões e debates; Desenvolver programa de incentivo eficaz para que as novas gerações conheçam e possam preservar com o sentimento de pertencer, fazer parte, se integrar ao local; Incentivar o projeto de vida das novas gerações, contemplando no processo de formação e a realidade local.

Questão 4 - Quais locais podem ser considerados importantes para a Geoconservação? Por quê? Como valorizá-los?

A identificação do patrimônio geológico a partir do olhar dos monitores pôde ser apreendida também através da questão 4 do World Café, uma vez que foi solicitado que eles refletissem sobre esses locais a partir da geoconservação (Figura 49). 
Grupo 1

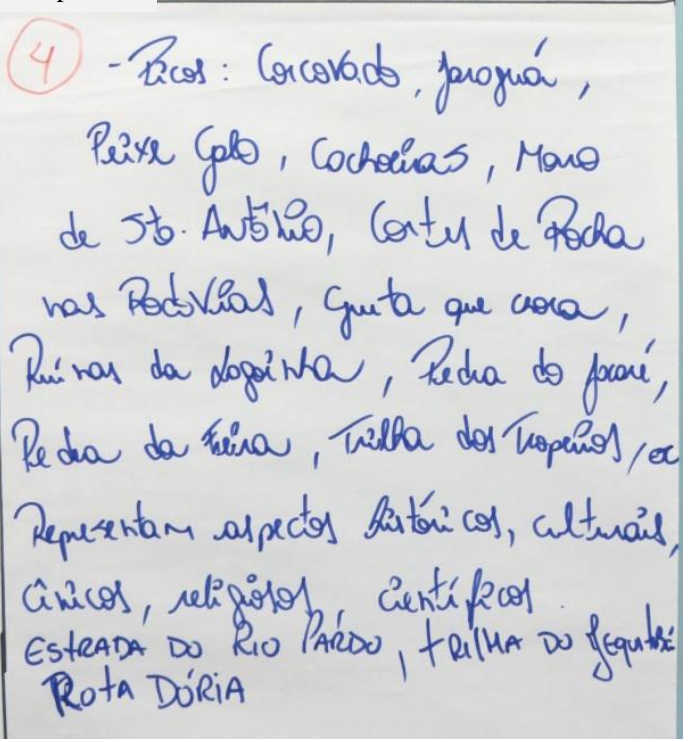

Grupo 3

Duais locais podem ser considerados importantes para a Geoconsmaçä?

Bor quê? lomo vatorigá-los?

Unidades de Consenaciano vés.

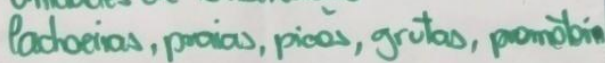
ithas a paisagens.

Plas seus udones scrici, antientais, nots rel.

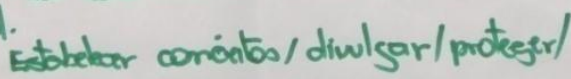
promover

\section{Grupo 4}

4. Montanhas, ilhas, praias, costōes, cachoinas.

- Cachaira da Áua Buanca

$\rightarrow$ Pico Concorado

- Illa Anchieta - Ilha Mar Virado

- Gruta do Pirata

- Praia Fazenda

- Buraco Meteoro Fazenda Cambucá

Patrimönio, exumples importantes de for macoes rechosas, que tem potencial para o GEOTURISMO.

Podem ser utilizados como locais para a educapa ambiental.

Para valorizá-los é preciso fajer com que as

pessoas contregam e respeitem esse patrimäno.
Grupo 2

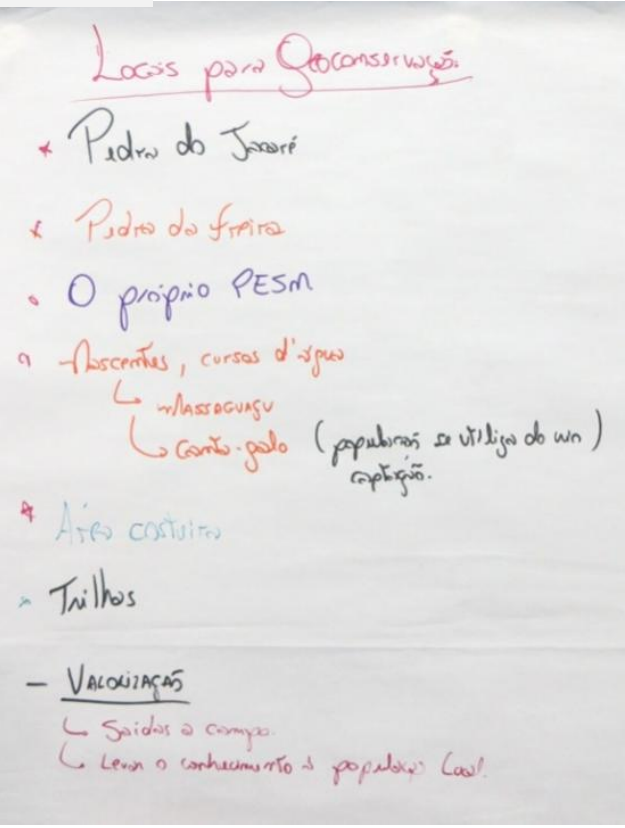

Grupo 5

Quais Locais podem ser considerados importantes para a Geoconservacáo?

Por què? como censervá'

1:- Montanhas, Rios, Praias, Costoés

Rochosos, eachoeiras, floresta, Fauna, Lencóes freaticos, Nascentes,

etc... Preservacáo da vida e conservaés da Biodiversidade, manutencáo

pora as futuras geracoes.

3:- Educáo Ambiental e a Geoconservocáo

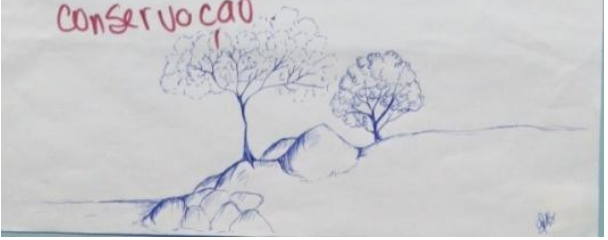

Figura 49 - Respostas da Questão 4 do World Café: Quais locais podem ser considerados importantes para a Geoconservação? Por quê? Como valorizá-los? 
A partir da realidade socioambiental local e das peculiaridades inerentes a cada um desses pontos, decorreram discussões acerca da importância de como valorizá-los no contexto local.

Os locais e aspectos apresentados foram:

- Feições geomorfológicas: paisagens, montanhas, cachoeiras, área costeira, praias, grutas, picos, promontórios, ilhas, Pico do Corcovado, Pico do Jaraguá, Morro do Santo Antônio, Gruta que Chora, Cachoeira da Água Branca, Ilha Anchieta, Ilha Mar Virado, Gruta do Pirata, Praia da Fazenda, Buraco de Meteoro Fazenda Cambucá, Pedra do Jacaré, Pedra da Freira;

- Rochas: Cortes de rochas nas rodovias e costões rochosos;

- Patrimônio Cultural: Ruínas da Lagoinha;

- Geobiodiversidade: PESM, UCs, fauna, floresta, trilhas, trilha dos tropeiros, estrada do Rio Pardo, Trilha do Jequitibá e Rota Dória;

- Recursos hídricos: Nascentes d'água (rios Massaguaçu e Canta-Galo), rios e lençol freático.

Em relação aos valores, foram indicados que:

- Representam aspectos históricos, culturais, cênicos, religiosos e científicos;

- Pelos seus valores sociais, naturais e ambientais;

- O patrimônio consiste em exemplos importantes de formações rochosas, que tem potencial para o geoturismo. Podem ser utilizados como locais para a educação ambiental;

- Preservação da vida e conservação da biodiversidade, manutenção para as futuras gerações.

Para a geoconservação, os participantes indicaram as seguintes estratégias:

- Saídas a campo e levar o conhecimento à população local.

- Estabelecer conceitos, divulgar, proteger, promover.

- Fazer com que as pessoas conheçam e respeitem esse patrimônio

- Educação ambiental e geoconservação 
A metodologia do World Café proporcionou grande interação entre os participantes e propostas advindas de atores sociais diversos que, de certa forma, entraram em consenso para propor as estratégias e reconhecer o patrimônio geológico. A participação dos grupos foi intensa, suscitou reflexões sobre o tema que não está na pauta de discussão dos gestores e funcionários do parque, monitores ambientais e outros atores que estão ainda muito preocupados com a preservação biológica.

A atividade teve como resultado a inserção do tema da geoconservação e promoveu várias reflexões sobre como abordá-la a partir de diferentes estratégias. A reflexão sobre o lugar foi promovida bem como as possibilidades de abordagens futuras do tema, principalmente a partir da inserção no Plano de Manejo do PESM.

\section{c) Mapeamento Socioambiental}

O mapeamento socioambiental foi desenvolvido no curso de formação de professores na praia do Puruba, em Ubatuba, com a participação de 18 professores nessa atividade.

O olhar dos professores sobre o ambiente e a análise reflexiva coletiva a partir da metodologia do mapeamento socioambiental associada ao trabalho de campo proporcionou o (re)conhecimento e a reflexão sobre o lugar, estabelecendo relações entre os aspectos observados e os conflitos socioambientais e a proposição de soluções para os problemas/conflitos levantados.

Além disso, a ênfase na geodiversidade como eixo central do processo formativo e reflexivo, possibilitou o desenvolvimento do olhar geocientífico em uma perspectiva socioambiental (SANTOS, 2010). O (re)conhecimento da geodiversidade nesse ambiente, as relações entre os elementos que compõem a paisagem do lugar, e a reflexão sobre a necessidade de geoconservação e como abordar essa temática na escola foram os resultados obtidos a partir da metodologia. A realização do Mapeamento Socioambiental durante o trabalho de campo pode ser observado na Figura 50.

As análises dos dados foram realizadas a partir das categorias temáticas definidas por Bacci e Santos (2013a), as quais contemplaram os mapas, contendo os elementos ambientais de cada um dos grupos, o mapa síntese e as reflexões e discussões entre os grupos nos diversos momentos do trabalho de campo. Ao final da atividade os grupos apresentaram suas considerações acerca dos temas tratados, refletindo de forma propositiva sobre possíveis soluções para os problemas socioambientais levantados. O mapa síntese socioambiental, bem como a legenda criada pelos professores podem ser observados na Figura 51. 

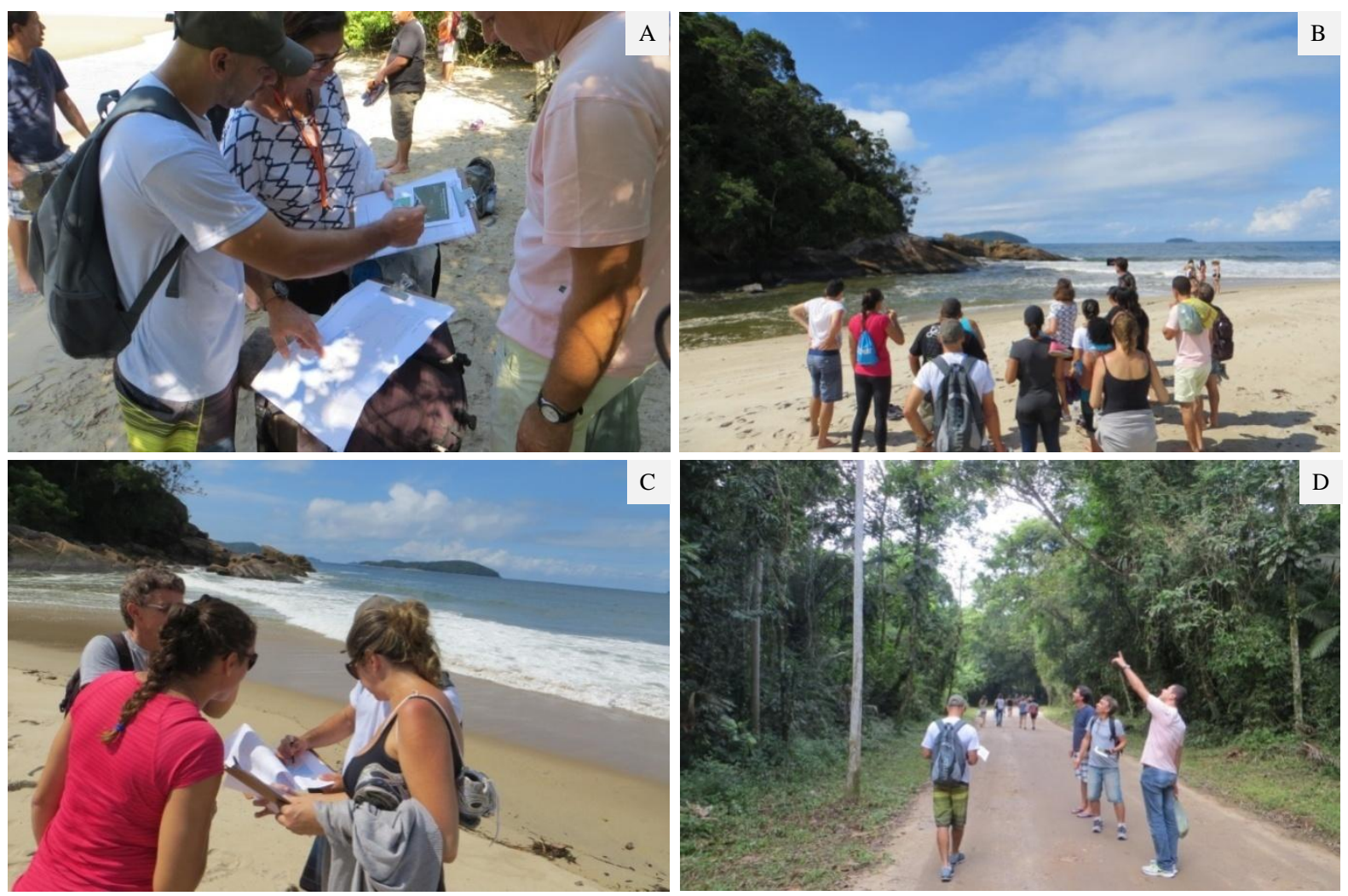

Figura 50 - Trabalho de campo realizado durante o Mapeamento Socioambiental no bairro do Puruba, Ubatuba (SP). A) utilização do roteiro geointerpretativo para a localização dos aspectos observados na foz do QuiririPuruba; B) explanação no costão rochoso da praia do Puruba; C) realização do mapeamento na praia do Puruba; D) observação da biodiversidade na via principal do bairro do Puruba. (Fotos: Eliana Mazzucato). 


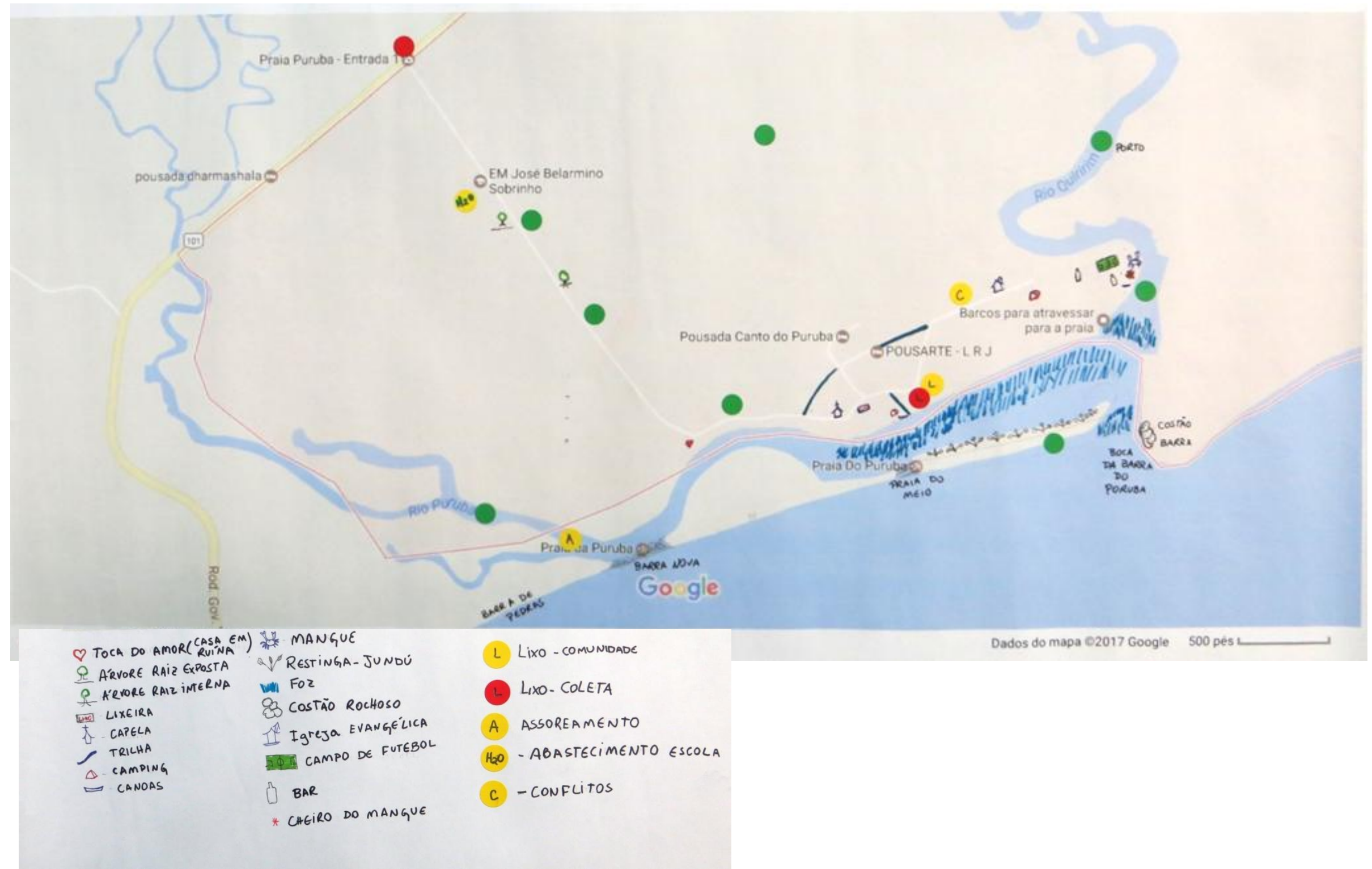

Figura 51 - Mapa Socioambiental Síntese elaborado pelos participantes do curso "Estratégias de Geoconservação no PESM" na escola do Puruba. A legenda é composta pelos elementos percebidos visualmente, sendo identificados da esquerda para a direita como: toca do amor, árvore raiz exposta, árvore raiz interna, lixeira, capela, trilha, camping, canoas, mangue, restinga - jundú, foz, costão rochoso, igreja evangélica, campo de futebol, bar, cheiro de mangue. Os adesivos coloridos representam uma escala de qualidade do lugar compondo um índice de criticidade: a cor verde se refere aos aspectos positivos, representando no mapa a vegetação preservada; o amarelo os conflitos de escala intermediaria, representando o assoreamento, o abastecimento de água da escola e os conflitos do bairro; o vermelho corresponde ao conflito de maior criticidade, apresentando o problema da coleta de lixo, e o risco de atropelamento dos alunos no ponto de ônibus da rodovia. 
Bacci e Santos (2013a) estabeleceram três categorias de análise dos dados a partir do mapeamento socioambiental.

a) Categoria 1: percepção visual direta

Essa categoria apresenta relação com a observação, sendo analisada a partir da espacialização dos elementos observados em campo nos mapas. A partir do princípio V.E.R.A.H. (OLIVEIRA, 2017), os elementos ambientais observados foram:

- Vegetação (Figura 52): tipo (árvore, arbusto, herbácea; espécie exótica ou nativa; raiz profunda ou raiz exposta; costão rochoso, mangue, restinga, planície costeira, encosta), uso (frutífera, medicinal, pesquisa científica, comercial), densidade (variações naturais da densidade ao longo da planície costeira);

- Erosão (Figura 53): tipo (escorregamento, queda blocos, erosão costeira), localização (encosta Serra do Mar, praia), origem (natural, antrópica), efeitos (risco aos residentes, danificação da estrada, prejuízos à fauna e flora, mudanças na paisagem, assoreamento);

- Resíduos/esgoto (Figura 54): volume (alta temporada, baixa temporada), origem (turistas, moradores, escola), tratamento e destino (posto de coleta, coleta seletiva, tratamento, destino);

- Água (Figura 55): tipo (doce, salobra, salgada), vazão (pequena, média, grande), situação (cor, odor, temperatura, assoreamento);

- Habitação, ocupação e vias de acesso (Figuras 56 e 57): tipo (residencial, pública, comercial, religiosa), características (tamanho, material, idade), localização (próxima à igreja católica, próxima à igreja evangélica), tipos de vias (asfaltada, de terra, rodovia), calçamento (sem calçamento para pedestres), estacionamento. 

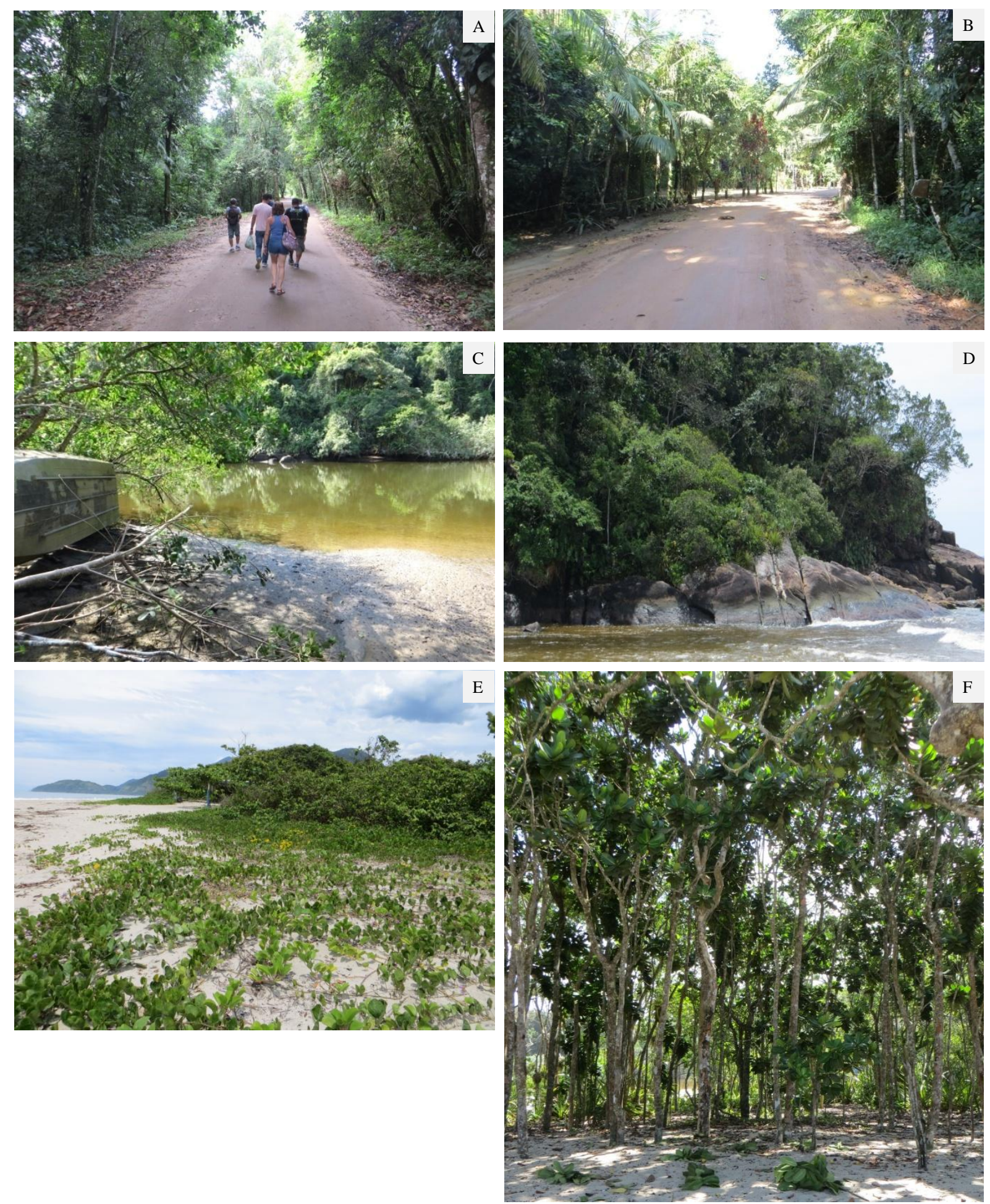

Figura 52 - Imagens referentes aos tipos de vegetação encontrados durante o Mapeamento Socioambiental no bairro do Puruba. A) vegetação mais densa presente na área de planície; B) vegetação menos densa na planície próxima à praia; C) mangue na foz do rio Quiriri; D) ecossistema de costão rochoso; E) Jundu na praia do Puruba; F) vegetação de restinga na praia do Puruba (Fotos: Eliana Mazzucato) 

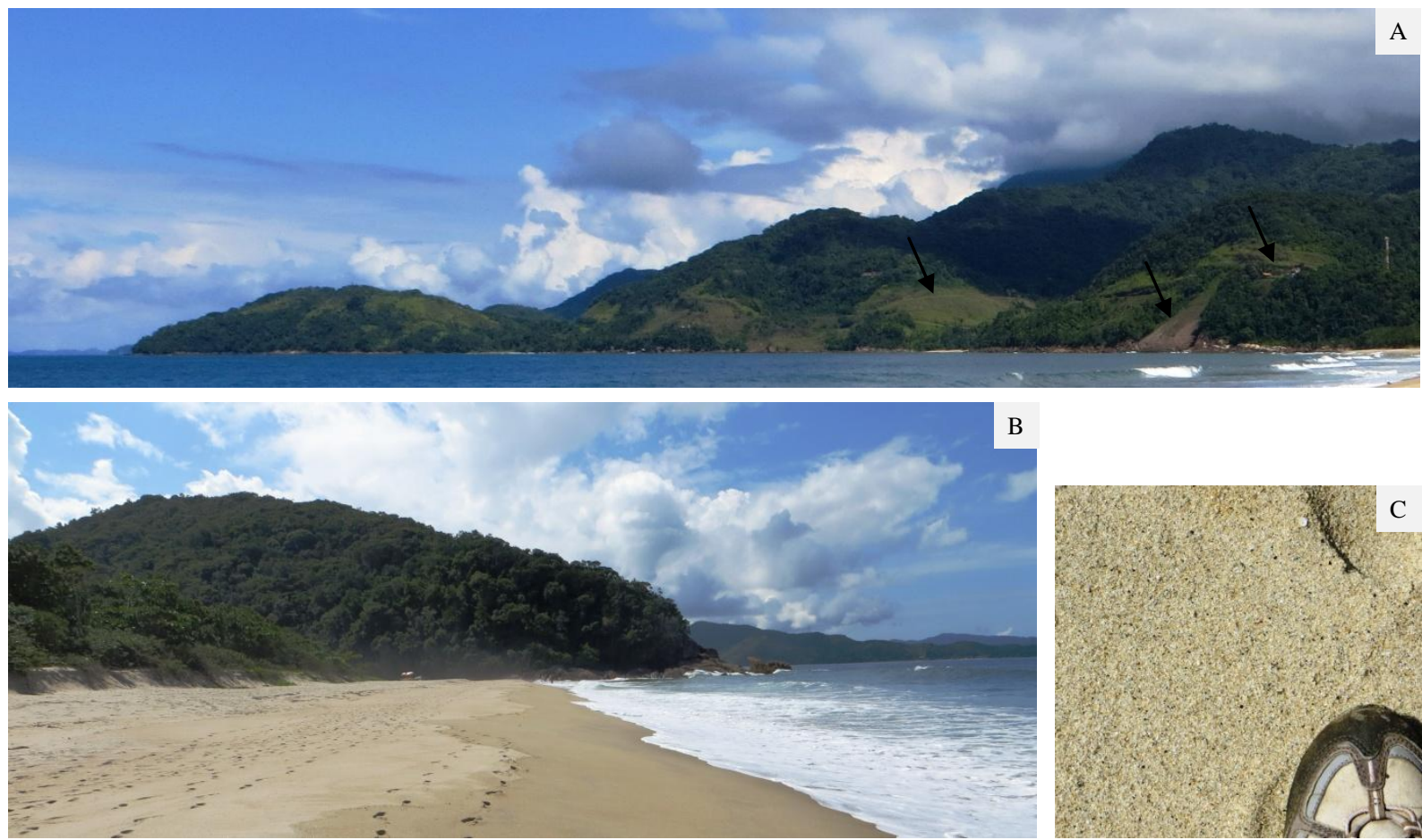

B

Figura 53 - Imagens da dinâmica erosiva nas encostas da Serra do Mar e na praia do Puruba observadas no Mapeamento Socioambiental. A) detalhe das ocupações da Serra do Mar e marcas de escorregamentos; B) presença de patamares na praia, indicativo de processos de deposição e erosão costeira; C) detalhe da textura da areia presente na praia do Puruba (Fotos: Eliana Mazzucato).
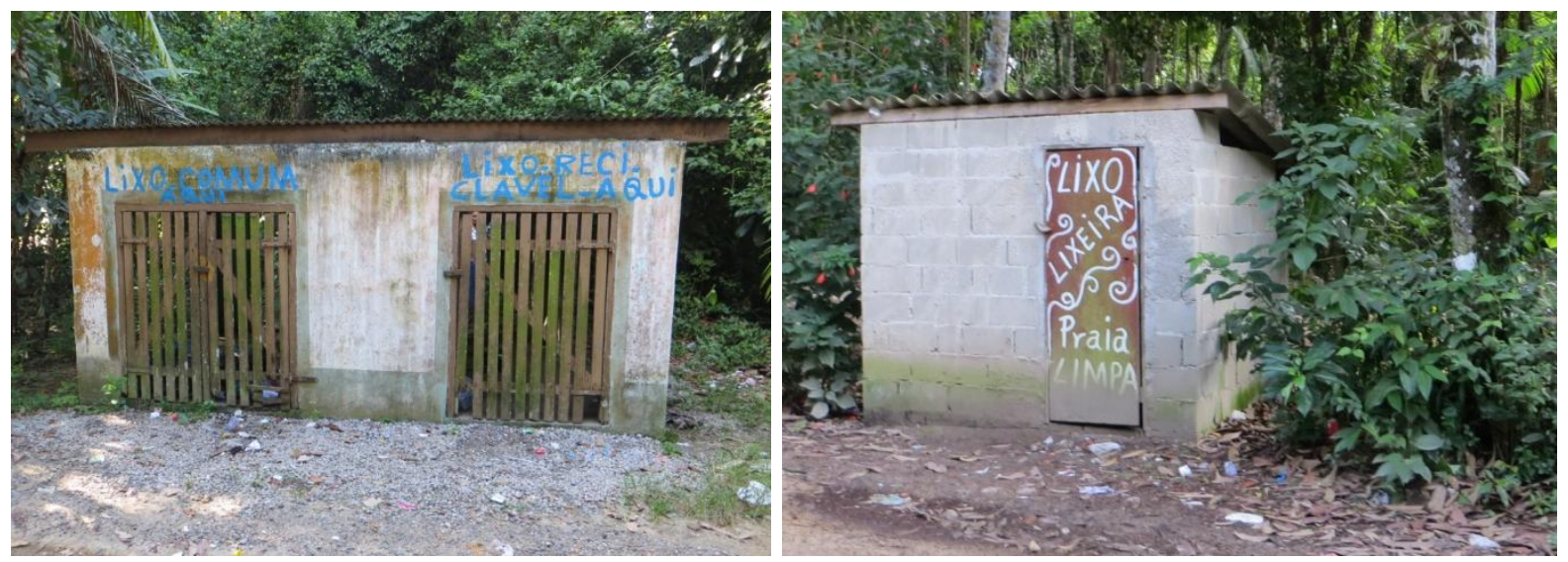

Figura 54 - Imagens referentes ao local de deposição de resíduos observados no Mapeamento Socioambiental (Fotos: Eliana Mazzucato) 

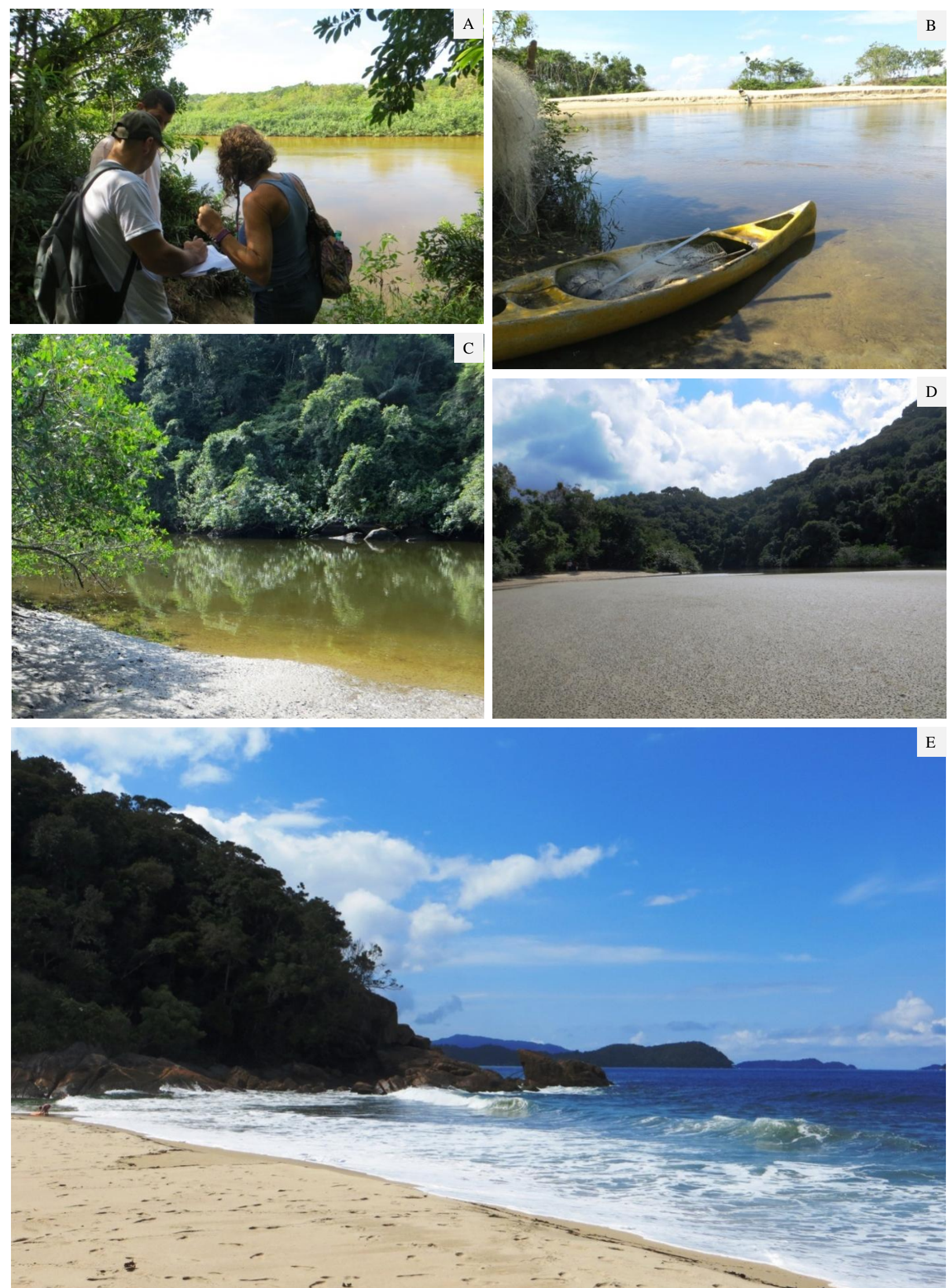

Figura 55 - Imagens dos aspectos observados no Mapeamento Socioambiental relativos à hidrografia. A) percurso do rio Puruba; B) trecho mais à jusante do rio Puruba; B) percurso do rio Quiriri, próximo à área de mangue; C) Foz dos rios Quiriri e Puruba em período de maré baixa; D) Praia do Puruba (Foto: Eliana Mazzucato). 

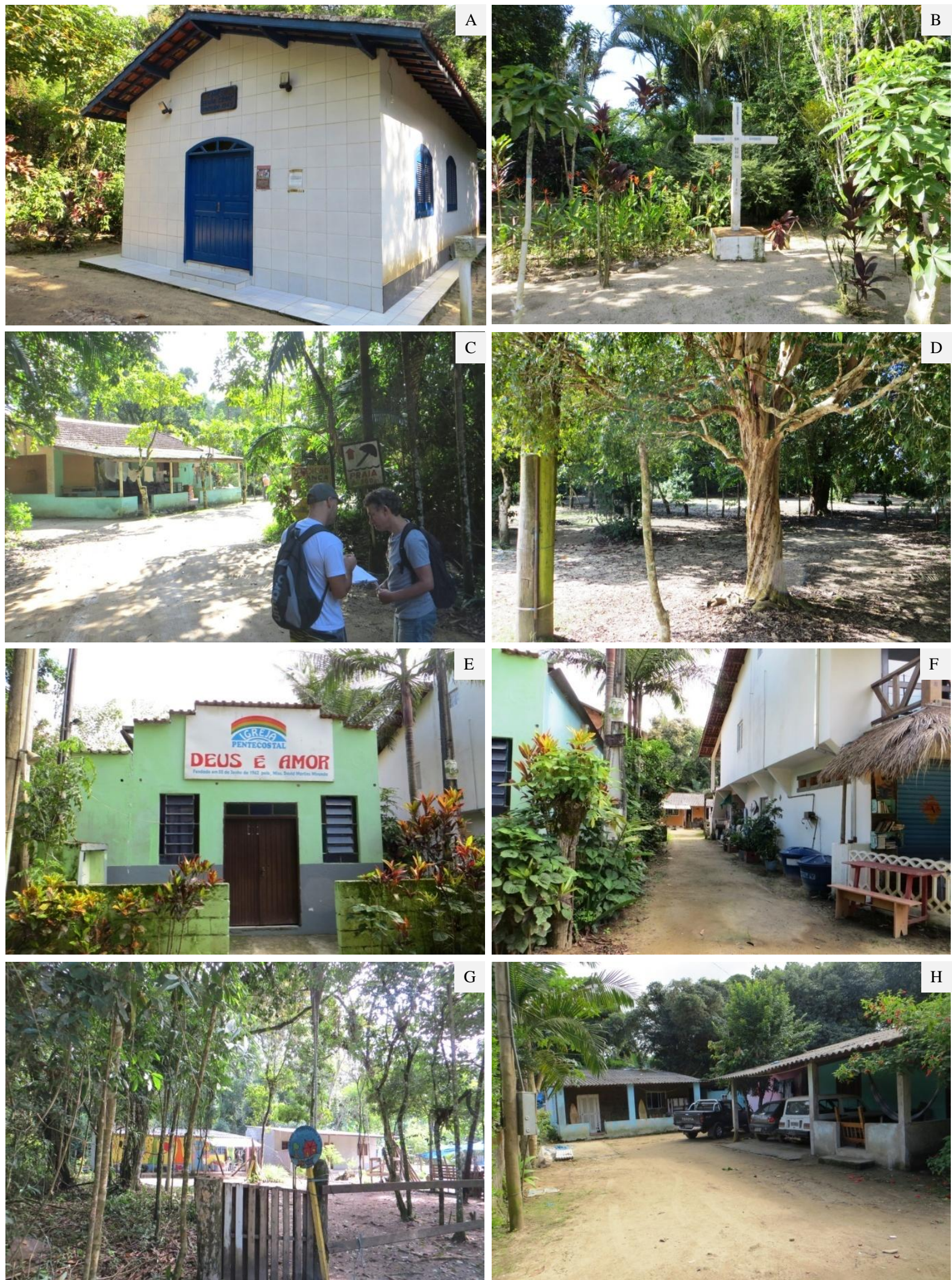

Figura 56 - Imagens dos aspectos habitacionais do Puruba observados no Mapeamento Socioambiental. A) Capela Santa Cruz; B) cruz localizada em frente à capela; C) residências da primeira parte do bairro, próximas à capela da igreja católica; D) área de camping; E) Igreja Pentecostal; F, G e H) aspectos das vias e residências da segunda parte do bairro, próximos à Igreja Pentecostal (Fotos: Eliana Mazzucato). 


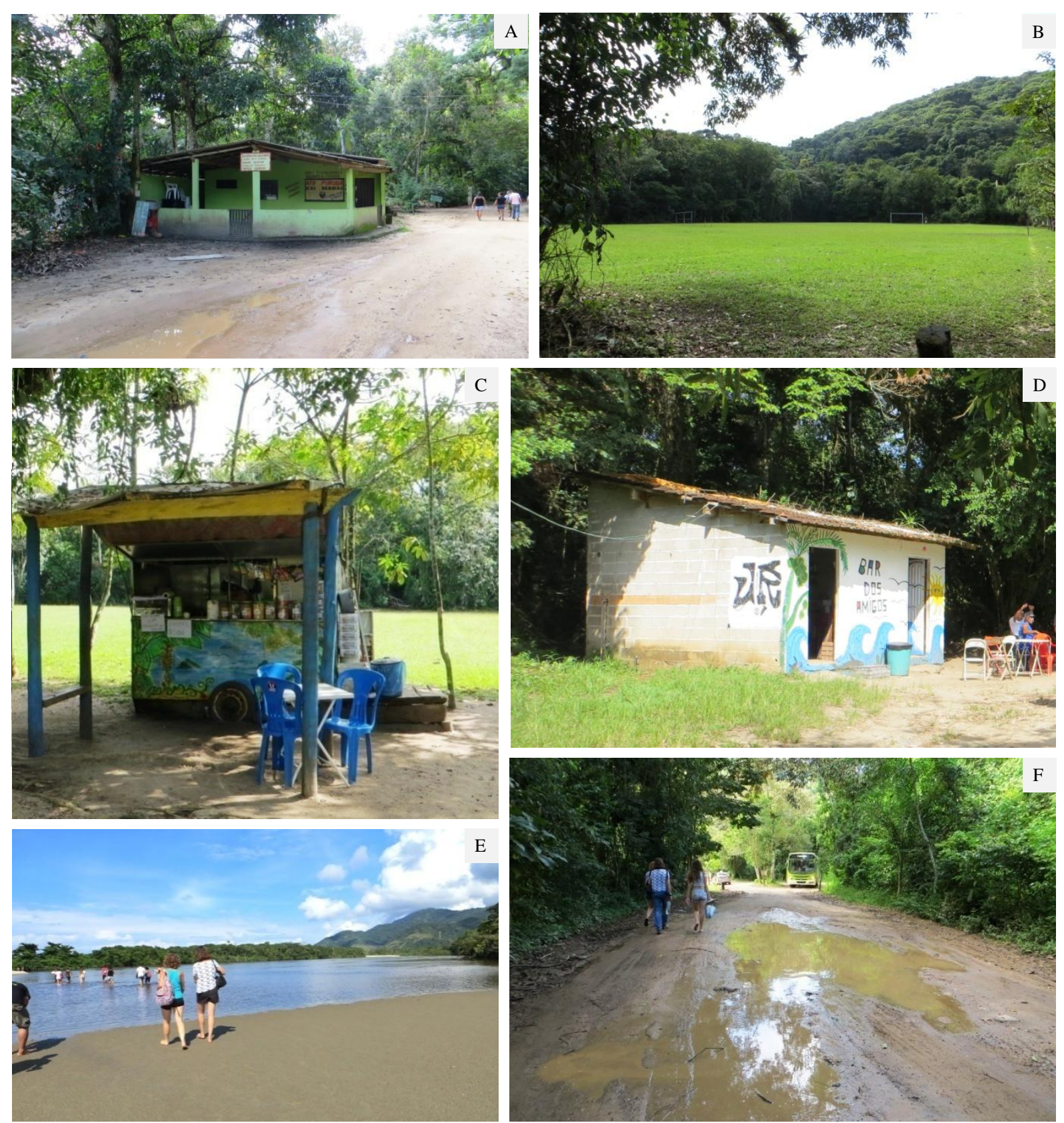

Figura 57 - Imagens dos aspectos habitacionais do Puruba observados no Mapeamento Socioambiental. A, C e D) bares e restaurantes próximos à praia do Puruba; B) campo de futebol; E) acesso pela foz dos rios QuiririPuruba para a praia do Puruba; F) via de acesso do bairro e linha de ônibus municipal (Foto: Eliana Mazzucato).

Todos os grupos identificaram na paisagem e apontaram no mapa os elementos do ambiente propostos nas orientações para a atividade. Os mapas elaborados pelos grupos tiveram composições diferentes, variando na quantidade de detalhes e nas formas de representações.

Essa variação de informações pode estar relacionada ao próprio conhecimento que os participantes possuem do lugar, e como o percebem e vivenciam. Além disso, o cuidado em elaborar o mapa influencia na quantidade de informações representadas, que pode seguir as 
orientações apresentadas para a elaboração da atividade, ou podem criar novas possibilidades para o desenvolvimento da metodologia.

Os aspectos observados, que compõem a percepção visual do mapeamento fomentou uma série de reflexões durante o percurso, fato identificado através do interesse dos participantes em levantar questionamentos e discutir em conjunto. Nesse sentido, foram observadas reflexões relacionadas à interação homem - ambiente, inserindo o seu papel em relação aos processos das dinâmicas superficiais com ênfase no assoreamento dos rios e no aceleramento dos processos erosivos nas encostas da Serra do Mar, o uso e ocupação do bairro associado à conservação ambiental, a interação da geodiversidade com a biodiversidade, principalmente no condicionamento da diversificação de ambientes (tipos de solo, inclinação do terreno, blocos rochosos), uso dos espaços e construções, e precariedade das vias de acesso e transporte público.

b) Categoria 2: reflexão sobre o lugar

Essa categoria apresenta as problematizações dos aspectos observados e das relações estabelecidas com o real, associando assim os aspectos históricos, socioculturais, econômicos, políticos e ambientais. A análise dessa categoria se pautou nas reflexões observadas e anotadas durante o campo e durante a elaboração do mapa síntese. Alguns dos aspectos observados estão na Figura 58. As principais reflexões levantadas foram:

- Relação entre o histórico do bairro e aquisição de terrenos por empresa farmacêutica proprietária de grande área do local, que se apropria da biodiversidade para resguardar as pesquisas e uso dos recursos naturais. Os questionamentos ocorreram sobre o quanto esta empresa está interessada na preservação e por quanto tempo a área permanecerá intocada na região; a falta de informações sobre as reais intenções da empresa e a falta de contato com a comunidade foram outros pontos levantados;

- Ampliação e transformações do bairro devido à introdução da igreja evangélica. O bairro apresenta-se dividido em função das representações religiosas ali presentes. Os conflitos são relatados pelos moradores e os impasses entre os interesses para com o lugar são evidentes, o que enfraquece a comunidade diante de objetivos comuns, como a preservação da área.

- Transformações do bairro a partir do aumento do interesse turístico. O local tem sido cada vez mais visitado pelos turistas. A praia do Puruba foi eleita uma das sete praias 
mais limpas e belas de Ubatuba, o que tem atraído muitos turistas. Porém a falta de infraestrutura tem gerado problemas, principalmente em feriados prolongados e no verão, quando muitos carros chegam ao local. De outro lado, o turismo também gera renda aos locais, que tomam conta dos carros, oferecem alimentação e estadia (camping). Porém a falta de estrutura sanitária e de abastecimento também gera problemas ambientais;

- Transformações da cultura tradicional (uso de diferentes tipos de canoas, observadas na Figura 59);

- Dificuldade de travessia do rio, devido a ausência de barqueiro da prefeitura. Isso se identificou como um problema para os moradores locais que não conseguem atravessar a pé o rio Puruba, o qual se coloca como obstáculo natural ao acesso à praia, pois o barqueiro mantido pela prefeitura foi retirado do local. Os professores também colocaram este problema, pois isso prejudicou as saídas de campo e aulas que envolviam a ida até a praia. No caso dos turistas, isso não se evidencia como problema, pois eles pagam barqueiros locais para atravessar o rio, o que gera também alguma renda aos mesmos;

- Precariedade de vias de acesso e riscos devido à ausência de calçada para pedestres. Além disso, muitos veículos são estacionados em locais indevidos. Isso é resultado da falta de planos para receber os turistas e também da falta de educação dos visitantes, que não estão preocupados em estacionar adequadamente os veículos. Como o acesso à praia se dá preferencialmente de carro, há problemas na estação turística. A praia está há $2 \mathrm{~km}$ da Rodovia $(\mathrm{BR}$ - 101) e pode ser acessada a pé a partir desta, tendo um ponto de ônibus no acesso a partir da mesma. Porém esse meio é usado praticamente apenas pelos moradores locais;

- Risco de atropelamento dos alunos da escola devido à ausência de calçada, e, principalmente ao posicionamento do ponto de ônibus na rodovia $(\mathrm{BR}-101)$. A falta de transporte contínuo gera muitas vezes a espera dos alunos na beira da rodovia, o que tem gerado vários problemas.

- Construções abandonadas sendo local de risco, frequentado pelos alunos da escola;

- Baixa qualidade nos serviços de coleta de resíduos e ausência de coleta seletiva; 
Entretanto, observa-se uma série de particularidades do bairro que também chamaram atenção dos participantes sobre o convívio e as qualidades do lugar, e do forte interesse turístico, como observados na Figura 60.
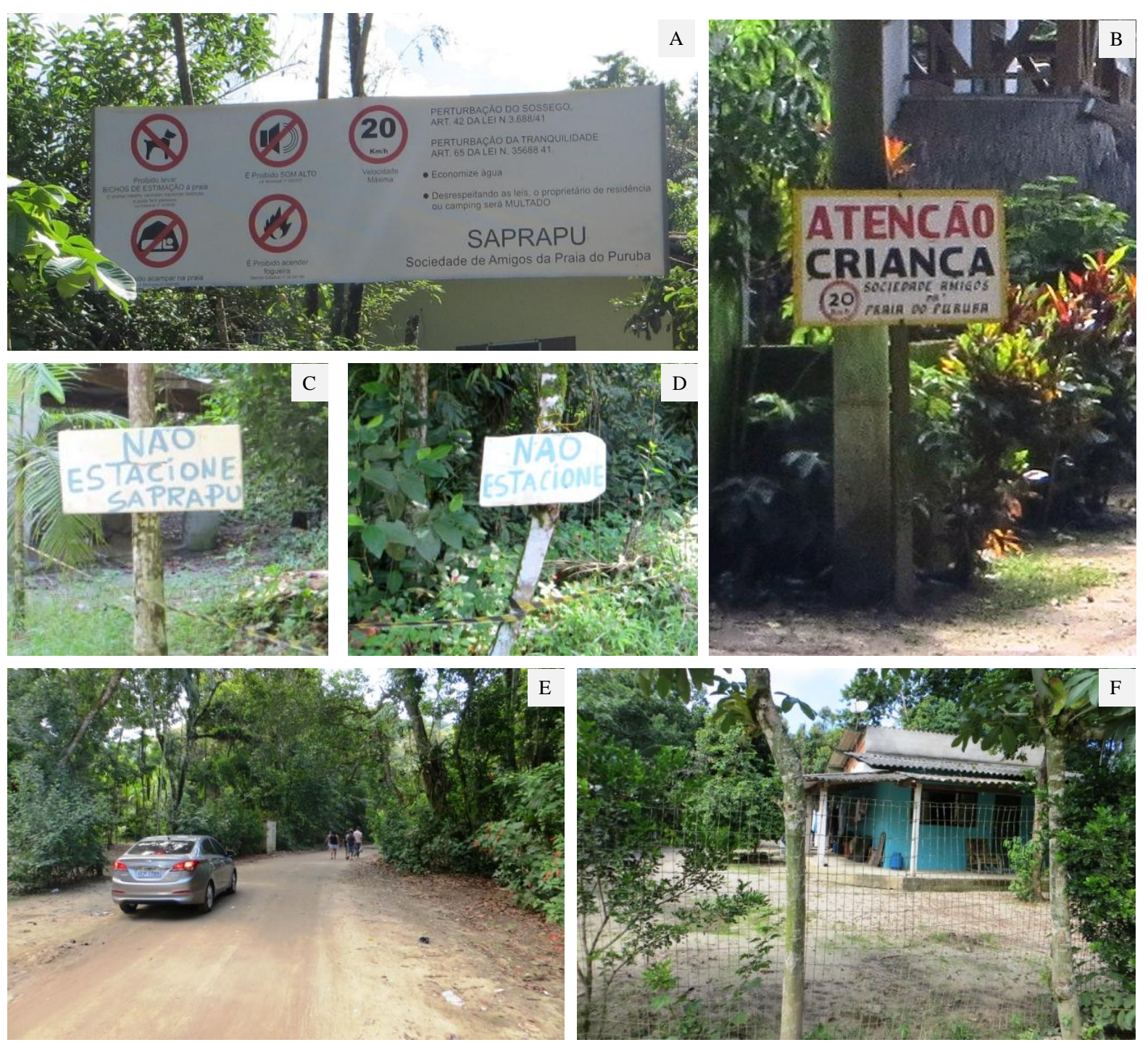

Figura 58 - Aspectos conflituosos e relações estabelecidas no bairro do Puruba no Mapeamento Socioambiental. A) placa instalada pela Sociedade de Amigos da Praia do Puruba (Saprapu) sobre os cuidados que devem ser tomados no bairro, como a proibição de levar animais de estimação à praia, a proibição de som alto, o limite de velocidade $(20 \mathrm{~km} / \mathrm{h})$, a proibição de acampar na praia, e, a proibição de ascender fogueira, chamando atenção também para as leis contra a perturbação do sossego e perturbação da tranquilidade. B) placa da Saprapu chamando a atenção para a presença de crianças na região, reforçando o limite de velocidade para $20 \mathrm{~km} / \mathrm{h}$; C e D) placas de não estacione, contendo também faixa delimitando a área; E) via de terra, com ausência de calçada ou qualquer marcação de mão dupla; F) residência destoando da maioria com presença de grade (Foto: Eliana Mazzucato) 

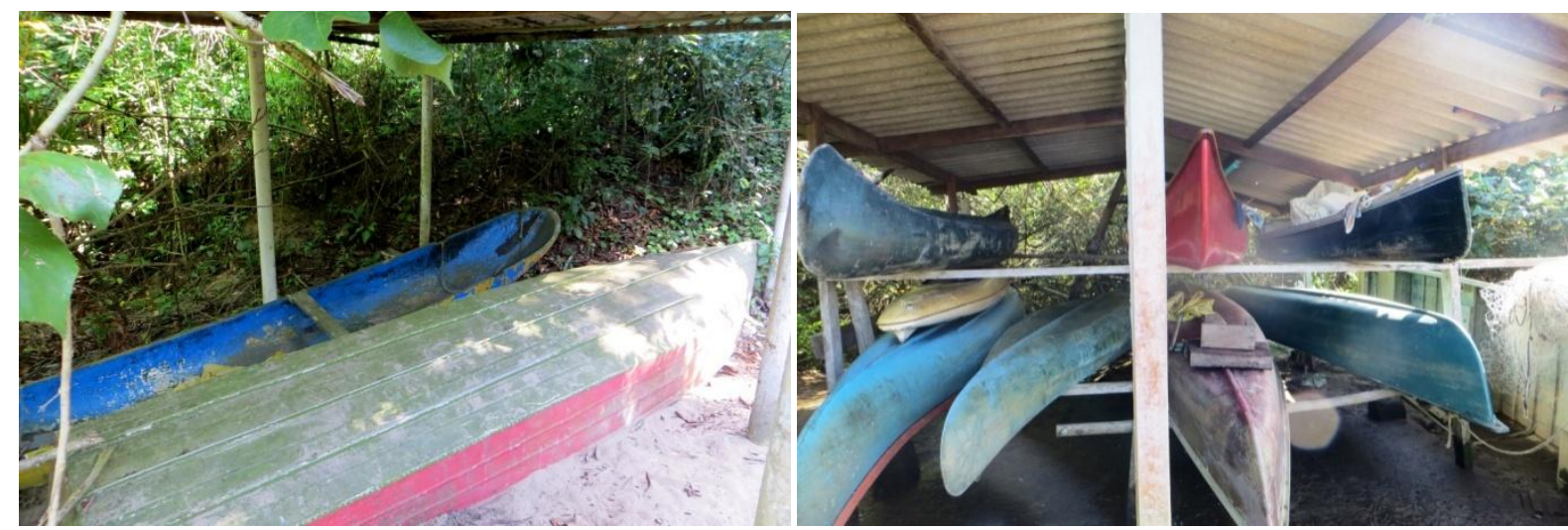

Figura 59 - Canoas utilizadas pelos moradores locais do bairro, demonstrando o uso de canoas caiçaras e outras canoas concomitantemente (Foto: Eliana Mazzucato).
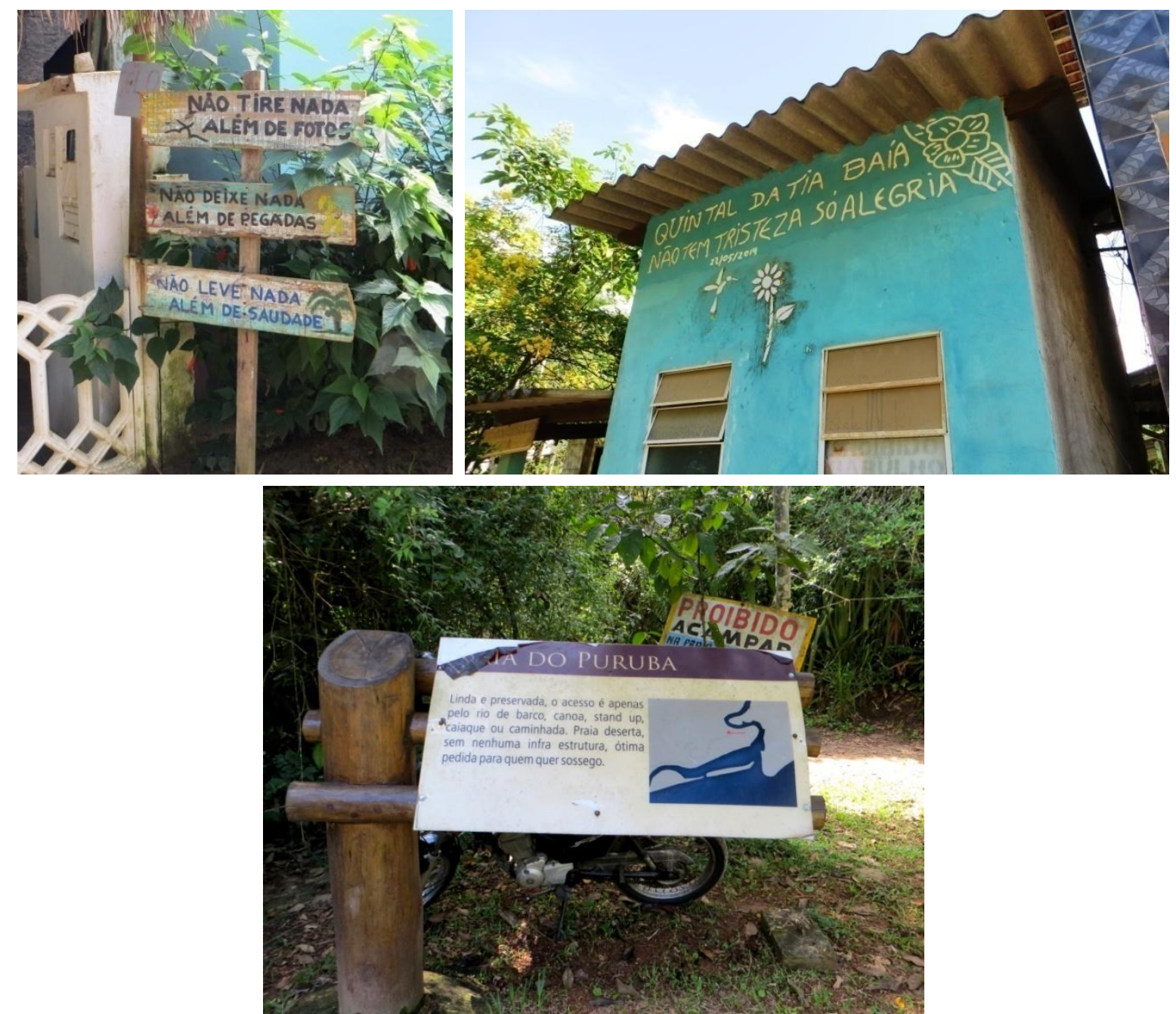

Figura 60 - Aspectos relacionados ao turismo crescente da região. A) mensagens deixadas pelos moradores do bairro chamando a atenção para a conservação da natureza da região; B) casa de moradores do bairro contendo mensagem receptiva; c) painel informativo sobre a praia do Puruba (Fotos: Eliana Mazzucato). 
c) Categoria 3: proposição sobre a transformação do lugar

A percepção crítica do ambiente esteve associada às reflexões sobre quais caminhos podem ser seguidos para solucionar as questões/problemas levantados. Nesse sentido há um enfoque no papel da escola em atuar na sustentabilidade local, as propostas levantadas foram:

- Problematização dessas questões em sala de aula;

- Utilização de metodologias participativas como as apresentadas no curso (World Café e Mapeamento Socioambiental) e a metodologia do trabalho de campo na abordagem de temas transversais e de conceitos diversos presentes no currículo escolar;

- Abordagem dos problemas socioambientais nas reuniões com a Secretaria de Educação e Diretoria Regional de Ensino;

- Escola como promotora de reuniões com os atores locais e entidades responsáveis para discutir propostas de melhorias do lugar;

- Promover o fortalecimento da participação da comunidade através das associações de bairro, uma vez que muitos moradores são funcionários da escola, da Unidade Básica de Saúde (UBS) e da prefeitura e poderiam participar de instâncias de decisão.

$\mathrm{Na}$ formação teórica e prática sobre a geoconservação emergiram muitas reflexões sobre a mudança de olhar que essa abordagem proporcionou. Assim, diante desse novo saber, os participantes puderam refletir sobre os locais que vivem e trabalham, o alcance de suas ações para com o meio, a questão da escala de tempo geológico, a discrepância e insustentabilidade em relação à escala de uso dos recursos naturais.

As atividades participativas e a formação em Geociências com ênfase na valorização e divulgação do patrimônio geológico lançaram novos interesses sobre o lugar, proporcionando uma mudança de olhar e um repensar das posturas dos moradores, gestores, monitores e demais atores sociais. Diante dessa reflexão, os professores perceberam a importância do entendimento da geodiversidade e sua contribuição para se posicionar de forma crítica e propositiva para com o ambiente. A principal estratégia de geoconservação considerada nesse contexto é a divulgação das Geociências no âmbito escolar, para criar um novo olhar para o reconhecimento do ambiente e sensibilização quanto à geoconservação.

O mapeamento socioambiental constituiu-se, como afirmam Bacci e Santos (2013a e b), num importante instrumento colaborador em processos político-pedagógicos para a formação continuada de professores em exercício. Ele contribuiu também para a 
Aprendizagem Social em processos de educação para a sustentabilidade local e também como proposta metodológica para elaboração de estratégias de geoconservação.

Diante o desenvolvimento dessas diferentes metodologias, uma síntese dos resultados foi elaborada, considerando o diagnóstico socioambiental (Tabela 8), o levantamento da percepção geoambiental (Tabela 9 e 10) e, as estratégias de geoconservação (Tabela 11). 
Tabela 8 - Síntese dos resultados do diagnósticos socioambiental com base nos atores locais.

\begin{tabular}{|c|c|c|c|}
\hline \multicolumn{4}{|c|}{ Diagnóstico socioambiental } \\
\hline & Moradores locais & Gestores & Monitores/professores/funcionários \\
\hline $\begin{array}{l}\text { O papel dos } \\
\text { atores sociais }\end{array}$ & $\begin{array}{l}\text { Reconhecem sua relação harmônica com o ambiente } \\
\text { local, valorizando sua cultura e modos de vida, } \\
\text { mantendo os usos tradicionais do território. Além } \\
\text { disso, reconhecem seu papel diante a conservação da } \\
\text { natureza e na manutenção das culturas tradicionais do } \\
\text { país, principalmente quilombolas e caiçaras. }\end{array}$ & $\begin{array}{l}\text { A gestão dos núcleos do PESM reconhece seu papel } \\
\text { em garantir a conservação da natureza, com destaque } \\
\text { para a biodiversidade. Contudo, revelam considerações } \\
\text { quanto aos elementos da geodiversidade e a interação } \\
\text { socioambiental. }\end{array}$ & $\begin{array}{l}\text { Reconhecem seu papel na conservação da } \\
\text { natureza local a partir de sua vivência e da sua } \\
\text { inserção nos seus respectivos ambientes de } \\
\text { trabalho (áreas do parque, escolas e praias do } \\
\text { litoral norte) possuindo amplo conhecimento de } \\
\text { campo, e interagindo com comunidades locais e } \\
\text { funcionários da UC. }\end{array}$ \\
\hline $\begin{array}{l}\text { Relação } \\
\text { comunidade e } \\
\text { UC }\end{array}$ & $\begin{array}{l}\text { Vivenciaram as transformações decorrentes do } \\
\text { avanço do turismo, da especulação imobiliária } \\
\text { (chegada da BR-101) e da criação da UC. Suas visões } \\
\text { com relação à UC foram se transformando a medida } \\
\text { que foram reconhecidas como comunidades } \\
\text { tradicionais e com direitos em relação ao ambiente, } \\
\text { participando ativamente desse processo. } \\
\text { Reconhecem o papel da UC em preservar a região e } \\
\text { elementos da paisagem. }\end{array}$ & $\begin{array}{l}\text { As ações dos gestores proporcionam ampliar a } \\
\text { interação do parque com a sociedade, com destaque } \\
\text { para o programa de Uso Público, apoiado no } \\
\text { ordenamento da visitação e na educação ambiental. } \\
\text { Reconhecem que os moradores da região não se } \\
\text { apropriam totalmente do parque, e que é pouco visitado } \\
\text { pelos turistas, em particular o núcleo de Caraguatatuba. }\end{array}$ & $\begin{array}{l}\text { Muitos desses atores reconhecem a riqueza } \\
\text { cultural relacionada às comunidades tradicionais } \\
\text { da região, valorizando ações de divulgação e } \\
\text { conscientização junto a essas comunidades, de } \\
\text { modo a atenuar seus impactos ambientais e para } \\
\text { reconhecerem a importância do parque. }\end{array}$ \\
\hline $\begin{array}{l}\text { Conflitos } \\
\text { Socioambientais }\end{array}$ & $\begin{array}{l}\text { Passaram e ainda passam por processo de resolução } \\
\text { de conflitos, principalmente pela garantia dos direitos } \\
\text { territoriais e uso dos recursos naturais de forma } \\
\text { sustentável. Além disso, apontam inseguranças } \\
\text { quanto às mudanças na gestão da UC e do governo } \\
\text { municipal e do avanço do turismo de massa. } \\
\text { Preocupam-se também quanto às novas gerações da } \\
\text { comunidade, que tem procurado alternativas de vida, } \\
\text { representando uma ameaça à preservação da cultura } \\
\text { tradicional. }\end{array}$ & $\begin{array}{l}\text { A identificação dos conflitos segundo essa perspectiva } \\
\text { se relaciona com a conciliação entre os interesses } \\
\text { conservacionistas do parque e os interesses das } \\
\text { comunidades tradicionais (ZHCAn). Além disso, } \\
\text { pontuaram alguns dos principais fatores que ameaçam } \\
\text { a conservação na região sendo eles: a ocupação } \\
\text { irregular de áreas do parque; a facilitação dos crimes } \\
\text { ambientais mediante obras de infraestrutura como vias } \\
\text { de acesso, portos e dutos; o turismo de massa e a } \\
\text { expansão da urbanização; mineração; baixo número de } \\
\text { funcionários para a fiscalização e monitoramento das } \\
\text { áreas do parque; coleta e tratamento inadequados de } \\
\text { resíduos por parte dos municípios. }\end{array}$ & $\begin{array}{l}\text { Os conflitos socioambientais segundo esses atores } \\
\text { centram-se em: deficiência dos serviços básicos } \\
\text { dos municípios (saneamento básico, coleta e } \\
\text { tratamento de resíduos); conflito de interesses } \\
\text { econômicos (exploração recursos naturais) em } \\
\text { contraposição aos interesses conservacionistas; } \\
\text { sobreposições territoriais na área; transformações } \\
\text { recentes (crescimento populacional, turismo de } \\
\text { massa, obras de infraestrutura como ampliação de } \\
\text { portos e rodovias). }\end{array}$ \\
\hline
\end{tabular}


Tabela 9 - Síntese dos resultados das percepções geoambientais com base nos atores locais.

\begin{tabular}{|c|c|c|}
\hline \multicolumn{3}{|c|}{ Percepções Geoambientais } \\
\hline \multirow{4}{*}{ 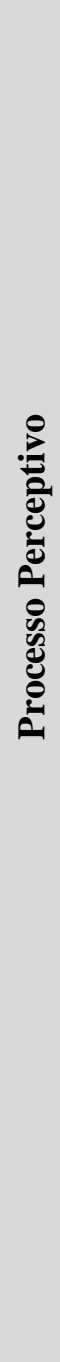 } & & Moradores tradicionais \\
\hline & Sensações & $\begin{array}{l}\text { Aspectos visuais: Reconhecimento da paisagem } \\
\text { através da identificação de elementos } \\
\text { socioambientais: natureza, roças, casas humildes, } \\
\text { energia elétrica, e outros. Elementos da } \\
\text { biodiversidade: vegetação, mato, jundu da praia, a } \\
\text { juçara. E, da geodiversidade: montanha, pedra, } \\
\text { costa, água, cachoeira, a trilha do rio, a nossa serra } \\
\text { do mar; } \\
\text { Aspectos olfativos: boa qualidade do ar. }\end{array}$ \\
\hline & Motivação & $\begin{array}{l}\text { Interesses: O interesse estabelecido para com o } \\
\text { ambiente local remonta fatores culturais e de } \\
\text { pertencimento: relação de comunidade e parentesco } \\
\text { com as pessoas, local para a manutenção da cultura } \\
\text { e da agricultura tradicional e apropriação do lugar. } \\
\text { Necessidades: O uso dos recursos é condição para a } \\
\text { sobrevivência e para manutenção dos costumes e da } \\
\text { vivência num local preservado com acesso aos } \\
\text { recursos. Possuem práticas sustentáveis de manejo, } \\
\text { agricultura tradicional. }\end{array}$ \\
\hline & Cognição & $\begin{array}{l}\text { Apropriação: Reconhecem o lugar como parte de } \\
\text { suas histórias de vida, sua cultura está integrada } \\
\text { com o ambiente } \\
\text { Interpretações: Interpretam o lugar a partir de seus } \\
\text { elementos geoambientais, como o fato de ser } \\
\text { preservado e de atribuir a ele a condição de } \\
\text { patrimônio. } \\
\text { Saberes tradicionais: Os saberes e práticas } \\
\text { tradicionais desses atores revelam as compreensões } \\
\text { que tem do ambiente local, que predominam em } \\
\text { relação aos saberes científicos. Segundo eles, } \\
\text { possuindo consciência diferente dos habitantes dos } \\
\text { centros urbanos, e suas práticas de manejo agridem } \\
\text { o ambiente em menor intensidade. }\end{array}$ \\
\hline
\end{tabular}

\section{Gestore}

Aspectos visuais: Identificação do patrimônio geológico e da geodiversidade através dos pontos extremos da Serra do Mar (cumes e picos) que marcam a paisagem. Também dão ênfase aos paredões rochosos nas encostas da serra, matacões e costões rochosos das enseadas, diversidade hídrica com os cursos d'água, os grandes rios e os materiais rochosos presentes nesses rios.

Desenvolver estratégias de gestão para a conservação da natureza fundamentada em bases normativas.

A Serra do Mar contribui com a preservação da Mata Atlântica, impondo dificuldade de acesso para a ocorrência de crimes ambientais. A geodiversidade também influencia na biodiversidade do parque, perceptível nos diversos ecossistemas da região e na diversidade biológica relacionada aos diferentes níveis de declividade e altitude da Serra.

Os saberes científicos predominam sobre os tradicionais e às sensações em relação ao lugar.

\section{Monitores/professores/funcionários ONG}

Aspectos visuais: Reconhecimento dos elementos socioambientais: áreas rurais, restaurantes, comunidades tradicionais, praças e centros urbanos; elementos da biodiversidade: mata atlântica, fauna e flora, ambiente natural; e da geodiversidade: praias, cachoeiras, rios, montanhas, ilhas, costões rochosos, mar, picos e recursos naturais.

Aspectos olfativos: boa qualidade do ar

Aspectos auditivos: identificação dos sons das aves

Relacionam aspectos socioambientais à qualidade de vida proporcionada em um ambiente preservado. Desse modo, revelam interesses como: viver em contato com a natureza, bem-estar e saúde física e mental, possibilidade de desfrutar os recursos naturais e existência de áreas de lazer (praias, rios, trilhas)

Interesses e necessidades relacionados ao trabalho.

Para a interpretação desse ambiente, reconhecem seu valor patrimonial e a importância dos serviços ecossistêmicos. No caso desses atores locais que também são moradores tradicionais, há valorização da relação sociocultural com o ambiente, ou seja, representam um conhecimento intermediário, no qual estão explícitos os saberes tradicionais e científicos, bem como as sensações. 


\begin{tabular}{|c|c|c|c|c|}
\hline \multicolumn{5}{|c|}{ Percepccões Geoambientais } \\
\hline \multirow{3}{*}{ 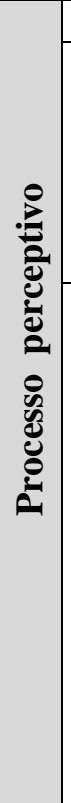 } & & Moradores tradicionais & Gestores & Monitores/professores/ funcionários ONG \\
\hline & Avaliação & $\begin{array}{l}\text { A avaliação quanto ao socioambiente é positiva, } \\
\text { valorizando seus atributos: tranquilidade e sossego, } \\
\text { baixa violência, beleza, satisfação em viver no } \\
\text { lugar, qualidade da água dos rios, a exuberância da } \\
\text { mata atlântica. O lazer é voltado para as trilhas, as } \\
\text { praias. }\end{array}$ & $\begin{array}{l}\text { Reconheceram o valor cênico desses elementos } \\
\text { para a paisagem da região. Além de destacar a } \\
\text { geodiversidade como suporte para a biodiversidade } \\
\text { e sua preservação. }\end{array}$ & $\begin{array}{l}\text { Destacaram a qualidade de vida, as boas condições para } \\
\text { a saúde, o clima, a tranquilidade, a natureza preservada, } \\
\text { a beleza, o equilíbrio entre homem e natureza, o povo } \\
\text { acolhedor e a satisfação em viver e trabalhar na área. }\end{array}$ \\
\hline & Conduta & $\begin{array}{l}\text { Revelam práticas que aliam a conservação da } \\
\text { natureza ao uso dos recursos naturais (práticas de } \\
\text { manejo) tendo, portanto, uma conduta preocupada } \\
\text { com a sustentabilidade. } \\
\text { Também foram revelados elementos na conduta } \\
\text { desses atores que dizem respeito a sua permanência } \\
\text { no lugar, ou seja, o processo perceptivo deles faz } \\
\text { com que não queiram sair do lugar onde nasceram. }\end{array}$ & $\begin{array}{l}\text { Identificam a relevância da geodiversidade para a } \\
\text { gestão do território e a potencialidade de inseri-la } \\
\text { no Programas de Uso Público do parque. }\end{array}$ & $\begin{array}{l}\text { Possuem condutas de preservação da natureza } \\
\text { (manutenção do ambiente natural, açôes contra o tráfico } \\
\text { de animais, preservação de trilhas, ensino e } \\
\text { conscientização, participação de projetos relacionados à } \\
\text { temática do meio ambiente). Também valorizam a } \\
\text { cultura tradicional, o desenvolvimento de pesquisas e a } \\
\text { maior interação e participação das pessoas junto aos } \\
\text { órgãos ambientais. No âmbito educativo, ressaltam a } \\
\text { realização de oficinas e vivências, promoção da } \\
\text { cidadania e sustentabilidade, valorização da troca de } \\
\text { conhecimentos e saberes, promoção da responsabilidade } \\
\text { moral e ética, ampliar o alcance à informação, educação } \\
\text { ambiental e conscientização. }\end{array}$ \\
\hline
\end{tabular}

Conclusão 
Tabela 10 - Síntese dos resultados das percepções geoambientais dos atores locais que participaram do curso "Estratégias de geoconservação no Parque Estadual da Serra do Mar".

Percepções Geoabientais pelos monitores, professores e funcionários de ONG que participaram dos cursos

\begin{tabular}{|c|c|}
\hline Patrimônio & $\begin{array}{l}\text { Os atores identificam prioritariamente o patrimônio histórico. Associam o principal elemento do patrimônio cultural (ou construído) às } \\
\text { construções históricas. } \\
\text { O patrimônio natural é reconhecido nas florestas, embora secundariamente. } \\
\text { Em relação às responsabilidades atuais de proteção do patrimônio, foram apontadas o Governo Estadual e o Instituto Florestal e ICMBio. } \\
\text { As indicações sobre quem deveria também ser responsável recaem em maior parte à Prefeitura e ao Governo Federal. }\end{array}$ \\
\hline Geodiversidade & $\begin{array}{l}\text { O conceito de geodiversidade para esse grupo está relacionado à etimologia da palavra, em comparação ao termo "biodiversidade" } \\
\text { indicando em maior quantidade a "diversidade geológica" para definir geodiversidade. Também indicaram aspectos mais específicos, } \\
\text { relacionados aos elementos da geodiversidade, como solo, substrato rochoso, etc. } \\
\text { Já a definição do conceito natureza abiótica demonstrou que muitos associavam o termo aos elementos da geodiversidade ou se referiram } \\
\text { apenas à etimologia da palavra, como natureza sem vida. No entanto, parcelas de respondentes relacionaram a natureza abiótica aos } \\
\text { aspectos físicos e químicos da natureza (tais como temperatura, umidade, clima e nutrientes) ou ainda reforçaram a relação com a } \\
\text { biodiversidade, reconhecendo a natureza abiótica nos ecossistemas, e, aos elementos da biodiversidade. }\end{array}$ \\
\hline Patrimônio Geológico & $\begin{array}{l}\text { Praias, zona costeira, costão rochoso, relevo, hidrografia, rochas, grutas, fósseis, solos e sedimentos foram identificados como elementos } \\
\text { do patrimônio geológico. Além desses elementos, foram identificados como patrimônio geológico elementos associados, como os } \\
\text { manguezais e a biodiversidade. Artefatos arqueológicos talhados nas pedras e monumentos históricos constituídos por rochas da região } \\
\text { foram associados ao patrimônio cultural. }\end{array}$ \\
\hline Geoconservação & $\begin{array}{l}\text { As ameaças identificadas foram antrópicas (ocupação áreas irregulares, construções nos costões rochosos e naturais, má gestão das áreas } \\
\text { de risco, desmatamento, poluição, queimadas, mineração, especulação imobiliária, turismo de massa, obras de infraestrutura, fragilidade } \\
\text { na gestão da UC, falta de informação e conhecimento, dentre outros) e naturais (erosão costeira). } \\
\text { Os caminhos apontados para a conservação do patrimônio geológico foram: conscientização e sensibilização, inserção da temática na } \\
\text { escola, contratação de pessoas com conhecimento em geoconservação, criação de leis, fiscalização, congelamento das áreas e, uma gestão } \\
\text { mais participativa. }\end{array}$ \\
\hline
\end{tabular}


Tabela 11 - Síntese dos resultados das estratégias de geoconservação elaboradas através de metodologias participativas durante o curso "Estratégias de Geoconservação no Parque Estadual da Serra do Mar".

\begin{tabular}{|c|c|c|c|c|}
\hline \multicolumn{5}{|c|}{ Metodologias participativas como promotoras de estratégias de geoconservação } \\
\hline \multirow{8}{*}{ 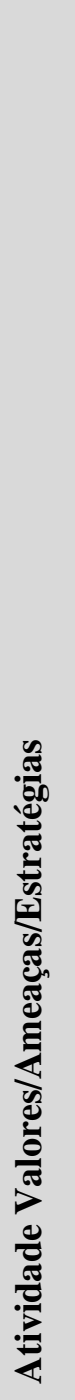 } & "Geossítios" & Valores & Ameaças & Estratégias de Geoconservação \\
\hline & Gruta que Chora & $\begin{array}{l}\text { Valor histórico-cultural: lenda associada ao lugar } \\
\text { Valor científico: caracterização e formação da gruta } \\
\text { Valor estético: beleza cênica do lugar } \\
\text { Valor turístico: lazer e prática de surf } \\
\text { Valor educativo: potencial para práticas educativas e de } \\
\text { conscientização }\end{array}$ & $\begin{array}{l}\text { Antrópica: pichação, } \\
\text { poluição, despejo inadequado } \\
\text { de lixo, vazamento de óleo } \\
\text { Natural: alternância das } \\
\text { marés e intemperismo }\end{array}$ & $\begin{array}{l}\text { A definição da geoconservação levou em conta os aspectos } \\
\text { teóricos abordados no curso e o conhecimento prévio dos atores. } \\
\text { Ressaltam a participação da comunidade para a fiscalização e } \\
\text { monitoramento do geossítio. Também reforçam a necessidade de } \\
\text { capacitação da comunidade em parceria com as ONGs, a } \\
\text { implantação de medidas de segurança, e facilitação da } \\
\text { acessibilidade e implantação de sinalizaçâo no local. Divulgação } \\
\text { através de redes sociais e jornais. }\end{array}$ \\
\hline & Piscina Natural & $\begin{array}{l}\text { Valor histórico cultural: evidências da Catástrofe de } 1967 \\
\text { Valor científico: processos geológicos de movimentos de } \\
\text { massa, intemperismo, erosão, transporte e deposição, além } \\
\text { de conter afloramentos e blocos rochosos; turístico (beleza } \\
\text { cênica e lazer) } \\
\text { Valor educativo: base para o conhecimento dos processos } \\
\text { naturais e a conscientização. }\end{array}$ & 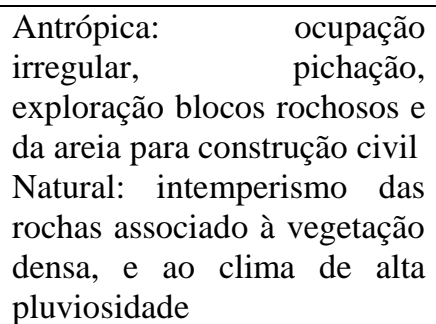 & $\begin{array}{l}\text { Consideraram a participação do PESM na fiscalização e } \\
\text { monitoramento do geossítio, a necessidade de reconhecimento } \\
\text { municipal, a implantação de medidas para segurança e } \\
\text { acessibilidade. Estabelecimento de parcerias, divulgação e } \\
\text { sinalização do local. }\end{array}$ \\
\hline & Gruta do Pirata & $\begin{array}{l}\text { Valor científico: presença do charnockito, diques e } \\
\text { granito. Além de consistir em um suporte para o } \\
\text { desenvolvimento da biodiversidade } \\
\text { Valor turístico: potencial de visitação (praias e trilhas). }\end{array}$ & $\begin{array}{l}\text { Turismo desordenado e de } \\
\text { massa, risco de acidentes } \\
\text { com os visitantes, possível } \\
\text { limitacão do acesso. }\end{array}$ & $\begin{array}{l}\text { Ordenar a visitação através do geoturismo, implantação de } \\
\text { infraestrutura de acesso e criação de normas de visitação; } \\
\text { incentivo ao turismo de aventura; instalação de placas e painéis } \\
\text { com informações sobre a geodiversidade. }\end{array}$ \\
\hline & $\begin{array}{l}\text { Cachoeira Véu de } \\
\text { Noiva }\end{array}$ & $\begin{array}{l}\text { Valor histórico e cultural: proximidade com as Ruínas da } \\
\text { Lagoinha } \\
\text { Valor estético: beleza cênica, } \\
\text { Valor científico: evidência elementos geológicos, Valor } \\
\text { turístico: lazer e prática de esportes }\end{array}$ & \multirow{4}{*}{$\begin{array}{lrr}\text { Ameaças relacionadas } & \text { ao } \\
\text { turismo de massa } & \text { e } \\
\text { desordenado, com } & \text { a } \\
\text { ocorrência de visitação sem } \\
\text { monitoramento, e } r \text { a } \\
\text { necessidades de manutenção } \\
\text { da trilha. }\end{array}$} & \multirow[t]{4}{*}{$\begin{array}{l}\text { Mapeamento e catalogação dos locais de relevância geológica e } \\
\text { estabelecimento de legislação específica. Divulgar a importância } \\
\text { desses locais para os moradores locais, além de fazer } \\
\text { recomendações de normas de segurança e limitar a visitação. } \\
\text { Instalar placas e painéis. Promover a fiscalização e } \\
\text { monitoramento com base na legislação do Parque Estadual. }\end{array}$} \\
\hline & $\begin{array}{ll}\text { Pico } & \text { do } \\
\text { Massaguaçu } & \end{array}$ & $\begin{array}{l}\text { Valor estético: beleza cênica } \\
\text { Valor cultural por dividir os municípios de Ubatuba e } \\
\text { Caraguatatuba. }\end{array}$ & & \\
\hline & $\begin{array}{l}\text { Costão Rochoso } \\
\text { da Brava de } \\
\text { Itamambuca }\end{array}$ & $\begin{array}{l}\text { Valor estético: beleza cênica } \\
\text { Valor cultural: local de prática de pesca }\end{array}$ & & \\
\hline & Pico do Caxambu & $\begin{array}{l}\text { Valor científico: vista panorâmica } \\
\text { Valor estético: beleza cênica }\end{array}$ & & \\
\hline
\end{tabular}




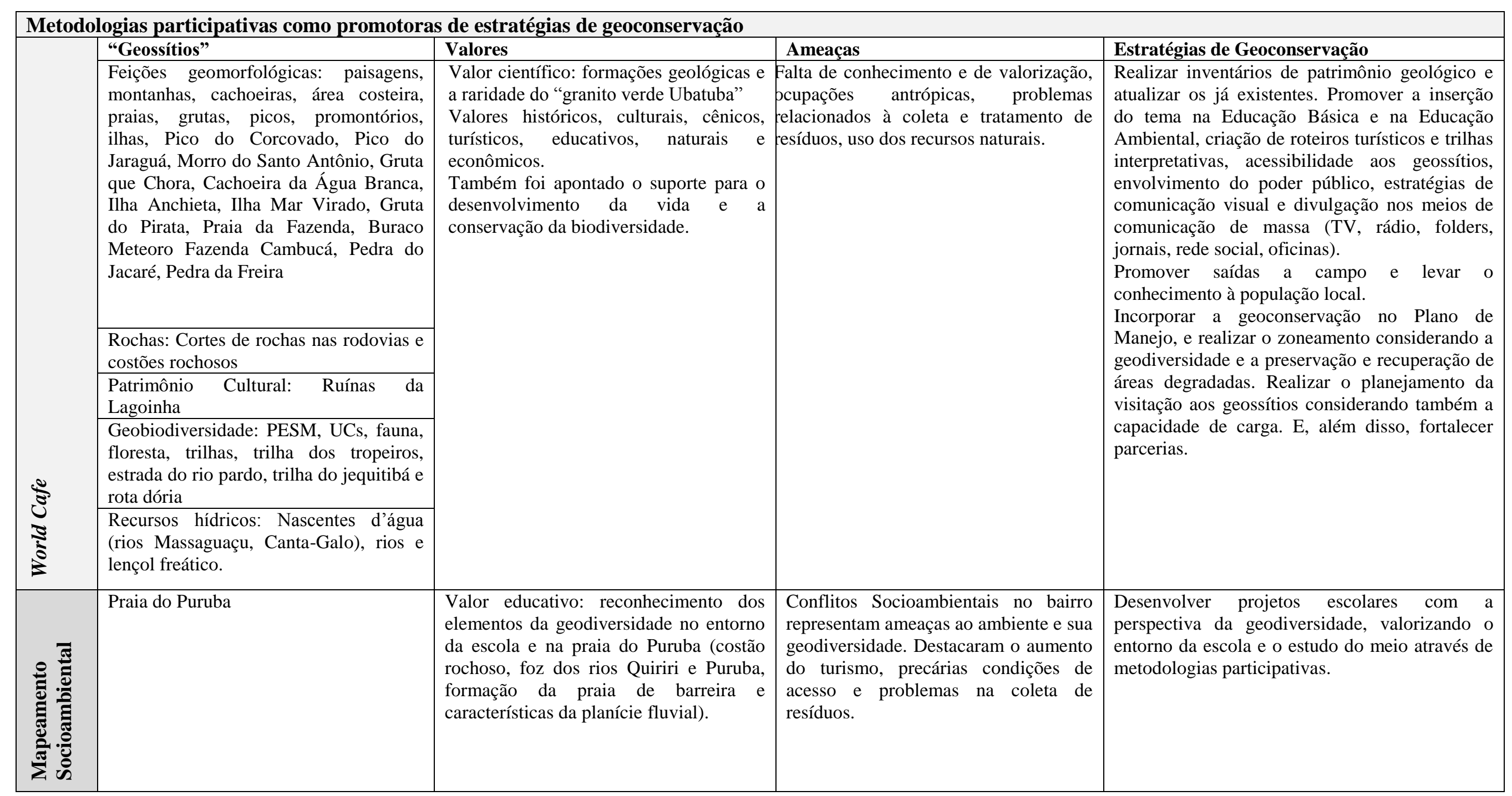

Conclusão 


\section{CONSIDERAÇÕES FINAIS}

O desenvolvimento da pesquisa teve como pressuposto o entendimento da implantação de estratégias de geoconservação no contexto das Unidades de Conservação, em particular, nos núcleos Picinguaba e Caraguatatuba do Parque Estadual da Serra do Mar. Para isso, as estratégias de geoconservação foram associadas às diretrizes para Educação Ambiental em Unidades de Conservação (ENCEA-ICMBIO, 2011), as quais reconhecem as possibilidades educativas nesses espaços e desenvolvem a participação na gestão para uma conservação da natureza integrada e participativa.

A trajetória da pesquisa se desenvolveu de forma a promover estratégias de geoconservação por meio da divulgação e valorização da geodiversidade e do patrimônio geológico, tendo como eixo estruturante uma série de análises sobre o envolvimento dos atores locais nas estratégias de geoconservação.

As estratégias educativas para a geoconservação possuem amplas possibilidades que se apresentam no ambiente escolar e não-escolar. No ambiente escolar, possibilitam ampliar os conhecimentos em Geociências para desenvolvimento de projetos ambientais. No ambiente não-escolar, temos exemplos de atividades em Unidades de Conservação (BRASIL, 2016) em várias regiões do Brasil e orientações que podem ser usadas não apenas para a biodiversidade mas também para a geodiversidade, considerando-as ambas parte dos ambientes naturais e que necessitam de estratégias específicas de conservação. Os pressupostos da educação ambiental crítica e da Aprendizagem Social como norteadores das estratégias educativas são considerados referenciais nesse processo.

A pesquisa valorizou a apreensão das diversas perspectivas sobre o lugar e percebeu a importância do estabelecimento de parcerias com os núcleos Picinguaba e Caraguatatuba, com a escola municipal de Ubatuba "José Belarmino Sobrinho" e, com a ONG Instituto Argonauta. Envolveu e considerou, portanto, a visão dos atores locais das instituições parceiras (funcionários envolvidos com a gestão dos núcleos, monitores ambientais, guias de turismo, professores, funcionários da ONG e outros) e de moradores da região, constituídos pelos tradicionais (caiçaras e quilombolas) e moradores antigos para a elaboração de tais estratégias.

Ao contrário do que se encontrou na literatura em relação à participação social no contexto da geoconservação, nas quais as estratégias são elaboradas por um grupo da sociedade, geralmente pesquisadores e acadêmicos, a pesquisa envolveu os atores locais e promoveu a participação destes no processo. O entendimento do contexto socioambiental dos 
núcleos Picinguaba e Caraguatatuba do Parque Estadual da Serra do Mar gerou resultados que consideram o olhar dos atores locais em uma perspectiva histórica sobre as transformações nesse ambiente. Intercalando assim visões e opiniões sobre a temática da conservação da natureza, as relações estabelecidas com o lugar e, os conflitos socioambientais locais.

Nessa perspectiva, a interpretação dos dados permitiu estabelecer relações com a temática da geoconservação e os conflitos socioambientais identificados por esses atores sociais que consistem em ameaças inerentes à geodiversidade e ao patrimônio geológico. Do mesmo modo, a forte relação estabelecida com a paisagem local por esses moradores pode ser contributo para o planejamento de ações de sensibilização e conscientização na região.

O levantamento e a interpretação das percepções geoambientais revelaram que os atores locais reconhecem a geodiversidade na configuração da paisagem local, o que contribui sobremaneira com o modo que realizam avaliações e atuam sobre esse meio. As sensações e sentimentos presentes em relação aos aspectos da geodiversidade (montanhas, praias, costões rochosos, rios, cachoeiras, dentre outros) constituem-se em referências de pertencimento, qualidade de vida, bem estar e beleza, atribuídos a essas paisagens. Pode-se considerar a geodiversidade como intrínseca ao lugar e parte do socioambiente, favorecendo a valorização desses aspectos pelas comunidades e influenciando suas atitudes no sentido de conservar esses lugares.

O conceito da geodiversidade suscitou incertezas e dificuldades de compreensão para os moradores tradicionais, o que nos fez entender que nem sempre é necessário partir de uma abordagem conceitual para o desenvolvimento das estratégias. Em relação aos gestores, monitores ambientais, professores e funcionários da ONG esta abordagem conceitual foi possível, considerando o contexto do curso de formação e as experiências prévias destes grupos em relação à temática da conservação. Assim, foram utilizadas diferentes estratégias de entendimento da percepção ambiental desses atores, auxiliadas pelas metodologias usadas na pesquisa.

Observamos que na perspectiva dos gestores há valorização do conhecimento científico, com a identificação da geodiversidade e do patrimônio geológico através dos cumes e picos presentes na região, afloramentos e costões rochosos, praias e a diversidade hídrica, associando-os aos aspectos da biodiversidade. Do mesmo modo, sua contribuição para a geoconservação vai ao encontro das estratégias relacionadas ao Uso Público do Parque, propondo a inserção da temática durante as atividades de visitação e de educação ambiental. A perspectiva técnica também chama a atenção, através da reflexão sobre a necessidade de 
levar em conta a geodiversidade e o patrimônio geológico nos processos de licenciamento ambiental, elaboração e atualização do plano de manejo e do zoneamento do território.

$\mathrm{Na}$ perspectiva dos monitores ambientais, funcionários da ONG e professores, a geodiversidade foi relacionada etimologicamente à categoria diversidade geológica $(83 \%$ do total) em comparação ao termo biodiversidade, o qual possuem maior familiaridade. Esses atores identificaram os elementos da geodiversidade, relacionando-os a aspectos locais tanto pelo conhecimento científico quanto pela percepção. A utilização do termo natureza abiótica gerou incerteza conceitual entre os respondentes, sendo relativamente pequeno o grupo de pessoas que o relacionou aos aspectos da geodiversidade ou à natureza sem vida (33\% do total).

O patrimônio de acordo com esses grupos de respondentes foi identificado principalmente através dos aspectos históricos $(84 \%$ do total indicou "algo que tenha importância para a humanidade" e $83 \%$ do total, "algo que tenha importância para a história"), associando o patrimônio cultural (ou construído) às construções históricas (84\% to total) e, o patrimônio natural, às florestas ( $83 \%$ do total). Nessa perspectiva, a dificuldade em abordar o patrimônio geológico partiu desse pressuposto, ou seja, pela percepção dos respondentes, o patrimônio está relacionado aos elementos históricos e culturais. Mesmo na identificação do patrimônio natural, este foi relacionado principalmente às florestas.

Para eles, a responsabilidade de proteção do patrimônio recai sobre o Governo Estadual e o Instituto Florestal/ICMBio, refletindo, portanto, a atual gestão ambiental do território, uma vez que o parque abrange grande parte dos municípios de Caraguatatuba e Ubatuba e sua gestão é feita pelo Estado de São Paulo, contendo áreas de sobreposição com o Parque Nacional da Serra da Bocaina, gerido pelo ICMBio. Para esses respondentes, as Prefeituras e o Governo Federal também deveriam ser responsáveis pela proteção do patrimônio, indicando, portanto a atribuição da gestão governamental. Nesse sentido, chamou a atenção as poucas indicações dadas ao IPHAN e ao CONDEPHAAT, órgãos que atuam diretamente na proteção do patrimônio do Brasil e de São Paulo.

O fomento ao planejamento e desenvolvimento local baseados na proteção do patrimônio geológico carece também de instrumentos legais que possam amparar atividades econômicas e geoturísticas. Ferreira (2016) afirma que o patrimônio geológico brasileiro já possui legislação para a sua proteção direta nas modalidades de patrimônio paleontológico e patrimônio espeleológico e que a Lei $n^{\circ}$ 9.985/2000 das unidades de conservação é um dos instrumentos mais adequados à proteção do patrimônio geológico. No entanto, a legislação estadual e municipal, como decretos que criem os geoparques ou ainda que tais áreas constem 
nos planos diretores municipais, deverá ser desenvolvida para assegurar a preservação dos geossítios e as atividades geoturísticas.

Nesse contexto, o patrimônio geológico foi reconhecido a partir de referências no relevo da Serra do Mar e na paisagem costeira, sendo que alguns respondentes relacionaram o patrimônio a elementos da biodiversidade e outros aspectos socioculturais. Desse modo, mesmo que a palavra patrimônio geológico carregue consigo a ideia de elementos estritamente geológicos, a percepção de patrimônio pode fazer com que as pessoas o correlacionem com outros elementos, sendo ainda pouco identificado o valor patrimonial nos aspectos da geodiversidade.

O curso "Estratégias de Geoconservação no Parque Estadual da Serra do Mar" contribuiu com um primeiro contato dos participantes com a temática. No contexto da aprendizagem, foi imprescindível a introdução aos conceitos das Geociências, propiciando uma fundamentação teórica básica, para em seguida abordar a geoconservação. $O$ desenvolvimento de aulas dialogadas, trabalhos de campo e atividades didático-pedagógicas baseadas na Aprendizagem Social possibilitou a troca de conhecimentos e a valorização e divulgação da geodiversidade e do patrimônio geológico.

Para a estruturação do curso levou-se em conta os dados do diagnóstico socioambiental e o levantamento das Percepções Geoambientais dos moradores locais, o que favoreceu uma abordagem contextualizada e significativa para esses atores. A partir dessa abordagem e da integração de metodologias participativas, os participantes estabeleceram relações entre os conteúdos e os aspectos do ambiente local, realizando o reconhecimento da geodiversidade e do patrimônio geológico e refletindo sobre as estratégias de geoconservação.

As metodologias participativas tiveram como base o World Café e o Mapeamento Socioambiental. Apesar do curto espaço de tempo para o desenvolvimento do curso, pôde-se notar sua relevância para os atores locais à medida que demonstraram a apropriação desses saberes. Os diálogos decorridos no curso e as representações construídas a partir das atividades no contex to das metodologias participativas foram indicadores desse aprendizado.

Como exemplo destaca-se a Figura 41, que possui a representação do geossíto "Gruta que Chora" pelo grupo de participantes no núcleo Picinguaba. No esquema elaborado, observa-se a representação da gruta como geossítio e da litologia do afloramento na gruta e em subsuperfície. Nesse exemplo, verifica-se também a indicação dos responsáveis pela geoconservação tendo como pressuposto o estabelecimento de parcerias e a gestão integrada. Houve assim, o reconhecimento de três principais grupos de atores para a geoconservação: as instituições e órgãos governamentais relacionados com o turismo; as instituições de ensino, 
comerciantes e agências de turismo; e, os próprios participantes do curso, como guias de turismo, monitores ambientais e as comunidades.

As estratégias de geoconservação definidas através das metodologias participativas reforçaram essa ideia de gestão integrada, lançando olhar também sobre as instituições governamentais, o PESM, a participação das comunidades, as parcerias com ONGs, associações de bairro, comitê de bacias hidrográficas, dentre outros, o que nos indica uma percepção da necessidade de participação integrada de vários grupos de atores sociais. Nesse quadro, os participantes salientaram os estudos científicos e a constante renovação dos inventários observando a contribuição dos conhecimentos locais, e a necessidade de divulgação dessas informações. Ações de valorização e divulgação, bem como o ordenamento da visitação e o estabelecimento de estruturas visando à acessibilidade e a segurança foram recorrentes nas estratégias concordando com a aptidão turística da região. Nota-se que para os geossítios inseridos no PESM a fiscalização e o monitoramento poderiam ser atribuição do parque.

Os atores tiveram autonomia para identificar e refletir sobre as estratégias de geoconservação, considerando a apropriação de conceitos relacionados às Geociências e a consolidação da importância da geoconservação em continuidade aos trabalhos já desenvolvidos pelo NAP GeoHereditas na região.

A Aprendizagem Social como um dos eixos norteadores da pesquisa valorizou os atores locais, através do estabelecimento de parcerias, do diálogo e do reconhecimento de seus conhecimentos e experiências. Essa interação fortaleceu práticas colaborativas entre os atores locais, desenvolvendo assim o olhar geocientífico e socioambiental para o (re)conhecimento da geodiversidade e suas interações socioambientais. E, sobretudo, tornou as estratégias de geoconservação significativas para esses atores, reconhecendo seu papel desde a identificação do patrimônio geológico, a implementação e o monitoramento da geoconservação.

Foi possível observar que no contexto da Aprendizagem Social os autores reconhecem as bases necessárias para que ela se desenvolva: participação - diálogo - coresponsabilização.

As experiências relatadas por Santos (2015) e Soares (2016) apontam que a Aprendizagem Social traz em seus fundamentos teóricos a base para promover processos educativos que envolvam a comunidade local, a preservação ambiental, a cooperação mútua e a possibilidade de mediação de conflitos. A educação para a geoconservação que se baseia nesses pressupostos converge com a aprendizagem no contexto da Educação para Sustentabilidade que "para além de conhecimentos, teorias e valores a: aprender a fazer 
perguntas críticas; a esclarecer os próprios valores; a imaginar futuros mais positivos e sustentáveis; a pensar sistematicamente; a responder através da aprendizagem aplicada; e a explorar a dialética entre tradição e inovação" (UNESCO, 2011).

Considera-se que promover a geoconservação baseando-se na geodiversidade e no patrimônio geológico das regiões é um dos contributos para garantir o desenvolvimento sustentável destes locais.

Diferente do ensino tradicional ou de metodologias transmissivas de conteúdo, as metodologias participativas possibilitam o aprendizado em comunidade. Nesse sentido, destaca-se Capra (2009) ao afirmar que a Aprendizagem Social:

\begin{abstract}
"Incentiva uma mudança do ensino e aprendizado "transmissivo" baseado em especialistas, para a aprendizagem "transformadora", baseada na comunidade. No primeiro, o conhecimento do conteúdo deveria ser transferido para cidadãos de todas as idades, particularmente nos primeiros anos. As pessoas tiveram que aprender sobre a natureza para melhor compreendê-la e protegê-la. Com o tempo, os educadores reconheceram a importância de uma aprendizagem mais experiencial, relacionando o desenvolvimento de competências da cabeça (cognitivas), do coração (emotivas), e das mãos (habilidades). Hoje, a educação para a sustentabilidade é menos uma questão de transmitir o conteúdo da ecologia aos cidadãos e mais sobre a utilização dos princípios subjacentes aos processos ecológicos para ajudar as comunidades e seus membros a responder o desafio da sustentabilidade de modo adequado às suas situações. Esses princípios não só ajudam as pessoas a compreenderem melhor a natureza, mas também ajudam-nos a compreender melhor a si mesmo, e as comunidades em que vivem e trabalham e a conceber a educação para uma vida sustentável com base nesses princípios (CAPRA, 2009, p. 13, tradução nossa).
\end{abstract}

Portanto, a pesquisa se alinha a esse pensamento à medida que confere valor para a perspectiva dos atores locais, e, integra análises dos contextos, do lugar e das percepções das pessoas. O desenvolvimento da etapa voltada para o ensino proporcionou a apreensão de novos conceitos e saberes, interagindo com os saberes locais, procurando sensibilizá-los para a geoconservação através dos aspectos cognitivos, emotivos e nas suas habilidades.

As estratégias educativas também podem contemplar o treinamento de gestores, técncios governamentais e as populações em área de existência de patrimônio geológico para promover o planejamento e desenvolvimento local.

Conclui-se que, a partir dessa abordagem, é possível refletir sobre estratégias de geoconservação na perspectiva socioambiental e que as metodologias participativas contribuem com essa área de pesquisa à medida que orientam sobre o estabelecimento de laços entre os atores locais com a geoconservação. Ressaltam ainda a importância da 
geodiversidade sobre diversas perspectivas, apreendendo seus valores a partir dos atores locais, somados às pesquisas científicos, de inventário e de valorização e divulgação.

As possibilidades advindas da identificação das Unidades de Conservação no Brasil como espaços educativos demonstram que é possível aprender no e com o ambiente, consolidando os aspectos cognitivos e afetivos na relação de ensino, promovendo vínculos com o local e desenvolvendo a proteção ambiental. A valorização da geodiversidade se mostrou um caminho propício para sensibilizar as pessoas para a geoconservação. Essa pesquisa trouxe à tona a importância da geoconservação no reconhecimento do valor intrínseco da natureza e integrado do ambiente, em sua geo, socio e biodiversidade 


\section{REFERÊNCIAS BIBLIOGRÁFICAS}

ALMEIDA, F.F.M. Origem e evolução da plataforma brasileira. Rio de Janeiro: DNPM, Boletim da divisão de Geologia e Mineralogia, 1967. p. 1-36. v. 241.

Tectono-magmatic activation of the South American Platform and associated mineralization. In: IUGS, Int. Geol. Congress, 24, Montreal, Proc Section, 1972, 3, p. 339 346.

ALMEIDA, F. F. M.; HASUI, Y.; BRITO NEVES, B. B.; FUCK, R. A. Províncias estruturais brasileiras. In: Atas do VIII Simpósio de Geologia do Nordeste, Campina Grande, 1977, p. 363-361. Boletim Especial.

ALMEIDA, F. F. M.; HASUI, Y.; BRITO NEVES, B. B.; FUCK, R. A. Brazilian Structural Provinces: an introduction. Earth-Science Reviews, Amsterdam, v. 17, n. 1-2, p. 1-29, 1981.

ALMEIDA, F. F. M.; CARNEIRO, C. D. R. Origem e Evolução da Serra do Mar. Revista Brasileira de Geociências, São Paulo, v. 28, n. 2, p. 135 - 150, 1998.

ALMEIDA, F. F. M.; CARNEIRO, C. D. R.; BARTORELI, A. Magmatismo pós-paleozoico no Brasil. In: HASUI, Y.; CARNEIRO, C. D. R.; ALMEIDA, F. F. M.; BARTORELLI, A. (org.). Geologia do Brasil. São Paulo: Beca, 2012, p. 430 - 452.

ALVES, Z.M.M.B.; SILVA, M.H.G.F.D. Análise qualitativa de dados de entrevista: uma proposta. Paidéia, Ribeirão Preto, n. 2, p. 61-69, 1992.

ANJOS, A.C.C. Diálogos entre Patrimônio, Meio Ambiente e Aprendizagem Social: uma experiência de Educação Patrimonial em pesquisa-ação no bairro paulistano de Santo Amaro. 2016. 330p. Tese (Doutorado em Educação) - Faculdade de Educação, Universidade de São Paulo, São Paulo, 2016.

ARAUJO, M.A.R. Unidades de Conservação no Brasil: da República à Gestão de Classe Mundial. Belo Horizonte: SEGRAC, 2007. 272p.

ARRUDA, R. "Populações tradicionais" e a proteção dos recursos naturais em unidades de conservação. Ambiente \& Sociedade, Campinas, n. 5, p. 79 - 92, 1999.

ARRUDA, K.E.C.; GARCIA, M.G.M.; DEL LAMA, E.A. Geological Heritage Inventory as a Subsidy for Geotourism: Caraguatatuba - São Paulo State, Brazil. In: VIII International ProGEO Symposium, Reykjavík, Iceland, 2015. 
ARRUDA, K.E.C.; LAMA, E.A.; GARCIA, M.G.M. Inventário e quantificação do Patrimônio Geológico do Município de Caraguatatuba, São Paulo. Geociências, UNESP Rio Claro, 2017, no prelo.

AVELAR, S.; MANSUR, K.L.; ANJOS, S.C.; CASCONCELOS, G.F. Community Perceptions for Geoconservation of a Coastal Area in Rio de Janeiro, Brazil. Geoheritage, v. 7, p. $275-283,2016$.

AZEVÊDO, M.TM. Geodiversidade e geoturismo na bacia do Tejo português - uma abordagem preliminar. In: II Congresso Nacional de Geomorfologia. Publicações da Associação Portuguesa de Geomorfólogos, v. 3, p. 161-165, 2006.

BACCI, D.C.; PIRANHA, J.M.; BOGGIANI, P.C.; DEL LAMA, E.A.; TEIXEIRA, W. Geoparque - Estratégias de Geoconservação e Projetos Educacionais. Geologia USP, São Paulo, v. 5, 2009, p. 7-15.

BACCI, D.C.; JACOBI, P.R.; SANTOS, V.M.N. Aprendizagem Social nas Práticas Colaborativas: exemplos de ferramentas participativas envolvendo diferentes atores sociais. Alexandria, v. 6, n. 3, p. 227-243, 2013.

BACCI, D.C.; SANTOS, V.M.N. Mapeamento socioambiental como contribuição metodológica à formação de professores e aprendizagem social. Geologia USP, São Paulo, v. 6, p. 19-28, 2013a. Publicação Especial.

BACCI, D.C.; SANTOS, V.M.N. Mapeamento socioambiental como contribuição para a gestão dos recursos naturais. In: JACOBI, P.R. (Coord.); XAVIER, L.Y.; MISATO, M.T. (Coords. Editoriais). Aprendizagem Social e Unidades de Conservação: aprender juntos para cuidar dos recursos naturais. São Paulo: IEE/PROCAM, 2013b, p. 64 - 73.

BACCI, D.C.; BOGGIANI, P.C. O currículo do curso de Licenciatura em Geociências e Educação Ambiental - LIGEA-USP: formação de professores com visão sistêmica do Planeta Terra. In: BACCI, D.C. (org.). Geociências e Educação Ambiental. Curitiba: Ponto Vital, 2015, p.12-33.

BENSUSAN, N. Conservação da biodiversidade em áreas protegidas. Rio de Janeiro: FGV, 2006. 176p.

BIZZI, L. A.; SCHOBBENHAUS, C.; VIDOTTI, R. M.; GONÇALVES, J. H. (orgs.). Geologia, tectônica e recursos minerais do Brasil: texto, mapas \& SIG. Brasília: CPRM, 2003, 692p. 
BLANK, A.G.; CARNEIRO, M.H.; SECKENNDORFF, R.W.V.; OSTINI, S. A pesca do cerco-flutuante na Ilha Anchieta, Ubatuba, São Paulo, Brasil. Série Relatórios Técnicos, São Paulo, n. 34, p. 1-18, 2009.

BRASIL. Constituição (1988). Constituição da República Federativa do Brasil. Brasília, DF: Senado, 1988.

. Decreto $n^{\circ}$ 23.793, de 23 de Janeiro de 1934. Aprova o Código Florestal. Diário

Oficial da União, Rio de janeiro, RJ, 9 fev. 1934. Disponível em: <http://www.planalto.gov.br/ccivil_03/decreto/1930-1949/d23793.htm>, Acesso em 4 abr. 2017

. Decreto $\mathrm{n}^{\circ} 1.713$, de 14 de Junho de 1937. Cria o Parque Nacional de Itatiaia. Diário Oficial da União, Rio de Janeiro, RJ, 18 jun. 1937. Seção 1. Disponível em: $<$ http://legis.senado.gov.br/legislacao/ListaNormas.action?numero=1713\&tipo_norma=DEC

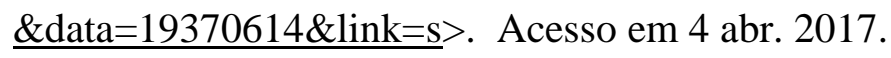

. Decreto-Lei $n^{\circ} 25$, de 30 de Novembro de 1937. Organiza a proteção do patrimônio histórico e artístico nacional. Diário Oficial da União, Rio de Janeiro, RJ, 6 dez. 1937. Disponível em: <https://www.planalto.gov.br/ccivil_03/decreto-lei/Del0025.htm>. Acesso em 4 abr. 2017.

. Lei $n^{\circ}$ 4.771, de 15 de Setembro de 1965. Institui o novo Código Florestal. Diário Oficial da União, Brasília, DF, 9 jun. 1965. Seção 1. Disponível em: <http://www.planalto.gov.br/ccivil_03/Leis/L4771.htm>. Acesso em 4 abr. 2017.

. Lei $N^{\circ}$ 5.197, DE 3 de Janeiro de 1967. Dispõe sobre a proteção à fauna e dá outras providências. Diário Oficial da União, Brasília, DF, 5 jan. 1967. Disponível em: http://www.planalto.gov.br/ccivil_03/leis/L5197.htm. Acesso em 4 abr. 2017.

. Lei ${ }^{\circ} 9.985$, de 18 de julho de 2000. Regulamenta o art. 225 , $§ 1^{\circ}$, incisos I, II, III e VII da Constituição Federal, institui o Sistema Nacional de Unidades de Conservação da Natureza e dá outras providências. Diário Oficial da União, Brasília, DF, 19 jul. 2000. Disponível em: <http://www.planalto.gov.br/ccivil_03/leis/L9985.htm>. Acesso em: 4 abr. 2017.

. Decreto $n^{\circ} 4.340$, de 22 de agosto de 2002. Regulamenta artigos da Lei no 9.985, de 18 de julho de 2000, que dispõe sobre o Sistema Nacional de Unidades de Conservação da 
Natureza - SNUC, e dá outras providências. Diário Oficial da União, Brasília, DF, 23 ag. 2002. Disponível em: <http://www.planalto.gov.br/ccivil_03/decreto/2002/d4340.htm>. Acesso em: 4 abr. 2017.

Decreto $n^{\circ} 4.887$, de 20 de novembro de 2003. Regulamenta o procedimento para identificação, reconhecimento, delimitação, demarcação e titulação das terras ocupadas por remanescentes das comunidades dos quilombos de que trata o art. 68 do Ato das Disposições Constitucionais Transitórias. Diário Oficial da União, Brasília, DF, 21 nov. 2003. Disponível em: < http://www.planalto.gov.br/ccivil_03/decreto/2003/d4887.htm>. Acesso em: 4 abr. 2017.

Decreto $n^{\circ} 5.758$, de 13 de Abril de 2006. Institui o Plano Estratégico Nacional de Áreas Protegidas - PNAP, seus princípios, diretrizes, objetivos e estratégias, e dá outras providências. Diário Oficial da União, Brasília, DF, 17 abr. 2006. Disponível em: < http://www.planalto.gov.br/ccivil_03/_Ato2004-2006/2006/Decreto/D5758.htm>. Acesso em: 4 abr. 2017.

Decreto $\mathrm{n}^{\circ} 6.040$, de 7 de fevereiro de 2007. Institui a Política Nacional de Desenvolvimento Sustentável dos Povos e Comunidades Tradicionais. Diário Oficial da União, Brasília, DF, 8 fev. 2007. Disponível em: < http://www.planalto.gov.br/ccivil_03/_ato2007-2010/2007/decreto/d6040.htm>. Acesso em: 4 abr. 2017.

Lei $n^{\circ} 11.959$, de 29 de junho de 2009. Dispõe sobre a Política Nacional de Desenvolvimento Sustentável da Aquicultura e da Pesca, regula as atividades pesqueiras, revoga a Lei ${ }^{\circ} 7.679$, de 23 de novembro de 1988, e dispositivos do Decreto-Lei ${ }^{\circ} 221$, de 28 de fevereiro de 1967, e dá outras providências. Diário Oficial da União, Brasília, DF, 30 de jun. de 2009. Disponível em: <http://www.planalto.gov.br/ccivil_03/_ato20072010/2009/lei/l11959.htm>. Acesso em 25 jun. 2017.

Ministério Do Meio Ambiente. Instituto Chico Mendes de Conservação da Biodiversidade (ICMBio). World Wildlife Fund Brazil (WWF - Brasil). Educação Ambiental em Unidades de Conservação: Ações voltadas para comunidades escolares no contexto da gestão pública da Biodiversidade. Brasília: Qualytá, 2016. 63p.

BRILHA, J. Património Geológico e Geoconservação: A Conservação da Natureza na sua Vertente Geológica. Braga: Palimage Editores, 2005. 190p. 
. Geoconservation and protected areas. Environmental Conservation. v. 29, n. 3. 2002.

. A importância dos Geoparques no Ensino e Divulgação das Geociências. Geologia USP, São Paulo, v. 5, p. 27 - 33, 2009. Publicação Especial. Inventory and quantitative assessment of geosites and geodiversity sites: a review.

Geoheritage, v. 8, p. $119-134,2016$.

BRILHA, J.; DIAS, G.; PEREIRA, D. A geoconservação e o ensino/aprendizagem da Geologia. In: Simpósio Ibérico do ensino de Geologia, XIV Simpósio sobre enseñanza de la Geología, XXVI Curso de actualização de professores de Geociências. Aveiro. 2006. Livro de Actas, Universidade de Aveiro, p. 445 - 448.

BROWN, J.. The World Café: living knowledge through conversations that Matter. 2001a. 342p. Ph.D Thesis. Fielding Graduate Institute, Santa Barbara, 2001a. Disponível em www.theworldcafe.com>. Acesso em 24 abril 2017.

The World Café: Living knowledge through conversations that matter. Unpublished doctoral dissertation, the Fielding Institute, available through Pegasus Communications, Cambridge, Maat, 2001b. Disponível em: < https://thesystemsthinker.com/the-world-cafeliving-knowledge-through-conversations-that-matter/ >. Acesso em 19 maio 2017.

BUREK, C.V. ; PROSSER, C.D. The history of geoconservation: an introduction. In:

The history of geoconservation. London: Geological Society, 2008, p. 1 - 5. Special Publications.

CAMARGO, M.E. World Café: Métodos de diálogo e criação coletiva como ferramenta de Educação Ambiental. In: JACOBI, P.R. (org.) Aprendizagem Social: Diálogos e Ferramentas Participativas: Aprender juntos para cuidar da água. São Paulo: IEE/PROCAM, 2011, p. $33-36$.

CAMPOS, J.F. (Org.). Santo Antônio de Caraguatatuba: Memória e Tradição de um Povo. Caraguatatuba: FUNDACC, 2000.

CAPRA, F. Foreword. In: WALS, A.E.J. (ed.) Social Learning: towards a sustainable world: Principles, perspectives, and praxis. $2^{\circ}$ published. Netherlands: Wageningen Academic Publishers, 2009, p. $13-16$.

CARLOS, A.F.A. O lugar no/do mundo. São Paulo: Hucitec, 1996. 
CARVAlHO, I. C.M. Educação Ambiental: A formação do sujeito ecológico. 3 ed. São Paulo: Cortez, 2008.

CASTRO, A.R.S.F.; MANSUR, K.L.; CARVALHO, I.S. Diagnóstico da relação da comunidade com o patrimônio geológico por meio de instrumento de coleta de dados. Terrae Didática, v. 11, n. 3, 2015, p. 162-172.

CEPAGRI. CENTRO DE PESQUISAS METEOROLÓGICAS E CLIMÁtICAS APLICADAS À AGRICULTURA. Clima dos municípios paulistas. Disponível em: 〈http://www.cpa.unicamp.br/outras-informacoes/clima-dos-municipios-paulistas.html >. Acesso em: 18 mai. 2017.

CORDANI, U.G; DELHAL, J.; LEDENT, D. Orogeneses superposeés dans le précambrien du Brésil sud-oriental (états du Rio de Janeiro et Minas Gerais). Revista Brasileira de Geociências, v. 3, n. 1, p. 1-22. 1973.

CPRM. COMPANHIA PESQUISA DE RECURSOS MINERAIS. Geodiversidade. Disponível em: < http://www.cprm.gov.br/publique/Gestao-Territorial/Geodiversidade-162>. Acesso em 16 maio 2017.

CRAPS, M.; MAUREL, P. (eds). Social Learning Pool of Questions. An instrument to diagnose Social Learning and IC-tools in European River Basin Management. Combined WP2/WP3 report of the HarmoniCOP Project, 2003. 65p.

CROFTS, R.; GORDON, J.E. Geoconservation in protected areas. In: Worboys, G. L.; Lockwood, M.; Kothari, A.; Feary, S.; Pulsford, I. (Eds.). Protected Area Governance and Management, Canberra: ANU Press, 2015, p. 531-568.

CRUZ, O. Contribuição geomorfológica ao estudo de escarpas da Serra do Mar. Rev. IG, São Paulo, v. 11, n. 1, p. 9-20, 1990.

DAHER, C.S. Ocupações humanas no Parque Estadual da Serra do mar: Análise e espacialização dos Autos de Infração Ambiental no Núcleo Caraguatatuba. 2012. 102p. Dissertação (Mestrado em Recursos Naturais) - Escola Superior de Agricultura Luiz de Queiroz, Universidade de São Paulo, Piracicaba, 2012.

DATAGEO. SISTEMA AMBIENTAL PAULISTA. Infraestrutura de Dados Espaciais Ambientais do Estado de São Paulo IDEA-SP. Base Territorial Ambiental Unificada. Disponível em: <http://datageo.ambiente.sp.gov.br/>. Acesso em 8 jun. 2017. 
DD. DECLARAÇÃO DE DIGNE. Declaração Internacional dos direitos à memória da Terra. Digne, França, 1991. Tradução de Carlos Fernando de Moura Delphin, 2009. Diponível em: <http://portal.iphan.gov.br/uploads/temp/Declaracao_Internacional_dos_Direitos_a_Memoria _da_Terra.pdf>. Acesso em 15 mai. 2017.

DEL RIO, V. Desenho Urbano e Revitalização na Área Portuária do Rio de Janeiro: A Contribuição do Estudo da Percepção Ambiental. 1991. 548p. Tese (Doutorado em Arquitetura e Ubanismo) - Faculdade de Arquitetura e Ubanismo, Universidade de São Paulo, São Paulo, 1991.

DEL RIO, V.; OLIVEIRA, L. (Orgs.). Percepção ambiental: a experiência brasileira. São Paulo: Studio Nobel. 1996.

DEL RIO, V. Cidade da Mente, Cidade Real: Percepção e Revitalização da Área Portuária do RJ. In: DEL RIO, V.; OLIVEIRA, L. (Orgs.). Percepção ambiental: a experiência brasileira. São Paulo: Studio Nobel. 1996.

DIEGUES, A.C. Etnoconservação da Natureza: enfoques alternativos. In: DIEGUES, A.C. (Org.). Etnoconservação: Novos Rumos para a Conservação da Natureza. São Paulo: HUCITEC, 2000.

O mito moderno da natureza intocada. $3^{a}$ ed. São Paulo: HUCITEC, 2001. $161 \mathrm{p}$.

DUARTE, R. Entrevistas em pesquisas qualitativas. Educar em Revista, n. 24, p. 213-225, 2004.

ELALI, G.A.; MEDEIROS, S.T.F. Apego ao lugar (vínculo com o lugar - Place attachment). In: CAVAlCANTi, S.; Elali, G.A. (orgs.). Temas básicos em Psicologia Ambiental. Petrópolis, RJ: Vozes, 2011, p. 53 - 62.

ENCEA. ICMBio. Diretrizes para Estratégias Nacional de Comunicação e Educação Ambiental em Unidades de Conservação. 2011, 48p. Disponível em: http://www.icmbio.gov.br/portal/images/stories/comunicacao/publicacao_encea.pdf. Acesso em 16 mai. 2017.

ESTERCI, N. Populações Tradicionais. In: RICARDO, B.; CAMPANILI, M. (Eds.). Almanaque Brasil Socioambiental. $2^{\mathrm{a}}$ ed. São Paulo: ISA, 2008. 
FERNANDES, M.E.S.A.C. 2014. O World Café e o aprendizado pelo diálogo: limites e possibilidades de um território de sentidos no processo de formação "Diagnóstico socioambiental na APA Embu Verde: Educação Ambiental para a sustentabilidade na bacia do rio Cotia”, Embu das Artes, SP. 210p. Tese (Doutorado em Educação) - Faculdade de Educação, Universidade de São Paulo, São Paulo, 2015.

FERREIRA, M.W.S. Enquadramento legal e institucional para a promoção da geoconservação no Brasil e propostas de desenvolvimento. 2016. 116p. Dissertação (Mestrado em Geociências - Ramo de Património Geológico e Geoconservação), Escola de Ciências, Universidade do Minho, Portugal, 2016.

FIERZ, M. S. M. As abordagens sistêmica e do equilíbrio dinâmico na análise da fragilidade ambiental do litoral do estado de São Paulo: contribuição à geomorfologia das planícies costeiras. 2008. 410p. Tese (Doutorado em Geografia) - Departamento de Geografia, Faculdade de Filosofia, Letras e Ciências Humanas. Universidade de São Paulo, São Paulo, 2008.

FORATTINI, O.P. Qualidade de vida e meio urbano. A cidade de São Paulo, Brasil. Ver. Saúde públi., São Paulo, v. 25, n. 2, p. 75-86, 1991.

FRANCO, A.R. Etnocartografia e Análise dos Valores da Geodiversidade com Comunidades Tradicionais de Artesãos em Pedra-Sabão da Região do Quadrilátero Ferrífero - Minas Gerais. 2014. 138p. Dissertação (Mestrado em Análise e Modelagem de Sistemas Ambientais) - Departamento de Geografia, Instituto de Geociências, Universidade Federal de Minas Gerais, Belo Horizonte, 2014.

FRANCO, M.I.G.C. Ferramentas participativas: A importância do fazer coletivo. In:JACOBI, P. (Coord.). Aprendizagem Social: diálogos e ferramentas participativas: aprender juntos para cuidar da água. São Paulo: IEE/PROCAM, 2011, p. 29 - 32.

GARCIA, M.G.M. Gondwana Geodiversity and Geological Heritage: Examples from the North Coast of São Paulo State, Brazil. Anuário do Instituto de geociências - UFRJ, v. 35, p. $101-111,2012$.

GARCIA, M.G.M.; DEL LAMA, E.A.; BUOROTTE, C.; MARTINS, L. Interpretação geológica em trilhas em unidades de conservação: exemplo do Litoral Norte de São Paulo. In: Anais do II Simpósio Brasileiro de Patrimônio Geológico - GeoBRheritage, Ouro Preto, 2013. 
GARCIA, M.G.M.; MARTINS, L.; DEL LAMA, E.A.; BUOROTTE, C. O inventário do Patrimônio Geológico da região costeira do Estado de São Paulo: base metodológica, adaptações e considerações. In: Anais do $47^{\circ}$ Congresso Brasileiro de Geologia, Salvador, Bahia, 2014, p. 47.

GARCIA, M.G.M.; BRILHA, J.; LIMA, F.F.; VARGAS, J.C.; PÉREZ-AGUILAR, A.; ALVES, A.; CAMPANHA, G.A.C.; DULEBA, W.; FALEIROS, F.M.; FERNANDES, L.A.; FIERZ, M.S.M.; GARCIA, M.J.; JANASI, V.A.; MARTINS, L.; RAPOSO, M.I.B.; RICARDI-BRANCO, F.; ROSS, J.L.S.; FILHO, W.S.; SOUZA, C.R.G.; BERNARDES-DEOLIVEIRA, M.E.C.; BRITO NEVES, B.B.; CAMPOS NETO, M.C.; CHRISTOFOLETTI, S.R.; HENRIQUE-PINTO, R.; LOBO, H.A.S.; MACHADO, R.; PASSARELLI, C.R.; PERINOTTO, J.A.J.; RIBEIRO, R.R.; SHIMADA, H. The inventory of Geological Heritage of the State of São Paulo, Brazil: Methodological Basis, Results and Perspectives. Geoheritage, v. 9, p. 1-20, 2017.

GEOSSIT. 2014. Disponível em: http://www.cprm.gov.br/geossit/. Acesso em 22 mar. 2016.

GIGLIOTTI, C.M.C; SANTOS, M. J. A expansão urbana de Caraguatatuba (1950-2010): Uma análise das transformações sócio espaciais. Rev. eletrônica Caminhos de Geografia, Uberlândia, v. 14, n. 46, p. 150-159, 2013.

GIL, A.C. Métodos e técnicas de Pesquisa Social. $6^{\text {a }}$ ed. São Paulo: Atlas, 2008. 200p.

GONTIJO-PASCUTTI, A. H. F.; HASUI, Y.; SANTOS, M. dos; JÚNIOR, A. V. S.; SOUZA, L. A. de. As Serras do Mar e da Mantiqueira. In: HASUI, Y.; CARNEIRO, C. D. R.; ALMEIDA, F. F. M.; BARTORELLI, A. (Org.). Geologia do Brasil. São Paulo: Beca, 2012, p $549-573$.

GRAY, M. Geodiversity: valuing and conserving abiotic nature. Edt. John Wiley \& Sons, Ltd, Chichester, England. 2004.

Geodiversity: the origin and evolution of a paradigm. In: BUREK, C.V.; PROSSER, C.D. (eds.) The History of Geoconservation. Geological Society, London, Special Publications, 300, p. $31-36,2008$

. Valuing and conserving abiotic nature, $2^{\mathrm{a}}$ ed. Londres, John Wiley \& Sons, 2013, $508 \mathrm{p}$.

HARMONICOP. Public participation and the European Water Framework directive. Role of Information and Communication Tools. Work Package 3 report of the HarmoniCOP 
project. MAUREL P., ed LEUVEN, K.U. - Centre for Organizational and Personnel Psychology, 2003.

HASUI, Y. CARNEIRO, C.D.R.; COIMBRA, A.M. The Ribeira folded belt. Revista Brasileira de Geociências, vol. 5, p. 257-266, 1975.

HASUI, Y. A grande colisão pré-cambriana do sudeste brasileiro e a estruturação regional. Geociências UNESP, v. 29, n. 2, p. 141-169, 2010.

Sistema Orogênico Mantiqueira. In: HASUI, Y.; CARNEIRO, C. D. R.; ALMEIDA, F. F. M.; BARTORELLI, A. (Org.). Geologia do Brasil. São Paulo: Beca, 2012, p 331-372. HEILBRON, M.; MACHADO, N. Timing of terrane accretion in the Neoproterozoic Eopaleozoic Ribeira orogen (SE Brazil). Precambrian Research, v. 125, p. 87-112, 2003.

HEILBRON, M.; PEDROSA-SOARES, A. C.; CAMPOS NETO, M. C.; SILVA, L. C.; TROW, R. A. J.; JANASI, V. A. A província Mantiqueira. In: MANTESSO-NETO, V.; BARTORELli, A.; CARNEIRO, C. D. R; BRITO NEVES, B. B. (Org.). Geologia do continente sul-americano: evolução da obra de Fernando Flávio Marques de Almeida. São Paulo: Beca, 2004, p 204-235.

HENRIQUES, M.H.H.; REIS, R.P.; BRILHA, J.; MOTA, T. Geoconservation as an Emerging Geoscience. Geoheritage, v. 3, p. 117 - 128, 2011.

HIRUMA, S.T.; RICCOMINI, C.; MODENESI-GAUTTIERI, M.C.; HACKSPACHER, P.C.; NETO, J.C.H.; FRANCO-MAGALHÃES, A.O.B. Denudation history of the Bocaina Plateau, Serra do Mar, southeastern Brazil: Relationships to Gondwana breakup and passive margin development. Gondwana Research, v. 18, p. $674-687,2010$.

IBGE. Instituto Brasileiro de geografia e Estatística. Carta do Brasil - escala 1:50 000. Folha Caraguatatuba (SF-23-Y-D-VI-1), 1974.

Síntese de indicadores sociais: uma análise das condições de vida da população brasileira. 012. Estudos e Pesquisas Informação Demográfica e Socioeconômica, n. 29, 2012. Carta do Brasil - escala 1:50 000. Folha Ilha Anchieta (SF-23-Y-D-VI-2), 1974. Disponível em: <http://portaldemapas.ibge.gov.br/portal.php\#mapa16015>. Acesso em: 21 jun. 2017. 
Carta do Brasil - escala 1:50 000. Folha Picinguaba (SF-23-Z-C-I-3), 1974. Disponível em: <http://portaldemapas.ibge.gov.br/portal.php\#mapa16014> . Acesso em : 21 jun. 2017.

. Carta do Brasil - escala 1:50 000. Folha Ubatuba (SF-23-Y-D-III-4). $2^{\text {a }}$ ed. 1981. Disponível em: <http://portaldemapas.ibge.gov.br/portal.php\#mapa15985>. Acesso em: 21 jun. 2017.

. Estimativas da população residente no Brasil e unidades da Federação com data de referência em $1^{\circ}$ de julho de 2016. Disponível em: http://cod.ibge.gov.br/F1L. Acesso em $\underline{27}$ de abril de 2017.

INSTITUTO PÓLIS. Diagnóstico Urbano Socioambiental: Município de Caraguatatuba. 2013a. Disponível em: http://litoralsustentavel.org.br/wp-content/uploads/2013/04/1.Caraguatatuba_18.03.13.pdf. Acesso em 14 de jun. 2017.

. Diagnóstico Urbano Socioambiental: Município de Ubatuba. 2013b. Disponível em: http://litoralsustentavel.org.br/wp-content/uploads/2013/04/1.-Ubatuba_19.03.13.pdf. Acesso em 14 de jun. 2017.

ITESP (Fundação Instituto de Terras do Estado de São Paulo). Relatório Técnico-Científico sobre os Remanescentes da Comunidade de Quilombo de Camburi, Ubatuba-SP. 2002. 36p.

IUCN/UNEP/WWF. International Union for Conservation of Nature and Natural Resources/United Nations Environment Programme/World Wildlife Fund. World conservation strategy: living resource conservation for sustainable development. Gland, Switzerland, 1980.

IUCN. Guidelines for Protected Area Management Categories. CNPPA with the assistance of WCMC, IUCN, Gland, Switzerland and Cambridge, UK, 1994. 261p.

. Resolutions and Recommendations. Gland, Switzerland: IUCN, 2009.

. Disponível em: <http://www.iucn.org/about/>. Acesso em: 4 fev. 2016.

JACOBI, P.R. Meio ambiente e sustentabilidade. In: O município no século XXI: cenários e perspectivas. Fundação Prefeito Faria Lima - CEPAM. Ed. Especial. São Paulo, p. 175-183, 1999.

. Educação Ambiental, Cidadania e Sustentabilidade. Cadernos de Pesquisa, n. 118, p. $189-205,2003$. 
Educação Ambiental: o desafio da construção de um pensamento crítico, complexo e reflexivo. Educação e Pesquisa, São Paulo, v. 31, n. 2, p. 233 - 250, 2005.

Meio ambiente, educação e cidadania: diálogo de saberes e transformação das práticas educativas. In: JACOBI, PR.; MONTEIRO, F.; FERNANDES, M.L.B. Educação e Sustentabilidade. São Paulo: Evoluir Cultural, 2009, p. 7 - 25.

. (Coord.). Aprendizagem Social: diálogos e ferramentas participativas: aprender juntos para cuidar da água. São Paulo: IEE/PROCAM, 2011,86p.

(Coord.). XAVIET, L.Y.; MISATO, M.T. (Coord. editoriais) Aprendizagem social e unidades de conservação: aprender juntos para cuidar dos recursos naturais.

KUHNEN, A. Percepção Ambiental. In: CAVALCANTE, S.; ELALI, G.A. (Orgs.). Temas básicos em Psicologia Ambiental. Petrópolis, RJ: Vozes, 2011, cap. 21, p. 250 - 266.

LIMA, F.L. Proposta metodológica para o inventário do patrimônio geológico brasileiro. 2008.170p. Dissertação (Mestrado em Geociências) - Escola de Ciências, Universidade do Minho, Portugal, 2008.

LIMA, M.R.; MELO, M.S.; COIMBRA, A.M. Palinologia de sedimentos da Bacia de São Paulo, Terciário do Estado de São Paulo, Brasil. Rev. IG, São Paulo, v. 12, p. 1-20, 1991.

MACHADO, L.M.C.P. Paisagem valorizada: A Serra do Mar como espaço e como lugar. In: DEL RIO, V.; OLIVEIRA, L. Percepção Ambiental: A experiência brasileira. São Paulo: Studio Nobel, 1996.

MANSUR, K.L. Projetos Educacionais para a Popularização das Geociências e para a Geoconservação. Geologia USP, Publicação Especial, São Paulo, v. 5, p. 63 - 74, 2009.

MANSUR, K.L.; SILVA, A.S. Society's Response: Assessment of the performance of the "Caminhos Geológicos" (“Geological Paths") Project, State of Rio de Janeiro, Brazil. Geoheritage, vol. 3, PP. 27-39, 2011.

MANZINI, E.J. Considerações sobre a transcrição de entrevistas. In: A entrevista na pesquisa em Educação e Educação Especial: uso e processo de análise. (Material utilizado para obtenção do título de Livre-docência em Educação). Faculdade de Filosofia e Ciências, UNESP - Marília. Observatório Nacional de Educação Especial (ONEESP), 2008. 
MARCÍliO, M.L. Caiçara: Terra e População: Estudo de Demografia Histórica e da História Social de Ubatuba. $2^{\mathrm{a}}$ ed. São Paulo: Edusp, 2006.

MEDEIROS, R. Evolução das Tipologias e Categorias de Áreas Protegidas no Brasil. Ambiente \& Sociedade, v. 9, n. 1, 2006.

MIZUSAKI, A. M. P.; FILHO, A. T. O Magmatismo Pós-Paleozóico no Brasil. In: MANTESSO-NETO, V.; BARTORELLI, A.; CARNEIRO, C. D. R; BRITO NEVES, B. B. (Org.). Geologia do continente sul-americano: evolução da obra de Fernando Flávio Marques de Almeida. São Paulo: Beca, 2004, p 281 - 291.

MMA. MINISTÉRIO DO MEIO AMBIENTE. Plano Estratégico Nacional de Áreas Protegidas - PNAP: Decreto $n^{\circ}$ 5.758, de 13 de abril de 2006. Brasília, 2006.

MMA. MINISTÉRIO DO MEIO AMBIENTE. Sítios Ramsar. Disponível em: < http://www.mma.gov.br/areas-protegidas/instrumentos-de-gestao/s\%C3\%ADtios-ramsar>. Acesso em: 16 mai. 2017.

. Sistema Nacional de UCs - SNUC. Disponível em: < http://www.mma.gov.br/areasprotegidas/sistema-nacional-de-ucs-snuc>. Acesso em: 16 mai. 2017.

MOHRIAK, W. U. Recursos energéticos associados à ativação tectônica mesozóicocenozóica da América do Sul. In: MANTESSO-NETO, V.; BARTORELLI, A.; CARNEIRO, C. D. R; BRITO NEVES, B. B. (Org.). Geologia do continente sul-americano: evolução da obra de Fernando Flávio Marques de Almeida. São Paulo: Beca, 2004, p 293 - 319.

MONTEIRO, F. Aprendizagem Social e Educação para Sustentabilidade. In: JACOBI, PR.; MONTEIRO, F.; FERNANDES, M.L.B. Educação e Sustentabilidade. n: Evoluir Cultural, 2009 , p. $27-66$.

MORALES, J.M. Guia prático para la interpretación del Patrimonio: El arte de acercar el legado natural y cultural al público visitante. $2^{\text {a }}$ ed. Sevilha: Junta de Andalucía, Consejería de Cultura, 2001.

MOTA, I.S. Uma via cênica no Parque Estadual da Serra do Mar - PESM. 2007. 194p. Dissertação (Mestrado em Engenharia Civil). Faculdade de Engenharia Civil, Arquitetura e Urbanismo. Universidade Estadual de Campinas, Campinas, 2007.

MUCIVUNA, V.C. Estratégias de Geoconservação aplicadas À geodiversidade do municipio de Bertioga - SP e às fortificações do litoral paulista. 2016. 140p. Dissertação 
(Mestrado em Ciências) - Instituto de Geociências, Universidade de São Paulo, São Paulo, 2016.

NIETO, L.M. Geodiversidad: propuesta de una definicion integradora. Boletin Geologico y Minero, tI2, p. 3-12, 2001.

OLIVATO, D. Análise da participação social no contexto da gestão de riscos ambientais na bacia hidrográfica do rio Indaiá Ubatuba - SP - Brasil. 2013. 293p. Tese (Doutorado em Geografia) - Departamento de Geografia. Faculdade de Filosofia, Letras e Ciências Humanas, Universidade de São Paulo, 2013.

OLIVEIRA, L. Percepção Ambiental. Revista Geografia e Pesquisa, v. 6, n. 2, 2012.

PACHECO, J.; BRILHA, J. Importância da interpretação na divulgação do patrimônio geológico: uma revisão. Comunicações Geológicas, v. 101, n. 1, p. 101 - 107, 2014.

PEREIRA, R. G. F. A. Geoconservação e desenvolvimento sustentável na Chapada Diamantina (Bahia, Brasil). 2010. 295p. Tese (Doutorado em Geociências) - Universidade do Minho. Escola de Ciências. Portugal. 2010.

PERrotTA, M. M.; SALVADOR, E. D. LOPES, R. C.; D’AGOSTINO, L. Z.; PERUFFO, N.; GOMES, S. D.; SACHS, L. L. B.; MEIRA, V. T.; GARCIA, M. G. M. LACERDA FILHO, J. V. Mapa Geológico do Estado de São Paulo, escala: 1:750 000. São Paulo: Programa Geologia do Brasil, PGB, CPRM, 2005.

POLETTE, M.; SILVA, L.H.M.M. Zona Costeira. In: RICARDO, B.; CAMPANILI, M. (Eds.). Almanaque Brasil Socioambiental. São Paulo: ISA, 2a ed., 2008, p.

POZO, J. I.; CRESPO, M. A. G. A aprendizagem de conceitos científicos: da aprendizagem significativa à mudança conceitual. In: A aprendizagem e o ensino de ciências: do conhecimento cotidiano ao conhecimento científico. Tradução de Naila Freitas. 5 ed. Porto Alegre: Artmed, 2009, cap?, 77 - 117.

PRETI D. (org) O discurso oral culto $2^{\mathrm{a}}$. ed. São Paulo: Humanitas Publicações FFLCH/USP, 1999 - (Projetos Paralelos. V.2) 224p.

PIRANHA, J.M.; DEL LAMA, E.A.; BACCI, D.C. Geoparks in Brazil - strategy of Geoconservations. Geoheritage, vol 3, 2011p, 289 - 298. 
PROCHOROFF, R. O patrimônio geológico de Ilhabela-SP: estratégias de geoconservação. 2014. 176p. Dissertação (Mestrado em Mineralogia Experimental e Aplicada) - Instituto de Geociências, Universidade de São Paulo, São Paulo, 2014.

PROSSER, C. Terms of endearment. Earth Heritage, 17, p. 12-13. 2002a . Speaking the same language. Earth Heritage, 18, p. $24-25.2002$ b.

PROSSER, C. D.; BRIDGLAND, D.R.; BROWN, E.J.; LARWOOD, J.G. Geoconservation for science and society: challenges and opportunities. Proccedings of the geologists' Association, vol. 122, n. 3, 2011.

REVERTE, F. C. Avaliação da geodiversidade em São Sebastião-SP, como patrimônio geológico. 2014. 208 p. Dissertação (Mestrado em Mineralogia Experimental e Aplicada) Instituto de Geociências, Universidade de São Paulo, São Paulo, 2014.

RICCOMINI, C. O Rift Continental do Sudeste do Brasil. 1989. 256 p. Tese (Doutorado em Geologia Sedimentar) - Instituto de Geociências, Universidade de São Paulo, São Paulo, 1990.

RICCOMINI, C.; SANT'ANNA, L. G.; FERRARI, A. L. Evolução Geológica do Rift Continental do Sudeste do Brasil. In: MANTESSO-NETO, V.; BARTORELLI, A.; CARNEIRO, C. D. R; BRITO NEVES, B. B. (Org.). Geologia do continente sulamericano: evolução da obra de Fernando Flávio Marques de Almeida. São Paulo: Beca, 2004, p 383 - 405.

ROSS, J.L.S.; MOROZ, I.C. Mapa Geomorfológico do Estado de São Paulo. Revista do Departamento de Geografia, São Paulo, v. 10, p. 41-58, 2011.

SANSOLO, D.G. Planejamento ambiental e mudanças na paisagem do núcleo Picinguaba do Parque Estadual da Serra do Mar - Ubatuba, São Paulo. 2002. 457p. Tese (Doutorado em Geografia Física) - Departamento de Geografia - Faculdade de Filosofia, Letras e Ciências Humanas, Universidade de São Paulo, São Paulo, 2002.

SANTOS, P. L. A. Patrimônio Geológico em áreas de proteção ambiental: Ubatuba-SP. 2014. 207 p. Dissertação (Mestrado em Mineralogia Experimental e Aplicada) - Instituto de Geociências, Universidade de São Paulo, São Paulo, 2014.

SANTOS, V.M.N. Formação de professores para o estudo do ambiente: projetos escolares e a realidade socioambiental local. 2006. 279f. Tese (Doutorado em Ciências) - Instituto de Geociências, Universidade Estadual de Campinas, Campinas, 2006. 
Educar no ambiente: Construção do olhar geocientífico e cidadania. São Paulo: Annablume, 2011.

Metodologias Participativas como Práticas de Aprendizagem Social para Sustentabilidade e Geoconservação. (Projeto de pesquisa de pós-doutorado) - Instituto de Energia e Ambiente, Universidade de São Paulo, São Paulo, 2015.

SANTOS, V.M.N.; BACCI, D.C.Mapeamento socioambiental para Aprendizagem Social. In: JACOBI, P.R. (Coord.). Aprendizagem social: diálogos e ferramentas participativas: aprender juntos para cuidar da água. São Paulo: IEE/PROCAM, 2011, 86p.

SÃO PAULO (Estado).Decreto no 10.251, de 30 de Agosto de 1977. Cria o Parque Estadual da Serra do Mar e dá providências correlatas. Diário Oficial Estado do Estado de São Paulo, São Paulo, SP, 31 ago. 1977. Disponível em: < http://www.al.sp.gov.br/norma/?id=152524>. Acesso em 12 abr. 2017.

.Decreto $\mathrm{n}^{\circ} 13.313$, de 6 de março de 1979. Dá nova redação ao artigo 2. ${ }^{\circ}$ do Decreto $\mathrm{n}^{\circ}$ 10.251, de 30 de agosto de 1977, que dispõe sobre a criação do Parque Estadual da Serra do Mar, com a finalidade de incorporar ao seu perímetro área situada na região denominada Picinguaba, $1 .^{\circ}$ perímetro de Ubatuba, conforme Processo SA. $n^{\circ} 89.20877$, bem como de retificar sua linha perimétrica entre os pontos P25 e P30, nos termos do Processo SA. 44678

Resolução SC nº40 de 6 de junho de 1985. Tombamento da Serra do mar e de Paranapiacaba. Diário Oficial Estado do Estado de São Paulo, São Paulo, SP, 15 jun. 1985. SÃo PAulo. Secretaria DO MEIO AMBIEnTE. Plano de Manejo do Parque Estadual da Serra do Mar. São Paulo: Instituto Federal, 2006.

Secretaria do meio Ambiente. Zoneamento Ecológico-Econômico do litoral norte de São Paulo. São Paulo: SMA/CPLEA, 2005. 56p.

Decreto $\mathrm{n}^{\circ}$ 56.572, de 22 de dezembro de 2010. Dispõe sobre a expansão do Parque Estadual da Serra do Mar em áreas de domínio público e dá providências correlatas. Diário Oficial Estado do Estado de São Paulo, São Paulo, SP, 23 dez. 2010. Disponível em: <https://www.al.sp.gov.br/norma/?id=160696>. Acesso em 12 abr. 2017.

Lei $\mathrm{n}^{\circ}$ 16.260, de 29 de Junho de 2016. Autoriza a Fazenda do Estado a conceder a exploração de serviços ou o uso, total ou parcial, de áreas em próprios estaduais que especifica e dá outras providências correlatas. Diário Oficial Estado do Estado de São Paulo, São Paulo, SP, 30 jun. 2016. Disponível em: < 
http://www.al.sp.gov.br/repositorio/legislacao/lei/2016/lei-16260-29.06.2016.html> . Acesso em 12 abr. 2017.

SÃO PAULO (ESTADO). SECRETARIA DO MEIO AMBIENTE. FUNDAÇÃO PARA A CONSERVAÇÃO E A PRODUÇÃO FLORESTAL. Manual de Gestão das Unidades de Conservação do Estado de São Paulo. São Paulo: Páginas \& Letras, 2014, 328p.

SCHOBBENHAUS C.; CAMPOS D. A. A evolução da Plataforma Sul-Americana no Brasil e suas principais concentrações minerais. In: Schobbenhaus C.; Campos D.A.; Derze G.R.; Asmus H.E. (coords.). Geologia do Brasil. Brasília: DNPM, 1984, p. 9-53.

SCHOBBENHAUS, C.; CAMPOS, D.A.; QUEIROZ, E.T.; WINGE, M.; BERBERT-BORN, M.L.C. (eds.) Sítios Geológicos e Paleontológicos do Brasil. Brasília: DNPM, 2002, v. 3, $554 \mathrm{p}$.

SCIFONI, S. A construção do patrimônio natural. 2006. 205p. Tese (Doutorado em Geografia) - Departamento de Geografia, Faculdade de Filosofia, Letras e Ciências Humanas, Universidade de São Paulo (USP), São Paulo, 2006.

SERRANO, E. \& RUIZ-FLAFIO, P. Geodiversity: a theoretical and applied concept. Geographica Helvetica, 62, 140-147, 2007.

SHARPLES, C. A methodology for the identification of significant landforms and geological sites for geoconservation purposes. Tasmania: Forestry Comission, 1993.

. Concepts and principles of geoconservation. 2002. Documento PDF, publicado eletronicamente em Tasmanian Parks \& Wildlife Service website: <www.dpiw.tas.gov.au/inter.nfs/webpages/SJON-57W4FD>. Acesso em 14 jan. 2017.

SILVA, A.C. O litoral norte do Estado de São Paulo: Formação de uma região periférica. IGEOG-USP. São Paulo: Série Teses e Monografias, n. 20, 1975.

SILVA, A.C.A.B. Reflexões acerca do ambientalismo: as conferências oficiais da ONU no Brasil. In: LOUREIRO, C.F.; SÁNCHEZ, C.; ACCIOLY, I.B.; COSTA, R. N. (org.). Pensamento ambientalista numa sociedade em crise. Macaé: NUPEM/UERJ, 2015.

SILVA, C.R.; RAMOS, M.A.B.; PEDREIRA, A.J.; DANTAS, M.E. Começo de tudo. In: SILVA, C.R. (ed.). Geodiversidade do Brasil: conhecer o passado, para entender e prever o futuro. Rio de Janeiro: CPRM, 2008. Cap. 1, p. 11 - 20. 
SIMÕES, E. O Dilema das Decisões sobre Populações Humanas em Parques: Jogo compartilhado entre Técnicos e Residentes no Núcleo Picinguaba. 2010. 390p. Tese (Doutorado em Ambiente e Sociedade) - Instituto de Filosofia e Ciências Humanas, Universidade Estadual de Campinas, Campinas, 2010.

Territórios em disputa: do impasse ao jogo compartilhado entre técnicos e residentes. São Paulo: Annablume, 2014.

SISTEMA AMBIENTAL PAULISTA. Parque Estadual Serra do Mar - Caraguatatuba. 2017. Disponível em: 〈http://www.parqueestadualserradomar.sp.gov.br/ >. Acesso em: 17 mai. 2017.

SOARES, D. B. Formação continuada de professores em geociências com metodologias participativas: contribuições à educação para geoconservação. 2016. 189p. Dissertação (Mestrado em Ensino e História de Ciências da Terra) - Instituto de Geociências, Universidade Estadual de Campinas, Campinas, 2016.

STANLEY, M. Geodiversity. Earth Heritage, 14, p. 15 - 18, 2000.

STIGLITZ, J.E.; SEM, A.; FITOUSSI, J. The measurement of economic performance and social progress revisited. OFCE(Centre de recherche em économie de Sciences Po). n. 200933. 2009.

TASSARA, E.T.O.; ARDANS, O. Mapeamentos e Diagnósticos: intervenções participativas no campo socioambiental. In: FERRARO JUNIOR. L.A. (Org.) Encontros e Caminhos: Formação de Educadoras (es) Ambientais e Coletivos Educadores. Brasília MMA, Departamento de Educação Ambiental, v. 2, 2007, p. 219 - 226.

TILDEN, F. Interpreting Our Heritage. The University of North Carolina, Press, 1957.

TOFFOLI, D.; MANSUR, G. Cultura caiçara. Disponível em: <http://fundart.com.br/tradicao/comunidades/caicara/>. Acesso em 23 maio 2017.

TRIVIÑOS, A.N.S. Introdução à pesquisa em Ciências Sociais: A pesquisa qualitativa em Educação. São Paulo: Atlas, 1987.

TUPINAMBÁ, M.; TEIXEIRA, W.; HEILBRON, M. Evolução tectônica e magmática da Faixa Ribeira entre o Neoproterozoico e o Paleozoico Inferior na Região Serrana do Estado do Rio de Janeiro, Brasil. Anuário do Instituto de geociências - UFRJ, v. 35, n. 2, 2012, p. $140-151$. 
UNESCO. Education for Sustainable Development: an Expert Review of Processes and Learning. Section for Education for Sustainable Development Division of Education for Peace and Sustainable Development. Paris, Franc., 2011, 132 p.

UNESCO. United Nations Educational, Scientific and Cultural Organization. Unesco Global Geoparks. Paris, France, 2016. Disponível em:

<http://unesdoc.unesco.org/images/0024/002436/243650e.pdf > . Acesso em 5 abr. 2017.

URBAN, T. Saudades do matão: relembrando a história da conservação da natureza no Brasil. Curitiba: UFPR, 1998. 374p.

URQUÍ, L.C.; LÓPEZ MARTÍNEZ, J.; DURÁN VALSERO, J. Patrimonio geológico y geodiversidad: investigación, conservación, gestión y relación com los espacios naturales protegidos. Cuadernos del Museo Geominero, 7, IGME, Madrid, 2007

VELASQUEZ, C. Quilombolas. In: In: RICARDO, B.; CAMPANILI, M. (Eds.). Almanaque Brasil Socioambiental. São Paulo: ISA, $2^{\mathrm{a}}$ ed., 2008.

WALS, A.E.J. (org.). Social learning towards a sustainable world: principles perspectives, and praxis. Wageningen: Wageningen Academic Publishers, 2007.

WINGE, M.; SCHOBBENHAUS, C.; SOUZA, C.R.G.; FERNANDES, A.C.S.; BERBERTBORN, M.; QUEIROZ, E.T.; CAMPOS, D.A. (eds.) Sítios geológicos e paleontológicos do Brasil. Brasília: CPRM, 2009, v. 2, 516p.

WINGE, M.; SCHOBBENHAUS, C.; SOUZA, C.R.G.; FERNANDES, A.C.S.; BERBERTBORN, M.; FILHO, W.S.; QUEIROZ, E.T. (eds.). Sítios Geológicos e paleontológicos do Brasil. Brasília: CPRM, 2013, v. 3, 332p.

ZALÁN, P. V.; OLIVEIRA, J. A. B. Origem e evolução estrutural do Sistema de Riftes Cenozóicos do Sudeste do Brasil. Boletim de Geociências da Petrobras, Rio de Janeiro, v. 13, n. 2, p. 269-300, 2005. 
ANEXOS 
ANEXO A - Notícias dos cursos propostos

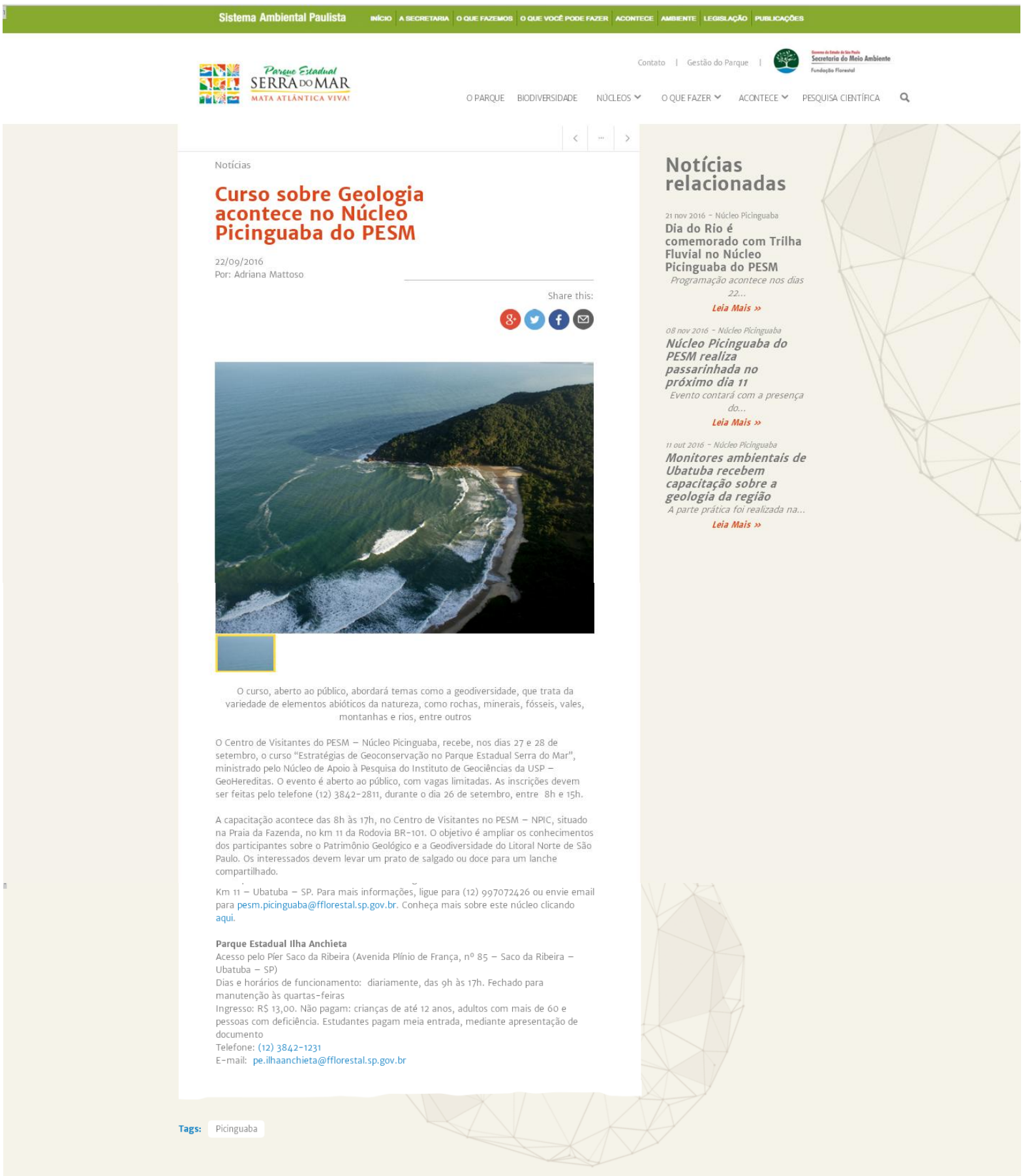

Fonte: <http://www.parqueestadualserradomar.sp.gov.br/pesm/curso-sobre-geologia-acontece-nonucleo-picinguaba-do-pesm/> e,

<http://fflorestal.sp.gov.br/2016/09/22/curso-sobre-geologia-acontece-no-nucleo-picinguaba-dopesm/>. 


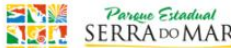

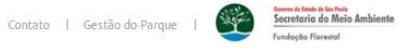

GHË MATA ATLANTICA VI

Noticias

Núcleo Caraguatatuba sedia curso de capacitação para monitores ambientais

20/09/2016

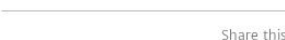

Share this:

Notícias

relacionadas

18 ago 2016 - Núcleo Caraguatatutu

Nucleo Caraguatatuba

vai até a cidade e

Aç̄es fazem parte das

comemoraç̧êes do aniversário de

39 anos do

Leia Mais *

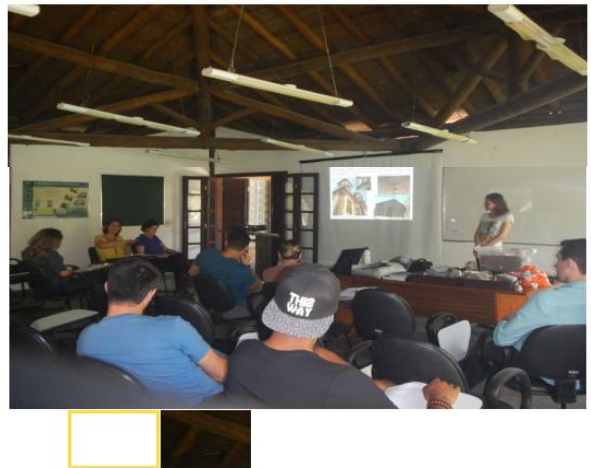

Durante dois dias,
socioambientais

O Núcleo Caraguatatuba realizou nos dias 12 e 13 de setembro, das $9 \mathrm{~h}$ às $17 \mathrm{~h}$, uma

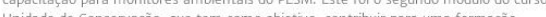
socioambientais. Neste módulo, foram abordados temas relacionados à geologia, come: geoconservação, geodiversidade e patrimônio geológico. por melo de apresentaçoes graficas, debates, metodologia participativa trabatho de

Serviço

O Parque Estadual Serra do Mar - Núcleo Caraguatatuba fica na Rua do Horto Florestał. 1200 - Rio do Ouro - Caraguatatuba - SP. Para mais informaçōes e agendamento ligue

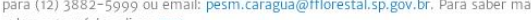

sobre este núleocinue aqu

Fonte: <http://www.parqueestadualserradomar.sp.gov.br/pesm/nucleo-caraguatatuba-sediacurso-de-capacitacao-para-monitores-ambientais/>. 
Pastila Estadual
SERRADOMAR

hilide MATA ATLANTICA VIV

Notícias

Monitores ambientais de

Ubatuba recebem

capacitação sobre a geologia

da região

$11 / 10 / 2016$

Por: Adriana Mattoso
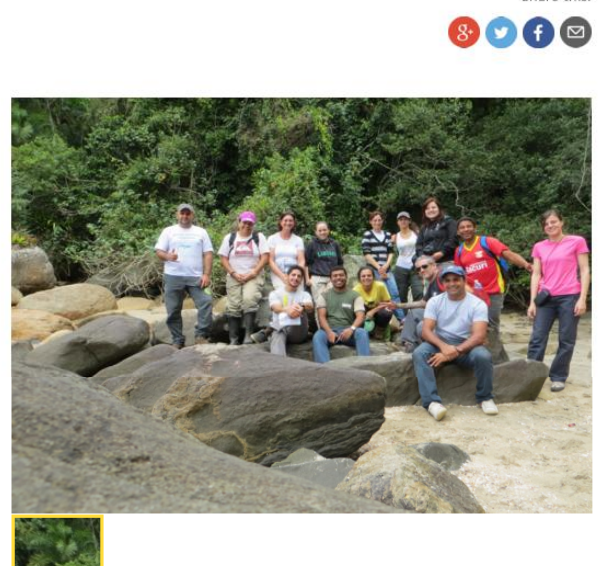

A parte prática foi realizada na Pralia Saco das Taquaras, que está inserida no PESSM -

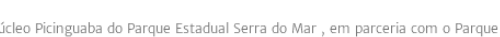

Estadual Iha Anchieta (PEIA) promoveu, nos dias 27 e 28 de setembro, um Curso de

Estratégias em Geoconservaçăo no Parque Estadual Serra do Mar. A capacitaçăo foi

ministrada pelo Núcleo de Apoio à Pesquisa (NAP) - GeoHereditas do Instituto de

Geeciênncias - IGC/USP, com o objetivo de ampliar os conhe
Geológico e da Geodiversidade do Litoral Norte de São Paulo.

O curso - com duração de dois dias, com aulas teóricas e práticas - faz parte dả

Área de Proteç̃̃o Ambiental Marinha litoral Norte. novos contecidos a serem abordados cont os grupos que percorrem as trithas das duas

unidades. "O curso propictiou a interaç̧á entre os participantes, que puderam aperfeiçcos grupos, e tirar eventuais dúvidas a respeito das características geológicas da regiàn fisses resultados poderão ser vistos no atendimento aos visitantes, que terão mais informaç̃os sobre a geologia da nossa região e as diferentes formas de se proteger esse patrimônio"

SERVIço

列 aqui.

Foto: Eliana Mazzucato

Tags: Picinguaba

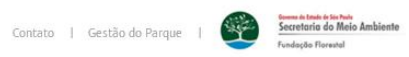

Notícias

relacionadas

Dia 2016 - Núcle

do com Trilha

Fluvial no Núcleo

$22 .$.
Leia Mais »

Núcleo Picinguaba do

PESM realiz

passarinhada no

Evento contará com a presenç

do...
Leia Mais ”

Monitores ambientais de

Ubatuba recebem

capacitação sobre a

geologia da região

Leia Mais »

Fonte: <http://www.parqueestadualserradomar.sp.gov.br/pesm/monitores-ambientais-deubatuba-recebem-capacitacao-sobre-a-geologia-da-regiao/ > 


\section{Página 10 \\ Núcleo Caraguatatuba do PESM sedia curso de capacitação para monitores ambientais}

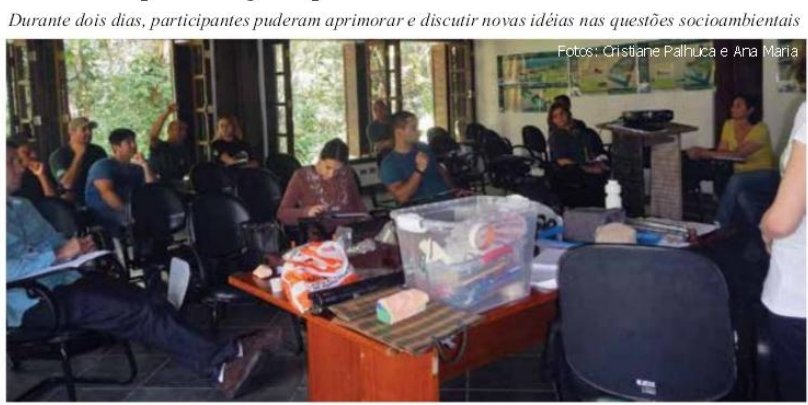

O Núcleo Caraguatatuba re- nitores, além de incentivar no- uma parceria com o Instituto alizou nos dias 12 e 13 de se- vas idéias e abordagens para de Geociências da USP. Imtembro, das $9 \mathrm{~h}$ às $17 \mathrm{~h}$, uma questões socioambientais. portante ainda destacar a par$\begin{array}{lll}\text { capacitação para monitores Neste módulo, foram abor- } & \text { ticipação dos Conseheiros da } \\ \text { ambientais do PESM. } & \text { dados temas relacionados UC, do GAC ( Grupo de Apoio }\end{array}$

Este foi o segundo módul do curso na Unidade de Con-

servação, que tem como obdados temas relacionados UC, do GAC (Grupo de Apoio à geologia, com servação, geodiversidade e Serviço

jetivo, contribuir para uma
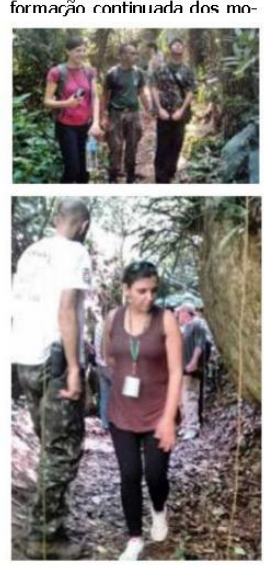

Durante a capacitação, os

A Mar compartilharam conhecimen- tal, 1200 - Rio do Ouro to por meio de apresentaçóes Caraguatatuba -SP.Para ma gráticas, debates, metodolo informaçoes e agendamento gia participativa e trabalho de ligue para (12) 3882-5999 ou

A capacitação é resultado de tal.sp.gov.br.
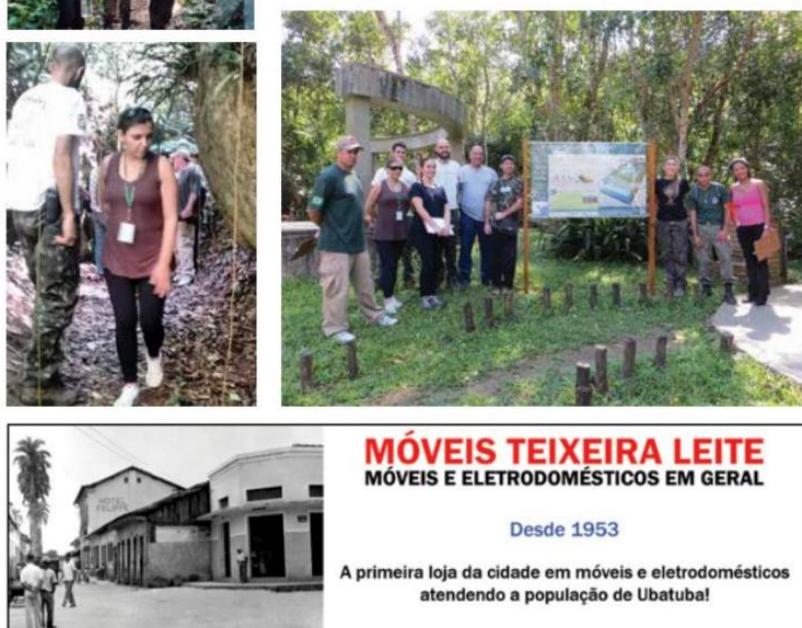

MÓVEIS TEIXEIRA LEITE MÓVEIS E ELETRODOMÉSTICOS EM GERAL

Desde 1953

A primeira loja da cidade em móveis e eletrodomésticos atendendo a população de Ubatuba!

Av. Dona Maria Alves 235 - Centro - Ubatuba - SP - Fones (12) 3832-1915 / 3832-2700
Outubro 2016

\section{PROMATA recebe alunos da capital para atividades em floresta e mangue}

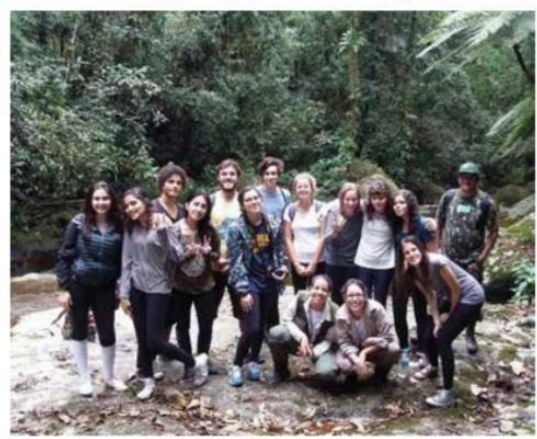

No último dia 28 , alunos da to e o cacau como sobremesa. por integrantes da PROMATA foi adquirida de produtores para atividades educacionais locais, temperos e abumas e visitaç̃̃o no Sitio do Corco- locais, temperos e e alguma vado e no mangue da Praia de cozimento também segui vado no migue da Prata de cozimento também segu Pela manhã Alunos e profes- Os alunos parabenizaram as sores realizaram uma trilha cozinheiras, alguns até levana Mata Atlântica, lá puderam ram o cacau para casa. Aos "sentir" de perto todo seu po- alunos e professores, num tencial, grandeza e importân- bate-papo informal, foi passacia. Realizaram também um do um pouco do histórico da levantamento ecológico de ocupação do litoral e os prouma parcela da mata através blemas - agora algumas solde uma armadilha - montada ções - da criação da unidade pelo oceanógrafo Guilherme de conservação que atinge 24 horas antes - de serrapi- grande parte do município. Iheira. Após o almoço os alunos se Após a atividade fizeram uma dirigiram ao mangue da Praia visita à cachoeira do lugar para Dura para também realizar leuma pausa a contemplaçao e vantamento ecológico de uma ate um banho de água fria lite- parcela do local, aproveitaram ralmente. $\mathrm{O}$ almoço ficou por para conhecer o espaço e $v i$ conta de Benedita Aparecida venciar o territorio, suas bele(Ditinha), Marlene Amorim e zas e potencialidades.

Rosalia Luiza. Foram servidos $O$ evento acontece graças a frango com mandioca, saladas uma parceria entre PROMATA

Do sitio experimentaram a rente de Extensão e Educação banana "chips" como tira gos- Ambiental Raul Oliveira Costa

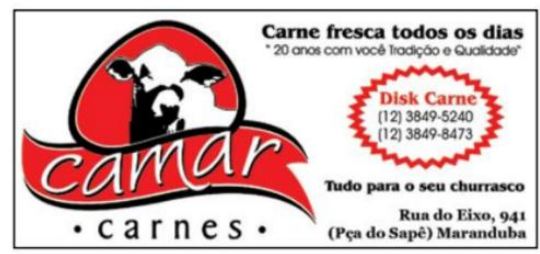

Fonte: www.jornalmaranduba.com.br, edição 89, outubro/2016. 
ANEXO B - Perfil dos atores entrevistados

Tabela 122 - Perfil moradores locais entrevistados

\begin{tabular}{|l|l|l|l|l|}
\hline Nome & Sexo & Idade & Cidade & Localidade \\
\hline M1 & F & & Ubatuba & Praia do Cambury \\
\hline M2 & M & 53 anos & Ubatuba & Praia do Cambury \\
\hline M3 & F & 44 anos & Ubatuba & Quilombo Cambury \\
\hline M4 & M & 89 anos & Ubatuba & Quilombo Cambury \\
\hline M5 & F & 60 anos & Ubatuba & Sertão da Fazenda \\
\hline M6 & M & 66 anos & Ubatuba & Sertão da Fazenda \\
\hline M7 & F & & Ubatuba & Sertão da Fazenda \\
\hline M8 & M & 67 anos & Ubatuba & Picinguaba \\
\hline M9 & F & 43 anos & Ubatuba & Sertão da Fazenda \\
\hline M10 & M & 22 anos & Ubatuba & Sertão da Fazenda \\
\hline M11 & M & 61 anos & Ubatuba & Sertão da Fazenda \\
\hline M12 & M & 78 anos & Ubatuba & Sertão da Fazenda \\
\hline M13 & F & 40 anos & Ubatuba & Sertão da Fazenda \\
\hline M14 & F & F anos & Ubatuba & Ubatumirim \\
\hline M15 & M & 75 anos & Ubatuba & Puruba \\
\hline M16 & F & Ubatuba & Puruba \\
\hline M17 & Caraguatatuba & Rio do Ouro \\
\hline M18 & Fio do Ouro \\
\hline
\end{tabular}

Tabela 133- Perfil gestores entrevistados

\begin{tabular}{|l|l|l|l|l|}
\hline Apelido & Gênero & Tempo de atuação & Formação & Cargo \\
\hline G1 & M & 4 anos & Geógrafo & Gestor UC \\
\hline G2 & M & 8 anos & Engenheiro Florestal & Gestor UC \\
\hline
\end{tabular}




\section{ANEXO C - Perfil participantes cursos}

Tabela 14 - Perfil participantes curso "Estratégias de geoconservação no Parque Estadual da Serra do Mar" núcleo Caraguatatuba e Picinguaba

\begin{tabular}{|c|c|c|c|c|c|c|c|}
\hline Nome & Sexo & Idade & Cidade atual & $\begin{array}{l}\text { Tempo de } \\
\text { habitação }\end{array}$ & Escolaridade & Profissão & $\begin{array}{l}\text { Tempo } \\
\text { atuação } \\
\text { PESM }\end{array}$ \\
\hline $\mathrm{C} 1$ & $\mathrm{M}$ & 38 & São Sebastião & 15 anos & $\begin{array}{l}\text { Superior } \\
\text { Completo }\end{array}$ & $\begin{array}{l}\text { Técnico em } \\
\text { Informática e } \\
\text { Técnico } \\
\text { Administrativo }\end{array}$ & 2 anos \\
\hline $\mathrm{C} 2$ & $\mathrm{~F}$ & 28 & Ubatuba & & & & \\
\hline C3 & $\mathrm{M}$ & 53 & São Sebastião & 1 ano & $\begin{array}{l}\text { Superior } \\
\text { Completo }\end{array}$ & $\begin{array}{l}\text { Bombeiro } \\
\text { Civil/Tecnólogo em } \\
\text { Segurança do } \\
\text { Trabalho }\end{array}$ & \\
\hline $\mathrm{C} 4$ & $\mathrm{~F}$ & 38 & Caraguatatuba & 28 anos & $\begin{array}{l}\text { Superior } \\
\text { Completo }\end{array}$ & $\begin{array}{l}\text { Professora educação } \\
\text { ambiental }\end{array}$ & 4 meses \\
\hline $\mathrm{C} 5$ & $\mathrm{~F}$ & 44 & Caraguatatuba & 7 anos & $\begin{array}{l}\text { Superior } \\
\text { Completo }\end{array}$ & Bióloga & \\
\hline C6 & M & 23 & Caraguatatuba & 23 anos & $\begin{array}{l}\text { Superior } \\
\text { Completo }\end{array}$ & $\begin{array}{l}\text { Monitor Ambiental/ } \\
\text { Biólogo }\end{array}$ & 3 anos \\
\hline $\mathrm{C7}$ & $\mathrm{F}$ & 30 & Caraguatatuba & 8 anos & $\begin{array}{l}\text { Superior } \\
\text { Completo }\end{array}$ & $\begin{array}{l}\text { Educador-Monitor } \\
\text { Ambiental - } \\
\text { Turismóloga }\end{array}$ & $\begin{array}{l}7 \text { anos e } \\
\text { meio }\end{array}$ \\
\hline $\mathrm{C} 8$ & $\mathrm{~F}$ & 31 & Ubatuba & 3 anos & Superior & $\begin{array}{l}\text { Turismóloga/gestora } \\
\text { ambiental }\end{array}$ & 3 anos \\
\hline C9 & $\mathrm{M}$ & 17 & Ubatuba & 17 anos & $\begin{array}{l}\text { Ensino Médio } \\
\text { Incompleto }\end{array}$ & Estudante & \\
\hline $\mathrm{C} 10$ & M & 38 & Caraguatatuba & 22 anos & $\begin{array}{l}\text { Ensino Médio } \\
\text { Completo }\end{array}$ & $\begin{array}{l}\text { Moto boy, Bombeiro } \\
\text { Civil e vigilante }\end{array}$ & \\
\hline $\mathrm{C} 11$ & $\mathrm{M}$ & 29 & Ubatuba & $\begin{array}{l}3 \text { anos e } \\
8 \mathrm{~m}\end{array}$ & $\begin{array}{l}\text { Ensino Médio } \\
\text { Completo }\end{array}$ & $\begin{array}{l}\text { Guia, } \\
\text { eletromecânico, } \\
\text { tatuador, serralheiro }\end{array}$ & 2 anos \\
\hline $\mathrm{C} 12$ & $\mathrm{~F}$ & 25 & Ubatuba & 1 ano & $\begin{array}{l}\text { Ensino Médio } \\
\text { completo }\end{array}$ & Bióloga & \\
\hline C13 & $\mathrm{F}$ & 26 & Caraguatatuba & & $\begin{array}{l}\text { Ensino Médio } \\
\text { Completo }\end{array}$ & $\begin{array}{l}\text { Moto boy, Bombeiro } \\
\text { Civil e Vigilante }\end{array}$ & \\
\hline $\mathrm{C} 14$ & $\mathrm{M}$ & 35 & Ubatuba & 12 anos & Técnico & $\begin{array}{l}\text { Guia de turismo, } \\
\text { Técnico em Guia de } \\
\text { Turismo }\end{array}$ & 1 ano \\
\hline $\mathrm{C} 15$ & $\mathrm{~F}$ & 38 & Caraguatatuba & 2 meses & $\begin{array}{l}\text { Superior } \\
\text { Completo }\end{array}$ & Gestão Pública & 4 anos \\
\hline $\mathrm{C} 16$ & $\mathrm{M}$ & 65 & Ubatuba & 35 anos & $\begin{array}{l}\text { Ensino } \\
\text { Fundamental } \\
\text { Incompleto } \\
\end{array}$ & $\begin{array}{l}\text { Agente recursos } \\
\text { ambientais }\end{array}$ & 29 anos \\
\hline $\mathrm{C} 17$ & M & 39 & Caraguatatuba & 1 ano & $\begin{array}{l}\text { Superior } \\
\text { Completo }\end{array}$ & Biólogo/Professor & \\
\hline $\mathrm{C} 18$ & M & 42 & Caraguatatuba & & $\begin{array}{l}\text { Ensino Médio } \\
\text { Completo }\end{array}$ & Funcionário Público & \\
\hline C19 & $\mathrm{M}$ & 31 & São Paulo & & $\begin{array}{l}\text { Pós } \\
\text { Graduação }\end{array}$ & $\begin{array}{l}\text { Chefe de Unidade de } \\
\text { Conservação APA } \\
\text { Itupararanga }\end{array}$ & \\
\hline $\mathrm{C} 20$ & $\mathrm{~F}$ & 32 & São Paulo & & $\begin{array}{l}\text { Superior } \\
\text { Completo }\end{array}$ & Bióloga & \\
\hline $\mathrm{C} 21$ & M & 43 & Ubatuba & 42 anos & Técnico & Guia e carretos & 1 ano \\
\hline $\mathrm{C} 22$ & $\mathrm{M}$ & 41 & Ubatuba & 14 anos & $\begin{array}{l}\text { Superior } \\
\text { Completo }\end{array}$ & Guia de turismo & \\
\hline
\end{tabular}




\begin{tabular}{|c|c|c|c|c|c|c|c|}
\hline $\mathrm{C} 23$ & $\mathrm{~F}$ & 29 & $\begin{array}{l}\text { São José dos } \\
\text { Campos }\end{array}$ & 2 anos & $\begin{array}{l}\text { Superior } \\
\text { Completo }\end{array}$ & $\begin{array}{l}\text { Supervisora de Meio } \\
\text { Ambiente/Bióloga }\end{array}$ & \\
\hline $\mathrm{C} 24$ & $\mathrm{~F}$ & 37 & Ubatuba & $\begin{array}{l}1 \text { ano e } 4 \\
\text { meses }\end{array}$ & $\begin{array}{l}\text { Superior } \\
\text { Completo }\end{array}$ & $\begin{array}{l}\text { Turismóloga/guia de } \\
\text { turismo }\end{array}$ & \\
\hline $\mathrm{C} 25$ & $\mathrm{M}$ & 42 & Ubatuba & 42 anos & $\begin{array}{l}\text { Ensino Médio } \\
\text { Completo }\end{array}$ & Marinheiro Promata & \\
\hline C26 & $\mathrm{M}$ & 34 & Ubauba & 34 anos & Pós graduação & $\begin{array}{l}\text { Guia de } \\
\text { turismo/turismólogo }\end{array}$ & \\
\hline $\mathrm{C} 27$ & $\mathrm{M}$ & 58 & Ubatuba & 40 anos & $\begin{array}{l}\text { Superior } \\
\text { Completo }\end{array}$ & $\begin{array}{l}\text { Técnico de apoio a } \\
\text { pesquisa Instituto } \\
\text { Florestal SP }\end{array}$ & 31 anos \\
\hline $\mathrm{C} 28$ & $\mathrm{M}$ & 29 & Caraguatatuba & & & & \\
\hline $\mathrm{C} 29$ & $\mathrm{~F}$ & 33 & Ubatuba & 2 anos & $\begin{array}{l}\text { Superior } \\
\text { Incompleto }\end{array}$ & Estudante & \\
\hline C30 & $\mathrm{M}$ & 32 & Caraguatatuba & & $\begin{array}{l}\text { Superior } \\
\text { Completo }\end{array}$ & Gestor unidade & 8 anos \\
\hline
\end{tabular}

Conclusão 
Tabela 15 - Perfil participantes curso "Estratégias de geoconservação no Parque Estadual Serra do Mar" na Escola Municipal José Belarmino Sobrinho

\begin{tabular}{|c|c|c|c|c|c|c|c|}
\hline Nome & Sexo & Idade & Cidade atual & $\begin{array}{l}\text { Tempo de } \\
\text { Residência }\end{array}$ & Escolaridade & Profissão & $\begin{array}{l}\text { Tempo } \\
\text { atuação } \\
\text { na escola }\end{array}$ \\
\hline P1 & $\mathrm{F}$ & 34 & Ubatuba & 11 anos & Superior & $\begin{array}{l}\text { Professora - } \\
\text { Educação Física }\end{array}$ & 1 anos \\
\hline $\mathrm{P} 2$ & $\mathrm{~F}$ & 43 & Paraty & 37 anos & Superior & Professor - Letras & 4 anos \\
\hline $\mathrm{P} 3$ & $\mathrm{M}$ & 41 & Ubatuba & 20 anos & $\begin{array}{l}\text { Pós- } \\
\text { Graduação }\end{array}$ & $\begin{array}{l}\text { Professor - PEB I - } \\
\text { Pedagogia }\end{array}$ & 19 anos \\
\hline P4 & $\mathrm{F}$ & 23 & Ubatuba & 23 anos & Superior & $\begin{array}{l}\text { Professora - Língua } \\
\text { Portuguesa }\end{array}$ & 3 anos \\
\hline P5 & $\mathrm{M}$ & 36 & Ubatuba & 36 anos & Superior & $\begin{array}{l}\text { Professora - } \\
\text { Matemática }\end{array}$ & 3 meses \\
\hline P6 & $\mathrm{F}$ & 70 & Ubatuba & 12 anos & Superior & $\begin{array}{l}\text { Professora - } \\
\text { Geografia }\end{array}$ & 12 anos \\
\hline P7 & $\mathrm{F}$ & 59 & Ubatuba & 15 anos & Superior & Professora - Artes & 5 anos \\
\hline P8 & $\mathrm{F}$ & 34 & Paraty & 34 anos & $\begin{array}{l}\text { Pós - } \\
\text { Graduação }\end{array}$ & Professora - PEB I & 2 anos \\
\hline P9 & $\mathrm{F}$ & 37 & Ubatuba & 16 anos & Superior & $\begin{array}{l}\text { Professora - } \\
\text { Matemática }\end{array}$ & 9 anos \\
\hline P10 & $\mathrm{M}$ & 28 & Ubatuba & 28 anos & $\begin{array}{l}\text { Pós - } \\
\text { Graduação }\end{array}$ & $\begin{array}{l}\text { Professor - } \\
\text { Educação Física }\end{array}$ & 4 anos \\
\hline P11 & $\mathrm{F}$ & 27 & Ubatuba & 27 anos & Superior & Professora - PEB I & 4 anos \\
\hline P12 & $\mathrm{M}$ & 46 & Ubatuba & 46 anos & Mestrado & $\begin{array}{l}\text { Professor - Língua } \\
\text { Portuguesa e } \\
\text { Literatura }\end{array}$ & \\
\hline P13 & $\mathrm{M}$ & 48 & Ubatuba & & Superior & Professor - Inglês & \\
\hline P14 & $\mathrm{F}$ & 49 & Ubatuba & 17 anos & Superior & Professora & \\
\hline P15 & $\mathrm{M}$ & 43 & Ubatuba & & Superior & $\begin{array}{l}\text { Professor - PEB I - } \\
\text { Pedagogia }\end{array}$ & \\
\hline P16 & $\mathrm{F}$ & 36 & Ubatuba & 4 anos & $\begin{array}{l}\text { Pós - } \\
\text { Graduação }\end{array}$ & Professor - História & 4 anos \\
\hline P17 & $\mathrm{F}$ & 32 & Ubatuba & 32 anos & $\begin{array}{l}\text { Superior } \\
\text { incompleto }\end{array}$ & $\begin{array}{l}\text { Professora - Língua } \\
\text { Portuguesa }\end{array}$ & \\
\hline P18 & $\mathrm{F}$ & 47 & Ubatuba & 47 anos & Mestrado & Professor - Letras & 6 anos \\
\hline P19 & $\mathrm{F}$ & 55 & Ubatuba & 55 anos & Superior & $\begin{array}{l}\text { Professor - Língua } \\
\text { Portuguesa }\end{array}$ & 6 anos \\
\hline P20 & $\mathrm{F}$ & 56 & PAraty & 56 anos & Superior & $\begin{array}{l}\text { Professor - PEB I - } \\
\text { Pedagogia }\end{array}$ & 4 anos \\
\hline $\mathrm{P} 21$ & $\mathrm{~F}$ & 39 & Paraty & 39 anos & Magistério & Professor - PEB I & 5 anos \\
\hline P22 & $\mathrm{F}$ & 22 & Ubatuba & 21 anos & Superior & $\begin{array}{l}\text { Professora - } \\
\text { Matemática }\end{array}$ & 4 anos \\
\hline P23 & $\mathrm{F}$ & 60 & Ubatuba & 20 anos & Superior & $\begin{array}{l}\text { Professora - } \\
\text { Biologia }\end{array}$ & 17 anos \\
\hline P24 & M & 29 & Paraty & 29 anos & $\begin{array}{l}\text { Pós - } \\
\text { Graduação }\end{array}$ & $\begin{array}{l}\text { Professor - PEB I - } \\
\text { Letras }\end{array}$ & 3 anos \\
\hline $\mathrm{P} 25$ & $\mathrm{~F}$ & 37 & Paraty & 37 anos & $\begin{array}{l}\text { Superior } \\
\text { Completo }\end{array}$ & $\begin{array}{l}\text { Professora - PEB I - } \\
\text { Pedagogia }\end{array}$ & 4 anos \\
\hline
\end{tabular}


Tabela 16 - Perfil dos funcionários da ONG - Instituto Argonauta

\begin{tabular}{|c|c|c|c|c|c|c|}
\hline Nome & Sexo & Idade & Cidade atual & $\begin{array}{l}\text { Tempo de } \\
\text { Residência }\end{array}$ & Escolaridade & Profissão \\
\hline F1 & $\mathrm{M}$ & 27 & Ubatuba & 2 anos & Superior Completo & Biólogo \\
\hline $\mathrm{F} 2$ & M & 41 & Ubatuba & 41 anos & $\begin{array}{l}\text { Superior } \\
\text { Incompleto }\end{array}$ & \\
\hline F3 & M & 33 & Ubatuba & 1,8 meses & Superior Completo & Gestor Ambiental \\
\hline F4 & $\mathrm{F}$ & 28 & Ubatuba & 1,8 meses & Pós-Graduação & Bióloga \\
\hline F5 & $\mathrm{M}$ & 27 & Ubatuba & 2 anos & Superior Completo & Biólogo \\
\hline F6 & $\mathrm{M}$ & 32 & Ubatuba & $1^{\mathrm{a}}, 7 \mathrm{~m}$ & Superior Completo & Biólogo \\
\hline F7 & $\mathrm{M}$ & 34 & Ubatuba & 8 anos & Superior Completo & Oceanógrafo \\
\hline F8 & $\mathrm{M}$ & 53 & Ubatuba & 23 anos & Pós-Graduação & Turismo \\
\hline F9 & $\mathrm{M}$ & 40 & Ubatuba & $1^{a} 8 \mathrm{~m}$ & Especialização & Biólogo \\
\hline F10 & $\mathrm{M}$ & 54 & Ubatuba & 18 meses & Doutorado & Oceanógrafo \\
\hline F11 & $\mathrm{M}$ & 22 & Ubatuba & 22 anos & $\begin{array}{l}\text { Ensino } \quad \text { Médio } \\
\text { Completo }\end{array}$ & Monitor de Campo \\
\hline F12 & $\mathrm{M}$ & 50 & Ubatuba & 25 anos & $\begin{array}{l}\text { Ensino } \quad \text { Médio } \\
\text { Completo }\end{array}$ & Monitor de Campo \\
\hline F13 & $\mathrm{M}$ & 32 & Ubatuba & 27 anos & $\begin{array}{l}\text { Ensino } \quad \text { Médio } \\
\text { Completo }\end{array}$ & Monitor de Campo \\
\hline F14 & $\mathrm{F}$ & 29 & Ubatuba & 2 anos & Superior Completo & Oceanógrafa \\
\hline F15 & $\mathrm{M}$ & 39 & Ubatuba & 39 anos & Superior Completo & Educação Física \\
\hline F16 & $\mathrm{M}$ & 45 & Ubatuba & 45 anos & $\begin{array}{l}\text { Ensino } \quad \text { Médio } \\
\text { Completo }\end{array}$ & $\begin{array}{l}\text { Técnico em turismo e } \\
\text { Monitor de campo }\end{array}$ \\
\hline F17 & $\mathrm{F}$ & 30 & Ubatuba & $3^{a} 2 m$ & Superior Completo & Bióloga \\
\hline F18 & $\mathrm{M}$ & 35 & Ubatuba & 2,5 anos & $\begin{array}{l}\text { Superior e técnico } \\
\text { em andamento }\end{array}$ & Biólogo \\
\hline F19 & $\mathrm{M}$ & 33 & Ubatuba & 6 anos & Pós-Graduação & Oceanógrafa \\
\hline
\end{tabular}


ANEXO D - Roteiro entrevistas comunidade

1. Apresentação da pesquisadora e da pesquisa

2. Questões sobre o perfil do Participante: Nome, Local de nascimento, idade, quantos anos reside no município e profissão.

3. Você sabe como foi a história de criação do parque aqui nesta área? Como isso afetou os modos de vida e as comunidades locais? E como é a relação do Parque com a comunidade?

4. E a natureza, você acha que é um patrimônio essa natureza preservada? As montanhas, rios, pedras, plantas?

5. Você acha que é um privilégio morar aqui? Por quê?

6. E quando você vai a grandes cidades, ou em lugares que a natureza está desmatada, o que você sente?

7. O que você acha da paisagem daqui, das montanhas, das pedras que tem na praia?

8. Você acha que essa conservação da natureza está ameaçada? Por que?

9. Como é a relação da comunidade com a conservação da natureza, tem alguma prática tradicional de conservação?

10. O que você acha que poderia melhorar aqui?

11. Você acha que o turismo traz algum benefício para a região? Vem muitos turistas no parque?

12. Qual a importância do parque? Seu papel para a região?

13. Quais lugares você costuma ir para ter lazer em contato com a natureza? 
ANEXO E - Roteiro entrevistas gestores

Apresentação da pesquisa

Objetivos da entrevista: no âmbito da gestão do patrimônio natural, como a Geoconservação tem sido abordada pelos gestores nos núcleos Picinguaba e Caraguatatuba?

Entender a participação das comunidades na gestão do patrimônio natural.

Diagnosticar possíveis conflitos entre gestores e comunidade em relação à conservação do patrimônio natural.

Entender os projetos educativos no parque e a possibilidade de inserção dos temas geológicos.

\section{$\underline{\text { Gestão }}$}

- Você tem conhecimento de que a IUCN, em 2015 incluiu a geoconservação como parte importante a ser considerada pela Gestão. A geodiversidade é incluída como parte da natureza a ser conservada, considerando o Patrimônio Geológico, as paisagens cênicas, solos e água. (Protected area governance and management, IUCN, 2015)

- Na gestão do Patrimônio Natural, estão incluídas a Geodiversidade e o Patrimônio Geológico?

Se sim. Como se dá esta abordagem no PESM?

Se não, como poderia ser abordado este tema no PESM?

- Há na área do parque algum local que considere Patrimônio Geológico? Poderia elencar alguns locais que considera como Patrimônio Geológico na região (fora do parque)?

- Considera que o Patrimônio Geológico está ameaçado?

- Quais ações o Parque poderia propor para o reconhecimento deste patrimônio pela comunidade? E para sua conservação?

- Quais valores estão presentes nestes locais? Estético, Científico, Cultural, Didático, Turístico, Econômico?

- Por exemplo, possuem grande beleza, forte valor para a identificação das comunidades locais, sustenta uma biodiversidade, interesse científico, paisagem, cachoeiras, afloramentos, didático, turístico.

- Como a gestão entende a presença do ecoturismo ou turismo ecológico no parque? É bem desenvolvido como atividade econômica e de lazer? Já ouviu falar em 
geoturismo, depois da explicação, acha possível o seu desenvolvimento no litoral norte?

Comunidade

- Você acha que as comunidades têm contribuído na conservação da natureza do PESM.

- Quais os mecanismos de participação social efetivos na gestão?

- Elas têm participado efetivamente na gestão?

- Existem problemas relacionados à gestão em relação as comunidade do entorno? Quais? O que é realizado para diminuir os problemas.

- As comunidades poderiam contribuir de que forma para conservação do patrimônio geológico?

\section{Educação}

- Há alguma parceria com a diretoria municipal ou estadual de ensino para receber professores e alunos da rede pública e privada, num trabalho conjunto entre os monitores e os professores da região? Como são as visitas das escolas no Parque?

- Como acontece a formação dos monitores?

- Há abordagens sobre educação patrimonial?

- Como são desenvolvidos os programas de Educação Ambiental no parque? Qual a abordagem (naturalista, conservacionista, ou crítica)? Há projetos de EA com a comunidade do entorno ou apenas para quem visita o parque?

- Acha que cabem temáticas sobre o patrimônio geológico?

- As pesquisas da área de Geociências e/ou Geoconservação (NAP GEOHEREDITAS) têm influenciado alguma estratégia de educação/divulgação/conservação aqui no parque? 
ANEXO F - Questionário

Questionário: Percepç̃̃es sobre a Conservação e a Geodiversidade do Litoral Norte de São Paulo

Pesquisadora: Eliana Mazzucato, Instituto de Geociências - USP. Contato: mazzucato@usp.br Orientadora: $\operatorname{Prof}^{a} \operatorname{Dr}^{\mathrm{a}}$ Denise de La Corte Bacci, Instituto de Geociências - USP.

Nome:

Idade:

Naturalidade:

Cidade atual:

Escolaridade:

Há quanto tempo?

Profissão/Formação:

Há quanto tempo trabalha no Parque?

1. O que você entende por Unidade de Conservação?

2. Quais locais você costuma frequentar para ter momentos de lazer em contato com a natureza? Qual sua relação com este lugar, você se sente pertencente a ele?

3. Quais elementos você destacaria como mais importantes na sua cidade: (pode escolher mais de uma alternativa)
( ) Biodiversidade
( ) História
( ) Paisagem
( ) Monumentos
( ) Casas
( ) Praças
( ) Montanhas
( ) Igrejas
( ) Rochas
( ) Comércio local
( ) Artesanato
( ) Festas tradicionais
( ) Rios
( ) Escolas
( ) Alimentação
( ) Qualidade de vida
( ) Recursos hídricos
( ) Museus
( ) Pessoas
( ) Obras de arte
( ) Arquitetura
( ) Beleza
( ) Prédios
( ) Lazer
( ) Cultura
( ) Turismo
( ) Pousadas
( ) Parque
( ) Bares
( ) Outros:

4. Você se considera privilegiado por trabalhar/viver em área de conservação da natureza?

( ) $\operatorname{Sim}($ ) Não

Por quê? O que você sente em relação ao seu papel na conservação da natureza? 
5. Quais benefícios você considera que o Parque traz para a região? (pode escolher mais de uma alternativa)
( ) Melhoria na qualidade de
( ) Preservação da paisagem
( ) Ofertas de empregos vida natural
( ) Oportunidade de empregos no
( ) Valorização dos terrenos no entorno do Parque
( ) Preservação de fontes e nascentes de água
( ) Preservação de espécies
( ) Desenvolvimento do Turismo
( ) Aumento de pesquisas
( ) Programas educativos
( ) Presença de novos
loteamentos
Parque
( ) Preservação cultura
tradicional
( ) Outros: nativas (animais e vegetais)

( ) Maior segurança

6. Para você, quais seriam os principais conflitos socioambientais da região?

7. Você já visitou um local totalmente desmatado? O que sentiu?

8. Quando você ouve a palavra patrimônio, o que pensa? (pode escolher mais de uma alternativa)
( ) algo que tenha valor para a ciência e para a
( ) algo da natureza
tecnologia
( ) algo que tenha valor para a história
( ) algo importante para você
( ) algo antigo
() algo em ruína
( ) algo importante para a humanidade
( ) uma herança
() algo cultural
( ) um conhecimento

9. A quais elementos naturais e construídos você associa a palavra Patrimônio? (pode escolher mais de uma alternativa)
( ) As florestas
( ) Monumentos
( ) Praias
( ) Ruas
( ) Cachoeiras
( ) Os animais
( ) Paisagens
( ) Rios
( ) Artesanatos
( ) Cultura
( ) Igrejas
() Artefatos
( ) Relevo
( ) Rochas (Pedras)
( ) Construções
arqueológicos
( ) Tradições
( ) Fósseis
( ) Comidas 

( ) Festas Tradicionais
( ) Línguas
( ) Pessoas
Outros:

10. Geodiversidade é (pode escolher mais de uma alternativa):
( ) Algo da natureza
( ) Paisagem
( ) fósseis
( ) Recursos Naturais
( ) Diversidade
( ) Montanhas
( ) Onde a
( ) Ecossistemas
Geológica
() Rios
Biodiversidade se
( ) Pedras preciosas
( ) Tudo que nos rodeia
( ) Substrato Rochoso
desenvolve
( ) Onde a humanidade
( ) Terra
( ) Natureza abiótica
( ) Solo
( ) minerais
( ) Processos
se desenvolve
Geológicos

11. O que você pensa quando ouve falar sobre a natureza abiótica do Litoral Norte?

12. Para você, há na região algum elemento que você identifica como Patrimônio Geológico? Poderia elencar alguns desses elementos que considera Patrimônio Geológico na região (dentro e fora do parque)?

13. Você acha que o patrimônio geológico da região está ameaçado ou depredado? O que você faria para a sua conservação?

14. Quem você acha que é responsável pela proteção do patrimônio do Litoral Norte? (pode escolher mais de uma alternativa)
() Prefeituras
() Polícia
( ) Agências de Turismo
( ) Governo Estadual
( ) Escolas
( ) Monitores Ambientais
( ) Governo Federal
( ) ONGs
( ) Pescadores
( ) Instituto Florestal/ICMBio
( ) Moradores
( ) Lideranças comunitárias
( ) CONDEPHAAT
( ) Turistas
( ) IPHAN
( ) Comerciantes
( ) Indústrias
( ) Outros 
15. Quem você acha que deveria estar envolvido na proteção do patrimônio do Litoral Norte? (pode escolher mais de uma alternativa)
( ) Prefeituras
( ) Polícia
( ) Escolas
( ) Governo Estadual
() ONGs
( ) Instituto Florestal/ICMBio
( ) Moradores
( ) CONDEPHAAT
() Turistas
( ) IPHAN
( ) Comerciantes

( ) Agências de Turismo

( ) Monitores Ambientais

( ) Pescadores

( ) Lideranças comunitárias

( ) Indústria

( ) Outros:

Observações: 
ANEXO G - Roteiro para o mapeamento socioambiental participativo

(Re)conhecimento do Lugar - Puruba - Ubatuba (SP)

Proponentes: Vania Maria Nunes do Santos; Denise de La Corte Bacci; Eliana Mazzucato

Local: Escola Municipal José Belarmino Sobrinho

Estrada do Puruba, S/N. Puruba, Ubatuba - SP

Data: 09/04/2017

\section{Introdução:}

O diagnóstico socioambiental é um instrumento didático-pedagógico de planejamento e ação que promove a participação dos diferentes atores locais no levantamento de diferentes informações sobre o lugar, com o uso de mapas, fotografias aéreas ou imagens de satélite e saídas de campo. Sua realização possibilita o (re)conhecimento do lugar e seus problemas, bem como o compartilhamento de conhecimentos, vivências e percepções sobre a realidade socioambiental. O levantamento dos elementos ambientais locais serve para a compreensão do mundo físico em que vivemos e para estabelecer inter-relações com contexto socioculturais, como exemplo, a relação da qualidade da água analisada, o tipo de solo e vegetação presentes e os usos do solo e a forma de ocupação do espaço local. O estudo do ambiente, com enfoque no local e seu entorno, favorece a compreensão da natureza como um sistema integrado, em seu contexto social.

\section{Objetivos:}

- Elaborar um diagnóstico da realidade socioambiental local, visando o (re)conhecimento do lugar, seus problemas e conflitos por meio do mapeamento;

- Promover a percepção da realidade socioambiental local, por meio da elaboração de mapas-síntese-propositivos.

\section{Orientações para a realização da atividade:}

1. Represente no mapa os elementos socioambientais observados na paisagem (água, vegetação, solo, habitação, ruas, lixos, esgoto, etc.);

2. Destaque no mapa os locais ou situações do roteiro que mais lhe chamaram a atenção e/ou que consideraram mais problemáticos;

3. Descreva a área mapeada, ressaltando tudo que foi visto e sentido (cheiros, sensações boas e ruins, impressões e percepções do grupo) com destaque para o que o grupo considerou mais relevantes.

\section{Reflexões:}

Quais os problemas ambientais identificados no local?

Que medidas têm sido adotadas para resolver esses problemas?

O que na opinião do grupo deveria ser feito para resolvê-los? 
ANEXO H - Lenda da gruta que chora

\section{Lenda da Gruta que Chora}

Contam lá nas bandas da praia da Sununga, localizada na parte Sul de Ubatuba-SP, que há bastante tempo uma moça muito bonita, de nome Marcelina, vivia com sua mãe na mais completa alegria. A jovem tinha a pele suavemente morena, olhos claros e cabelos negros, era belíssimo o seu corpo de menina nova, graciosa como que só. De uma hora para outra, sem que nada acontecesse, Marcelina deixou-se cair prostrada em sua cama simples, sem vontade nenhuma, nem sorrir a bela moça queria. Sua mãe, Sinhá Anália, já havia percebido, não sem preocupação, que a menina estava diferente e parecia piorar conforme os dias se sucediam. Tentou de tudo, chás de ervas, banhos de folhas e flores, mas nada fazia efeito. Sinhá Anália contava para as comadres o que estava acontecendo com sua menina e todos diziam que era problema de idade. Inconformada, perguntava à filha o que estava acontecendo, mas a menina era categórica, jurava que nada havia de errado e que comia pouco ou quase nada para não ficar gorda como umas mulheres que vira na cidade certa vez. Não podia ser normal aquilo, Sinhá Anália bem o sabia, ainda mais depois que virou rotina acordar durante a madrugada com os soluços da filha. Como pensasse que era tristeza, conteve ao máximo seu ímpeto de correr ao quarto de Marcelina para saber o que se passava. Até que não resistiu e surpreendeu a moça soluçando palavras desconexas, como se pedisse para alguém não partir. A garota estava sozinha no quarto! Depois de ser flagrada pela mãe, não restou alternativa a não ser contar a verdade. Foi com perplexidade que a mulher ouviu palavra por palavra, tudo meio sem nexo, sobre a história do dragão que morava na Toca da Sununga. Todo mundo conhecia o caso na região e até mesmo evitava passar por aquelas bandas. Os pescadores nem se atreviam a chegar perto porque as ondas gigantes engoliam canoa, rede, tudo. As pessoas sabiam que o tal monstro existia, mas só Seu Antero tinha visto. Era um bicho horroroso, tinha metade do corpo de dragão e a outra metade era roliça, como uma cobra, e se rastejava no chão. Pois bem, desde que Seu Antero falou do dragão que vivia na gruta, Marcelina não parou de pensar nele, com um misto de medo e curiosidade. Contou à mãe que de tanto pensar no bicho, ele foi lá ter com ela, entrou no quarto no meio da madrugada. Vendo o assombro de Sinhá Anália, tentou acalmar a mãe, já idosa, dizendo que ele ficou encolhido, tão pequeno, que parecia não fazer mal a ninguém, até que virou um homem. A mulher não podia crer no que estava ouvindo, era loucura da sua filha, teria que chamar um doutor, aquilo de mostro virar homem não era certo, ainda mais dentro de sua própria casa. Depois falou que tinha passado a noite embalada nos braços daquele lindo moço de olhos claros. Mesmo depois de uma noite tão especial, a garota sentiu-se infeliz porque o moço partiu logo ao amanhecer, quando o galo cantou três vezes. Ela ficou no quarto chorando, sem disposição para nada, só pensava em esperar a noite chegar para receber a visita do amado. Agoniada, a mãe da jovem, só podia rezar para todos os santos que conhecia, até promessa fez. Demorou muito tempo e apareceu um velho pobre, andarilho, batendo à porta de Sinhá Anália em busca de um prato de comida. Ao entrar na casa, como faltasse assunto, a mulher foi logo narrando o drama de sua filha. Ouviu calado, inexpressivo, e ao fim do relato, disse já ter ouvido, bem longe dali, falar do monstro que atormentava a população daquele bairro. Por tal motivo ele estava lá, para expulsar aquela criatura do mal. Era uma espécie de mago e sabia como fazer isto.

Logo o bairro todo estava sabendo da vinda do ancião e na manhã seguinte todos se acotovelavam em frente à Toca da Sununga. Já no local, o pobre monge ergueu os braços e fez o sinal da cruz, acompanhado de todos que estavam lá, fez uma prece ao Senhor e espargiu sobre a pedra que forma a toca um pouco da água que carregava consigo. Para espanto dos presentes, imediatamente um trovão violento fez estremecer a terra, e o mar se agitou violentamente, avançando sobre a praia, chegando a bater nas rochas. Depois as águas 
recuaram e o mar abriu-se ao meio, bem em frente à toca, por onde o mostro passou, horripilante, rugindo, para se esconder definitivamente nas profundezas do oceano. Ninguém mais ouviu falar do dragão. Dizem que Marcelina viveu por muito tempo, acanhada e triste, porém bela como sempre fora! "Hoje, quem se postar no interior da lendária gruta, perceberá cair lá de cima, das ranhuras da pedra, uma sequencia de pequeninas gotas que se infiltram na areia branca e fina que alcatifa o chão. Dizem alguns que são remanescentes gotas da água benta espargida pelo monge, que ainda caem a fim de que o dragão jamais possa voltar. Outros, porém, afirmam que são lágrimas de Marcelina, que lá voltou muitas vezes na esperança de que o dragão, feito moço bonito, ainda voltasse para ficar com ela a noite inteira até os albores da manhã!"”.

(Versão livre. Fonte: http://noitesinistra.blogspot.com.br/) 
APÊNDICES 


\section{APÊNDICE A - Roteiro geointerpretativo Trilha do Puruba}
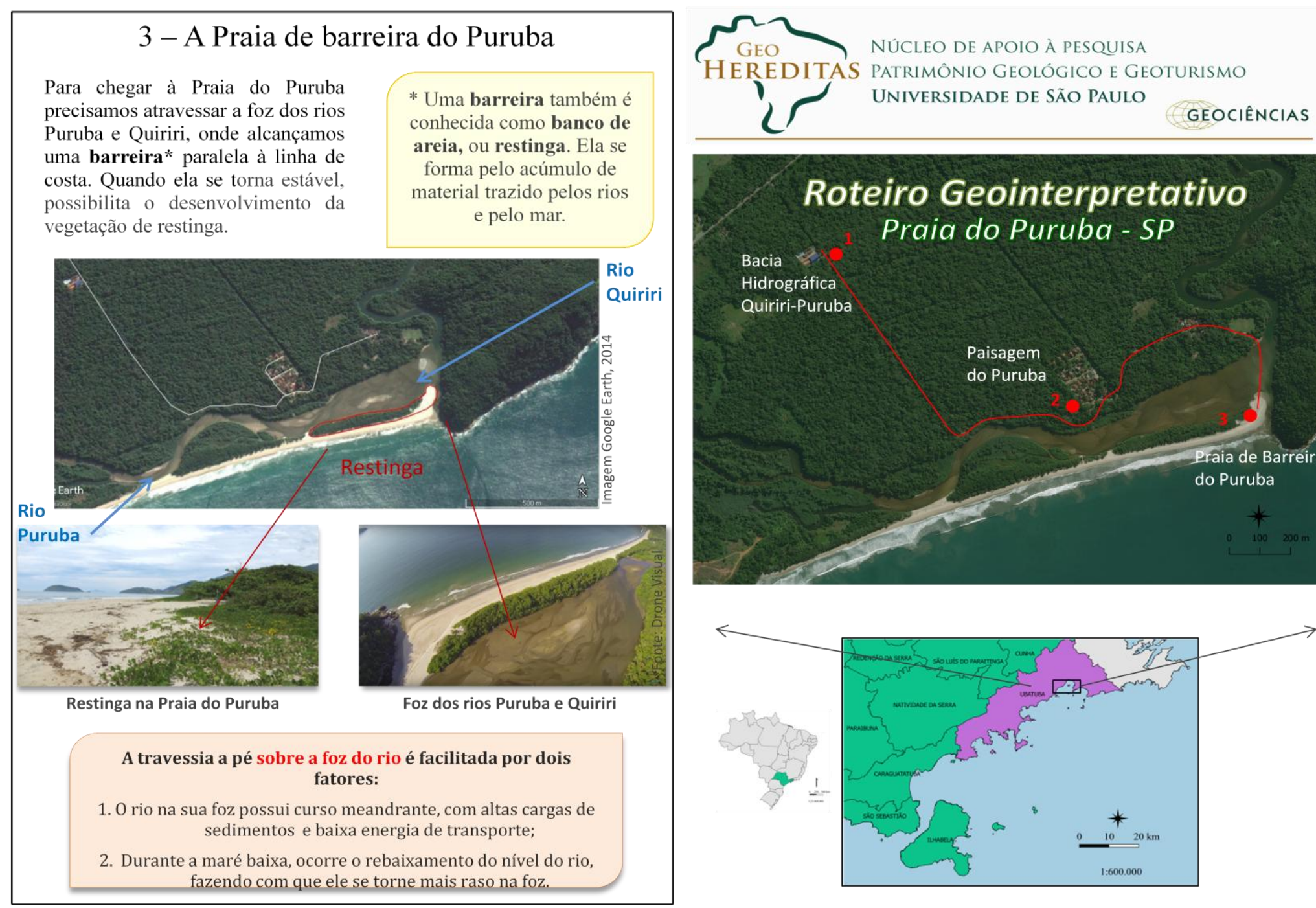

precisamos atravecida como banco de

ma pelo acúmulo de

$$
\text { e pelo mar. }
$$
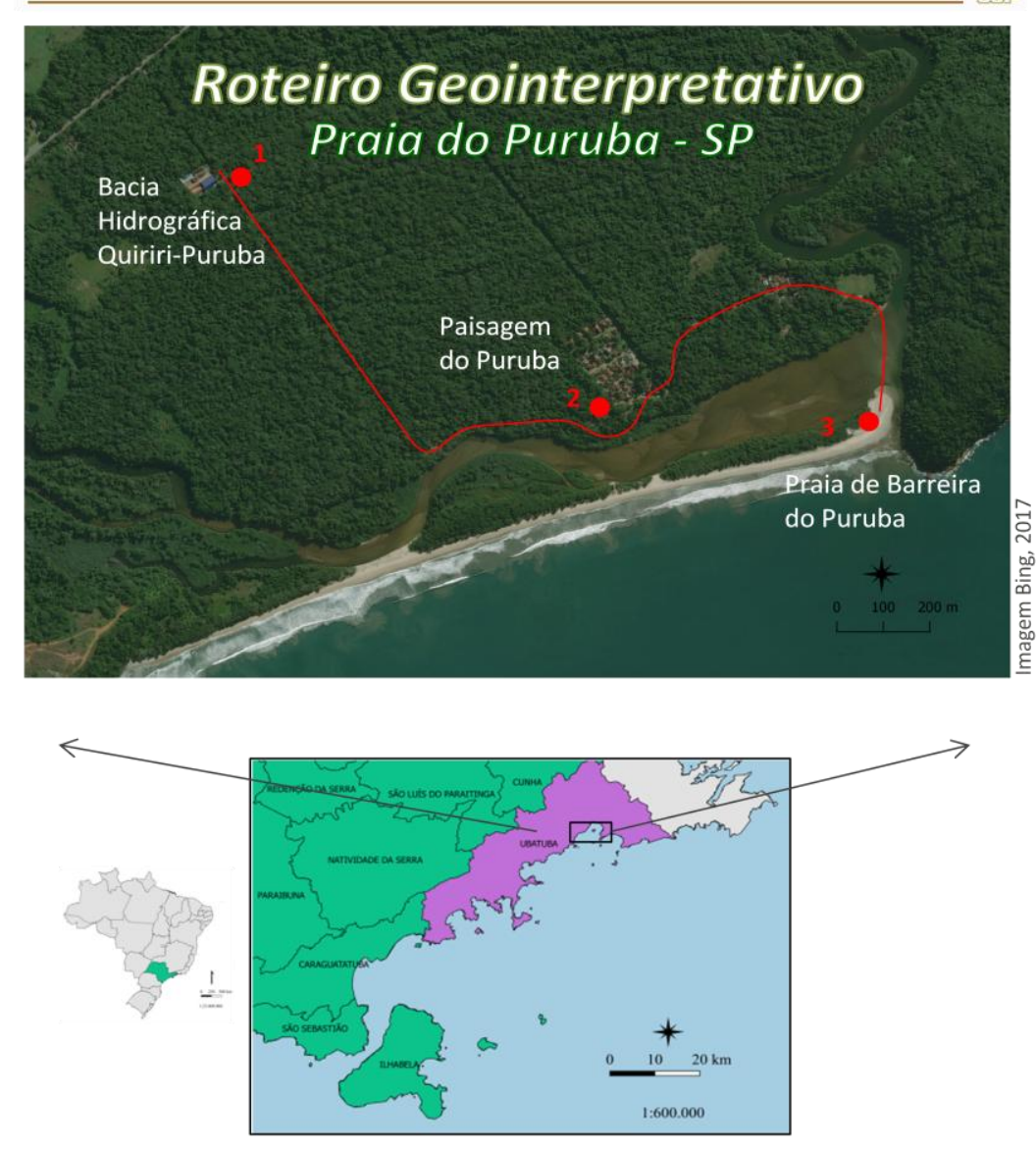

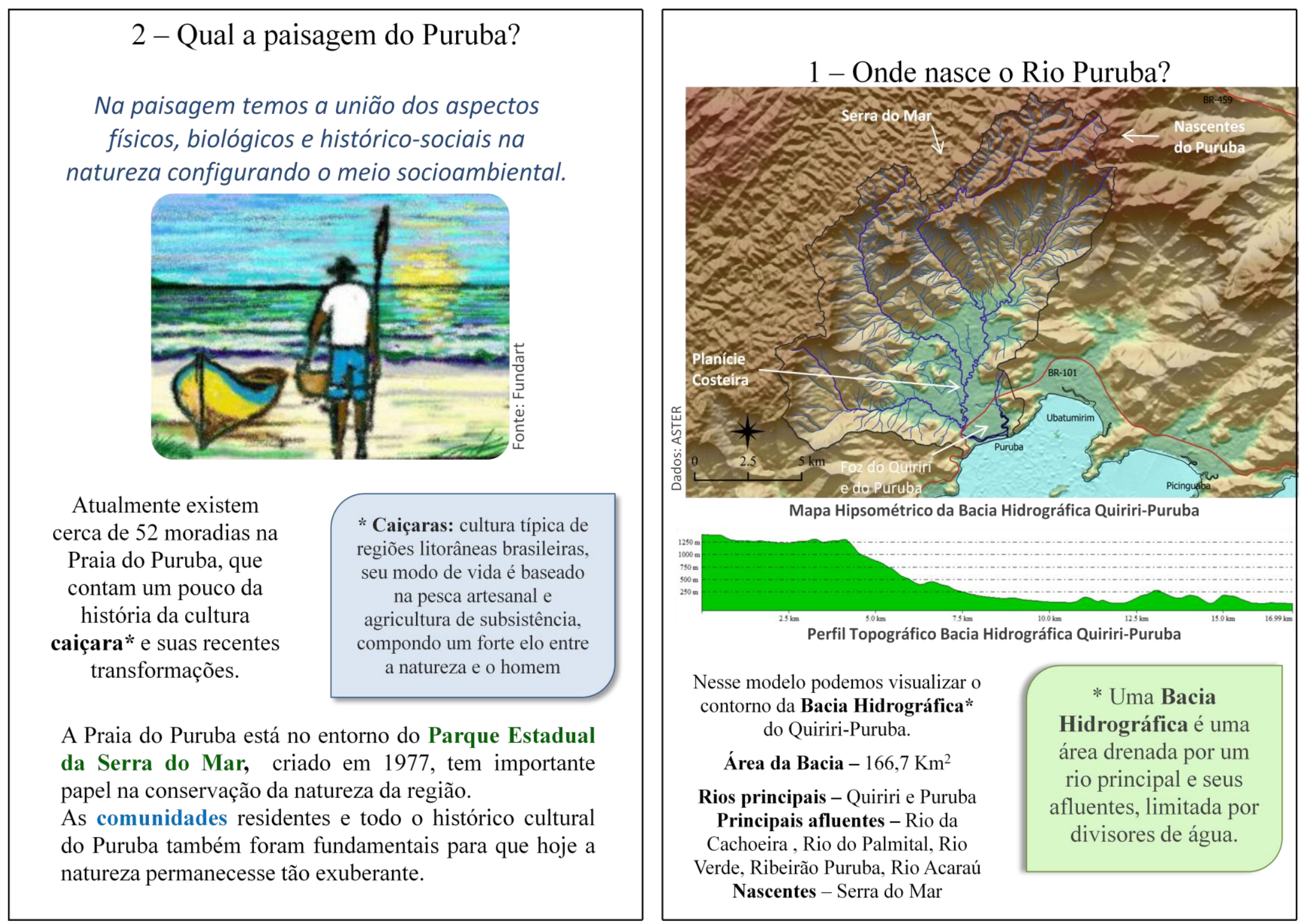
APÊNDICE B - Tabelas de total de indicações dos questionários por grupo de respondentes

Tabela 17 - Quais benefícios você considera que o Parque traz para a região? (Questão 5)

\begin{tabular}{|c|c|c|c|c|}
\hline \multirow[t]{2}{*}{ Categorias } & \multicolumn{4}{|c|}{ Grupo de respondentes } \\
\hline & Professores & $\begin{array}{l}\text { Monitores } \\
\text { Picinguaba }\end{array}$ & $\begin{array}{c}\text { Monitores } \\
\text { Caraguatatuba }\end{array}$ & $\begin{array}{c}\text { Funcionários } \\
\text { ONG }\end{array}$ \\
\hline $\begin{array}{l}\begin{array}{l}\text { Preservação de espécies } \\
\text { nativas } \\
\text { vegetais) }\end{array} \text { (animais } \\
\end{array}$ & 20 & 14 & 12 & 17 \\
\hline $\begin{array}{l}\text { Preservação de fontes e } \\
\text { nascentes de água }\end{array}$ & 18 & 14 & 12 & 17 \\
\hline $\begin{array}{l}\text { Preservação da paisagem } \\
\text { natural }\end{array}$ & 20 & 12 & 11 & 17 \\
\hline $\begin{array}{l}\text { Melhoria na qualidade de } \\
\text { vida }\end{array}$ & 16 & 11 & 9 & 9 \\
\hline Aumento de pesquisas & 10 & 11 & 10 & 12 \\
\hline Programas educativos & 10 & 12 & 10 & 7 \\
\hline $\begin{array}{l}\text { Desenvolvimento do } \\
\text { Turismo }\end{array}$ & 4 & 11 & 9 & 11 \\
\hline $\begin{array}{l}\text { Preservação } \\
\text { tradicional }\end{array}$ & 12 & 10 & 4 & 7 \\
\hline $\begin{array}{ll}\begin{array}{l}\text { Oportunidades } \\
\text { empregos no Parque }\end{array} & \text { de } \\
\end{array}$ & 4 & 7 & 2 & 5 \\
\hline $\begin{array}{l}\text { Valorização dos terrenos } \\
\text { no entorno do Parque }\end{array}$ & 5 & 3 & 1 & 1 \\
\hline Maior segurança & 2 & 4 & 0 & 3 \\
\hline Ofertas de empregos & 1 & 3 & 0 & 4 \\
\hline 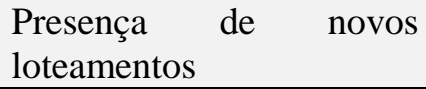 & 0 & 0 & 0 & 0 \\
\hline
\end{tabular}


Tabela 18 - Quais elementos você destacaria como mair importantes na sua cidade? (Questão 3)

\begin{tabular}{|c|c|c|c|c|}
\hline \multirow[t]{2}{*}{ Categorias } & \multicolumn{4}{|c|}{ Grupos de respondentes } \\
\hline & Professores & $\begin{array}{c}\text { Monitores } \\
\text { Picinguaba }\end{array}$ & $\begin{array}{c}\text { Monitores } \\
\text { Caraguatatuba }\end{array}$ & $\begin{array}{c}\text { Funcionários } \\
\text { ONG }\end{array}$ \\
\hline Paisagem & 22 & 14 & 12 & 17 \\
\hline Biodiversidade & 20 & 13 & 11 & 19 \\
\hline Cultura & 18 & 12 & 7 & 13 \\
\hline Recursos hídricos & 11 & 11 & 8 & 16 \\
\hline Turismo & 15 & 13 & 7 & 11 \\
\hline Qualidade de vida & 16 & 11 & 7 & 12 \\
\hline Rios & 12 & 11 & 8 & 13 \\
\hline Montanhas & 12 & 8 & 7 & 13 \\
\hline Festas tradicionais & 14 & 9 & 5 & 8 \\
\hline Beleza & 12 & 6 & 5 & 12 \\
\hline História & 13 & 8 & 5 & 8 \\
\hline Pessoas & 8 & 9 & 6 & 8 \\
\hline Artesanato & 11 & 7 & 4 & 9 \\
\hline Lazer & 7 & 7 & 7 & 8 \\
\hline Alimentação & 8 & 9 & 4 & 6 \\
\hline Parque & 4 & 9 & 8 & 6 \\
\hline Rochas & 4 & 8 & 6 & 7 \\
\hline Escolas & 5 & 5 & 4 & 6 \\
\hline Monumentos & 6 & 2 & 2 & 3 \\
\hline Igrejas & 5 & 3 & 2 & 3 \\
\hline Museus & 1 & 2 & 3 & 4 \\
\hline Pousadas & 4 & 2 & 1 & 3 \\
\hline Comércio local & 2 & 3 & 0 & 4 \\
\hline Arquitetura & 3 & 5 & 0 & 1 \\
\hline Praças & 3 & 3 & 1 & 2 \\
\hline Casas & 4 & 2 & 0 & 2 \\
\hline Obras de arte & 2 & 2 & 0 & 3 \\
\hline Bares & 3 & 1 & 0 & 2 \\
\hline Prédios & 2 & 1 & 0 & 1 \\
\hline Shoppings & 1 & 1 & 0 & 1 \\
\hline
\end{tabular}


Tabela 19-Quando você houve a palavra patrimônio, o que pensa? (Questão 8)

\begin{tabular}{|l|c|c|c|c|}
\hline Categorias & \multicolumn{4}{|c|}{ Grupo de respondentes } \\
\hline & Professores & $\begin{array}{c}\text { Monitores } \\
\text { Picinguaba }\end{array}$ & $\begin{array}{c}\text { Monitores } \\
\text { Caraguatatuba }\end{array}$ & $\begin{array}{c}\text { Funcionários } \\
\text { ONG }\end{array}$ \\
\hline $\begin{array}{l}\text { algo importante para a } \\
\text { humanidade }\end{array}$ & 20 & 14 & 9 & 16 \\
\hline $\begin{array}{l}\text { algo que tenha valor } \\
\text { para a história }\end{array}$ & 20 & 13 & 10 & 15 \\
\hline algo cultural & 14 & 11 & 6 & 10 \\
\hline uma herança & 12 & 9 & 4 & 10 \\
\hline $\begin{array}{l}\text { algo importante para } \\
\text { você }\end{array}$ & 8 & 9 & 6 & 9 \\
\hline $\begin{array}{l}\text { algo que tenha valor } \\
\text { para a ciência e para a } \\
\text { tecnologia }\end{array}$ & 8 & 9 & 5 & 7 \\
\hline um conhecimento & 7 & 6 & 3 & 6 \\
\hline algo da natureza & 4 & 11 & 2 & 5 \\
\hline algo antigo & 6 & 9 & 1 & 4 \\
\hline algo em ruína & 0 & 5 & 4 & 9 \\
\hline
\end{tabular}


Tabela 20 - A quais elementos naturais e construídos você associa a palavra Patrimônio? (Questão 9)

\begin{tabular}{|c|c|c|c|c|}
\hline Categorias & Grupos de re & dentes & & \\
\hline & Professores & $\begin{array}{c}\text { Monitores } \\
\text { Picinguaba }\end{array}$ & $\begin{array}{c}\text { Monitores } \\
\text { Caraguatatuba }\end{array}$ & $\begin{array}{c}\text { Funcionários } \\
\text { ONG }\end{array}$ \\
\hline Construções Históricas & 20 & 12 & 10 & 7 \\
\hline As florestas & 18 & 13 & 10 & 17 \\
\hline Paisagens & 11 & 10 & 6 & 15 \\
\hline Cultura & 8 & 11 & 8 & 15 \\
\hline $\begin{array}{l}\text { Artefatos } \\
\text { arqueológicos }\end{array}$ & 8 & 10 & 6 & 17 \\
\hline Praias & 13 & 10 & 4 & 14 \\
\hline Festas Tradicionais & 13 & 9 & 7 & 11 \\
\hline Os animais & 8 & 8 & 7 & 16 \\
\hline Monumentos & 13 & 9 & 5 & 12 \\
\hline Rios & 10 & 8 & 5 & 15 \\
\hline Fósseis & 5 & 10 & 7 & 16 \\
\hline Tradições & 7 & 11 & 6 & 13 \\
\hline Cachoeiras & 9 & 9 & 5 & 11 \\
\hline Igrejas & 10 & 7 & 3 & 8 \\
\hline Rochas (Pedras) & 6 & 8 & 6 & 7 \\
\hline Línguas & 5 & 9 & 4 & 9 \\
\hline Pessoas & 4 & 8 & 2 & 9 \\
\hline Comidas & 5 & 8 & 2 & 7 \\
\hline Artesanatos & 3 & 7 & 3 & 6 \\
\hline Relevo & 5 & 5 & 0 & 6 \\
\hline Ruas & 5 & 5 & 1 & 2 \\
\hline
\end{tabular}


Tabela 21 - Quem você acha que é responsável pela proteção do patrimônio do Litoral Norte? (Questão 14)

\begin{tabular}{|c|c|c|c|c|}
\hline \multirow[t]{2}{*}{ Categorias } & \multicolumn{4}{|c|}{ Grupo de respondentes } \\
\hline & Professores & $\begin{array}{l}\text { Monitores } \\
\text { Picinguaba }\end{array}$ & $\begin{array}{c}\text { Monitores } \\
\text { Caraguatatuba }\end{array}$ & $\begin{array}{c}\text { Funcionários } \\
\text { ONG }\end{array}$ \\
\hline Governo Estadual & 19 & 12 & 10 & 17 \\
\hline $\begin{array}{l}\text { Instituto } \\
\text { Florestal/ICMBio }\end{array}$ & 17 & 13 & 9 & 16 \\
\hline Prefeituras & 15 & 13 & 8 & 13 \\
\hline Governo Federal & 16 & 6 & 9 & 14 \\
\hline Moradores & 15 & 12 & 8 & 10 \\
\hline Monitores Ambientais & 13 & 11 & 8 & 10 \\
\hline Pescadores & 12 & 10 & 6 & 10 \\
\hline Polícia & 9 & 10 & 7 & 11 \\
\hline $\begin{array}{l}\text { Lideranças } \\
\text { comunitárias }\end{array}$ & 15 & 9 & 5 & 8 \\
\hline Escolas & 12 & 10 & 6 & 8 \\
\hline ONGs & 11 & 9 & 4 & 9 \\
\hline Turistas & 11 & 8 & 6 & 7 \\
\hline Agências de Turismo & 8 & 9 & 4 & 7 \\
\hline CONDEPHAAT & 6 & 7 & 6 & 8 \\
\hline IPHAN & 11 & 5 & 4 & 7 \\
\hline Comerciantes & 9 & 7 & 3 & 8 \\
\hline Indústrias & 9 & 6 & 3 & 7 \\
\hline
\end{tabular}


Tabela 22 - Quem você acha que deveria estar envolvido na proteção do Patrimônio do Litoral Norte? (Questão 15)

\begin{tabular}{|l|c|c|c|c|}
\hline Categorias & \multicolumn{4}{|c|}{ Grupos de respondentes } \\
\hline & Professores & $\begin{array}{c}\text { Monitores } \\
\text { Picinguaba }\end{array}$ & $\begin{array}{c}\text { Monitores } \\
\text { Caraguatatuba }\end{array}$ & $\begin{array}{c}\text { Funcionários } \\
\text { ONG }\end{array}$ \\
\hline Prefeituras & 18 & 13 & 11 & 16 \\
\hline Governo Federal & 19 & 14 & 11 & 14 \\
\hline Governo Estadual & 18 & 12 & 11 & 16 \\
\hline $\begin{array}{l}\text { Instituto } \\
\text { Florestal/ICMBio }\end{array}$ & 19 & 14 & 9 & 14 \\
\hline Moradores & 20 & 13 & 8 & 14 \\
\hline $\begin{array}{l}\text { Lideranças } \\
\text { comunitárias }\end{array}$ & 19 & 11 & 9 & 13 \\
\hline Monitores Ambientais & 15 & 13 & 10 & 13 \\
\hline Escolas & 18 & 12 & 8 & 10 \\
\hline Pescadores & 16 & 12 & 7 & 13 \\
\hline ONGs & 16 & 11 & 7 & 10 \\
\hline Polícia & 13 & 12 & 10 & 11 \\
\hline Turistas & 14 & 12 & 7 & 10 \\
\hline Comerciantes & 13 & 12 & 9 & 13 \\
\hline Agências de Turismo & 13 & 12 & 6 & 6 \\
\hline Indústria & 12 & 12 & 5 & 7 \\
\hline CONDEPHAAT & 9 & 10 & 5 & 6 \\
\hline IPHAN & 11 & 8 & & 8 \\
\hline
\end{tabular}


Tabela 23 - Geodiversidade é: (Questão 10)

\begin{tabular}{|c|c|c|c|c|}
\hline \multirow[t]{2}{*}{ Categorias } & \multicolumn{4}{|c|}{ Grupo de respondentes } \\
\hline & Professores & $\begin{array}{l}\text { Monitores } \\
\text { Picinguaba }\end{array}$ & $\begin{array}{c}\text { Monitores } \\
\text { Caraguatatuba }\end{array}$ & $\begin{array}{c}\text { Funcionários } \\
\text { ONG }\end{array}$ \\
\hline Diversidade Geológica & 19 & 13 & 10 & 16 \\
\hline Solo & 9 & 10 & 5 & 13 \\
\hline Substrato Rochoso & 5 & 12 & 7 & 13 \\
\hline Recursos Naturais & 10 & 13 & 4 & 10 \\
\hline Algo da natureza & 9 & 12 & 5 & 7 \\
\hline Montanhas & 5 & 12 & 5 & 11 \\
\hline Processos Geológicos & 7 & 11 & 4 & 10 \\
\hline Terra & 8 & 11 & 3 & 9 \\
\hline minerais & 3 & 10 & 5 & 11 \\
\hline Paisagem & 5 & 10 & 2 & 10 \\
\hline Ecossistemas & 6 & 10 & 2 & 9 \\
\hline fósseis & 1 & 8 & 4 & 13 \\
\hline Rios & 4 & 7 & 1 & 9 \\
\hline $\begin{array}{l}\text { Onde a Biodiversidade } \\
\text { se desenvolve }\end{array}$ & 2 & 8 & 1 & 10 \\
\hline Pedras preciosas & 0 & 9 & 4 & 8 \\
\hline $\begin{array}{l}\text { Onde a humanidade se } \\
\text { desenvolve }\end{array}$ & 1 & 7 & 3 & 6 \\
\hline Tudo que nos rodeia & 3 & 6 & 2 & 5 \\
\hline Natureza abiótica & 0 & 7 & 1 & 8 \\
\hline
\end{tabular}

